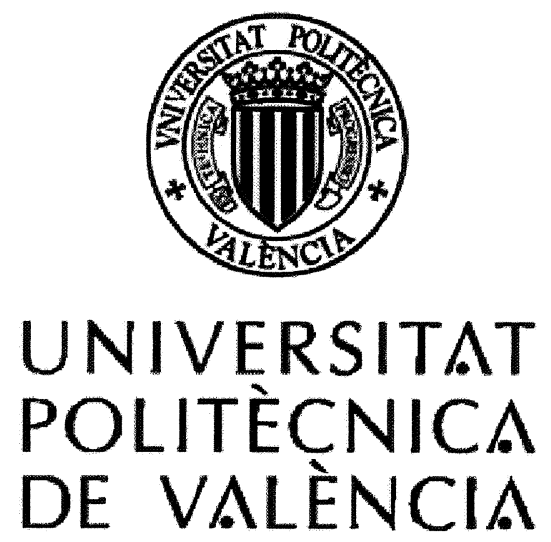

DEPARTAMENTO DE PINTURA

Programa de Doctorado Artes Visuales: Producción, Gestión, Restauración

\title{
PRESENCIA DE LA MUERTE EN LA GRÁFICA MEXICANA
}

TESIS DOCTORAL

Presentada por:

Francisco Ulises Plancarte Morales

Dirigida por:

Dr. José Manuel Guillén Ramón

Dr. Daniel Manzano Águila

Valencia, noviembre 2008 



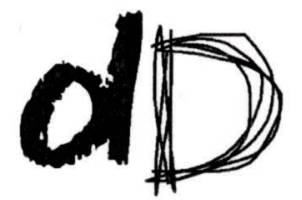

Universitat Politècnica de Valencia 



\section{A Elisa Suárez}

y a su tribu:

María Fernanda, a Saskia Carmina y a Günter León

Plancarte Suárez 



\section{INTRODUCCION}

Postraos... aquí la eternidad empieza.

Polvo es aquí la mundanal grandeza.

Dísticos grabados a la entrada de un panteón.

La presente investigación nació a propósito de las clases que con el tema de ciudad-identidad, se impartieron en el Programa de Doctorado en Bellas Artes en la Academia de San Carlos de México por profesores de la Universidad Politécnica de Valencia durante el año 2003.

Uno de los objetivos era tratar de definir cuáles eran los elementos ligados a la identidad y que, además, tuviese la permanencia del pasado, del presente y por supuesto la proyección hacia el futuro. Una primera respuesta en mi caso, apuntó hacia la cultura y al recurrente uso del tema de la muerte y en el uso de símbolos concretos que tienen que ver con ella. La muerte no solo se presenta de manera individual y festiva como la "calavera" en la que ha sido desde hace mucho tiempo una referencia de identidad de la cultura mexicana, tanto dentro, como fuera del país; también está la muerte trágica individual y colectiva representada en accidentes, incendios, enfermedades y epidemias, en movimientos raciales o políticos, y donde lo violento se opone a lo natural, pudiendo resultar del empleo de la fuerza o de algún accidente brusco como lo son golpes, heridas, traumatismo de origen criminal (asesinato) o delictuoso (homicidio, golpes y heridas involuntarias) o bien pueden proceder también de un acto suicida, incluso de un accidente, ya sea fortuito o bien producido por culpa de la propia víctima.

Por la tanto, la muerte es un personaje vivo en el arte mexicano con una rica variedad representativa: diosa, humana o personaje crítico, fúnebre o festivo de la sociedad. "La muerte -dice Octavio Paz en su libro de "El laberinto de la soledad," - es un espejo que refleja las varias gesticulaciones de la vida". 
Por otra parte el escenario de la Muerte como sujeto ha sido el espacio representado por el lugar de características semejantes al mundo de los vivos. He pretendido en la medida de lo posible, utilizar y limitar la representación de la Muerte al espacio urbano debido a dos aspectos fundamentales: La cantidad de impresos sobre el tema que se han generado en la Ciudad de México y por otro a la riqueza visual con que se ha representado por infinidad de artistas ya que la misma ciudad ha sido recurrente en el aspecto gráfico y ha sido utilizada constantemente como tema desde tiempos antiguos y con mayor frecuencia a lo largo de la segunda mitad del siglo XIX hasta nuestros días. Aquí intervienen lecturas de entornos sociales, políticos y culturales que le han permitido al artista conceptualizar su visión de acuerdo a situaciones históricas determinadas.

Nuestra hipótesis ha partido de la idea de que la muerte se presenta de manera universal, siendo quizá el único destino común de todo ser viviente. Si bien la muerte ha sido estudiada desde distintos enfoques, su inclusión implícita o explícita a través de la imagen en impresos, grabados y estampas es el motivo principal de este trabajo. La muerte por lo tanto representa una respuesta a los imaginarios simbólicos pudiendo ser estudiada en el marco de las Bellas Artes y procediendo a revisar su presencia a partir de tres aspectos principales: a) De imágenes religiosas protectoras de enfermedades y muertes repentinas; b) La repercusión en editores y grabadores como aspecto comercial a partir de la segunda mitad del siglo XIX, y c) La resignificación política, social festiva o satírica del concepto de la muerte mediante la obra gráfica. Dichos aspectos aislados o integrados permitirán estudiar a las imágenes no solamente como un aspecto de la ausencia de la vida, sino también como una historia de las mentalidades.

El objetivo general se ha construido a partir de cuatro secciones que corresponden a tiempos y concepciones distintas sobre la muerte mexicana y que se encuentran al mismo interrelacionadas: la prehispánica, la colonial, la surgida de la independencia, la moderna y contemporánea. Estos temas se abordan de manera mas especifica en cada uno de ellos mediante apartados 0 sub capítulos que son acompañados de imágenes gráficas que tienen la 
intención de ilustrar y de reforzar el texto indicándose al final de la investigación su procedencia respectiva.

En el primer capitulo se presentan definiciones y conceptos del grabado así como de sus divisiones en cuanto técnicas y sistemas de estampación que tienen la intención de orientar al lector en cuanto a los asuntos del relieve, del hueco, y la planografía se refieren.

Dentro de la significancia de la muerte se presentan en un apartado distintos enfoques de estudio desde el aspecto médico, simbólico, poético y artístico. Para comprender el producto cultural surgido de la integración de las aportaciones tanto española como la nativa en el periodo colonial he considerado presentar una concepción muy amplia del aspecto de la muerte prehispánica en el Valle de México basada en los estudios de los cronistas antiguos y también de los estudiosos contemporáneos.

El segundo capítulo contempla un breve recorrido a través del origen del papel y el desarrollo de la imprenta en la Nueva España y la abundante producción de libros, estampas, sermonarios, oraciones, etc., generada para el consumo popular donde hemos incluido la literatura en la espiritualidad novohispana que tiene como finalidad preparar al individuo para enfrentarse a la muerte con la intención de premiar los sacrificios en el Cielo, y la salvación del alma.

Aunados a estos aspectos se encontraban implementos que acompañaban a los que atravesaban por el proceso agónico: los testamentos, el velorio, las campanas, las exequias, y los monumentos funerarios. Estos elementos presentes en el periodo colonial y vigentes con pocas variantes se encuentran hasta nuestros días como parte de la cultura nacional. Se expone asimismo una obra literaria llamada "La Portentosa vida de la Muerte emperatriz de los sepulcros vengadora de los agravios del altísimo y muy señora de la humana naturaleza", siendo ilustrada con grabados al aguafuerte y cuyo personaje principal es la Muerte que nace, crece y muere como cualquier ser vivo, y que se pretende afirmar que puede ser el antecedente directo de las "calaveras" en la segunda mitad del siglo XIX.

He dejado para lo último la historia de una congregación religiosa cuya finalidad era la de socorrer al ser agónico en el difícil tránsito hacia el otro mundo llamada los Hermanos de la Buena Muerte. Personajes misteriosos y 
discretos ayudaban a salvar el alma débil y lo conminaban al arrepentimiento. La devoción a San Camilo de Lelis fue acompañante de la sociedad en buena parte de la Colonia y su imagen fue promovida mediante grabados y estampas populares donde es común observarlo luchando contra fuerzas malignas por la salvación de las almas.

En el tercer capítulo se abarca una extensión histórica y documental muy amplia alrededor del siglo XIX y su producción tanto en litografías como de grabados con una marcada influencia fúnebre y que va del México Independiente hasta la segunda mitad del siglo XIX, cuando se manifiesta en México un desarrollo en la prensa escrita y con ella las imágenes de una mancuerna ligada al aspecto comercial que contempla una cultura visual surgida de hechos delictivos cuyos representantes para la prensa porfirista serán las clases marginales. Estos pueden ser los casos presentados de Jesús Negrete (a) "El Tigre de Santa Julia", de Francisco Guerrero (a) "El Chalequero" y de María Villa (a) "La Chiquita"

En este vasto entorno se produjeron imágenes de guerra, así como documentos de situaciones cotidianas mediante periódicos, almanaques, grabados comerciales, estampas, donde la litografía el grabado y la prensa formaron una unidad de información que será desarrollada de manera excepcional por editores y grabadores populares de tipos y escenas mexicanas representando a la muerte mediante "calaveras" y esqueletos y que permiten asociar estos grabados a las figuras de Manuel Manilla y José Guadalupe Posada como ilustradores y de Antonio Vanegas Arroyo como editor.

En el cuarto capítulo hemos abordado aspectos alrededor de la muerte en la gráfica moderna y contemporánea que abarca el siglo XX comenzando con la creación de agrupaciones políticas de artistas como la Liga de Escritores y Artistas Revolucionarios (LEAR) y del Taller de Gráfica Popular (TGP) que produjeron obra de impacto social y que además coincidieron con problemáticas naciones e internaciones importantes. La estampa y el grabado tuvieron en esos años una repercusión masiva, ya que su lenguaje se basaba en mensajes directos y en la necesidad de formar cuadros de unidad nacional frente a la carestía, la riqueza desproporcionada, o la educación socialista. Presentes cada 2 de noviembre, las publicaciones del TGP en forma de 
"calaveras" a la manera de Posada y Vanegas Arroyo fueron la válvula de escape de la sociedad mexicana

Una forma similar de demandas sociales años mas tarde fue la que se produjo en los años sesenta y culminó con el llamado Movimiento Estudiantil del 68, que tuvo en sus inicios un surgimiento insignificante que con el tiempo dio paso a demandas estudiantiles con la consecuente muerte de cientos de estudiantes la tarde del 2 de octubre. Si bien, el movimiento pudo generar numerosa propaganda y cartelística realizada en mimeógrafo, linóleo y madera, serigrafía, offset y fotograbado, se pretende sólo tener una muestra representativa de esos años de lucha política.

La obra gráfica en conjunto de Francisco Moreno Capdevila y Jesús Martínez, en torno a la figura de la muerte adquiere hondas raíces prehispánicas en una búsqueda interior para encontrar su razón de existir y en la dualidad de su pasado / presente. La muerte es utilizada a manera de los antiguos códices prehispánicos, cuya lectura puede ser leída desde perspectivas distintas: visual, colorística, compositiva, independientemente de su propia lectura gráfica e histórica. Un caso aparte es el artista Juan Soriano, quien utilizó el esqueleto como una constante en sus aguafuertes y plasmó delicadas y pequeñas escenas de características eróticas en las planchas de metal de reducido tiraje.

La última parte de este capítulo está enfocado a la gráfica actual que ha tenido un despunte en los últimos años gracias al interés de las nuevas generaciones. Si bien el tema y lo que conlleva no son novedosos para nuestra cultura, si se plantean diferentes concepciones y tratamientos con nuevas tecnologías en cuanto a la manera de plantear soluciones interpretativas donde la violencia y la muerte van de la mano en las grandes urbes como la ciudad de México.

Al concluir este trabajo deseo hacer patente mi agradecimiento a la Universidad Autónoma de México por la estancia sabática en la ciudad de Valencia, España en el segundo semestre de 2008, así como a los señores Doctores que han tenido la gentileza de realizar la lectura correspondiente. A la Escuela Nacional de Artes Plásticas y a su director el Mtro. Ignacio Salazar por el apoyo recibido. 
Este trabajo no hubiera sido posible sin aquellas personas que tuvieron la gentileza de proporcionarme información de libros, estampas, grabados, e impresos en relación a mi interés como lo han sido el personal del Fondo Reservado de la Hemeroteca Nacional (FRHN) para la consulta abierta de libros y periódicos de los siglos XIX y XX; el Centro de Estudios sobre Historia de México (CONDUMEX); el Centro de Investigaciones y Estudios Superiores en Antropología Social (CIESAS); la Biblioteca de la Escuela Nacional de Antropología e Historia; el Museo Soumaya y a su directora la señora Soumaya Slim; la Biblioteca "Samuel Ramos" de la Facultad de Filosofía y Letras; el Centro Cultural Casa Lamm (CCCL) que me permitió consultar material sobre arte contemporáneo; al señor Marek Keller, por las facilidades para consular el material que custodia del artista Juan Soriano, al historiador Dr. Eduardo Báez Macías, y de manera especial, a los señores directores de Tesis, Dr. D. José Manuel Guillén Ramón, grabador y catedrático de la Universidad Politécnica de Valencia, España por su cuidadosa orientación en el desarrollo de la presente investigación y al Dr. D. Daniel Manzano profesor de la ENAP / UNAM

He dejado hasta el final no un reconocimiento, sino la gratitud a mi familia por haberles robado el tiempo que pudimos haber pasado juntos, pero que considero ha valido la pena para dedicar varias horas a este escrito, en el que por supuesto los errores son míos y los aciertos son ajenos. 
Detente amigo,

¿Por qué te vas pasando sin hablarme?

Que porque soy de tierra y tú de carne Apresuras el paso tan veloz

Escucha un momento,

Compañero el pedido que hago es corto y voluntario,

Reza un padre nuestro y un sudario

$Y$ prosigue tu marcha

¡Aquí te espero!

\footnotetext{
Epitafio del señor Florentino Sarmiento

muerto el día 27 de enero de 1898 y sepultado en el panteón indígena del pueblo de Teotlalpan, Tlaxcala.
} 



\section{Prologo}

\section{CAPITULO I La imagen y la muerte}

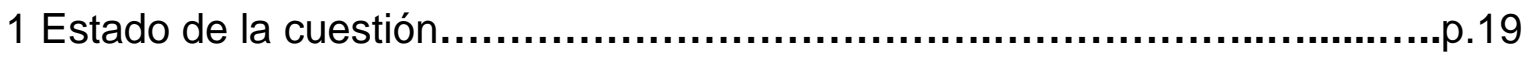

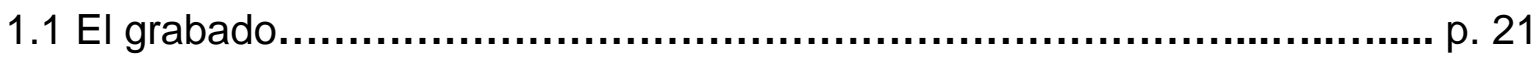

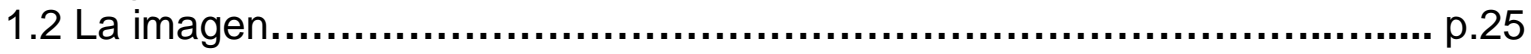

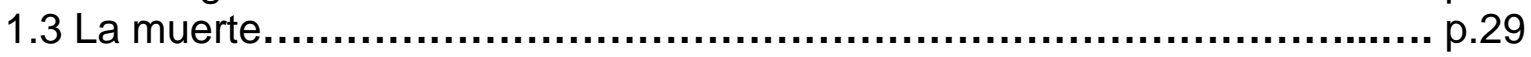

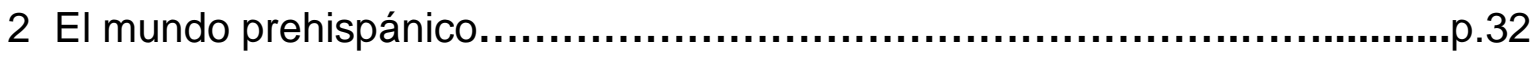

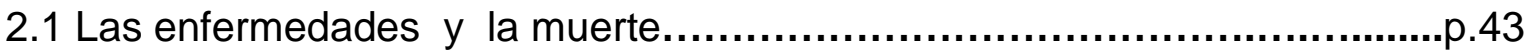

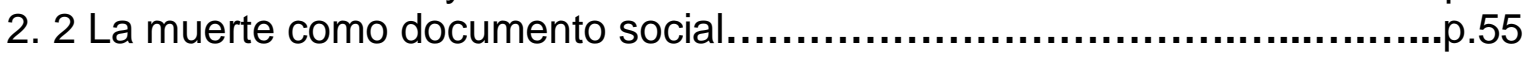

\section{CAPITULO II La presencia de la muerte en el grabado novohispano}

Introducción

1 La imagen estampada y el grabado

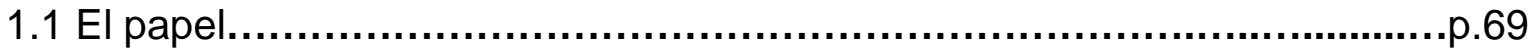

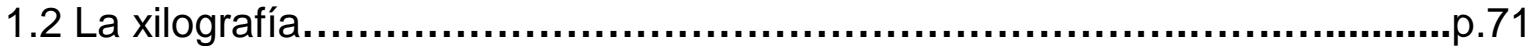

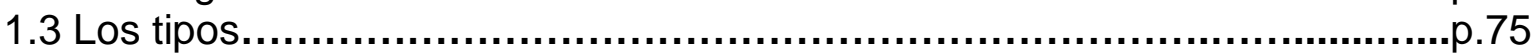

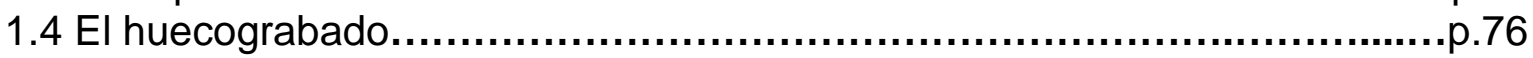

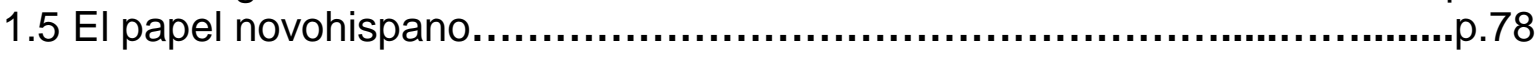

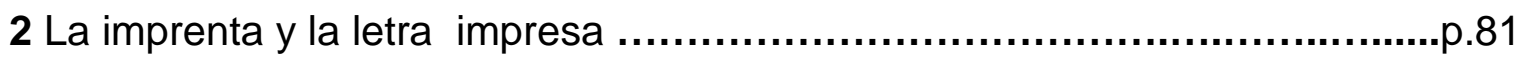

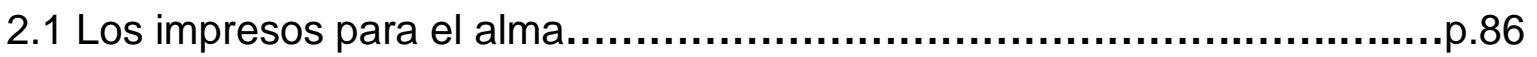

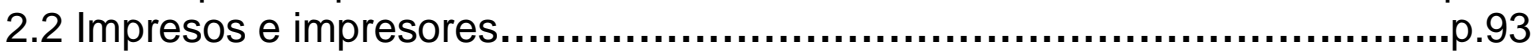

2.3 Los impresos y la muerte...............................................................

3 La muerte en el imaginario colectivo de la Colonia..................................p.100

3.1 El Purgatorio en el imaginario colectivo.............................................p.105

3.2 La muerte en el interior de la cofradías.............................................p.112

3.3 El ser agónico y el sermón fúnebre....................................................p.117

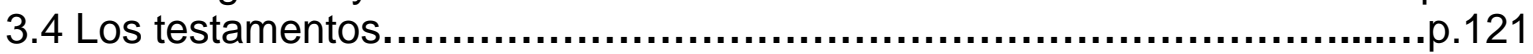

3.5 Preparación del cuerpo y el ataúd.......................................................124

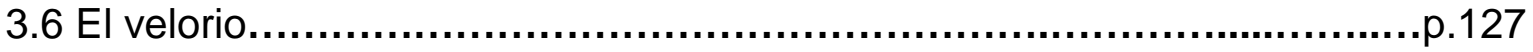

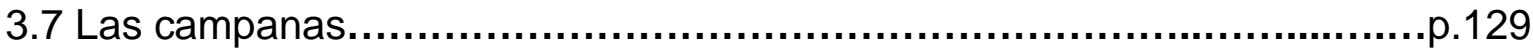

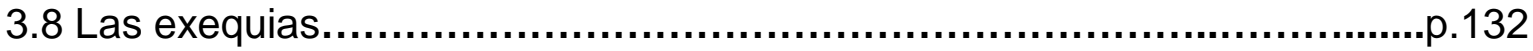

3.9 La eternidad de la presencia espiritual...............................................136

4 La gráfica popular en el siglo XIX...........................................................139

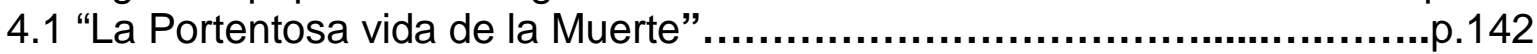

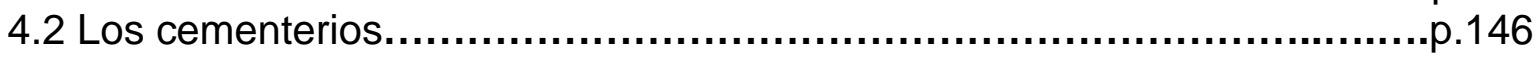

4.3 La congregación de los Hermanos de la Buena Muerte.............................p.148

4.4 La gráfica camiliana......................................................................... 154 


\section{CAPITULO III La presencia de la muerte en el México independiente}

Introducción

1 El grabado y la litografía en el siglo XIX............................................167

2 La muerte en la gráfica política y popular en los impresos del siglo XIX........................................................................ 178

3 La criminalidad impresa.............................................................p.185

3.1 El entorno social en la criminalidad en el siglo XIX.................................191

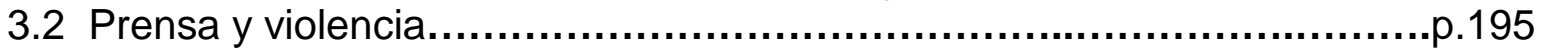

3.3 La imprenta de Vanegas Arroyo..........................................................197

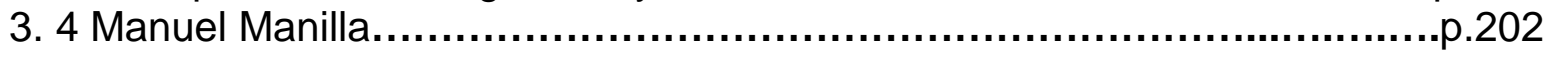

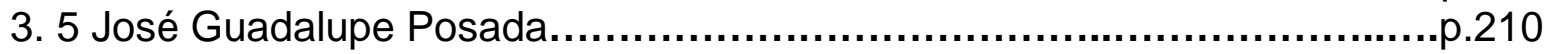

3. 6 "El Tigre de Santa Julia"............................................................p.219

3.7 Feminicidios en los impresos de Posada...........................................p.226

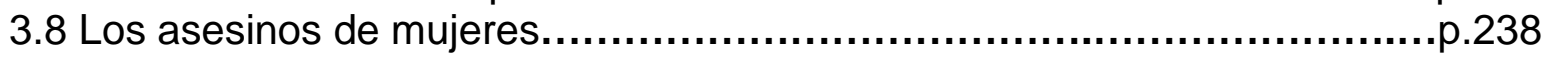

\section{CAPITULO IV La muerte en la gráfica moderna y contemporánea}

Introducción

1 La Liga de Escritores y Artistas Revolucionarios (LEAR)......................p. 251

1.1 La obra gráfica de la LEAR...........................................................2.255

2 El Taller de Gráfica Popular (TGP) ..................................................268

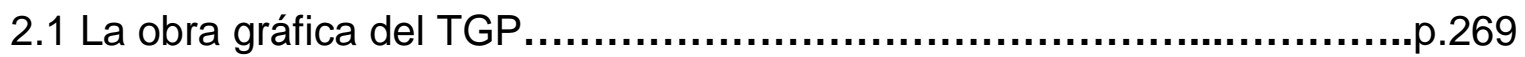

2.2 Leopoldo Méndez, el grabador...........................................................28.

3 La Sociedad Mexicana de Grabadores (SMG) .................................p.293

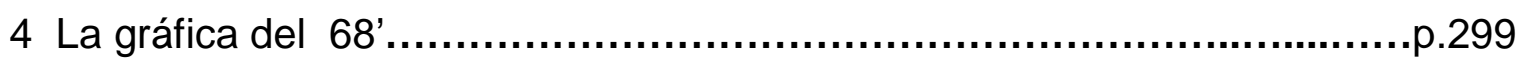

4.1 La muerte en la obra gráfica

de Francisco Moreno Capdevila.........................................................306

4.2 José de Jesús Martínez Álvarez ......................................................319

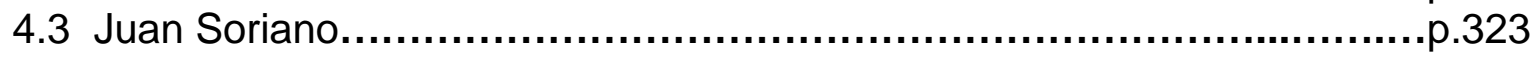

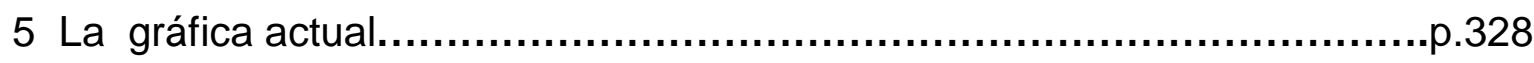

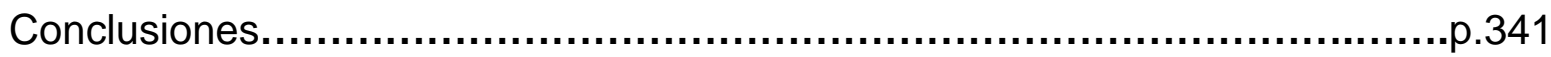

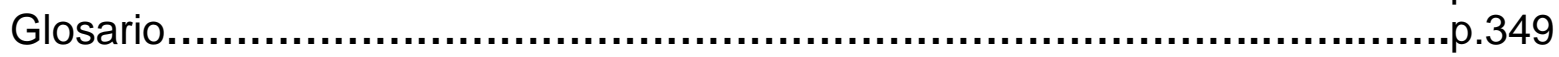

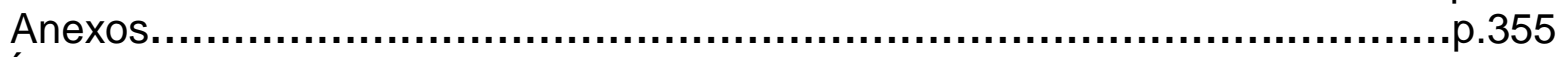

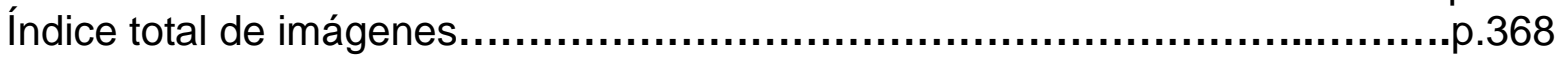

Fuentes 


\section{I \\ LA IMAGEN Y LA MUERTE}



Capítulo 1

Estado de la cuestión

1.1 El grabado

1.2 La imagen

1.3 La muerte

Capítulo 2

El mundo prehispánico

2.1 Las enfermedades y la muerte

2. 2 La muerte como documento social 



\section{Estado de la cuestión}

Si bien por un lado existe una forma de identificación de lo mexicano bajo la forma de un pasado común, se han presentando a lo largo de su historia como nación diferentes formas de manifestarlo y asumirlo tanto social como culturalmente. La Conquista española ocurrida en 1521 marcó, indudablemente un cambio en el orden geográfico, social, político y consecuentemente cultural tanto para la Europa medieval como para la América naciente. El mundo reconoció en ello que había que replantear el concepto del sistema egocéntrico del universo, establecido siglos atrás, que sostenía que la Tierra era esférica y se mantenía inmóvil en el centro del gran globo cósmico ${ }^{1}$. Pero más allá de eso supuso el inicio de la búsqueda de identidad del joven continente.

Es importante destacar que no es lo mismo ser conquistador que ser conquistado ya que este aspecto se contempla la imposición de otra cultura. Este hecho ha provocado toda una actitud cultural del mexicano en prácticamente todos los ámbitos de su vida, y tal situación parece haberse conservado entre las culturas indígenas, en una curiosa relación de espacio atemporal, debido en mucho a la conservación hasta tiempos recientes de las estructuras sociales coloniales.

Rowe y Schelling $^{2}$ han comprobado que la mezcla de elementos europeos e indígenas americanos en algunos rasgos como los modos de pensamiento y perspectivas, más bien mágicos que racionales con ligeras variantes han permanecido hasta el presente en muchas culturas de América Latina. Por otra parte, debido a los medios masivos de información que conlleva la modernización, se presentan cambios discontinuos en las estructuras más profundas de la sociedad para volcarse transformando los elementos de la cultura popular y con ello una cultura híbrida. En esta amalgama es posible establecer tres vertientes: la aculturación, el mestizaje y la transculturación. El primer término consiste en considerar que es un movimiento unidireccional de conversión y sustitución de una cultura por otra, en el caso de América, la indígena por la europea. El mestizaje es una mezcla

\footnotetext{
${ }^{1}$ Cfr. O'Gorman, La invención de América, México, FCE, 1958, p. 21.

${ }^{2}$ William Rowe y Vivian Schelling, Memoria y Modernidad, cultura popular en América Latina, Editorial Grijalbo, México, 1993, p. 30
} 
de razas donde ninguna de las dos está erradicada. La transculturación se emplea como premisa para establecer la transformación de culturas, en particular de la europea por la indígena popular.

Probablemente algunos de los símbolos vigentes que más nos identifican como mexicanos son aquellos que corresponden a las tradiciones populares que han permanecido en una relación indivisible a lo largo de la historia de México, tanto en las poblaciones rurales como en las grandes ciudades. Jean Charlot mencionaba la integración de las tradiciones prehispánica y colonial en términos contemporáneos en el arte popular. Esta mezcla no hispánica y no indígena, es una tercera fuente del lenguaje mexicano moderno. ${ }^{3}$

Sin duda alguna que el estudiar el aspecto popular de una cultura tan compleja como la mexicana da pie para muchas reflexiones. En este sentido, el grabado puede abordarse desde la visión de lo popular y dentro de éste, el aspecto de la muerte como concepto universal.

Para los grabadores del pasado, lo popular era estar ligado la mayoría de las veces a la realidad del momento, y todo su entorno se convertía en una temática para ser abordada, aún la escena más común podía transformarse en un gran tema de representación exacta y perceptiva que el autor concretaba en la gráfica. El grabado justamente por estas razones es que forma parte de esa tradición popular en México -que no es la única ni la más importante-, pero su historia y su desarrollo han ido paralelos a la historia de un México profundo.

En los artistas, la belleza está en lo que su ojo observa, ya que así se vuelven espectadores y críticos de lo social. Ya el gran artista francés Gustav Coubert escribía que el arte y el talento deben servir al artista como medios capaces de aplicar sus facultades personales, a las ideas y las cosas de la época en la que vive, por lo que cada momento histórico debe ser representado solamente por aquellos que lo han vivido, sus propios artistas. De ésta manera es extensa la lista de los grabadores anónimos y reconocidos que se han abocaron a la búsqueda y encuentro de un lenguaje personal. Históricamente a partir de este hecho es que comienza a plantearse la separación entre el arte formal o académico, y el arte de las masas o popular. Paradójicamente en la

\footnotetext{
${ }^{3}$ Jean Charlot, El renacimiento del muralismo mexicano 1920-1925, México, Domés, 1985, p. 45.
} 
actualidad muchos de los grabadores de ascendiente académica realizan obra de carácter público y popular imitando a los maestros antiguos y .su inquietud declarada es hacer que el trabajo artístico sea un medio idóneo para describir y luchar por la transformación del entorno y que en la mayoría de los casos son el testimonio gráfico de un momento social o cultural que vale la pena consignarlo en el metal, la piedra o la madera y divulgarlo en infinidad de copias a manera de espejo que repite imágenes infinitas.

Asimismo, a diferencia de otras disciplinas artísticas como la pintura y la escultura, el grabado en general, ha llegado más lejos al introducir nuevas formas de expresión utilizando las viejas técnicas e implementando nuevos recursos tecnológicos, acorde a los nuevos tiempos, es decir, en el grabado es posible combinar las formas convencionales de reproducción con la originalidad de las soluciones halladas en el uso de la fotocopia, el esténcil, el mimeógrafo y la transferencia de imagen, adoptando otros procedimientos para lograr diferentes acoplamientos modernos.

\subsection{El grabado}

Para clarificar este término, el Dr. José Manuel Guillén ha escrito que con el término de grabado hacemos referencia a una amplia diversidad de manifestaciones de la obra gráfica y se utiliza actualmente a menudo para hacer referencia a la obra gráfica impresa y seriada, englobando las diferentes técnicas. En el término grabado y estampación se encuentran implícitas las dos fases que intervienen en la realización de una obra gráfica impresa. Tan importante en el resultado final es la realización de la imagen y los recursos técnicos para grabarla o fijarla en el soporte, como el uso apropiado de las tintas el papel y la prensa. Siendo estas dos fases: el grabado y la estampación, complementarias. Asimismo existe el llamado grabado original, también denominado grabado de artista. Es el que ejecuta un artista obedeciendo a su propio impulso creador, para realizar una obra original sobre madera metal o piedra, consiguiendo lo que se denomina una matriz, que una vez entintada traslada mediante presión a un papel. ${ }^{4}$

\footnotetext{
${ }^{4}$ Consúltese, catálogo de la exposición: Archivo Gráfico, grabados, litografías y serigrafías, Universidad Politécnica de Valencia, Valencia, España, 2003. p. 23
} 
A su vez, se le denominará matriz a la plancha en hueco o relieve susceptible de ser entintada y estampada. También se denomina matriz al molde de carácter tipográfico. En litografía se trata de la piedra en la que se hace el dibujo original, que puede ser transferido otras piedras al utilizar tinta y papel. ${ }^{5}$ Entenderemos pues por grabado el resultado del trabajo realizado sobre una superficie de madera o metal, llamada plancha, por medio de instrumentos cortantes, punzantes o de ácidos que atacan la superficie metálica. El resultado es la estampa, soporte generalmente de papel al que se ha trasladado la imagen por medio de la tinta, al poner en contacto la hoja con la plancha grabada entintada y ejercer presión con un tórculo o una prensa vertical. Por extensión también recibe el nombre de grabado la estampa así realizada, de manera que se confunde el proceso con el resultado. ${ }^{6}$ Grabar, histórica y etimológicamente quiere decir hacer una incisión y deberemos llamar por ello "grabados" aquellas pruebas estampadas de una plancha matriz cuya realización se haya efectuado por medio de incisiones en su materia.

En término más amplios es la incisión a una superficie y de la cuál es posible imprimir copias con el mismo resultado obtenido. ${ }^{7}$ Debido a la enorme variedad sobre el tema, la clasificación de técnicas y procedimientos varía de un autor a otro, sin embargo, para nuestro trabajo utilizaremos aquel que con el término de "grabado" hace una referencia al producto de la "obra gráfica" y donde se han realizado tallas 0 incisiones. A los medios que no requieren 0 precisan de estos cortes como la litografía y la serigrafía se les denominará como "sistemas de estampación".

Con el término "grabado y estampación" se encuentran implícitas las dos fases que intervienen en la realización de una obra gráfica impresa tanto por su realización como imagen, como por su proceso técnico.

El procedimiento del grabado y la estampación se divide de la siguiente forma

a) En relieve: xilografía, latón, cobre, acero, etc. utilizando gubias o buriles y ácidos

\footnotetext{
${ }^{5}$ Ibid.

${ }^{6} \mathrm{http}: / / g o y a . u n i z a r . e s /$ InfoGoya/Obra/TecnicaGrabado.html

7 Mariano Rubio Martínez, Ayer y hoy del grabado y sistemas de estampación, conceptos fundamentales, historia técnicas, Barcelona, editorial Tarraco, 1979, p 19.
} 
b) En hueco: con varios procedimientos técnicos llamados grabado al aguafuerte, al aguatinta, y mezzotinta, realizados mediante buril y punta seca sobre metales que pueden ser hierro, cobre, acero, o zinc

c) Litografía: Es la sensibilización de una piedra calcárea sobre la que se dibuja.

d) Serigrafía: Es la emulsión aplicada sobre una fina malla ajustada sobre un bastidor. (No hablaremos de ella, a lo largo de este trabajo por la carencia de ejemplos que tocar)

El procedimiento de impresión de manera básica para el grabado es la siguiente: se debe considerar que la realización del dibujo sobre la plancha por el artista habrá que hacerse a la inversa, es decir, a manera de espejo para imprimirse al derecho. Para trabajar el relieve el artista puede utilizar madera de pie mediante buriles (instrumentos de pequeña lanza de acero templado con un mango de madera que se empuña en el hueco de la mano) de punta rectangular, triangular o romboidal para atacar maderas duras y pulidas que dejan el surco fino. O bien, madera de hilo mediante gurbias que son herramientas de corte con formas de uñeta, media caña, plana o navajas procurando tener cuidado con la veta o hilo propio cuyo efecto es más natural y menos complicado en su realización. Su impresión se logra mediante rodillos de hule o caucho que permiten la distribución uniforme de la tinta sobre su superficie y que posteriormente se imprime.

En metal las técnicas pueden variar. Es posible realizar el dibujo sobre la plancha con un punzón de acero templado llamado "punta seca" pero con el inconveniente de que su tiraje (o impresión) es corta porque se ejerce la fuerza de la mano para profundizar la línea en el metal. De esta manera se levanta una rebaba sobre el surco que se abre lo cual produce un efecto fresco y espontáneo; también puede usarse el buril directo sobre la plancha de metal, (en México llamada talla dulce) y cruzando las líneas el artista puede lograr una gama de grises a negros profundos. El aguafuerte a su vez, es un barniz protector que se aplica sobre la plancha y que al dibujar con la punta deja al descubierto ese barniz que el ácido profundiza la herida. El barniz de aguatinta 
se asocia casi siempre con el aguafuerte porque produce mediante su resina que se funde y se adhiere a la plancha una calidad aterciopelada y que da tonalidades que van de lo suave a lo intenso.

La litografía fue inventada en 1798 por Senefelder, y es denominada una técnica de impresión planográfica o plana que permite la obtención de múltiples ejemplares de una imagen realizada con materiales grasos. La piedra es procesada utilizando un mordiente -como en el aguafuerte, pero muchísimo más rebajado-, pero no para provocar huecos o relieves sobre la superficie, sino para fijar la imagen. El lenguaje vulgar no suele distinguir entre grabado y litografía, ambos procedimientos dan lugar a estampas, y apreciamos que en el uso coloquial se emplea la denominación estampa sin precisar si se refiere a litografía o grabado. La litografía como medio de expresión posee una gran versatilidad, adaptándose a muy diferentes lenguajes. En poco más de 200 años de historia, la litografía ha evolucionado considerablemente ${ }^{8}$

La litografía se logra dibujando con un lápiz graso compuesto de una mezcla de negro de humo, cera, jabón y sebo, sobre una piedra litográfica (piedra con anhídrido carbónico). Para que la grasa no pase a las zonas no dibujadas, se cubre toda la piedra con una leve película de goma arábiga acidulada., y a continuación, se remoja la piedra con agua. Las superficies no dibujadas absorben el agua, y las dibujadas con el componente graso la rechazan. Seguidamente se pasa el rodillo impregnado en tinta grasa. De nuevo, la tinta se deposita únicamente sobre la zona dibujada, pues la humedad de la parte sin dibujar repele la tinta. Finalmente, la imagen se estampa con la ayuda de la prensa litográfica que hace que la tinta depositada sobre el dibujo de la piedra pase al papel. ${ }^{9}$

En la xilografía, se ahuecan los blancos y se entintan con rodillo las líneas negras que definen contornos y masas. En el huecograbado se entinta la línea con ayuda de un tampón limpiándose la superficie e imprimiéndose sobre papel de algodón húmedo. Ahora bien, en la impresión de la litografía se utilizan rodillos anchos de cuero repartiéndose uniformemente la tinta sobre la

\footnotetext{
${ }^{8}$ Archivo Gráfico, grabados, litografías y serigrafías, op. cit., p. 25.

${ }^{9}$ http://goya.unizar.es/InfoGoya/Obra/TecnicaGrabado.html
} 
piedra, mojándola en forma constante para que pueda ser rechazada la grasa del lápiz especial utilizado para dibujar la forma y el sombreado.

\section{2 La imagen}

La función más objetiva de la comunicación es la transmisión de imágenes, y con el nombre de imagen designamos un sistema de datos sensoriales estructurados que son producto de una misma "escena". Abraham Moles nos dice que:

la imagen es una cosa material: es un documento de papel o conjunto de señales eléctricas; la imagen es pues, objetiva en el sentido de que este objeto particular es siempre accesible a un observador cualquiera que puede captarla ${ }^{10}$

Asimismo, indica que la imagen es un soporte de la comunicación visual que materializa un fragmento del entorno óptico (universo perceptivo), susceptible de subsistir a través de la duración y que constituye uno de los componentes principales de los medios de comunicación ${ }^{11}$. En el caso de las imágenes que se encuentran ligadas al texto siempre tendrá que existir un emisor y un receptor en el que no siempre el mensaje emitido es claro. Para Monserrat Galí en su estudio titulado La imagen como fuente para la historia y las ciencias sociales: El caso del grabado popular, las imágenes presentan desviaciones de entendimiento, debido entre otras cosas a los siguientes aspectos:

a) Las imágenes nunca están solas y forman parte de un contexto histórico y cultural, y en el caso de los grabados, éstos en ocasiones pertenecen a una serie específica o bien responden a intereses comerciales editoriales donde es posible recuperar información complementaria alrededor de su factura y someterla a una revisión crítica.

\footnotetext{
${ }^{10}$ Abraham Moles, La imagen: comunicación funcional, traducción de Gastón Melo, Editorial Trillas, México, 1991, p. 11.

${ }^{11}$ Ibidem, p. 24.
} 
b) Las imágenes pueden ser pruebas documentales y aunque en ocasiones no se puede saber quien es el autor, se da por hecho que expresa la mentalidad del autor que es muchas veces el pensamiento del editor.

c) Las obras pictóricas, escultóricas, gráficas, etc., sólo constituyen una parte fragmentaria de la relación del artista y su mundo.

d) Las obras no necesariamente pueden ser representativas de una época o de un estilo definido

e) Es necesario establecer un corpus o conjunto de imágenes que fundamente los aspectos cronológicos, geográficos, temáticos y estilísticos. ${ }^{12}$

Veamos entonces, distintos enfoques de cómo se ha abordado el asunto de las imágenes y su relación con el estudio de las sociedades:

Un antecedente es la obra de John Ruskin que consideraba que los monumentos históricos eran documentos más fieles que los escritos y formuló la teoría de que el arte, esencialmente espiritual, alcanzó su cenit en el gótico de finales de la Edad Media, con un estilo de inspiración religiosa y ardor moral. ${ }^{13}$ En el campo de la historia del arte, Abraham Moritz Warburg (18661929) contaba con un proyecto denominado Atlas Mnemosyne, que constituye una colección de imágenes con nada o, muy poco texto, mediante la cual pretendía narrar la historia de la memoria de la civilización europea. ${ }^{14} \mathrm{Su}$ legado intelectual dejó a seguidores reconocidos como Erwin Panofsky, Meyer Shapiro y Ernest Gombrich quienes utilizaron a la imagen desde el punto de vista iconológico como una contribución al uso de la imagen como documento social.

\footnotetext{
${ }^{12}$ Monserrat Galí Boadella, La imagen como fuente para la historia y las ciencias sociales: El caso del grabado popular, en Imágenes e Investigación social, Instituto Mora, México, 2005.

${ }^{13}$ John Ruskin. Crítico de Arte (1819-1900) Autor de Las siete Lámparas de la Arquitectura (1849), Las Piedras de Venecia (1851-53), y Pintores Modernos ((1843-60).Gran Espasa llustrado, Diccionario Enciclopédico, España, 2002, p. 1508.

${ }^{14} \mathrm{http}: / /$ es.wikipedia.org/wiki/Aby_Warburg
} 
Autores como el historiador y crítico alemán Paul Westheim ${ }^{15}$ hacían uso de las imágenes para interpretar la historia y el desarrollo del grabado alemán. Allí, la xilografía puede leerse como un desarrollo de la historia de las técnicas del grabado y de la estampa en las que el lector puede darse cuenta de como las herramientas y los materiales utilizados en diferentes momentos de la historia son substituidas por otros, permitiendo mayor rapidez en la producción de grabados que demandaba el mercado. Westheim señalaba el agotamiento de la técnica de la xilografía primitiva en el medioevo europeo llevando su texto a comprender las razones del surgimiento del grabado en metal. Sin embargo, otros autores serán quienes lleven el estudio de este tema a mayor profundidad. ${ }^{16}$

Por su parte, Herbert Read en Imagen e $1 d e a^{17}$ plantea que existen símbolos que son articulados por los sentidos concibiéndose la historia del espíritu o intelectual como la historia del desarrollo artístico donde el artista establece símbolos para la representación de la realidad al cobrar conciencia de nuevos aspectos al representar su conciencia en imágenes plásticas, que son a su vez adquiridos por el intercambio cultural. Es decir, una "ilusión de lo real, donde en la época moderna conviven la sensación y la imaginación, el sentimiento y el pensamiento". ${ }^{18}$

Tanto W. M. Ivins ${ }^{19}$ en Imagen impresa y conocimiento como el historiador Peter Burke ${ }^{20}$ en El uso de la imagen como documento histórico, han tratado de encontrar el valor documental e histórico de la imagen en general y en particular del grabado como alternativa de las fuentes tradicionales. Podemos considerar que, gracias al enorme archivo del testimonio de las imágenes puede reconstruirse en parte fragmentaria la

\footnotetext{
${ }^{15}$ Paul Westheim, El grabado en madera, traducción de Mariana Frenk, Breviarios FCE, núm. 95, México 1954.

${ }^{16}$ En una revisión posterior a este texto, Westheim agregaría un capítulo dedicado al grabado mexicano, a su historia y a sus artistas más representativos, Esto pudo ser posible debido al exilio del autor en nuestro país en el que consideraba que los grabadores mexicanos se encontraban a la altura de los artistas europeos.

${ }^{17}$ Herbert Read, Imagen e Idea, Breviarios FCE número 127, quinta reimpresión, México 1985. p. 72.

${ }^{18}$ El autor se mantiene en la idea de usar la sensibilidad en la creación de imágenes plásticas, p. 129.

${ }^{19}$ W. M. Ivins jr. Imagen impresa y conocimiento Análisis de la imagen prefotográfica, versión castellana de Justo G. Beramendi, Editorial Gustavo Gili, Colección Comunicación Visual.

${ }_{20}$ Peter Burke, Visto y no visto, El uso de la imagen como documento histórico, Colección Crítica letras de humanidad, traducción Téofilo de Lozoya, 2001.
} 
historia de las mentalidades. Así estas imágenes que acompañan al texto literario generalmente son vistas como complementos que permiten al lector redondear el concepto que se estudia y permite reflexionar sobre la imagen observada, pero en la realidad toda imagen puede ser sujeto de estudio histórico que indudablemente responde a una situación de cambio, de espacio físico y de contexto de realización. ${ }^{21}$ Por supuesto que su lectura y su consabida interpretación son tareas sumamente complejas de entender como lo explica Burke:

Las imágenes son testigos mudos y resulta difícil traducir a palabras el testimonio que nos ofrecen. Pueden haber tenido por objeto comunicar su propio mensaje, pero no es raro que los historiadores hagan caso omiso de él para 'leer entre líneas' las imágenes e interpretar cosas que el artista no sabía que estaba diciendo ${ }^{22}$

No exento de un planteamiento materialista, Walter Benjamín ${ }^{23}$, en un texto titulado La obra de arte en la época de su reproductibilidad técnica considera que el grabado y la estampa justamente por éste caracter reproductible han estado acompañando al ser humano en su quehacer cotidiano y que esta condición la hace transformable en igual medida que con las "conquistas de la técnica" adquiriendo valores diferentes para el que la produce y otro valor para el que la compra. El primero indica que la obra vale como testigo o documento vivo dentro de un acto ritual. Lo segundo vale de manera independiente por la experiencia profana de la belleza estética ${ }^{24}$.

Con base en la historia de las mentalidades, el interés por estos temas ha cobrado fuerza a partir de los trabajos de los historiadores como Michel Vovelle, Philippe Aries, Jacques Le Goff y Georges Duby, por citar algunos autores quienes utilizaron tanto documentos como imágenes para apoyar sus investigaciones, en los que la muerte no se ve de manera aislada y carente de

\footnotetext{
${ }^{21}$ Un ejemplo podría ser la obra del fotógrafo catalán Martí Llorens en el ex Convento de San Francisco en Pachuca Hidalgo, llamada La máquina de la memoria en las cuales las "imágenes históricas" creadas por él mismo, juegan con la capacidad del tiempo para "transportarnos hacia delante y detrás" mediante un documento visual lo que arroja una reconstrucción falsa de los hechos de manera intencionada. "Propone artista catalán colarse por la puerta trasera de la historia." La Jornada, 26 de octubre 2005.

${ }_{22}$ Peter Burke, Visto y no visto El uso de la imagen como documento histórico, Traducción Teófilo de Lozoya, Crítica, Barcelona, 2001, p. 18.

${ }^{23}$ Walter Benjamín, La obra de arte en la época de su reproductibilidad técnica, traducción de Andrés E. Weikert, Itaca Ediciones, 2003.

${ }^{24}$ Véanse los capítulos I y II en la obra mencionada.
} 
valor, sino que se ha vuelto protagonista principal de estudios de caso. Hasta hace poco tiempo, la bibliografía sobre este aspecto en nuestro país se había dejado a un lado por considerarse que se acercaba más a temas sobre salud y demografía. Estudios contemporáneos publicados como el de Verónica Zárate en Los nobles ante la muerte en México, actitudes, ceremonias y memoria permiten acercarnos a las actitudes y disposiciones de un sector social en la Colonia antes de fallecer. Otros estudios permanecen inéditos bajo la forma de tesis, como el de Jaime Morera sobre Las pinturas coloniales de ánimas del Purgatorio; El Hospital del Divino Salvador, de Cecilia Berstein; La idea del mal $y$ el demonio en los sermones novohispanos Arquidiócesis Metropolitana, siglo XVII, de Berta Gilabert Hidalgo, o Los Calendarios y la gráfica decimonónica como expresión visual del acontecer político y social en México, 1821-1850 de María Esparza Liberal. Hace falta, sin embargo, el otro lado de la moneda, las pautas de conducta de las otras clases abajo y de épocas más recientes de la historia moderna. Sabemos que la conciencia individual estaba íntimamente relacionada con lo colectivo y que afortunadamente para nosotros, esa actitud seguidora se reflejaba en las demás clases sociales. Por lo tanto, se infiere que las pautas de conducta infieren sobre la sensibilidad colectiva en la que los valores materiales e ideológicos desempeñan un papel principal.

\subsection{La muerte}

Un hecho que atañe el desarrollo normal de la existencia, es la muerte que amenaza a todas las fases y los instantes del ciclo de la vida, de la actividad cotidiana y de cualquier ideología. La muerte está ligada e identificada plenamente con todo el mundo sobrenatural que conforma un sistema de creencias sociales debatido entre las influencias religiosas celestes 0 terrenales. La muerte se observa como un suceso de paso en donde puede existir otra vida "mas allá", situación relacionada con el catolicismo y que en general la asimilamos como una verdad sin discutir.

La muerte es en cuanto que hay un personaje vivo, portador de ella misma al mismo tiempo. En ese mundo sobrecogedor y desconocido a difuntos y ánimas; nahuales y brujos se les tiene gran respeto y veneración, a la muerte se le ve en actitudes de convivencia popular sobre todo en la tradición indígena 
del 2 de noviembre compartiendo las viandas del hogar. Físicamente la muerte es un esqueleto, el personaje central de un acto festivo-luctuoso. El morir parece trágico, la vida después de la muerte no tanto, debido al concepto de inmortalidad y a la salvación, tradición propagada por los agustinos en 1620 y sostenida por el clero secular.

Según el diccionario Larousse, la muerte es la cesación completa de la vida y que la personificación de la muerte es generalmente en forma de esqueleto. En términos generales significa destrucción, o aniquilamiento. ${ }^{25}$ No obstante para la mayoría de las culturas el tema y el concepto siguen siendo una incógnita, un misterio al que se le rinde culto y se le organizan rituales para convocarla en esta la dialéctica de la vida. Cooper $^{26}$ en su Diccionario de Símbolos nos dice que la muerte es el cambio de un estado del ser a otro, la reunión del cuerpo con la tierra y del alma con el espíritu, a la vez que es el ocultamiento de la vida; la esencia y cualidad de los muertos es que les permite mirar todo. Louis-Vincent Thomas ${ }^{27}$ afirma que uno de los acontecimientos más universales del hombre es la muerte. Podemos prever algunos acontecimientos del acontecer diario o de las siguientes semanas, y de meses, pero definitivamente el momento, el día y la hora en que ocurrirá nuestra muerte nos es desconocida y su llegada, en nuestra cultural occidental y latinoamericana, va acompañada de la tristeza y de la fatalidad. Heidegger mismo señalaba una terrible verdad: el ser humano es un ser para la muerte. Así la vida y la muerte se encuentran permanente e infinitamente indivisibles. Tal vez sea más fácil entender su lado opuesto, ya que en contraposición la vida se puede decir que proviene del latin vita. El diccionario de la Real Academia Española, indica que es “... la fuerza o actividad interna substancial, mediante la que obra el ser humano que la posee”, además de ser “...la unión del alma después de la muerte". A su vez, en el Diccionario Terminológico de Ciencias Médicas las palabras muerte y vida tienen el siguiente significado:

Muerte (de mors) Extinción, término de vida

Vida (de vita) Estado de actividad de los seres organizados.

\footnotetext{
${ }^{25}$ Diccionario Larousse Enciclopédico, 1ª edición, México 1999., p., 834

26 J. C. Cooper, Diccionario de símbolos, Gustavo Gili, 2ª . Edición, Barcelona, 2002.

${ }^{27}$ Louis Vincent Thomas, Antropología de la Muerte, traducción de Marcos Lara, Fondo de Cultura Económica, 1a. edición en español, México, 1983,
} 
El Dr. Ruy Pérez Tamayo, en su ensayo sobre el final de la vida, -que no es otra cosa que la muerte-, indica que ésta se da a partir de un proceso con distintos niveles de organización:

La muerte es un proceso que ocurre en seres vivos, se inicia cuando los cambios son irreversibles, se caracteriza por la pérdida de la complejidad de su organización y por la disminución en el contenido de energía, y termina cuando la diferencia de este contenido energético con el medio ambiente es cero ${ }^{28}$

Según fray Joaquín Bolaños en "La Portentosa Vida de la Muerte", la palabra muerte se deriva etimológicamente del verbo latino mordeo que significa "morder", que según su idea recibió a raíz de la mordida dada por Adán a "la fruta vedada en el Paraíso"29.

Para Georges Bataille, la muerte y el erotismo fueron conceptos estrechos del hombre del Paleolítico superior, surgidos a causa del deseo, concepto asociado a su vez a la esencia de su ser. De lo poco que se conoce de ellos es que por lo menos si tenían la idea de que morirían ${ }^{30}$. Por otro lado, las antiguas sepulturas del Paleolítico inferior hablan ya de esa angustia de la muerte que le motivaba, al igual que al hombre contemporáneo, a dar sepultura a los cadáveres, probablemente como una superstición que revela respeto y miedo al mismo tiempo. ${ }^{31}$ Así planteado parecería un proceso dialéctico: el erotismo está vinculado al nacimiento, a la reproducción que incesantemente repara los estragos de la muerte. Curiosa relación que, como se verá más adelante, también la tenían los aztecas.

El concepto de la muerte está asociado a aspectos de dualidad que aparecen en la mayoría de las culturas: el bien y el mal; el cielo y el infierno, Dios y el Diablo, lo bueno y lo malo; la izquierda y la derecha, la destrucción y

\footnotetext{
${ }^{28}$ Ruy Pérez Tamayo, El final de la vida, en "Letras Libres", revista mensual, enero, año X, número 109, México, 2008.

${ }^{29}$ Citado por María. I. Terán Elizondo en Los recursos de la persuasión, México, El Colegio de Michoacán, p. 51

${ }^{30}$ En este sentido Bataille describe de manera general las pinturas rupestres de Lascaux y su imagen del bisonte herido. Esta representación es el acto que permite al autor hablar de la "conciencia de la muerte", Georges Bataille, Las lágrimas de Eros, traducción de David Fernández, Ensayo Tusquets, 3ª . Edición, 2002.

${ }^{31}$ Ibid., pp. 41-42.
} 
la construcción; lo eterno y lo efímero, la carne y el pecado. La muerte, señora omnipresente, venerada en muchas culturas y temida por otras tantas, su representación como Memento mori se da en casi todos los aspectos del conocimiento: filosofía, literatura, religión, danza, fantasías, el folklore, etcétera. La representación de la muerte mediante la imagen ha generado inspiración a artistas de todos los tiempos, tanto de escultores, poetas, dibujantes y grabadores, entre otros tantos. Actualmente también en los medios impresos, como el periódico, las revistas especializadas, el cine, el video, la danza o el teatro contemporáneo, han propiciado la curiosidad, el morbo o el culto hacia la muerte, o dicho en otras palabras, en torno al tema se ha creado toda una estética de la muerte."

"La obra de arte -dice Thomas- particularmente las artes plásticas ofrecen la muerte en espectáculo, ya sea con fines edificantes o de protesta, ya con una finalidad lúdica". ${ }^{32} \mathrm{Y}$ es que, a través de diferentes épocas y culturas las representaciones que de la muerte se han hecho es el de una figura negativa, contraria a lo festivo, que se le relaciona como portadora de enfermedades y malos augurios, símbolo del inframundo y cómplice del diablo.

En México la muerte se considera como nupcial y natal: "...la muerte mexicana -dice Cardoza y Aragón- es una muerte vital, un canto a la vida, sublimada en los sacrificios, no nos trataba como hombres, sino como dioses..." ${ }^{33}$ Así, el pueblo mexicano en su expresión artística ha tomado a la muerte en broma, pues expresa la alegría de vivir frente a la muerte, el propósito de alzarse contra ella mediante el ejercicio de los instintos que defienden la vida. ${ }^{34}$

\section{El mundo prehispánico}

Tal vez sea difícil hallar una cultura que adquiriera el sentido de grandeza como nación por medio de sus conquistas espirituales ${ }^{35}$ y territoriales como lo hizo la

\footnotetext{
${ }^{32}$ Louis Vincent Thomas, Op. cit., p. 189.

${ }^{33}$ Luis Cardoza y Aragón, José Guadalupe Posada, Dirección General de Publicaciones, colección de arte número 15, UNAM, 1963, p. 21.

${ }_{34}$ Juan José Arreola, citado por Paul Westheim en La Calavera, p. 86-87.

${ }^{35}$ En este sentido Laurette Sejourné, menciona que el término adecuado es el de "unidad espiritual".
} 
civilización azteca. Al respecto se cuenta con información, así como con documentos sobre acontecimientos ligados a la vida cotidiana estrechamente relacionados con el tema de la muerte, gracias a los códices antiguos y a cronistas españoles como Hernán Cortés, Bernal Díaz del Castillo, Fray Bernardino de Sahagún y Zumárraga, y a cronistas indígenas como Ixtlixóchitl, Tezozómoc y Chimalpain.

Las excavaciones arqueológicas confirman que parece ser que al final de la época del preclásico medio en la cuenca del valle de México aparece el culto a los muertos pues existen lugares destinados para los enterramientos, surgiendo nuevas prácticas funerarias y una mayor riqueza en las ofrendas. En esta idea el desarrollo del culto depende de la economía y de la acumulación de transferencia de capital. Esta forma de sepultar a los muertos en el cementerio o panteón nos permite inferir algunos conceptos en culturas muy antiguas: Un planteamiento u organización urbana; la asociación de objetos y de utensilios cotidianos; el manejo de las transferencias de capital hacia el consumo ritual; el concepto de objetivización de los símbolos de su mundo y finalmente sus creencias religiosas.

Antes de 200 a. C., el culto a los muertos se expresaba de forma más elaborada: Hay tumbas con paredes de piedra y techo de laja en Tlapacoya y

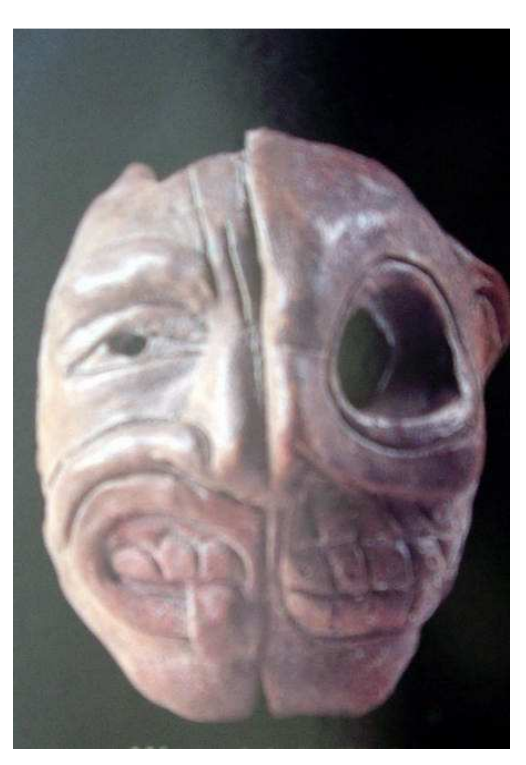

Fig. 1 Cabeza dual: La vida y la muerte
Cuicuilco en la zona del Valle de México e incineración de cadáveres en Teotihuacan. Por otra parte los datos arqueológicos antes del contacto de las culturas española y mexica hablan y dejan testimonio de varias culturas ligadas al culto de la muerte, y en especial de los mexicas. ${ }^{36}$ Para las culturas prehispánicas la vida y la muerte estaban íntimamente relacionadas, y existe una máscara dual que representa la vida y de la muerte. (fig. 1) La costumbre de rendir culto a los muertos se practicaba en la época prehispánica con el objetivo primordial de solicitar a los dioses su protección. En el Códice Chimalpopoca se

\footnotetext{
${ }^{36}$ Jesús Ángel Ochoa, La muerte y los muertos, Culto servicio, ofrenda y humor de una comunidad, SEP, col. septetentas, núm. 153, pp. 33-36.
} 
relata que los primeros hombres fueron creados con los huesos de los dioses difuntos y de esta manera el mexicano antiguo no veía en la muerte motivo de temor o tristeza, ya que no concebía que la muerte significara el fin de su existencia. Una diferencia básica entre muchas de las religiones del mundo, especialmente las monoteístas y las creencias del México antiguo, radica en que, para las demás religiones el lugar donde se permanecerá después de muerto tiene mucho que ver con la manera en cómo se vivió la vida, también de acuerdo a las actitudes adoptadas y sentimientos asumidos en la vida cotidiana con el resto de la gente. Entre los aztecas el hecho de cometer algún "pecado" implicaba el cumplimiento de duras penitencias y los "pecados públicos de la carne", estaban penados con la muerte que podía ser llevada de diferentes modos violentos. ${ }^{37}$ (fig. 2)

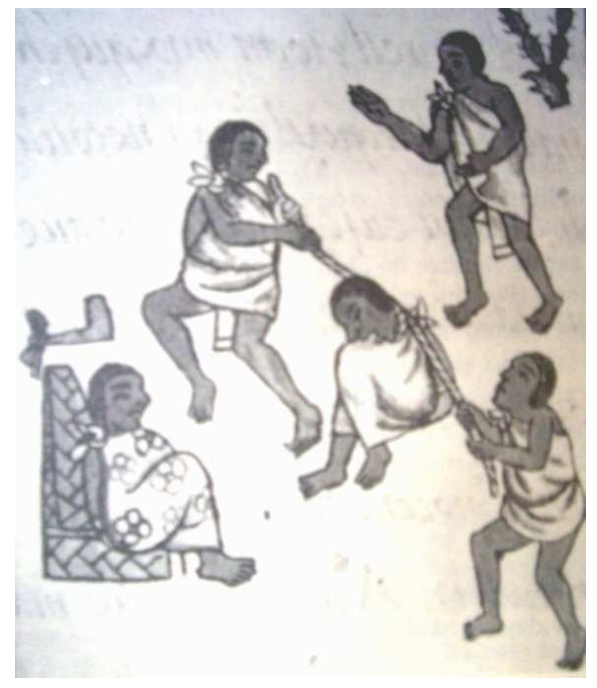

Fig. 2 Muerte por ahorcamiento en el Códice Florentino definía el lugar donde transcurriría su inmortalidad principalmente lo determinaban las causas o la forma en que moría, pues existía la creencia de que la vida es un paso para la muerte y de nuevo, el regreso a la vida. Esta parece ser una creencia común en el Altiplano Central, como en Cacaxtla Tlaxcala, antiguo centro prehispánico donde se han encontrado restos pictóricos en murales que muestran como la guerra divinizaba y concedía cualidades heróicas sobrenaturales al que moría en la contienda. ${ }^{38}$ Sahagún menciona que:

.Decían los antiguos que cuando morían, los hombres no perecían, sino que de nuevo comenzaban a vivir, casi despertando de un sueño, y se volvían en espíritus o dioses... Y cuando alguno se moría, de él solían decir que ya era téot. ${ }^{39}$

\footnotetext{
${ }^{37}$ Paul Westheim, La calavera, traducción de Mariana Frenk, México, FCE/ SEP, 1985, p. 17.

${ }^{38}$ Una descripción mas completa la ofrece María Foncerrada de Molina en "Cacaxtla: muerte en la guerra”, en Arte Funerario, Instituto de Investigaciones Estéticas, UNAM, pp. 51-64.

${ }^{39}$ Westheim, op. cit., p. 25.
} 
La misma divinidad de Quetzalcóatl cuando muere a los cuatro días desaparece y después de otros cuatro se provee de flechas, para finalmente surgir bajo la forma de una gran estrella (lucero del alba), que habla de un renacer final. La mitología azteca aborda el tema de la muerte de la siguiente manera: Mictlantecuhtli, dios de la muerte le entregó los huesos de los hombres y mujeres difuntos a Quetzalcóatl (serpiente emplumada), quien se dirigió al Tamoanchan (lugar de origen) para dárselos a Coatlicue (diosa de la tierra). Ahí ella los molió en un metate y enseguida Quetzalcóatl, al igual que los demás dioses creadores, fecundaron la masa y crearon al hombre con su propia sangre. Entonces existía entre las culturas prehispánicas una cosmovisión vertical del mundo, conformado a nuestro entender por varios paraísos y varios infiernos que no tenían un significado moral. En su conjunto integraban un mundo superior y otro inferior donde los muertos moraban y en el que al parecer, habían espectros o fantasmas como ahora les denominamos a los seres inanimados que son aparecidos en el mundo de los vivos. ${ }^{40}$ fig. 3)

Uno de los paraísos correspondía a Tláloc y tenía el nombre de

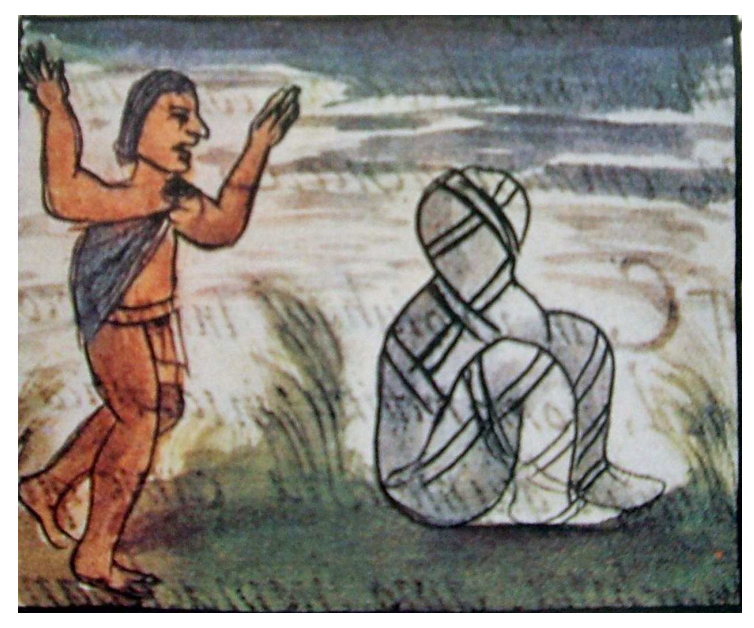

Fig. 3 Aparición de un fantasma en el Códice Florentino
Tlalocan. Ahí eran recibidos los que morían ahogados o por otras causas que tuvieran relación con el elemento agua (hidropesía, por gota o a causa de un rayo), y se pensaba que en este lugar había gran regocijo, ya que existía una gran cantidad de vegetación y alimentos que crecían sólo para solaz de los que ahí moraban. Asimismo, los paraísos se dividían de acuerdo al paso del sol en Oriental y Occidental. El primero era el hogar de los guerreros, de los caídos en batallas y de los que nutrían al sol (Tonatiuh) con su sacrificio para prolongar la diaria existencia de la deidad. El occidental era el hogar de las mujeres que morían en el parto (las Cihuateteos), sacrificándose al procrear

\footnotetext{
${ }^{40}$ Véase Alfonso Caso, El pueblo del Sol México, FCE/ SEP, 1983, pp. 76-87.
} 
futuros guerreros. Los muertos que no eran elegidos para habitar en el paraíso de Tonatiuh, iban al Mictlan (lugar de los muertos), o mundo inferior donde reinaba Mictlantecuhtli y la reina Mictlancihuatl (señora del lugar de los muertos). En este mundo se establecían todos los que morían por muertes naturales no relacionadas con otras moradas. No obstante, dichas almas tenían que vencer varios retos y peligros para que pudieran continuar su existencia. Por este motivo iban provistos de amuletos y obsequios para el viaje. Este viaje duraba cuatro días (número sagrado). El viajero iniciaba su camino a través de dos montañas enormes que chocaban entre ellas y amenazaba con aplastarlo; posteriormente enfrentaba una terrible lagartija cuyo nombre era Xalchitonal, que trataba de detener su paso, y después tenía que escapar de un cocodrilo monstruoso. Pero no quedaba ahí el viaje, también tenía que cruzar ocho desiertos y subir ocho colinas. Asimismo, en el trayecto había que soportar un viento helado llamado itzehecayan, que le arrojaba incesantemente piedras y cuchillos de obsidiana.

Cada alma debía tener su propio guía. A veces en las ofrendas funerarias era incluido un itzcuintle, o perros que guiaban al muerto a través del río. Cuando finalmente el alma llegaba a su destino, ofrecía obsequios al Señor y Señora de los Muertos, quienes lo llevaban a una de las 9 regiones en que se dividía el Mictlan o morada de los muertos. Los aztecas consideraban que cuando el sol desaparecía en el horizonte era cuando se levantaban de dormir los muertos y se "bajaba" al Mictlan. Al examinar los utensilios y materiales utilizados en los rituales celebrados cada veinte días para realizar los sacrificios humanos, permite darse una idea del concepto de muerte en el mundo de lo real y cotidiano entre estos grupos prehispánicos. El testimonio de un conquistador dice:

Estaban allí unos braseros con incienso, que es su copal, y con tres corazones de indios que aquel día habían sacrificado y se quemaban... Y estaban todas las paredes de aquel adoratorio tan babadas y negras de costras de sangre, asimismo el suelo, que todo hedía muy malamente... ${ }^{41}$

\footnotetext{
${ }^{41}$ Laurette Séjourné en Pensamiento y religión en el México antiguo, traducción. de A. Orfila Reynal, (México, FCE, 1994), p. 19.
} 
En esta compleja sociedad este tipo de acciones no respondían sino a la filosofía profunda de la religión azteca, ya que el hombre no tenía otro fin que el de alimentar al sol con su propia sangre, sin la cual el astro moriría agotado. (fig. 4) Así planteado, pareciera que la muerte era para ellos un privilegio, por lo que aquel ciudadano que ofrecía el corazón sabía que contribuía a un fin muy importante para la sociedad. Sin embargo, Laurette Sejourne en Pensamiento y religión en el México antiguo ${ }^{42}$, plantea que no todo era agradable dentro de este terrible espectáculo de masas, ya que aquel que no concurriese a las ceremonias de sacrificio se le imponían graves

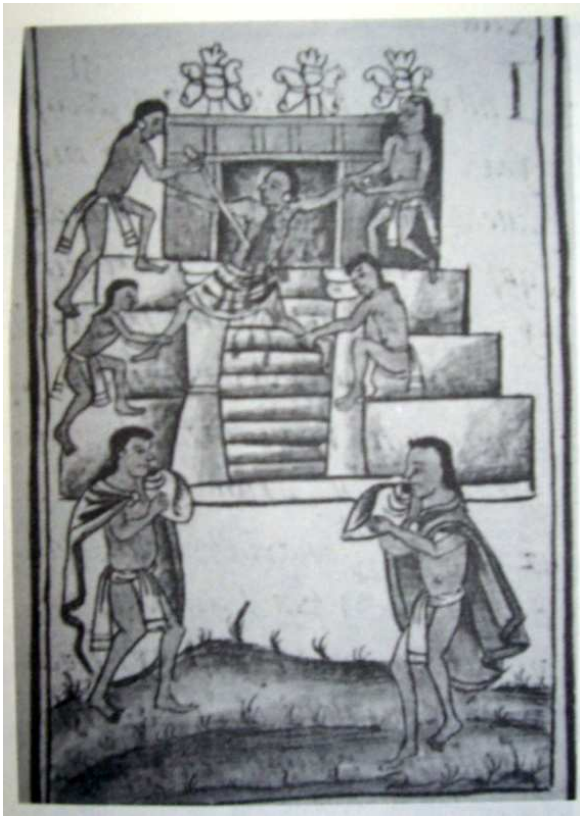

Fig. 4 Extracción del corazón de un sacrificado según el Códice Florentino sanciones: Toda persona que se retirara antes de que se hubiese consumado el evento era tenida por infame, indigna de empleo o cargo público; además, el cronista Tezozomoc escribe que los jefes y señores eran invitados a asistir a las ceremonias bajo pena de ser sacrificados si faltaban. Un detalle significativo era cuando se aplicaban medidas para aquellos que iban al sacrificio en conflicto interno, presos de angustia, en mar de lágrimas se desmayaban o eran presos del pánico. Es comprensible y lógico que no todos los inmolados y espectadores se encontraran convencidos de tal ritual de la muerte. Sin embargo, este fenómeno bien podría ser una escenificación de angustia y dolor colectiva que consumía de manera física a unos y psicológica a otros, pero tal vez no tan lejana de la catarsis buscada en las escenificaciones del teatro griego. El padre Sahagún deja una descripción terrible de la piedra de los sacrificios que, a manera de torneos de gladiadores entre Caballeros Águila y Tigres, se presentaba en honor de Xipe Totec.

hacían subir al cautivo sobre la piedra redonda a manera de muela y estando sobre al piedra el cautivo venía uno de los sacerdotes... el cual era como padrino de los que allí morían, y tomaba una soga, la cual salía por el ojo de la muela, y atabánle con la cintura con ella. Luego le daba su espada de palo, la

${ }^{42} \mathrm{Ibid}, \mathrm{p} 22$ 
cual en lugar de navajas tenía plumas de aves pegadas por el corte y dábale cuatro garrotes de pino con que se defendiese y con que tirase su contrario. El dueño del cautivo dejándolo de esta manera ya dicha sobre la piedra, íbase en su lugar y desde allí miraba lo que pasaba con su cautivo, estando bailando. Luego los que estaban aparejados para la lid comenzaban a pelear con el cautivo de uno en uno. Algunos cautivos que eran valientes cansaban a los cuatro peleando y no le podían rendir; luego venía otro quinto, que era izquierdo, el cual usaba de la mano izquierda por derecha; éste se rendía y quitaba las armas y daba con él en tierra; luego venía el que se llamaba loallaoa, y le abría los pechos y le sacaba el corazón. Algunos de los cautivos, viéndose sobre la piedra atados luego desmayaban, y perdían el ánimo, y como desmayados y desanimados, tomaban las armas, más luego se dejaban vencer y les sacaban los corazones sobre la piedra... ${ }^{43}$

Dentro de las divinidades es importante mencionar dos personajes recurrentes en la mitología ligados a la victoria y a la muerte en las

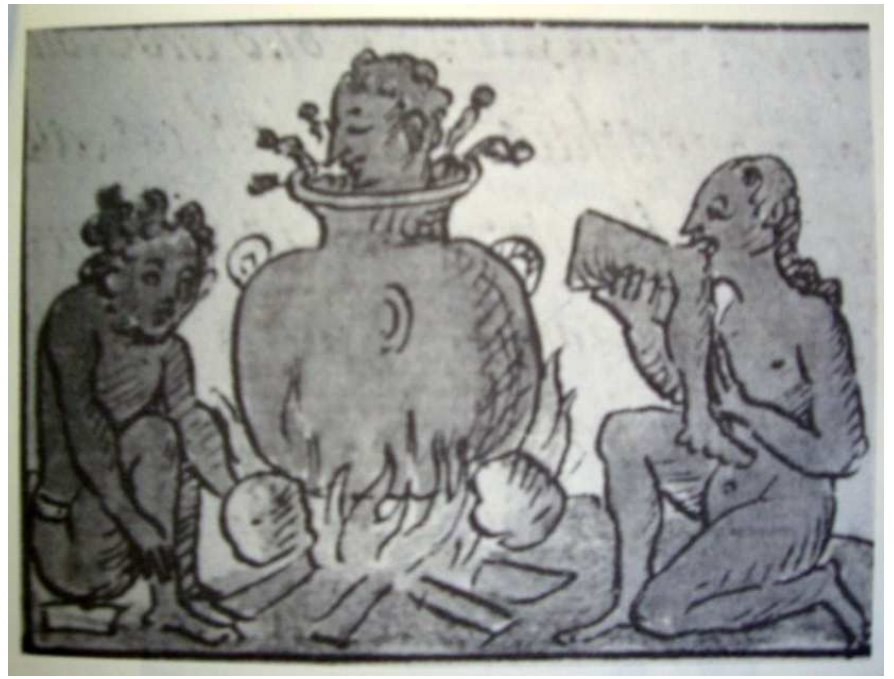

Fig. 5 Preparación de un cuerpo para comerlo, según el Códice Florentino. celebraciones aztecas:

Huitzilopochtli, Señor de la guerra, y Xipe Tótec, Señor de la penitencia o Señor desollado. Morir en la guerra o en la piedra de los sacrificios se consideraba como un alto honor, que a veces se pagaba con la muerte y ser devorado por el enemigo. (fig. 5)Por otra parte, el concepto de la

resurrección (de la vida a la muerte y con ésta a la vida eterna) se encuentra presente en el mito de Quetzalcóatl, donde se cuenta que después de incinerarse como castigo por haberse embriagado, muere para purificar su alma, la cual regresa posteriormente bajo la forma de Venus. Si la muerte y la guerra eran para los aztecas la purificación divina, a Quetzalcóatl no le queda más remedio de sus pecados ya no divinos sino humanos que entrega a través del sacrificio personal para restaurar la unidad original del sol. Noble fin que los sacerdotes aztecas tuvieron entonces que seguir como norma de purificación redentora. Tal vez no es más que el espíritu escapando de las tinieblas y

\footnotetext{
${ }^{43}$ Laurette Séjourné. Op. cit., p. 170.
} 
reencontrando su origen luminoso. Se ha querido ver aquí una relación entre Quetzalcóatl y sus seguidores para establecer un puente entre la tierra y el cielo. Existe una curiosa similitud, entre el acto de morir dignamente en actos de guerra y el acto de amor. Westheim ${ }^{44}$ menciona que en el Códice Borgia se representa la procreación a través de una escena donde un hombre y una mujer tomados de las manos sostienen con la otra entre ambos un cuchillo de pedernal (técpatl). En el Códice Vaticano A, el cuchillo de pedernal se encuentra en posición vertical entre los dos y encima de cada uno de ellos se yergue una lanza. El término técpatl significa 'objeto cortante', 'matar', pero en este contexto también simboliza 'fuego', 'llama', 'vivificación' o 'fecundación'.

Entre los textos conservados y recuperados por uno de los estudiosos más importantes de la literatura prehispánica, Miguel León Portilla, se encuentran los documentos eróticos en náhuatl de Aquiauhzin de Ayapango (poeta que vivió entre la región de Chalco y Amecameca), compuestos probablemente hacia 13 Caña (1479), donde se muestran varios ejemplos de cuando fueron los chalcas a cantarlo por primera vez en Tenochtitlán. ${ }^{45}$ En ellos se observa como la guerra se transforma finalmente en un evento erótico /pornográfico, refiere León Portilla. Estos textos literarios permiten conocer otros aspectos de la vida cotidiana de los aztecas anteriores a la conquista, mismos que develan las múltiples relaciones que tenía la guerra y la muerte con la vida colectiva y privada de los aztecas.

Algunos de los fragmentos de la poesía pueden ser ilustrativos:

“...Revuélveme como masa de maíz,

Tu, señor, pequeño Axayácatl,

Yo a ti por completo me ofrezco,

Soy yo, niñito mío, soy yo, niñito mío.

Alégrate, que nuestro gusano se yerga.

¿Acaso no eres un águila, un ocelote,

tú no te nombras así, niño mío?

¿Tal vez con tus enemigos de guerra no

harás travesuras?

\footnotetext{
${ }^{44}$ P. Westheim, La Calavera, Op., cit., p. 33.

${ }^{45}$ Miguel León Portilla, Aquiauhzin de Ayapango, poesía erótica náhuatl, en "Revista Plural", número 49, México, 1975, pp. 32-42.
} 
Ya así, niño mío, entrégate al placer.

Nada es ni falda, nada mi camisa,

Yo, mujercita, estoy aquí,

Viene él a entregar su armoniosos canto,

Viene aquí a entregar la flor del escudo.

¿Acaso de algún modo somos dos?

Yo mujer me unté las manos con ungüentos,

Me acerco con mi falsa de fruto espinoso.

Los veré a todos perecer..."

Aún cuando en todas las culturas existe una idea definida de la muerte, existen diversas interpretaciones sobre el tema que se manifiestan de manera variable, pues lo que es establecido por una cultura es modificado o transformado substancialmente por otra. ${ }^{46} \mathrm{El}$ concepto de muerte entre los indígenas americanos chocaba con los principios espirituales de la cultura española occidental, por lo que bajo esta óptica las culturas mesoamericanas aparecen como pueblos bárbaros y fanáticos de la sangre y de los sacrificios, en los que es difícil aceptar su religión y la actitud contemporánea del poco respeto a la vida.

Ya desde tiempos prehispánicos existía una fecha determinada para la celebración del día de muertos y de alguna manera, pese a los conquistadores, tal celebración se conservó y perduró a lo largo de los tiempos coloniales. Los cronistas de Indias mencionan el día de muertos sin indicar la fecha como un día al año, en especial una noche de la celebración de tiempo/ espacio, que es descrita de esta manera:

y en este dí(a) hacían fiestas de los defunctos, porque ofrecían por ellos, an(te) el Demonio muchas gallinas y maíz y mantas y vestidos y comida e otras cosas y en particular cada uno hacía en su casa gran fiesta y a las imágenes que tenían de sus padres y papás defunctos sahumaban con incienso e sacrificábanse las leng(uas) y orejas y piernas y brazos y sus partes (genitales) y con la sangre untab(an) estos ídolos de sus pasados y cubríanlos de un papel, y cada u(n) año hacen lo mesmo, de manera que en ellos se parecían cua(n)tos había

\footnotetext{
${ }^{46}$ s/a, "La muerte en el México Prehispánico" en Revista Arqueología Mexicana, CNCA, Vol. VII, número 40, noviembre -diciembre de 1999, p. 10.
} 
que se acordaban y tenían memoria de ellos $\mathrm{p}$ (or) los papeles y sangre que cada año les ponían... "47

La presencia del arte en el México Antiguo es fundamentalmente religiosa y es posible que al observar sus huellas al caminar le haya sugerido crear un instrumento capaz de reproducir el mismo fenómeno en centros religiosos a partir de darles forma concreta. Necesitaba esas imágenes para venerarlas. Así al crearlas, los dioses representaban los diferentes elementos de la naturaleza y los diferentes grupos y actividades humanas. Las máscaras que se han conservado y la pintura mural nos hablan de ese mundo antiguo.

Es por eso que la pintura corporal adquiría al poco tiempo un significado distinto en la vida ritual permitiendo al mismo tiempo un adorno en fiestas y danzas, y como distintivo de categorías sociales: el tocado, los brazaletes, las narigueras, las orejeras, los bezotes ${ }^{48}$. Al mismo tiempo las marcas eran efectuadas en el rostro y en el cuerpo con colores específicos simbolizando deidades con el ánimo de ser impresionantes al verlos.

En la vida cotidiana la muerte impresa fue utilizada en sellos de piedra, barro cocido o hueso de excelente factura decorativa, y aparecen en el llamado periodo Preclásico Medio al establecerse en el Valle de México pequeñas aldeas y es en Tlatilco ("donde las cosas están escondidas") donde surgen las primeras manifestaciones que son utilizadas para el uso de pintaderas corporales. El arqueólogo Arturo Romano Pacheco al hacer una descripción minuciosa de los enterramientos de los primeros habitantes en este lugar menciona que entre las ofrendas de cerámica, piedra, obsidiana, asta hueso concha y chapopote “...también se hallaron pintaderas planas y cilíndricas, sonajas y silbatos..."

\footnotetext{
${ }^{47}$ Ibid.

48 Los bezotes son un adorno-emblema que seguramente causaba gran impacto a los espectadores, ya que amalgamaba el alto rango militar con una profunda simbología, sobre todo cuando la pieza hacía referencia simbólica a alguna deidad. Así, al manifestar lo sagrado, se convertía en la imagen del dios mismo y expresaba que su portador estaba en comunicación con las deidades [...] La colocación del bezote en la zona inferior del labio implicaba que, al hablar, la pieza se moviera armónicamente de acuerdo con la emotividad con que se articulaban las palabras, dando el efecto visual - simbólico de que era el dios mismo quien ejercía el poder y gobernaba; de ahí que con este emblema labial se legitimara el poder territorial y el don de mando sobre uno o varios señoríos Véase: Biblioteca Luis Ángel Arango http://www.lablaa org/blaavirtual/publicacionesbanrep/bolmuseo/1997 enjn42/enjn02a.htm

${ }^{49}$ Arturo Romano Pacheco, "La ofrenda funeraria en Tlatilco", Arte Funerario, Op. cit., pp. 101107.
} 


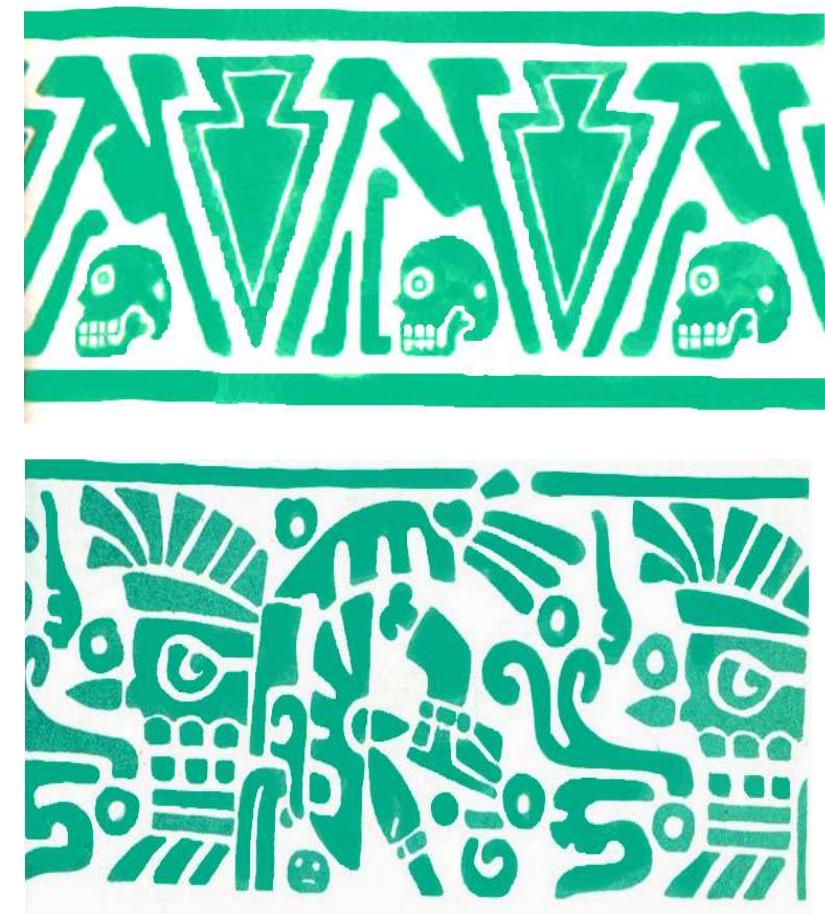

Fig. 6 y 7 Impresión de sellos prehispánicos

Ahora bien a partir de los elementos decorativos se pueden hacer dos grupos de manera general: los que se refieren a la religión y a la mitología y otro con temas geométricos que incluyen formas animales vegetales $y$ animales. $Y$ a partir de su forma se puede suponer su aplicación: los sellos planos que consisten de un mango y una forma variada y cuya superficie se halla grabado un motivo cualquiera y los sellos cilíndricos huecos o sólidos que sirven para desplazar el dibujo en relieve que sirve para imprimir. (figs. 6 y 7 )

En el libro Sellos del Antiguo México, Jorge Enciso muestra dos ejemplos de tipo cilíndrico procedentes de la Ciudad de México, los cuales poseen un diseño geométrico repetitivo. ${ }^{50}$ Uno de los sellos posee dos líneas gruesas a manera de cenefas que marcan la parte superior e inferior en el que se observan tres repeticiones en la forma de cuchillos o flechas de pedernal (el citado técpatl), ahuecado en su interior y como elemento central, tiene un contorno blanco como refuerzo. En el interior y al lado izquierdo de la composición (en la estampación queda a la derecha) se encuentra un cráneo con un fémur. Llama la atención un pequeño orificio situado antes de la base del cráneo. El otro ejemplo está formado por dos figuras que pertenecen a la representación de Mictlantecutli (Señor del lugar de los muertos). Su nariz de pedernal se aprecia en una calavera tocada con plumas de guerra y ojos y dientes descarnados. La figura central maneja una doble lectura: por un lado parece un rostro visto de perfil con la boca abierta y por el otro los elementos

\footnotetext{
${ }^{50}$ Jorge Enciso, Sellos del Antiguo México, México, Editorial Innovación, 1985.
} 
decorativos se encuentran a su alrededor y consisten en partes del cuerpo desmembrados como son pedazos de lanzas, orejeras y narigueras fragmentadas, puntas de obsidiana, una pierna ataviada con cascabeles, y que se presentan como trofeos de guerra. Si bien hay abundancia de sellos y de variedad de temas, pocos son los ejemplos que

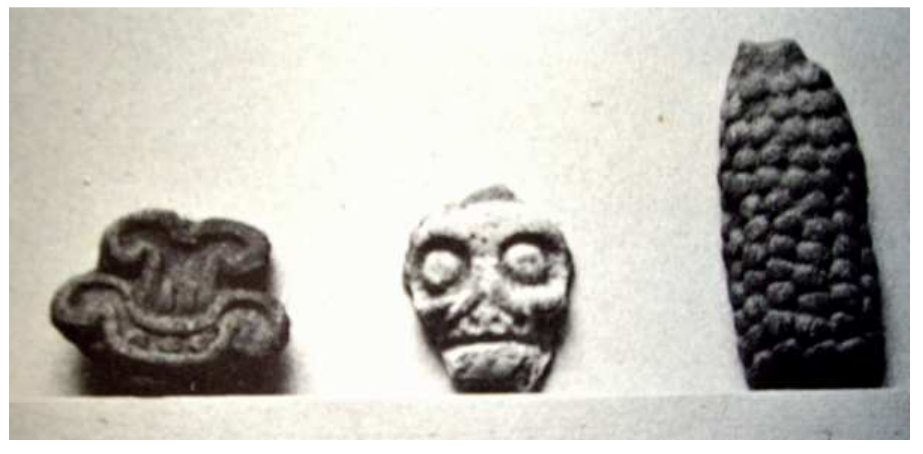

Fig. 8 Matrices de sellos de piedra del Museo / Anahuacalli. Propiedad de Diego Rivera se han conservado del tema de la muerte. En el Museo Anahuacalli (Casa del Anáhuac) construido por Diego Rivera al final de su vida, en el sur de la Ciudad de México, se encuentra una pequeña colección de ellos, y en una vitrina podemos observar una mascara pequeña de muerte de penetrante mirada al lado de un sello en forma floral y de elote realizados en piedra y con clara procedencia de la zona de Cuicuilco. (fig. 8)

\subsection{Las enfermedades y la muerte}

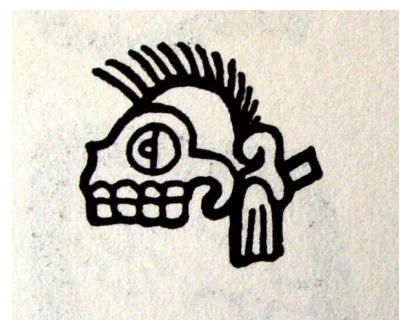

Fig. 9 La muerte como signo representando los días para los aztecas
En América, antes de la llegada de los españoles, se conocían diversas enfermedades que al igual que en otras civilizaciones en otras partes del mundo, habían diezmado a la población. No en balde la muerte era respetada y temida al grado de asignarle un día en la vida cotidiana azteca. (fig.9) Es conocido la idea de considerar que los antiguos habitantes de nuestros pueblos eran gente sana y que las enfermedades y la muerte masiva fue producto del encuentro con los europeos. Asimismo, se han encontrado en forma recíproca que de tierras americanas, los europeos se llevaron enfermedades y epidemias al viejo mundo. Ahora sabemos que la 
cuestión de la salud no tiene que ver con estos aspectos, sino más bien con la ignorancia y el desconocimiento de la época y por supuesto del avance científico para erradicar las enfermedades. Lo que pudo ser posible fueron las diferencias inmunológicas llevadas por los diferentes grupos raciales en un momento determinado que destaparon una caja de Pandora que en la mayoría de los casos duró años. Sabemos, por las descripciones de crónicas, noticias y relaciones de las enfermedades que azotaban a los pobladores del Valle de México como la diarrea, las fiebres, el matlazáhuatl (peste) la rubéola, la tosferina, el garrotillo (enfermedad de la garganta por hinchazón o inflamación), el tabardillo o tabardete como se le denominaba entonces a la tifoidea, o la disentería. Como caso aparte está la sífilis considerada como enfermedad venérea. El clérigo Francisco López de Gómara ${ }^{51}$ menciona en la Historia de la Conquista de México el huizauatl o viruela en el siguiente pasaje:

Con esta guerra muchos dineros a Diego Velázquez, la honra y un ojo a Pánfilo de Narváez y muchas vidas de indios que murieron, no a fierro, sino de dolencia; y fue que, como la gente de Narváez salió a tierra, salió un negro con viruelas; el cual las pegó en la casa que lo tenían en Cempoallan, y luego un indio a otro; y como eran muchos, y dormían y comían juntos, cundieron tanto en breve, que por toda aquella tierra anduvieron matando. En las casas morían todos, y en muchos pueblos la mitad, que como eran nueva enfermedad para ellos, y acostumbraban bañarse a todos males, bañábanse con ellas, y tollíanse; y aun tiene por costumbre o vicio entrar en baños fríos saliendo de calientes, y por maravilla escapaba hombre que las tuviese; y los que vivos quedaron, quedaban de tal suerte, por haberse rascado; que espantaba a los otros con los muchos y grandes hoyos que se les hicieron en las caras, manos y cuerpo. [...]

Llamaron los indios a este mal huizauatl, que suena la gran lepra. De la cual, cosa muy señalada, contaban después ellos sus años. Parésceme que pegaron aquí las bubas que pegaron a los nuestros...

Por otra parte el conquistador, Bernal Díaz del Castillo menciona un pasaje en el que ".... Otro día dijo Sandoval que se quería volver a Tezcuco, y los de Chalco le dijeron que querían ir con él para ver y hablar a Malinche y

\footnotetext{
${ }^{51}$ López de Gómara, Francisco, Historia de la conquista de México, estudio preeliminar de Juan Miralles Ostos, México, Col. "sepan cuantos...", tercera edición, Editorial Porrúa, número 566, México, 1997.
} 
llevar consigo dos hijos del señor de aquella provincia que había pocos días que era fallecido de viruelas."

Existen testimonios de los informantes del padre Sahagún que durante el asedio de México- Tenochtitlan, por parte de los españoles se desató entre la población una gran peste llamada hueyzáhuatl, o hueycocoliztli, donde una de las víctimas más célebres iba a ser el caudillo Cuitláhuac. La narración recogida por Miguel León Portilla en la Visión de los Vencidos es rica en detalles y vale la pena conocerla:

Cuando se fueron los españoles de México y aún no se preparaban los españoles contra nosotros primero se difundió entre nosotros una gran peste una enfermedad general. Comenzó en Tepeíhuitl. Sobre nosotros se extendió: gran destruidora de gente. Algunos bien los cubrió, por todas partes (de su cuerpo) se extendió. En la cara, en la cabeza, en el pecho, etcétera. Era muy destructora enfermedad. Muchas gentes murieron de ella. Y nadie podía andar, no más estaban acostados, tendidos en su cama. No podía nadie moverse, no podía volver el cuello, no podía hacer movimientos de cuerpo; no podía acostarse cara abajo, ni acostarse sobre la espalda, ni moverse de un lado a otro. $Y$ cuando se movían algo, daban de gritos. A muchos dio de muerte la pegajosa, apelmazada, dura enfermedad de granos. ${ }^{52}$

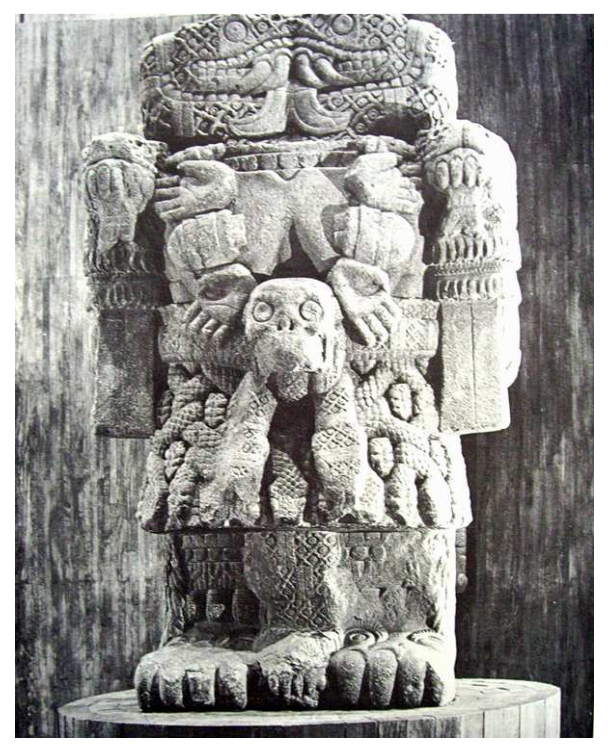

Fig. 10 La deidad de la Coatlicue
Durante el siglo XV1, las epidemias fueron prácticamente las más temidas entre la población, ya que es indudable que después de la conquista vino un largo periodo de recuperación donde las cuestiones insalubres han de haber sido las más difíciles de vencer. Era como si la imagen de la señora de la tierra y de la muerte estuviera presente siempre: Coatilicue. (fig. 10) Ya don Bernal Díaz del Castillo mencionaba la "enfermedad de las bubas" o "mal gálico) ${ }^{53}$ entre los

\footnotetext{
${ }^{52}$ Miguel León Portilla, Visión de los Vencidos relaciones indígenas de la conquista, UNAM, quinta edición, México, 1971, pp. 101-102.

${ }^{53}$ El mal gálico, también llamado mal napolitano, es la actual sífilis (treponematosis venérea). En Sayra Guinnette, Aldana Hernández, La treponematosis en la historia de Colombia: una mirada desde la Ecología Histórica.
} 
mismos españoles y como estos personajes eran segregados de milicias y de favores debido a su naturaleza enfermiza como sucedió a Rodrigo Rancel:

como Cortés conocía a Rodrigo Rancel que no era para darle ningún cargo, a causa que estaba siempre doliente y con grandes dolores de bubas y muy flaco, y las zancas y piernas muy delgadas y todas llenas de llagas, cuerpo y cabeza abierta... ${ }^{54}$

También menciona la enfermedad de la "modorra" que es probable que haya sido un virus infeccioso en la persona del licenciado y músico Luis Ponce, que “...le dio una muy recia calentura y echóse en la cama y estuvo cuatro días amodorrido sin tener el sentido que convenía, y todo lo más del día y de la noche era dormir. ${ }^{, 55}$ Tal parece que no fue un caso aislado ya que líneas más adelante menciona a fray Tomás Ortiz que venía en el mismo navío que

dió pestilencia en ellos porque de más de cien personas que en ellos venían les dio modorra y dolencia, de que murieron en la mar y después que desembarcaron en la villa de Medellín, y murieron muchos de ellos. ${ }^{56}$

Tan sólo entre 1519- 1520 (justo cuando cae la ciudad de MéxicoTenochtitlan) la capital sufre epidemia de viruela (conocida también como la peste roja que mató a grandes cantidades de personas, sobre todo de infantes), sucediéndose en 1531 de sarampión, 1545 y 1576 de peste, siendo ésta, la más terribles de cuantas se hayan sufrido en la Nueva España ya que un cálculo aproximado fue de dos millones de personas muertas a tal grado que iglesias y cementerios resultaron insuficientes, razón por la que se tuvieron que cavar grandes fosas para arrojar a cientos de personas muertas en el mismo día. Para los primeros días de 1529 el cabildo de la ciudad de México ordena que los "indios que murieran de pestilencia fueran a enterrarse si eran

http://www.inversa.unal.edu.co/articulos_publicados_en_html/publicado_vol1_no2_la_treponem atosis_en_la_historia_de_colombia.htm. (12 de julio de 2008)

${ }^{54}$ Bernal Díaz del Castillo, Historia verdadera de la conquista de la Nueva España, introducción y notas de Joaquín Ramírez Cabañas, editorial Porrúa, col. "sepan cuantos", número 5, México 2004 , p. 443.

${ }_{55}$ Ibid., p. 510.

${ }^{56}$ lbid., p 510-511. 


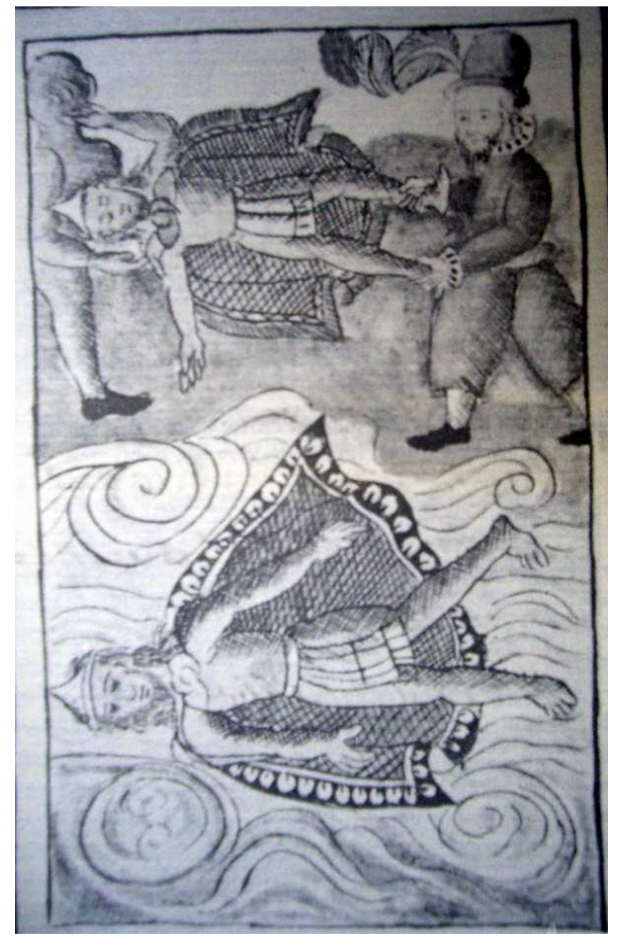

Fig. 11 Españoles arrojando los cadáveres de los nobles mexica a la laguna según el Códice Florentino

cristianos en la iglesia o en su cementerio o en sepultura honda y que no fueran enterrados en cualquier parte" ${ }^{57}$ (fig. 11)

La enfermedad de la peste comenzaba con fuertes dolores de cabeza, para después ser fiebre, después se sufría fuertes hemorragias por nariz, ojos y oído muriendo en tan sólo en nueve días. En los Anales de Tecamachalco se dice que en sólo tres días se enterraron 410 personas. ${ }^{58}$ Un factor importante sin duda para la transmisión de las enfermedades debieron de ser entonces el comercio, las concentraciones de pobladores, los obrajes y comercios y la movilidad de las personas

Europa misma había sufrido en los siglos XIV y XV los estragos de la peste conocida como entonces como la Muerte Negra, herencia a su vez del mundo clásico. Entre cerca de 500 a.C. y el 550 d. C., hubo extensos contactos entre poblaciones animales y las civilizaciones de China, Asia central, India, el Alto Nilo y el Mediterráneo dando por resultado una confluencia general de enfermedades euroasiáticas y africanas que generó un caldo de cultivo para microorganismos que se propagan generosamente en los climas templados. La viruela, por ejemplo, fue siempre contagiosa a causa de la inmunidad innata, que unida a la peste Antonina (probablemente el sarampión) la hicieron mortífera a causa de su combinación letal.

Giovanni Boccacio a propósito de las huidas de individuos de las grandes ciudades que provocaba la peste había escrito "El Decamerón"59 a partir de la epidemia el año de 1348 en Florencia y menciona que "...al

\footnotetext{
${ }^{57}$ Rodríguez, María de los Ángeles, Usos y costumbres funerarias en la Nueva España, México, El Colegio de Michoacán / El Colegio Mexiquense, 2001, p.175.

58 Ibid.

${ }^{59}$ El autor sitúa a siete mujeres y tres hombres a que cuenten historias y cuentos mientras la ciudad es presa de la muerte.
} 
empezar la enfermedad, nacíanles a las hembras y varones en las ingles o en los sobacos, unas hinchazones que a veces alcanzan a ser como una manzana común, y otras como un huevo, y otras menores y mayores otras." $Y$ contaba esta anécdota:

presencié, entre otras veces, esta experiencia un día: yacían en la vía pública los harapos de un pobre hombre muerto algo antes y dos puercos, llegándose a ellos, oliéronlos y asiéronlos con los dientes, según su costumbre, y a poco, tras algunas convulsiones como si hubieran tomado veneno, ambos cayeron muertos en tierra sobre los mal compuestos andrajos". 60

Existen tres variedades de la peste la bubónica, la neumónica y la septicémica: Aún cuando las tres son mortales, la primera, la bubónica es la más común. El agente principal ahora lo sabemos es la rata negra y la pulga que se alimenta de su torrente sanguíneo y como viven cerca de los seres humanos puede darse fácilmente el contagio. Se caracteriza por pústulas negruzcas seguidas de ensanchamiento de los nodos linfáticos en las axilas, las ingles o el cuello según la picadura de la pulga. Después ocurre una hemorragia subcutánea produciendo las pústulas purpúreas llamadas bubas (de ahí su nombre). Esta hemorragia produce muerte celular e intoxicación del sistema nervioso conduciendo a desórdenes neurológicos y psicológicos que pueden explicar los rituales de una danza macabra que acompañaron a la Muerte Negra.

La peste neumónica es menos frecuente y puede ser transmitida de persona a persona y su periodo de incubación es corto: de dos a tres días. En cambio, la peste septicémica es transmitida por insectos y sus bacilos entran en grandes cantidades en el torrente sanguíneo y en unas cuantas horas se forma un salpullido que cobra su forma mortal ocurriendo la muerte en el mismo día, incluso antes de que se formen las bubas que la identifican.

Por destino histórico, la peste fue desatada debido al comercio y a los continuos viajes de exploración que modificaron en forma sustantiva el equilibrio de las enfermedades. Parece ser que los cambios climáticos

\footnotetext{
${ }^{60}$ Giovanni Bocaccio, El Decamerón, Círculo de Lectores, Complejo Editorial Mexicano, 1972, pp. 14-15.
} 
empezaron a alterar la ecología y con esto el mapa del mundo cambió drásticamente. ${ }^{61}$

En no pocos casos se volvió tema de literatura como el Diario de la peste de 1722 de Daniel Defoe, basado en hechos sucedidos en Europa en donde describe que:

hubo quejas de que nadie se ocupaba de recoger a los muertos de las casas en las que todos los habitantes habían perecido, sino que a veces los cadáveres permanecían varios días insepultos, hasta que el hedor llegaba a las casa vecinas, y en consecuencia las contamina. ${ }^{62}$

Otras epidemias están relacionadas con las condiciones de insalubridad y la falta de higiene, como es el cólera (Vibro cholerae). No es difícil suponer que

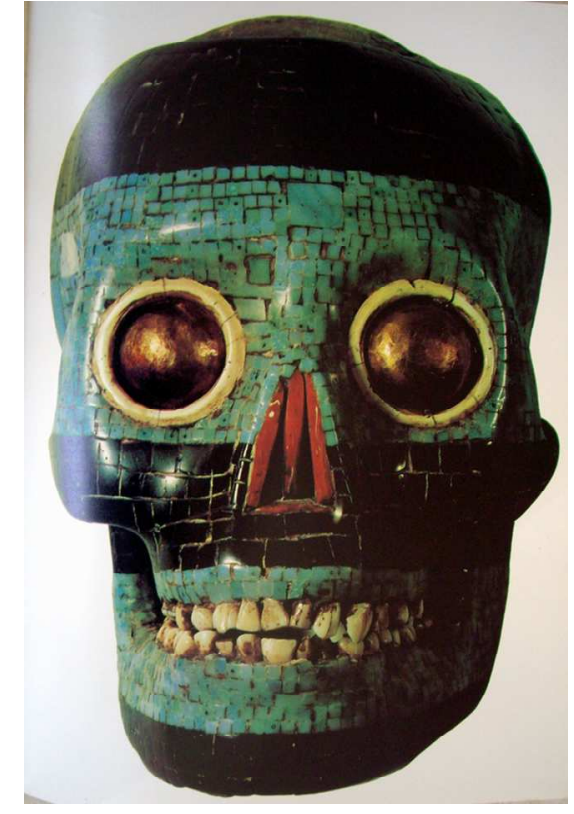

Fig. 12 Máscara azteca sobre cráneo humano debido a las guerras constantes entre los pueblos indígenas prehispánicos hubiera condiciones terribles de insalubridad y que el vencido en guerras 0 en enfermedades fuera usado como ornamento de poder como lo es la calavera azteca revestida de turquesa. (fig. 12) En el caso de la viruela y el sarampión son enfermedades contagiosas que están relacionadas con la inmunidad de la población que no está preparada para resistir una bacteria que invade en forma masiva y se reproduce rápidamente en el cuerpo humano. En el caso del matlazahuatl no se han definido los agentes que permiten su identificación plena y su desarrollo en el ser humano; pero, indudablemente están relacionados con el tifo y la peste cuyos agentes transmisores son los piojos y pulgas que requieren de un animal o ser humano huésped para desencadenar la enfermedad en potencia y a una

\footnotetext{
${ }^{61}$ Sobre el tema, consúltese el libro de Robert S. Gottfried, La Muerte Negra, desastres en la Europa medieval, traducción de Juan José Utrilla, Fondo de Cultura Económica, primera edición en español, 1989.

${ }^{62}$ Daniel Defoe, Diario del año de la Peste, traducción de Carlos Pujol, Editorial Bruñera, Barcelona, 1985.
} 
velocidad vertiginosa. Aunque no se debe descartar que un excelente sostén son las condiciones de poca higiene que existía en la Ciudad de México acompañadas de otros factores complementarios como la pobreza, el hambre, los hábitos, además de un detalle que puede ser determinante en esta situación: la contaminación de las heces fecales vertidas en la vía pública.

En efecto, en la Colonia sobrevivían los canales de comunicación que los mexicas habían construido para poder trasladarse en la ciudad acuática de Tenochtitlan; pero al término de la Conquista y con la colonización, los españoles comenzaron a construir pequeños puentes y acequias para poder transitar por ella y separar las zonas habitadas de los indios.

Es justamente en estas acequias donde se vertían todo tipo de residuos humanos o comerciales (tintorerías y curtidurías sobre todo) y debido a los vapores contaminantes que de ella emanaban infectaron al mismo tiempo calles, canales y ríos que se convirtieron seguramente en focos de propagación. ${ }^{63}$

En el periodo colonial se sabe que el matlazahuatl se manifestó con gran intensidad en $1575-1575,1588,1595-$ $1596,1641,1667$ y 1696 dando muerte a miles de habitantes. (fig. 13) Al parecer dicha enfermedad se había manifestado antes de la llegada de los españoles, ya que se han encontrado

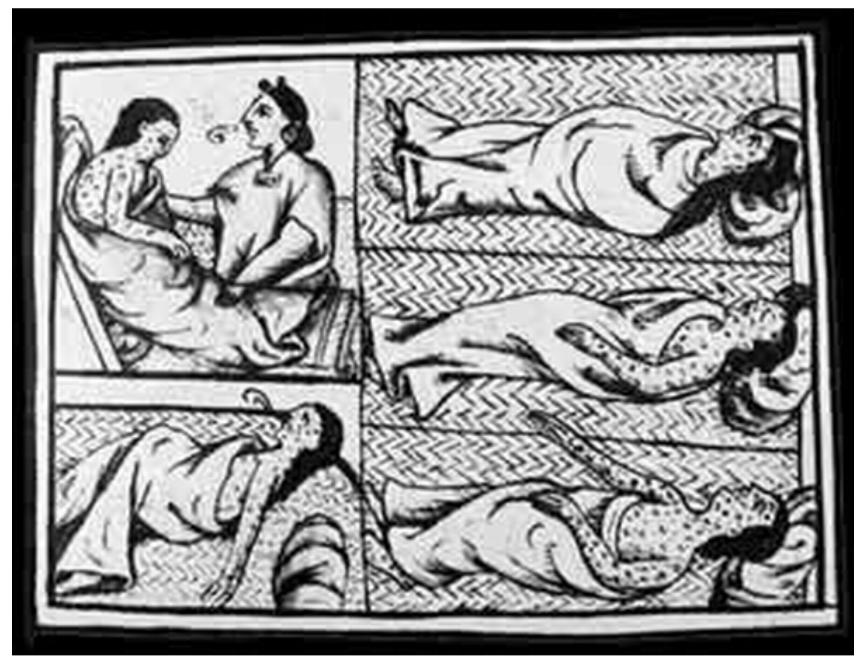

Fig. 13 Las enfermedades del cuerpo, según el Códice Florentino registros en los códices. Según los estudiosos, el primer brote se registró en el año 583 d. C., y el segundo importante en el año 1116, debido entre otras cosas a que las sociedades

\footnotetext{
${ }^{63}$ En algunas ciudades de Europa durante el siglo XVII, se había prohibido el riego de frutos y hortalizas con aguas negras. En la Nueva España excrementos humanos y basura se mezclaban lanzados tranquilamente desde los balcones de las casas al grito de "iAguas!", expresión que aún los mexicanos de hoy en día conservamos cuando avisamos de un peligro o cuidado que nos rodea.
} 
precolombinas estaban infectadas de piojos y no tenían un régimen de higiene. ${ }^{64}$ Lo que queda documentado en épocas posteriores es una aparición entre los meses que van de agosto a noviembre de 1736 en un obraje del pueblo de Tacuba, que tenía todas las condiciones para el primer brote de la enfermedad, ya que justamente en ese año cayeron sobre la ciudad fuertes lluvias que permitieron graves inundaciones con la consabida pérdida de las vías de comunicación en tierra y el crecimiento del río Azcapotzalco o de los Remedios muy cercano al lugar de los hechos. Para rematar, en la misma zona, se hallaban varios molinos lo que significaba que los pueblos de Tacuba y Azcapotzalco estaban bajo un constante tráfico de personas.

En la Nueva España el matlazahuatl fue muy estudiado por diversas personalidades científicas e históricas y cada una trató de encontrar por su lado una posible respuesta a la sintomatología del matlazahuatl. Orozco y Berra encontró que los síntomas correspondían

\begin{abstract}
“...a un frío en todo el cuerpo, después sentían un incendio como de volcán que les devoraba las entrañas dificultad para respirar, los ojos se ponían encendidos y rubicundos y cefalea, señal de una fiebre elevada. Una buena parte de los pacientes sufría hemorragias nasales durante uno o dos días continuos. También era frecuente que se formaran parótidas que llegaban muchas veces a supurarse y muchos enfermos padecían ictericia de la que pocos se escapaban. En lo más agudo de la enfermedad, al tercer o cuarto día, los enfermos entraban en delirio tan violento, que era necesario para sosegarlos usar de ataduras y crespos. Casi todos los enfermos recaían una, dos, y hasta tres veces por falta de dieta " .5
\end{abstract}

Desde el siglo XVIII las autoridades del cabildo de la Ciudad de México preocupadas por la enfermedad habían encargado al presbítero Cayetano Cabrera Quintero que buscara las posibles causas encontrando éste que la causa era "un castigo divino y natural ya que el clima y el ambiente de la ciudad eran propicios para favorecer la propagación de diversas pestilencias y fiebres" y opinó que ciertos fenómenos naturales "habían presagiado la epidemia trayendo como consecuencia un castigo celestial". En lo que acertó Cabrera

\footnotetext{
${ }^{64}$ América Molina del Villar, La Nueva España y el matlazahuatl 1736-1739, Centro de Investigaciones y Estudios Superiores en Antropología Social, México, 2001, p. 61.

${ }^{65}$ Ibid., p. 66.
} 
Quintero fue en la razón de considerar que entre las lanas del obraje de Tacuba había proliferado el contagio. Con tal motivo, el Ayuntamiento de la ciudad recomendó que: "siendo el ambiente el que más con su putrefacción corresponde al aire por medio de él [...] se eche bando general que en todas las calles y barrios se pongan luminarias que los purifiquen". ${ }^{66}$ De este modo, se prohibieron entonces las actividades sociales sobre todo de los enterramientos y las ceremonias fúnebres ya que contaminaban el ambiente de tal manera que se recomendó a curas, sacerdotes y clérigos no aumentar las sumas que tenían que cubrir por derecho de entierros ya que los mismos vecinos tenían que trasladar a sus muertos a los cementerios de la ciudad atravesando "todas las calles, calzadas y acequias que con el sol causan el contagio, pudiendo suceder que para juntar los derechos se demoran los entierros dos o tres días". 67

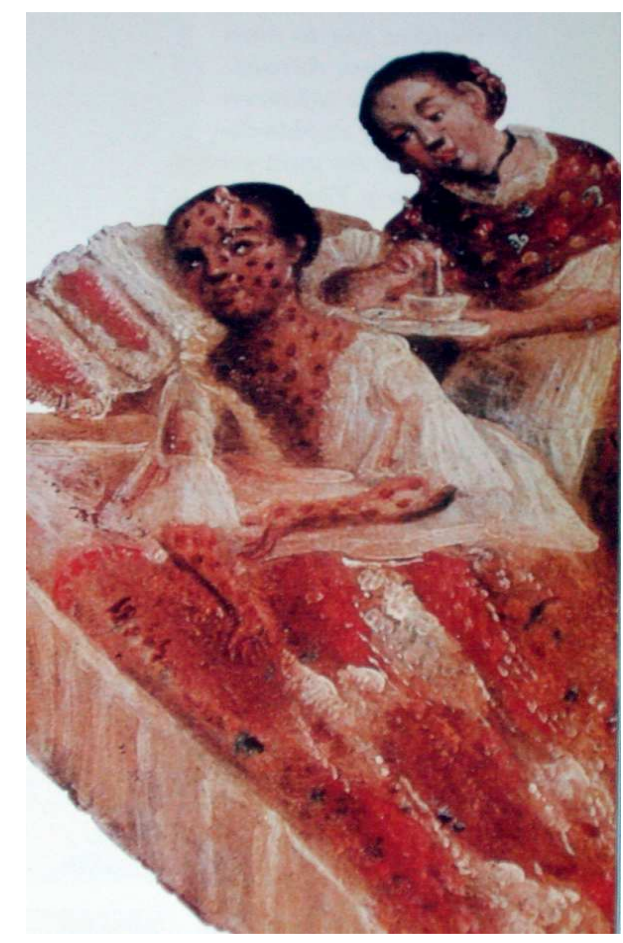

Fig. 14 El cuidado de los enfermos del cuerpo. Según una pintura del siglo XVIII
Importante para su entendimiento es considerar que el asunto de las enfermedades respondía al temperamento, la condición y el sexo, ya que en la época que tratamos se consideraba de acuerdo con el manual italiano de Capello Compendio Medicinal, ${ }^{68}$ que las mujeres y los niños estaban más expuestos a la peste porque en sus cuerpos estaban llenos de humedades, de lo cual en consideración a la misma lógica era aplicable a los indios. (fig. 14)

Tal vez, sin saberlo, las mismas autoridades virreinales aumentaron la peligrosidad del matlazahuatl debido a la

\footnotetext{
${ }^{66}$ Ibid., p. 147.

${ }^{67}$ Ibid., p.148.
}

${ }^{68}$ El título era Compendio medicinal de maravillosos y experimentados remedios contra la peste, así preservativos como curativos para beneficio universal: recogidas de la experiencia y doctrina de muchos y graves autores. Impreso tres veces en los reinos de España, reimpresión de José Bernardo de Hogal, ministro e impresor del Real Apostólico Tribunal de la Santa Cruzada, México, 1737. 
excesiva cantidad de indios concentrados en los arrabales de la ciudad con el fin de protegerlos y de que vagaran en las calles sin control de las autoridades. Por su parte el virrey informaba el 16 de abril de 1737 al Consejo de Indias que

Fuera de estas humanas providencias se ha solicitado también el socorro espiritual de las divinas con plegarias, novenas, rogativas a Dios, su Santísima Madre y santos especiales, abogados de esta ciudad y pueblo, procurando aplacar su justísima ira con procesiones y públicas penitencias; no ha bastado; mucho debe de ser el número y mucho la gravedad de nuestras culpas o poco eficaz el arrepentimiento, cuando con todo esto se hace sorda su inmensa clemencia. ${ }^{69}$

Muy pronto las capacidades de casas y hospitales y boticas se vieron rebasadas para atender la gran cantidad de gente que llegaba implorando ayuda $^{70}$. $Y$ así de un repente la sociedad entera se vio involucrada en un problema de salud pública que en lugar de cesar se agudizaba día a día, incluso contagiando de muerte a hombres piadosos y religiosos que aportaron fuerzas y dinero a tan encomiable labor.

En provincia, por ejemplo, se pidieron limosnas fuertes a ganaderos, hacendados y dueños de trapiches, siendo en la mayoría de los casos inútiles dichos esfuerzos. Las razones del fracaso estriban entre muchas causas en que la mayor parte de la población era de indios que era a su vez el sector más desprotegido y menos alimentado por lo tanto con menos defensas del cuerpo para resistir la enfermedad.

Sobre este punto, se sabe que en la Nueva España se daba un cuidado especial a la comida y la salud ${ }^{71}$ y que en el tratamiento y la dieta recomendada para este tipo de enfermedades vertidas en el mencionado Compendio Medicinal, consistían en una combinación de carbohidratos, proteínas, caldos de res y carnero, cebolla, arroz, nabo, garbanzo, pan, tortilla y el atole, se

\footnotetext{
${ }^{69}$ Ibid., p. 152.

${ }^{70}$ La parte positiva de la epidemia fue la creación de nuevos hospitales y centros de atención costeados por vecinos adinerados y altas autoridades civiles y religiosas entre ellos el virrey Vizarrón Eguiarreta. Ibid. p. 158.

${ }^{71}$ América Molina menciona como ejemplos el libro de fray Agustín Farfán (1592) Tratado breve de medicina y de todas las enfermedades que a cada paso se ofrecen, y el de Gregorio López llamado Tratado de Medicina.
} 
mencionaban asimismo, una larga lista de alimentos que podían consumirse entre ellos tallarines y carne de ternera así como la miel y el vinagre.

Cabrera Quintero sugería tratamientos por cada área del cuerpo: para las cefaleas se habrían de tomar "...agua de sacbiosa, agua de triaca alcanforada, agua espirit, cal volátil de cuernos de ciervo, jarabe de culantrillo y tomarla antes de cada comida o como ungüento en la piel. Para las hemorragias nasales se recomendaba "fomentos de vinagre, una onza de nitro y alcanfor disuelto" y combinar "agua y vinagre para purificar las habitaciones de los enfermos después de ingerir una píldora de mirra y azafrán". Para las náuseas y los vómitos sugería "los theriacales, sudoríficos, viperino y antipestilenciales". Ya visto con el tiempo, un aspecto positivo se anotaba Cabrera y Quijano al negarse a que al enfermo se le practicasen sangrías en las bubas o tumores ya que

el médico [solo] atormenta al enfermo de mil maneras, lo aprieta y casi quebrándoles los miembros, tazándole y exprimiéndole sangre de varias partes, finge que le saca daño, que aunque sane ya se ve, no es más que un embuste y castigo por sus pecados" ${ }^{\prime \prime 2}$

No se ha mencionado todavía que la medicina a la que acudían la mayoría de los indios enfermos era la hechicería y los rituales mágicos así como ceremonias de imágenes o de individuos que acompañados de la idolatría de viejos dioses prehispánicos persistieron muchos siglos y a los que gran parte de la población era afecto en contradicción con la Iglesia y su doctrina.

En conclusión la mortal enfermedad del matlazahuatl se extendió por gran parte de la Nueva España tardando mucho tiempo para reponerse no sólo por las cantidades enormes de muertos sino por la escasez de alimentos, carestía, hambre y enfermedades que la acompañaron y la reorganización de cientos de pueblos abandonados y de autoridades españolas e indígenas que fueron víctimas de tal infortunado mal que para su desgracia volvió a presentarse numerosas veces.

72 Ibid., p, 166. 


\section{2 La muerte como documento social}

A partir del Concilio de Trento (1545 -1563) la iglesia mexicana se acercó a los asuntos indígenas relacionados de los legados, sepulturas y misas. De estas reuniones se derivaron diversas juntas eclesiásticas y sus respectivas acciones tuvieron como finalidad la de "...amoldar la pastoral de la Iglesia a la vida, costumbres y necesidades de los indios de la Nueva España". En el Tercer Concilio Provincial Mexicano de 1585 se sentaron las bases que habrían de regir a la Iglesia novohispana y sobre todo su posición con respecto a la muerte y más concretamente a las herencias arrebatadas a los moribundos por el clero secular o regular que despojaban a aquellos descendientes directos 0 ascendientes en el referido artículo mortis. Es evidente que los pueblos indígenas tuvieron costumbres y normas propias para heredar bienes que tuvieron variaciones en costumbres y modos en las zonas culturales de la República Mexicana. Para poder proceder en orden se pedía entonces convencer a los indios que estuviesen bajo una disposición testamentaria.

Se conocen cerca de veinte ordenanzas indicadas para indígenas fechadas entre 1539 y 1625 que corresponden a los poblados del México Central, Yucatán y Guatemala que se refieren entre otros asuntos a los testamentos, el entierro cristiano, la disposición de bienes, el nombramiento del escribano, y la suerte de los huérfanos.

Estas acciones tenían en primer lugar la intención de lograr la cohesión del núcleo indígena bajo los preceptos cristianos, y aprovechar de paso un control político y social; y por otra parte, establecer la nueva institución de la tenencia de la tierra y suprimir "la falta de orden y concierto" en los actos del gobierno. Es en pocas palabras una reeducación de los valores principales del indio bajo al pauta de la cultura impuesta del más fuerte.

Para este "control indígena" algunas de estas ordenanzas hablan de un comportamiento y conducta personal; la idolatría con "copal, papel y otras cosas"; sacrificio de animales; vida marital; homosexualidad: incesto; compra de mujeres para casarse; bigamia, fiestas de guardar; encubrimiento de relaciones de parentesco; delincuencia; asesinato; hechicería; ayunos; 
entierros; robos; esclavitud; apropiarse de bienes ajenos; poner nombres; insignias y divisas del pasado a los hijos; dejarse coleta; comer y cenar en mesas con manteles; funciones de gobernadores; de escribanos; de Mayordomos; agradecimientos a Dios; persignarse y santiguarse; rezo de oraciones, etc.

En cuanto a la muerte dichas ordenanzas mencionan que hacer en caso de estar cercana ésta y de la ausencia de un sacerdote donde otro indio pusiese auxiliar a los moribundos.

26 Otro si, mando que si la enfermedad de los tales enfermos fuere en acrecentamiento, que los curaren y sirvieren tengan cuidado de avisar al cacique o a la persona que los padres religiosos de doctrina tuvieren puesta en cada pueblo, para que envíen a llamar a algún Padre, si estuviere cerca de allí en parte que pueda venir para confesar y consolar a los enfermos, e para que ordene su ánima, y se disponga a bien morir. $Y$ encargo a los Padres de doctrina que porque ellos no se podrán hallar en todos los pueblos y necesidades, que pongan y señalen en cada pueblo personas de indios más entendidos y más espertas en la doctrina, con instrucciones que les den para ello, e para que ayuden a bien morir a los tales enfermos, etcétera. ${ }^{73}$

Otra ordenanza se refiere a sobre a quien dejar sus bienes los moribundos:

20 Ítem, no consientan que los dichos enfermos en los testamentos y última voluntad con que murieren quiten los bienes y hacienda que tuvieren a sus hijos y mujeres y lo den a parientes, compadres $u$ otros extraños, antes hagan que cuando quedaren algunos menores dividan y partan los bienes y hacienda de sus padres por iguales partes de manera que ninguno de ellos reciba agravio, ni persona alguna les ocupe ni tome las dichas haciendas que ansí quedaren de los dichos, so pena que lo pagarán por sus personas y haciendas. ${ }^{74}$

Una manera de acercarse a la sociedad indígena de la preconquista y de la Colonia es a través de los testamentos. A partir de este planteamiento se considera que las culturas legan sus bienes en vida a sus parientes y amigos más cercanos. Aquí se pueden contemplar varios aspectos: los sociales y los económicos, el modo de ver la vida, la salud, el lenguaje y la manera de

\footnotetext{
${ }^{73}$ Teresa Rojas R. et. al., Vidas y bienes olvidados, testamentos indígenas novohispanos, CIESAS, México, 1999, p. 47.

${ }^{74}$ Ibid., p. 49.
} 
expresarlo, la tenencia de la tierra y el compadrazgo, la herencia y las sucesiones, así como la relación de los pobladores indígenas con la cultura europea.

Existen diversos estudios ${ }^{75}$ que han permitido estudiar el tránsito de la vida a la muerte en los primeros tiempos de la Colonia y la permanencia de rasgos de identidad estables que han perdurado a lo largo de los siglos. Para ellos un dato valioso es la fecha tan temprana del año de 1530, en la que los indígenas redactan frente a un escribano probar en primera instancia la

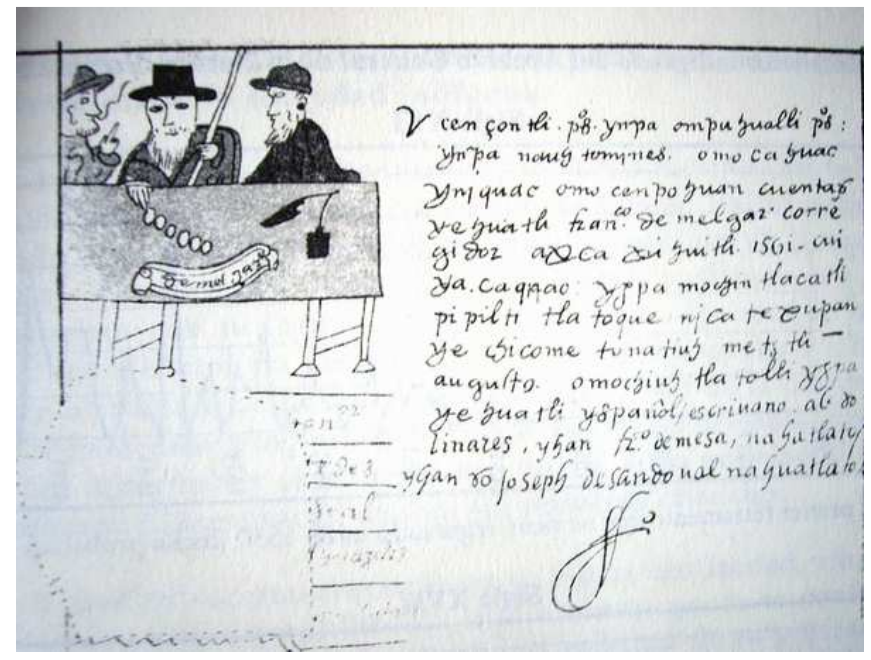

Fig. 15 Documento testamentario con imágenes indígenas y texto en castellano antiguo de 1561.

propiedad de casas y terrenos de manera individual 0 colectiva y con esto establecer la clara división entre ellos y los españoles como se observa en la figura 15.

En México, gracias a estudios recientes alrededor de los testamentos indígenas sabemos que algunas culturas prehispánicas, como la náhuatl dejaron documentos pictográficos de las disposiciones sobre los bienes de moribundos hechas en papel amate o sobre papel europeo y que casi todas fueron sacadas a la luz pública debido a problemas a sus sucesores o comunales de la región y que fueron aceptadas como instrumentos jurídicos en la impartición de justicia en los tribunales novohispanos.

\footnotetext{
${ }^{75}$ Dos estudios pueden ser destacados para tratar este asunto: Cline, S.L., y Miguel León Portilla (eds.) The testaments of Culhuacan. Los Ángeles University of California, 1984, (UCLA, Latin Americans Center Publications) y Antonio García Abasolo, La vida y la muerte en Indias. Cordobeses en América (siglos XVI- XVIII), Córdoba, Publicaciones del Monte de Piedad y Caja de Ahorros, 1982.
} 
Se conocen varios casos, como aquel donde se manifiesta pictográficamente la genealogía y plano de tierras, huerta y casas de la familia de Miguel Damián de Tepetenchi, Tlalnepeantla, Xochimilco del año de 1576 realizado en papel amate. (fig. 16) Otro es el plano pictográfico de casas, solar y chinampas de Tlachuquac, San Juan, ciudad de México del testamento de Madalena Tiacapan en 1564 (trasunto de 1567) y en él suponemos que la testamentaria reparte sus bienes para proteger a sus hijas Joana y María Papan y a sus respectivos maridos llamados Simón de Gante y Alonso Quahtli de la ambición de su marido un tal Antonio Tlaui que vive en otro lugar fuera del

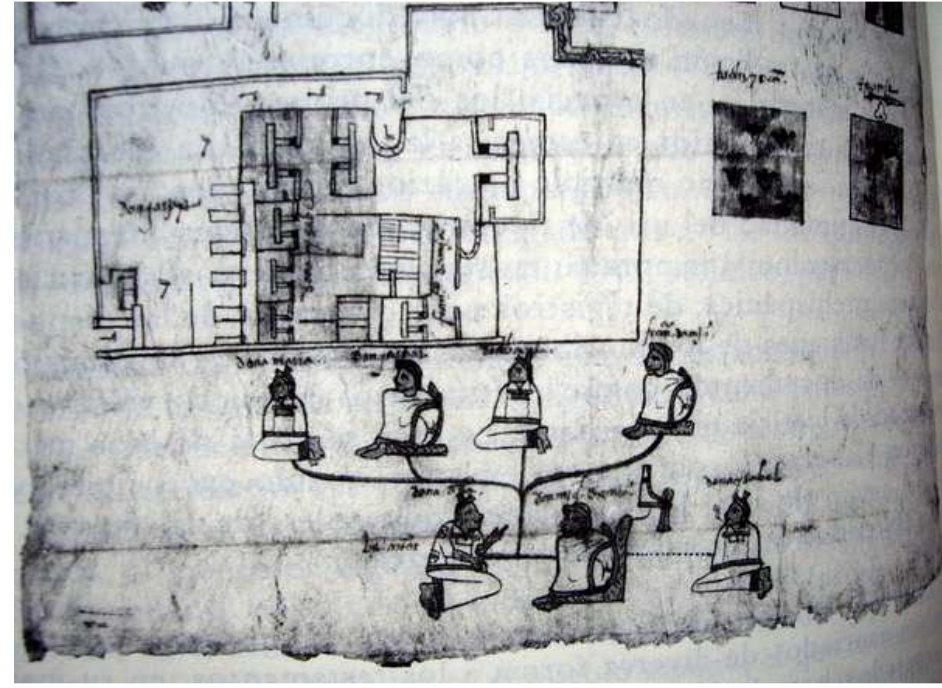

Fig. 16 Plano de tierras, huerta y casas Pertenecientes a Miguel Damián. hogar conyugal "porque en ningún tiempo no pretenda lo que dejo a mis hijas". Deja asimismo sus últimas disposiciones en caso de que falleciese que consisten en

que se compren dos pesos de candelas, otro peso para que se digan misas por su ánima así como declara y manda que una manta de pluma que me están acabando, que acabada que sea y pertenezca a mis nietos, hijos de Joana Tiacapan, e si viniere su padre no la pretenda [...], Madalena Tiacapan., ${ }^{76}$

La forma de la estructura jurídica de la cultura impuesta, funcionó en forma adecuada prosiguiendo con la forma de vida previa, permitiéndonos conocer la cantidad y la calidad de los bienes acumulados de manera particular; el pensamiento y la actuación de la Iglesia y el enfrentamiento ideológico con una religión completamente ajena a la propia. Una aproximación

\footnotetext{
${ }^{76}$ Teresa Rojas R. et. al., Vidas y bienes olvidados, op. cit,, pp. 116-119.
} 
al asunto de cómo se enfrentaron los primeros conversos al asunto de los testamentos son los Memoriales del padre Motolinía en el que menciona a Don Pablo, indígena de la ciudad de Quauhnavac (Cuernavaca) que pudo ser de los primeros indígenas en hacer testamento en una curiosa mezcla de culturas:

Y este Pablo perseverando en su buena cristiandad, vínose a confesar generalmente, que entonces pocos se confesaban, y él, bien confesado, luego enfermó de su postrera enfermedad, en la cual otras dos veces purificando su ánima con el sacramento de la penitencia, Hizo testamento, en que distribuyó a pobres algunas cosas de las que él poseía el cual testamento no se acostumbraba en esta tierra, sino que dejaban las casas y heredades a sus hijos, y el mayor, si era hombre, lo poseía, y tenía cuidado de sus hermanos y hermanas, como lo tenía el padre en su vida ${ }^{77}$

Entre las causas para la imposición-adopción del testamento en la población indígena se encontraban dos causas fundamentales: el aspecto ideológico por medio de la religión como ya hemos comentado, y la segunda el establecimiento de autoridades indígenas para controlar y reforzar el estado español en las tierras conquistadas por medio del cabildo. Se puede afirmar que la realización de testamentos fue un éxito -salvo casos excepcionalessobre todo después de las crisis agrícolas y las epidemias al que habremos de referirnos en otro apartado.

En el caso de la encomienda sucedía a menudo que los mismos encomenderos se apropiaran de las tierras indígenas que quedaban sin protección aumentando sus bienes y declarándose como poseedores de ellos. Con este fin el emperador Carlos V en 1546 prohibió a los encomenderos pudieran

...suceder en las tierras y heredamientos que huvieren quedado vacantes, por haver muerto los Indios de sus encomiendas sin herederos ó sucesores, y en ellas sucedan en los Pueblos donde fueren vezinos... ${ }^{78}$

Las probables guías para la redacción de los testamentos fueron el Formulario de actas extrajudiciales de la sublime arte de la Notaría de Micer Miguel del Molino y Suma de notas copiosas según el estilo y uso destos reinos

\footnotetext{
77 Ibid., p. 27.

78 Ibid., p.31.
} 
de Fernando Díaz de Valdepeñas y sobre todo el Confesionario Mayor en lengua mexicana y castellana de fray Alonso de Molina que fue divulgado entre los feligreses de la Colegiata de Guadalupe en 1565. Es este un ejemplar con grabados en madera e impreso en México en la casa de Antonio de Espinosa en 1569 conteniendo en la portada la crucifixión de Jesucristo. El folio 61 del Confesionario es interesante en cuanto a su contenido ya que se refiere a la cabeza o principio del testamento. El texto está dividido en dos partes: la izquierda escrito en náhuatl, a la derecha su versión al castellano y como refuerzo ilustrativo en la parte central de la hoja se encuentra un grabado en madera con la imagen celestial de Jesucristo cubierto con una capa y un lienzo en las piernas que porta un estandarte con la señal de la Santa Cruz, a su derecha un obispo como su representante en la tierra bendice el acto, mientras que una paloma (el Espíritu Santo) es testigo del sagrado momento.

En 1538, el emperador Carlos V había dispuesto una ordenanza para arzobispos y obispos sobre los lugares de entierro de los naturales de la Nueva España para que "vecinos y naturales se puedan enterrar libremente en iglesias o monasterios que quisieran y por bien tuvieren" En forma complementaria, la Corona instruyó en 1554 a los prelados para que pudiesen bendecir el camposanto donde reposaran indios, esclavos personas pobres y miserables que hubieran muerto lejos de las iglesias para poder darles cristiana sepultura.

En 1546, nuevamente el emperador Carlos $V$ dispuso una nueva ordenanza general de veinte puntos en relación de los asuntos de la muerte, en la que la número 18 es significativa sobre los entierros indígenas:

Que los indios cristianos que fallecieran sean enterrados en sagrado, y que los lleven en andas con la cruz delante y los que con él fueren vayan en procesión, rezando por su ánima y se procure, estando malos, que se confiesen, haciéndolo saber al religioso más cercano. ${ }^{79}$

Las disposiciones de la Iglesia eran muy rígidas en los asuntos de la muerte. Tan sólo el primer Concilio de 1554 dispuso que carecieran de eclesiástica sepultura los que no se confesaran por lo menos una vez al año y

${ }^{79}$ Ibid., pp. 54-55. 
los que no tuvieran el sacramento de la eucaristía en el tiempo que eran obligados. Los que si definitivamente se les negaba sepultura eran a los que se daban muerte por su propia mano (suicidas) a los infieles, a los excomulgados y a los censurados. María de los Ángeles Rodríguez en su investigación Usos y costumbres funerarios en la Nueva España ${ }^{80}$ encontró en el Archivo General de la Nación en el ramo correspondiente a "Inquisición" un proceso en 1557 contra Catalina García y el indio Domingo, del pueblo de Chiahuastepec, Oaxaca, por haber enterrado en el patio de la iglesia (atrio) a un indio que no era bautizado. Otro ejemplo sucedió en Ayotzingo donde se encontró de nombre José "colgado de un lazo [...] desesperadamente por si mismo"; además se sabía que este hombre no había cumplido con sus deberes religiosos, por ello el teniente de cura pregunta con urgencia al padre si debe ser enterrado en sagrado; se le contesta que "no se le dé sepultura eclesiástica a esta persona".

${ }^{80}$ María de los Ángeles Rodríguez, Usos y Costumbres funerarios en la Nueva España, El Colegio de Michoacán / El Colegio Mexiquense, México, 2001. 



\section{II \\ LA PRESENCIA DE LA MUERTE \\ EN EL GRABADO NOVOHISPANO}



Introducción

\section{La imagen estampada y el grabado}

1.1 El papel

1.2 La xilografía

1.3 Los tipos

1.4 El huecograbado

1.5 El papel novohispano

\section{La imprenta y la letra impresa}

2.1 Los impresos para el alma

2.2 Impresos e impresores

2.3 Los impresos y la muerte

\section{La muerte en el imaginario colectivo de la Colonia}

3.1 El Purgatorio en el imaginario colectivo

3.2 La muerte en el interior de la cofradías

3.3 El ser agónico y el sermón fúnebre

3.4 Los testamentos

3.5 Preparación del cuerpo y el ataúd

3.6 El velorio

3.7 Las campanas

3.8 Las exequias

3.9 La eternidad de la presencia espiritual

\section{La gráfica popular en el siglo XIX}

4.1 "La Portentosa vida de la Muerte"

4.2 Los cementerios

4.3 La congregación de los Hermanos de la Buena Muerte

4.4 La gráfica camiliana 



\section{Introducción}

El objeto de este segundo capítulo, es revisar la relación entre las imágenes religiosas y la producción de impresos populares del siglo XVI al siglo XIX.

Con la llegada de los españoles a las tierras mesoamericanas llegó la religión católica y el arte religioso europeo. Al grupo inicial de españoles creyentes, la evangelización se fue agregando a los indígenas conversos en cuyas conciencias poco a poco se había producido la implementación de la cosmovisión occidental del orden divino propuesta por el cristianismo, creciendo día con día la iglesia del mundo novohispano. Una vez establecido en los territorios conquistados en el aparato administrativo español, la vida social empezó a desarrollarse siguiendo el modelo peninsular. En el aspecto religioso, al clero regular de los primeros tiempos se fue añadiendo el clero secular, y la iglesia se organizó de tal manera que la religión católica se enseñaba con la palabra y se ilustraba con imágenes. A medida que la evangelización ganaba terreno, la demanda de las mismas iba en aumento, protegiendo a la población con una enorme variedad iconográfica, donde independiente de su valor artístico, las imágenes representan un valor histórico que consigna la prédica religiosa ya que por medio de su producción se manifiesta que no todo acaba con la muerte, sino que el alma es inmortal donde existe un Paraíso para una vida justa, y un infierno de tormento para los pecadores.

Más adelante, en el siglo XIX la muerte se tradujo en manifestaciones litográficas con evidencias visuales de las ceremonias luctuosas, los túmulos, los retratos mortuorios, las descripciones visuales de objetos ligados al comercio de la muerte como lo fueron las cajas de metal, las cajones de madera, la ropa de luto, los cirios, las lápidas, monumentos funerarios, los epitafios, y las esquelas. Es evidente pues, que la muerte adquiere características propias, donde existe una constante en el uso de las imágenes en el marco de la cultura popular.

Por otra parte, el marco temporal al que nos referiremos en este capítulo, será el que comprenden los siglos XVI al XIX, porque en este vasto 
periodo podemos notar un incremento en el número de impresos que hablan concretamente de la salvación y de otros temas afines. No es casual que en dichos siglos haya cobrado más fuerza la idea del Cielo y del Infierno.

En México, el grabado en madera y metal fueron introducidos desde los primeros tiempos de la Conquista y utilizados en libros e impresos con el carácter de adoctrinamiento religioso. La litografía en cambio, es traída por el artista italiano Claudio Linati en la segunda década del siglo XIX y permitió el nacimiento del periódico y la representación de la vida cotidiana, donde a su vez, la imagen y la palabra escrita se convirtieron en el medio más importante de expresión en el siglo XIX. Por otra parte, el grabado y con ello la ilustración de temas nacionales, se desarrollan comercialmente gracias a editores populares que difunden las noticias por narradores o cantadores de corridos en hojas de papel de vistosos colores lo que permitirá su adquisición por la población analfabeta a precios bajos. Un aspecto jocoso del 2 de noviembre de cada año, son las "calaveras" o pequeños textos en verso que son acompañados de grabados con el tema de la muerte y que se venían utilizando como válvula de escape social para las clases marginadas del porfiriato. La obra gráfica de Manuel Manilla y José Guadalupe Posada se encuentran ligadas a Vanegas Arroyo que supo la forma de hacer un producto vendible con hondas raíces mexicanas. De tal manera, que su producción permitió afrontar las competencias con otras casas editoras por varios años mediante un ingenioso mecanismo de distribución de sus productos en el interior de la república con piezas intercambiables del grabado, conservando las imágenes a las que solo se les agregaban los nuevos detalles de acuerdo a las necesidades del cliente y respondiendo a intereses comerciales. 


\section{La imagen estampada y el grabado}

\subsection{El papel}

Circunstancia afortunada en las artes gráficas fue el uso del papel como vehículo de difusión de las ideas. Sin papel no hay impresión, y sin impresión no existiría el libro y el grabado. Los orígenes del papel se remontan al antiguo Egipto cuando de las orillas del Nilo se sacaban los tiernos juncos (papyrus) que secados y mezclados con una especie de almidón se colocaban unos sobre otros sobre un tablero para secarlos y lograr obtener tiras o rollos de hasta 10 metros. (fig. 1) Elaborado desde el año 3000 antes de Cristo y usado durante 2, 500 años fue probablemente junto con el pergamino el material más usado hasta que fue desplazado por el papel. ${ }^{1}$ Debido a que su fabricación era cara, los textos escritos

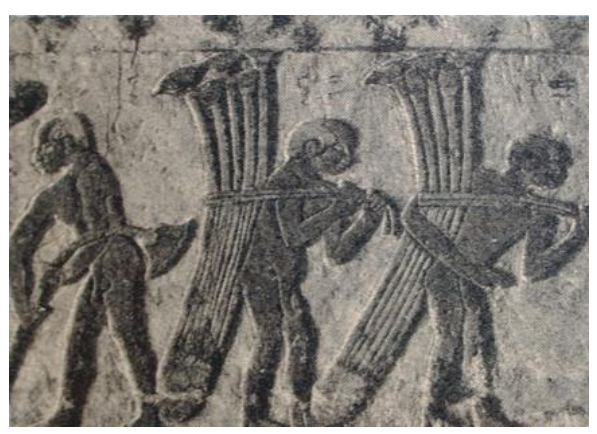

Fig. 1 Recolección del papiro bajorrelieve egipcio eran raspados y vueltos a utilizar conociéndose como palimpsesto (voz griega que significa borrado nuevamente) al manuscrito que todavía conserva huellas de otra escritura anterior en la misma superficie, pero borrada expresamente para dar lugar a la que ahora existe, esto se debió a la carencia de papel o pergamino sobre todo a partir del siglo VII. ${ }^{2}$

Se ha considerado que la fabricación del papel se debió a los chinos durante la dinastía Han (200 a C a 265 d. C) al mezclar materiales fibrosos con trapos molidos. ${ }^{3}$ Se sabe asimismo que era un secreto guardado celosamente bajo pena de muerte, hasta que unos prisioneros chinos, capturados en la batalla de Samarcanda que se encontraban en poder de los árabes, dieron a conocer la técnica a sus nuevos amos difundiéndose a través del contacto a partir del siglo $\mathrm{XII}$, con los grandes puertos europeos situándose la primer referencia a un molino papelero en Xativa (Valencia) hacia 1056 y de ahí a Italia 25 años más tarde. ${ }^{4}$

\footnotetext{
${ }^{1}$ El papel periódico en la comunicación social y la cultura, Secretaría de Gobernación, PIPSA, México 1988, p, 15.

${ }^{2}$ http://es.wikipedia.org/wiki/Palimpsesto

3 lbídem.

${ }^{4} \mathrm{http}: / / \mathrm{www}$.arqhys.com/articulos/acuarela-historia.html
} 
Para la fabricación del papel era necesario -como lo es hoy-grandes volúmenes de agua de la mejor calidad ${ }^{5}$ así como de enormes molinos ${ }^{6}$ que fuesen capaces de triturar trapos de algodón mejorando los procesos de engomado sustituyendo las colas vegetales, por colas animales; de acabados más lisos mediante el satinado de sus papeles; y haciendo posible la marca de cada fabricante en las delicadas filigranas del papel. El proceso técnico de la fabricación del papel no evolucionó mucho de los siglos XIV al XVIII, sin embargo es necesario clarificarlo para su entendimiento: Los trapos o cuerdas se recogían en las calles por gente especializada quien los separaba por colores, y grado de impureza para llevarlos al molino y proceder al

$\overline{\mathrm{X}}$ vetulis pannis tenuem contexo papyrum ${ }_{3}$ Papyrus E Vertiturin gyros dum mola feabra fuos, in's rons fis

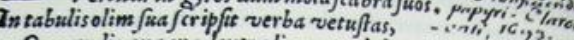
Quas rudis ex cara dextra liquente dabat.

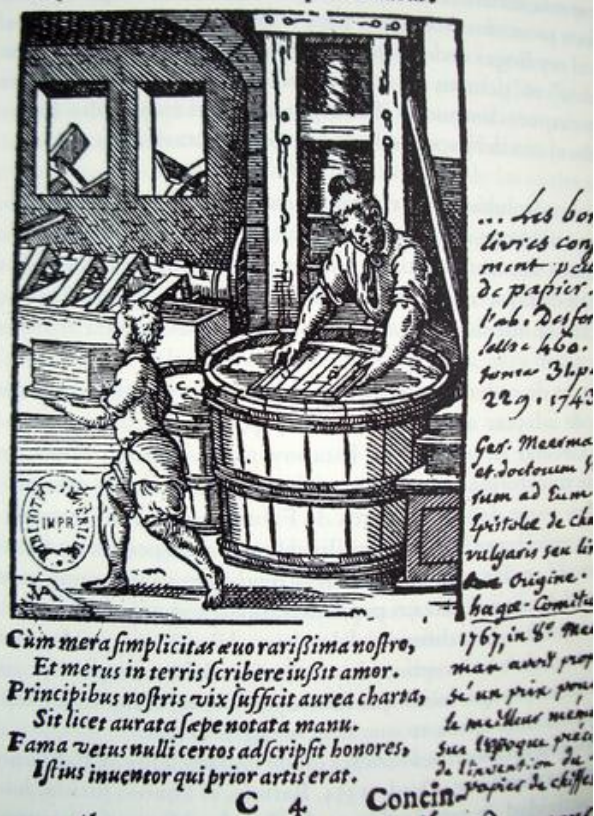

Fig. 2 Fabricación de papel en la Edad Media con notas manuscritas al costado de otro impresor

pudrimiento, es decir, se cortaban en pedazos y colocados en espacios subterráneos donde con ayuda del agua, eran puestos a fermentar y se les eliminaba la grasa, aislándose la celulosa. ${ }^{7}$ Una vez triturados los trapos, en esta forma de pasta de papel eran llevados a una cuba de agua caliente a cierta temperatura sumergiéndose un marco de madera con hilos que filtraban el agua y retenían la pasta. (fig. 2) Después de un breve periodo de secado, un obrero-artesano alzaba la forma sí obtenida y la ponía sobre un fieltro para absorber el agua para posteriormente prensarla numerosas veces. Se

\footnotetext{
${ }^{5}$ La cantidad de agua era aproximadamente de 1 kilo de papel por dos mil litros de agua.

${ }^{6}$ El uso de los molinos en la fabricación del papel, es un avance tecnológico ya que hubo de adaptar la función del molido de granos a la función de destazar trapos mediante clavos y cuchillas de la forma más eficiente.

${ }^{7}$ Ésta recolección de trapos viejos fue una actividad remunerativa durante siglos de tal manera que los mercaderes de trapos extendieron sus dominios fuera de los centros productores de papel llegando hasta las ferias comerciales donde no pocos hicieron verdaderas fortunas. Como la industria de la fabricación del papel involucró a demasiadas personas como surtidores de materias primas fue necesario solicitar al Estado el establecimiento del monopolio lo que motivó que muchas fábricas de papel fabricaran variantes de papel de mala calidad, pero más accesible al público consumidor.
} 
llevaban las hojas secas a un gran tendedero donde se satinaban y alisaban por medio de un pedernal hasta que finalmente se formaban en manos de 25 hojas y en ramas de veinte manos que se ofrecían al consumidor. ${ }^{8}$

A partir del tiempo, se fueron creando oficios propios que tenían que ver con la industria del papel como fabricantes de cartón, de naipes, candeleros, etc. Sin embargo, el principal cliente eran los impresores que necesitaban de volúmenes enormes para el funcionamiento de las pesadas prensas, de tal manera que en muchas ocasiones impresores y molineros de papel se encontraran asociados. Así como se ligaron a la industria editorial, los papeleros de fuerte apoyo económico se relacionaron con la confección del libro y con los fundidores de punzones y caracteres grabados, de tal manera que la venta de papel se condicionaba a la venta de libros ${ }^{9}$

Para dejar más claro este punto, se puede afirmar que la prosperidad del negocio del papel se encuentra unida a la del libro. De tal manera, que en el panorama geográfico europeo, la bonanza editorial está fuertemente ligada a la invención de la imprenta y a la conquista de occidente. ${ }^{10}$

\section{2 La xilografía}

Hemos visto a lo largo de este trabajo como el texto y la xilografía se han unido desde los primeros tiempos del invento de la imprenta en Europa. (fig. 3) Para este hecho concreto debieron de pasar múltiples etapas evolutivas en medios y técnicas que no pueden considerarse como hechos aislados producto de una cultura o de un taller en específico, sino, como un esfuerzo continuo de siglos de invenciones e innovaciones provenientes de lugares tan distantes que respondieron a necesidades de producción

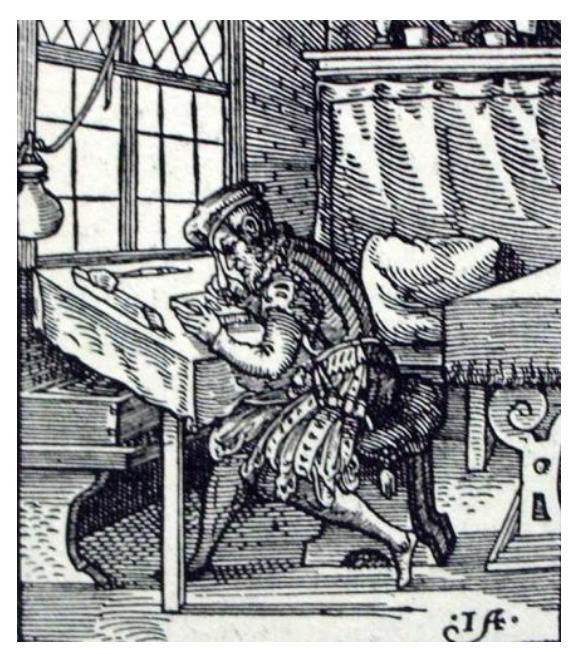

Fig. 3 Grabador xilógrafo

\footnotetext{
${ }^{8}$ Lucien Febvre/ Henri-Jean Martín La aparición del libro, FCE, CONACULTA; México 2002. Véase el capítulo "Las condiciones de desarrollo de los centros papeleros: condiciones naturales e industriales". p. 7.

${ }^{9}$ Ibidem, p. 16

${ }^{10}$ Existen todavía algunos de los más antiguos fabricantes de papel como Fabriano en Italia abierta en 1276, y Arches en Francia, abierta en 1492. http://es.wikipedia.org/wiki/Acuarela.
} 
básicamente y a lograr productos competitivos en el mercado del libro en el que el grabado y la estampa tuvieron un lugar destacado.

Las imágenes xilográficas primitivas como técnica reproductora de dibujos tienen un origen curioso. En un principio se ofrecían en las ferias populares como pinturas en miniatura que representaban escenas religiosas confeccionadas alrededor de escenas de la Pasión y de las vidas de santos encargadas por Iglesias y conventos convirtiéndose más tarde en productos de alta demanda, en las cuales no existía la menor intención de conseguir alternativas técnicas, si no más bien al contrario, el buscar un afán mercantilista sin pretensiones artísticas. Es decir, se trataba de reemplazar un acabado ilusorio por medio de la navaja y de la madera, de tal forma, que el consumidor al adquirirlo creyera que poseía un resultado similar. El carácter popular de estas xilografías encontró un camino adecuado para su desarrollo consumista en la Edad Media debido principalmente a dos factores diferentes y paradójicamente unidos: la evolución del libro, y el desarrollo de la ilustración en madera que aspiraba a convertir cada imagen grabada en una obra maestra basada en la producción en serie.

Importante es mencionar que si bien al principio la obra individual fue lenta, con la demanda de grabados en el mercado fue posible una respuesta rápida debido a una compleja división del trabajo producto de una creación colectiva en la que la que el artesano se especializaba en una sección del grabado y al final, el trabajo conjunto se coloreaba con acuarelas marcadas por el contorno negro de la imagen impresa. ${ }^{11}$ Es decir, los originales respondían a modelos tradicionales en los cuales se empleaban signos y símbolos reconocidos por todos y precisamente por esto populares.

La xilografía tuvo pues, que seguir un camino paralelo en el que el realismo representado suponía una diferenciación de los medios de representación pictóricos. Mientras la pintura se volcaba hacia las clases capaces de adquirirlo como producto a precios altos evolucionado en fondo y forma en el sentido de conveniencia del paisaje y el retrato; el grabado en madera tendió hacia lo espiritual, habiendo de conformarse con las limitaciones

\footnotetext{
${ }^{11}$ La acuarela tiene un origen antiguo y empezó con la invención del papel en China poco después de 100 a. C. http://es.wikipedia.org/wiki/Acuarela.
} 
de la técnica por una simplificación de la idea y de la finalidad práctica y comercial: el libro mismo. (fig. 4)

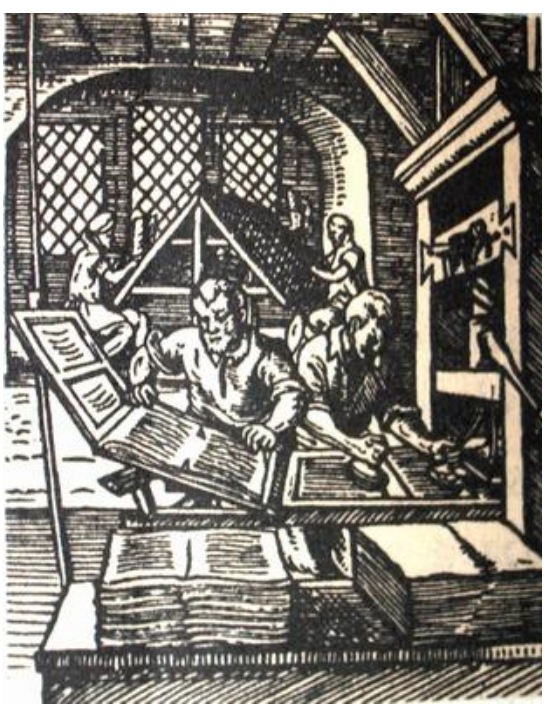

Fig. 4 Taller de imprenta

De hecho, el trabajo es a simple vista sencillo, pero encierra grandes complejidades desde el momento de pensar el dibujo a la inversa para ser impreso al derecho. Otro tanto, representa dejar los espacios negros que deben ser cuidadosamente cortados a navaja para proporcionar la trama de un volumen a una distancia prudente. Los blancos dejados podrán estar destinados para colorearse usando la línea negra como referencia visual suponiendo entonces que el artesano debe de trabajar con extraordinaria habilidad manual.

Asunto que merece ser acotado es la interpretación de los contenidos didácticos y simbolistas carácter nemotécnico cuya función era de apoyo al estudio de los Evangelios. En lugar de usar palabras se recurre a signos/ imágenes para enseñar y educar y con esto hacer más fácil el entendimiento sobre el comportamiento humano del bien y el mal. No se puede hablar de que esta idea sea aislada y un concepto aventurado, sino más bien responde a estructuras muy bien organizadas y planteadas desde tiempos antiguos. Westheim mencionaba que muchos de las ediciones de libros de estampas entre los que se contaban la Biblia pauperum, el Ars moriendi, el Speculum humanae salvattionis; el Canticum canticorum contenían estos códigos de signos- imágenes. Por ejemplo, el Ars memorativa publicado en 1475 en la imprenta de Antón Sorg, mencionaba la forma de descifrar esos signos:

[...] la liebre te recordará un hombre pusilánime, porque ella es también muy pusilánime. Viendo un lobo acuérdate de un hombre voraz, porque el lobo come mucho, y de un hombre casto y puro acuérdate al ver un cordero. Otros símbolos parecidos eran: la bodega, como símbolo del frío; una barca, de lo móvil, la paja de lo seco; el retrete del mal de olor; una máquina de reloj, de lo artificioso; las aves, del vuelo; una serpiente del arrastrarse; el orfebre de lo sutil; un manantial, de lo fresco, Y si es atinada la interpretación de San Ambrosio, los símbolos usados para designar a los evangelistas fueron exactamente lo mismo: el rostro humano significa 
discreción; la cabeza de león, valentía; el toro, moderación , y el águila, justicia.$^{12}$

Desde su aparición, el grabado en madera en el siglo $\mathrm{XIII}^{13}$ hizo su aparición toda una imaginería popular de carácter religiosa. Los primeros ejemplos, fueron sencillos, sin texto, que mostraron una curiosidad en el ser medieval: de un bloque de madera que podía ser impresa repetidas veces con ayuda de una capa de tinta repartida sobre su superficie, responde al contexto en el que la Iglesia tenía el papel principal e intelectual como formadora de conciencias humanas donde las imágenes contenidas como adornos en pinturas, muros y vitrales la hacían más atrayente y al mismo tiempo temerosa de una vida pecaminosa y de dolor. Con este fin, se cree que los primeros

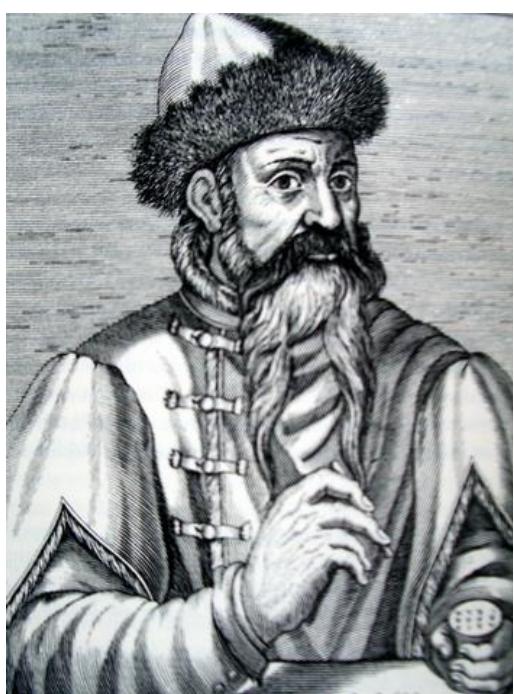

Fig. 5 .Johannes Gutemberg Grabado en cobre de Kupferstich von Theret 1584.

talleres se formaron cerca de los claustros, adquiriendo una enorme difusión las estampas de santos como las de la virgen de Bruselas (1423); de San Sebastián de Viena (1437); de San Roque para adornar las viviendas humildes y protectora de la peste; de San Cristóbal, patrono de viajeros que preservaba contra la muerte repentina, y Santa Apolonia de los dolores de muelas, entre otras, que llevaban indulgencias. ${ }^{14}$

Si bien existen ejemplos xilográficos antes de la aparición del libro, se conoce la figura de especialistas en metal como es el caso de Jean Gensfleisch (conocido por Gutemberg o Gutenberg) de la ciudad de Maguncia, quien tenía el oficio de orfebre y pudo fundir tipos metálicos después de muchos intentos para ser utilizados en la elaboración de páginas. ${ }^{15}$ (fig. 5) Si la ciudad de Valencia, fue como se ha escrito, el origen del papel en Europa; Maguncia en Alemania, fue pues, la cuna de la imprenta.

\footnotetext{
12 Paul Westheim, El Grabado en madera, FCE, México, 1954, pp. 75-77.

${ }^{13}$ El grabado xilográfico fue usado también en naipes impresos.

14 Lucien Febvre/ Henri-Jean Martín La aparición del libro, op. cit., p. 25.

${ }^{15}$ Los impresos hechos antes de 1480 , se conocen como incunables.
} 


\section{3 Los tipos}

El procedimiento de realización de los tipos metálicos era a base de fabricarlos con un punzón de metal en cuyo extremo se encontraba la letra o el signo a utilizar obtenido de una matriz para después proceder a fundirlo. Hubo talladores de tipos o modelos impuestos de excelente factura en sus diseños, de tal manera que en ocasiones esas características pasaron a ser conocidas, usadas y difundidas en pueblos y ciudades más grandes hasta conservarse en nuestros tiempos como la "cancilleresca", " itálica", "garamond", etc. Utilizados en un principio de latón, bronce, plomo, plata, hierro y antimonio, su fabricación en acero tardó mucho en descubrirse como el material más resistente. (fig. 6) Otro oficio relacionado con la imprenta fue el de tipógrafo, artesano componedor de matrices o fundidor de tipos que viajaba de ciudad en ciudad y de taller en taller arreglando caracteres en las imprentas.

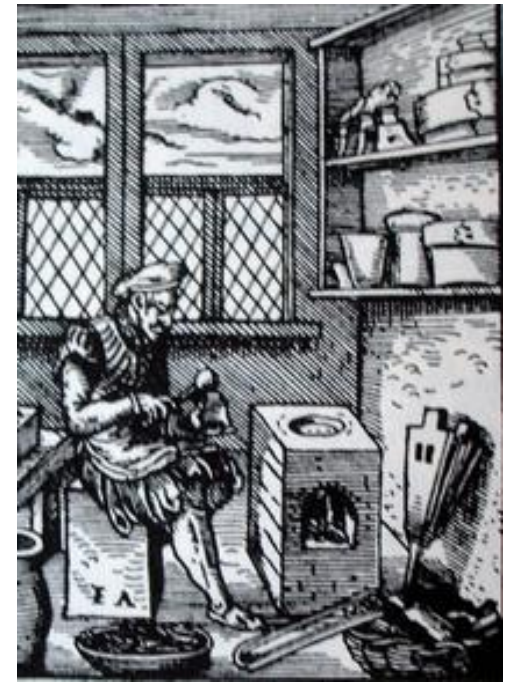

Fig. 6 Fundidor de tipos. Xilografía de Jost Amman, 1568 del tipo de letras que se iba a usar y su composición, esta labor le correspondía al cajista quien colocado de pie sobre una caja de madera de varias separaciones que contuviera las letras completas del alfabeto, incluyendo signos y puntuaciones los ubicaba sobre el componedor, tira donde se depositaba la línea de las letras depositándola el cajista en la galera quedando depositadas a su vez, entre dos interlíneas, para finalmente llevarlas a la forma donde se sujetaban con maderas atándose sólidamente con cordones para entintar sobre la página.

La estampa xilografía, es pues, como hemos visto anterior a la imprenta, y fue el impresor Albrecht Pfister el primero en utilizar la preciosa combinación de la imagen y el texto en una colección de fábulas: el Edelstein (piedra preciosa) de Ulrich Boner sólo con el fin de hacer más atractivo el libro y de explicar el significado del texto ${ }^{16}$. Esta costumbre se hizo popular en Alemania, pasando a otros lugares de Europa donde se desarrollaron estilos, y

\footnotetext{
${ }^{16}$ Lucien Febvre/ Henri-Jean Martín, op. cit., pp. 91- 98.
} 
modos de ver independientes formándose poco a poco ilustradores de magnífico talento ilustrando Biblias, tratados eclesiásticos, morales y piadosos, así como libros de horas, y literatura para el paso al más allá, aumentando el número de lectores, de compradores y de ejemplares, naciendo el libro ilustrado. Si bien es cierto, que la clase popular no era culta, el uso de las estampas gráficas sueltas aportó el interés por los impresos mejorando la imagen estampada por medio de otro procedimiento de más calidad: el grabado calcográfico o grabado en cobre ${ }^{17}$.

\section{4 El huecograbado}

En cuanto a los instrumentos y herramientas utilizados en el grabado, todo parece indicar que las gubias utilizadas para la escultura permitieron entresacar los blancos de la plancha para después construir gubias más finas de trazo más uniforme llamadas uñetas. Las herramientas para el buril surgieron en los talleres de orfebres y plateros debido que ésta era utilizada para detalles de las piezas moldeadas en los hornos. El burilista debía de utilizar la herramienta para perfilar los contornos que debía grabar sobre la pieza. El origen del aguafuerte proviene de los armeros que marcaban y adornaban sus armas y personalizarlas así en el campo de combate.

Durante mucho tiempo, los xilógrafos intentaron competir con los grabadores en cobre, tratando de imitar sus técnicas lineales de gran complejidad. (fig. 7) Es de admirar, sin embargo la calidad alcanzada por algunos talladores de

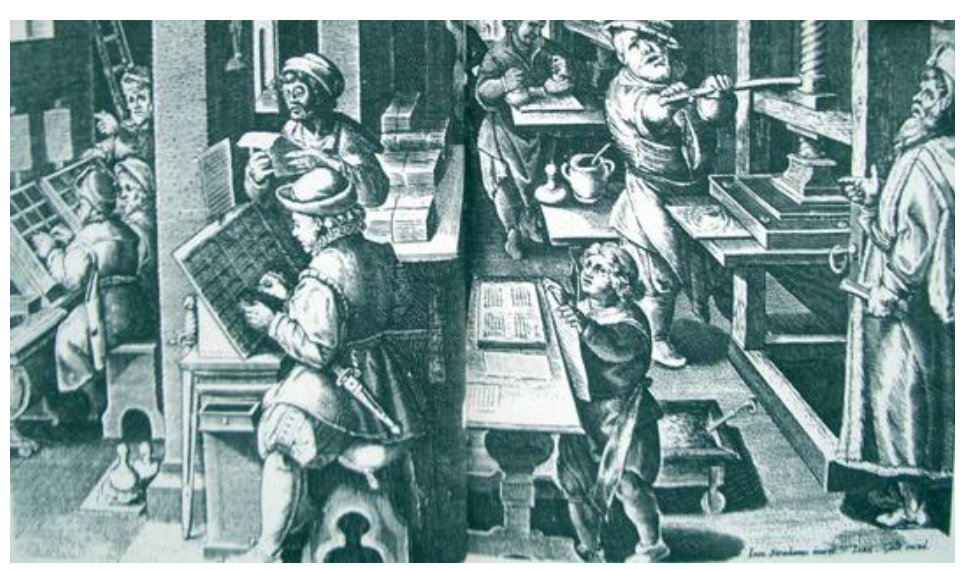

Fig. 7 Taller de xilografía y de imprenta Buril sobre metal

\footnotetext{
${ }^{17}$ Según estos autores, el primer libro ilustrado con este procedimiento es el Monte Santo de Dio de Antonio Bettini de Sierra con tres grabados en hueco.
} 
madera era asombrosa. Tan así que en algunos talleres de xilografía se garantizaba al cliente la fidelidad de su dibujo al trasladarse al taco de madera. El grabado en hueco o talla dulce se atribuye a Masso Finiguerra, florentino experto en niellatori siendo el nielo, una labor de esmalte negro hecho de plata y de plomo fundidos con azufre ${ }^{18}$. Con el fin de tener copia de sus calcos, se le ocurre a Finiguerra, entintar los huecos o surcos estampándolos sobre un papel humedecido con ayuda de una prensa. ${ }^{19}$

El grabado se incorpora al libro consiguiendo un mayor perfección técnica, con procedimientos y técnicas nuevas como el aguatinta, otorgándosele al grabado la categoría de libro de arte desarrollándose al mismo tiempo, una concepción nueva de producción y distribución de impresos mediante la organización de su gremio y la libertad de trabajo liberándolos de los editores pasando de Italia a Francia y Holanda principalmente.

A fines del siglo XVIII y comienzos del siglo XIX, se realizaron invenciones que influyeron de manera decisiva en la comunicación impresa: la invención del grabado a contralibra o madera de pie por el artista santiagués Jacobo Piedra (1722-1779) y popularizada años más tarde en Inglaterra por Thomas Bewick; en 1798 Robert inventa en Francia, una máquina para la fabricación papel de acabado satinado accionada por complejos sistemas hidráulicos; Koening, crea a partir de la necesidad de producción de un periódico en Londres, una prensa de impresión accionada por energía; y finalmente Senefelder en Alemania, inventa el procedimiento de la litografía a partir de la necesidad de transcribir más rápido las notas musicales al papel pautado. Veamos un poco más este último aspecto en palabras de Ivins:

\footnotetext{
${ }^{18}$ Los nielos son adornos realizados en metales preciosos introduciendo en los surcos abiertos a buril el "nielo" mezcla de plata, cobre, plomo, bórax y azufre, es decir una pasta de esmalte. En el siglo xv, existía en Alemania una relación muy estrecha entre grabadores y orfebres, ya que se grababa mucho sobre plata. El arte de grabar a partir de placas grabadas se originó en los talleres de orfebrería del sur de Alemania, entre 1430 y 1470, los grabadores fueron principalmente joyeros. Por ejemplo, Schongaüer o Albrecht Dürer -1471-1528-, hijo de un orfebre, que realizó numerosos diseños para joyas que están influidas por el estilo renacentista italiano Maria Teresa Jiménez Priego, Perfil del joyero en http://e-spacio.uned.es/fez/eserv.php?pid=bibliuned:ETFSerie7-2964BD8D-5335-BD0F-5236BD94AB66F086\&dsID=PDF

${ }_{19}$ Mariano Rubio Martínez, Ayer y hoy del grabado y sistemas de estampación, Editorial Tarraco, Barcelona, p. 21.
} 
[:::] La ventaja de la litografía estaba en que el dibujo del artista y el impreso eran prácticamente idénticos: no había necesidad de que otra mano retocara su dibujo, y menos aún había que copiarlo utilizando otro medio expresivo; podía hacerse de cualquier modo y el artista podía emplear a voluntad cualquier esquema lineal o no emplear ninguno. Permitía el uso de la gama más completa de tonos entre el negro y el blanco, y los reproducía con gran facilidad Una litografía podía ser tan laxa y abocetada como la "Carrera" de Manet, o tan elaborada como la "Hermana de Du Guesclin" de Delacroix; en otras palabras, con ella se podía hacer cualquier cosa, desde el más tosco de los bocetos a lápiz o tiza hasta algo sólo equiparable a los más detallados y trabajados óleos. Eliminaba totalmente la necesidad de ese traductor- intermediario que eran el grabador, con su inevitable gramática sistematizada, con su sintaxis de matrices lineales. Sin embargo, adolecía de una desventaja que compartía con los grabados en cobre: había que imprimirla con una prensa distinta a la usada para los textos, por lo que exigía dos impresiones separadas cuando se trataba de ilustraciones de libros. ${ }^{20}$

La imagen, permite la comprensión del texto por un lado, y por otro, la producción artística de grabados y estampas en libros y carteles. Aspectos que a su vez generan dos corrientes: la académica, compuesta por grabadores de reproducción que manejan el oficio de manera correcta; y la otra de creaciones libres de gran calidad en su dibujo.

\section{5 El papel novohispano}

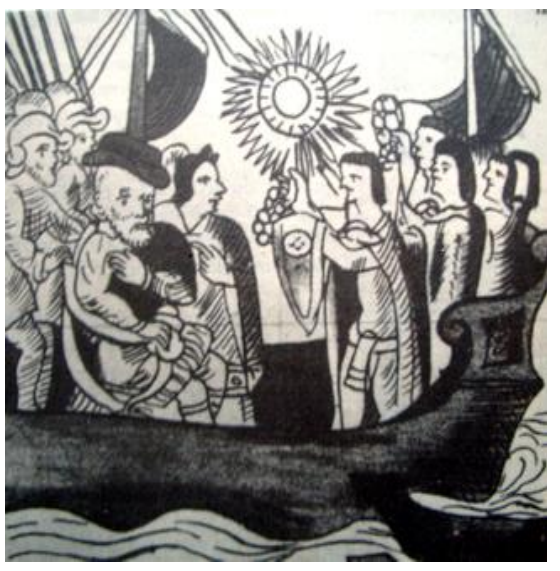

Fig. 8 Hernán Cortés en el Códice Florentino mantiene en sus rodillas un papel sobre el cual escribe
Hasta la llegada de los españoles, el libro y el impreso adquieren forma definitiva ya que con la conquista los europeos traían en su equipaje provisiones de papel con el fin de registrar en forma escrita lo que sus ojos veían. (fig 8) Este hecho se confirma por los documentos enviados por Cortés a Carlos V llamadas Cartas de Relación redactadas en un papel español de la clase llamada de marquilla en contraposición al llamado "papel de la tierra"

\footnotetext{
${ }^{20}$ W. M. Ivins, Imagen impresa y conocimiento, análisis de la imagen prefotográfica, Gustavo Gili, Barcelona, p. 157.
} 
como se nombraba al indígena. Debido a la extremada necesidad de tener papel entre 1532 y 1534, el rey dispuso para que Juan de Zumárraga estableciera una imprenta y molino de papel disponiendo que en México se le ayudara con una cantidad salida de las arcas reales. Por lo menos hasta 1538 , el futuro obispo no logró concretizar esta idea ya que escribió al respecto:

Poco se puede adelantar en lo de la imprenta por la carestía del papel, que esto dificulta las muchas obras que acá están aparejadas y de otras que habrán de nuevo darse a la estampa; pues que se carece de las más necesarias, y de allá son pocas las que vienen. ${ }^{21}$

Debieron de pasar muchos años, hasta el año de 1580 cuando fue posible la construcción en el pueblo de Culhuacan cercano a México "un molino y un batán en el que se haze papel, y procede de una fuente donde está

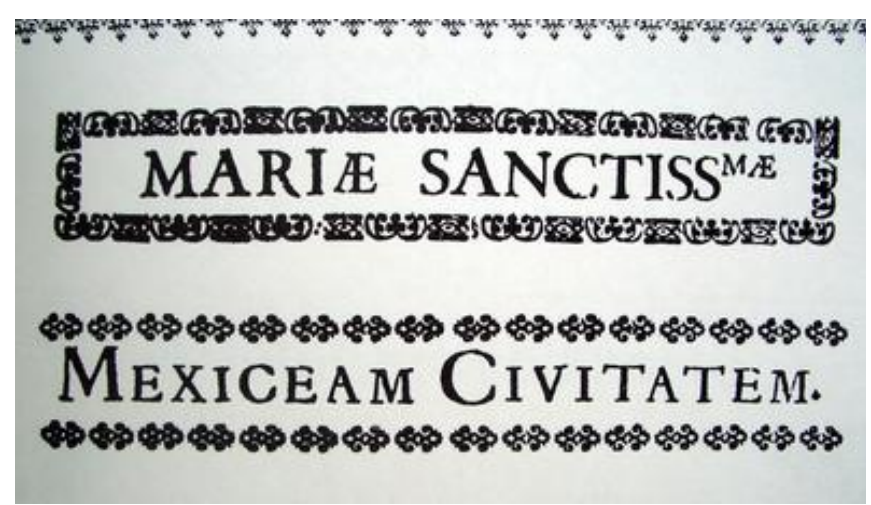

Fig. 9 Impresos mexicanos del siglo XVIII asentado". ${ }^{22}$ Este hecho indica que el papel allí fabricado se hacía de trapos, y era por tanto de la clase llamada de barba por la irregularidad de sus bordes. A este papel también se le llamaba catalán que siendo hecho pliego por pliego, sus bordes estaban llenos de partículas como dientes de sierra. Es posible también que si se utilizaran pencas de maguey o cortezas de amate, se tundieran en batán para obtener pulpa y fabricar papel. Según Luis Chávez Orozco, para finalizar el siglo XVI se habían editado cerca de 231 libros de 11 imprentas establecidas en la capital la mayoría de ellas dedicadas a la edición de libros y estampas con fines de catequización y devoción. (fig. 9)

Un dato interesante tomado del Compendio General de las contribuciones y gastos que ocasionan todos los efectos, editado en Cádiz, es que para 1762, el papel utilizado para la industria editorial así como los

\footnotetext{
${ }^{21}$ El papel periódico, op. cit., p. 30.

${ }^{22}$ Ibid.
} 
impresos surgidos de la creatividad de los grabadores mexicanos era compuesto de papel común de colores en resmas sueltas, papel común suelto o en balones, papel de marquilla (con filigrana), papel de marca mayor (tamaño folio máximo) y papel flote de Génova. Un papel que llegaba en grandes cantidades, que no pagaba fletes, ni contribución alguna por ser monopolio del Estado era el papel sellado, indispensable en todos los asuntos oficiales y legales y que constituía un verdadero impuesto establecido por cédula real de 1638 por Felipe IV con la indicación de que “....ordenamos y mandamos... no se pueda hazer, ni escribir escritura, ni instrumento público, ni en otros despachos si no fueren en papel sellado". ${ }^{23}$

La industria ligada al papel consumía grandes cantidades y se ha documentado históricamente que navíos fletados únicamente con cargas de papel arribaban al Puerto de Veracruz en forma constante, lo que es indicativo de la dependencia que en este sentido se tenía de España, y de los impresos y estampas religiosas provenientes en especial de Roma como veremos en un capítulo destinado para ello.

Para fechas inmediatas a la Independencia nacional, los negocios con relación a la imprenta y al grabado decayeron debido a causas políticas y económicas y a la crisis con España. Coincidió que con la llegada de la litografía en México se empezó a generar una forma de comunicación diferente entre el consumidor y un medio gráfico permitiendo que la rapidez de impresión fuese a su vez el desarrollo y la expansión de la ideas de una manera más eficaz donde el texto se acompañaba de la imagen en un procedimiento que hizo florecer el mercado editorial, solamente superado por el invento de la fotografía (1826) que permitirá a su vez el desarrollo de la tecnología en forma de fotograbado pero eso es un asunto fuera de este contexto.

Estamos de acuerdo con las palabras de Ivins quien resume de esta manera la relación entre el grabado y la estampa en el siglo XIX como medio de comunicación:

Con el siglo XIX entramos en una época en que puede decirse que la imagen impresa ha alcanzado la mayoría de edad. No sólo empleó todos

${ }^{23}$ Ibidem, pp. 32-33. 
los procedimientos antiguos sino que inventó más técnicas nuevas que todas las conocidas en la historia precedente.

Muy probablemente el número de imágenes impresas entre 1800 y 1901 fue considerablemente superior al número total de imágenes impresas antes de 1801. Estaban destinadas a todas las clases sociales y perseguían todos los fines imaginables. A finales de siglo, la manifestación gráfica exactamente repetible se había convertido en algo corriente tanto en los libros como en las revistas y periódicos. ${ }^{24}$

2 La imprenta y la letra impresa

El primer libro llegado al Nuevo Mundo, según Bernal Díaz del Castillo, fue el que trajeron de Europa Juan Guerrero y Jerónimo de Aguilar en 1519, soldados náufragos y supervivientes de Santo Domingo quienes arribaron a la península de Yucatán donde permanecieron conviviendo con los nativos de la zona, hasta convertirse en personajes de altísimo nivel hasta la llegada de Cortés. Bernal Díaz se refiere a su aspecto con estas palabras:

De suyo era moreno e tresquilado a manera de indio esclavo, e traía un remo al hombro e una $\operatorname{cotara}^{25}$ vieja calzada y la otra en la cinta, e una manta vieja muy ruin e un braguero peor, con que cubría sus vergüenzas, e traía atado en la manta un bulto, que eran Horas muy viejas. ${ }^{26}$

A partir de aquí transitaron a las Indias, libros religiosos, también de materias profanas y fabulosas, a los que eran aficionados los lectores españoles; tal por eso vez, la Corona prohibió repetidamente a partir de 1531, que se les llevaran a las Indias porque distraían a los indios de las tareas de evangelización.

Existían cuatro maneras de hacer llegar libros a la Nueva España: en las valijas de los viajeros, para su uso personal; otra en calidad de pedido para comerciar con ellas como hacían Diego Mexía vendedor de Sevilla con Alonso de Losa, Juan Treviño o Pedro Balli en la Nueva España. ${ }^{27}$ Otra forma era

\footnotetext{
24 Ivins, op. cit., p. 135

${ }^{25}$ Coraza defensiva para el cuerpo.

${ }^{26}$ Bernal Díaz del Castillo, Historia verdadera de la conquista de la Nueva España, introducción y notas de Joaquín Ramírez Cabañas, Editorial Porrúa, col. "sepan cuantos", número 5, México 2004, cap. XXIX.

${ }^{27}$ Citado por Juana Zahar Vergara, Historia de las librerías de la Ciudad de México, una evocación. Centro Universitario de Investigaciones Bibliotecológicas, UNAM, México, pp. 4-5.
} 
venderlos directamente, a vender sus mercancías a la metrópoli; y la última la que funcionaba "sobre pedido" como Juan Fajardo quien buscaba en España los títulos que previamente le encargaban.

Los fenómenos de la conquista y la dominación europea, unidas a la integración con las culturas indígenas nativas de gran inventiva y creatividad, crearon nuevos códigos visuales con base en la introducción de la imprenta y con ella la posibilidad de imprimir libros. En el aspecto a las costumbres funerarias éstas se adoptaron desde recién concluida la Conquista, mezclándose aspectos de las dos culturas. Así López de Gómara, capellán de Cortés, relata que "[...] de las hojas deste metl (maguey) hacen papel que corre por todas partes para sacrificios y pintores [...]"28

Ya existían por supuesto en Europa abundancia de títulos y de géneros: de caballería (Amadís de Gaula, o la Sergas de Esplandía 1510); de viajes como el libro de Marco Polo (De consetuidinibus et conditionibus orientalium regionum 1485) y de reflexión espiritual como los Libros de Horas, o alguna edición de la misma Biblia (1456).

Al mismo tiempo de estas prohibiciones el emperador concedió en 1525 a la casa de los impresores alemanes de Jacobo Cromberger establecidos en Sevilla permiso para el establecimiento de casas de impresión. Un familiar de Jacobo, llamado Juan Cromberger firmó contrato el 12 de julio de 1539 con el cajista oficial Giovanni Paoli (Juan Pablos) para que instalase un taller de imprenta en la capital de la Nueva España. ${ }^{29}$

El comercio de libros de Sevilla a América duró por lo menos hasta 1717 debido al traslado de la Casa de Contratación a Cádiz. Estableciéndose de manera eficaz, el comercio en obras de arte y de religión que fue en este rubro bastante pródigo: libros de literatura y arte, libros corales, partituras, cancioneros eclesiales, Biblias, sermonarios, y vidas de santos "[...] cuyos grabados o contenido temático fueron la principal fuente de inspiración de los

\footnotetext{
${ }^{28}$ Menciona antes en la página 308, que "Beben el licor que destila un árbol llamado metl, a cocido con ocpatli, que es una raíz a quien, por su bondad, llaman medicina del vivo. Poco es saludable, mucho es dañoso y emborracha gentilmente...". Francisco López de Gómara, Historia de la conquista de México, estudio preliminar de Juan Miralles Ostos, Editorial Porrúa, tercera edición, col. "sepan cuantos", número 566, México, 199, p. 332,

${ }^{29}$ Juana Zahar Vergara, op. cit.
} 
artistas, al igual que las estampas romanas, con preferencia de las devociones sobre las didácticas o apaisadas [...]"30

Los cargamentos se llenaban en la Nao de retablos, de pinturas en lienzo y tablas de personajes históricos o de escenas campiranas junto con medallas de estaño, reliquias, relicarios, tapices, instrumentos musicales o vidrios de Venecia, y se ofrecían al mejor postor, creándose una transacción comercial a través de la consignación, creándose al mismo tiempo fortunas enormes y de reclamaciones judiciales en ambos lados del Atlántico debido a los peligros que encerraba el mar. Irving Leonard ${ }^{31}$ reseña una carta fechada en la Ciudad de México en 1581, donde menciona que los libros viajaban en barcos encerrados en barriles de vino y toneles de fruta seca y así clandestinos pasaban las revisiones en las aduanas. El control del cargamento era llevado a cabo por comisarios dependientes del Tribunal del Santo Oficio ubicados en los puertos, quienes veían y examinaban la literatura que se quisiera introducir a la Nueva España ejerciendo un riguroso control de 16 reglas sobre los llamados "libros herejes" referentes a la iglesia luterana, o calvinista; de supersticiones; magia; suertes adivinatorias; astrología; o ediciones no autorizadas de la Biblia.

La prohibición se extendía a la entrada y al uso de los libros en los reinos españoles, es decir, venta, producción, posesión y lectura. Para detectar dicha literatura se realizaban estudios que determinaban las categorías de libros totalmente prohibidos, de libros expurgados 0 anotados. Lo anterior se concentraba en un Índice y catálogo de libros prohibidos y expurgados que iba acumulando las obras de reciente cuño que tenían estas características. ${ }^{32}$

A los poseedores de libros censurados se les aplicaba, desde luego, la sanción de la excomunión mayor: ipso facto latae sententiae, trina canonica monitione praemissa.

\footnotetext{
${ }^{30}$ En efecto, basta observar el cuadro de mercancías religiosas que se presenta en el corpus del texto para conocer el origen de la estampería distribuida en la Nueva España lo cual implica que debió de existir una gran diversidad de talleres gráficos en la ciudad de Roma, es decir, la diversificación de manufacturas litúrgicas para surtir no solo el mercado novohispano, sino el de todo el Nuevo Mundo. Véase a Mina Ramírez Montes, Arte en tránsito a la Nueva España durante el siglo XVI, en Anales del Instituto de Investigaciones Estéticas, número 60, UNAM; Número 60, 1989, p. 205.

${ }^{31}$ Citado por Teresa Eleazar Serrano y Jorge A. Talavera en La obra de imprenta y la Inquisición en la Nueva España: Los libros prohibidos, Inquisición Novohispana, volumen II, UNAM/ UAM, p. 395.

32 Ramón Aguilera Murguía y Xóchitl Martínez, Libros, Inquisición y Devoción, en Inquisición Novohispana, volumen II, UNAM/ UAM/ México, $1^{\text {a }}$ edición, 2000, p. 364.
} 
Un interesante documento de Mina Ramírez ${ }^{33}$ muestra el tránsito de mercancías en la Nueva España que como se puede observan en la siguiente tabla se tenía mucha demanda por parte de los consumidores y que para efectos del tema, se exponen sólo los productos ligados al grabado y la estampa que nos permite conocer el origen, la cantidad y el precio de la mercancía en ese entonces. Seguida a ésta, se presenta una comparación a otros productos que se ofertaban en la época como son los instrumentos musicales y lienzos pintados:

\begin{tabular}{|c|c|c|c|c|}
\hline Obra & Cantidad & Procedencia & Precio & Fecha \\
\hline Estampas & 2950 & Venecia & $\begin{array}{r}30 \\
\text { reales } \mathrm{c} / \mathrm{u}\end{array}$ & $1590 / 07 / 07$ \\
\hline $\begin{array}{l}\text { Estampas de la } \\
\text { Sagrada } \\
\text { Escritura }\end{array}$ & $\begin{array}{r}32 \\
\text { docenas }\end{array}$ & Roma & $\begin{array}{c}18 \\
\text { reales docena }\end{array}$ & $1586 / 06 / 27$ \\
\hline $\begin{array}{l}\text { Imágenes de } \\
\text { pliego }\end{array}$ & 168 & Roma & $\begin{array}{c}2 \\
\text { reales docena }\end{array}$ & $1584 / 05 / 24$ \\
\hline $\begin{array}{l}\text { Imágenes de } \\
\text { devoción } \\
\text { comunes }\end{array}$ & $\begin{array}{r}2 \\
\text { gruesas }\end{array}$ & Roma & $\begin{array}{c}7 \\
\text { reales gruesa }\end{array}$ & $1586 / 06 / 25$ \\
\hline $\begin{array}{l}\text { Imágenes de } \\
\text { devoción finas }\end{array}$ & $\begin{array}{r}13 \\
\text { docenas }\end{array}$ & Roma & $\begin{array}{l}\text { 6, } 188 \\
\text { maravedís }\end{array}$ & $1586 / 06 / 25$ \\
\hline Imágenes de papel & $\begin{array}{r}2 \\
\text { gruesas }\end{array}$ & Venecia & $\begin{array}{c}8 \\
\text { reales gruesa }\end{array}$ & $1584 / 05 / 24$ \\
\hline $\begin{array}{l}\text { Libro de devoción } \\
\text { en estampa }\end{array}$ & 144 & Venecia & $\begin{array}{c}6 \\
\text { reales docena }\end{array}$ & $1590 / 07 / 14$ \\
\hline
\end{tabular}

33 Mina Ramírez Montes, Arte en tránsito a la Nueva España durante el siglo XVI, Anales del Instituto de Investigaciones Estéticas, número 60, 1989, pp. 207-209. 


\begin{tabular}{|c|r|r|r|r|}
\hline Obra & Cantidad & Procedencia & Precio & Fecha \\
\hline Monocordio & 1 & Flandes & $\begin{array}{r}3 \\
\text { ducados }\end{array}$ & $1586 / 06 / 21$ \\
\hline Lienzos pintados & 34 & Francia & $\begin{array}{c}374 \\
\text { maravedis } \\
\text { c/u }\end{array}$ & $1590 / 07 / 06$ \\
& & & & \\
& & & & \\
\hline
\end{tabular}

Este manejo extraordinario de volúmenes de libros y de imágenes religiosos demuestra que debieron de haber sido muy solicitados como ayuda espiritual en la sociedad novohispana y además de que es posible que sus compradores, lejos de Europa, y de familiares cercanos aventurándose en tierras extrañas se aferraran a la lectura de textos bíblicos. Otros, se refugiaron en la riqueza de las imágenes. Más grave, fue la situación de aquellos que por alguna circunstancia tuvieron que ver con el Tribunal del Santo Oficio.

Conocemos por los documentos históricos, que en el aspecto cotidiano se acostumbraba llevar consigo alguna imagen religiosa para la protección diaria. De tal manera que aquellos que fueron apresados llevaban algo de valor como dinero o joyas, ropa, y pequeños enseres que se les confiscaba y se anotaba en un expediente. Algunos de esos bienes consistían en navajas, rosarios, hebillas, tijeras, imágenes y láminas de santos, libros, oraciones y sermones, entre otras cosas.

La impresión de oraciones y novenas estuvo controlada por la Iglesia, como autoridad máxima quien nombraba a autoridades eclesiásticas o visitadores que indicaban en que taller se realizaba la impresión en cuestión, el tipo de oración, a quien iba dedicada y el responsable de la edición.

Estas oraciones estaban compuestas en verso o en prosa rogando o suplicando al santo dedicado o a Dios, y siguiendo la costumbre llevaba indicado el número de repeticiones de cada oración para alcanzar el perdón de los pecados y la salvación de una o varias almas que se encontraban en el Purgatorio. 


\section{1 Los impresos para el alma}

Hans Lenz ${ }^{34}$ en su investigación sobre la historia del papel en México, comenta que el primer libro impreso en nuestro país fue la "Escala Espiritual" de San Juan Clímaco traducida por Juan de Estrada siendo "Esteban Martín el imprimador", dato del que no hay manera de comprobarse. En cambio, en ese mismo año de 1539 se imprimiría en el taller de Juan Pablos la "Breve y más compendiosa doctrina cristiana en lengua mexicana y castellana", y este si efectivamente es el libro más antiguo que se puede comprobar. ${ }^{35}$ Debido a que la impresión de libros era previamente autorizada por las autoridades españolas, la producción editorial de los casi 179 impresos en los primeros tiempos de la dominación española se consagran casi exclusivamente a catecismos, confesionarios, doctrinas, cartillas, diccionarios y gramáticas de las lenguas indígenas y algunos pocos de corte

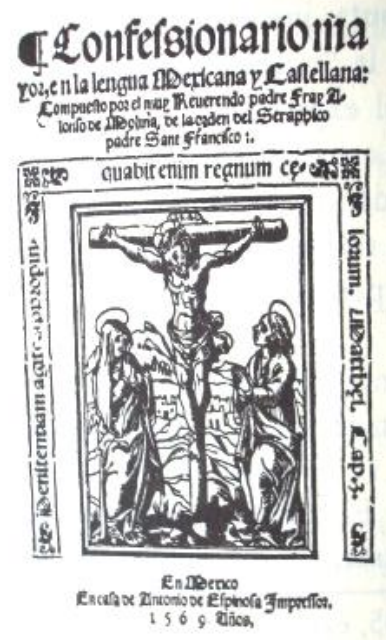

Fig. 10 Confesionario de la lengua mexicana y castellana, 1569 . histórico. (fig. 10) De esos primeros inicios, el grabado se presenta mediante diversas formas: frontis, estampas religiosas, retratos, escudos de armas, planos y visitas, funerales, alegorías y naipes realizados en madera en principio $y$ de manera posterior en planchas de plomo y cobre.

La bibliografía impresa novohispana es abundante y tiene características eminentemente religiosas con sus títulos y contenidos adaptados o reproducidos del Viejo Mundo. Otro libro reconocido es la Doctrina Cristiana para instrucción e información de los indios por manera de historia de fray Pedro de Córdova e impresa por Juan Cromberger el año de $1544 .{ }^{36}$

\footnotetext{
${ }^{34}$ Hans Lenz, Historia del papel en México y cosas relacionadas: 1525-1950, 2a , edición 2001, Miguel Ángel Porrúa, CRUCP, p. 39.

35 José Luis Martínez, Origen y desarrollo del libro en Hispanoamérica, La Gaceta del Fondo de Cultura Económica, número 225, septiembre de 1989, pp. 31- 33.

${ }^{36}$ Ernesto de la Torre Villar, Breve historia del libro en México, UNAM, 1990, pp. 48-49.
} 
Afín al tema, encontramos algunas obras que son interesantes: El

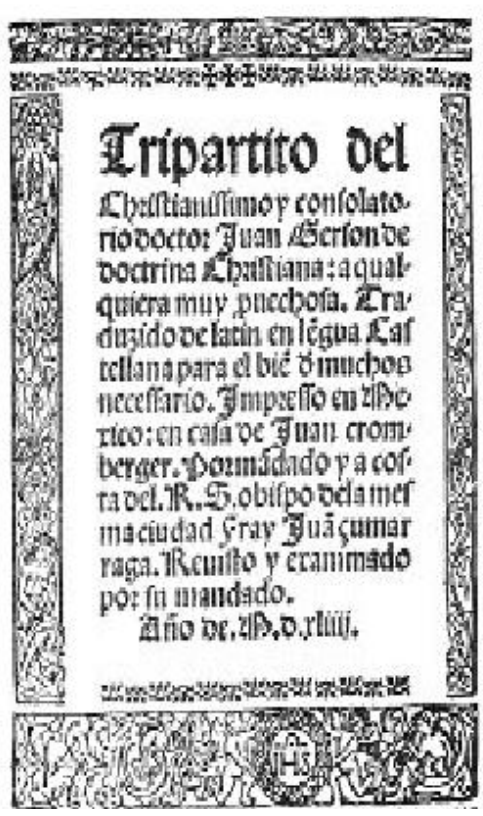

Fig. 11 Tripartito. De Juan Gerson. 1544.

Manual de Adultos, impreso dispuesto por el presbítero Pedro de Logroño copiado de un libro romano sobre la manera de administrar los sacramentos y el Tripartito del Cristianísimo y consolatorio doctor Juan Gerson de doctrina Cristiana de 1544 sobre una versión aparecida en Toledo en $1526^{37}$ (fig. 11) y que Ernesto de la Torre Villar en su capítulo sobre el origen de la imprenta en México, es el primero en ostentar un grabado impreso en la Nueva España "[...] que representa a la Virgen rodeada de ángeles haciendo entrega de la casulla a San Ildefonso". ${ }^{38}$ La carátula de esta joya de la imprenta menciona en letra gótica que fue impreso en México por Juan Cromberger "[...] por mandato y a costa del R. S. Obispo de la misma ciudad Fray Juan de Zumárraga".

Asimismo, De la Torre, menciona el que lleva por largo título la Regla Cristiana breve para ordenar la vida y tiempo del cristiano que se quiere salvar y tener su alma despierta para que Jesucristo more en ella, mencionando que en el colofón que es "...la doctrina de los proficientes que trata de la regla y vida cristiana, con la forma de la oración mental y aparejo de bien morir".

Indudablemente en estos asuntos de la salvación del alma del siglo XVI en la Nueva España es necesario mencionar la Rhetorica Cristiana, de fray Diego Valadés, impreso en 1579. Concebido como "el arte de descubrir tratar y disponer todo aquello que pertenece a la salud de las almas", la Rethorica, aborda en sus seis partes problemas de evangelización indígena americana a partir de una cuidadosa observación de la gente y sus costumbres, por supuesto asumiéndose con la mentalidad conquistadora de la espiritualidad ajena.

\footnotetext{
${ }^{37}$ Ibidem p. 50

${ }^{38}$ Ibidem.
} 
"Por consiguiente, por autoridad divina - escribe fray Diego-, venimos a vosotros a fin de ilustrar vuestra inteligencia con los rayos de la divina luz y libertad vuestros espíritus y cuerpos de la pesadísima sujeción que los oprime. Porque si bien la esclavitud de los hombres es insufrible, mas intolerable es todavía es que el diablo, enemigo del género humano, os tiene atados y sujetos."

Un aporte interesante en la Rethorica (fig. 12) son los veintiséis grabados en cobre del autor (por lo menos firma ocho de ellos) que fueron hechos con una

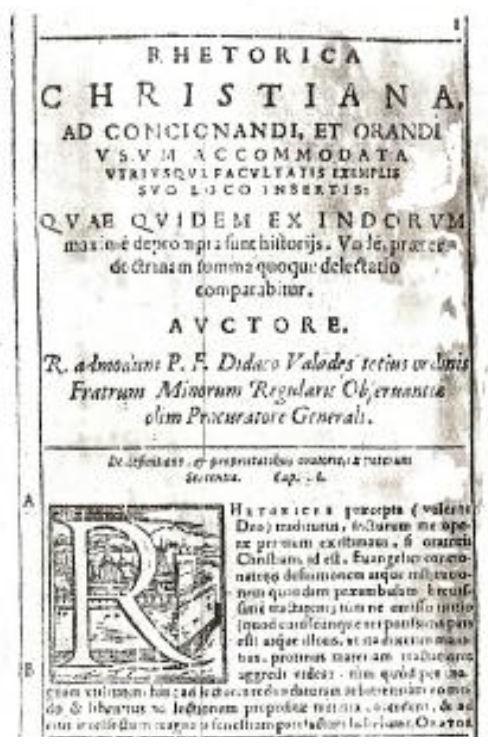

Fig. 12 Rhetórica Chistiana. 1579 mezcla de trazo renacentista y de sentimiento indígena, y que, según el mismo explica:

[...] porque no conocen las letras, ni se dedican a la lectura, por lo menos que añadimos algunos grabados, tanto para facilitar la memoria como para que mejor y más claramente se entiendan los ritos y costumbres de los indios [... $]^{40}$

Los títulos dicen todo en cuanto a su contenido: El filósofo pagano, El filósofo cristiano, Las siete artes liberales, El pontífice hebreo, la dignidad pontificia, etc. Tal vez, los más interesantes sean a partir donde presenta el mundo indígena en una visión prehispánica falsa de la realidad mexicana, en el que por ejemplo, el dios Huitzilopochtli, aparece como un dios romano, o los indios vestidos con ropajes clásicos. En la contradictoria obra de fray Diego Valadés, encontramos que aunque presenta una imagen equivocada del Nuevo Mundo ha tenido la gracia de mostrar y de incluir a los indios americanos dentro de la recreación y pasión cristiana. Por eso resulta curiosa esa imagen del pecador del Nuevo Mundo cubierto de plumas y tocados extraños que tiene la oportunidad de alcanzar la gracia celestial guiados por la figura del ángel como se observa en la fig. $13^{41}$

\footnotetext{
${ }^{39}$ Francisco de la Maza, Obras Escogidas, IIE. UNAM, 1992, Fray Diego Valadés escritor y grabador franciscano del siglo XVI, p.116.

40 Ibidem, 119.

41 Menciono contradictorio, porque el pequeño estudio de Francisco de la Maza indica que el fraile Valadés conocía los dos aspectos de la conquista de México: era español por parte de padre; e indígena, por parte de madre, es decir, mestizo.
} 
Es necesario recordar que numerosas pinturas, estampas y grabados saltaron del papel a los muros conventuales novohispanos como manera didáctica de evangelización. Veamos este asunto con más claridad. ${ }^{42}$

Entre las primeras vinculaciones de la muerte y el grabado que se realizaron en

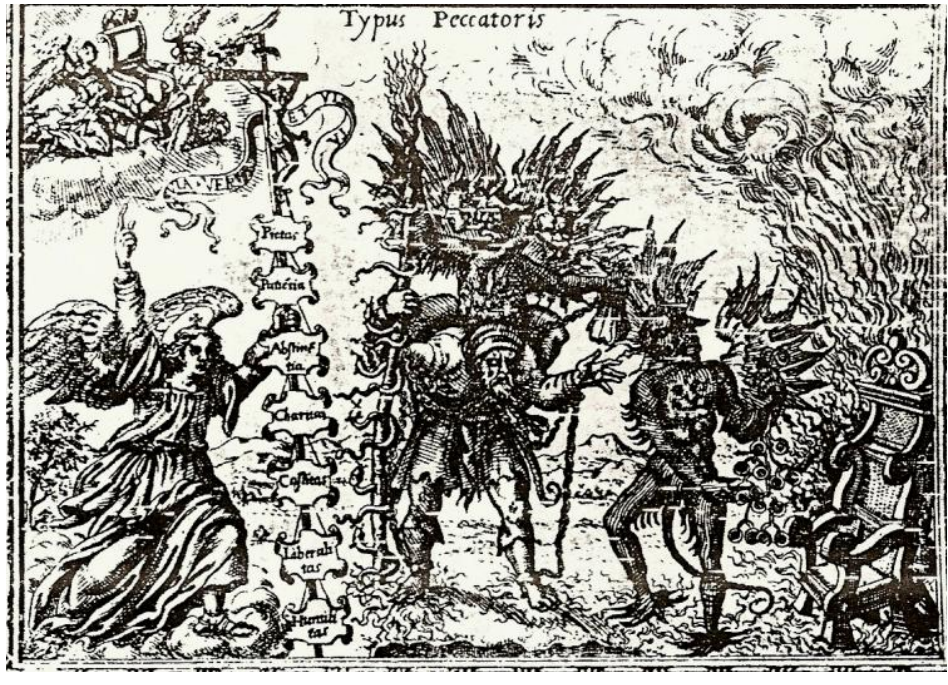

Fig. 13 Imagen del pecador, Fray Diego Valadés. Siglo XVI la Nueva España, se encuentra la amenaza permanente del acecho de una "muerte súbita" que no era otra cosa que el temor a morir de sarampión, gripe, o viruela introducidas al Nuevo Mundo por los españoles.

Elena de Gerlero, escribe que en los primeros tiempos de la Colonia,

estas primeras imágenes tienen su origen en las xilografías y grabados europeos para que sirvieran de medicina espiritual. Dichas imágenes eran esculpidas, pintadas y grabadas con el tema de las "Armas de Cristo" en conventos tanto franciscanos como agustinos en Acolman y Huejotzingo en la Nueva España. ${ }^{43}$ Esta "autoprotección divina" o estampa protectora, contra la "muerte súbita" tiene una semejanza de origen en la Edad Media planteada con el grabado europeo como bien explica Paul Westheim por esa referencia a colgar en las paredes de sus casas las imágenes de santos. ${ }^{44}$ Existe una producción importante de hojas sueltas que reproducen imágenes de santos y que fueron adquiridos a precios accesibles para la protección de las casas observándose que algunas de estas imágenes tenían una carga de perdón ya que tenían la fortuna de contener gracias e indulgencias.

\footnotetext{
42 Ibidem, p. 126.

${ }^{43}$ Elena de Gerlero, La escatología en el arte monástico novohispano del siglo XVI, en Arte Funerario, Coloquio Internacional de Historia del Arte, vol. I, UNAM, México 1987.

${ }^{44}$ Paul Westheim, loc. cit., pp. 21-22.
} 


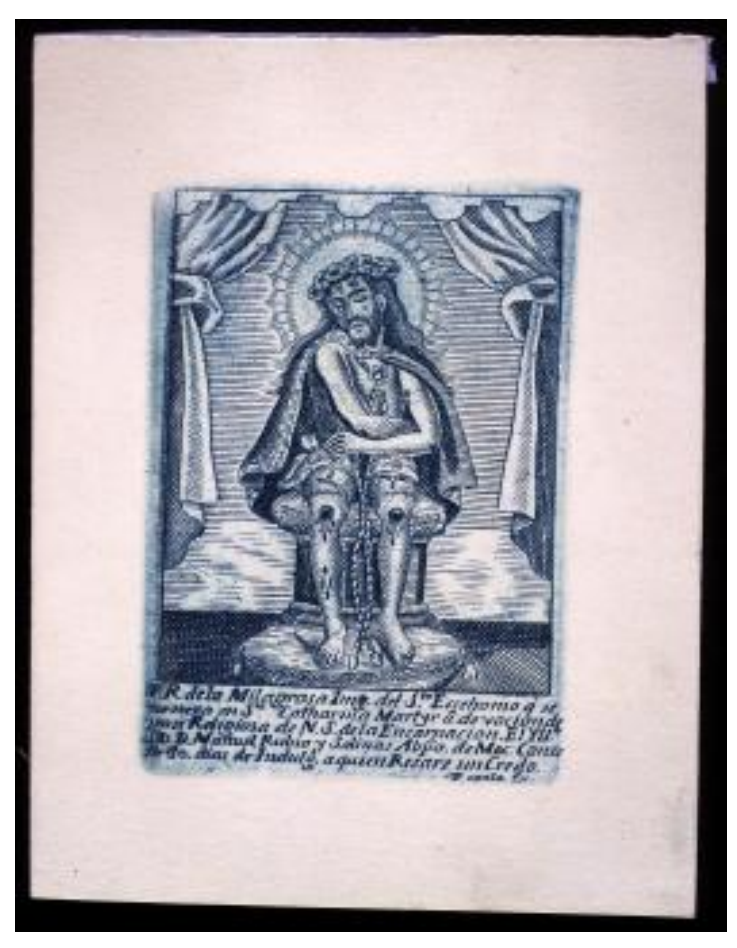

Fig. 14 Ecce Homo con indulgencias de 40 días Aguafuerte

Así por ejemplo, en España "el eminentísimo S. D. Luis Antonio arzobispo de Toledo concedió 100 días de indulgencias a todas las personas que delante de la estampa rezasen un credo [...]"45 (fig. 14)

La sociedad novohispana, utiliza a las imágenes de los santos como un importante medio de comunicación, las usaba también como objetos de culto que veneraba en sus hogares, en sus templos y que sacaban en procesión por sus calles. Las imágenes podían tener así dos funciones básicas: por ser medios didácticos insuperables para difundir mensajes y símbolos o ser objetos de devoción generadores y receptores de toda una gama de sentimientos religiosos. En ambas funciones, sin embargo no solo estaba presente lo religioso, pues las imágenes de los santos eran también instrumentos de representación que daban prestigio a quienes las encargaban o bien podían utilizarse para reforzar la presencia corporativa.

El historiador Antonio Rubial ha encontrado que la multiplicación de las imágenes en el periodo colonial se dio por medio de dos vertientes: el uso didáctico para autoridades eclesiásticas y civiles; y en objetos de veneración por parte del sector popular que podía rendirle culto en la intimidad del hogar, en el que la imprenta jugó un papel importante mediante la venta masiva de impresiones de portadas y grabados sueltos vendidos de manera independiente:

\footnotetext{
${ }^{45} \mathrm{BSR} /$ María José Esparza Liberal, Los calendarios y la gráfica decimonónica como expresión visual del acontecimiento político y social en México. 1821-1850. Tesis de maestría en Historia del Arte, FF y L, 2004, pp. 26- 27.
} 
Un uso similar tenían las imágenes religiosas grabadas en esas guías de oraciones que eran las novenas en las patentes, contratos y sumarios de gracias e indulgencias de las cofradías (hojas donde constaban los privilegios espirituales que éstas ofrecían), así como en coplas, loas, gozos y gacetillas y en los escapularios (trozos de tela para colocarse sobre el pecho y espalda que llevaban bordada la imagen de la Virgen o un santo) ${ }^{46}$

Un claro ejemplo en este sentido seria la imagen de Santa María Magdalena que se convirtió en un medio eficaz para difundir los mensajes de arrepentimiento y del perdón en los actos de penitencia.

En la tarea de grabar, los indígenas figuraron desde temprana fecha al encuentro entre Occidente y América. Tal vez, es en esta tarea donde el sincretismo encontró su lugar primigenio, lo que permitió la combinación de ambas tradiciones culturales. Las obras elaboradas por los indígenas presentan diversos aspectos primitivos, pero siempre propositivos y creativos. Para Francisco Díaz de León existe una estrecha relación entre estos primeros grabados europeos y los mexicanos, con la diferencia de que en estos últimos se realzan siempre la importancia de la belleza del grabado popular, donde además abundan láminas anónimas de las imágenes religiosas de mayor devoción en México. De ejecución tosca, indudablemente, tal vez sea demasiado severa la opinión de García Icazbalceta cuando dice que "son indignas de mención las detestables láminas que solían grabarse en los siglos XVII y XVIII, como las que acompañan la edición de las Cartas de Cortés\$,47

El estudio de lo que llamamos "imaginaría popular" ha ocupado desde siglos atrás a muchos estudiosos por lo que la historia del grabado novohispano, está circunscrita a ejemplares de índole religiosa, producidos casi siempre al buril o aguafuerte más que a maderas grabadas. Existe, por fortuna entre los documentos relacionados con la Inquisición, una estampa de la Virgen del Rosario que grabó Juan Ortiz en el año de 1571, en el que pueden advertirse las características de la imaginaría que privó como prototipo para

\footnotetext{
${ }^{46}$ Antonio Rubial, Santos para pensar, Enfoques y materiales para el estudio de la hagiografía novohispana, Revista Prolija Memoria estudios de cultura virreinal, FFy L/ Claustro de Sor Juana, año 1 , volumen 1, p. 139

47 Manuel Romero de Terreros, Grabados y grabadores en la Nueva España, México, Ediciones Arte Mexicano, 1948, pp.5-14.
} 
editores e imagineros en el México del siglo XVI. A semejanza de trabajos europeos de éste y el siglo anterior la imagen ejerce interés por su composición de sabor parecido a ciertas obras ejecutadas en los Países Bajos y también por el colorido con que fue realzada. No conocemos ningún otro ejemplo de estampa mexicana del mismo período que hubiese sido destinada, como ésta, para fines populares. ${ }^{48}$

La serie denominada Información Gráfica, publicada por el Archivo General de la Nación, ha permitido que se puedan contemplar el rescate de muestras tipográficas, orlas y capitulares usados por los indígenas en las imprentas del siglo XVIII. ${ }^{49}$ Algunas de estas muestras fueron utilizadas en la realización de libros $y$, no obstante que el trabajo se observa tosco técnicamente, estéticamente es agradable; también se pueden advertir en ellos, aún sin ser conocedor de las técnicas del grabado, una amalgama de concepciones estéticas en plecas y diseños que muestran un panorama de la utilización de las herramientas y técnicas de la imprenta en México.

El trabajo de investigación de Silvia Fernández Hernández ${ }^{50}$ titulado La transición del diseño gráfico colonial al diseño gráfico moderno en México aporta un aspecto poco comprendido en cuanto a la aparición y desarrollo del diseño gráfico en México. En dicho estudio se aborda como a través de los impresos realizados se llevaron a cabo la impresión de libros de alta calidad, y donde se abordaban cuidadosamente aspectos tipográficos, compositivos, de ilustración, de filetes y viñetas, etc.; es decir, de un conjunto de elementos de estilos y formas europeas y nacionales creando un producto de características únicas con diseños que adquirieron rasgos nacionales sobre todo a partir del siglo XIX.

En México - dice la autora- esta tendencia se siguió con la exaltación de
los sentimientos, el nacionalismo y las ilustraciones litográficas a color; todo
ello unido para dar a luz éxitos editoriales que formaron un nuevo estilo
moderno. Pero fue cuando se sentaron las bases del México independiente,
ya sin la censura de la inquisición y con el desarrollo del mercado interno,
cuando se transformaron los establecimientos de ordenanzas en casas

${ }^{48}$ Francisco Díaz de León, El grabado como ilustración de la música popular, México, Seminario de Cultura Mexicana, pp. 6-7.

${ }^{49}$ Cfr. Elementos tipográficos del siglo XVIII. AGN, México, 1981.

50 Silvia Fernández Hernández, La transición del diseño gráfico colonial al diseño gráfico moderno en México (1777-1850), en Empresa y Cultura en tinta y papel (1800-1860) Instituto de Investigaciones Dr. José María Mora/ UNAM, México 2001, pp. 15-26. 
editoriales capitalistas de libre comercio, que importaron maquinaria moderna y materias primas de nuevo tipo, a la vez que construyeron una nueva red de distribución y circulación de sus productos. ${ }^{51}$

\section{2 Impresos e impresores}

El cronista Luis González Obregón comentaba que en la Nueva España las imprentas publicaban impresos de todas clases desde folletos como novenas, trisagios y jaculatorias ${ }^{52}$; hasta gruesos volúmenes llenas de imágenes de vidas de santos misioneros. Es, en esta época, cuando nacen las llamadas "gacetas" y hojas volantes donde la información se combina con anuncios de la aparición de cometas, de calamidades, hambre, los monstruos marinos que creían ver los barcos mercantes, las brujas o hechiceras de pactos demoníacos, o los terremotos que acababan con ciudades 0 aldeas enteras. ${ }^{53}$ En el floreciente comercio de libros e impresos del siglo XVII -para entonces regulado por el Real Tribunal del Santo Oficiosobresalen notables impresores y grabadores en la Nueva España dedicadas a la publicación de literatura para los agónicos y ayudar a bien morir (fig. 15) como las imprentas de Felipe de Zúñiga y Ontiveros, la Biblioteca Mexicana de Eguiara y Eguren; la de José Bernardo de Hogal; la de la Rosa; de Miguel Rivera Calderón; la Imprenta Mexicana; o bien la imprenta del Colegio de San Ildefonso.

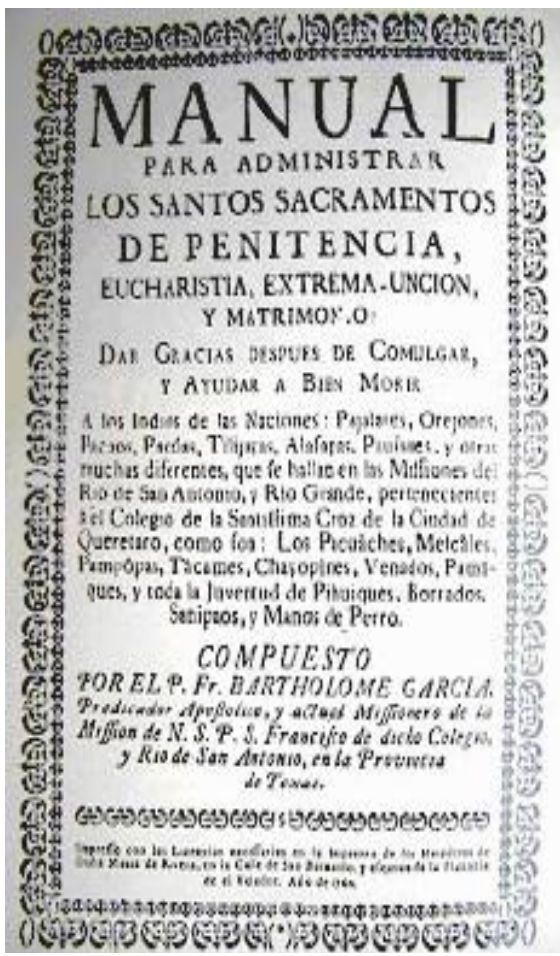

La historiadora María José Esparza ${ }^{54}$ menciona que muchas de las imprentas eran negocio

Fig. 15 Manual para administrar los santos sacramentos de Bartolomé García familiar que se heredaban a hijos o a hermanos, es decir, a miembros de diferentes generaciones estableciendo lazos de

\footnotetext{
${ }^{51}$ Ibidem., p. 24.

52 Trisagio: oración de adoración y alabanza a la Santísima Trinidad. Jaculatoria: oración breve y fervorosa.

${ }^{53}$ Luis Gonzáles Obregón, op. cit., p.127.

${ }^{54}$ Véase nota 79 en María José Esparza Liberal, op. cit.
} 
parentesco profundos entre ellas. El mismo Juan Cromberger había obtenido de la Corona española los derechos exclusivos de venta de libros y ganancias esta misma exclusividad debían heredarla sus descendientes ${ }^{55}$. Como aspecto relevante podemos mencionar la gran cantidad de mujeres que se hicieron cargo de las imprentas a la muerte del marido por lo menos hasta $1821^{56}$. Así leemos en los pies de imprenta las siguientes referencias: 1594, María Figueroa viuda de Ocharte; 1611- 1614 Catalina del Valle; viuda de Pedro Balli; 1641- 1684 Paula Benavides, viuda de Bernardo Calderón; 1675-1685 Viuda de Ribera Calderón y Benavides; 1683- 1894 Viuda de Rodríguez Lupercio; 1684- 1700 María Benavides; viuda de Juan de Rivera; 1707-1714 Gertrudis de Escobar y Vera, viuda de Miguel Rivera Calderón; 1731-1747 viuda de Francisco Rivera Calderón; 1741-1755, viuda de Bernardo de Hogal, etc.

Entre los grabadores notables encontramos a José Eligio Morales quien ilustra y graba al cobre algunas estampas para el Llanto a la fama. Reales exequias de la reina doña Amalia de Sajoni, Francisco Silverio, José de Nájera, Mariano Navarro, Juan Ortuño, José Simón Larrea, Francisco Agüera, autor de los grabados en metal de La Portentosa Vida de la Muerte; Manuel López, Mariano Torreblanca y Manuel Villavicencio, aguafuertista de imágenes religiosas.

Asimismo existieron libros en la Nueva España que permitían afrontar el gran paso entre este mundo y el más allá con publicaciones conocidas como Ars moriendi, o libros de bien morir que alcanzaron gran difusión como el de Alejo Venegas del Busto titulado Agonía del tránsito de la muerte. Más adelante en el siglo XVIII se utilizaron otros textos como los de Diego Osorio, Manual para administrar los Santos Sacramentos (1748); de Francisco Javier Lazcano, Guía práctica canónico moral del sacerdote acerca de los enfermos (1760); Antonio Arbiol, Visita de enfermos y ejercicio santo de ayudar a bien morir (1775); y Juan Crasset, La dulce y santa muerte (1788).

\footnotetext{
${ }^{55}$ Juana Zahar Vergara, op. cit. p. 3.

${ }^{56}$ Es posible que después de la Independencia se hayan sentado bases sociales y económicas distintas para que nuevas familias se ocuparan de la fabricación de libros e impresos, ya que la Constitución de Cádiz de 1812 otorgaba la "...libertad de escribir, imprimir y publicar las ideas políticas sin necesidad de licencia, revisión o aprobación alguna anterior a la publicación, bajo las restricciones y responsabilidades que establezca la ley", lo que permitió en suma, la ansiada libertad de expresión. Véase, María Esparza Liberal, op. cit., p. 25.
} 
La fabricación de libros era una actividad complicada que englobaba a un sinnúmero de participantes en un taller con una división del trabajo compleja que prácticamente no varió desde el siglo XVII hasta el siglo XIX. Tan sólo dentro de las artes gráficas donde se encuentran enmarcadas la producción de textos e imágenes, la actividad de los tipógrafos era una parte de los artesanos ligados a la producción de libros.

Everardo Gonzáles ${ }^{57}$ ha estudiado el proceso recurriendo a fuentes de la época de donde sabemos que los tipógrafos estaban compuestos por cajistas, obreros que ajustaban y ordenaban los textos que permanecían casi siempre de pié "justificando" las líneas que se realizaban con rapidez pasmosa juntando letras que unidas formaban palabras, líneas y páginas. Las letras se obtenían de cajas (especie de tableros donde las letras estaban acomodadas por tipos y clase con signos especiales con letras mayúsculas por un lado, y minúsculas por otro). La mirada atenta hacía que no pudieran distraerse de su velocidad y eficiencia dependía su salario y su permanencia en el trabajo. Para realizar su trabajo el cajista debía de leer el texto y pararlo auxiliándose de un componedor, es decir de una regla metálica donde se ajustaban o "justificaban" las letras para fijarlas sobre esa línea con tornillos. Un buen cajista debía "parar" un promedio de diez mil letras, y por supuesto saber leer al revés, es decir de derecha a izquierda.

Posteriormente después de formar varias líneas de texto se formaba un pequeño paquete, se llevaba el texto a una mesa llamada mármol, de tal manera que ya una vez impresa la hoja se llevaba la compaginación ordenada. Estas pruebas eran revisadas por los correctores, con la espalda encorvada revisaban cuidadosamente línea por línea, armados de unas pinzas para hacer los cambios necesarios. Existía asimismo, una jerarquía dentro de las imprentas que iban desde aprendices hasta veteranos en el oficio, siendo el de más alto rango el regente que conocía todas las fases de impresión. Otros personajes en un taller o imprenta, eran desde luego, los redactores y los escritores que podían ser trabajadores de un periódico (que era el trabajo más pesado por el corto tiempo de aparición del periódico) o de una imprenta.

$\overline{57}$ Everardo G. Carlos González, Los tipógrafos y las artes gráficas. Procesos de trabajo y espacio laboral en las imprentas mexicanas del siglo XIX. En Empresa y Cultura, op., cit., pp. 27- 50. 
El impulso mecánico que movían las prensas, podía provenir de dos fuentes: la fuerza animal o de máquinas de vapor. El proceso de impresión con la prensa de brazo pasaba por el siguiente proceso, que podemos imaginarlo con facilidad por la siguiente cita:

Colocada en forma de tabla, el operario la cubre de tinta por medio de un rodillo elástico, después de colocar el papel previamente mojado, en el cuadro llamado tímpano, y de doblar sobre el cuadro con agujeros, frasqueta, que está encima y que sirve para sostener el papel preservando al mismo tiempo de manchas las partes de la hojas que no deban recibir la señal de los caracteres, ambos cuadros reunidos bajan sobre la forma, que con la ayuda de un manubrio se desliza hasta colocarse debajo de la platina, llamada cuadro, a la cual se da un movimiento de presión por medio de una palanca, quedando entonces verificada la presión. Volviendo el manubrio en sentido inverso, se desdobla el aparato, para repetir la misma operación hasta el fin de la tirada. Una provisión de tinta semilíquida está depositada en una ranura situada al extremo de la mesa, y el operario hace girar el rodillo, el cual a su vez hace pasar cierta cantidad de tinta a la superficie plana de la mesa. El impresor toma luego el rodillo portátil, y lo provee de tinta que al fin traslada a la prensa. ${ }^{58}$

La venta de libros e impresos se llevaba a cabo en un principio en la Plaza Mayor de la Ciudad de México en tiendas (almacenes fijos), alacenas (locales comerciales de diversos géneros) y cajones de ropa (tiendas de madera móviles) que vendían también libros, donde al cabo del tiempo los mismos talleres ofrecerían su mercancía en sus mismos locales comerciales pasando a ser dichos lugares impresores y mercaderes de libros. Han llegado hasta nosotros los nombres de los propietarios que tomaban también el nombre de la calle donde se encontraban: la "Librería de Don Manuel Cueto" (calle de Madero); la "Librería del Arquillo" (5 de Mayo); la "Librería de don Joseph de Jáuregui" (Venustiano Carranza); la "Librería de Antonio Espinosa" (5 de Febrero); la "Librería de Don Francisco Rico" (Brasil); de "Don Manuel del Valle" (Tacuba 24); la "Librería de la Gazeta" (Espíritu Santo hoy Isabel la Católica); la Librería de Don Pedro Bazares (en la calle de Brasil); y la de Agustín Dherbe (calle de República del Salvador).

Otros puntos de venta eran cercanos a iglesias y conventos como el Real Convento de Predicadores; La Portería del Convento Grande de San Francisco; La Portería del Convento de San Sebastián de Carmelitas

${ }^{58}$ lbid. p. 36. 
Descalzos; el Convento de Santo Domingo el Real; la sacristía del V. Orden tercero de penitencia de N. S. P. Francisco de esta Corte y la portería del real Colegio de San Ildefonso. ${ }^{59}$

Veamos detenidamente en nuestro siguiente apartado los temas del alma y de la muerte en los impresos coloniales.

\section{3 Los impresos y la muerte}

La experiencia de la muerte en el discurso religioso está ligada a la visión que la religión católica se encargó de difundir en buena parte del mundo. Heredera de la tradición medieval, el catolicismo novohispano sufrió modificaciones, al mismo tiempo que adquirió alteraciones en la aplicación de sus ideas en el Nuevo Mundo que lograron en el pensamiento de los individuos la creencia de que la permanencia en la tierra era limitada y estéril en comparación con la vida eterna.

Para la transmisión del pensamiento cristiano se trasplantaron y se adaptaron los medios utilizados en España para hacer que los novohispanos conocieran y se adentraran en la fe religiosa y lo que llevaba consigo: impresión de catecismos, confesionarios y devocionarios, prédicas e impresión de sermones, exempla, hagiografías, fomento de actividades ligadas al espíritu, manufactura de arte sacro, celebraciones, y fiestas de culto religioso.

Era preciso pues, estar atento a las cosas útiles que permitieran estar en comunión con el porvenir que les aguardaba y luchar en este breve espacio de vida contra tres enemigos poderosos: el Demonio ${ }^{60}$, el Infierno y el Pecado.

En el Concilio de Trento $^{61}$ se afirmó que el mal acechaba al hombre constantemente con el fin de hacerlo caer en pecado; no obstante el momento en que intensifica sus ataques al máximo es cuando es inminente la muerte.

\footnotetext{
59 Juana Zahar Vergara, op. cit., pp 23-27.

60 Aunque encontré diferentes significados, entre sus diferentes alusiones en el fondo representan el espíritu del mal y lo maligno: Maligno, Lucifer, Demonio, Satanás, Belzebul, Diablo, Belcebú, Asmodeo, Azael, y Satán.

${ }^{61}$ El Concilio de Trento (1545-1563) tuvo como fin la reunión de altos jerarcas eclesiásticos de la iglesia católica y en ella después de 18 años de discusiones se definieron los objetivos en el mundo católico como el pecado ( $5^{\mathrm{a}}$. sesión); la salvación del alma ( $6^{\mathrm{a}}$ sesión); naturaleza y función de los sacramentos; y la importancia de la extremaunción (13a sesión). BSR/ Berta
} 


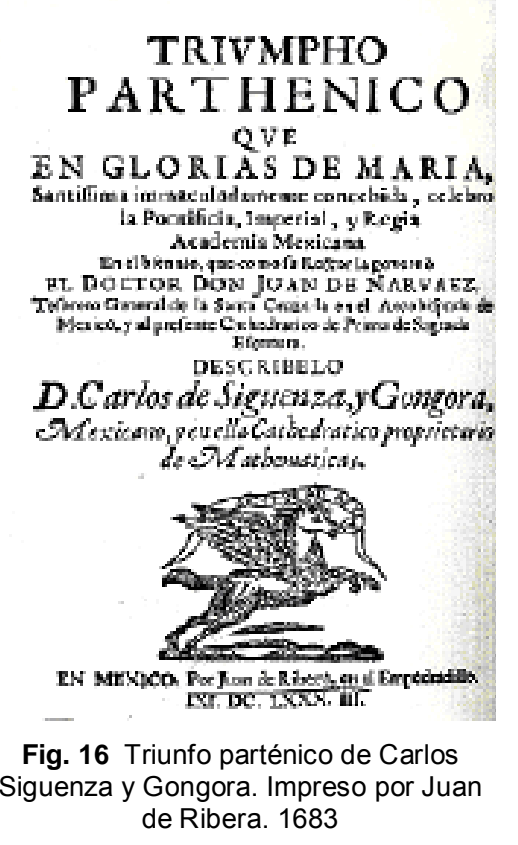

Por ejemplo, El Catecismo del Santo Concilio de Trento para los párrocos ordenado por disposición de San Pío $V$ mencionaba que el tiempo era prestado en esta vida "donde somos, no ciudadanos, sino forasteros". ${ }^{2}$ Este concepto de "permanencia temporal", por así llamarlo de manera contemporánea tuvo repercusiones en forma general, no es casual entonces, el término de Viador en algunos impresos de la época, refiriéndose al que en esta vida aspira y camina hacia la eternidad. (fig. 16) Ahora bien, el discurso de la muerte tenía la finalidad de conmover y de hacer reflexionar a los fieles mediante un lenguaje más directo postridentino para la conmoción no sólo del cuerpo del pecador, sino también de su alma. La Iglesia buscaba en la mayoría de los casos apelar a los sensibles sentidos mediante sermones y pláticas haciendo constantes llamados a sus feligreses para que estuvieran preparados para el momento de la muerte, ya que el cuerpo humano mismo era visto como una forma inmunda de ser en proceso de descomposición gradual donde ni siquiera valía la pena su cuidado pues de lo contrario se estaría cometiendo el pecado de vanidad.

La muerte no se presentaba en las mismas condiciones para todos en la Nueva España, ésta se presentaba en tres tipos: La muerte natural, la muerte repentina o accidental y la muerte santa. ${ }^{63}$

En el primer caso, la muerte natural se presentaba con el tiempo suficiente para preparar todo con anticipación, y permitía preparar todo y encomendar su alma mediante misas, dar limosnas y sólo podía llevarse a cabo la buena muerte si se tenía los sacramentos: La confesión considerada como "la tabla de la salvación" del alma humana. La comunión, punto donde el moribundo debía de recibir la comunión que se denominaba de viático -ya

Gilabert Hidalgo. La idea del mal y el demonio en los sermones novohispanos Arquidiócesis metropolitana, siglo XVII, maestría en Historia FFy L. 2005.

${ }^{62}$ BSR. Citado por Javier Otaola Montagne, en Muerte y Salvación. Sociedad novohispana entre los siglos XVII y XVIII, Tesis en Historia. FF y L, UNAM, México, 2002, p. 14.

${ }^{63}$ Ibidem. 
mencionado líneas más arriba- y la tradición marcaba que el Santo Viático debía salir en procesión por las calles hasta llegar a la casa del agonizante saliendo la gente y acompañando con cantos para pasar a orar por el alma de la persona que esperaba la muerte. Y por último la extremaunción considerado como una forma de purificación que consistía en aplicar el aceite de oliva que bendecía el obispo el Jueves Santo al enfermo moribundo.

En cuanto al aspecto de la muerte repentina o accidental es la que por sus condiciones en que se presenta podía dejar problemas a la familia y al alma del difunto ya que por las circunstancias estas personas, muertas en forma violenta, ya sea asesinadas, o ahogadas, o bien en herejía o locura, no alcanzaban a recibir los sacramentos. ${ }^{64}$ La muerte santa era sólo aspirada por aquellos que por sus virtudes terrenales podían ser dignas del tránsito hacia la muerte digna y en la que la comunidad religiosa sobre todo, podía tener más seguro el acceso a ser elevada al cielo. Se conocen casos de personajes importantes en los que su agonía mereció que fueran considerados como santos. Por ejemplo el fraile franciscano Antonio Marfil de Jesús murió en olor a santidad ya que:

"antes y después de expirar el fraile fue visitado por todo tipo de
personas que reconocían en él a un santo. Su cuerpo tuvo que ser
custodiado por guardias para evitar que fuera ultrajado por todos
aquellos que querían hacerse de una reliquia. Muchos tuvieron que
conformarse entonces con tocar o besar alguna parte del cuerpo de fray
Antonio y, los que no alcanzaron a llevarse alguna ofrenda, partieron a
sus casas con el recuerdo de aquel suave olor que rodeaba al
cadáver". 65

Existe pues, una relación directa, e indisoluble entre la vida y la muerte. La muerte es la que castiga nuestras faltas premiando nuestros sacrificios y castigando a los pecadores para los que no hay perdón en la otra vida, por eso en la sociedad novohispana se preparaban para la muerte, dejando atrás las riquezas, los placeres y amistades. Dicho de otra manera, una buena muerte debería de ser una tarea de toda la vida pretendiendo con esto llegar a la patria celestial.

\footnotetext{
${ }^{64}$ Cuando se trata de deceso en niños que por su edad no podían alcanzar los santos óleos, la ceremonia luctuosa corresponde al despedimiento del angelito.

${ }^{65}$ Javier Otaola, op. cit., p. 37-38.
} 
En 1737, el sermón moral de Bartolomé Felipe de Ita y Parra titulado "Los pecados", única causa de las pestes, permite asomarnos a la mentalidad del

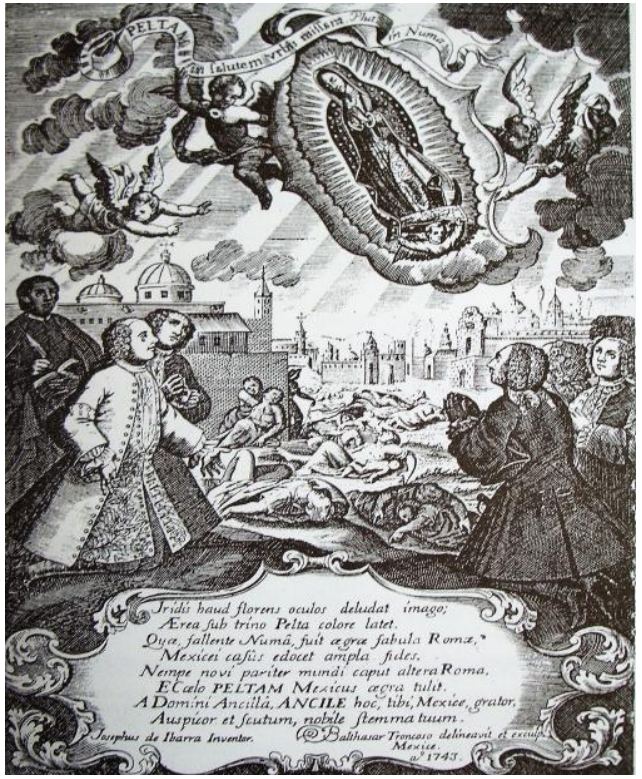

Fig. 17 Escudo de Armas de México. De Josephus Ibarra y Balthasar Troncoso Buril de 1743 momento ya que para entonces el matlazáhuatt $^{66}$ es el miedo mismo a la muerte. Las invocaciones a las divinidades del cielo debieron de ser necesariamente muy urgentes ya que en un grabado en buril de José de Ibarra para el Escudo de Armas de México, se ve un cuadro lastimoso de la ciudad debido a los desastres de la peste de 1743. La imagen es elocuente en cuanto a su composición: En primer plano las de figuras de los donantes, prominentes personajes de la sociedad novohispana rezan postradas ante la presencia de la Virgen de Guadalupe que es bajada por unos ángeles a la tierra. En el segundo plano hombres, mujeres y niños yacen sobre las calles de la ciudad, a consecuencia de la peste maligna. (fig. 17)

\section{La muerte en el imaginario colectivo de la Colonia}

Los desastres son una forma de permitirnos estudiar la vida cotidiana conociendo actitudes y respuestas de la sociedad ante los fenómenos y desgracias colectivas El grabado registra a manera de testimonio visual esos eventos en los que el imaginario colectivo se presentaba en respuestas de tipo espiritual. Manuel Romero de Terreros $^{67}$ en su libro sobre el arte virreinal muestra un aguafuerte del incendio de la iglesia de San Juan de Dios en el que vemos una imagen donde convergen en el minúsculo grabado una

\footnotetext{
${ }^{66}$ Matlazáhuatl, nombre náhuatl asignado a una enfermedad con características de peste y tifo, América Molina del Villar, La Nueva España y el matlazáhuatl 1736-1739, El Colegio de Michoacán/ CIESAS, México, 2001.

${ }^{67}$ Algunas de las imágenes consultadas de este periodo están perdidas o son de propiedad particular lo cual no permite saber ni las medidas ni su procedencia. Este aguafuerte según leemos en el pié de la imagen perteneció a la colección de Romero de Terreros y se encuentra perdido. Manuel Romero de Terreros, El arte en México durante el virreinato. ilustración 118.
} 
heterogénea población que curiosea el incendio: sacerdotes que miran la escena, soldados que forman vallas para impedir el acceso a personas, algunas personas que parecen heridas son socorridas por otras personas que las llevan cargando hacia lugares más seguros. En primer plano el carruaje del virrey es escoltado por su guardia personal, mientras que en el cielo, San Juan de Dios mira la escena de su iglesia ardiendo. (fig. 18)

Los temblores de tierra producían sensaciones de miedo y angustia en la población. Uno de ellos sucedido en la ciudad de Oaxaca en marzo de 1727 describía así la situación:

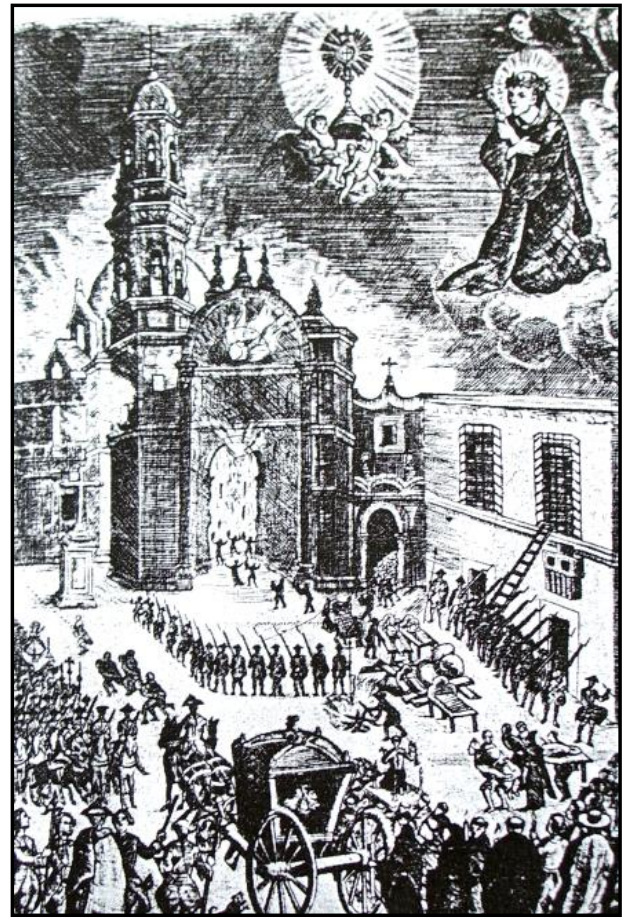

Fig. 18 Incendio en la iglesia de San Juan de Dios. Aguafuerte

Un horrible terremoto -afirma José Antonio Gaysacudió la tierra con oscilaciones espantosas, derribando muchos edificios y quebrantando los demás en términos de quedar inhabitables. Continuaron ese día y los siguientes repitiéndose los vaivenes, causando indecible pavor a la población que se agitaba en continuo sobresalto, pasando las noches bajo de tiendas o en chozas de palma o de zacate por miedo de perecer en la caída de los edificios [...] Para aplacar la ira de los cielos, se pensó en aquellas circunstancias llevar por procesión, a la capilla de Guadalupe que servía de catedral y hacer un solemne novenario, a la venerada Virgen de la Soledad. ${ }^{68}$

Para la población sufriente dicho espectáculo confuso de edificios derrumbándose, de gente muerta y herida, debió de ser una imagen parecida al Juicio Final. $^{69}$ En el sentido espiritual se gritaban los pecados ${ }^{70}$ y otros más rezaban en voz alta y rogaban a Dios que se acabara su sufrimiento. Un detalle significativo es que para estos fines se encomendaba a algún santo que fuera bueno contra las catástrofes naturales; pero si por algún motivo, el santo no

\footnotetext{
${ }^{68}$ Javier Otaola, Muerte y Salvación, op. cit., p. 23.

${ }^{69}$ Por lo menos algunas personalidades científicas se preocuparon de conocer el origen de estas catástrofes naturales en las que están incluidos los cometas, como el sacerdote Carlos de Sigüenza y Góngora (1645-1700) pero el común de los ilustrados creía en diversas interpretaciones y teorías que iban desde considerar la fuerza de los rayos solares sobre los cuerpos terrestres hasta la ira divina.

${ }^{70}$ Del texto de Berta Gilabert, se desprenden de su estudio varios tipos de pecados, de gravedad y por lo tanto de penitencias. "En una carta del siglo XIII se menciona incluso que la blasfemia en contra del Espíritu Santo no es susceptible de perdón ni en este mundo ni en el futuro", op. cit., p. 42.
} 
cumplía su cometido, se recurría a otra figura santa, hasta dar así con el santo efectivo sucesivamente hasta acabar con el problema.

Lo mismo sucedía con la aparición de epidemias, eclipses o cometas, que la Iglesia "explicaba" para la población iletrada y temerosa. Es importante subrayar, que la presencia del grabado popular se manifiesta en las inquietudes de tratar de explicarse las causas de los fenómenos naturales, mezclando el aspecto supersticioso; el científico, y el religioso. Un ejemplo es

EXPOSICION ASTRONOMICA

DE EL COMETA,

Que el Ańo de r68 6 . por los mefes de voviembre, y Diziembre, yeffe An̆nde 1681 . por los mefes y le ha obfervado en la Ciudad de C diz,

EL P. EUSEBIO FRANCISCO KINO Dela Compañia de Jesvs.

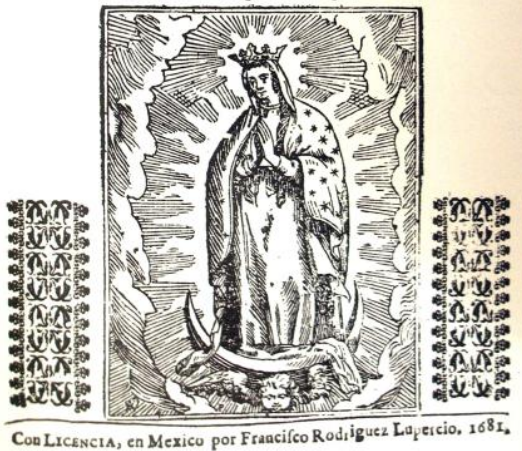

Fig. 19 Exposición astronómica del cometa Impreso por Francisco Rodríguez Lupercio. 1681. el grabado de la Virgen de Guadalupe que acompaña la portada del libro Exposición Astronómica de El Cometa, escrito a propósito de la aparición de un cometa por Eusebio Francisco Kino e impreso por Francisco Rodríguez Lupercio en 1681. (fig. 19)

Por otra parte, en diversos documentos del Tribunal del Santo Oficio se han encontrado testimoniales de individuos castigados por herejía o que predicaran o escribieran en contra de las ideas de la fe tomando como base la astrología, tal y como pasó con el ciudadano Gaspar Rivero de Vasconcelos mulato libre $y$ canonista descendiente de portugueses,

natural de la ciudad de Tánger en África, que terminó recluido por “....astrólogo judiciario, calumniador del Santo Oficio y sus ministros y sospechosos de la $\mathrm{fe} \mathrm{71}$

La aparición de un fenómeno celeste como un cometa se interpretaba como una "señal del cielo" de una desgracia terrenal. Un cántico popular del siglo XVIII, titulado Es una señal del cielo demuestra esta relación directa:

\footnotetext{
${ }^{71}$ Véase el estudio de Mariana Masera Textos poéticos populares y popularizantes en la Nueva España del siglo XVII, Revista de Literaturas Populares, FFy L, UNAM, pp. 5-18.
} 
Es una señal del cielo

o algún presagio a la tierra

anuncio de alguna guerra

ruina de nuestro suelo.

Muchos hay en la creencia

Que esa peregrina estrella

A pesar de ser tan bella

Trae su fatal consecuencia.

Hombres de crecida ciencia

Abrigan algún recelo,

Osando romper el velo

De su sentido profano;

Dicen que para el cristiano

Es una señal del cielo.

Ese astro que a su camino

Se apresura dócilmente

Porque el Dios Omnipotente

Le señala su destino,

$Y$ como el Creador Divino

En sus obras nunca yerra,

El hombre piensa y se aterra

Entre dudas confundido;

Pues trae de consigo

Algún presagio a la tierra.[...]

No alcanza mi entendimiento

A conocer presuroso

Ese cuerpo tan luminoso

Que recorre el firmamento;

Que con paso grave y lento

Va remontando su vuelo.

¡Oh, imagen de desconsuelo!

¿Qué nos vendrás a anunciar?

Algún desastre en el mar

O ruina de nuestro suelo. ${ }^{72}$

Dos siglos más tarde, en el imaginario popular de los tiempos del grabador Posada, los cometas y los terremotos seguían siendo presagio de desorden universal con la diferencia de que los siniestros se difundían más rápidamente en la República Mexicana debido a los sistemas de distribución de Vanegas Arroyo impresor de la obra de Posada. Por ejemplo, el 2 de noviembre de 1894, a la 6 y 34 minutos se registró un temblor de tierra

\footnotetext{
${ }^{72}$ Vicente T. Mendoza, Glosas y décimas de México, colección: Letras Modernas, Fondo de Cultura Económica, séptima reimpresión 1996., pp. 122-123.
} 
conmocionó a la capital causando derrumbes de casas y bardas. El "Diario del Hogar" registraba en estos términos los pormenores:

El aspecto que presentaban las calles era pavoroso verdaderamente. Las mujeres, y hasta muchos hombres, oraban y pedían misericordia a gritos. Los niños lloraban invocando a sus madres, como hacen siempre. Los vagones, coches y demás vehículos se detuvieron repentinamente, porque las bestias que de ellos tiraban se resistían a andar, extendiendo las patas para conservar el equilibrio. La luz eléctrica se apagó por algunos minutos, de la misma manera que los aparatos de muchas casas de comercio. No se podía transitar por las calles, debido al gentío que les obstruía arrodilladas. $^{73}$

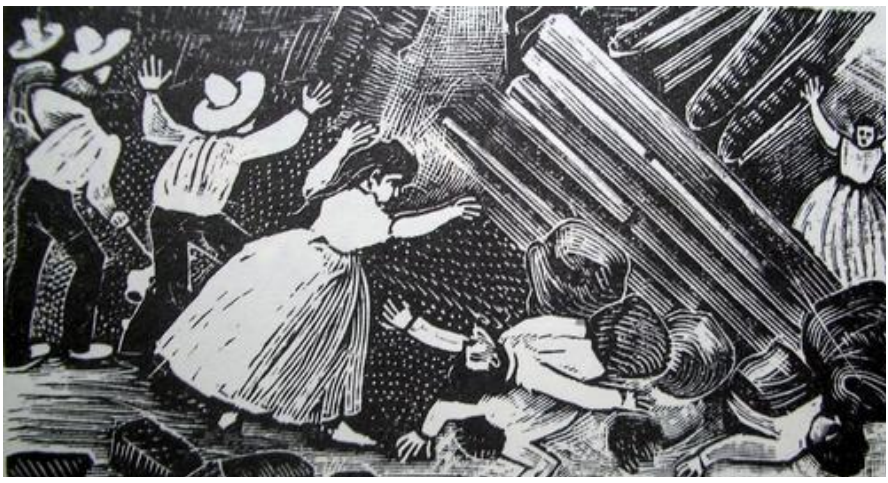

Fig. 20 "Sublime creador del cielo y de la tierra, señor líbranos de otro temblor" Grabado de José G. Posada

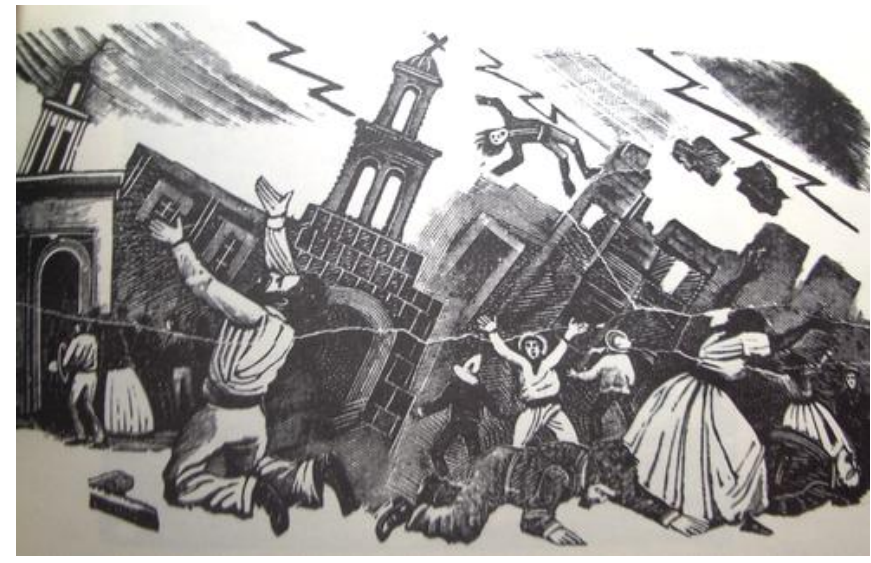

Fig. 21 "Terrible y conmovedora espantosa y aterradora catástrofe" Grabado de Posada
Con esta idea, Posada realiza el grabado "Sublime creador del cielo y de la Tierra, Señor líbranos de otro temblor", donde se observa la caída de muros de piedra de un templo ante la desesperación de hombres y mujeres que incapaces sólo alcanzan a mirar el desorden del temblor.

Un segundo grabado titulado "Terrible $y$ conmovedora espantosa $y$ aterradora catástrofe", dividido en dos cuadros presenta a un hombre en la calle abierta postrado de rodillas invocando al cielo ante la fuerza del siniestro.

En el lado opuesto otro grabado muestra el temblor como un "congelamiento"

${ }^{73}$ Olga Sáenz, José Guadalupe Posada entre cometas y terremotos, Anales del Instituto de Investigaciones Estéticas, número 56, UNAM, 1986, pp..205-221. 
de la imagen misma del temblor: la perspectiva es inclinada y los personajes prácticamente "vuelan en el aire". Un rayo cruza la escena lo cual enfatiza el desequilibrio de la composición.

Por otra parte los cometas siempre han sido relacionados con presagios funestos como portadores de la muerte en forma colectiva por medio de guerras, incendios, hambres y epidemias pero fundamentalmente con el fin del siglo XIX y con el fin del mundo de lo cual la prensa del momento dejó documentos al respecto:

Según dice El Nacional en la última sesión de la Sociedad de Geografía y Estadística, el Sr. Epstein hablando de un pronóstico del meteorologista Falb, dijo lo siguiente: "Que el célebre meteorologista Falb ha hecho últimamente el pronóstico de que el 13 de noviembre de 1899 de las 2 a las 5 de la mañana, serán sorprendidos los habitantes de la tierra por una colisión de un cometa descubierto por Tempel en el año de 1866 con el globo terrestre, lo que causará según Falb la destrucción de éste último " 74

Un aspecto consecuente en la mentalidad colectiva colonial era el miedo ante la muerte inminente ante los fenómenos naturales, lo cual generaba una sensación de angustia por los pecados cometidos en vida mientras era juzgado por Dios: Aquí el Purgatorio ocupaba un lugar importante. Veamos este aspecto en el siguiente apartado.

\subsection{El Purgatorio en el imaginario colectivo}

En el imaginario novohispano, el difunto debía enfrentarse al juicio universal al que deberían de pasar todo ser humano en su fe cristiana: el Purgatorio. En este lugar "el alma sufría la angustiosa ausencia de Dios y las "dolorosísimas" penas de un fuego que era avivado por la divinidad", como se observa en muchas pinturas y xilografías primitivas ${ }^{75}$

Aparecido el término desde el siglo XII, el Purgatorium era una clara referencia a un espacio intermedio entre el cielo y el infierno, al que el Concilio de Trento de 1563 reafirmó como sitio de purificación del alma. ${ }^{76}$ El tiempo que

\footnotetext{
${ }^{74}$ Ibidem.

75 Julio César Cervantes López, La archicofradía de la Santísima Trinidad. Una cofradía novohispana. Tesis en Historia, FF y L. 2002. nota 56.

${ }^{76}$ En las escenas que se muestran en la historia del arte, el Purgatorio está representado por la imagen de la Santísima Trinidad en la cima de la composición y a su alrededor o debajo de ella
} 
una persona tenía que estar en el Purgatorio era indefinido que dependía de la cantidad y la importancia de los pecados cometidos; así como el grado de arrepentimiento, y la cantidad de rezos y plegarias que hicieran amigos además de familiares en la Tierra. ${ }^{77}$ La presencia del Purgatorio en la espiritualidad

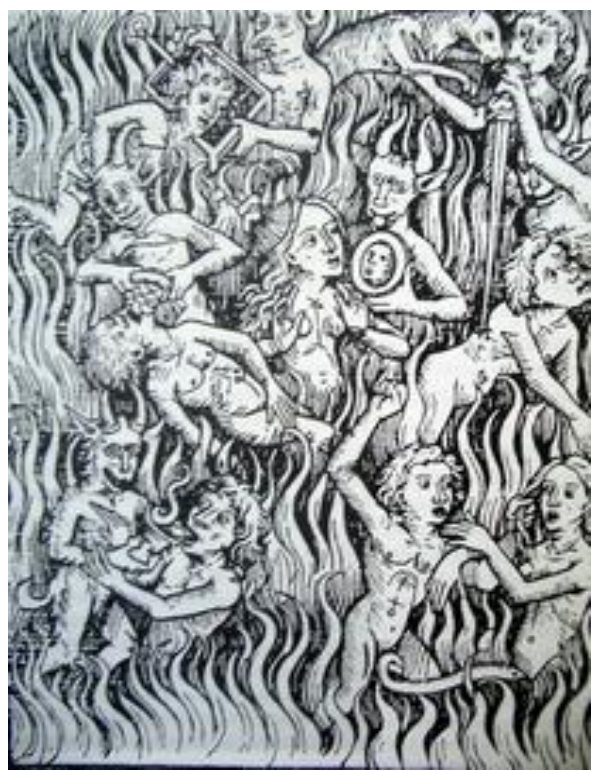

Fig. 22 "Ánimas del Purgatorio". Xilografía medieval alemana. Impreso en Ulm, 1486. novohispana se manifestó principalmente en la pintura donde rebasó el ámbito devocional y representaban un medio de prédica a través de imágenes que coexistían y se complementaban con la prédica oral y escrita, de tal manera que la ubicación del Purgatorio para algunos teólogos y para los creyentes quedó definida como un lugar que no era arriba en el cielo (como morada del Creador), sino abajo en el Infierno. ${ }^{78}$ En lo tocante al aspecto gráfico, Peter Burke afirma que

"[...] las imágenes de las ánimas eran muy raras en la cultura occidental antes del siglo XIV y las del diablo antes del siglo XII, aunque pueden encontrarse algunas a partir del siglo IX [en cuanto a] la figura del demonio peludo, con cuernos, garras, cola, alas de murciélago y un tridente en la mano, tardó mucho tiempo en ser elaborada.[...] ${ }^{79}$

Una primera referencia en el manejo de las ideas de la ánimas y sus correspondientes castigos es el grabado que comienza este apartado, procedente de un devocionario impreso en la ciudad de Ulm, Alemania en 1486, (fig. 22) en el que muestra a estos seres demoníacos entre el fuego de largas llamas provocando tormentos en aquellos humanos descalificados en la

alguna divinidad como intercesora que ruega por la salvación de las almas. Enseguida los santos o ángeles que ayudan a salir a las almas atormentadas del fuego a través de bulas 0 cintas salvadoras.

77 Julio César Cervantes López, op. cit., véase nota 57.

${ }^{78}$ BSR/ Jaime Ángel Morera, Las pinturas coloniales de ánimas del Purgatorio, Tesis en Historia, FFy L., UNAM, México, 1999, p. 35

${ }_{79}$ Peter Burke, Visto y no visto. El uso de la imagen como documento histórico, Traducción de Teófilo de Lozaya, Editorial Crítica, España 200, p. 59. 


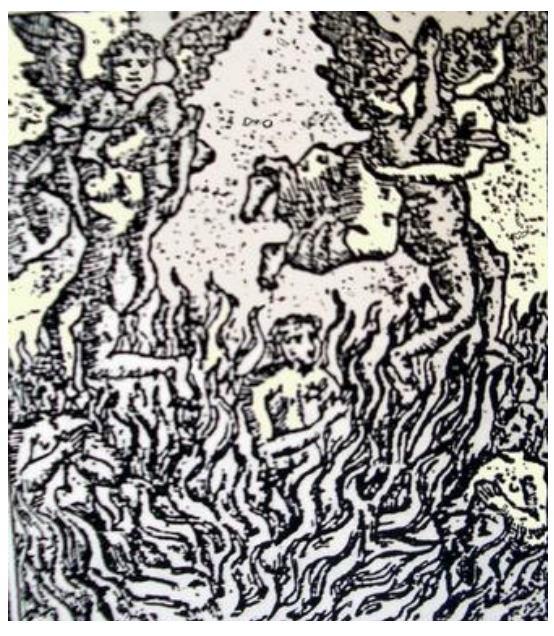

Fig. 23 "Animas del Purgatorio". Xilografía

Biblia, en actitudes que tienen que ver con la vanidad, la ira, la gula, la pereza, la envidia, la lujuria, y la soberbia.

Otra variante es la imagen en la figura 23, en el que se muestra a dos ángeles alados con unas pequeñas cruces arriba de sus cabezas que elevan a dos condenados del fuego eterno, mientras en la parte inferior algunas almas condenadas esperan la gracia de la ayuda celestial.

La Corona Española a través del rey Carlos II, promovió el culto de las imágenes y de las ánimas a todo el territorio dominado por medio de la cédula real que indicaba lo siguiente:

EL REY. Por cuantos habiéndose puesto en mis manos un memorial que parece haber sido escrito por el Obispo de las Islas Canarias, el cual persuade a que por todos medios se frecuenten los sufragios de las Almas del Purgatorio, para que (como es justamente debido) sean continuamente socorridas con ellos. Y reconociendo Yo cuan propia obligación de todos los Católicos es esta, lo acepta [apta] que será a los ojos de Dios, y cuanto aplacará su ira, y lo que es mi ejemplo podrá mover a tan gran piedad, he mandado que a este efecto se dedique en mi nombre el día en que cumplo años; y juntamente he resuelto se remitan estos papeles a los Prelados de las Iglesias, y regiones de mis Dominios, encargándoles mucho, que cada uno en su jurisdicción persuadan a que todas las personas de cualquier calidad, y estando que sean señalen un día en el año, en que ejerciten alguno o algunos de los sufragios que el memorial contiene: $Y$ por la presente ruego, y encargo a los Arzobispos y obispos de las Iglesias Metropolitanas y Catedrales de las Indias, y a los Provinciales de las religiones dellas, lo ejecuten de conformidad, como lo espero de su devoción y celo, y que me den cuenta de lo que obraren, para cuyo efecto se les remite con este despacho copia impresa de memorial referido. Fecha Madrid a primero de septiembre de mil seiscientos y ochenta y dos años. Yo el Rey. ${ }^{80}$

En dicho Memorial se encuentra un grabado que muestra a una ánima en un caldero sobre una parrilla con una leyenda: benditas y afligidas almas del Purgatorio apelan a la piedad cristiana y católica devoción de los nobilísimos y caritativos pechos españoles, a fin de que las socorriesen para conseguir la

\footnotetext{
${ }^{80}$ Así en el texto de Jaime Ángel Morera, Las pinturas coloniales, op. cit., pp. 64-65.
} 
disminución de sus penas las ánimas se comprometían a ayudar con su protección a los "piadosos españoles" de las tentaciones de esta vida y de las tentaciones del Demonio. Para la fecha del cumpleaños del Rey, el Arzobispo de México Francisco Aguilar y Seijas, había comenzado los sufragios respectivos.

Se conservan diversos testimonios de algunos novohispanos que tuvieron visiones acerca del Purgatorio. Muchos de estas interpretaciones de monjas y clérigos acompañadas de huellas físicas se consideraron como "revelaciones" que hicieron de sus protagonistas candidatos a la canonización; en otros casos, los visionarios terminaron en la Inquisición como víctimas del Demonio. Uno de estos casos (no sabemos su desenlace) sucedió a la V. M. Tomasina de San Francisco del Convento de Jesús María de la Ciudad de México que tuvo este desarrollo:

Una noche durante su noviciado se le apareció en un sueño el alma de un clérigo que le pedía determinadas oraciones para salir de los tormentos del Purgatorio, creyendo que sólo había sido un sueño lo contó a su confesor, en otra ocasión soñó que el espectro del clérigo le decía:

[...] es posible Tomasina que no hagas lo que te pido, ni me compadezcas de las penas gravísimas que me atormentan. Muy bien haces en obedecer a tu confesor, pero si el experimentara a la más mínima parte de mis dolores no se persuadiera a que estás soñando: las oraciones han de ser en comunidad, y el ayuno a pan y agua lo has de hacerte. Respondióle Tomasina, sin despertar: Lo que a mi me pertenece lo haré de muy buena gana luego al instante, pero en lo que toca a las oraciones no se si me creerán las Religiosas, aunque no se los diga. Tenía cuando esto decía puesta la mano izquierda sobre la frente, y descubierto el brazo, y diciéndole el difunto "si te creerán", se lo cogió por la sangradera. ¡O Dios santísimo, como será el fuego que eternamente ha de abrasar, y no consumir a los que mueren en tu desgracia, si tan activo es el temporal en que las almas tus queridas, y que vehementísimamente te aman, se purifican! Llególe el incendio a la Madre Tomasina hasta las mismas entrañas, a cuyos gritos, y al olor de carne quemada despertaron todas sus conovicias y maestras con notable asombro. Dióse cuenta al llustrísimo Arzobispo D. Fray Payo Enríquez de Ribera a cuyo Provisor y Vicario General Doctor D. Antonio de Cárdenas y Salazar, mostrándoles las quemaduras de los cinco dedos, y recibiéndoles sus dichos jurados a algunos cirujanos que parecieron los más a propósito por su práctica, declaró no ser fuego del que en el mundo se veía el que no solo había abrasado a nuestra novicia, sino dejándole encogido el brazo y contraídos los nervios [...]". ${ }^{81}$

${ }^{81}$ Ibidem, p. 68. 
Dicho de otra forma, si la conducta humana resultaba leal a las enseñanzas correctas de la religión demostrando el amor a Dios y su relación a

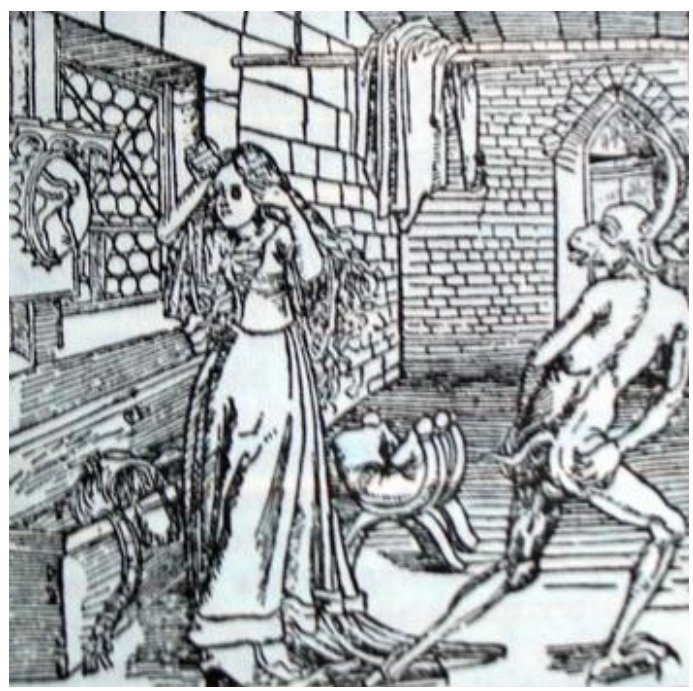

Fig. 24

Ritter von Turn (Caballero de Turn)

Basilea 1493. los indicativos que marcaban la Iglesia el sujeto podía ser recompensado con el cielo. En caso contrario la persona era condenada al sufrimiento eterno del infierno. El proceso entonces de la muerte quedaba pues relegada a dos polos extremos: a la vida casi pura de los santos y del buen camino cristiano; y en otro, la maldad de los herejes y pecadores sin ninguna posibilidad de salvación.

Por eso desde la tierra se podía pedir por aquellas figuras que habiendo muerto en santidad y en proceso de

ser beatificadas (Ánimas del Purgatorio) pudiesen hacer algo intercediendo celestialmente contra los desastres, las enfermedades y la presencia demoníaca. Para esto las obras de caridad comprendidas a favor de vivos o muertos era requisito sin el cual no era posible obtener la salvación en el cielo sino también en la tierra y en sus actos diarios

Estas figuras aliadas del Cielo, que son herencia de la imaginería medieval, siempre estaban siempre prestas para socorrer al necesitado. En contraposición a las ánimas, los demonios alados y las figuras serpentosas como la

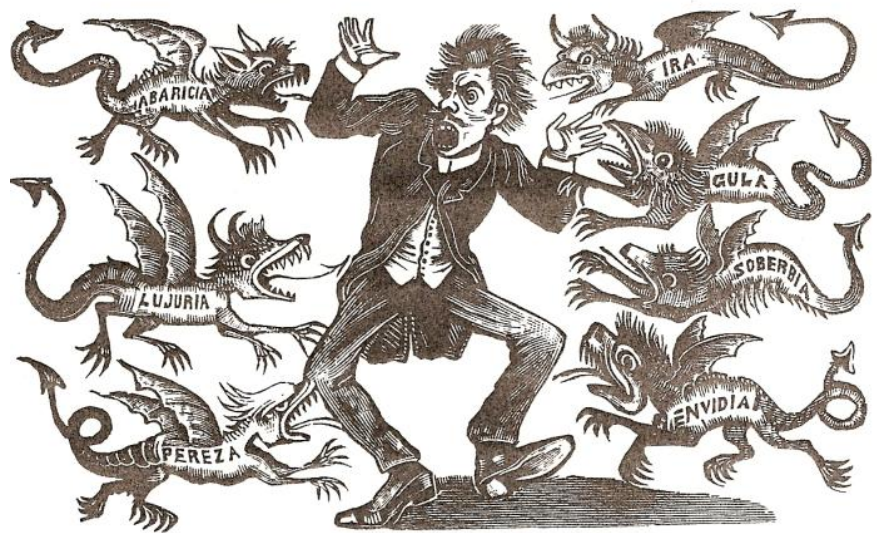

Fig. 25 "Los siete pecados capitales". Grabado de José Guadalupe Posada utilizada para la xilografía de El Caballero de Turn, (fig. 24) constituyeron la imagen propia del ser maligno tentador del individuo y de la sociedad en general, través de los pecados capitales 
Los grabadores Manilla y Posada en la segunda mitad del XIX utilizaron figuras para mostrar la maldad del ser humano, y es común ver en sus trabajos a figuras con pico de aves de larga cola y cuernos demoníacos como sinónimo del mal, indudablemente de marcado origen en la xilografía europea. (fig. 25)

Lo mismo sucede en otra obra llamada "Sensacional acontecimiento espantoso parricidio" en la que suponemos una escena rural, un muchacho ranchero sostiene un puñal contra su padre que se encuentra en el suelo. A su lado la asustada madre mira aterrorizada mientras diversos personajes malignos colocados a su alrededor azuzan al adolescente a cometer el crimen. (fig. 26)

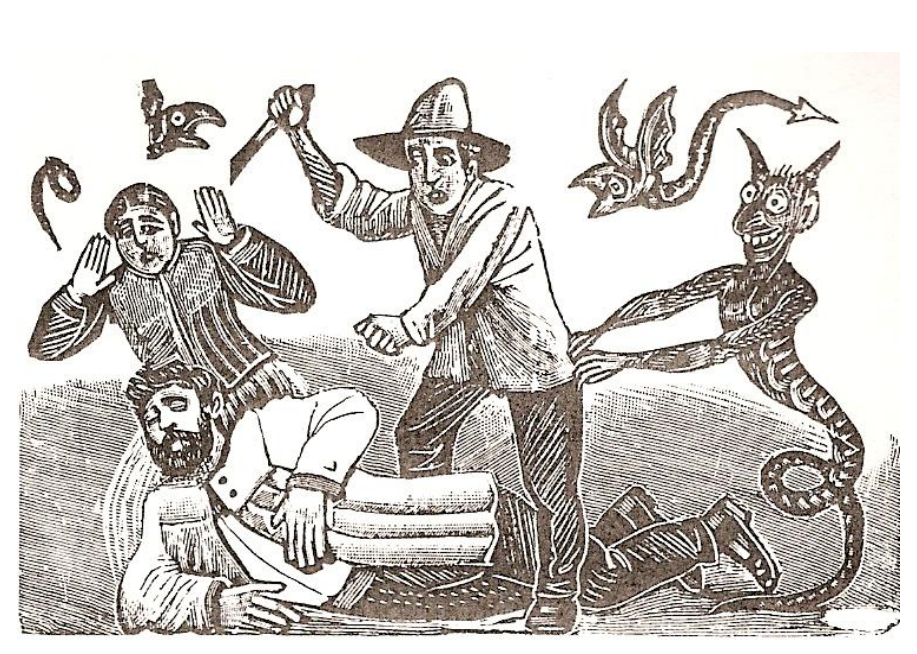

Fig. 26 ¡Sensacional acontecimiento! Espantoso parricidio y verdadero ejemplo en el Saltillo, el primero del mes pasado. Grabado de Posada

Una concepción antagónica de la maldad es la idea del cielo como premio a las acciones en la vida, y por otro lado la tierra como castigo por pecadores en la que el tiempo se eterniza y es el que verdaderamente le preocupa al individuo, y en el que la figura del sacerdote debe y tiene que ser considerado un intermediario celestial. ${ }^{82}$ Esta percepción se observa en el grabado La tierra se traga a José Sánchez por dar muerte a sus hijos y a sus padres. (fig. 27) El grabado es elocuente porque al situarse en la época en que la Iglesia había sido despojada de muchos de sus bienes y recursos, al final de cuentas era su tarea como salvadores de almas.

\footnotetext{
${ }^{82}$ La imagen curiosa puede interpretarse como también una forma de protección física ya que el sacerdote se encuentra colocado de tal manera en la perspectiva de Posada que tal parece que se representa como un escudo protector de los indígenas.
} 
En esta época resulta complicado situar los límites entre lo social y lo individual. La sociedad era el entorno que le daba cabida a las personas y el individuo no podía escaparse tan fácil de su medio sobre todo de la comunidad espiritual a la que pertenecía, y la misma sociedad desigual de ricos y pobres, invitaba, mediante impresos a los

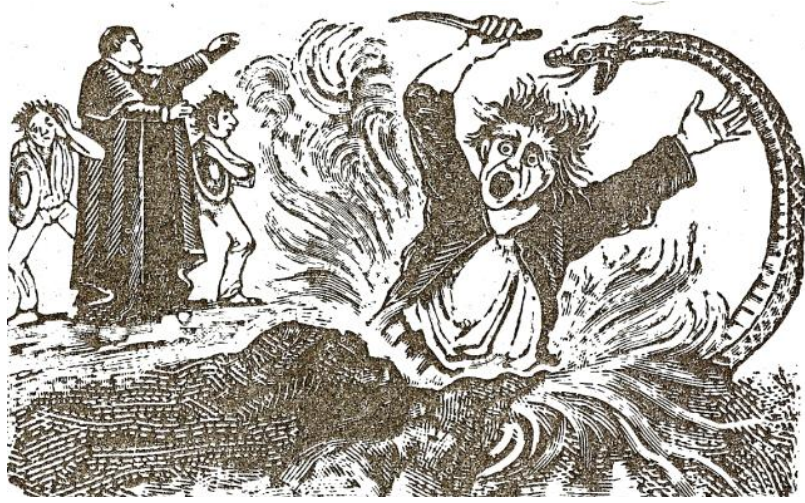

Fig. 27 La tierra se traga a José Sánchez por dar muerte a sus hijos y a sus padres. Grabado de Posada

feligreses a practicar el ejercicio de la oración, los valores y la caridad en forma

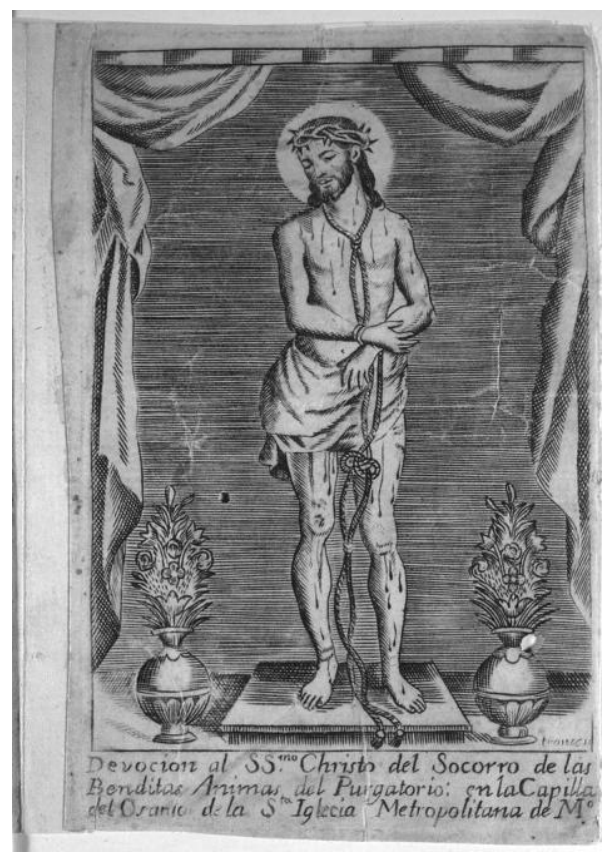

Fig. 28 Devoción al Ssmo. Christo del Socorro de las Benditas Ánimas del Purgatorio: en la Capilla del Osario de la Santa Iglesia del Osario de la Sta. Iglecia Metropolitana de Mo. de limosnas y de donaciones que servían "para purificar al donante para ayudarlo en su carrera de salvación"

Un aspecto final en este apartado es la consideración de la Iglesia para el perdón de los pecados terrenales mediante las indulgencias que eran también impresas y ofertadas en grabados y estampas populares (fig. 28) El término de indulgencia proviene del latín indulgentia que se define como la "facilidad de perdonar o disimular las culpas o en conceder gracias; remisión que hace la Iglesia de las penas debidas por los pecados. $^{83}$ Es decir, que tenían como

finalidad librar al fiel de los tormentos corporales y satisfacer la justicia divina, liberando el sentimiento de culpa tanto de pensamiento como de carne. Tales indulgencias fueron tan abiertas y de todos los sentidos que llegaron a ser un negocio completo de la Iglesia emprendiendo campañas propagandísticas para convencer a los fieles de las ventajas para sus almas si conseguían

${ }^{83}$ Julio Cesar Cervantes, loc. cit., nota 59. 
indulgencias. Los enfermos y moribundos podían ganarlas si "pronunciaban con la voz o con el corazón el nombre de Jesús por lo menos tres veces", y casi todas las congregaciones religiosas de la Nueva España ofrecían cierto tipo de perdón por la visita a una parroquia, a una iglesia, una oración o la repetición constante de un santo así como el ofrecimiento de misas de difuntos, bulas, rosarios, etcétera. ${ }^{84}$

\section{2 La muerte en el interior de las cofradías}

Las cofradías tienen un origen español, pero ya antes en México existían fuertes lazos religiosos que se manifestaban a través de sus cultos y creencias sobre manera en la figura sacerdotal que les auguraba obtener buenas cosechas o éxito en la caza, la pesca o en otras actividades características de la época prehispánica. Según las abundantes fuentes documentales, en la sociedad mexica existían habitantes dedicados de tiempo completo a funciones castrenses, sacerdotales, administración pública y a las actividades artesanales, que activaban el comercio local o territorial.

En los mercados se podían conseguir toda clase de productos que se ofrecían por los diversos artesanos que producían todo tipo de servicios. Además había, artesanos especializados en la construcción (oficiales en la cal y el adobe), escultores, pintores, tejedores de petates, artesanos fabricantes de instrumentos musicales, carboneros, huaracheros, plateros, orfebres mosaiqueros, tejedores de plumas (para escudos guerreros), etc. Dependiendo del gremio, los artesanos poseían un dios y una fiesta al año; en otros gremios poderosos por su influencia como la de los artesanos de plumas, quienes tenían hasta ocho dioses y hacían fiesta dos veces al año sacrificando un esclavo o bien comprándolo entre todos.

Esta forma de unión social se mantuvo inalterable hasta antes de la Conquista española quienes la modificaron espiritualmente suprimiendo los dioses tutelares de las artes y oficios incorporando el ritual católico y

\footnotetext{
${ }^{84}$ Según el libro del Apocalipsis de San Pablo, las ánimas descansaban de sus tormentos por lo menos un día al año y esa fecha correspondía a la fiesta de los fieles difuntos, el domingo de Resurrección, y se retomaban los rezos por los fieles el día lunes. Véase nota 60.
} 
sustituyendo algunas festividades o imágenes paganas por cristianas lo que redundó en una sincretismo, un híbrido festivo de lo indígena con lo español. ${ }^{85}$

Más aún, los practicantes de cada oficio ocuparon determinadas calles de la ciudad lo cual permitió con el tiempo un mejor control sobre los habitantes dedicados a las actividades regidas por las autoridades virreinales: Ios plateros en la calle de San Francisco (hoy Francisco Madero), los forjadores de Tabaco en la calle de Tabaqueros (cerca de la calle actual de Corregidora), los cereros cerca del Empedradillo al lado de Catedral, y así sucesivamente.

La principal función que tuvo la institución de la cofradía en la Nueva España fue la de incrementar la participación en el culto y promover la caridad y la fraternidad más allá de los sacramentos básicos, así como rendirle culto a Dios, a la virgen o algún santo $y$ promover las virtudes cristianas. (fig. 29) Las cofradías aparecieron con el cristianismo desde el siglo VII y si en un principio

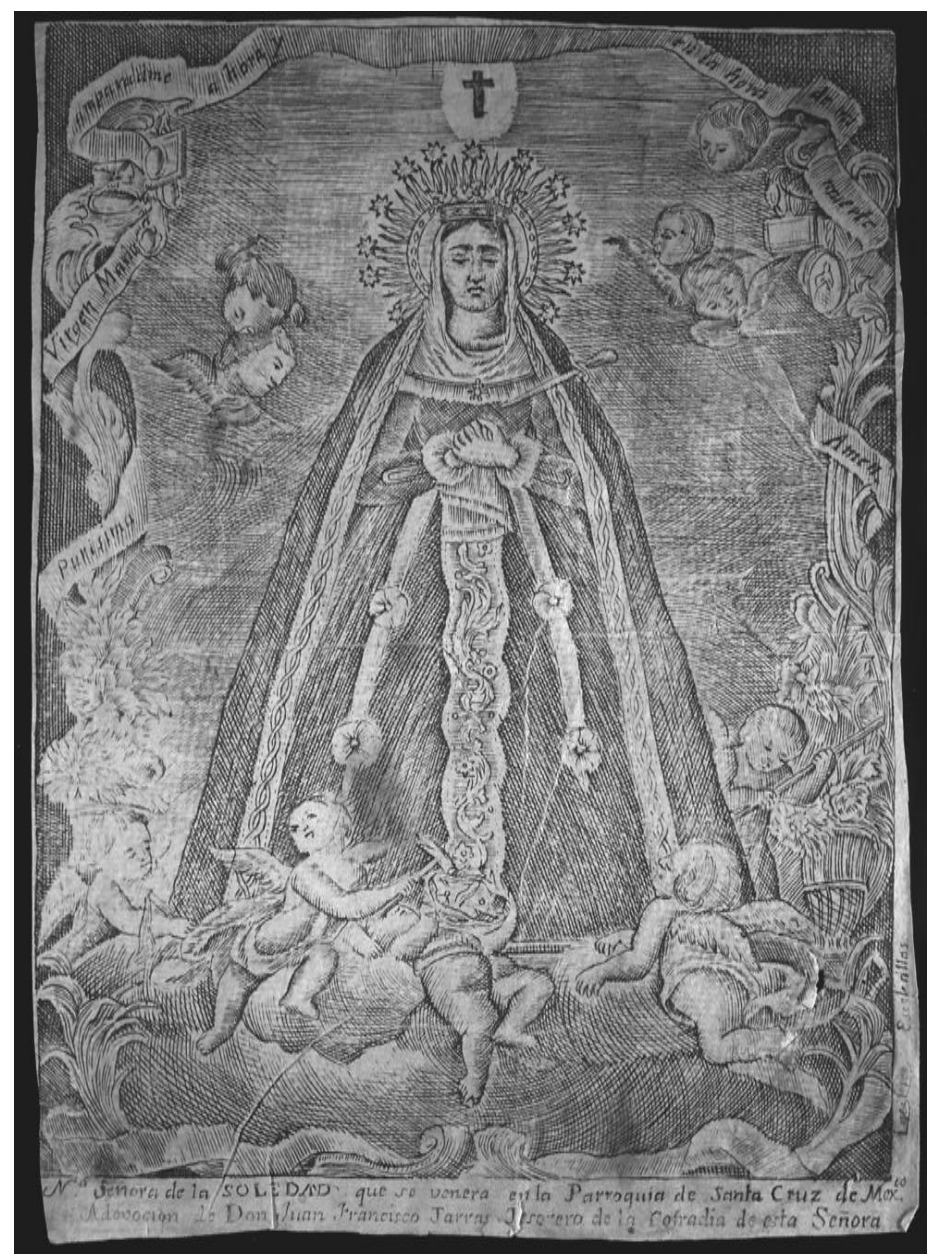

Fig. 29 N.a Señora de la Soledad que se venera en al Parroquia de Santa Cruz de Mexco.

Adevocion de Don Juan. Francisco Jarras. Tesorero de la Cofradía de esta Señora

Buril sobre metal

crearon desconfianza, con el tiempo se estableció una relación estrecha con la Iglesia en la que las cofradías de beneficencia llevaban a cabo obras de caridad en nombre de un santo, así como brindar ayuda que debía prolongarse

\footnotetext{
${ }^{85}$ Dubravka Mindek, Fiestas de gremios ayer y hoy, CONACULTA, 1a. Edición 2001.
} 
después de la muerte, a través de los rezos ${ }^{86}$. En la Nueva España, las cofradías tuvieron un auge importante debido entre otras cosas a que en el siglo que corresponde a la conquista en el Nuevo Mundo en Europa se incrementó notablemente el número de sus agremiados, y en un lugar virgen donde todo estaba por hacer relacionado con obras sociales como hospitales, escuelas o demás instituciones caritativas, inexistentes en esos momentos su ayuda significó una aportación magnífica recibiendo el apoyo del Estado español.

Según estudios documentales, la primera cofradía en las tierras americanas correspondió a la de los Caballeros de la Cruz o archicofradía de los nobles con sede en la iglesia de la Santa Vera Cruz, siguiendo otras como la de Nuestra Señora de la Limpia Concepción y de la Purísima Concepción. Así como hubo cofradías solamente de españoles, hubo también de indios y de mixtos. La primera de indios fue la del Santísimo Sacramento creada por fraile Pedro de Gante en la segunda década del siglo XVI. ${ }^{87}$

La cofradía permitió un excelente medio para inculcar los valores cristianos entre la población indígena, y fueron asimismo, elementos esenciales para el proceso de formación de la nueva cultura colonial, mediante un planteamiento de identificación de acuerdo a las condiciones sociales impuestas por los españoles. En este sentido las cofradías fueron aceptadas por las comunidades indígenas como medios para el sincretismo cultural. En el aspecto religioso sirvieron para transformar su panteón al incorporarle nuevas divinidades. Por ejemplo cuando uno de sus miembros fallecía los hermanos ayudaban haciendo misas para la salvación del alma del agremiado, en consecuencia los muertos intercedían por los vivos una vez que alcanzaban la gloria. Las entradas producto de las colectas entre sus miembros, resultaban en cantidades altas y considerando que por lo menos en la fiesta de celebración de la del patrono de la cofradía y que duraban un mínimo de cuatro días podrá uno considerar que las entradas resultaban apetecibles para la Iglesia. En este sentido, puede decirse que el funcionamiento de las cofradías en la Nueva España, tuvo con ligeras variantes las mismas características en

\footnotetext{
${ }^{86}$ María de los Ángeles Rodríguez, Usos y Costumbres funerarias en la Nueva España, EI Colegio de Michoacán/ El Colegio Mexiquense, México, 2001, p. 109.

${ }^{87}$ BSR Julio César Cervantes López, La archicofradía de la Santísima Trinidad. Una cofradía novohispana, Tesis en Historia, Facultad de Filosofía e Historia, UNAM, México 2000, p.107.
} 
todas las comunidades. Por ejemplo un estudio de Julio Cesar Cervantes sobre la archicofradía de la Santísima Trinidad ${ }^{88}$ presenta los gastos en el aniversario de los muertos en el año de 1794 que se reparte de la siguiente manera

Gastos en el aniversario de los muertos de 1794

$p$-pesos $\quad r$-reales

\begin{tabular}{|c|c|}
\hline RUBRO & COSTO \\
\hline Misa Cantada & $6 \mathrm{p}$ \\
\hline 24 misas & $24 \mathrm{p}$ \\
\hline Música & $3 \mathrm{p}$ \\
\hline Al mozo & $5 \mathrm{p}$ \\
\hline Comida & $5 \mathrm{p.} 2 \mathrm{r}$. \\
\hline Total & $43 \mathrm{p} .2 \mathrm{r}$. \\
\hline
\end{tabular}

A estas celebraciones se agregaban otras no menos importantes como las misas especiales y novenas; además aquellas que tenían que ver con la concesiones de gracias, perdones e indulgencias llamadas "Jubileo" en las que se aprovechaba para hacer depósitos de dinero que sumado a los cooperaciones del cuadro anterior daba un aproximado de más de 1084 pesos.

Para que las fiestas tuvieran fuerza y arraigo se invitaba a personalidades altas de la iglesia a las que se les obsequiaban dulces o ropa, que si bien, representaban gastos extras, las cofradías sabían que con estas invitaciones se le daba importancia al gremio que debía mostrar un respeto y una disciplina en los eventos empleando los símbolos propios de la corporación como estandartes, escudos, y vestimenta de color.

Para la primera mitad del siglo XIX, encontramos que entre los oficios importantes que se desarrollaban en la ciudad por rama de actividad estaban los gremios que se dedicaban a la imprenta y papel y que contemplaban a los

88 Ibidem. 
impresores, grabadores, litógrafos, papeleros y encuadernadores. Lo cual es indicativo de que llegó a ser un gremio con fuerza, siendo el santo patrono de los impresores San Juan de Dios cuya fiesta se celebraba el 8 de marzo ${ }^{89}$

La presencia de estos gremios decayó con el paso del tiempo, prohibiéndose a partir de 1783 la creación de nuevas cofradías. Una muestra de la debilidad y la precaria situación por las que atravesaban los gremios y las cofradías fue la apertura de nuevas calles que rompieron los espacios de sus actividades cerradas al resto de la comunidad.

Por otro lado con la secularización del país y la implantación de la Ley de Nacionalización de los Bienes Eclesiásticos en 1859, las cofradías perdieron las propiedades que poseían en forma conjunta. Para rematar su situación tuvieron su golpe de gracia debido a los cambios sociales que vinieron después del imperio de Maximiliano pasando a la historia las procesiones, fiestas y celebraciones gremiales.

Hemos visto anteriormente como la religión trató de explicarse el asunto de la muerte a partir de la fugacidad de la vida, y de cómo el cristianismo marcó un momento fundamental en este sentido. Así en términos generales, la lucha del hombre se desarrollaba entre el bien y el mal, entre el Paraíso y el Infierno, o más concretamente entre la vida y la muerte. Las cofradías se preocuparon por la labor de sus cofrades para el momento de la muerte y dicha preparación tenía que ver con que llevaran una vida recta cumpliendo con sus obligaciones ante la Iglesia que a su vez proveía los instrumentos necesarios para tener una "buena muerte". Para llevar a cabo esta acción, la cofradía ofrecía a sus agremiados la venta de indulgencias lo que permitía acortar el camino para estar cerca de Dios. ¿Cuáles eran éstas? Se podía visitar iglesias, dar hospedaje a los peregrinos, visitar hospitales, así como dar de comer a los enfermos y lavarles los pies. Dichos ejercicios espirituales debían ser durante siete días continuos.

Ya para terminar este apartado, se debe decir que las cofradías ofrecían indulgencias de carácter "parcial", lo cual significó la presencia de los cofrades

\footnotetext{
${ }^{89}$ Un cuadro de Sonia Pérez Toledo incluido por Dubravka Mindek, sobre los artesanos de la ciudad de México es indicativo de la proliferación de oficios existentes en 1842 y su agrupación por actividades. op. cit., pp. 32-33.
} 
en actos de oficios divinos; así como, rezar y la asistencia a la iglesia de tal manera que el fiel se aseguraba una "salud espiritual inmejorable", con el único destino de alcanzar el Paraíso.

Así por lo menos las cofradías mantuvieron un serio compromiso consigo mismo y con sus integrantes de mantener una vida alejada del pecado y cumplir con los mandamientos para obtener la vida eterna. Asimismo, la cofradía permitió una salida espiritual en las celebraciones religiosas para mantener unida a la comunidad en torno de la muerte prestando un gran servicio no sólo por el descanso del cuerpo del difunto sino también por el descanso eterno de su alma.

3. 3 El ser agónico y el sermón fúnebre

La agonía constituía antes y ahora un momento de justificación de la vida antes del paso final y definitivo de la muerte en los que se trataba de enmendar los errores del pasado en los que se pasaba de la confesión a la reflexión, del $\begin{array}{llll}\text { pecado a la } & \text { paz } \\ \text { interna y } & \text { de } & \text { las } \\ \text { tentaciones } & & \text { del } \\ \text { cuerpo } & \text { a } & \text { la }\end{array}$ tranquilidad espiritual para llegar a un "éxtasis" que se interpretaba como el momento en que el alma abandonaba el

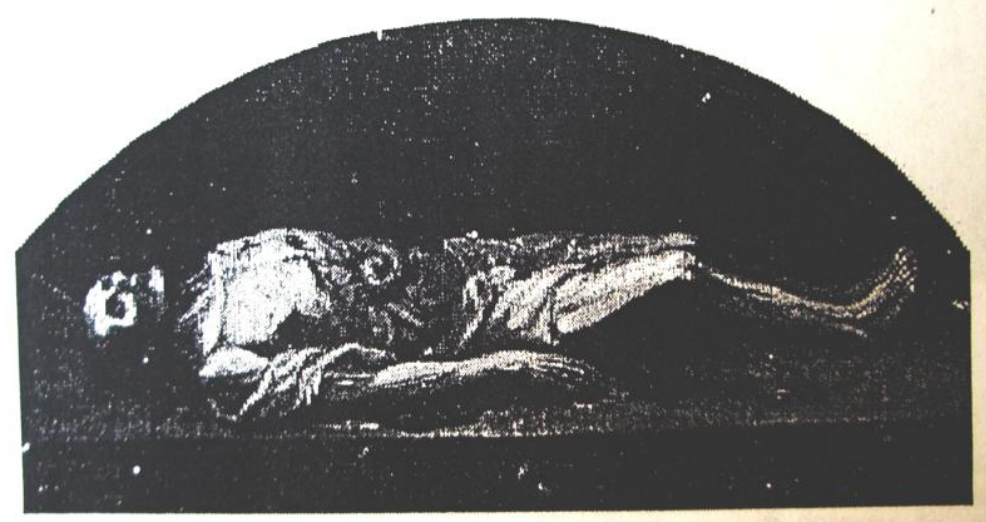

Fig. 30 "Pudridero". De una pintura anónima cuerpo para enfrentar al creador. (fig. 30)

Este momento involucraba a un gran número de personas cuya presencia era considerada como de suma importancia para la salvación del alma. Con el correr de los años se hizo un acto íntimo y privativo de la familia pero en ese entonces no había muerte más deshonrosa, que la solitaria y por ello se 
requería de la presencia solidaria de otras personas. Junto al lecho del moribundo eran entonces colocados objetos devocionales como reliquias que lo unían a la santidad. Así los escapularios, que daban al agónico la certidumbre de tener una buena muerte, libros de oraciones para ahondar en la palabra divina; agua bendita con aspersor para evitar la proximidad del demonio; velas que simbolizaban la luz de la fe y que seguiría ardiendo en la eternidad que a su vez representaban tres elementos: la cera de la abeja virgen que significa la carne de Cristo, el pabilo representa el alma y la llama simboliza su divinidad. Éstas podían ser blancas o amarillas y su tamaño variaba de acuerdo con la función como cirios de altar o cirios de penitentes. El costo de las velas era alto debido al monopolio de la cera ejercido por Castilla, por ejemplo, a mediados del siglo XVIII la libra de cera costaba más de un peso.

Para impedir los abusos cometidos por los confesores la Corona española se vio en la necesidad de prohibir el 25 de septiembre de 1770 que se abusara de la condición de moribundo y que por tal motivo se realizara un fraude a éste o a los familiares por parte de los miembros de la Iglesia que no tenían medida de ambición ante la posesión de bienes ajenos: “...pues con esta moderada providencia no se restringe ni limita la piedad porque al que le naciere de ella y de devoción la podrá hacer todo el discurso de su vida [...]". ${ }^{90}$ Un detalle interesante por parte de la Iglesia es que quien fuera llamado por un moribundo y acudiera muy tarde para impartir los sacramentos, era castigado con la reclusión en su iglesia y la obligación de decir misas por el difunto. Esta por demás decir, que en las diversas clases sociales existentes en la Colonia, la más propensa a enfermar y morir tempranamente era la mujer debido a la procreación y a la lactancia.

Por otra parte, varios ejemplos gráficos del siglo XVI se refieren al tema de los "Sermones Fúnebres", que no eran otra cosa que discursos cristianos elaborados sobre algun punto doctrinal o moral divididos en temas o funciones, realizados en el proceso de la dolorosa agonía de los personajes. Habría que recordar que era precisamente en éste tránsito cuando muchos de los bienes

90 Citado por Verónica Zárate Toscano, Los nobles ante la muerte en México, Actitudes, ceremonias y memoria (1750-1850), El Colegio de México / Instituto Mora, Centro de Estudios Históricos, 1ª. Edición, México 2000, p. 202. 
del moribundo pasaban a ser propiedad de alguna de las diferentes congregaciones religiosas entonces poderosas en la Nueva España. Para impedir estas actitudes ambiciosas de la Iglesia, se congregaban amigos y familiares ante un moribundo que podía fácilmente ceder, en momentos de debilidad, su fortuna al representante de Dios en la tierra. Debido a estas actitudes el aspecto testamentario se incrementó notablemente gracias al esfuerzo del gremio de los notarios que comenzaron a realizar su trabajo en forma eficiente. Con esto se permitía un reparto eficaz y justo de los bienes monetarios, muebles e inmuebles ante una autoridad suprema. Con esto se lograban futuras desavenencias legales y la presencia viva de los bienes del difunto.

Estos sermones fúnebres se pronunciaban en honor de civiles y religiosos y entre los que se incluían miembros de la nobleza. Estos escritos en

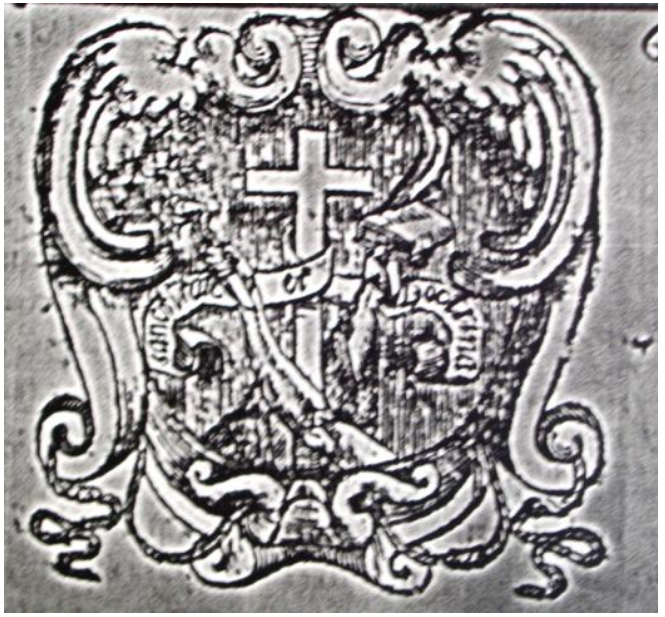

Fig. 31 " Fúnebre Panegyris" de Diego del Castillo Grabado en plomo verso o en prosa pertenecen a la categoría de literatura laudatoria y se pueden leer en él las virtudes terrenales del difunto hacia la Iglesia. Son interesantes porque permiten conocer datos biográficos del personaje, su vida en sociedad, su agonía, el sepelio y sus exequias, como sucedió a Diego del Castillo, comprador de plata, quien se consagró como patrono de su iglesia en el "Muy llustre Convento de las Señoras

Religiosas Descalzas de Santa Isabel, de esta Ciudad de México el día 29 de marzo de $1683^{\prime \prime 1}$ (fig. 31),

\footnotetext{
${ }^{91} \mathrm{CEH}$ Graxales, Francisco, Fr., Sermón Fúnebre En las exequias, que hizo la Provincia de México en su Convento grande de dicha Ciudad a Nuestro Rmo. P. M. FR. Joan Antonio Velasco Maestro General de todo el Real, y Militar Orden de Nuestra Señora de la Merced, Redención de Cautivos, Señor de las Varonias de Algar, y Escales, Diputado mayor de el Reyno de Valencia, Theologo de la Real Junta de la Concepción de María Santisima.
}

CEH Correa Antonio, Fr., Fúnebre Panegyris, que a las honras del muy piadoso y nobilisimo Republicano Diego del Castillo Comprador de Plata, consagro como a Patrono de su Iglesia El Muy llustre Convento de las Señoras Religiosas Descalzas de Santa Isabel, de esta Ciudad de México el dia 29 de marzo de 1683 Predico El P. Fray Antonio Correa Predicador mayor del Convento de N.P.S. Francisco desta Ciudad. 
De aquí se desprenden varias lecturas: por un lado, el fuerte lazo religioso que unía a la sociedad novohispana; y por otro, la acumulación de riqueza por parte de una clase dominante de origen español. Si se revisan los sermones fúnebres predicados en las exequias de los nobles y publicados en la Nueva España se puede hallar una historia de las mentalidades peculiar, en las que, era necesario invocar el temor a Dios para la repartición de los bienes acumulados en vida. Verónica Zárate en su libro Los nobles ante la muerte en México ha estudiado que los poderosos no veían en la riqueza un peligro para su salvación, sino más bien al contrario: la repartían entre los más necesitados para así ganar el cielo. Así, en las honras fúnebres del marqués de Villar del Águila, un panel pintado mostraba un globo "beneficiando a la tierra con una copiosa lluvia de monedas" con una octava que decía:

\section{Con una mano franca más que liberal pródigo se mostró con el mendigo y siendo su materia de cristal huyó su transparencia de testigo}

Derramaron sus manos el metal que otros retienen como fiel amigo por eso la piedad juzga su vuelo de mano de los pobres hasta el cielo ${ }^{92}$

Hasta aquí hemos visto que la muerte de los nobles se convertía en modelo para las clases sociales en la Nueva España, aunque muchas veces estos últimos fueron modificados en sus conductas por la cultura popular. Estos intercambios se debieron a la forma y al modo de enfrentarse a la muerte para ser preparado espiritualmente y físicamente del cuerpo para la última morada, desde amortajarlo, la ceremonia de velación y finalmente el acto de sepultura.

Veamos detenidamente como se manifestaban los implementos o complementos que eran usados cuando se presentaba la muerte en tiempos coloniales y que la mayoría se han conservado hasta nuestros díaas con ligeras variantes:

\footnotetext{
${ }^{92}$ Verónica Zárate Toscano, op. cit., p. 160.
} 


\section{4 Los testamentos}

Testamento proviene del latín testatio, (testimonio) y mens (entendimiento, o espíritu) es decir "testimonio de la voluntad del hombre", y fue a partir del siglo XII cuando se comenzaron a utilizar en Europa para dejar establecidos los bienes que en vida se generaron y su correcta repartición entre los deudos en los que podían estar familiares y los no familiares. Según parece su origen puede deberse al fortalecimiento de la economía medieval, al renacimiento urbano y a la expansión del occidente medieval. Puede deberse asimismo a la inestabilidad que se producía en los tiempos de guerra y de paz que motivó una manera de asegurar los bienes en caso de fallecimiento. Por otra parte, en esta época es definitivo el concepto de purgatorio en el imaginario colectivo que consiste en una especie de "limbo" entre el cielo y el infierno que permitió al mismo tiempo, un paralelismo religioso y social con el surgimiento de una clase intermedia entre los señores feudales y los vasallos llamados burguesía. ${ }^{93}$

Para el siglo XV, el testamento era reconocido entre autoridades religiosas y laicas y su registro debía darse ante un tribunal. Una función de los testamentos ligada a la religión cristiana era hacer cumplir con lo especificado por el firmante de dicho documento, lo que permitía la tranquilidad espiritual y el tránsito de una vida a otra. En su elaboración se comenzaba invocando el nombre de Dios Todopoderoso como una forma de creencia fuerte e indisoluble con la verdad y con la eternidad. Con el tiempo se fue diluyendo el aspecto espiritual para quedar el aspecto material de los bienes del difunto en los que las disposiciones testamentarias quedaban definidas de acuerdo a los deseos de viudez, matrimonio, obligaciones, terrenos y casas, reparto de bienes entre parientes, etc.

Existe en la obra de Bernal Díaz alusiones al testamento de herencia de poder y como se realizaba entre los viejos conquistadores venidos de España:

\footnotetext{
${ }^{93}$ Javier Otaola, Muerte y Salvación, op. cit.,p. 38-47.
} 
[...] Teniendo en sí la gobernación Marcos de Aguilar, como dicho lo tengo, y estaba muy hético y doliente de bubas, los médicos mandaron que mamase a una mujer de Castilla y con leche de cabras se sostuvo cerca de ocho meses, y de aquellas dolencias y calenturas que le dio falleció, y en el testamento que hizo mandó que sólo gobernase el tesorero Alonso de Estrada $[\ldots]^{94}$

Con la llegada de los españoles a la Nueva España, la realización de testamentos comenzó a arraigarse de forma por demás lenta, debido a que se consideraba que esta práctica conducía de manera inminente a estar a las puertas de la muerte, aún cuando existen ejemplos de testamentos indígenas claramente especificados en cuanto a propiedades para sus sucesores como el llamado "Códice Sierra".

Debido a esta situación, por ejemplo a principios del siglo XVIII, la Congregación de la Buena Muerte, dio a conocer el documento llamado Dificultad imaginada y facilidad verdadera en la práctica de testamentos cuyo objetivo principal era desterrar el miedo a la muerte y la elaboración de un testamento. $^{95}$

El testamento parece ser que siempre fue un documento caro, y conforme pasó el tiempo se fue haciendo cada vez más inalcanzable en cuanto al precio, lo cual dependía de la cantidad de hojas redactadas por el escribano y lo extenso y complicado lo cual hacía que muchas veces los jueces tuviesen que dictaminar el pago justo por el testamento.

Juan Ricardo Jiménez ${ }^{96}$ encontró lo que parece ser un formato o un esquema previo (machote) que respondería a las necesidades de rapidez y eficiencia que deberían de tener los escribanos en el siglo XVIII y que permite comprender las grandes dificultades por las que pasaban los notarios para las redacciones de documentos legales en cuanto al tiempo y al precio. De todos modos, las tarifas notariales lejos de bajar de precio, aumentaron y se mantuvieron en buena parte todavía del siglo XIX, de lo cual se deduce que el deseo de realizar un testamento por lo menos no estaba al alcance de todos los bolsillos.

\footnotetext{
${ }^{94}$ Bernal Díaz del Castillo, op. cit., p. 516

${ }^{95}$ Verónica Zárate Toscano, op. cit., pp. 27-28.

96 Juan Ricardo Jiménez Gómez, Un formulario notarial mexicano del siglo XVIII. La institución de escribanos de Juan Elías Ortiz de Logroño, Editorial de Miguel Ángel Porrúa / Universidad Autónoma de Querétaro, México, 2005.
} 


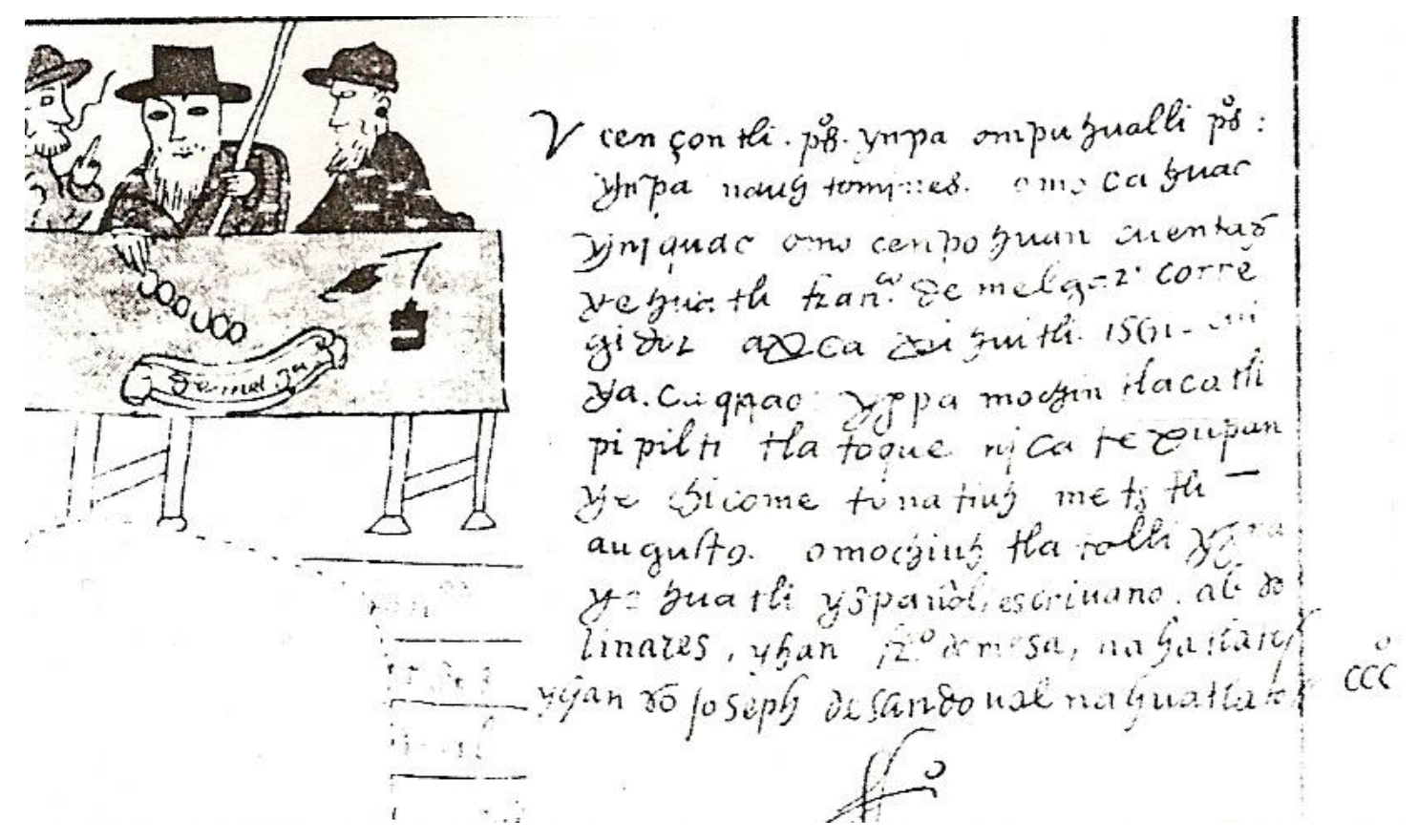

Fig. 32 Códice Sierra. En 1561. El intérprete Francisco Valdivieso y el escribano, recibieron 30 pesos por haber hecho las cuentas. Texupan, Oaxaca 1559.

Un aspecto que a su favor se puede agregar es que existían regulaciones a la repartición de las herencias y que la división de bienes era un asunto complicado sobre todo por la "quinta parte" que fue impuesta por las autoridades españolas incluso a los indígenas en el tránsito hacia la muerte (fig. 32), es decir, los deducibles que generaban los gastos del entierro como misas, limosnas, y otros gastos generados por el acto como gravámenes y extras.

Un acercamiento legal a este aspecto lo daba el libro "Práctica de testamentos" de Pedro Murillo Velarde, que como ya lo dijimos anteriormente era una combinación de asuntos religiosos y civiles y que ayudaba a entender este proceso que en términos generales se dividía en tres partes:

1.- El protocolo inicial. Es decir la invocación divina; los datos generales del testador como nombre, vecindad, edad, en los que se incluía el estado de salud. 
2.- La exposición de motivos. Entre otras cosas se escribían el estado civil, las disposiciones de deudas, reconocimiento de deudas, herederos, anulación de otros testamentos, disposiciones religiosas después de la muerte.

3.-El protocolo final. Con la fecha de la elaboración las firmas de todos los testigos, el testador, y el escribano acompañados de su signo.

A su vez el escribano seguía procedimientos que le permitirían realizar en forma conveniente su trabajo legal tales como el entendimiento entre el moribundo y él. Es decir entre lo que se decía y se escuchaba y lo que se escribía. Llamar a seis o diez testigos era también parte de su trabajo con la condición de que no fueran vecinos, ni familiares, que tuvieran la edad

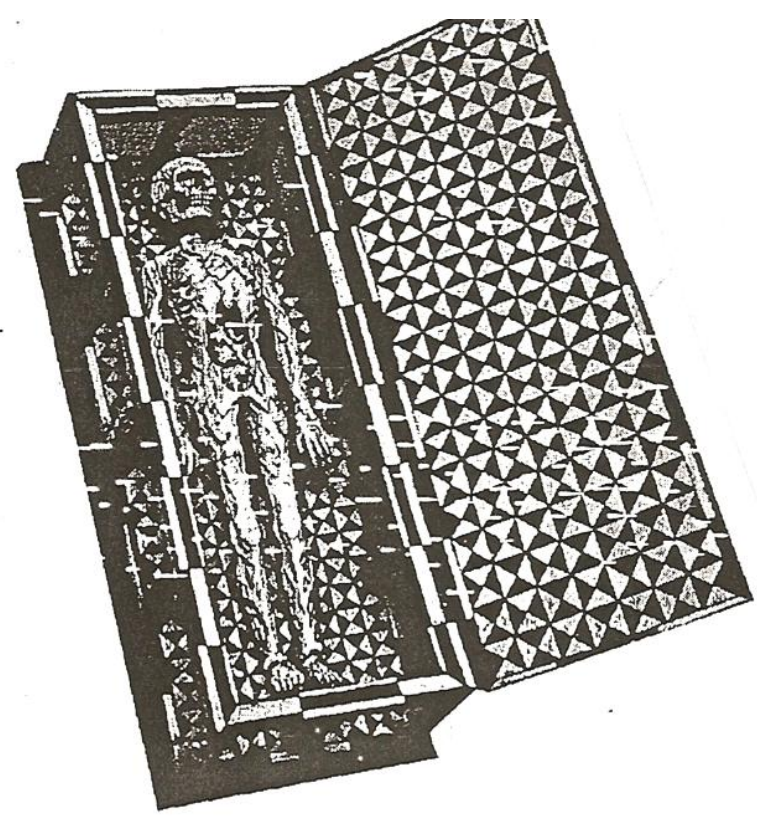

Fig. 33 Memento Mori.

El sarcófago incluye seis figuras: un papa, un emperador, un patriarca, un sultán, un monje y un caballero, símbolos de la oposición entre el mundo terreno y el espiritual. adecuada $\sin$ ser viejos, ni muchachos y que fueran sólo varones y sacar del lugar a la demás gente para que no oyera las disposiciones que se iban a tomar entonces.

3. 5 Preparación del cuerpo y el ataúd

El cuerpo ya sin vida era preparado por cirujanos y boticarios para extraerles las entrañas y untados con sal, ungüentos, aromas, confecciones, pólvora y barnices para impedir el mal olor y se procedía a ingresarlo a una caja o varias dependiendo su poder económico. (fig. 33) Cuando se trataba de autoridades importantes como reyes, virreyes y vasallos debían de estar presentes autoridades para el reconocimiento de estas acciones. Aún con esto, se daba el caso de que muchas veces se cometían irregularidades con los cuerpos al momento de practicar las disecciones anatómicas debido al poco conocimiento 
médico de la época. Algunos cuerpos por supuesto ya no llegaban a esta parte debido en estos casos extremos a la descomposición rápida del cuerpo. Algunos nobles como el tercer marques de Jaral de Berrio pedían incluso que antes de descomponerse su cuerpo se les mandara abrir y "sacar el corazón y entrañas para [sepultarlo] en campo santo". 97

Para impedir el lucimiento desproporcionado en la presentación de las cajas o del ataúd el 22 de marzo de 1693 se hizo público un Bando Real que pedía ante esto la humildad para el acto:

Que los ataúdes en que llevare a enterrar los difuntos no sean de telas ni de colores sobresalientes, ni de seda, sino de bayeta, paño u holandilla negra clavazón negro, pavoneado, y galón negro o morado, por ser sumamente impropio poner colores sobresalientes en el instrumento donde está el origen de la mayor tristeza, y sólo se permite que puedan ser de color y tafetán doble y no más los ataúdes de los niños hasta salir de la iglesia. ${ }^{98}$

Aún con estas disposiciones, tanto las cajas como los ataúdes seguían presentándose de formas adornadas exquisitas, compuestas de finas telas, con abundancia de oro y plata, sábanas de cambray y encajes finos lo que hizo de esto un verdadero negocio, ya que, en esta época se prestaban tanto el ataúd para presentar el cuerpo, como el cajón final para la tierra. La imagen 34 permite

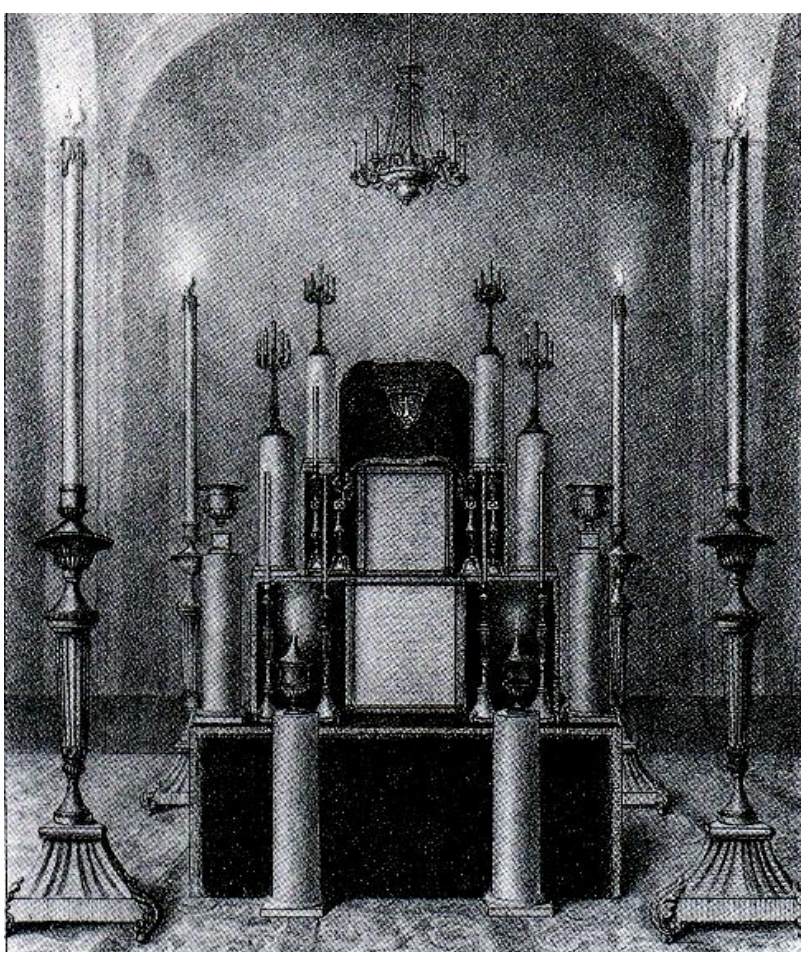
observar una presentación bien dispuesta para este fin. Esto es Fig. 34 Honras de Fray Manuel de S. Crisóstomo Litografía importante ya que la diferencia

\footnotetext{
${ }^{97}$ Verónica Zárate Toscano, op. cit. , p. 218

98 Ibidem, Bando del virrey Bucareli. p. 221.
} 
entre ataúd y caja es debido al arancel que especificaba que en cualquier entierro el ataúd se diera a un peso y la caja a dos pesos. ${ }^{99}$

Estos negocios debieron de ser comunes en esos tiempos sobre todo para gente carente de recursos económicos, ya que el "Diario de México" del año de 1812 publica una nota del alquiler de ataúd, sábanas, almohadas y utensilios de luto para los muertos, sobre todo considerando que se pasaba por crisis económicas aunque el pueblo bajo ni siquiera alcanzaba ese beneficio. (fig. 35) No es necesario decir la insalubridad que debió existir de deudos y difuntos al sólo contacto con los cuerpos, además de provocar el contagio de enfermedades. Esta costumbre cambió con el tiempo y el cuerpo pudo ser envuelto en una sábana blanca o la ropa de uso común del difunto y posteriormente enviado a la tierra. Como hemos visto, el ataúd cumplía en primer lugar la función de transportación

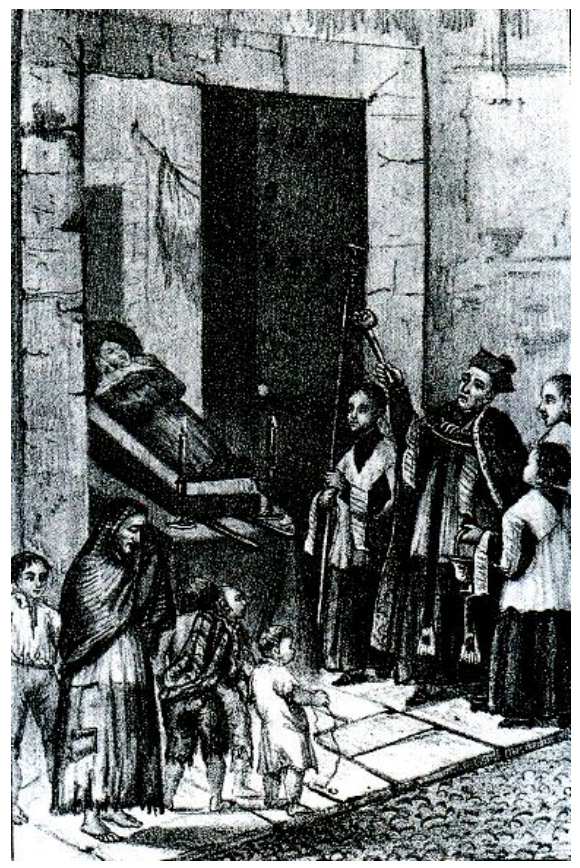

Fig. 35 Bendición a un cadáver en una vecindad. Litografía del siglo XIX.

del cadáver hasta el lugar de inhumación, en segundo, servía para darle sepultura y con eso, penetrar en las entrañas de la tierra.

Algunos nobles quisieron ser más explícitos en sus decisiones para con su cuerpo. Veamos algunos ejemplos: primer conde de Regla fue enterrado en un ataúd clavado y un contra-cajón para poder ser trasladado a una capilla familiar. Su hijo el segundo conde pidió que se utilizara un "cajón cubierto". El tercer conde pidió ser puesto "en un cajón de madera forrado de plomo, clavado y soldado". Cabe señalar que junto a sus restos se encontraba un frasco con los datos que indicaban su nombre lo que permitió su identificación al ser trasladados de lugar. Josefa Zabalza en su testamento pidió que se "...condujera su cadáver en una caja de plomo tapada herméticamente y otra de madera". Un detalle curioso es que años más

\footnotetext{
${ }^{99}$ María de la Ángeles Rodríguez, op. cit., p. 89.
} 
adelante, en 1856, una comisión municipal creada para informar sobre el estado real de los panteones de la ciudad recomendó que se prohibiera este tipo de materiales junto con el zinc, “...porque el día que una casualidad rompa las cajas, se hace un enorme desprendimiento de gases perniciosos para la salud". ${ }^{100}$

Una preocupación del mundo de los vivos durante mucho tiempo, fue el hecho de considerar la posibilidad de que por error fuesen enterrados vivos. Esta idea vino gestándose desde el siglo XVII cuando se ordenó guardar un periodo mayor a 24 horas antes de dar sepultura a los cuerpos, sobre todo en casos de muerte repentina o por heridas. Tal parece que el pedimento de los nobles era una constante en una época donde pudiese pensarse que eran comunes los enterramientos de personas vivas. Sin embargo es posible que esta idea haya surgido en tradiciones y leyendas de seres que eran sepultados sin que los médicos hayan constatado verdaderamente su muerte efectiva. Algunos nobles, pedían concretamente un plazo más amplio de 48 horas para que los facultativos estuviesen seguros de verificar el cuerpo ya sin vida. Hay que recordar que es en el siglo XVI cuando los relatos de los enterrados -vivos de este tipo tienen más fuerza.

\section{6 El velorio}

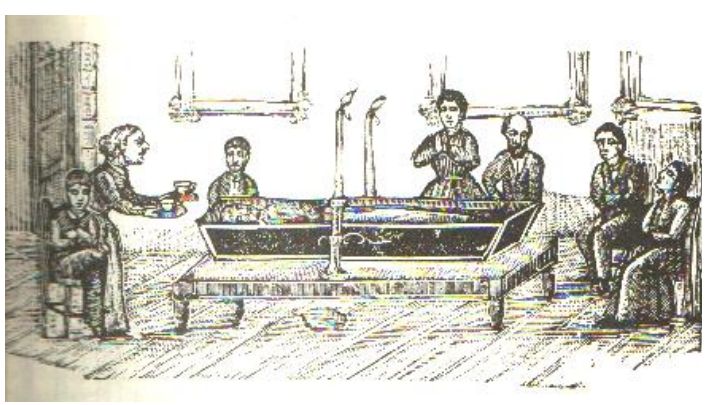

Fig. 36 Ceremonia de velación. Litografía
La utilización de velas o candelas ante el ataúd como una forma respeto (fig. 36), fue una costumbre que hasta la fecha se realiza hoy en día, y su significado tiene que ver con la luz que es la resurrección eterna en pequeñas capillas donde se oraba por la paz y el descanso del alma con infinidad de velas, de aquí el nombre de "capillas ardientes". La primera vela importante es la llamada del bien morir y era

${ }^{100}$ Verónica Zárate Toscano, op. cit., pp. 222-223. 
utilizada cada vez que se veía a un agonizante ponerla en sus manos antes de morir.

Más adelante se verá la utilización de la cera pero en este pequeño apartado mencionaremos que era de alto precio en los primeros tiempos de la Colonia y se agotaba cuando se requería para un funeral importante. Así sucedió con los funerales del visitador de su majestad Luis Ponce de León en la Nueva España en los que "[...] Cortés con todos los más caballeros de aquella ciudad se pusieron de luto y le llevaron a enterrar con gran pompa a Señor San Francisco, y con toda la cera que entonces se pudo haber; fue su enterramiento muy solemne para en aquel tiempo...."101

No se diga de su consumo masivo en los túmulos que eran un verdadero espectáculo de velas en grandes cantidades, que hablan de la

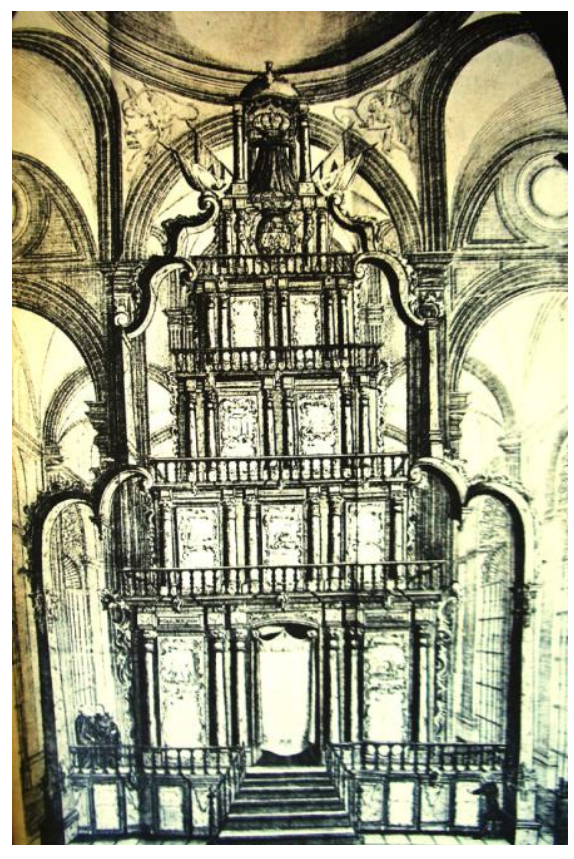

Fig. 37 Túmulo funerario. Litografía estrecha relación entre las cantidades de velas y la opulencia de las clases poderosas. (fig. 37) Un caso extraordinario fue el túmulo en honor de Carlos V levantado en San José de los Naturales en 1554 donde se gastaron más de 200 arrobas de cera. Es interesante saber que la escasez que produjo este enorme monumento funerario motivó un reciclado de la cera consumida para volver a ofrecerla al público.

Durante los entierros, la Iglesia recibía su dote de velas contemplado como arancel en términos muy específicos que les permitía alumbrar la ceremonia y el altar para ese acto o para otros diferentes velorios y entierros.

Otro uso de la cera era la que se utilizaba en las procesiones que acompañaban al cuerpo, -una por cada doliente- que le daban solemnidad al acto de acompañamiento. Para esto se podía pedir en el testamento hasta el color de la cera que podía ser amarilla o blanca. Cristóbal de Rebaguda, por ejemplo, pide que "[...] mando se compren seis cirios de cera blanca que pesen

${ }^{101}$ Bernal Díaz del Castillo, op. cit., p. 511. 
cada uno tres libras...”. O bien, el testamento de María de las Nieves en 1597, "[...] que pide que la cera labrada que se encuentre en su casa al momento de fallecer se utilice en su entierro...". Una manera de regular estas celebraciones ostentosas por parte de la comunidad fue la expedición de la Cédula Real del 22 de marzo de 1693 sobre la manera de guardar luto y pide "[...] que solo se pongan en el entierro doce cirios con cuatro velas sobre la tumba "102

\section{7 Las campanas}

Originalmente, las campanas han tenido la función de ser un medio de comunicación para que por medio de su tañido se convoque y se dé aviso y se ponga atención por medio de sus sonidos. Las campanas fueron utilizadas desde los primeros tiempos de la Colonia y aglutinaban a las clases sociales en un sitio determinado para la oración y la reflexión.

Luis Gonzáles Obregón en su libro sobre Las Calles de México, menciona que la ciudad creció en población, edificios, calles y plazas que fueron invadidos por nuevos monasterios, iglesias, hospitales, hospicios y colegios que

[...] todo el día, campanas y esquilas llamaban a misa o a sermón, repicaban hasta aburrir en las grandes festividades, o doblaban en las muertes de los reyes, de sus consortes, y de los príncipes, en las de los canónigos y de prelados, y en la de ricos vecinos que, en vida o al morir, habían legado a los monasterios, a los colegios, a los hospitales, cuantiosos legados para mejorar los edificios, fundar cofradías, dotar monjas o huérfanos, curar enfermos o socorrer menesterosos. ${ }^{103}$

Las campanas, pues, acompañaban a los habitantes de la Colonia en su vida cotidiana: anunciaban el amanecer con el toque de las "Ave Marías", después a las primeras misas, y posteriormente para comer, hora en que se aprovechaba para darle cuerda a los relojes. A las tres sonaba la campana de Catedral que después repetían el resto de las campanas colocadas en Catedral y en otras iglesias, para que con el transcurso del día sonara el Angelus,

\footnotetext{
${ }^{102}$ María de la Ángeles Rodríguez, op. cit, p. 122-123

${ }^{103}$ Luis González Obregón, Las calles de México, leyendas y sucedidos vida y costumbres de otros tiempos, prólogo de Carlos G. Peña y Luis G. Urbina, editorial Porrúa, colección "sepan cuantos", número 568, México 2003, p. 127.
} 
llamada de "las oraciones". A las ocho de la noche y para entonces todas las mujeres dentro de las casas, se oían durante un cuarto de hora la "plegaria de las ánimas". Para el día de difuntos después de la plegaria seguía el "doble" prolongado casi siempre media hora. $Y$ antes de las nueve de la noche se escuchaba el "toque de queda", que correspondía a la ronda de guardias o alguaciles que tenían a bien ofrecer seguridad en las oscuras y peligrosas calles de la ciudad. Para cerrar, a la media noche se escuchaban aún las pequeñas campanas de los conventos de frailes y monjas para rezar "maitines" en los coros. ${ }^{104}$

El toque fúnebre dado en la Iglesia significa el "llanto de los difuntos" que pide a Dios que se ruegue por ellos y en la vida religiosa de estos primeros tiempos, se abusó de tanto campanazo por parte de las diferentes congregaciones de la Iglesia, que sólo se redujeron a cuatro toques principales:

- El repique. Que se utiliza en festividades teniendo dos variantes el repiquete (sólo se tocan las campanas con los badajos) o al vuelo (generándose una vuelta completa de campana), como cuando se pregonaban festividades religiosas o civiles como el "Año Nuevo", el "Corpus", la Virgen de Guadalupe, festividades del monarca o del virrey en la Nueva España, de la familia real, bodas, bautizos, etc.

- El doble. Que se hace sólo para los difuntos. Aquí existe el toque de "vacante" que avisaba de la muerte de prelados y dignatarios de la Iglesia. Sesenta si era prelado importante. Cuarenta si era diganatario, treinta por canónigo. Veinte por racioneros y diez por mediorracionero; pero solamente a la hora en que morían, en los funerales o en los entierros.

- De plegaria. Utilizado para hacer la oración en casa o en los templos.

${ }^{104}$ Ibidem, pp. 158-160. 
- De rogativa. Utilizado para implorar y alcanzar remedio en alguna grave necesidad por causas fuertes como epidemias, inundaciones, sequías, granizadas, etc.

Se agregaría el toque de arrebato. Que consiste en "avisar" a la población de desgracias como motines, revueltas, o a fin de que acudieran los feligreses a causa de un incendio -muy común en la época- y con esto de ayudar a salvar las iglesias y su contenido religiosos.

Por otra parte, en el siglo XVII se introdujo el "toque de difuntos" que era a las 8 de la noche en la que habría que rezar por el eterno descanso de las almas durante un cuarto de hora. Asimismo, fue utilizado durante mucho tiempo como sonido que acompañó a los agonizantes siendo interesante que el toque de difuntos se diera en razón de su condición: si era sacerdote nueve campanadas, si es hombre de cualquier estado y calidad, siete y si era mujer, cinco. $^{105}$

En el caso de los altos jerarcas de la Iglesia y la nobleza, la situación cambiaba totalmente ya que se tocaban cien campanadas distribuidas a lo largo de la tarde hasta bien entrada la noche. Si el personaje era un virrey se agregaban cañonazos. En cambio el aviso de la muerte del rey como sucedió con la noticia de la muerte de Felipe $\mathrm{V}$ se acompañaba con doscientas campanadas que empezaban en la catedral seguida de conventos, iglesias y parroquias. No es necesario imaginar el enorme ruido contaminante que debió de existir entonces al tocar casi al unísono todas las campanas de la ciudad. Si consideramos que era una costumbre el uso de las campanas al agonizar, sepultar y rezar por el descanso del difunto, también es necesario señalar que muchos vecinos tuvieron que cambiar muchas veces de domicilio debido a los tremendos campanazos, que hicieron que en 1741 el arzobispo Alonso Núñez de Haro y Peralta hiciera un intento por regularizar la vida religiosa novohispana reduciendo el tañido de las campanas a su forma más simple. Desgraciadamente, al igual que en cualquier época y en cualquier situación,

${ }^{105}$ María de la Ángeles Rodríguez, op. cit., p. 122-123. 
estas disposiciones fueron ignoradas por muchos particulares y congregaciones religiosas que celebraban el "sermón de la muerte" con el que se otorgaban indulgencias a la población.

\section{8 Las exequias}

Otras ceremonias religiosas ligadas al aspecto fúnebre son las exequias que eran las honras que se hacían al difunto en las que acudían una multitud de personas a solicitud de los deudos y se éstas se hacían sólo para gente pudiente económicamente. El término proviene del latín excequiae, exsequi, y en la antigüedad, era una composición de carácter poético que se recitaba ante el cadáver donde se rezaba y se alababa al difunto.

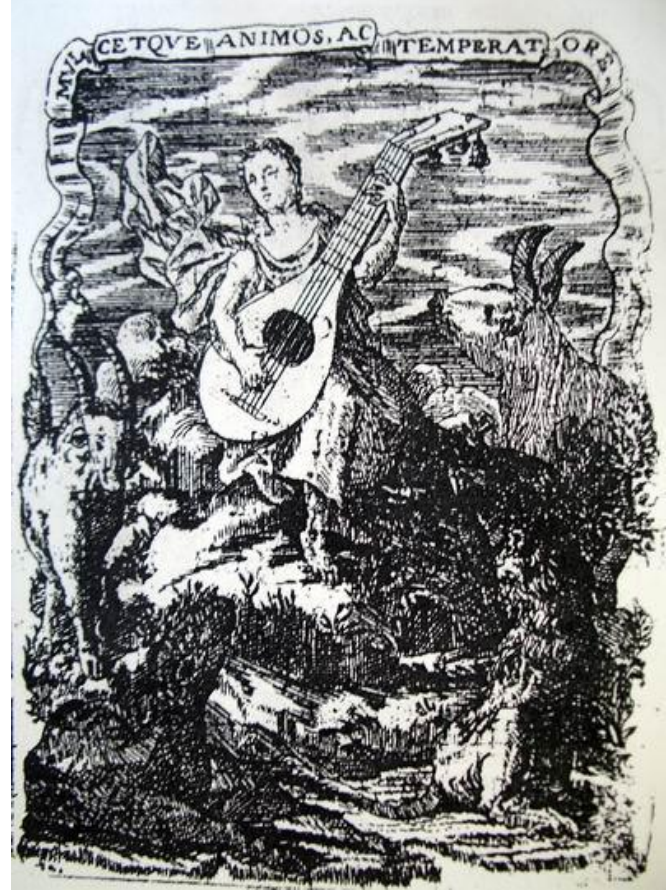

Fig. 39 Orfeo amansando a las fieras, del Túmulo de Isabel de Farnesio, México Buril sobre metal

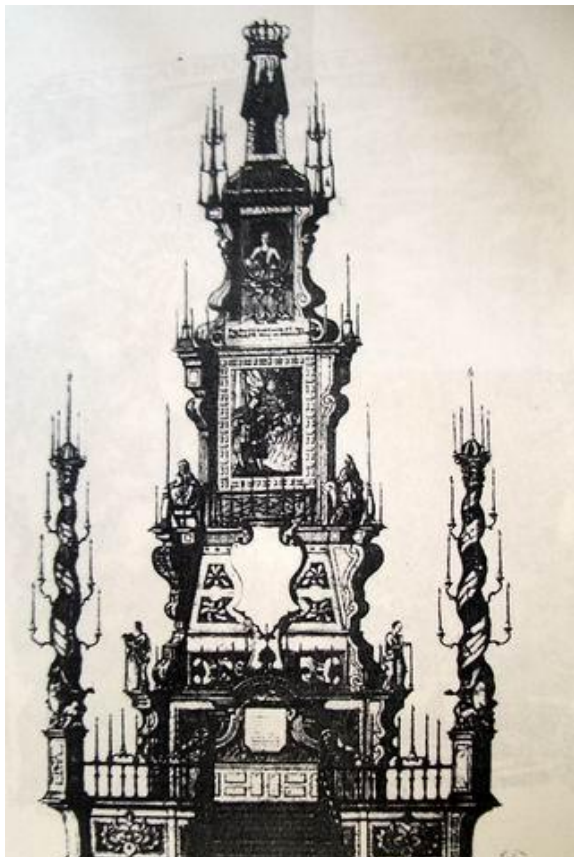

Fig. 38 Túmulo de Isabel de Farnesio, 1767. Aguafuerte

Existía el lucimiento público de personajes conocidos mediante el túmulo o pira funeraria que entraba dentro del aspecto de las honras fúnebres como en México el de la poderosa señora Isabel de Farnesio. (figs. 38 y 39 )

Se preparaban con semanas o meses de anticipación y su construcción arquitectónica era recordada por la sociedad durante mucho tiempo por medio de dibujos y grabados e incluso gracias a las descripciones que se 
incluían en los sermones fúnebres. Su altura era considerable y tenía que ser capaz la construcción de contener el peso de sus múltiples empresas, actos y hazañas. Se sabe de ejemplos que llegan casi a los 4 metros distribuidos en varios cuerpos. Según los grabados de la época y la descripción de la pira levantada en honor del tercer marqués del Villar del Águila, éste tenía seis cuerpos y sólo su base ya alcanzaba la altura de dos varas. ${ }^{106}$

María Jesús Mejías, estudiosa del tema, escribe sobre las características del túmulo:

[...] El túmulo, convertido en el elemento más vistoso de las exequias, se construía de madera, lienzo y, en general de materiales poco consistentes, pero enriquecidos con pinturas que simulaban materiales ricos como podían ser mármol, jaspe u oro, complementándose además con esculturas y pinturas que aludían a las virtudes y a los éxitos del difunto, todo ello recubierto de ricas colgaduras negras e iluminado con multitud de cirios. Se colocaba, por lo general, en el centro de la iglesia mayor, y a su alrededor se oficiaban las honras. Desde el momento en que se decidía su construcción, el comisario de los festejos designaba a los artistas y artesanos que participarían en ella, además se contactaba con el cabildo eclesiástico con el que trabajaba estrechamente para establecer los contenidos simbólicos y alegóricos, siendo sus autores casi siempre eclesiásticos, universitarios o eruditos locales En ocasiones, y sobre todo en las grandes ciudades, se convocaba a un concurso público para elegir el mejor diseño de túmulo, o se elegía entre varios proyectos. Por ejemplo, en Guatemala no se tienen noticias de la convocatoria de concursos públicos aunque para las exequias de Carlos III, el oidor-comisario si solicitó varios proyectos, más numerosos son los convocados en México y Lima, en ésta última destacan los de las exequias de Margarita de Austria, 1612, de Isabel de Borbón, 1645 o de Felipe IV, 1666, entre otros muchos [...] $]^{107}$

Era costumbre cubrir el túmulo de velas lo que llevaba el peligro de incendiarse parte de la nave donde se exhibiría el monumento funerario. Para esto se prevenían numerosas personas con baldes de agua para impedir un accidente que podía ser gigantesco. Existían piras en las que se puede realizar un cálculo de no menos de 400 velas encendidas. Las luces se distribuían sobre todo en las figuras que simulaban candeleros en los cuatro ángulos lo cual producía un efecto sorprendente y mágico en un espacio monumental y oscuro.

Dos factores pudieron acabar con la costumbre de las piras funerarias en la Nueva España: la regulación de altura para impedir la competencia entre

\footnotetext{
106 Ibidem p. 284.

${ }^{107}$ María Jesús Mejías Álvarez, Fiesta y Muerte Regia, Las estampas de túmulos reales del AGI, Consejo Superior de Investigaciones Científicas, Escuela de Estudios HispanoAmericanos, Sevilla, 2002, p. 135.
} 
la Casa Real española y la nobleza, así como la prohibición de colocar numerosas velas en espacios cerrados.

Los túmulos adquirieron con el paso del tiempo un recuerdo simbólico ya que al terminar la función se retiraban los adornos y otras partes se integraban en otras funciones o entierros.

Fue notable por sus características el llamado "Túmulo Imperial" que se erigió en la iglesia de San José de los Naturales. (fig. 40) El notable escritor Francisco Cervantes de Salazar describió el Túmulo con todo detalle, mencionando que el catafalco, fue levantado para celebrar las exequias de

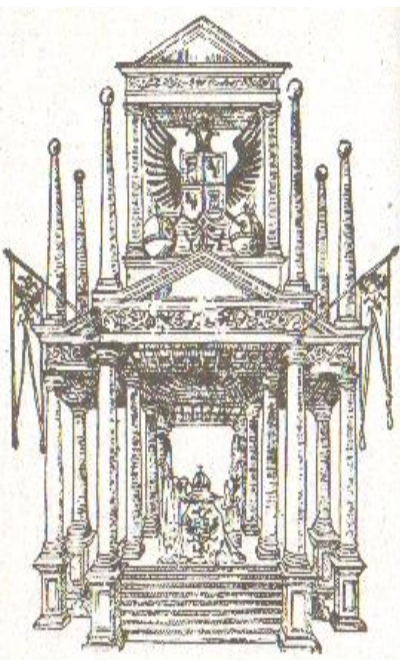

Fig. 40 Túmulo Imperial Xilografía
Carlos $\mathrm{V}$ y se celebró una misa de difuntos a la que asistieron personalidades de la época. Con objeto de tener una idea de este espléndido ejemplo del arte barroco, se conoce que el zócalo del túmulo tenía ocho pies de altura, cuarenta y cinco por cada lado. En sus cuatro costados, se abrían escaleras de doce grados y en las caras del zócalo repartidos 16 lienzos de pintura con diversos emblemas relativos al rey y a sus virtudes.

A la obra se añaden dos grabados que corresponden a la reconstrucción del túmulo de acuerdo al dibujo que publicó Manuel Toussaint en su libro denominado $\mathrm{La}$ Catedral de México y el segundo muestra el mismo túmulo según el esquema que aparece en la parte final del Códice de Tlaltelolco. El texto se acompaña con una descripción del túmulo que abunda en detalles según el grabado que aparecía en la primera edición. Es curioso observar la gran mezcla de elementos en la simbología que debería de contener el túmulo tanto del Nuevo Mundo como de Europa. Así leemos un ejemplo de tan larga descripción:

[...] Al otro lado del cuadro del pedestal, estaban muchos indios enlutados con candelas encendidas en las manos, mostrando con los rostros tristes gran sentimiento por la muerte de Cesar [...] Estaba al otro lado el Emperador teniéndole la Muerte de la mano y junto a él la Fé con una cruz 
en la mano, con el que le aseguraba la partida, pues aunque moría, no había vivido para si sino para el argumento y ampliación de la Fé [... $]^{108}$

Existe una referencia asimismo a una "Pira funeraria" que fue levantada en la Catedral de Puebla con motivo de la muerte de Carlos III y que fue grabada con sumo cuidado por José Nava sobre un dibujo de Ignacio Rincón y registrada en el libro Las Reales Exequias. Dicha imagen está compuesta de cuatro niveles coronados en su parte más alta de motivos de la Casa Real española de los que cuelgan dos pares de pendones a los lados. Su altura es considerable ya que se aprecia en el dibujo a nivel de la base de la cúpula principal de la Catedral. ${ }^{109}$

Francisco de Solano, en Las voces de la Ciudad $^{110}$, considera que este tipo de monumentos funerarios, que

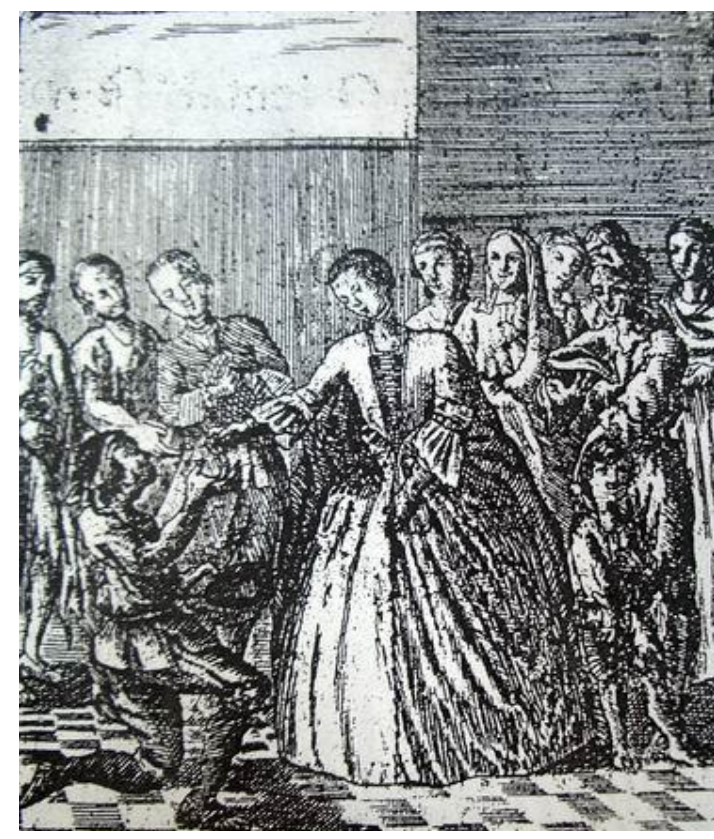

Fig. 41 La reina dando limosna a unos mendigos, del Túmulo de Isabel de Farnesio en México. Buril y aguafuerte resultaban un homenaje a las autoridades fallecidas en su cargo, tendiendo el mismo peso aglutinante de un "arco triunfal", se levantaban como espectáculo que permitía la cohesión de la ciudad colonial, cuyo fervor era recogido mediante la participación ciudadana, allí está, por ejemplo, la acción en vida de Doña Isabel de Farnesio dando limosna a los pobres, actitud que sería recordada por muchos, que le valió la elaboración de un Túmulo así como una serie de aguafuertes en su honor que habla de la virtud del desprendimiento hacia los demas. ${ }^{111}$ (fig. 41)

\footnotetext{
${ }^{108}$ Francisco Cervantes de Salazar, "Túmulo imperial", edición, prólogo y notas de Edmundo O’Gorman, Editorial Porrúa, col. sepan cuantos..:" núm. 25, México 2000, p. 188.

${ }_{109}$ Gonzalo Obregón, "El Libro Mexicano durante la Colonia", en Artes de México, número 131, año XV11, 1970, pp. 19-25.

${ }^{110}$ Francisco de Solano, "Las voces de la ciudad", en Aproximaciones a la historiografía de la Ciudad de México, Vol. 1 Coloquio de Historia del Arte, La Ciudad concepto y obra, (México, Instituto de Investigaciones Estéticas/ UNAM, 1987), pp 57- 77.

${ }^{111}$ Ibidem.
} 


\section{9 La eternidad de la presencia espiritual}

Probablemente se deba a esta época el surgimiento del monumento y la idea del epitafio que tienen como finalidad perpetuar en forma escrita las acciones heroicas y virtudes terrenales de los recién enterrados y más si merecen ser puestos en imágenes. (fig. 42) Queda claro que las inscripciones grabadas en piedra, sólo podían ser, en un principio, para los deudos nobles y después para aquellos que fueran capaces de pagar el trabajo de un artesano. Se conservan pocos ejemplos de epitafios, no así del siglo XIX donde proliferó tanto en la las grandes ciudades como en provincia incluso hasta en pueblos indios. En el primero de los casos, en la

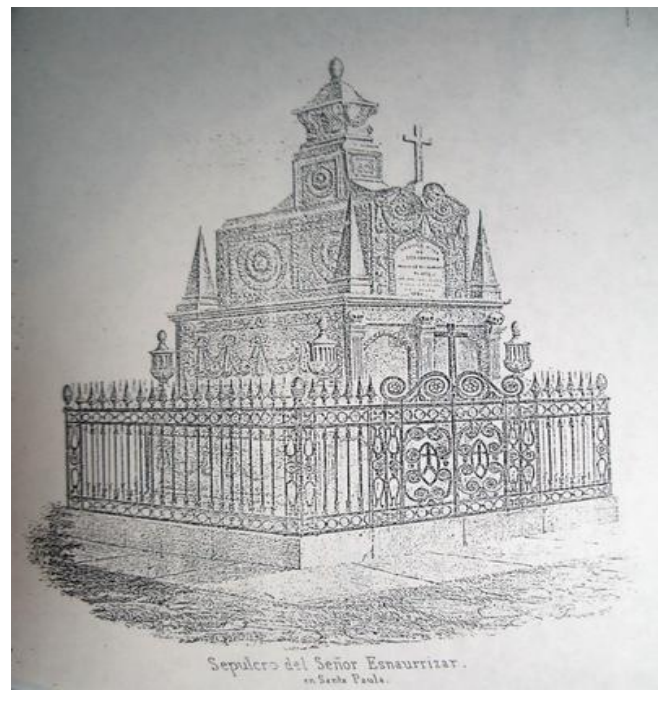

Fig. 42 Sepulcro del señor Esnaurrizar. Panteón de Santa Paula. Lápiz litográfico. Primera mitad del siglo XIX.

Hacienda del Molino de las Flores cercana

a Texcoco, se pudo leer un epitafio que se encuentra en un obelisco de mármol que dice en una de sus caras:

A la memoria del Exmo, señor don Miguel Jerónimo López de Peralta, Urrutia de Vergara Alfonso Flores de Valdés, Alborros, Gómez de Cervantes Velasco Padilla y Obando, marqués de Salvatierra.

En otra cara que da al norte continúa:

Fue maestrante de la real de Ronda, firmó la acta de Independencia de México, capitán de guardias del emperador Yturbide, gran cruz de la imperial orden de Guadalupe, general de brigada, consejero de Estado, senador, diputado, gobernador, alcalde, regidor y notable.

Y finalmente la cara al sur concluye con estas palabras:

Nació en México el 21 de marzo de 1789. Murió el día 4 de marzo de 1864. Sus hijos le consagran este mausoleo. ${ }^{112}$

\footnotetext{
${ }^{112}$ Verónica Zárate Toscano, op. cit., pp. 287-288
} 
La posibilidad de perpetuar la memoria del difunto en forma diferente a los demás se pudo realizar gracias a que fuera del interior de las iglesias y de los atrios existía la posibilidad de dejar una constancia de identificación y de ensalzamiento de virtudes del ser humano enterrado por medio de monumentos de mayores dimensiones. Mientras el cuerpo en su ataúd daba a todos la igualdad de condiciones, en realidad los nobles fueron los únicos fuera de la clase dominante- que pudieron diferenciar a los suyos con esta costumbre, de tal manera que la creación de placas de diversos materiales que iban desde la piedra, pasando por porcelana y terminando con granito con pensamientos versificados o en prosa llegaron a hacerse muy populares.

El Romanticismo, no estuvo exento en las obras mortuorias, y panteones sobre todo a principios del siglo XIX donde se acostumbraba lucir ante la sociedad el lujo y las buenas costumbres. En las revistas y periódicos de la época se leen temas como el llamado Panteón General que explica como el administrador "... se ha esmerado en ordenar, llenar de plantas y seguir

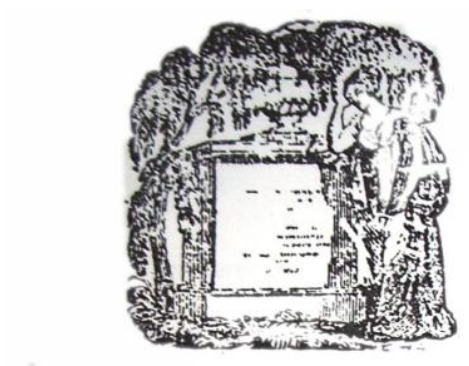

A LA PIEMATUIRI TIUEITE DE MI ADURADO TIO

\section{PEDRO JE LA MAIA.}

fallecido en Alaturioros el dia 13 D: Junio D. 1660

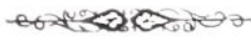

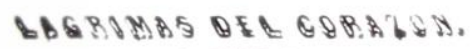
$\rightarrow$ Co

Fig. 43 Flores de la Montaña: A la prematura muerte de mi adorado tío Pedro Maza. Xilografía

construyendo sepulcros, hasta lograr que este triste lugar se haya convertido en un paseo bastante frecuentado."

El autor del artículo pone énfasis en las inscripciones de las lápidas y sus respectivas inscripciones encontrándose no pocas inscripciones y otras adornadas de poesías colocadas sobre lápidas cubiertas con cristal $y$ escritas con letras de oro y elegantes adornos. ${ }^{113}$ Se sabe de un raro ejemplar Flores de la Montaña escrito en San Luis Potosí, escrito por Gregorio de la Maza (fig. 43), que incluye un grabado probablemente una xilografía de una musa que descansa el brazo sobre el cuerpo de una tumba acompañada de la poesía de tema

\footnotetext{
${ }^{113}$ Monserrat Gali Boadella, Historias del Bello Sexo: La introducción del Romanticismo en México, Tesis para obtener el grado de Doctor en Historia del Arte, FFy L., UNAM, México, 1995, p. 374.
} 
mortuorio, en el que en alguna de sus partes dice: "En alas de mi suerte arrebatado/ Mi mísera existencia se derrumba// Y de sufrir y padecer cansado,/ Solo quiero el reposo de la tumba". ${ }^{114}$ Hay otras imagenes representadas románticamente en litografías en las que un ángel baja del cielo para llevarse el alma difunta. (fig. 44)

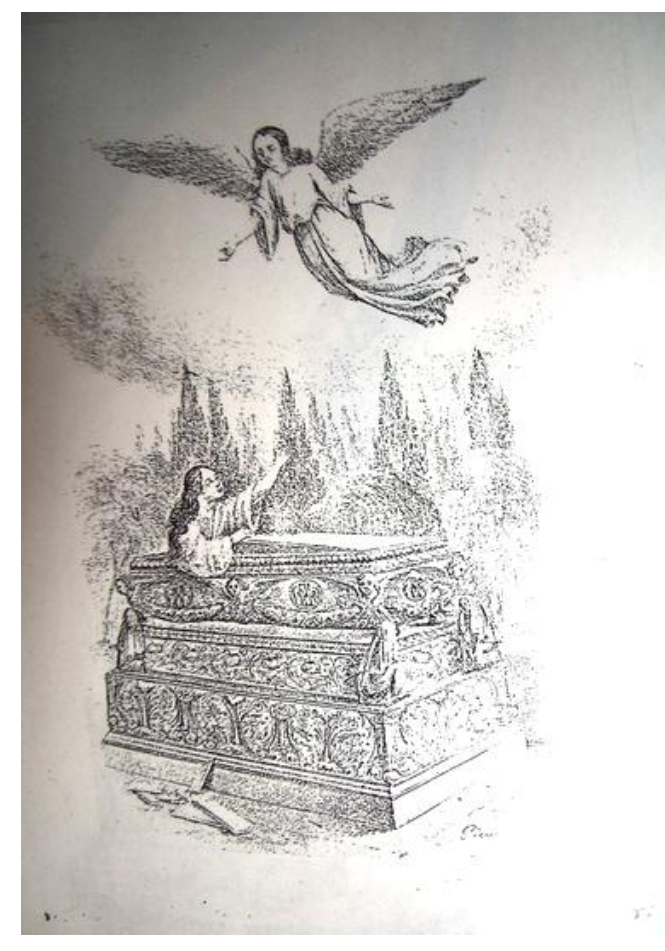

Fig. 44 Imagen Romántica de los Sepulcros. Lápiz litográfico. Primera mitad del siglo XIX.
Un aspecto interesante de esta difusión masiva de monumentos y epitafios se pueden observar en algunas poblaciones rurales donde están reunidas las creencias indígenas y el aspecto religioso $y$ donde existe un importante material funerario de monumentos, lápidas y textos que permanece virgen a los ojos de los estudiosos de la historia de las mentalidades que podrían en un momento dado separarse por grupos y contenidos comparándolos con otros cementerios paralelos lo que arrojaría resultados interesantes. Así por ejemplo, en una agrietada placa de porcelana del pequeño cementerio de Teotlalpan, en

Tlaxcala, se encuentra un epitafio del señor Florentino Sarmiento muerto en 1898 que lanza esta advertencia al visitante que pisa su suelo:

\author{
Detente amigo, \\ ¿Por qué te vas pasando sin hablarme? \\ Que porque soy de tierra y tú de carne \\ Apresuras el paso tan velos (sic) \\ Escucha un momento, \\ Compañero el pedido que hago es corto y voluntario, \\ Reza un padre nuestro y un sudario \\ $Y$ prosigue tu marcha \\ ¡Aquí te espero!
}

\footnotetext{
${ }^{114}$ Francisco de la Maza, Un Libro Romántico, en Obras Escogidas, prólogo y selección de Elisa Vargas Lugo, Comité Organizador "San Luis 400" Instituto de Investigaciones Estéticas, UNAM, México, 1992, p. 609.
} 


\section{La gráfica popular en el siglo XIX}

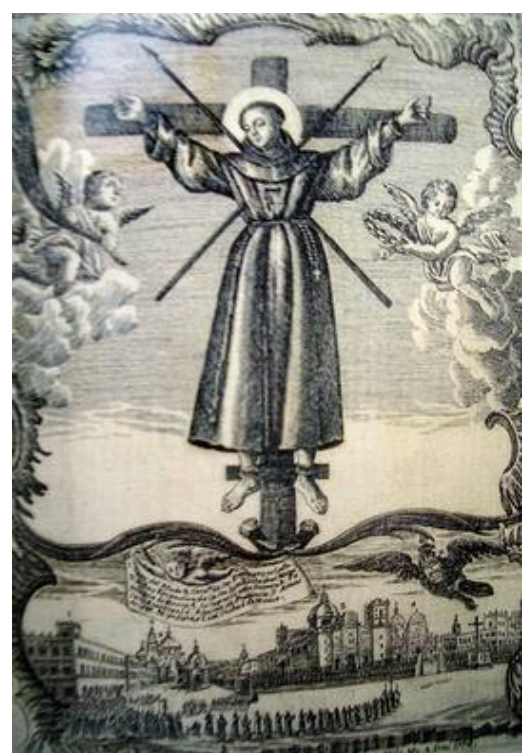

Fig. 45 E. Villavicencio. San Felipe de Jesús 1774.

Aguafuerte y aguatinta

Es evidente que la representación de la vida cotidiana tuvo evoluciones temáticas hacia diferentes miradas, y la muerte no fue la excepción. Si bien en un principio existió un discurso místico en las láminas de carácter religioso, con el tiempo, las ideas y las representaciones visuales cambiaron debido a situaciones de orden político y social.

El grabado abordó a fines del siglo XVIII el tema del martirio de los 23 mártires en Japón y la vida de San Felipe de Jesús, primer mártir mexicano muerto en Filipinas, y de la cual aquí se muestran dos láminas de gran belleza y complejidad de realización trabajadas en la técnica combinada del aguafuerte y aguatinta; a manera de cuadros de gran formato. Conservando la idea central del santo, la imagen es simétrica con un pequeño paisaje en el que en lo alto del cielo unos querubines acompañan al santo ya divinizado (fig. 45) El otro grabado adquiere complejidades de composición por la manera de resolver su trabajo gráfico quedando como una vista al Monte Calvario (fig. 46)

Pero, la muerte, como tema específico se contempla en la obra literaria " $L a$ Portentosa vida de la Muerte emperatriz de los sepulcros, vengadora de los agravios del altísimo, y muy señora de la hu al santomana naturaleza cuya célebre historia encomienda a los hombres de buen gusto" de fray Joaquín Bolaños. En esta obra se representa a la muerte en distintas caracterizaciones y la convierte en un personaje de una vida compuesta de aventuras, que tiene como objetivo central el recordar a los hombres su condición de mortales, para que este conocimiento sirva de freno contra el pecado y a cuyo pie se anota una cita bíblica que sirve de referencia tanto para el texto como para la imagen y fue publicado por primera vez en 1792 con grabados en metal. 


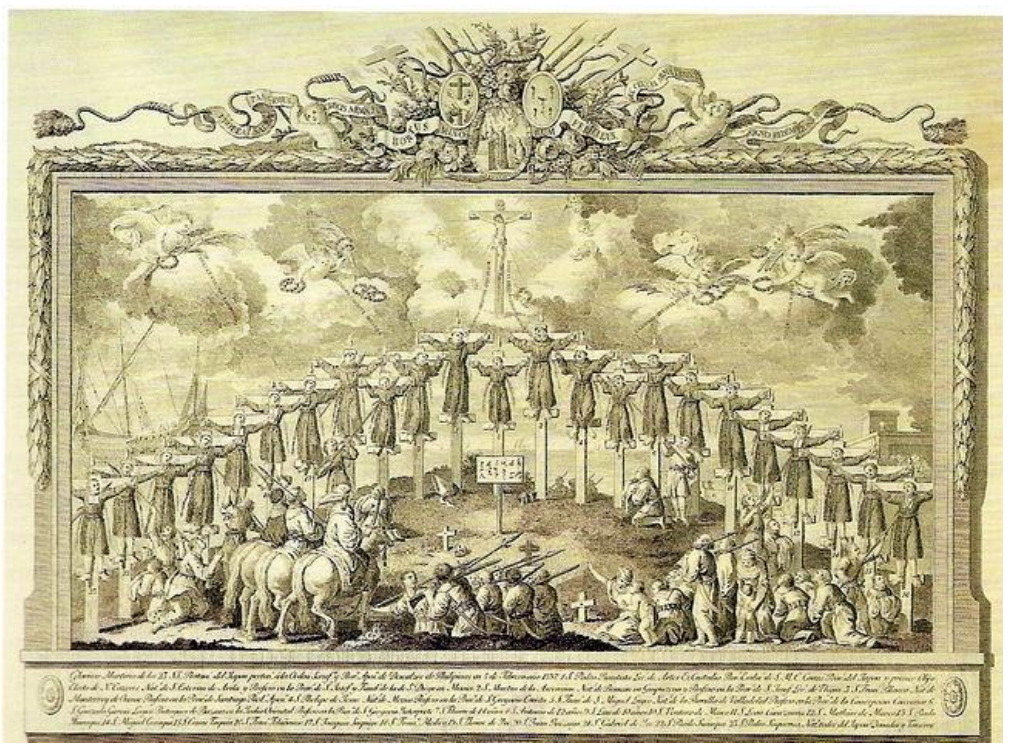

Fig. 46 Manuel Peleguer El martirio de los 23 mártires de Japón. 1794 Aguafuerte y aguatinta
Es

curioso

paradójico que la historia de la Muerte, en el texto de Bolaños, se desarrolle de forma similar a la vida de los seres humanos: se habla de la patria y padres del protagonista, árbol genealógico infancia, mayoría de edad, matrimonio, relaciones

de amistad, aventuras, triunfos, senectud y muerte [sic]. ${ }^{115}$ La vida de la muerte en La portentosa vida de la Muerte es una vida mundana que se inicia con los orígenes de la humanidad y concluye con el fin de los mortales el día del Juicio Final, ligándose de ésta manera a la historia del mundo y de la humanidad.

El libro debió tener un público restringido debido al tema tratado y nos habla de limitaciones que respondían a cambios políticos de Europa y considerando los tiempos en que se realizó a las pugnas internas de la Nueva España. El carácter satírico de las "estampas" era prohibitivo y se han encontrado edictos de esa época que mencionan que "[...] se han prohibido diferentes Estampas, Inscripciones, y Escritos Satíricos con notorio abuso de la Sagrada Escritura con extrañas representaciones".

En relación a las imágenes en libros o papeles en la época de la Colonia, Edelmira Ramírez en su investigación sobre la censura inquisitorial menciona que los autores y artistas que producían sus obras de acuerdo a los lineamientos establecidos continuamente se enfrentaron a la restricción impuesta por la clase dominante. ${ }^{116} \mathrm{Si}$ bien, debieron de ser imágenes concretas no se mencionan a cuales se refieren pero que debieron expresar

\footnotetext{
${ }^{115}$ Véase Ma. Isabel Terán, Los recursos de la persuasión, la portentosa vida de la Muerte de fray Joaquín Bolaños, México, El Colegio de Michoacán/ Universidad Autónoma de Zacatecas, 1997.

${ }^{116}$ Edelmira Ramírez Leyva, "La censura inquisitorial novohispana sobre imágenes y objetos", en Arte y Coerción Coloquio del Comité mexicano de historia del arte. IIE, UNAM; México, 1992, pp. 149-162.
} 
críticas abiertas contra la Iglesia. La Portentosa vida de la Muerte por alguna razón llega a pesar de tocar temas satíricos a nuestros días Es posible que el libro de Bolaños circulara libremente y que la temática haya originado un cambio debido al "adoctrinamiento moral" que de él presuntamente emergía; y esto debió ocurrir a través de los numerosos ejemplos que retratan a la sociedad novohispana.

En cuanto a la obra gráfica contenida en el libro de Fray Joaquín, el esqueleto

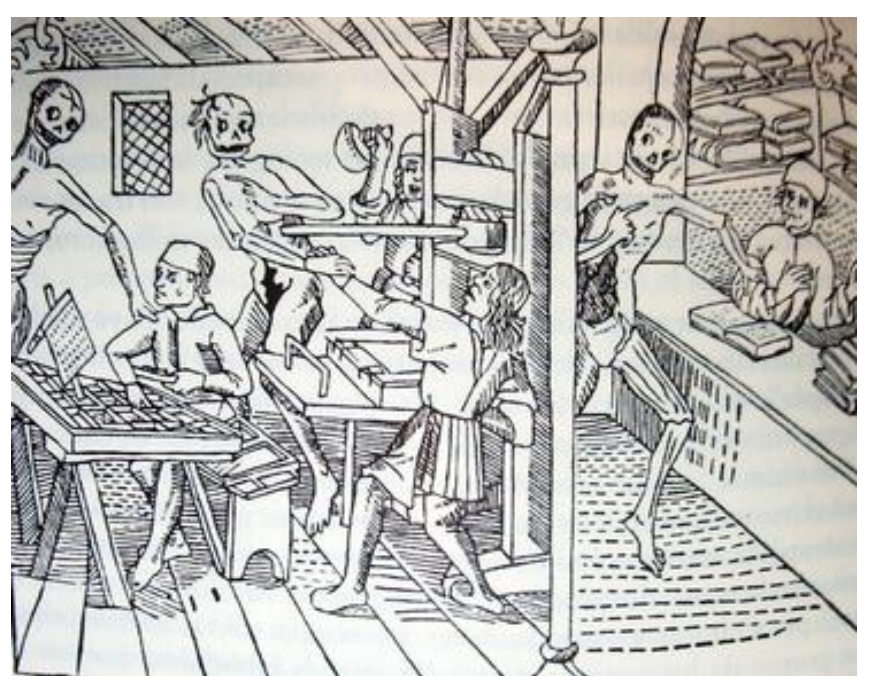

Fig. 47 La Danza Macabra. Xilografía medieval de 1499 ocupa siempre el lugar de la Muerte y la función de estos grabados es la de ilustrar el texto. El autor de los grabados es Francisco Agüero Bustamante y son 18 grabados al aguafuerte que se componen de dos elementos: un dibujo alusivo al pasaje del texto; y una frase anotada al pie que corresponde a un versículo bíblico.

Antes de la citada obra, la idea de la muerte representada como personaje en forma de esqueleto cobrando vida había sido tratada en diversas xilografías europeas. Sin duda alguna, un ejemplo directo es la estampa macabra de un taller de grabado en 1499 en la ciudad francesa de Lyon. (fig. 47) Allí los artesanos dedicados a la confección del libro, observan como son tocados por figuras mortuorias ante el asombro del un cajista y su ayudante. En el lado derecho en otra escena diferente el almacenista de libros también es tocado por la Muerte. En la parte inferior un texto en verso sobre la Muerte acompaña las imágenes, es evidente, pues, la vinculación entre la muerte y la realización de los impresos populares desde épocas remotas. 
Sin duda alguna, La Danza de la Muerte, del artista Hans Holbein el joven, es la obra más conocida en la Europa medieval, a través de los 41 grabados en madera. En sus tiempos, la peste, las enfermedades, el miedo, la guerra, entre otras cosas hacían mella en el imaginario colectivo que se identificó plenamente con un discurso narrativo bíblico del paso inminente de la muerte en el mundo de los vivos. (fig. 48) Holbein, plasma de manera magistral escenas donde la Muerte domina las acciones a su paso en el mundo, de tal manera que se hace decir al principio de la obra a San Pablo ${ }^{117}$ a manera de

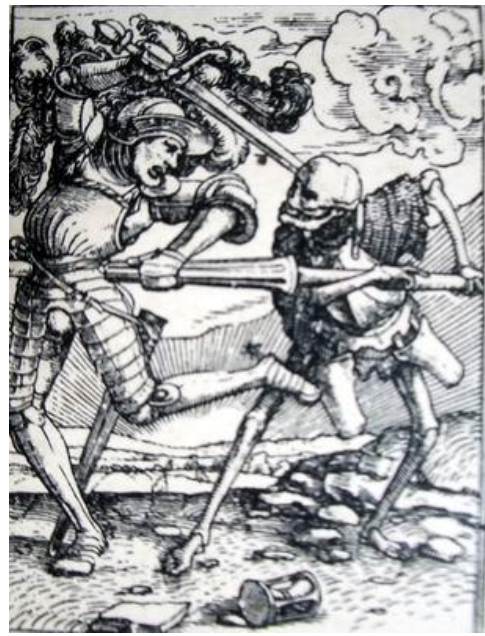

Fig. 48

"La Danza de la Muerte" de Hans Holbein. Xilografía verdugo ¡Oh, muerte, yo seré tu muerte!

\section{1 "La Portentosa vida de la Muerte"}

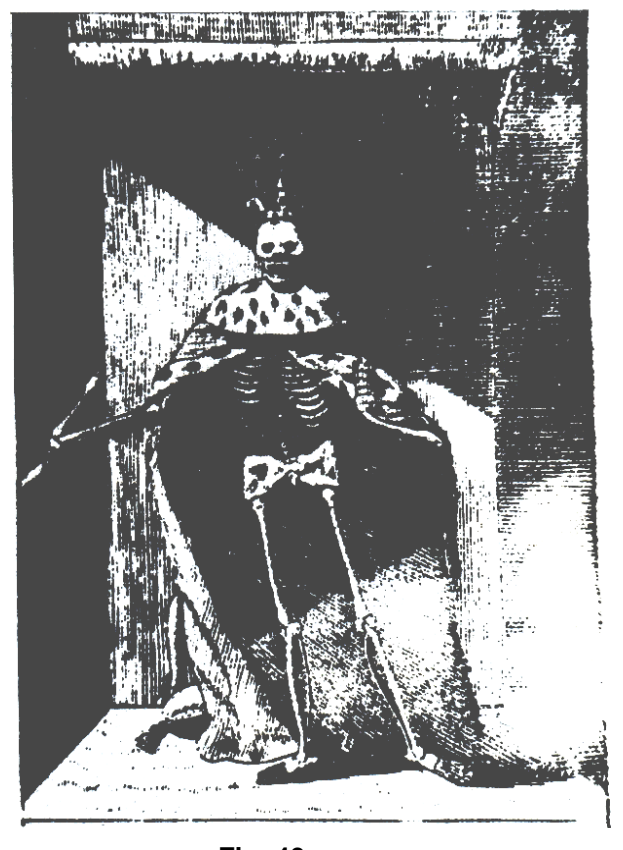

Fig. 49

En el Nuevo Mundo, a partir de la colonización de los europeos, la muerte en la literatura novohispana se encuentra relacionada con el fenómeno de la evangelización, en el que, a través de pasajes sencillos se adoctrina a la poblaciones indígenas. De este periodo se conocen textos donde se presenta una dualidad Muerte / Demonio, como forma de pecado este último y la Muerte como consecuencia de los actos humanos. Sin embargo, también esta dualidad engendra otra posibilidad: la salvación eterna por medio de oraciones como lo podemos ver

La Emperatriz de los Sepulcros: La Merte de fray Joaquín Bolaños.

${ }^{117}$ San Pablo, llamado el "Apóstol de las Gentes" 
en algunas imágenes gráficas. No importa el fin, sólo que la muerte nos conduzca a Dios. Es decir, pasar de una vida a otra, sin la angustia de estar en un lugar intermedio. Este es, justamente el caso de La Portentosa vida de la Muerte, ya que la historia es narrada por el personaje que tiene su propia vida como cualquier ser en la tierra, adquiere sensaciones humanas (sic) en las se puede ver como “la emperatriz de los sepulcros" (fig. 49) puede reír, o llorar, según el caso. Tiene la Muerte su propia corte compuesta de asquerosos gusanos, ratones y otros animalejos que se mantienen de carne humana y su origen se desarrolla a manera de reflexión humana.

Tan es así, que los males por los que atraviesa el mundo son sólo culpa de los hombres. A ellos, y a su comportamiento hay que acusar de la "vida" de la Muerte. Así en un pasaje dice:

[...] Todos tienen a la Muerte y pocos se recelan de sus padres, porque en llegando la Muerte, todas son amarguras y en llegando el pecado, saborea el apetito con la dulce miel de los placeres, pero advierta aquí todo racional viviente que también mata y no es menos activo el veneno que se ministra en copa de oro.

Bolaños mismo le crea al personaje de la Muerte adjetivos y situaciones a las de cualquier humano riendo de sus ocurrencias como es llevando una pierna de esqueleto en la escena de la figura 50. Debido a estas condiciones la "Majestad Infinita, infiel y desleal" a falta de estudios y de porvenir sale desterrada a conocer el ancho mundo con “... alegría risueña que hacía tan agradable la inocencia". La obra consta de 40 capítulos, un

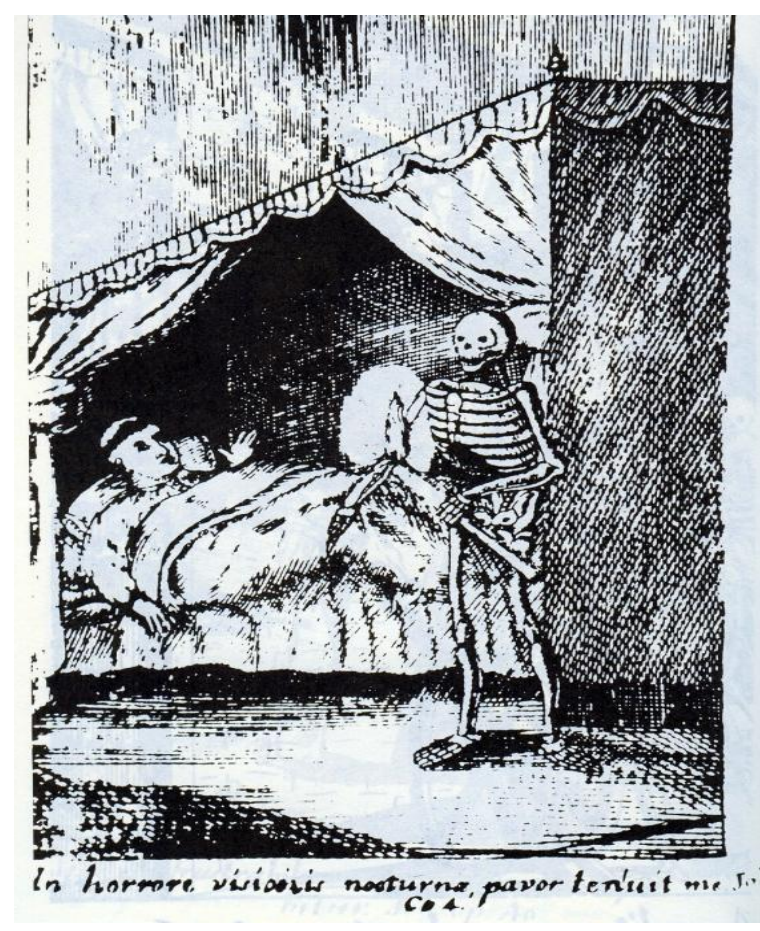
Prólogo, un Preámbulo, una conclusión y un testamento. En
Fig. 50

La Portentosa Muerte de fray Joaquín Bolaños. Aguafuerte de F. Agüero

\footnotetext{
${ }^{118}$ Blanca López de Mariscal, Fray Joaquín Bolaños, La portentosa vida de la Muerte..., p. 95.
} 
síntesis, el texto consta de ejes temáticos en los cuales, la Muerte se presenta y decreta que [...] luego en aquel instante, así como acabéis de espirar [....] sean arrojados vuestros cuerpos de vuestras mismas casas, y separados de vuestras familias [...] entregado en poder de los sacristanes y sepultureros a quienes damos plenaria facultad par arrojarlos a los horrores del sepulcro [...]. Posteriormente la Muerte toma posesión de su territorio y establece una relación con sus servidores, el Demonio, el Pecado y la Gula. En los capítulos siguientes la Muerte se presenta a los hombres pecadores. Un último bloque temático corresponde al Juicio Final, la senectud y el fallecimiento de la Muerte de donde la conclusión y el testamento forman parte de un espíritu reflexivo que inducen al lector a cambiar su forma de vida y a preocuparse para bien morir.

La obra, como hemos dicho, contiene 18 láminas que representan pasajes de la vida de la Muerte grabados en cobre en hojas sueltas sin foliar y firmadas por Agúero. Conocedor del grabado, el artista es reconocido por otras obras gráficas entre ellas la Novena de la Virgen de Loreto grabada al buril. No se sabe si Agúero pasó alguna vez por la Academia de San Carlos de la Nueva

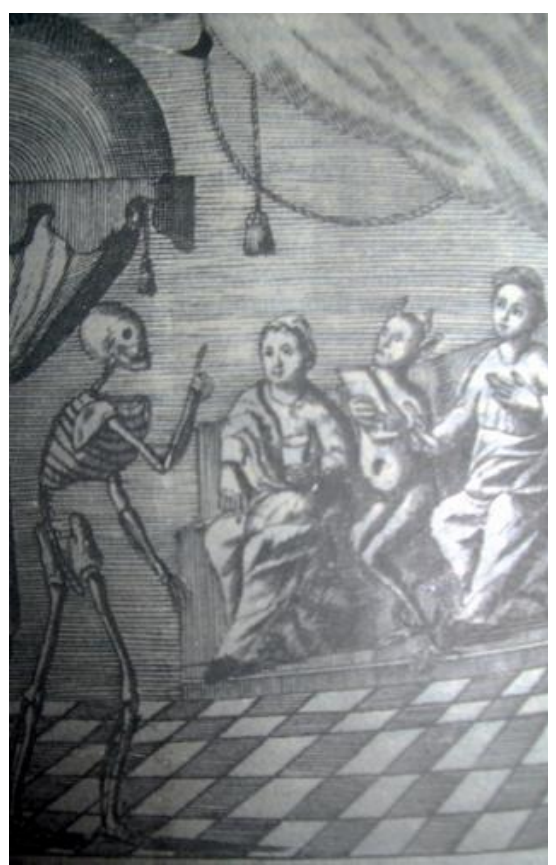

Fig. 51

La Portentosa Muerte de fray Joaquín Bolaños Aguafuerte de F. Agüero
España, o si fue un talento innato que sumado a las imprentas de la época ofreció sus servicios como artista / burilista, actividad en el que terminó siendo un tallista creativo. Sin embargo, su trabajo para La Portentosa Vida de la Muerte, en momentos adquiere ingenuidad al contemplar problemas de perspectiva y de construcción de la figura humana.

La figura de la Muerte en forma de esqueleto no respeta la anatomía y se nota desproporcionada, como se observa en la figura 51. De ahí surge la inquietud de un conocimiento de académico, haciendo que su trabajo por medio de la plancha sea considerado como pionero del género 
popular. Sus líneas aparentemente son trazadas a mano alzada lo cual habla de la destreza de Agúero, pero no de un burilista consumado que se hubiese apoyado en reglas o en instrumentos como el "velo" o el "berceau" (instrumento de línea paralelas que hacen un rayado sobre la plancha de metal), que permiten trazar líneas paralelas sobre la lámina. Un ejemplo de estos conjuntos de errores pueden observarse en las láminas donde la Muerte ocupa el primer plano de la composición empequeñecida por los elementos que la rodean. El piso reticulado en forma de mosaico mantiene el mismo tratamiento de finos ashurados cuando debió de ser mayor el efecto de mayor a menor escala y carece de luz y sombra y las figuras en segundo plano adquieren mayor realce que la que se encuentra más cercana al espectador; y las actitudes y dibujos sobre los personajes son adecuadas de acuerdo a las formas de fines del siglo XVIII. Una cortina sólo ha sido esbozada cuando debió ser la más trabajada para producir la sensación de habitación como debió de ser la intención original.

Otro ejemplo, más notable es un grabado que pertenece al capítulo XVIII, donde la Muerte se presenta en la cabecera de una cama ante un pecador, y un ser monstruoso puesto de perfil lanza una llamarada hacia el moribundo. Llama la atención porque años después, en la segunda mitad del siglo XIX, el grabador Manuel Manilla utilizará en forma continua un concepto similar artísticamente de seres monstruosos en el imaginario popular de forma-

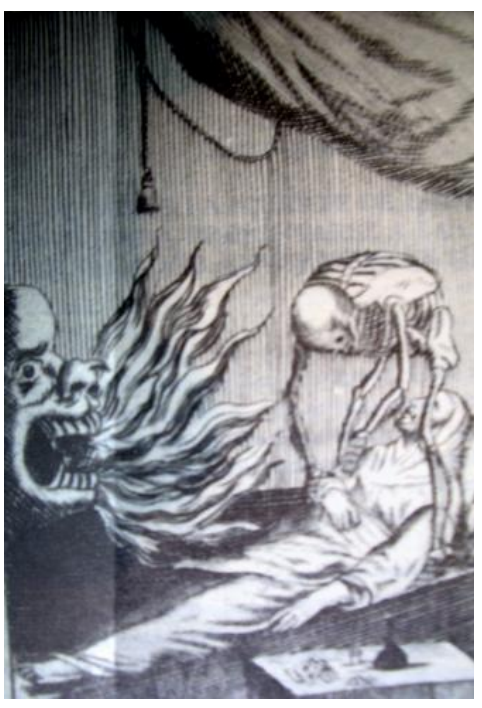

Fig. 52 La Portentosa Muerte de fray Joaquín Bolaños. Aguafuerte de F. Aguero

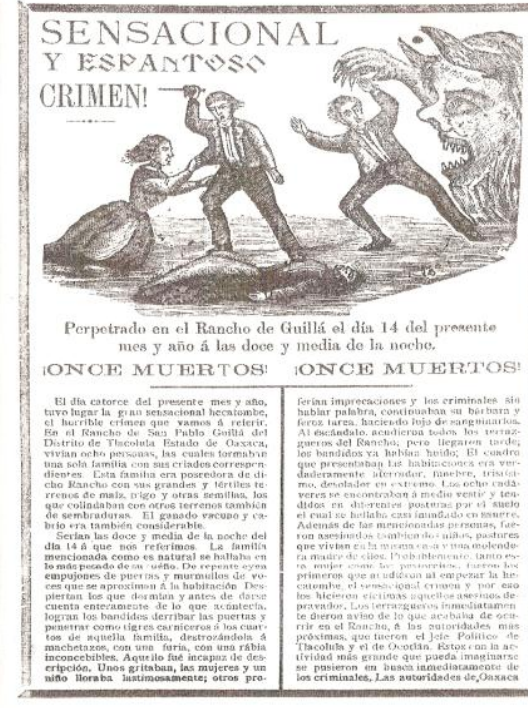

Fig. 53 "Sensacional y Espantoso crimen...". Xilografía de Manilla

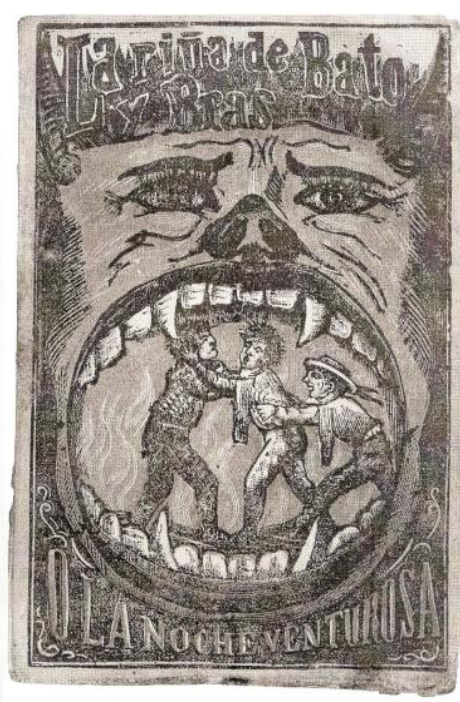

Fig. 54 "La niña de Bato y Bras. Xilografía para un cuento por de Manilla 
sencilla y directa para ilustrar la idea de la maldad, del miedo, y del Demonio en las publicaciones del editor Antonio Vanegas Arroyo como se observa en los ejemplos de las figuras 52,53 y 54 . Es posible que a partir de la obra de Fray Joaquín inicie lo que en el siglo XIX serán las famosas "calaveras", una de las expresiones más auténticas y sincréticamente mexicanas. Aunque Fernández Ledesma, en su atinado trabajo sobre las calaveras y la sátira en México comenta que es a fines del XVIII, cuando comienzan a aparecer impresos satirizando funerariamente a los personajes políticos y gente reconocida en el medio. Se ofrecía de esta manera un juicio prematuro y crítica de la actuación pública de los personajes aludidos. Estos impresos con el tiempo fueron conocidos popularmente con el nombre de "calaveras". ${ }^{119}$

\section{2 Los cementerios}

Como ya se ha comentado en este trabajo, después de establecida la Colonia en la Nueva España, muchos intentos se realizaron por parte de particulares para poder sepultar los cuerpos en los cementerios comunes con permiso de la Iglesia. Para quienes no podían aportar dinero a la Iglesia para su propio entierro existían corporaciones como la cofradía de la Caridad o de la Misericordia que se dedicaban a ayudar a aquellos víctimas de la violencia en la calles y sepultarlos en las fosas comunes que había en las afueras de la ciudad como Tepito, Tacuba o Iztacalco. Existía, sin embargo, la tenebrosa costumbre de arrojar cuerpos difuntos a los pies de iglesias, parroquias y conventos para que fuesen sepultados de manera digna y cristiana. Tan sólo "[...] en 1730 los sacerdotes de la Santa Vera Cruz se encontraron a la puerta de su iglesia, cuatro cadáveres en un solo día para ser inhumados.[...]"120

La Real Cédula de 1787 permitió la construcción de cementerios mediante la ley 11 , tít. 13 , parte $1^{\mathrm{a}}$, siempre y cuando hubiera consulta a arzobispos y obispos. Es finalmente hasta el 15 de mayo de 1804 cuando se expidió la circular acompañada de un diseño permitiendo la construcción de

${ }^{119}$ Gabriel Fernández Ledesma, "El triunfo de la muerte, las calaveras y la sátira en México", en Galera, Revista de bibliofilia y arte mexicano, Nueva época, Año 4, número 30, primavera 2002, pp. 5-7.

120 Javier Otaola, Muerte y Salvación... p. 51. 
cementerios. Para su construcción existían dos razones poderosas: el control en la apertura de fosas sepulcrales que corría paralela con el riesgo de hacer desencadenar una epidemia; y la solución de la falta de espacio en parroquias y conventos para enterramientos.

Hasta 1849 se pudo lograr un severo control por parte del gobierno

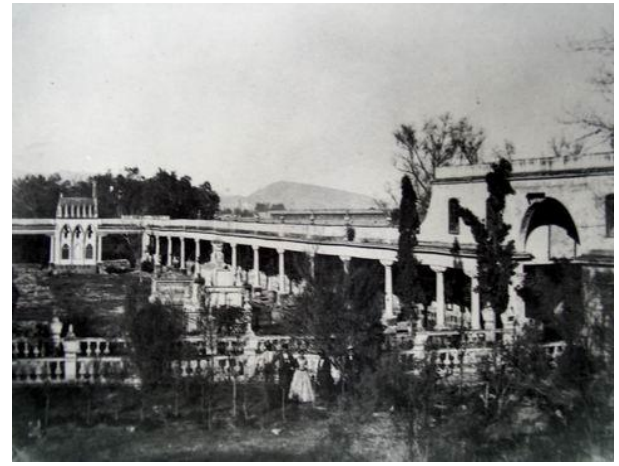

Fig. 55 Vista del Panteón de Santa Paula Fotografía
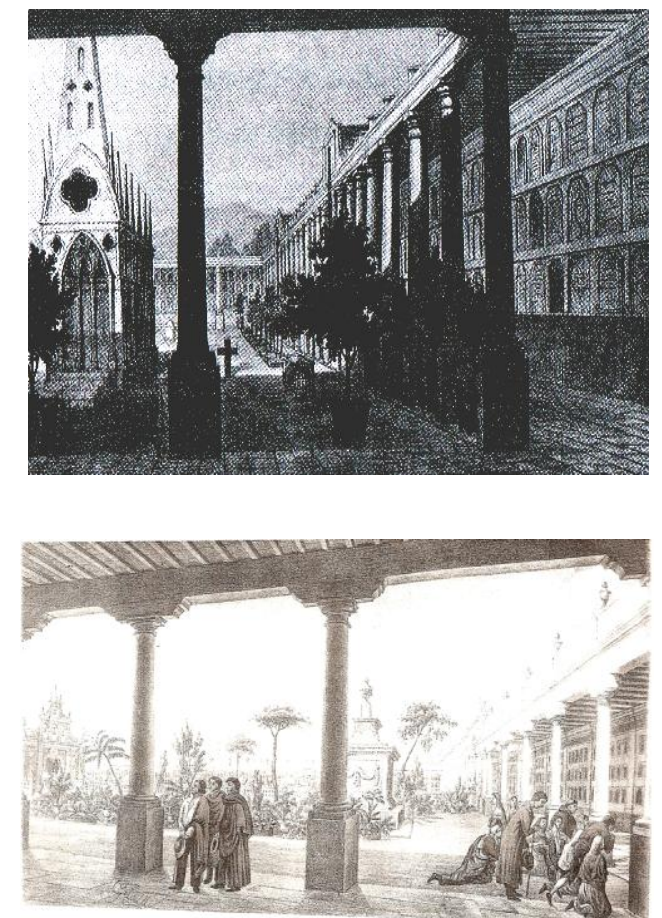

Figs. 56 y 57

Vistas del panteón de Santa Paula.

Litografías independiente para que no se enterrase cadáver alguno en lugares prohibidos so pena de recibir "cincuenta pesos de multa la primera vez, ciento por la segunda, quedando sujetos por la tercera a la pena que les imponga el gobierno", y se daba una relación de los panteones abiertos al público en esos momentos: San Fernando, Campo Florido, San Diego,San Antonio de las Huertas, Los Ángeles y Santa Paula. De ellos se conserva en imágenes tanto fotográficas como litográficas en abundancia el panteón de Santa Paula que en su momento llegó a ser considerado como un bello paseo familiar, que permitía visitar a los difuntos. Incluso en la pequeña fotografía se observa como un pequeño grupo de personas elegantes transitan por sus calles (fig. 55) mientras que las litografías que se presentan nos dejan ver todavía un paisaje de tintes románticos. (figs. 56 y 57)

De estos panteones, al de San Fernando, se le reconocía por su notable belleza. Situado en ese entonces en los límites de la ciudad a la altura de la antigua calzada de San Cosme y de lo que hoy es la calzada México-Tacuba, se 
acostumbró a tener entre sus reposados ilustres a gentes de la elegante sociedad de la ciudad, militares y hasta figuras públicas respetadas como Benito Juárez. Es decir, lo más selecto de la sociedad destacada del momento; además, es importante comentar para aquellos que nunca lo han visitado que es un panteón considerablemente pequeño que posee monumentos y tumbas funerarias muy bellas que incluso la prensa de la época describía como un acto social destacado. ${ }^{121}$

\section{3 La congregación de los hermanos de la Buena Muerte}

La orden de Clérigos Regulares Ministros de los Enfermos Agonizantes de San Camilo de Lelis ${ }^{122}$ fue fundada en 1586 por San Camilo de Lelis para cuidar a los enfermos y consuelo a los agonizantes. El papa Sixto $\mathrm{V}$ aprobó la orden y Clemente VI la confirmó concediéndole nuevos privilegios. En 1643 el papa Pío VI otorgó el permiso para que pudiera establecerse en España y fuera independiente de Roma y a la Nueva España llegaron en 1775 al frente del padre Martín Moya, estableciéndose en la casa de las Calderas donde levantaron su iglesia y su convento, con el tiempo esa calle fue conocida por el nombre de San Camilo. El hábito de los Camilos consistía en sotana y capa -

\footnotetext{
${ }^{121}$ Cerrado durante muchos años, el Panteón de San Fernando fue cercado por la gran ciudad y permaneció enrejado y abandonado. En nuestros días, el Gobierno del Distrito Federal en unión con otras instancias federales ha programado visitas guiadas a dicho panteón lo cual en cierta manera es una manera positiva de valorar nuestro pasado.

${ }^{122}$ El origen de este santo se remonta a mediados del siglo XVI en Nápoles donde vivía Camila Compelio, noble y rica que soñó estando encinta que le nacía un niño con una cruz en el pecho. Camilo nació hijo de un soldado en un establo en Bosquianico, provincia de Chieti el domingo 25 de mayo de 1550. De infancia y adolescencia problemática Camilo perdió a su padre a los 19 años cuando iban rumbo a la milicia y se fue a Roma casi desnudo y entró a trabajar en el Hospital de Santiago de los Incurables como voluntario cuidando enfermos. Su relación con San Felipe Neri y su dedicación y su amor a los desprotegidos le llevó a organizar un sistema de atención a los enfermos. Camilo pudo ordenarse sacerdote y llevó a buen camino su fe pudiendo otorgar a los agonizantes la extremaunción. En 1554 fundó la Congregación de los padres de la buena muerte. Camilo murió en 1614 y dejó veinte casas ocupadas por trescientos religiosos. Fue beatificado por Benedicto XIV en 1742 y canonizado en 1746, fundándose establecimientos en Portugal y España y de allí pasaron al Nuevo Mundo con una presencia fuerte en la ciudad de Lima, Perú. Berta Gilabert y Alberto Soto, Mortal Agonía Orden de Clérigos Regulares Ministros de los enfermos Agonizantes de San Camilo de Lelis en México, Caridad, salud, enfermedad y muerte en la ciudad de México (siglos XVIII y XIX). Tesis, licenciatura en historia, FFy L. UNAM, 2000, pp. 32-35.
} 
negra, ambos con una cruz roja al lado derecho, casi a la altura del hombro. El sombrero era de teja o acanalado. ${ }^{123}$ (fig. 58)

Esta orden fue conocida también como "camilos", "agonizantes", "padres de la buena muerte", "hermanos del bello morir", "crucíferos" y fue suprimida en 1861. Los padres camilos profesaron un voto extra, más que el común de

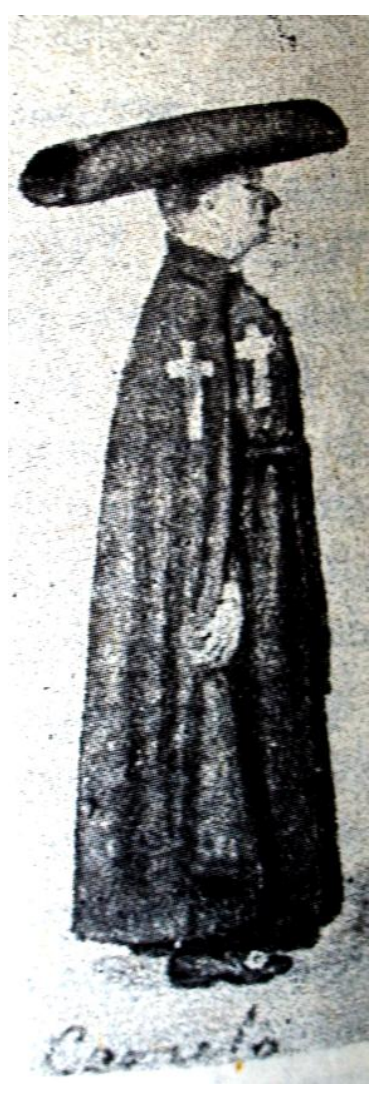

Fig. 58

Padre Camilo litografía del siglo XIX otras órdenes religiosas: obediencia, castidad, obediencia y la asistencia a los moribundos aún en tiempos de peste. En la orden existían tres clases de religiosos: a) Clérigos regulares (sacerdotes), b) Hermanos conversos (laicos) y c) Hermanos Oblatos 0 donados (empleados en los oficios de la casa).

En la Nueva España durante el siglo XVIII las condiciones insalubres de hacinamiento, de contaminación de los mantos freáticos con heces fecales, la falta de control con los cadáveres tuvieron como consecuencia la proliferación de enfermedades infecciosas en la población. Esto provocó un acercamiento a la religión y a su intercesión divina ante los destinos oscuros de la muerte, para su remedio terrenal, las posibilidades de solución se encontraban sólo cuatro opciones: la resignación a la muerte, la hospitalización, la invocación divina o la combinación de algunas de éstas. Con el mestizaje y el establecimiento de una cultura extranjera se conformó una idea sincrética en torno a la muerte y a los procesos asociados a ella, desarrollando formas propias de ritos y costumbres en torno a ella. Para ello bastaba que el enfermo se sintiera débil, enfermo o anciano para que se solicitase la ayuda del médico para que dictaminara sobre los problemas del cuerpo y que en su presencia se le informara sobre la gravedad de sus males y a su vez la Iglesia se encargase de curar el aspecto espiritual y difundir la necesidad que tenía el agonizante de confesarse, y de recibir la extremaunción. Así se estableció la necesidad de las visitas a enfermos por parte de religiosos y seculares para aplicar los "santos

\footnotetext{
${ }^{123}$ Antonio García Cubas, El libro de mis recuerdos, Editorial Porrúa, México 1986, p. 133.
} 
sacramentos" y asegurar que el moribundo tendría asegurada el alma ante Dios. Para este fin durante el siglo XVIII, se seguía un ritual que consistía en una larga procesión encabezada por dos soldados de caballería con la espada en la mano para abrir el camino. Un cura a su vez llevaba en las manos una copa con el Divino Señor Sacramentado mientras varios monaguillos realizaban varias actividades: uno cargaba un farol encendido y otros dos repartían incienso. Dos hombres más auxiliaban el ritual, uno tocando la campana y el otro, cargando una mesa cubierta y adornada para colocar el Sagrado Copón, en caso de que la humildad del lugar no permitiese lugar mejor. Atrás de ellos caminaban los archicófrades, un grupo de músicos interpretando himnos y gente del vecindario que quisiese acompañar al difunto cargando faroles, hachas y velas. Se alumbraban con velas las ventanas por donde transitaba el cuerpo siendo acompañados por los guardias que encontraran a su paso. La forma de aplicar los sacramentos se conoce a partir de los manuales de administración sacramental durante el siglo XVII y XVIII contenidos en la "Forma de administrar los sacramentos de la Eucaristía y Extremaunción, según el uso y observación de el Sagrado de la Santa Iglesia Metropolitana de esta Ciudad de México, en los que se detalla los pasos que han de seguirse cuando un clérigo llega a asistir a un enfermo en peligro de muerte.

Ahora bien, es indudable que detrás de todo, se encontraba el miedo a la muerte, y la esperanza de estar frente a la figura poderosa de Dios y resultaba imprescindible reflexionar en la banalidad de la vida y de la urgencia de asegurar la salvación del alma, y una de las maneras de recordarlo y tenerlo presente fueron los cuadros de Vanitas de origen europeo, que nos muestran el paso fugaz de la vida, de lo que somos, de lo que nos rodea, y hacia donde vamos. Por eso en muchos casos en la Nueva España el rito mortuorio se entremezclaba la voluntad del finado con lo que había dispuesto de forma y manera en contraposición con las costumbres, su linaje y sus posibilidades económicas. Es claro aquí que los miembros de las diversas cofradías gozaban de un entierro fastuoso, en cambio debió de ser pobre para los indígenas y las castas.

Por eso estas representaciones barrocas de la Iglesia que se apropia del discurso de la muerte mediante la pintura, la escultura y las imágenes 
gráficas están envueltas en lecciones de que el hombre debe de aprender a manera de un espejo la banalidad de la vida mediante la vista de cuerpos ya sin vida; de esqueletos estáticos o dinámicos; de gusanos que representan la podredumbre, o de clepsidras con el tiempo vencido, y que la materialidad y la vanidad no tendrán el mismo peso simbólico junto a los bienes espirituales de la paz y la salvación eterna.

Dentro del mismo aspecto, hay que considerar que el acto de morir por lo menos para las clases económicamente fuertes no era tan sencillo en la Nueva España por lo menos por dos razones: El modelo de procesión fúnebre en la ciudad de México recordaba la muerte de Jesucristo con gente vestida a la usanza antigua que representaban al pueblo judaico y católico, costumbre de la cual era difícil escapar ${ }^{124}$; y por otra parte que dicha ceremonia fúnebre hecha pública se convirtió en el acto más importante de devoción religiosa que aglutinaba a la sociedad entera desde los cirujanos que preparaban el cuerpo hasta los decoradores de ataúdes ${ }^{125}$ y fabricantes de cera que se consumían en enormes cantidades transformada en velas y cirios.

Por alguna razón, en el siglo XVIII, las estructuras de la sociedad novohispana cambiaron, dando un giro diferente. Las causas aunque no definidas permitieron una apertura en el gobierno virreinal estableciendo una nueva relación entre el Estado y la sociedad. En el terreno científico, por ejemplo, se permitió ahondar más en aspectos médicos y conocer más sobre las enfermedades y epidemias comunes en la época y sobre todo explicar racionalmente la presencia de la muerte ${ }^{126}$. Por eso es interesante que en este momento se permita el culto y la difusión de la imagen de San Camilo de Lelis. La presencia del médico en la cabecera del enfermo establecía una salvación del cuerpo y la presencia sacerdotal la salvación del alma Considero que bien

\footnotetext{
${ }^{124}$ Esta era una enorme procesión de casi una multitud, que incluía a autoridades civiles como gente de a pié y a caballo, a los diversos gremios vestidos de negro con músicos acompañantes, autoridades como regidores, alcaldes, corregidores, la imagen de Jesucristo Difunto metido en una urna de plata, niños vestidos y maquillados de espíritus angélicos y hasta soldados disparando sus armas. En el aspecto religioso se avisaba a todas las iglesias para el tañido de campanas hasta que el cuerpo recibiese sepultura después de tres días.

${ }_{125}$ Se conocían por "luterías", o sea establecimientos que alquilaban mortajas, ropa de luto y catafalcos, entre otros objetos.

${ }^{126}$ El gremio de cirujanos perteneciente al Protomedicato no fue tan ingenuo. Sabía que la atención a enfermos contagiosos podía traerle consecuencias a su propia salud, y en el caso de heridos o accidentados o víctimas de violencia, tampoco se atendían pretextando en la mayoría de los casos la ausencia de un mandato judicial. En el fondo representaba una crisis más en la sociedad virreinal.
} 
pudo ser un recurso de carácter espiritual para ayudar a bien morir sobre todo a las clases más desatendidas como fueron los indígenas.

Ya desde 1710, muchos años antes de su llegada a la Nueva España se creó una primera "Congregación de la Buena Muerte" dirigida específicamente a barrios indígenas castigados por epidemias y se sabe que las imágenes de San Camilo se comenzaron a popularizar en ese tiempo aún cuando no había una fundación religiosa establecida en la Nueva España dándose ésta hasta el $1^{\circ}$ de mayo de 1756 con el título de Casa del Sagrado Corazón de Jesús y de San Camilo de Lelis. ${ }^{127}$ Por eso la llegada de los padres camilos fue reconocida por los habitantes de la zona al grado de tejer leyendas a su alrededor. Tan así que con el tiempo, la calle situada a espaldas de la calle de San Camilo el pueblo le puso De la Buena Muerte (hoy $5^{\mathrm{a}}$ de San Jerónimo). ${ }^{128}$

A la orden de los camilos les tocó el cambio de colonia virreinal a nación

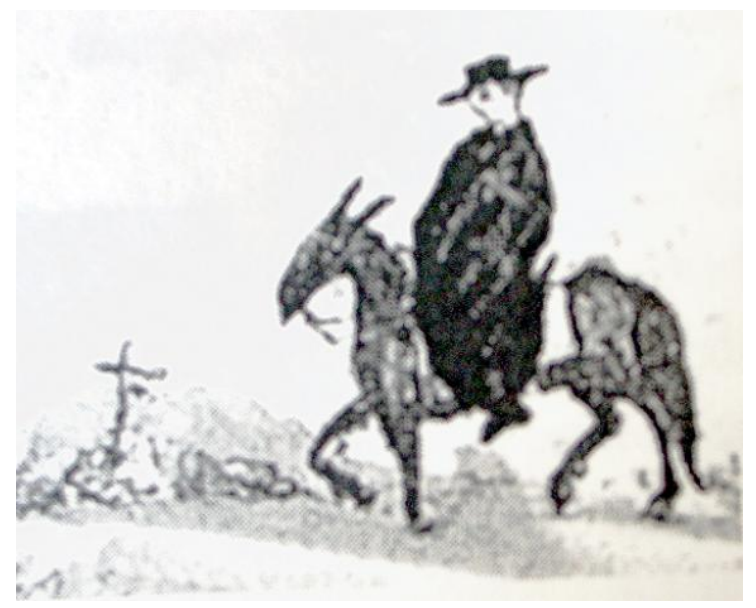

Fig. 59 El camilo montado en su mula. Litografía independiente y pese a ello su labor fue celebrada y aplaudida en términos generales por la sociedad mexicana al grado de ser representados gráficamente en forma humilde montados en una mula prestos a realizar su humanitaria labor alejados de la labor que otras órdenes religiosas no habían querido tomar ya sea por temor a enfermedades contagiosas o bien porque gozaban de atributos específicos que otras órdenes les procuraban en cuanto a prestigio y aceptación. $^{129}$ (fig. 59)

\footnotetext{
${ }^{127}$ Berta Gilabert y Alberto Soto, Mortal Agonía Orden de Clérigos Regulares Ministros de los enfermos Agonizantes de San Camilo de Lelis en México, p. 75.

${ }_{128}$ Luis Gonzáles Obregón, op. cit., p. 111.

129 El ingreso a las diferentes comunidades religiosas en si, era tardado. Pero los camilos lo transformaron en un proceso más complicado: Había que realizar una investigación sobre la "pureza de sangre" de los padres y los abuelos del presunto novicio (los indígenas y las castas quedaban fuera). Quedaba pues, realizar un extenso interrogatorio a la comunidad sobre su origen para poder formar un expediente teniendo que esperar hasta dos años para considerar tan solo la posibilidad de admisión. Berta Gilabert y Alberto Soto op. cit., pp. 84-87.
} 
También es necesario decirlo, la labor del padre camilo debió de ser difícil debido a la falta de higiene y al poco cuidado en el aseo personal de enfermos y moribundos. El cuerpo del enfermo debía tratarse como si fuera el de Cristo. Desempeñando su labor, se aprendía a asearles la cama, limpiarles los pies y la boca, a hablarles en voz baja "para no molestarlos ni afligirles" tal como había hecho casi siglo y medio antes, su fundador Camilo Compelio. Participaban en el lecho del enfermo sosteniendo un Cristo de bronce llamado el Cristo de la Buena Muerte, hincados y rezando durante largas horas no pudiendo comer ni beber absolutamente nada aunque fuera obsequiado.

Las estampas citadinas de los camilos debieron de hacer sentir bien a la comunidad en general llevando la cruz roja sobre su pecho que simbolizaba "el fuego de la caridad del prójimo que se abrigaba en el corazón del ministro de los enfermos", sobre todo después de las terribles epidemias como el matlazáhuatl y la viruela que dejaron para los camilos una buena reputación y gratitud entre la población, a tal grado de que se contaba que era común que cuando alguien se encontraba en la calle a un Ministro de los Enfermos se postrara ante él y se pusiera a rezar un padrenuestro y un avemaría para que en el momento de su muerte pudiese ser asistido por un padre camilo en ese tránsito fatal. Amador Portela el último padre camilo en México antes de que suprimiera su orden recordaba años más tarde:

Ellos eran solicitados con mucho empeño para asistir a los enfermos moribundos de las casas particulares, lo que practicaban diariamente por la mañana, tarde y noche. Con el fin de acudir con prontitud a la asistencia de los enfermos de los más lejanos barrios de la ciudad, se estableció la costumbre de que anduvieran montados en mulas, las que generalmente eran de color oscuro ${ }^{130}$.

Entre la segunda mitad del siglo XVIII y principios del XIX los ritos funerarios se secularizaron predominando el aspecto civil más que el religioso, de tal manera que fueron muy abundantes las alusiones a la muerte en cuadros, relojes, piras y grabados lo que implica la existencia de un público consumidor siendo constantes las imágenes del trance de la muerte en la iconografía colonial ya que representan la lucha del bien y el mal y la salvación del alma. Es importante mencionar que muchas de las obras

${ }^{130}$ Ibid. p. 105. 
religiosas de este periodo han salido de su contexto original lo cual dificulta su ubicación y hoy son parte de colecciones particulares y de museos y sería muy aventurado asegurar el público al que se le destinaba. Aunque es posible que hayan estado dirigidas a la comunidad religiosa compuesta de clérigos, monjas y personajes de la relacionados con la Iglesia o a personajes importantes con recursos económicos poderosos. Se conocen pinturas de retratos fúnebres o alegorías de la muerte que manejan discursos sobre la vanidad, el deterioro de la belleza del ser humano o la muerte con su guadaña con la presencia de demonios que pretenden advertir sobre las tentaciones de la vida y los peligros que corre el alma por el pecado. Caso contrario puede ser el aspecto de la gráfica religiosa con fines más populares pudiendo llegar a una distribución masiva por sus costos en tiempos que era difícil hacerse de imágenes piadosas, y aunque el mensaje puede ser el mismo las necesidades son distintas pero no por ello deja de ser efectivo y directo. La existencia de estas obras hablan de la necesidad social de que alguien socorra al agonizante y le ayude - junto con el médico- en este difícil tránsito esperando la llegada de las parcas y auxiliándole a salvar su alma débil y conminarlo al arrepentimiento profundo y sincero.

\section{4 La gráfica camiliana}

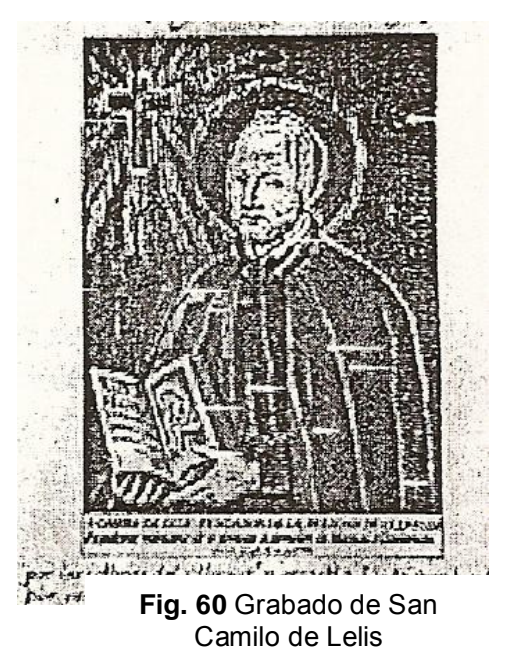

En aquel tiempo la devoción a San Camilo de Lelis fue promovida gracias a un grabado de Manuel Villavicencio grabado en 1782 de mano dura en la que aparece san Camilo de medio cuerpo y tres cuartos de perfil con sotana y manteo negros con la cruz del lado derecho sosteniendo el libro de regla, al fondo en la parte superior izquierda una cruz que refulge. (fig. 60) Un texto indicaba al penitente que hacer para ganar indulgencias: 
"Por cada Padre nuestro, Ave María, ó Gloria Patri que se rece delante de alguna Estápa ó Imagen de S. Camilo, se ganan 120 días de Indulta.a aplicable.s por las Almas del Purgat.o, y otros 120 á cada moribundo por cada minuto que tenga dicha Imagen en su Apos. To ó se encomendare á dho. Santo".

La figura del camilo con su indumentaria en la segunda década del siglo XIX, debió de ser interesante al grado de que el artista italiano Claudio Linati la litografió a color en su libro, "Trajes civiles, militares y religiosos de México" que si bien es la visión de un europeo idealizando la belleza no está ajena al romanticismo de su tiempo. Así lo complementa de manera descriptiva en el texto que acompaña sus figuras:

[...] viendo un hombre envuelto en su gran capa negra echada despreocupadamente sobre su espalda, con su mirada oscurecida por la sombra de un gran sombrero oblongo, con la cruz roja que sobresale del fondo oscuro de sus ropas, cree uno, quizás encontrar todavía uno de aquellos terribles agentes de la inquisición española y un recuerdo mezclado de horror nos trae las sangrientas escenas de aquel odioso tribunal. Pues bien, nos equivocamos, ese monje es un filántropo, a lo menos por su institución. Su misión es acompañar a los criminales al lugar de la ejecución, despertando los remordimientos, hacer que se arrepientan en su alma endurecida y prodigarles los consuelos de la religión, al abrirles su corazón a la esperanza del perdón..."131

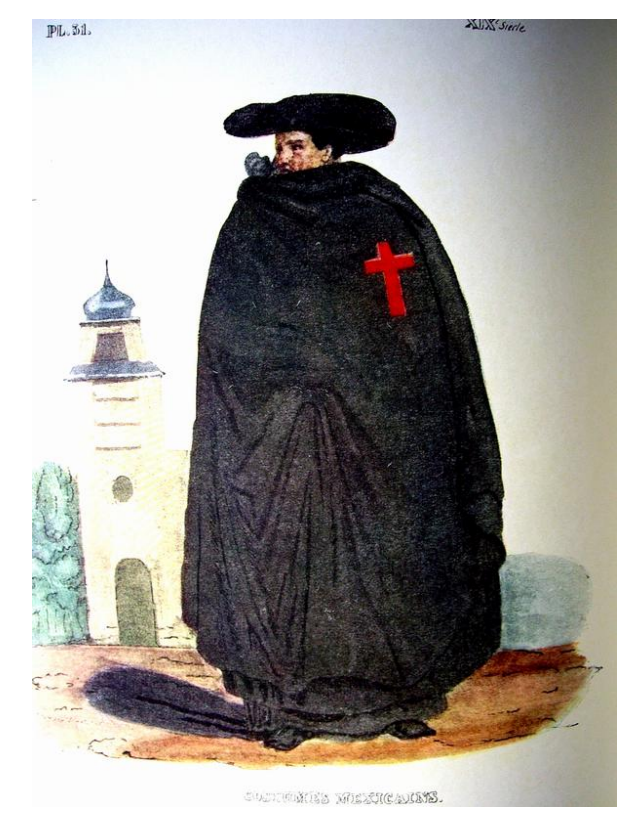

Fig. 61 Fraile Camilo. Litografía de Linati

131 Claudio Linati, op. cit., p. 101
La imagen muestra figura del padre camilo de pie embozado en una larga sotana y su largo sombrero ya descrito y al fondo una capilla religiosa en la que no se identifican características de alguna orden religiosa en la que quisiera creer que sólo se ha construido como una ambientación de la figura dibujada. (fig.61)

La imagen de San Camilo, por lo que se puede deducir, se hizo todavía más popular en la ciudad al grado de que su devoción casi no había un solo enfermo moribundo que no dejara de tener a su 
cabecera una de sus imágenes, sobre todo después de las epidemias que seguían azotando a la capital. Como parte de la integración de los padres camilos en la vida cotidiana, Vicente T. Mendoza recogió una hoja suelta de la Imprenta de la calle de Trepana (1843) con un cántico titulado El velorio del Parián con su atole catarino" que dice en una de sus partes

\author{
Muchos días agonizando \\ Estuvo el pobre difunto, \\ Los cuervos visten de luto \\ Y las tórtolas llorando \\ Lo estuvieron auxiliando \\ Un Camilo sacristán \\ Los cofrades de Birján \\ $\mathrm{Y}$ algunos otros parientes ${ }^{132}$
}

Asimismo, han llegado hasta nosotros pequeñas imágenes populares de ex votos que muestran a san Camilo asistiendo a los agonizantes en actitud piadosa mientras el Cielo espera la llegada de su alma. (fig. 62)

Los cambios en la vida política y social del país, permitieron con el tiempo, una visión distinta al concepto de la muerte. Con los constantes movimientos internos del país debido a revueltas políticas, los textos e imágenes presentan un rompimiento con una tradición del pensamiento religioso. Muchos han querido ver en ello una secularización de la vida cotidiana y la

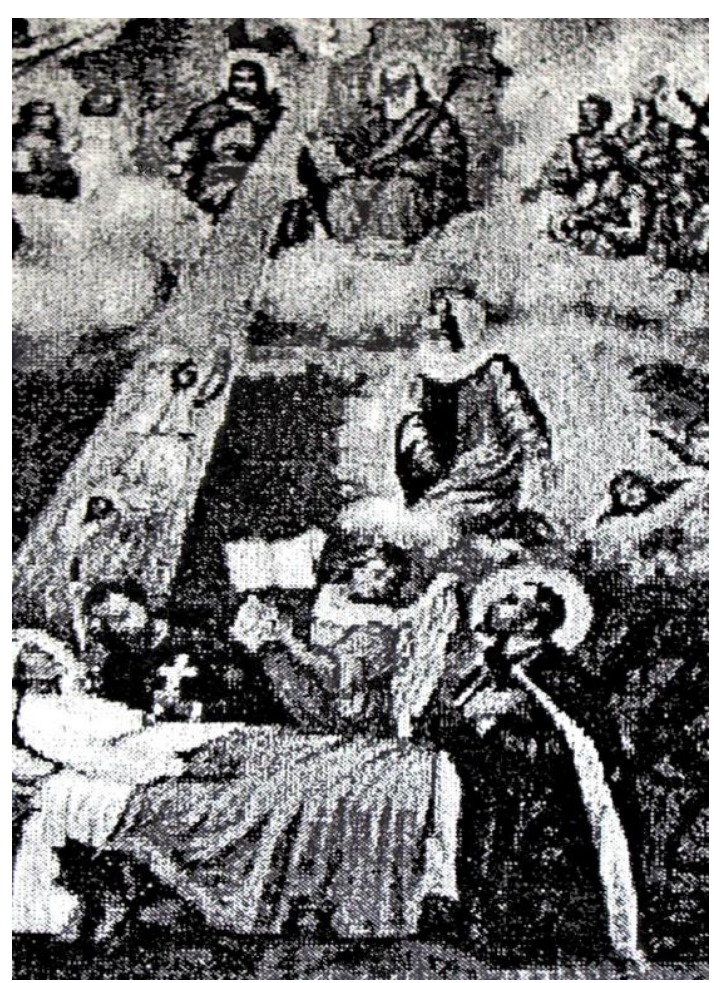
pérdida de lo que tiene que ver con el misticismo y la espiritualidad de entonces, Fig. 62 Estampa devocional de San Camilo de Lelis. representando el concepto de la muerte

\footnotetext{
${ }^{132}$ Vicente T. Mendoza, Glosas y Décimas de México, letras mexicanas, séptima reimpresión, 1996, FCE, México, p 159.
} 
como algo más concreto y más frío.

En efecto, la lucha de los conservadores y el partido liberal en el México decimonónico, de la ciencia contra la fe, de las leyes contra las sotanas rompieron el viejo esquema del miedo a la muerte por la terminación natural de un proceso físico de la vida. Sabemos ahora a través de la historia que Juárez al frente de los liberales promulgó leyes que terminaron después de varios años con el control que ejercía la Iglesia en el cuerpo y el alma del individuo entre ellas se preveía la confiscación de los bienes que la Iglesia para un interés público, el establecimiento del matrimonio civil y la apertura de los cementerios, que significó la caída de las órdenes religiosas hasta entonces existentes en México. En la vida cotidiana, los moribundos dejaron de contar con un apoyo sacerdotal y espiritual y debieron de enfrentar una nueva realidad de acuerdo a los nuevos tiempos que se presentaban: Todo debió de quedar en la invocación y en el deseo religioso.

Los ejemplos en la pintura popular y costumbrista hacen evidente los cambios, ya que al igual que en Europa, los fieles ya no necesitaron tanto la compañía del antiguo clérigo de sotana para la protección divina al igual que otros objetos de devoción. Así "el individuo necesitado de ayuda se muestra suplicante o en el momento de mayor desamparo, casi siempre frente al personaje sagrado a quien le reza pidiendo alivio". ${ }^{133}$

Otros ejemplos pictóricos muestran a los difuntos rodeados de su familia en tranquilidad aparente sin la lucha eterna entre el bien y el mal acompañados de textos explicativos donde se nota la pérdida física del ser humano y se lamenta de la forma más natural posible:

"Oh Parca horrenda, terrible destructora de la vida humana, espada brillante, que a nadie perdonas; Eres cosa triste. No hay quien te pueda tolerar, te presentas del mísero mortal con tu aspecto muy funesto par truncar su vida con ademán furioso cual no se puede comparar. Hiciste exterminar de la existencia a mi amada hermana Bernardina Madrueño, el día domingo 11 de julio del año 1852 siendo memorable para sus familiares tan triste acontecimiento." ${ }^{134}$

\footnotetext{
${ }^{133}$ Gloria Fraser, El arte de la devoción, Ex votos, Artes de México, número 53, México, 2000, p. 16.

Berta Gilabert y Alberto Soto, op. cit., p. 212.
} 
Con la aplicación de las Leyes de Reforma, finalmente llegó la orden para la supresión de las órdenes religiosas existentes en la República Mexicana en diciembre de 1860 y con ello la conclusión de la obra nunca acabada de los camilos lo que significó el fin de una época, enriqueciendo una tradición y una reflexión sobre la muerte y sus necesidades.

Todavía la imagen de San Camilo siguió colocándose en la cabecera de los

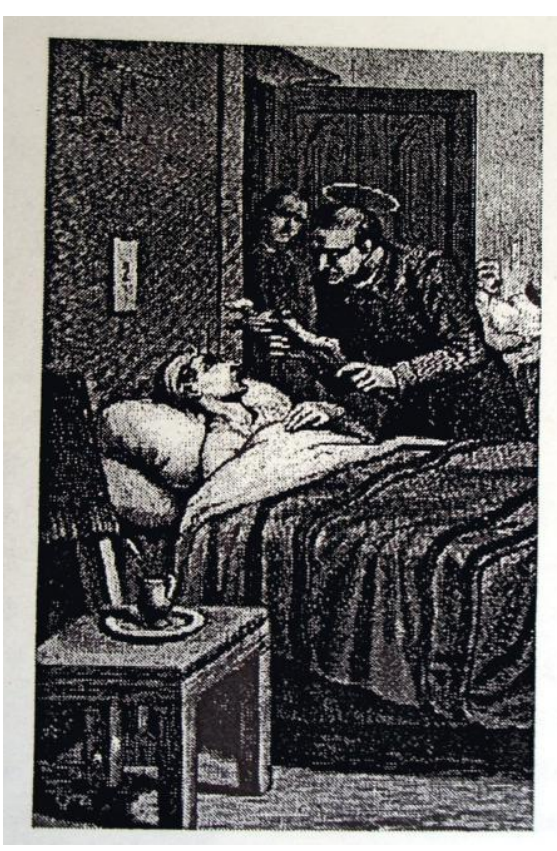

Fig. 63 San Camilo de Lelis moribundos pues se imprimieron gran cantidad de estampas lo que hace suponer que hayan sido litografías monocromáticas que se hacían acompañar de la "Oración de los enfermos", o del "Rosario de la buena muerte". Probablemente tomada de un santoral, en una de ellas se ve a San Camilo en una habitación agachado sobre un moribundo con un crucifijo en la mano. Al fondo contemplando la escena se encuentra un familiar observando la acción que transcurre dulcemente para el enfermo que tiene colocada una pequeña imagen del mismo santo en la cabecera de su cama. Lo interesante de la composición es que está exenta de demonios y calaveras, y por lo se aprecia en la imagen hasta sin un texto acompañante. (fig. 63)

Otra es todavía más popular y pertenece a la estampería religiosa de fines del XIX y principios del XX y fue realizada por el grabador José Guadalupe Posada y en ella se encuentra al agonizante con mirada de terror que observa en su habitación a los demonios que conllevan las tentaciones y vicios representados por bolsas de dinero, el juego, la bebida y las mujeres. En el otro extremo un padre camilo con un cirio en la mano permanece al lado del moribundo mientras el ángel de la guardia llora desconsolado. Colocados en la parte superior Dios, Jesucristo y el Espíritu Santo iluminan con su luz celestial al agonizante. A los pies de la cama San Camilo de Lelis parece pedir misericordia por el alma del pecador como vemos en la figura 64. 
Podemos decir que las representaciones artísticas en pintura y escultura de temas religiosos y en especial del momento de la muerte penetraron de manera más efectiva en el aspecto de la gráfica popular donde se distribuyeron en

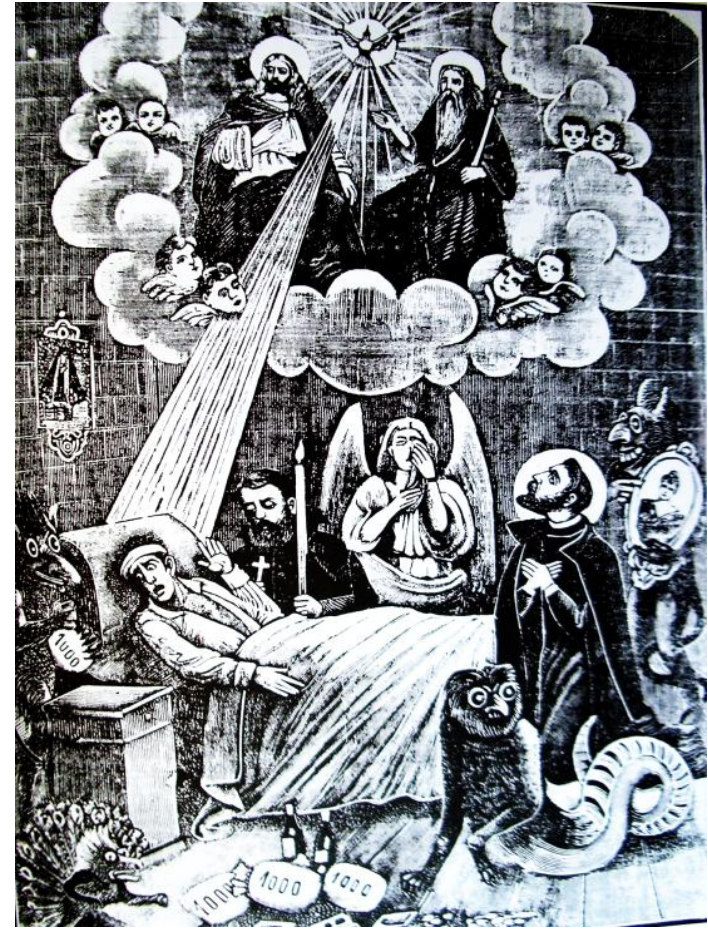

Fig. 64 San Camilo de Lelis. Grabado de José Guadalupe Posada

forma masiva gracias a la reproducción de talleres de litografía. En el caso concreto de la figura de san Camilo se mostraban acciones recreadas del santo varón que dieron tranquilidad espiritual a seres que necesitaban de su consuelo en el difícil tránsito de morir. Parece ser que existió por lo menos por un tiempo en los habitantes de la ciudad de México, la costumbre de enterrar los cuerpos con una pequeña estampa de san Camilo que los protegería durante un largo tiempo en su otra vida.

Localicé en una tienda de antigüedades con impresos del siglo XIX, una pequeña hoja doblada en cuatro partes de media carta con una oración y plegarias dedicadas a San Camilo de Lelis, impreso en la ciudad de Puebla. ${ }^{135}$ Su tamaño quizá corresponda a un uso estrictamente personal para llevarlo consigo en todo momento. En el texto se hace énfasis que el objeto de la devoción es dar un poderoso y eficaz protector para aquella hora fatal, y que es justamente San Camilo quien "...animará a proseguir la empresa comenzada para consuelo de los que se hayan en las últimas agonías por lo que la Santa Iglesia os ha dado el tributo de Protector de las almas en la hora de la muerte". Dice de esta manera la plegaria:

\footnotetext{
Glorioso San Camilo

Por bien de nuestra suerte

Piadoso acompañadnos

A la hora de la muerte.
}

\footnotetext{
${ }^{135}$ Hoja de plegarias a San Camilo de Lelis, s/f, Puebla, Pue.
} 


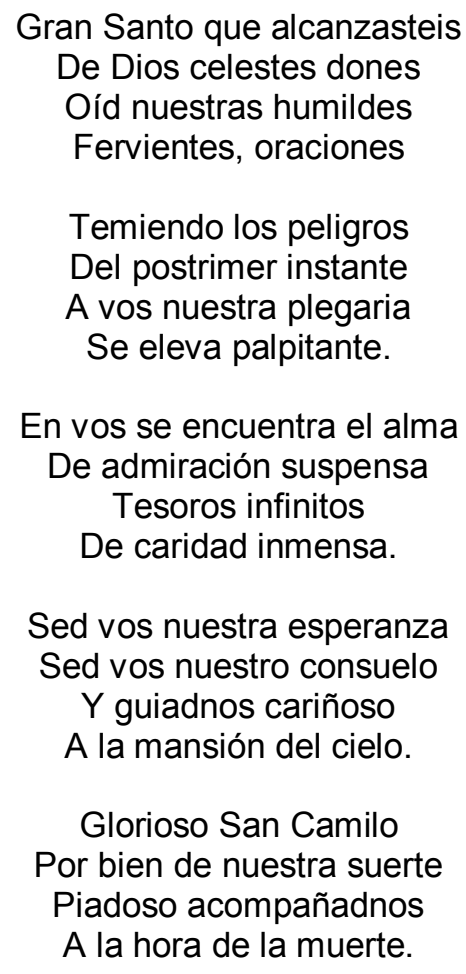

Un comentario final puede caber para cerrar este apartado, y es que, en nuestros días ha aparecido en los medios una desagradable noticia cultural: la destrucción del antiguo edificio que albergó al venerable convento de los Camilos en la calle de Regina 97 en el Centro Histórico de la Ciudad de México. Con múltiples usos a lo largo del tiempo como juego de pelota, sede de agrupación de colonos para las Californias, cuartel de soldados, baño para caballos de San Camilo, Seminario Conciliar Tridentino de México, Cerería de San Camilo, Teatro Ángela Peralta, y Escuela Secundaria Diurna Cesar A. Ruiz, la conocida como la "Casa de las Calderas" significaba un patrimonio histórico que merecía un espacio digno de conservarse en los tiempos modernos y por supuesto de mantenerla para futuras generaciones. ${ }^{136}$ Una suerte distinta corrió la casa de descanso que poseían los camilos en el entonces barrio lejano de Coyoacán y que se encuentra todavía de pie gracias a que sobrevivió convertida en un remedo de restaurante en el que una pequeña placa de piedra en una pared recuerda su uso en el pasado.

Aún hoy se maneja una imagen distorsionada de los camilos y la muerte en la cultura popular, prueba de ello es la historieta Tradiciones y Leyendas de la Colonia con 32 páginas del 27 de septiembre de 1964, con el título de "El

\footnotetext{
136 Judith Amador Tello, Se mutiló la historia de México, Proceso, número 1625, México, 23 de Diciembre, de 2007, pp. 66-68.
} 
Maldito del Templo de San Camilo" en el que se encuentra un personaje a la usanza del siglo XVI de larga cabellera con el rostro descompuesto en el lado

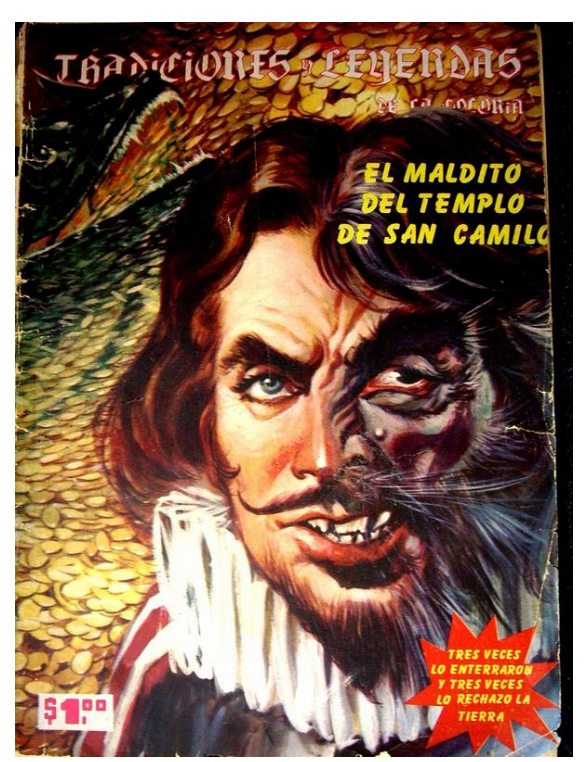

Fig. 65 La imagen de los camilos en el siglo XX derecho en un ser monstruoso; enseguida encerrada en una estrella roja a manera de sello con letras en amarillo se lee: TRES VECES LO ENTERRARON Y TRES VECES LO RECHAZÓ LA TIERRA. En el fondo se aprecian monedas de oro y una cabeza de reptil que semeja una serpiente. ${ }^{137}$ En el interior la historia era presentada por el actor e intérprete de películas de horror inglés Boris Karloff (!) ambientada en el ambiente novohispano a manera de la serie norteamericana de "Dimensión Desconocida". (fig. 65) Esto nos deja prácticamente sin comentarios al respecto.

137 "El maldito del Templo de San Camilo", Tradiciones y Leyendas de la Colonia, Revista Semanal publicada por "Ediciones Latinoamericana", S.S. número 65, 17 de septiembre de 1964. 

III

LA PRESENCIA DE LA MUERTE EN EL MÉXICO INDEPENDIENTE 

Índice Capitular

Introducción

1 El grabado y la litografía en el siglo XIX

2 La muerte en la gráfica política y popular en los impresos del siglo XIX

3 La criminalidad impresa

3.1 El entorno social en la criminalidad en el siglo XIX

3.2 Prensa y violencia

3.3 La imprenta de Vanegas Arroyo

3. 4 Manuel Manilla

3. 5 José Guadalupe Posada

3. 6 "El Tigre de Santa Julia"

3.7 Feminicidios en los impresos de Posada

3.8 Los asesinos de mujeres 



\section{Introducción}

En este tercer capítulo, se plantea que las representaciones gráficas en los primeros años del México del siglo XIX, se encontraron ligadas a los acontecimientos de España y que la litografía permitió el surgimiento de medios impresos.

En el México, del siglo XIX, se reflejan algunas de las características del Romanticismo: el individualismo; el culto a la naturaleza; el predominio de la sensibilidad sobre la razón, la nostalgia por un pasado y como consecuencia la ensoñación, el capricho, el extremo de la risa al llanto, lo sublime y lo grotesco, y México como nación que nace se observa en el lápiz lipgráfico como algo desconocido y atractivo, donde sus gentes son producto de una compleja mezcla racial conviviendo en un enorme crisol, negros, indios, mulatos, criollos y europeos

Los héroes de la Independencia en su camino de guerreros y de mártires muertos en batallas o fusilamientos son los primeros en ser glorificados por la litografía en su gesta libertaria y podríamos decir que sus retratos permitieron darles las características físicas que han perdurado al paso de los años. Con la gráfica se vuelven comunes el paisaje nacional del campo, la gente y la indumentaria; y en las ciudades se comparten espacios entre la fuerza de las armas con la paz serena de la vida bucólica del trópico.

En épocas realmente difíciles en la formación del Estado mexicano, en prácticamente todo el siglo XIX, han quedado dentro de este contexto las manifestaciones gráficas de la guerras intervencionista americana y francesa así como una interesante iconografía litográfica relacionada con la muerte, producto de las revueltas internas en la que varios escritores y particularmente los liberales, intentaron precisar el perfil de la nación, sirviéndose de las estampas para describir el estado social.

Con el tiempo, el excesivo costo de la litografía y la escasez de artistas grabadores, hicieron incosteable la producción de estampas lo cual redundó en la gran producción de imágenes fotográficas en el último tercio del siglo XIX, motivando que en muchas ocasiones, la fotografía compitiera con las imágenes 
grabadas y litográficas debido a su inmediatez. Es decir, la reproducción de imágenes daba paso a tecnologías más avanzadas, como por ejemplo, la técnica de reproducción en medio tono es decir, la traducción de las imágenes en puntos de diversas densidades para su impresión directa en el papel, que a fines del siglo XIX, alimentó principalmente los talleres de grabado que copiaban las imágenes en litografía o en grabado.

Para una ciudad en crecimiento, el periodismo brindó la posibilidad de multiplicar sus noticias y al mismo tiempo de abaratar los costos de un medio que ofrecía noticias frescas gracias a la incorporación de nuevos conceptos: formato diferente para un lector acostumbrado a periódicos reducidos; la inserción de publicidad a gran escala, el uso de la fotografía y sobre todo la accesibilidad del precio. La utilización de la imagen del delincuente peligroso, primero mediante la técnica del grabado, y después con refuerzos fotográficos, permitieron una doble interpretación de las imágenes enviadas a la sociedad mexicana. Por un lado, en una primera acción, la que llegaba al pueblo directamente por medio de volantes callejeros ilustrados en papeles de colores por grabadores populares y que cantores populares daban cuenta de los hechos sangrientos sucedidos en la vía pública. Por otro, el juicio de los lectores letrados que acudían a la información de periódicos del momento. Sólo el trabajo de editores como Vanegas Arroyo, Inclán, o Ireneo Paz, así como de grabadores populares como Manuel Manilla y José Guadalupe Posada siguieron relacionando la muerte en los aspectos cotidianos manejados desde el punto de vista de la nota roja en el imaginario colectivo como veremos en tres ejemplos destinados precisamente a los sectores marginales de la población. 


\section{EI grabado y la litografía en el siglo XIX}

Las representaciones gráficas en los primeros años del siglo XIX en América tienen semejanza con los acontecimientos que suceden en España. Los temas abordados, tanto en Europa como en América, se refieren la pérdida del trono por Fernando VII y éstas impresiones son generalmente de corte satírico. Inicialmente circularon libremente apoyando a la Corona española y fueron originalmente producidas en España o reimpresas en la Nueva España con contenidos diversos, aquí eran ofrecidas en el Portal de Mercaderes y dieron a los criollos la oportunidad de reflexionar sobre la situación política, económica y social de la Nueva España.

Esta producción se divide en tres vertientes: a) El grabado popular, generalmente anónimo y realizado en plomo o en aleaciones donde el tipo de trabajos que se hacían eran por lo común barajas, juegos y toda clase de volantes ilustrados y folletería barata dirigido a las clases bajas; b) La litografía destinada a la clase que podía adquirirlos en imprentas establecidas y de los cuales se sabe que existían cerca de noventa talleres en la Ciudad de México a lo largo del XIX; y c) El grabado practicado en forma rigurosamente académica, basado en su gran mayoría en la copia de modelos europeos, aspecto no abordado en este trabajo ${ }^{1}$. No obstante, con respecto a la temática tratada en los grabados producidos en esta época, hay que considerar dos puntos: El primero se refiere a los permisos y autorizaciones, pues ante todo debían respetar a las instituciones coloniales con el propósito de mantener el Estado. Por ejemplo, el 1 de febrero de 1809 se anunció en el Diario de México la venta de "...estampas finas, iluminadas que representan el juramento que hacen la España y América en manos de la religión de defender la causa de nuestro amado monarca Fernando VII...". El segundo punto se refiere a las condiciones políticas que comenzaban a surgir en la Nueva España, debido a que las imágenes antimonárquicas eran prohibidas y censuradas, pues en ellas se expresaban opiniones sobre la independencia y autonomía de la Corona

\footnotetext{
1 Véase la interesante relación de talleres litográficos en Nación de Imágenes, La litografía mexicana del siglo XIX, (México, MUNAL, 1994).
} 
Española. ${ }^{2}$ Para contrarrestar esta situación, en 1809 el virrey Francisco Javier De Lizana y Beaumont tomó fuertes medidas estableciendo primero una Junta Consultiva compuesta con tres oidores y unos meses más tarde estableció la Junta de Seguridad y Buen Orden. Ahí se juzgaron a los simpatizantes con las ideas y acciones insurgentes. A través de láminas grabadas y anónimas las ideas antimonárquicas fueron conocidas en forma clandestina, lo que permitió

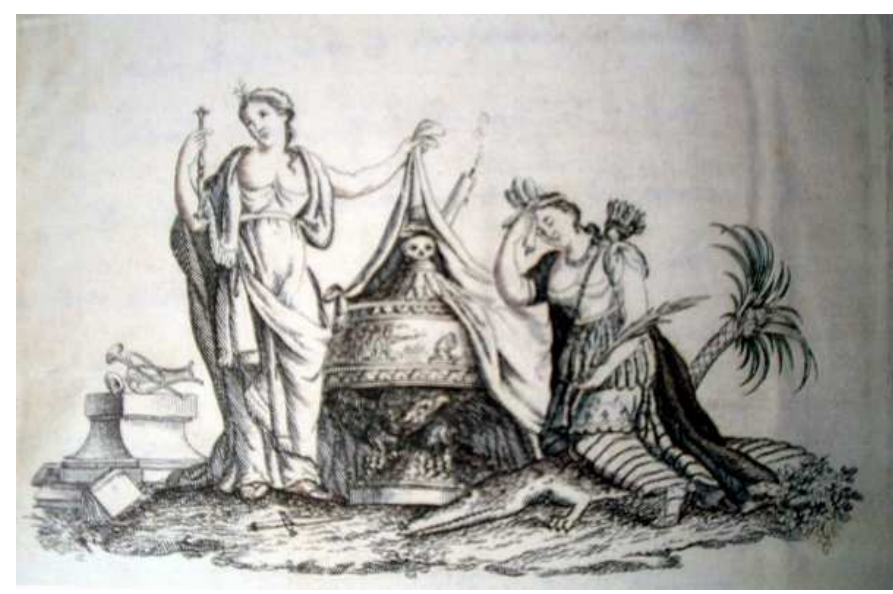

Fig. 1 Alegoría Fúnebre

su fácil distribución y difusión.

Existe una estampa de los primeros tiempos del México independiente de 1810 dirigida a todos los ciudadanos convocándolos a rendir homenaje a los próceres de la Patria; dicha estampa fue titulada "Alegoría fúnebre" y en ella se representa a dos mujeres indígenas que simbolizan a la Patria que flanquean una urna funeraria. La escena central corresponde al puntal de una calavera que en cuyo centro se encuentra grabada, apenas visible, la imagen de unos soldados disparando contra un sujeto arrodillado. (fig. 1)

De carácter determinante para la difusión de las ideas fueron la prensa y la litografía. Este método de reproducción fue introducido en México por el italiano Claudio Linati de Prevost en 1826 quien fundó un periódico llamado "El Iris" y ahí publicó nuestro autor artículos y litografías hablando de muchos temas pero en especial de reformas y de política, y realizó una alegoría en la que la Tiranía es representada por un bufón que sostiene en sus manos una calavera que simboliza a Europa. A sus lados un cura simboliza el poder de la Iglesia y un Diablo sostiene un hacha ensangrentada.

\footnotetext{
${ }^{2}$ Véase "La insurgencia de las imágenes y las imágenes de los insurgentes" de María José Esparza Liberal, en Catálogo de la exposición Los pinceles de la Historia, de la patria criolla a la nación mexicana, México, MUNAL, INBA, 2000, pp. 133-151.
} 
A lo lejos como testigos mudos se encuentran unos personajes ahorcados anónimos como prueba de silencio controlado. En la curiosa escena la Tiranía se apoya sobre un falso piso apoyado en cráneos humanos. (fig. 2)

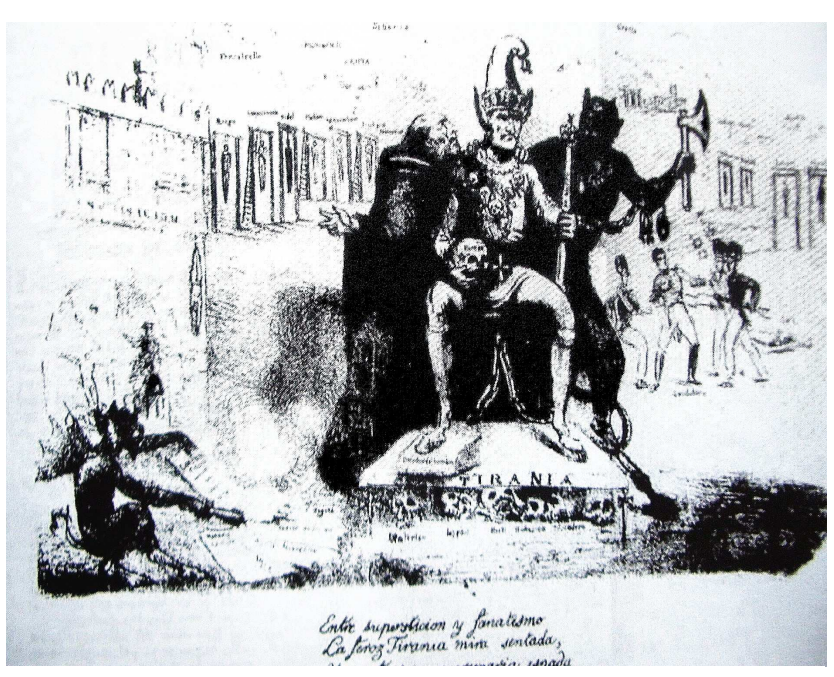

Fig. 2 "La tiranía", litografía de Claudio Linati

El texto que acompaña la imagen dice lo siguiente:

Entre la superstición y fanatismo La feroz tiranía mira sentada $Y$ con terror y mercenaria espada Doquier siembra la muerte el Despotismo

El contenido de algunas imágenes está compuesto de códigos y significados que va siendo construido de acuerdo con las circunstancias históricas y el desarrollo de la gráfica satírica, ${ }^{3}$ presentándose unidas la literatura, el lenguaje cotidiano y la retórica. En la Nueva España, esta forma se presenta hacia 1809 y del cual podemos observar en numerosos ejemplos en folletos y periódicos.

La sátira gráfica sirvió también a las logias masónicas de yorkinos y escoceses para atacarse mutuamente, en tan duras disputas que en ocasiones

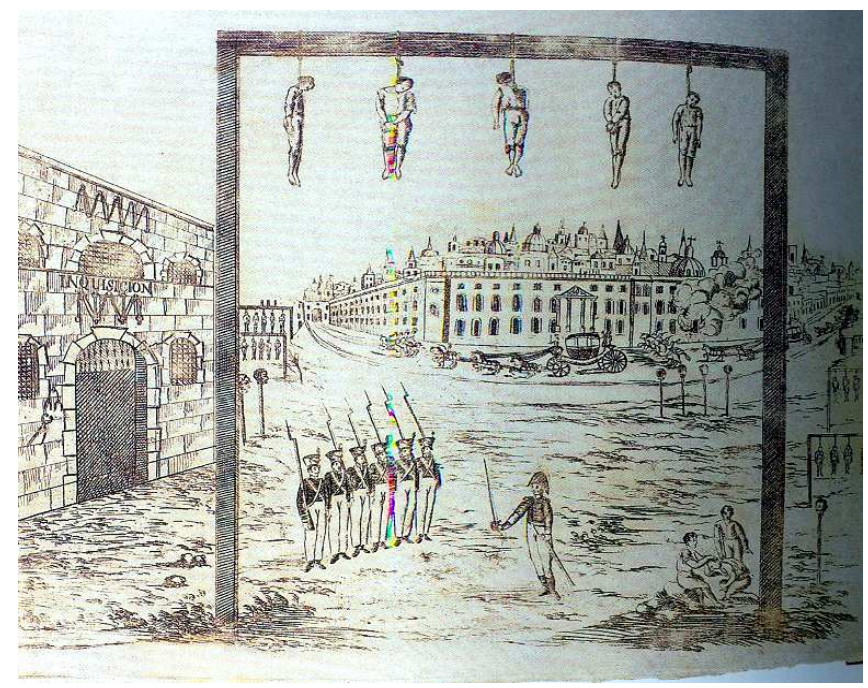

Fig. 3 "Premio de los americanos por gachupines y frailes. Grabado en metal terminaban con las muertes de

\footnotetext{
${ }^{3}$ Véase el apartado Helia Bonilla, "El Calavera y la vieja tradición del sueño y la alegoría", en "El Calavera: la caricatura en tiempos de guerra", Instituto de Investigaciones Estéticas, UNAM, número 79, 2001, pp. 104-114. Bonilla cita algunos ejemplos: Sueño alegórico de la mejicana doña María Francisca de Nava de 1809, y la lámina perdida que ilustró un folleto del Payo del Rosario titulado Tercer Coyote, en la cual se veía " un sueño raro que tubo Pascual:[acerca de ] las crueldades inauditas de los Gachupines y los justos motivos de su espulsión..." y algunos textos de Fernández Lizardi.
} 
algunos de sus integrantes. ${ }^{4}$ Un ejemplo es la lámina de autor anónimo (fig. 3) que muestra la conspiración del padre Joaquín Arenas descubierta en 1827, quien pretendía restaurar el poder de España en México. En el grabado aparece la imagen de cinco hombres ahorcados, a su izquierda, el edificio de la Santa Inquisición, y hacia el fondo unos edificios del que se destaca el que ocupaba el Tribunal del Santo Oficio por donde pasan I carruajes tirado por caballos y donde van personajes importantes ligados al virrey. En el marco derecho cuelgan otros ahorcados, mientras que en el centro de la imagen un pelotón se soldados se dispone a pasar por las armas a un cabecilla. Asimismo se observan pequeñas cabezas colocadas en estacas como se acostumbraba

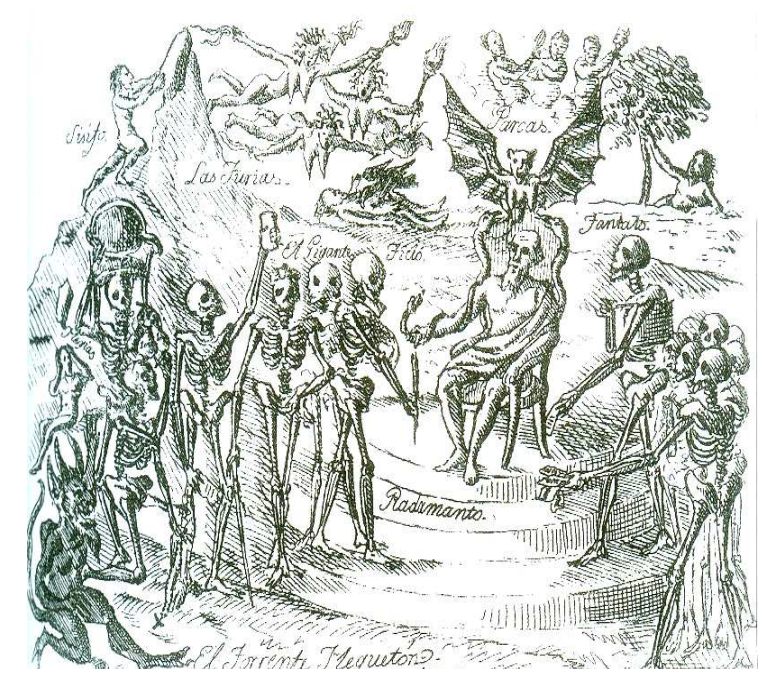

Fig. 4 Gran Logia Nación Mexicana y pira de los yorkinos. en los primeros tiempos del siglo XIX como escarmiento público. La lámina fue titulada "Premio de los americanos por gachupines $y$ frailes. Diálogo entre el padre Arenas, el General Arana y Don Agustín de Iturbide".

Otro grabado en metal de 1827 titulado "Gran Logia Nación Mexicana y pira de los yorkinos" de autor anónimo, (fig 4) presenta una pira de la logia en cuestión, cargada de emblemas de ésta misma. En un trono diabólico se encuentra sentado el jefe supremo quien sostiene una serpiente y se encuentra acompañado de un maligno ser alado. Tres escalones abajo se encuentra un grupo de muertes o esqueletos acompañados de los vicios que simbolizan: Sísifo, el gigante, que representa las furias. En tanto, un pequeño diablo mira divertido la escena. Este periodo poco estudiado en México representó una violencia política inusitada como antes en nuestro país porque tanto polkos como yorkinos, tuvieron victorias temporales: A los polkos, la oposición no los bajó de cobardes lo que significaba una inseguridad en la forma de inclinarse

\footnotetext{
${ }^{4}$ Helia Bonilla, La gráfica satírica y los proyectos políticos de nación (1808-1857), Catálogo de la exposición "Los pinceles de la Historia, de la patria criolla a la nación mexicana", México, MUNAL, INBA, 2000, pp.171-187.
} 
por algún partido. Una canción titulada $A$ los polkitos y soldados de mama dice en una de sus partes

\author{
¡Ay pobrecitos polkitos! \\ Buen petardo se han pegado, \\ Que pensaban ir por la lana \\ Y salieron trasquilados \\ Un polko se lamentaba \\ parado en la Alcaicería \\ y del miedo que tenía \\ diente por diente pegaba. \\ ¡Pobre criatura! Lloraba \\ por mamá y sus hermanitos. \\ Ellos son muy exquisitos, \\ Bien nacidos y decentes. \\ ¿Quién los metería a valientes? \\ ¡Ay pobrecitos polkitos! \\ -Dile a mama adorada, \\ le decía a su mamá Antón, \\ que me mande mi colchón; \\ las sábanas y la almohada. \\ Mas no, no le digas nada, \\ Porque estoy determinado \\ Para pintar mi venado \\ Poniendo otro en mi lugar, \\ Pues los que querían ganar \\ Buen petardo se han pegado. ${ }^{5}$
}

Con el movimiento de independencia de Europa, la nación mexicana se convirtió en un crisol de guerras constantes donde litógrafos y dibujantes de guerra que van desde las luchas fraticidas, hasta las invasiones extranjeras. En 1847, fuerzas expansionistas de los Estados Unidos invaden a México trayendo como consecuencia la pérdida de casi las tres cuartas partes de su territorio en la parte norte. El conflicto se inicia cuando los Estados Unidos.intentaron anexarse Texas desde 1804, pero hacia 1834 fue fuertemente alentada por Andrew Jackson y su colaborador Samuel Houston logrando en 1835 su independencia de México y proclamando la República de Texas e ingresando como parte de los Estados Unidos en 1845 teniendo como frontera natural el

5 Mendoza T. Vicente, Glosas y décimas de México, México, Fondo de Cultura Económica, Col. Letras Mexicanas, séptima reimpresión, 1996, p. 193. 
Río Bravo iniciándose así las acciones de batalla por ambas partes hasta concluir con el Tratado de Guadalupe Hidalgo el 2 de febrero de 1848.

Históricamente, México no se encontraba preparado para enfrentar una guerra

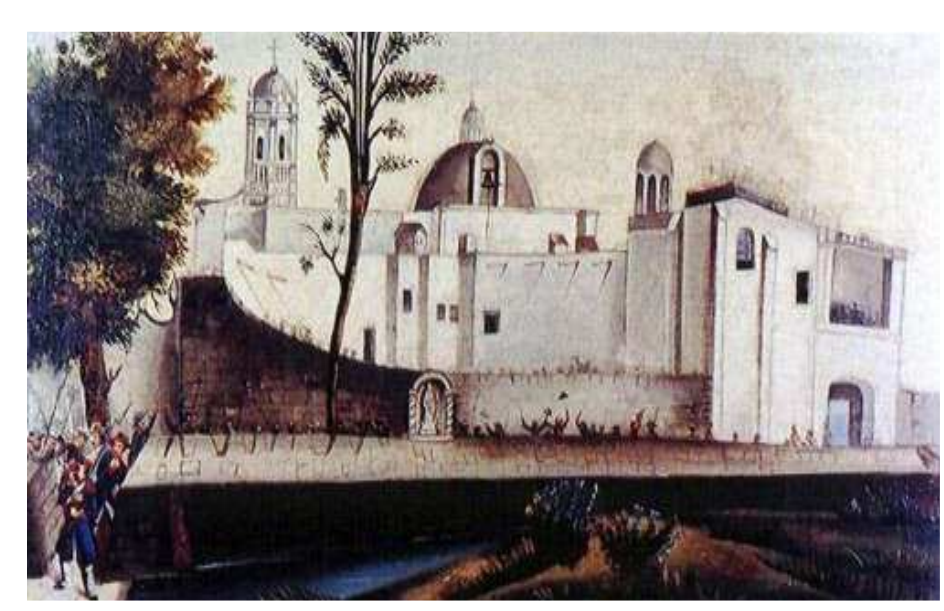

Fig. 5 Batalla de Churubusco. Litografía a color. puesto que no contaba con hombres preparados, ni armamento adecuado; pero aún así surgió una conciencia patriótica que definitivamente no bastó para el avance sobre territorio nacional. Las batallas más importantes fueron las de Cerro Gordo, Padierna, Convento de Churubusco, Molino del Rey, y Chapultepec. (fig. 5) De ellos, probablemente, sea ésta última la más conocida entre los mexicanos, ya que se recuerda como la hazaña de "Los Niños Héroes" que pelearon valerosamente en el Castillo de Chapultepec De esta manera los hechos nacionales se presentan como testigos gráficos mediante el grabado y la litografía ${ }^{6}$ aunque fueron en realidad muy pocos los dibujantes mexicanos que lo utilizaron debido a que:

En el caso mexicano, varios factores se congojan para esta escasez de imágenes es lógico pensar que la derrota y la pérdida de gran parte del territorio nacional no produjera muchas representaciones; por otra parte, la prensa sufrió en ese momento una gran censura e incluso se suspendió la publicación de los periódicos a causa de la situación. Además el conflicto provocó el cierre de los puertos y en especial el de Veracruz, lo que ocasionó una gran carencia de papel, sobre todo el litográfico.

\footnotetext{
${ }^{6}$ Algunos de las obras que son ilustradas mediante grabado y litografías son : "Apuntes para la historia de la guerra entre México y los Estados Unidos". (Imprenta de Manuel Payno y litografías de Plácido Blanco (1848). "Atacan las tropas del Gobierno el cerro de San Juan en Puebla el 10 de marzo de 1856 y entra el presidente Comonfort en el convento del Carmen" y "Batalla de Ocotlán, dada en los terrenos de la Hacienda de San Isidro el día 8 de marzo de 1856" en Historia de la Revolución de México contra la dictadura del general Santa Ana 18531855 Imprenta de Vicente García Torres. 1856
} 
También varios de los impresores más importantes de la capital se hallaban en fuera, como Ignacio Cumplido, que desde enero de 1846 se fue a Europa, y José Mariano Fernández de Lara, quien trasladó su imprenta a Querétaro al servicio provisional. Otros impresores dejaron sus actividades, como Vicente García Torres, para participar activamente en los combates....7

Un caso excepcional es Abraham López quien logra testimonios de la guerra contra los Estados Unidos por medio de un calendario que titula "El gran drama trágico de la república mexicana" en los calendarios de 1848, 1849 у 1850. En una estampa curiosa titulada "Entierro de los Americanos" vemos el cortejo fúnebre americano en una avenida capitalina

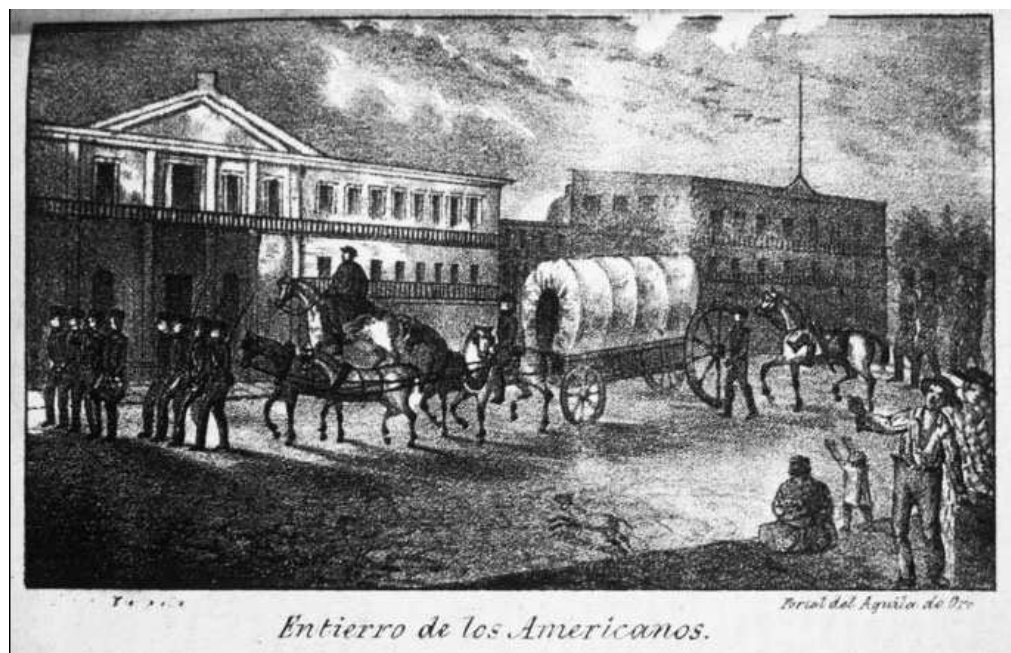

Fig. 6 Abraham López, Entierro de los Americanos, litografía mexicana muy bien lograda sobre todo el tratamiento lúgubre del ambiente. (fig. 6) No debe de pasar desapercibida en la imagen a los personajes situados en primer plano que comentan el asunto, o bien la poca importancia que demuestran los mexicanos al paso de un carro con difuntos.

Otro evento bélico importante durante la segunda mitad del siglo XIX, involucró a México y Francia y ha sido conocido históricamente como la Intervención Francesa (1862-1867); en la cual tropas francesas, austriacas y belgas ocuparon el país imponiendo la figura de Maximiliano de Habsburgo y su esposa Carlota Amalia. ${ }^{8}$ En mayo de 1862, los franceses son vencidos en la Batalla de Puebla bajo el mando del General Ignacio Zaragoza. Por otra parte un hecho que favoreció los cambios internos en México, fueron los problemas

\footnotetext{
${ }^{7}$ María Esparza Liberal, Abraham López, un calendarista singular, en Anales del Instituto de Investigaciones Estéticas, UNAM, Volumen XXVI, número 84, primavera de 2004, p. 29.

${ }^{8}$ Un antecedente es el conocido como la "Guerra de los Pasteles" el 9 de marzo de 1839 donde un pastelero francés, cuyo negocio estaba en Tacubaya, decía haber perdido sesenta mil pesos en pasteles, misma cantidad que reclamaba.
} 
europeos del monarca Napoleón III, dejando al emperador sin apoyo económico y político donde, después de 71 días de resistencia la ciudad de Querétaro cayó en manos de las tropas republicanas, siendo fusilado en el Cerro de las Campanas, junto con los generales imperialistas Tomás Mejía y Miguel Miramón, Algunas de las batallas mas importantes y ganadas del lado

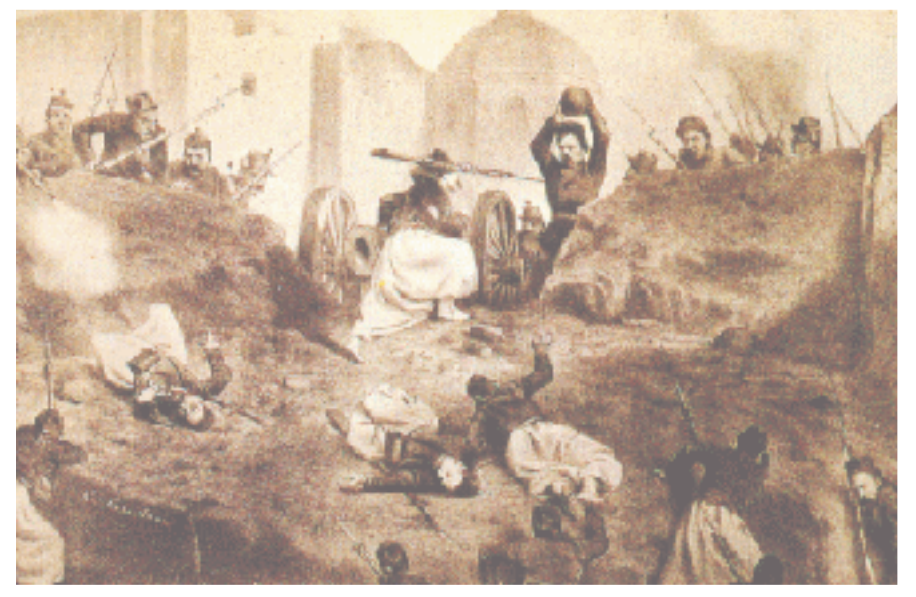
mexicano como la "Batalla del 2 de Abril" (fig. 7) son recreadas en la piedra litográfica sobre todo porque el héroe ahí fue Porfirio Díaz futuro presidente de la república. Estas batallas lograron con el tiempo la entrada de Benito Juárez a la capital del país como vencedor

Fig. 7 Batalla del 2 de Abril Litografía

y con ello dio paso al nacimiento de la República. ${ }^{9}$

Este periodo de intervención extranjera dio motivo a los litógrafos para ilustrar temas satíricos en la prensa nacional, en los cuales la guerra, y con ello la muerte, se presenta en ambos bandos. Constantino Escalante (1836-1868), realiza para el periódico La Orquesta, una obra donde se muestran tres aspectos de la expansión imperialista europea, a la que tituló como "Los tres santos franceses". (fig. 8) En el centro de la ilustración se

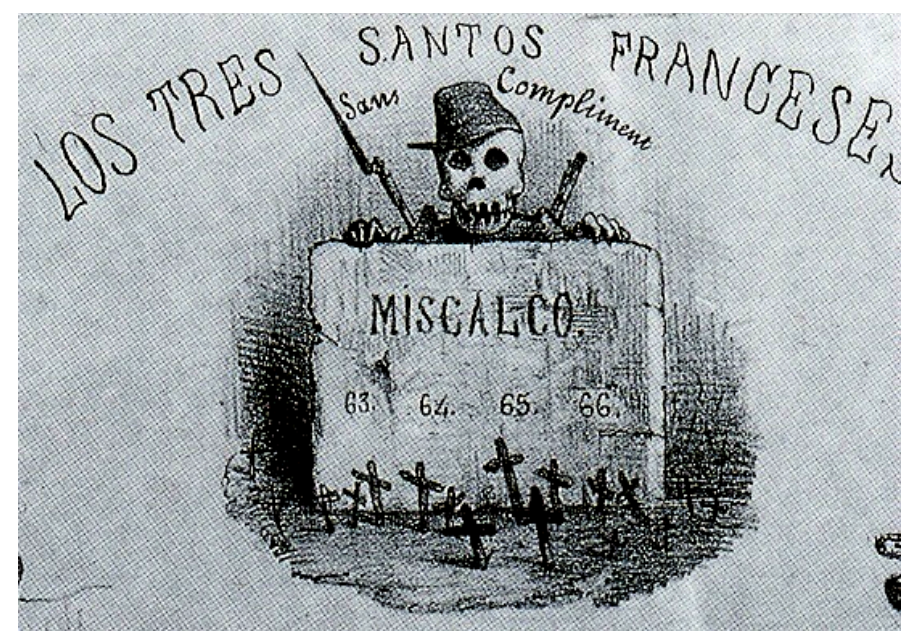

Fig. 8 Los tres santos franceses. (Detalle) Litografía

\footnotetext{
${ }^{9}$ http://es.wikipedia.org/wiki/Segunda_Intervenci\%C3\%B3n_Francesa_en_M\%C3\%A9xico
} 
encuentra la calavera de un soldado mexicano oculto atrás de una lápida con el título de "Miscalco" y los años de guerra llevados en ese momento de intervención, con un campo cubierto de cruces.

Es casi probable que el hecho histórico se refiera a Mixcalco en lo que era una tranquila plaza en el centro de la Ciudad de México, donde fueron pasados por las armas, algunos soldados mexicanos como escarmiento a los que tomaban las armas contra los franceses. Un caso histórico se refiere al notable guerrillero Nicolás Romero cuando es apresado en Papasindan y fusilado precisamente en la plaza de Mixcalco el 18 de marzo de 1865. Cuando le preguntaron si quería recibir ayuda espiritual, en respuesta despreciando a la muerte contestó que prefería dormir. ${ }^{10}$

Asimismo, al término del conflicto armado el fusilamiento de Maximiliano, Miramón y Mejía es socorrido por dibujantes, fotógrafos, pintores y litógrafos. Hesiquio Iriarte (1824-1903) hace su versión de la muerte del Emperador en "El Cerro de la Campanas", donde se aprecia una gran calidad de dibujante y de

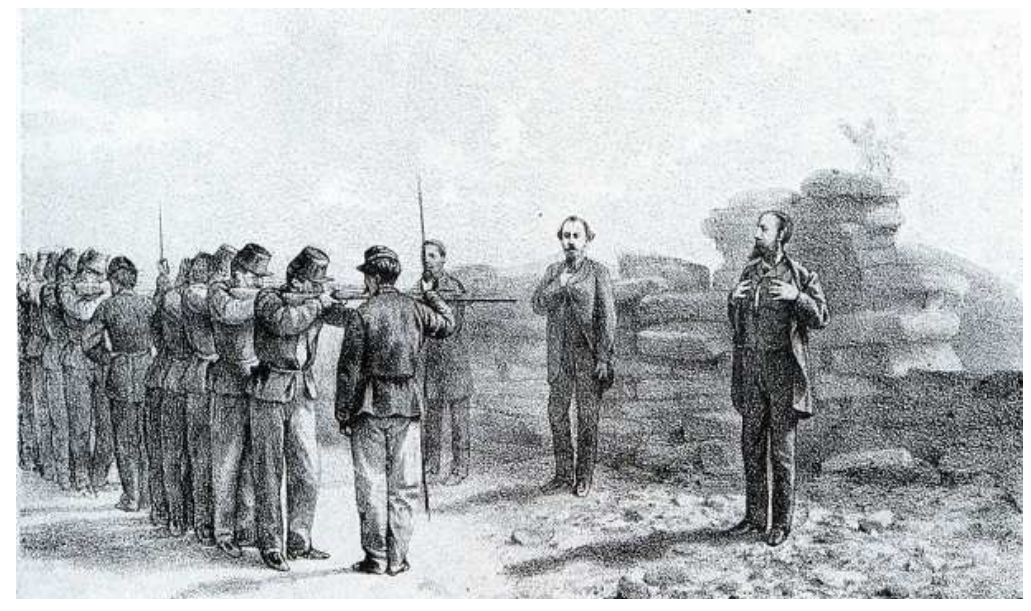

Fig. 9 El Cerro de las Campanas litografía

\begin{abstract}
fotógrafo, ya que a diferencia de otros, los rostros muestran un realismo y mucho de verdad con respecto a los sucesos históricos, hecho que denota la maestría en el manejo de ambas técnicas. (fig. 9) Considero que son válidos los
\end{abstract} comentarios de Oliver Debroise cuando comenta que esto fue posible gracias al apoyo fotográfico de las imágenes de la guerra.

\footnotetext{
10 José, Ortiz Monasterio, Patria", tu ronca voz me repetía... Vicente Riva Palacio y Guerrero, México, UNAM/ Instituto Mora, 1999, p. 79.
} 
[...] hasta la invención, en la penúltima década del siglo XIX, de la técnica de reproducción en medio tono (es decir la traducción de las imágenes en puntos de diversas densidades para su impresión directa en el papel), la fotografía alimentó principalmente los talleres de grabadores, que copiaban las imágenes en litografía o grabado.

En algunos casos, las imágenes fotográficas mismas, reproducidas a cientos de ejemplares, se convirtieron en vehículo de noticias. Esto es lo que sucedió, quizás por primera vez, durante la intervención francesa y el breve imperio de Maximiliano. ${ }^{11}$

Es decir aquí la fotografía acompaño, guió, y permitió la copia, aumentando el morbo de una "opinión pública" que demandaba una mayor demanda de imágenes de la guerra. Por lo tanto el trabajo del dibujante, del litógrafo y del grabador en general fue desplazado sin misericordia de ahí en adelante por el avance de la técnica de los daguerrotipistas extranjeros y mexicanos, mezclando muchas veces dibujo y fotografía, logrando fotomontajes interesantes

2 La muerte en la gráfica política y popular en los impresos del siglo XIX

Para bien o para mal, el grabado y la estampa estuvieron ligadas a artistas olvidados o desconocidos que hicieron a simple vista una obra menor o

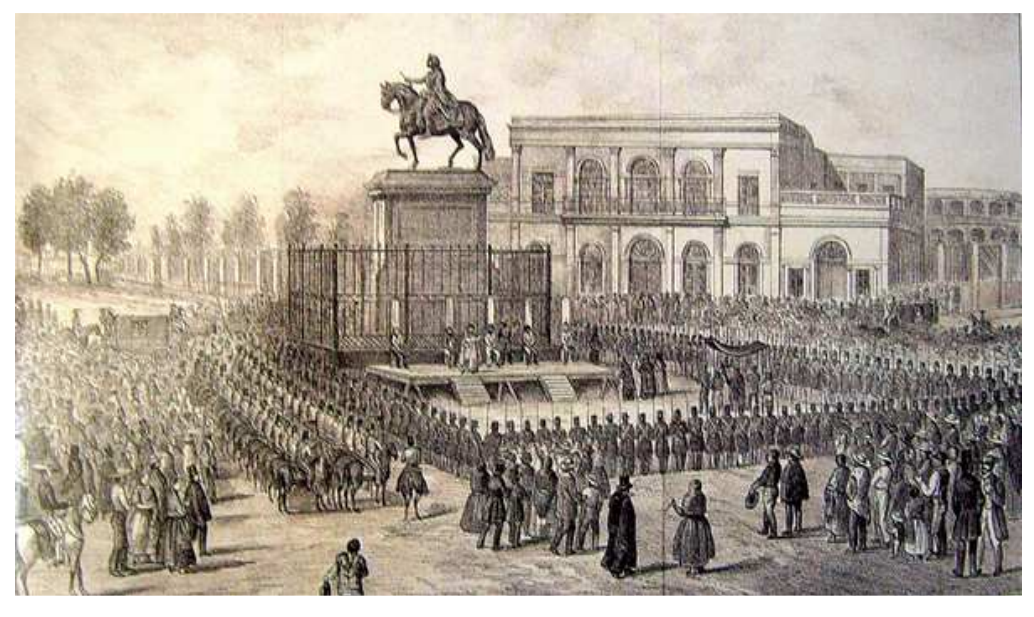

Fig. 10 Anónimo. Acto de la ejecución de los cinco reos condenados a muerte. simplista poniendo de manifiesto diversos cambios entre ellos los géneros editoriales e ilustrativos que se diversificaron y que a su vez fueron producto de complejos procesos culturales, económicos y políticos que esto plantea la

\footnotetext{
${ }^{11}$ Oliver Debroise, Fuga Mexicana, Un recorrido por la fotografía en México, México, Lecturas Mexicanas, $1^{a}$ edición, CONACULTA, 1994, p. 206.
} 
necesidad de entender las imágenes en el contexto para lo cual fueron creados. Puede decirse que prensa, grabado y litografía formaron una trilogía adecuada en cuanto a asuntos de morbo y nota roja se refiere de asaltos 0 muertes violentas sucedidos en áreas desprotegidas como rancherías y a caminos poco vigilados por las autoridades militares y recogidos de manera cotidiana debido a los vaivenes políticos y sociales en notas periodísticas como lo fueron la ejecución de reos condenados a muerte en una plaza pública y el asesinato del político liberal Melchor Ocampo. (figs. 10 y 11) El público receptor de literatura y de imágenes era de diversa índole y podría hablarse en forma contrastada de gente alfabetizada por un lado; y por otra, de la poca instrucción de los habitantes de la Ciudad de México que leían hojas volantes y las producciones de la prensa artesanal. ${ }^{12}$ El grabador tenía entonces que sujetarse a la ley de la oferta y la demanda y así el realizar los encargos que le

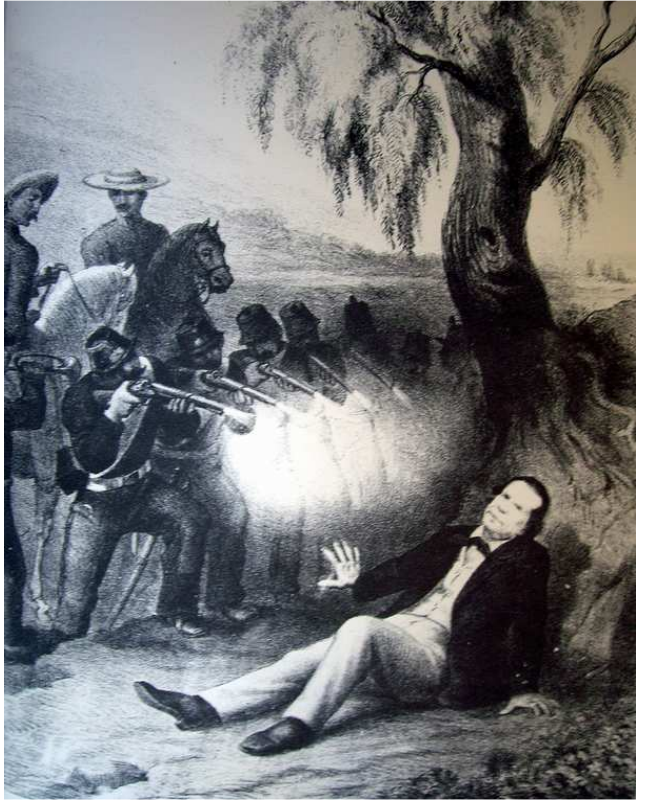

Fig. 11 Asesinato de Melchor Ocampo. Litografía eran requeridos de forma popular para todo tipo de asuntos.

De esta manera al revisar material hemerográfico de la segunda mitad del siglo X1X, como "El Monitor del Pueblo" y "El Monitor Republicano" es común ver anuncios de impresores, grabadores y artesanos que ofrecen sus servicios en la capital y generalmente localizados en la calle de San José del Real, lo que da una idea del asentamiento de este gremio en un sector de la ciudad. Se ofrecían desde anuncios, volantes, y sellos comerciales que con "...seriedad, honradez y buen gusto" podían ofrecer al comercio y al público en general, al

\footnotetext{
${ }^{12}$ Un comentario personal es que he encontrado otras fuentes que señalan la poca instrucción de la población a esto se debe entonces la lectura en grupo de cantos, corridos y noticias y de allí su distribución masiva.
} 
igual que en nuestros tiempos cualquier artesano. ${ }^{13}$ Un ejemplo de la variada labor que realizaban es que hacían "...grabados en madera y metal, madreperla y carey, y letreros pintados para comercios; asimismo decían electrotipar estereotipos"14 con extrema perfección y especializarse en fachadas de edificios, además de grabar sellos en goma y metal, diseñar estampillas y monogramas ${ }^{15}$

Díaz de León menciona nombres de grabadores presentes en el siglo XIX: Lagarza y Rangel, que grabaron programas de circo, toros, gallos, bailes $y$, naturalmente, coplas y corridos. Su trabajo es similar en los aspectos técnicos, puesto que emplearon el buril como instrumento para perfilar 0 enfatizar los blancos. La contribución de estos artistas, en la mínima historia del grabado en México, consiste en que se apropiaron de otro buril con canales múltiples, llamado "velo"16 que además de abrir dos, tres, cuatro o más tallas paralelas, modela la forma y economiza tiempo.

Entre la multitud de impresos que pueden auxiliar para el conocimiento del grabado popular de este tiempo, existe un almanaque que alcanzó gran popularidad durante varios lustros: El Padre Cobos, cuya publicación debió iniciarse en 1875. Entre las imágenes que lo ilustran se encuentran algunas maderas y litografías de época anterior a la llegada de Posada a la Ciudad de México. El de 1887 fue ilustrado con grabados en madera de boj por un artista muy hábil en el manejo del buril cuyo nombre se desconoce. Al siguiente año emprende, tal vez el mismo personaje, la confección a tinta de alegorías

\footnotetext{
${ }^{13}$ Estos son ejemplos aislados de publicidad en los medios impresos de entonces. Según parece es posible que hayan sido anuncios por contrato porque aparecen en números seguidos, para después desaparecer y anunciar otro tipo de productos.

${ }^{14} \mathrm{La}$ electrotipia proviene del griego electrón (eléctrico y typos, mode, modelo) y es el arte de reproducir caracteres de imprenta por medio de procesos electroquímicos. La utilización de dicha técnica fue debida al excesivo desgaste de los tacos de madera en el proceso de impresión y que logró ser superado por la galvanoplastia o electrotipia, es decir la reproducción en metal de superficies en relieve a través de la acción electrolítica. Ebrisa Onlin http://www.ebrisa.com/portalc/ShowArticle.do?articleld=76779 Hay dos sistemas clásicos para obtener un duplicado a partir de una forma tipográfica sin tener que imprimir una prueba de la placa original: la estereotipia y la galvanotipia. Las placas estereotípicas ocupan menos lugar que las placas de plomo y su principio es una matriz o molde tipográfico y se la separa de la forma original, luego se rellena la matriz de aleación tipográfica o plástica y de una sola matriz se pueden obtener varios estéreos. http://www.riat-serra.org/tgraf-3.pdf

${ }^{15}$ Jean Charlot, citado por Helia E. Bonilla en Manuel Bonilla protagonista de los cambios en el grabado decimonónico, col. Círculo del Arte, p. 13.

${ }^{16}$ José Guadalupe Posada lo empleaba en León en 1886 y falsamente se le adjudicó su introducción.
} 
litográficas destinadas al mismo calendario, en las que pone su toque irónico no exento de gracia. ${ }^{17}$

Al parecer sólo el grabador Antonio H. Galaviz, era quien promocionaba su trabajo en mayo de 1875. Este grabador elaboraba sellos, monogramas e impresos de todas clases, troqueles, retratos, placas profesionales, grabados de oro, plata bronce, concha, marfil, carey y todo lo concerniente al ramo a precios ínfimos. ${ }^{18}$

Debido a los numerosos cambios políticos de la nueva nación, folletos, periódicos e impresos de esta época posiblemente se hallen perdidos para siempre, pero de lo que se conserva en la Hemeroteca Nacional es una publicación interesante carácter efímero llamada "El Calavera" ${ }^{19}$ y es posiblemente la primera publicación periódica con caricaturas que se hace en el siglo XIX, en los tiempos de la invasión norteamericana de 1847.

Dicha publicación mantuvo una posición opositora al régimen, y mantuvo una posición liberal moderada a pesar de su corta vida (1․ de enero al 18 de junio de 1847, y aparecía dos veces a la semana), y lo más interesante es la aparición de un personaje a manera de calavera que satirizaba a los personajes políticos del momento, con un texto explicativo en verso y la imagen ilustrada litografiada.

De trazo duro, el dibujo que mostraba El Calavera no es de un artista consagrado, -quien por cierto nos es desconocido su nombre- pero lo importante es la idea directa, humillante para el contrincante y crítica en su contexto. En una imagen del 12 de enero de 1847 que ilustra la narración en forma de sueño llamada Va de Cuento se observan a personajes distinguibles como un militar, un

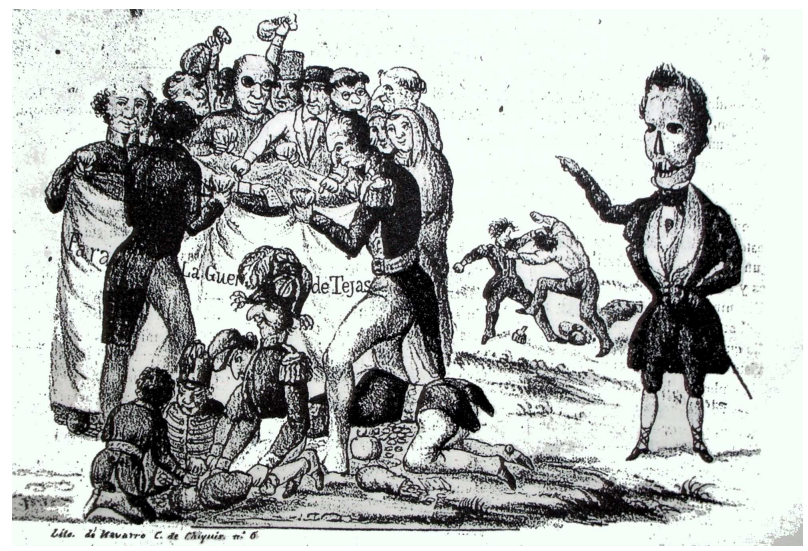

Fig.12 "El calavera" Litografía

17 Francisco Díaz de León, Gahona y Posada, grabadores mexicanos, México, Fondo de Cultura Económica, 1a. Edición en Colección Popular, 1985, pp. 9-11.

${ }_{18}^{18}$ Helia Emma Bonilla, op. cit., p. 14.

${ }^{19}$ Agradezco a la investigadora María José Liberal del Instituto de Investigaciones Estéticas de la UNAM el conocimiento de dicho periódico. 
religioso y un funcionario sosteniendo una gran bolsa que dice "Para la guerra de Tejas". Mientras el pueblo acude a dejar su apoyo en monedas en la parte de abajo otros militares oportunistas recogen el dinero del bolso desfundado. (fig. 12)

No exento del Romanticismo del momento, la que se presenta en el número del 2 de febrero del citado año, El Calavera vestido de levita y elegantes pantalones y melena al viento, observa nostálgicamente recargado en un promontorio rocoso como se hunde bajo las profundas aguas un navío que dice en su costado "República Mexicana". En las olas que empujan al barco al naufragio se ven los nombres de los estados de la república que se veían perdidos. (fig. 13)

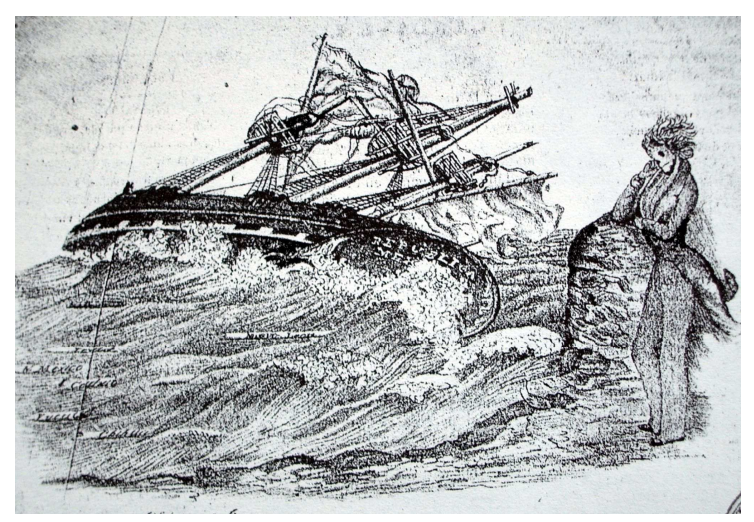

Fig. 13 "El Calavera " Litografía

Por su parte, Antonio Rodríguez en su recopilación de material gráfico alrededor de la figura del grabador Posada encontró dos grabados de calaveras pertenecientes a un tal Cortés y de otro artista de firma con sus iniciales J. C. M. (tal vez el mismo Cortés?) en las que se observa la utilización del buril que recuerda las composiciones y soluciones gráficas del maestro de Aguascalientes como se observa en el grabado titulado "Gran verbena de calaveras" (fig. 14) Algunos artistas olvidados pudieron ser recordados gracias a que obras suyas permanecen unidas a textos de relativa importancia como Manuel Restori (México pintoresco artístico y monumental, 1880) Antonio Altamirano (El General Porfirio Díaz

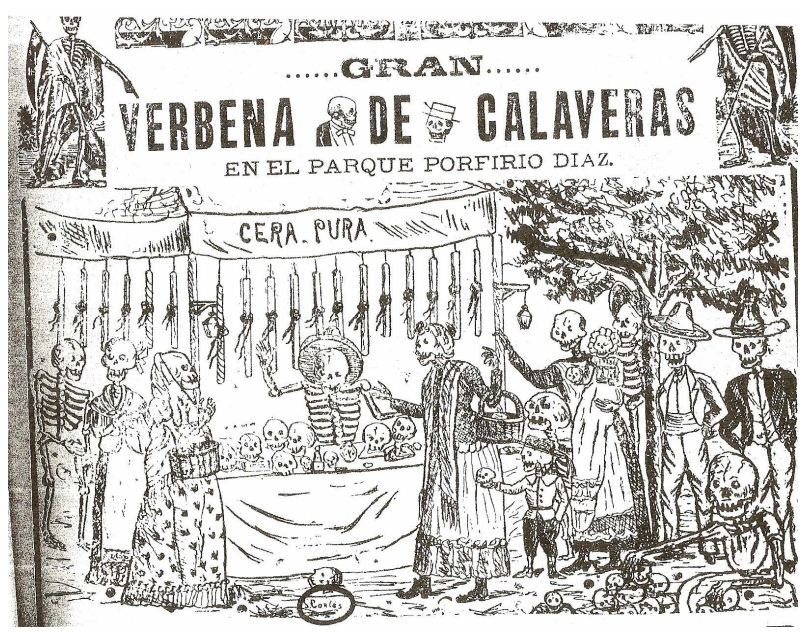

Fig. 14 Cortés. Gran Verbena de Calaveras. Grabado en metal 
en las batallas de Oriente, 1888); José Manuel Rivera, ilustrador de carátulas de periódicos politicos; Ramón Santos de Irigoyen (El Museo Mexicano, 1844); Mariano Ximénez (Ensayo de Geología) Herculano Méndez dibujante (La Jácara), 1867 y Alejandro Casarín, (El Padre Cobos, La Tarántula. ${ }^{20}$ He tenido oportunidad de ver su estilo suelto y afrancesado en las litografías en el periódico de corte satírico La Carabina de Ambrosio donde el blanco de burlas es el General Vicente Riva Palacio candidato a la presidencia y notable figura política por ser nieto del insurgente Vicente Guerrero y héroe de la Intervención Francesa $^{21}$.

Por otra parte, el historiador José de Jesús Domínguez en el prólogo a la novela Astucia, menciona que su autor, Luis Gonzaga Inclán (1816-1875), impresor y litógrafo en la primera mitad del XIX, fue un verdadero precursor del grabado popular en la Ciudad de México, ya que:

\begin{abstract}
"muchas personas de aquellas épocas recuerdan, en efecto la imprenta del señor Inclán. Todas ellas están de acuerdo en que ese establecimiento fue el precursor de los que hubo después en México para el expendio de esa literatura popular, sui géneris especialísima, cuyos productos son novenas, relatos en verso de catástrofes y sucesos sensacionales, leyendas milagrosas, "corridos" canciones en boga, etcétera. Como bien se sabe, en aquel tiempo el periódico no era patrimonio de las clases bajas. Estas se informaban de los acontecimientos del día únicamente por medio de los "papeles" que salían de las imprentas como la del señor Inclán. Y debido a su instinto poético el pueblo gustaba siempre mucho más de las relaciones en verso que de las en prosa. La sucesora de Vanegas Arroyo fue la sucesora de la de Inclán [...] la casa, donde se hacían impresiones y trabajos litográficos, era, además expendio de los mismos y de otras brujerías y tiritañas que le ganaban popularesca o alborozada clientela. Allí se vendían estampas de santos, novenas, corridos, o sea relaciones en verso de acontecimientos lejanos o propincuos, pero siempre palpitantes; y hasta -ensalzando lo religioso y lo profano con lo meramente infantiljuegos "de oca", que a la sazón estaban muy en boga y embelesaban a los niños [... ] Otros libros se imprimirían en las prensas del charro tipógrafo; aunque más me inclino a creer que privaron las hojas, folletos y estampas características y propias de la literatura popular."22
\end{abstract}

${ }^{20}$ Ricardo Pérez Escamilla, Arriba el telón. Los litógrafos mexicanos, vanguardia artística y política del siglo $X 1 X$, en el libro /catálogo: Nación de Imágenes, La litografía mexicana del siglo X1X, MUNAL, abril-junio 1994, pp. 19-41.

${ }_{21}^{2}$ La Carabina de Ambrosio, periódico joco-serio con caricaturas, México, 1 volumen, mayo1875-julio 1876.

${ }^{22}$ Véase el prólogo de José de Jesús Núñez y Domínguez a Astucia, México, Imprenta Universitaria, 1945, pp. IX- XXII. 
Del género de gráfica popular resultan imágenes como la del "Almanaque del Profeta Azteca" al utilizar la figura del esqueleto humano a las puertas de una pulquería de la que emerge de una figura prehispánica enmarcada por unos diablos. (fig. 15)

Como contraparte del otro México, la imagen a dos tintas de Jesús Martínez Carreón y Ricardo Iriarte del Almanaque Mexicano de Arte y Letras de 1895, presenta una ilustración de una escena romántica correspondiente al mes de noviembre. En esta estampa se muestra otro aspecto que se refiere a la

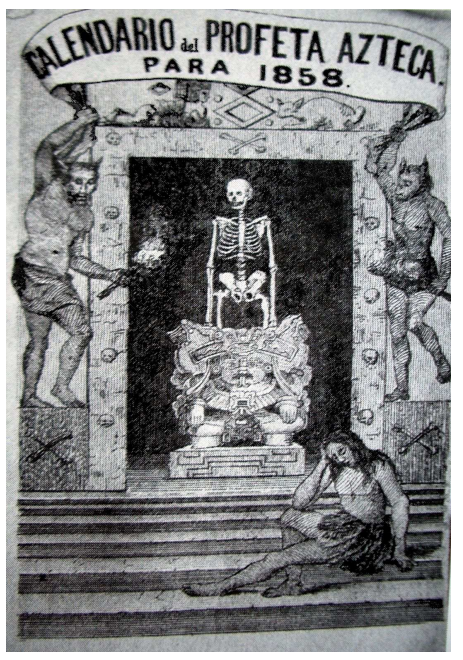

Fig. 15 Calendario del Profeta Azteca fantasía y la ensoñación de la celebración del 2 de noviembre. En ese México aquí retratado se observa a la gente de buenos modales y bien vestida, según el prototipo del momento, que acude a los cementerios. La estampa se encuentra dividida en dos partes: en la inferior se narra la visita al panteón de la clase alta de la ciudad, donde se advierte un monumento funerario elegantemente arreglado con coronas y listones.

Es preciso destacar que en los mismos encuentros entre gente de la misma clase alta, paradójica y contrariamente a las imágenes de esta celebración entre clases bajas de la época, ésta muestra las diferencia sociales, pues aquí los saludos se dan efusivamente, lo que denota un matiz en cuestión de celebración de la muerte entre clases. (fig. 16)

Lo que llama la atención es que los ejemplos gráficos de costumbres nacionales sobrevivientes son limitados y que son excepcionales los que sobresalen del resto por la calidad del dibujo y por su composición. Sus tallas están alejadas de lo

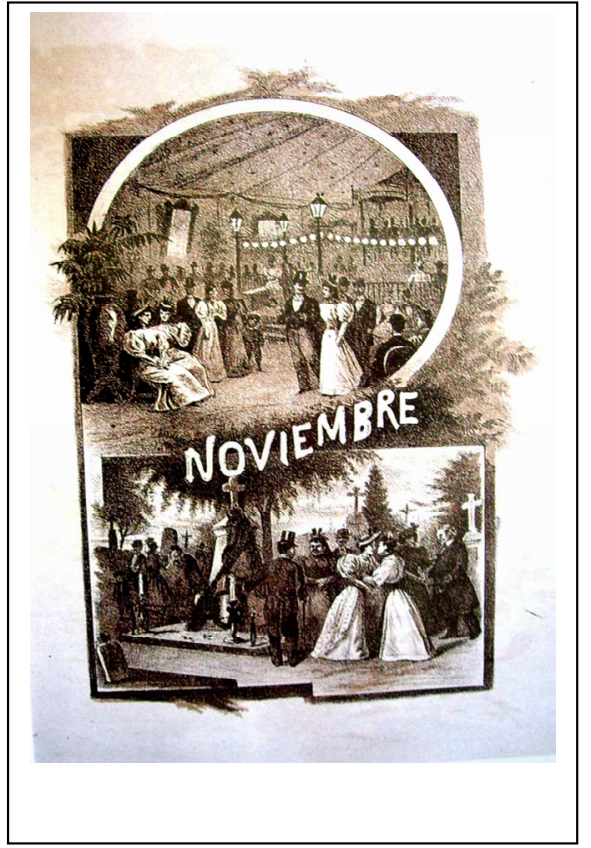

Fig. 16 Noviembre en el "Almanaque Mexicano". litografía de Jesús Martínez Carreón y Ricardo Iriarte 
que podríamos considerar del género "popular" y están más orientados hacia un afrancesamiento del producto ofrecido; y en cambio son constantes los grabados de figuras representativas como Manilla y Posada que gracias a su gran producción, sobre todo de este último han perdurado hasta nuestros días y que se pueden encontrar en librerías de viejo impresos originales de este periodo. Los constantes vaivenes políticos no permitían mostrar los aspectos cotidianos a los que se enfrentaba y gozaba el ciudadano común y corriente de la Ciudad de México. Cuando así lo muestra el dibujante en la piedra litográfica, en la madera y en el metal, es para polarizar el momento: para identificar al indio, (Trajes civiles, militares y religiosos de México, 1828), y los enormes monolitos producto de civilizaciones antiguas (México y sus Alrededores 18551856) y adular al chinaco, herencia de la guerra de intervención, o bien para menospreciarlos por su naturaleza campirana e ignorante. ${ }^{23}$ Así los retratos de las figuras públicas de diputados, magistrados, gobernadores y hasta del mismo presidente de la nación en turno son detallados, en actitudes de poses teatrales tomados de fotografías. Son escasos entonces, aquellos que vuelven la mirada al pueblo y dejan testimonios escritos o gráficos de esos momentos. Se entiende pues, que históricamente hay más puntos de interés político, que el ejercicio anecdótico de las clases populares y que en los tiempos del liberalismo de Juárez, hablar de las celebraciones de origen religioso del 2 de noviembre era ir en contra de los tiempos de modernidad.

\section{La criminalidad impresa: un recorrido en la ciudad de México}

La violencia y la criminalidad siempre han existido en las grandes ciudades, y en el caso de la Ciudad de México el sistema de impartición de justicia provenía de las leyes españolas con la diferencia de que existía paralelamente un aparato judicial indígena que conservó sus estructuras de control de sus habitantes. En sus numerosos cambios el aparato judicial siguió muchos años

\footnotetext{
${ }^{23}$ Un editorial del periódico de oposición La Orquesta de 1867, se refiere al asunto indígena en estos términos: "Nos simpatiza mucho la raza indígena. De ella procedemos, y a mucho honor tendremos en que de la española corre por nuestras venas algo de la sangre de un filósofo que fue Netzahualcóyotl, y de un valiente que fue Guatimotzin. Tanto valdría descender de Sócrates y de Gonzalo de Córdova; pero nos repugna, nos molesta la crueldad de los indios con los burros". (José Ortiz Monasterio, "Patria", tu ronca voz me repetía... Vicente Riva Palacio y Guerrero, UNAM, Instituto Mora; México, 1999, p. 114)
} 
el siguiente sistema: En la capital el control era asignado al alcalde mayor y a los agentes del corregidor (guardias de pito) que hacían rondas tanto diurnas como nocturnas entregando a los sospechosos a los alcaldes de la sala para su evaluación y castigo. En una ciudad en constante crecimiento demográfico y sin posibilidades económicas existía una desvinculación total entre los individuos y la sociedad. Por razones de identidad cultural, a estas diferencias sociales, donde los elementos no europeos sufrieron el impacto e integración a una cultura ajena a la propia se le ha llamado en términos antropológicos "aculturación"24 que derivó entre otros aspectos a observar que en el aspecto de justicia no se aplicaba por igual a todas las clases sociales, como en este caso diversos cronistas dejaron su testimonio de muertes, azotes y ahorcados de los que eran objeto criollos, mestizos y negros detenidos en la mayoría de los casos por robo y donde los castigos se imponían tanto a hombres como a mujeres por igual que iban desde la mutilación de un miembro hasta la muerte por medio de la horca. ${ }^{25}$

Como bien indica Marcela Suárez en su estudio acerca de la criminalidad y lo prohibido la diferenciación hace permanente un fenómeno latente de inestabilidad que a la larga son generadores de conflictos sociales:

\begin{abstract}
A la diferencia se le teme, a las clases subalternas también, por eso, es frecuente que tanto en el pasado como hoy, se identifique bajo nivel socioeconómico con criminalidad. Criminalidad a la que se teme, población de la que se duda, y se duda también de su comportamiento sexual ajustado a la norma. Así las clases desposeídas fueron y pueden ser las escogidas negativamente por los mecanismos de criminalización. ${ }^{26}$
\end{abstract}

\footnotetext{
${ }^{24}$ Aunque no es el objetivo de este trabajo polemizar en términos antropológicos me parece importante el concepto que utiliza el Dr. Beltrán en relación a la "aculturación" desde el aspecto lingüístico, cultural y social. Para profundizar en este tema consúltese a Gonzalo Aguirre Beltrán, El proceso de aculturación en México, UIA, Instituto de Ciencias Sociales, México 1970.

${ }^{25}$ Un estudio completo es el MacLachlan en el que utiliza al Tribunal de la Acordada para hacer una revisión de la delincuencia y de la vagancia colonial a partir de las instituciones novohispanas. Revisando el material bibliográfico de esta época histórica no he podido localizar ejemplos de la utilización de la imagen gráfica para subrayar los pasajes descritos. Véase a Colín M. Maculan La justicia criminal del siglo XVIII en México, SepSetentas, número 240, $1^{\text {a }}$ edición 1976

${ }_{26}$ Marcela Suárez, Sexualidad y norma sobre lo prohibido, La ciudad de México y las postrimerías del Virreinato. Tesis, Doctorado en Historia, FF y L. UNAM, México 1994, pp. 8-9.
} 
La simple vagancia era a menudo tratada con severidad para que sirviera de ejemplo a la sociedad. Por supuesto que las enormes cantidades de vagos y pendencieros sin oficio ni beneficio propiciaron diversos estallidos populares como el ocurrido el 8 de junio de 1692 en el que:

... Una turba de indios que acarreaba el cuerpo de un hombre, supuestamente muerto por los trabajadores mestizos del granero estatal, se reunió frente a la residencia del obispo exigiendo que se hiciera justicia. Por desgracia no fue posible localizar al obispo y un asistente dirigió a los indios al palacio virreinal. Cuando la multitud llegó al palacio, el virrey no se hallaba presente. Un reducido grupo de indios, que se negó a aceptar el hecho, lanzó piedras a las puertas del palacio. A la provocación, la guardia del palacio imprudentemente salió y ahuyentó al gentío de la plaza, pero inmediatamente se incorporaron más indios, que obligaron a los guardias a huir y buscar un lugar seguro en el patio del palacio. La multitud que ahora se hallaba enardecida intentó asaltar el palacio virreinal, ocasionando así la peor asonada en la historia colonial de México. La revuelta, en la que participaron todos los grupos raciales de la población, dio como resultado la destrucción parcial del palacio virreinal y otros edificios públicos y el saqueo de las tiendas y almacenes situados en los alrededores del palacio. ${ }^{27}$

Indígenas y complejas castas novohispanas sufrieron persecuciones y

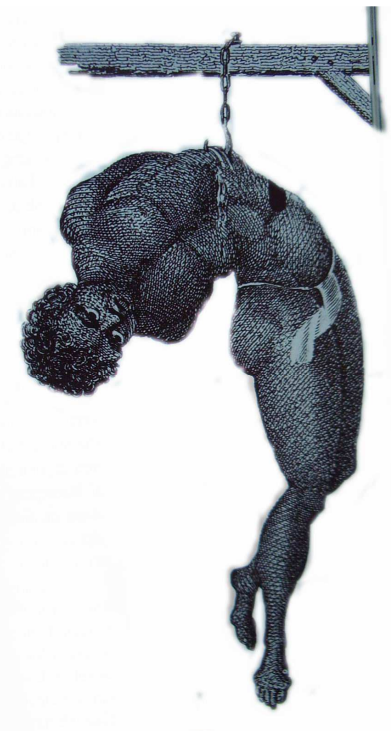

Fig. 17 Ejecución de un esclavo Grabado en metal castigos del Santo Oficio, del Obraje y de la Acordada, desde el siglo XV1, hasta bien entrado el siglo XIX. Diversos testimonios escritos que han llegado hasta nuestros días prueban el grado de inseguridad en que vivían los habitantes de la Ciudad de México y en especial de las clases más humildes y más desprotegidas con sólo el hecho de no poderse comunicar en español quedaban atrapados sirviendo toda su vida como trabajadores explotados en los obrajes españoles. En algunos casos los llamados Visitadores Reales lograron la libertad no solo de los apresados sino de familias enteras que se habían creado

${ }^{27}$ Ibid., p. 51 
producto de las relaciones sexuales en el interior de los lugares. Varios de estos casos, dramáticos por la narración de las víctimas, han sido rescatados por paleógrafos e historiadores contemporáneos que dan cuenta del grado de deshumanización a la que se había llegado con las clases marginadas.

En el libro de Vicente T. Mendoza Romance y Corrido, se encuentra un magnífico ejemplo de un romance de principios del siglo XVIII, ilustrado por un grabado que representa la ejecución de un reo llamado José Estrada Muñón condenado por asesinato. Probablemente la manufactura de dicho grabado debió de ser de plomo ya que en los ángulos de la placa se advierten con claridad los bordes que dejan los clavos que lo aseguraban a la madera. En la ilustración el verdugo empuña una cuchilla y se dispone a quitarle la vida al asesino en presencia de dos religiosos, uno que porta un estandarte y otro que le da la bendición y de un juez o enviado del virrey. El grabado se acompaña con un texto de por lo menos tres tamaños de fuentes tipográficas en la parte inferior que indican más detalles del hecho: "Breve, claro, llano, simple, narrativo, y verdadero a la violenta muerte, que (...) sabiamente ejecutó $D$. Joseph de Estrada Tuñon, el día 13 de Julio del año de 1710, en el Coronel Dom Gonzalo Gómez Mejía, Gentil Hombre de la Camara de fé Magestad y Governador, que fue de la Nueva Vera Cruz...28

Para impedir la vagancia y por ende los malas acciones el virrey Don Antonio María de Bucareli y Ursúa (1771-1779) abrió el Hospicio de Pobres con el propósito además, de brindar una ayuda a la población más necesitada de léperos y malvivientes, con la intención de que

...los verdaderos pobres, sean asistidos con todo lo correspondiente a una vida cristiana, precaviendo el que se defrauden las limosnas de los fieles por los vagos, malentretenidos y holgazanes, que abusan de la caridad que encuentran en pueblo tan piadoso como el de México cuando con su trabajo deberían contribuir a la indigencia del necesitado ${ }^{29}$

\footnotetext{
${ }^{28}$ El texto escrito en castellano antiguo es de difícil de lectura. Una pequeña transcripción es la presentada, Vicente T. Mendoza, El Romance español y el corrido mexicano. Estudio comparativo, UNAM; 1939, p.22.

${ }^{29}$ Citado por Marcela Suárez, op. cit., p. 55.
} 
En este contexto, la idea de la Corona ilustrada intentó hasta los primeros años del siglo XIX cambiar las costumbres y conductas asociadas al delito y con esto evitar escándalos y la indecencia en la vida pública, aspectos que se convirtieron en un control de la sexualidad al acosar a las casas de cita y a las mujeres públicas dedicadas a la vida galante. De esta manera, la complejidad de la impartición de justicia se debía entre otras cosas a la indefinición de términos, y a la vaguedad de interpretación por parte de los

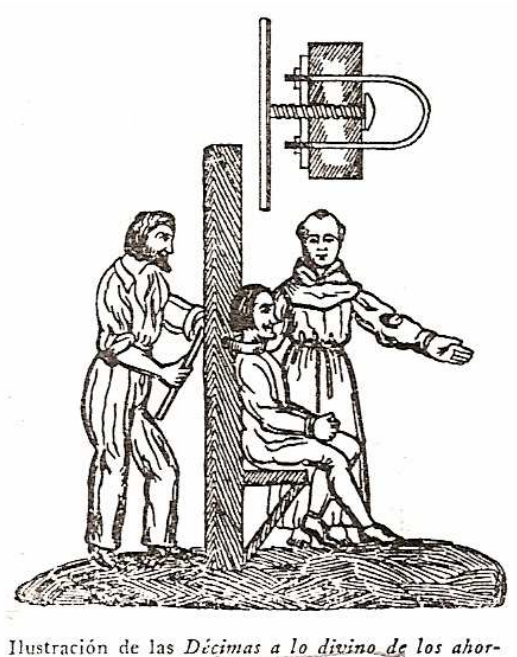

Fig. 18 Décimas a lo divino de los ahorcados. Xilografía de 1854. jueces. El delito, entonces, se consideraba como el "hecho cometido por uno en daño o deshonra de otro", y su clasificación compleja en los tiempos de la Independencia se dividía en públicos o privados. A los primeros correspondían entre otros, "a los que atentaban a la ofensa de Dios", la blasfemia, el homicidio, el adulterio, y la falsedad. A la segunda clasificación, cuando la acción correspondía al ofendido. Las distintas derivaciones del delito correspondían al robo, homicidio, riñas, heridas y golpes, delitos sexuales, fraude, portación de armas prohibidas, vagancia, ebriedad, y conductas sospechosas. De aquí se derivaban los que se atendían al lugar donde se cometían y al modo de ejecutarlos, es decir, "notorios" o "no notorios". "Conexos" o "inconexos" atendiendo al concurso de hechos delictivos, y todavía de aquí los "nominados", e "innominados", para seguir otra clasificación más absurda: "atroces" y "atrocísimos".etc. ${ }^{30}$

De la segunda mitad del XIX 1854, el citado Vicente T. Mendoza nos ha dejado un texto llamado "Los ocho ahorcados" con un grabado en madera de la escena de la aplicación de la pena de "garrote vil" de uno de los personajes. (fig. 18) Un fraile asiste al condenado que sentado de perfil espera el momento de morir. Un hombre barbado funge como ejecutor de la sentencia. En la parte

\footnotetext{
${ }^{30}$ BSR/ Teresa Lozano Armendares, La criminalidad en la Ciudad de México 1800-1812, Tesis de licenciatura en Historia, FF y L, UNAM, 1983. Sobre la tipificación, véase el capítulo II titulado "Delitos del orden común y su tipificación".
} 
superior del grabado se presenta a detalle el mecanismo de la maquinaria de tortura. Dicho texto completo dice;
Es posible Dios de mi alma que me he llegar a ver dentro de una sepultura donde fin he de tener.

Parto al suplicio a morir dentro de pocos instantes, ¡infeliz Cipriano Márquez! Quien te lo había de decir. Sueño eterno he de dormir; se me aterroriza el alma, la sepultura es mi cama, la tierra ha de ser mi centro, y pronto he de verme dentro ¡Es posible, Dios de mi alma!

-Adorada Patria mía, de este tu hijo, no te olvides, pues ya Francisco Ramírez, está en su última agonía.

¡Que infelicidad la mía!

¡Que terrible padecer!

De mi se pueden doler, pues me conduce un mal vicio en espantoso suplicio que me he de llegar a ver

-Hoy entre pena crecida, entre congoja mortales, se mira Antonio Gonzáles, pues que va a perder la vida; con tan penosa partida descenderá de su altura quedará en triste figura sin los auxilios humanos para pasto de gusanos dentro de su sepultura

-Dentro de pocos momentos mi existencia se ha de acabar, pues va Vicente Tovar a un patíbulo sangriento sirva, amigos, de escarmiento, lo que me venía a ver pues ya van a fenecer mis maldades y mi vicio en un terrible suplicio donde fin he de tener. 
3.1 El entorno social en la criminalidad en el siglo XIX

La Ciudad de México a principios del XIX trajo consigo conflictos sociales, manifestándose en la falta de vivienda para cerca de los 140, 000 habitantes $^{31}$. En las barracas del ejército se alojaban miles de conscriptos, y la mayoría de los habitantes de la ciudad vivían en vecindades, que no era otra cosa que antiguos conventos o construcciones coloniales habilitadas para viviendas donde en su interior se realizaban todo tipo de trabajos artesanales: sastrería, armeros, zapateros, costureros, impresores, etc. Los pobres de la Ciudad de

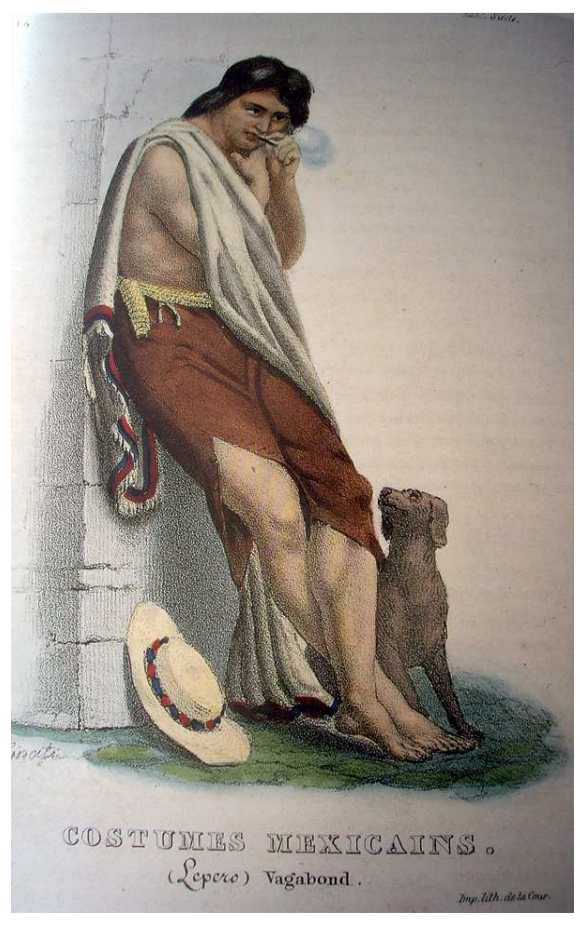

Fig. 19 Claudio Linati Lépero. Litografía a color
México eran de alrededor de 20,000 personas que constituían una seria amenaza para el orden social en los que era difícil, por no decir imposible realizar un control autoritario debido a la laberíntica ciudad formada por antiguos barrios cerrados como La Candelaria de los Patos, Tarasquillo, Santiago Tlatelolco, Tepito, Santa Clarita, La Viga, etc., donde reinaban la miseria, el alcohol, el desorden, la vagancia y la drogadicción como lo observó el litógrafo Linati. (fig. 19) Los delitos y crímenes cometidos resultaban en muchos casos por objetos inservibles o absurdos Por ejemplo, de los 14 robos cometidos por Pedro Trujillo y su cómplice Mariano León en accesorias y vecindades, en todos los casos los objetos robados fueron usados, además de maltratados, o en estado lamentable. Cito sin orden: “... una colcha vieja sanmigueleña, una frazadita, dos chaquetas de indiana hechas pedazos, unas naguas blancas de manta muy rotas, un capote de Batletón hecho pedazos, un sombrero de tres picos, unos retazos de indianilla inglesa, un chiquihuite de trapos viejos que por inservibles tiraron, etc." ${ }^{32}$ Otro tipo de delitos correspondían a robos por

31 Lozano Armendares, supra, p. 47.
32 lbid., p. $62-64$ 
alimentos como el sufrido en la tienda de Micaela Torres donde "...dos hombres se llevaron 6 jamones"; en la bodega de Domingo Coloma, cinco individuos falsificaron unas llaves para sacar "...11 tercios de azúcar, 8 tercios de cascalote y un tercio de almendra". ${ }^{33}$

Cayetano Paris fino observador de la ciudad, representó con el lápiz litográfico (fig. 20) al personaje más representativo de ese entonces: el llamado "lépero", que no era otra cosa que el vago y pendenciero callejero que a la menor oportunidad busca la oportunidad para robar y lo describe tanto escrito como visualmente:

[...] Sobre el escombro de una civilización degradada, vive en medio de una populosa ciudad en estado natural. Sin camisa, sin zapatos, un pedazo de cuero y una manta de lana forman su vestido Esta misma cubierta le sirve de cama en la noche y un portal o las gradas de una iglesia le sirven de habitación... ${ }^{34}$

En el aspecto del homicidio, la ley consideraba que existían tres tipos: el intencional, el culposo y el ocasional y donde en la mayor parte de los casos se debían a la ebriedad de los inculpados y de la variedad de las "armas" que se tenían a la mano en el momento de la acción que podían ser desde cuchillos, tijeras, hachas, machetes, piedras 0 ladrillos. La mayoría de los delincuentes eran hombres, con un gran porcentaje de españoles, seguido de indios y mestizos y de "....individuos que no sabían decir a que calidad pertenecían (!)".

A medida que la situación de la guerra de Independencia

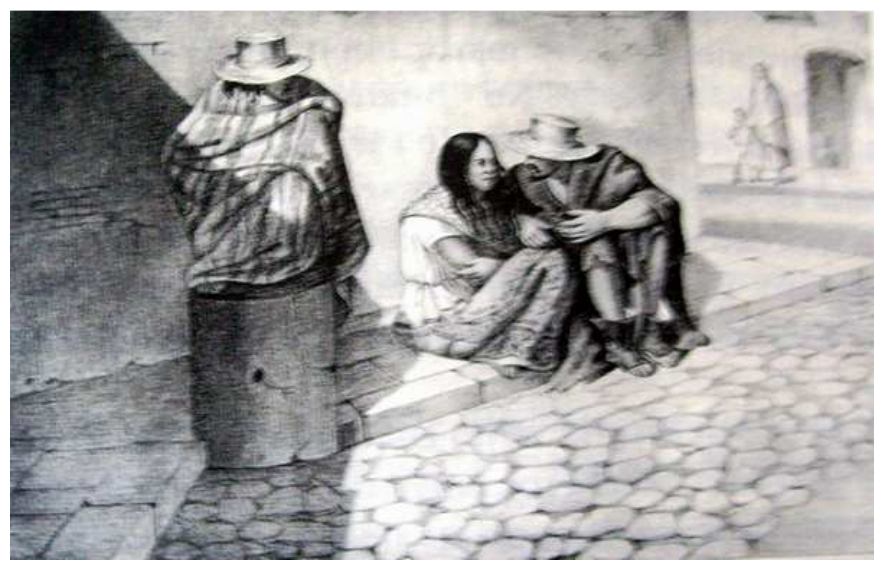

Fig. 20 Cayetano Paris “Populacho de México”, Litografía se llevaba a cabo, la capital se transformaba en un sitio peligroso debido a que era el eje de la vida política y aunque no el centro del movimiento de

\footnotetext{
33 Ibid., p. 72

${ }^{34}$ Linati, , op.cit., P. 72
} 
insurgencia. Algunos residentes decidían marcharse a lugares más seguros, al mismo tiempo otros habitantes entraban a la capital sin que existiese una manera de controlar la afluencia de viajeros dispuestos a quedarse lo cual atrajo mayor inseguridad a los capitalinos. No faltó por supuesto las acusaciones de que pertenecer al bando insurgente podía ser motivo de castigo como le pasó a Trinidad Vázquez que pudo fugarse el 20 de noviembre de 1812 “... auxiliado por su cómplice Lucas de Jesús, quien se hallaba en ese presidio porque lo cogieron mientras trabajaba en la fábrica de Tizapán por "iniciado de insurgente"

En la segunda mitad del siglo XIX, la ciudad de México, en un periodo de casi cuarenta años la población aumentó de 230, 000 a 470, 000 habitantes, pasando a ser de un imperio con Maximiliano a una República, y del presidencialismo de Benito Juárez a la dictadura de Porfirio Díaz. La prensa y

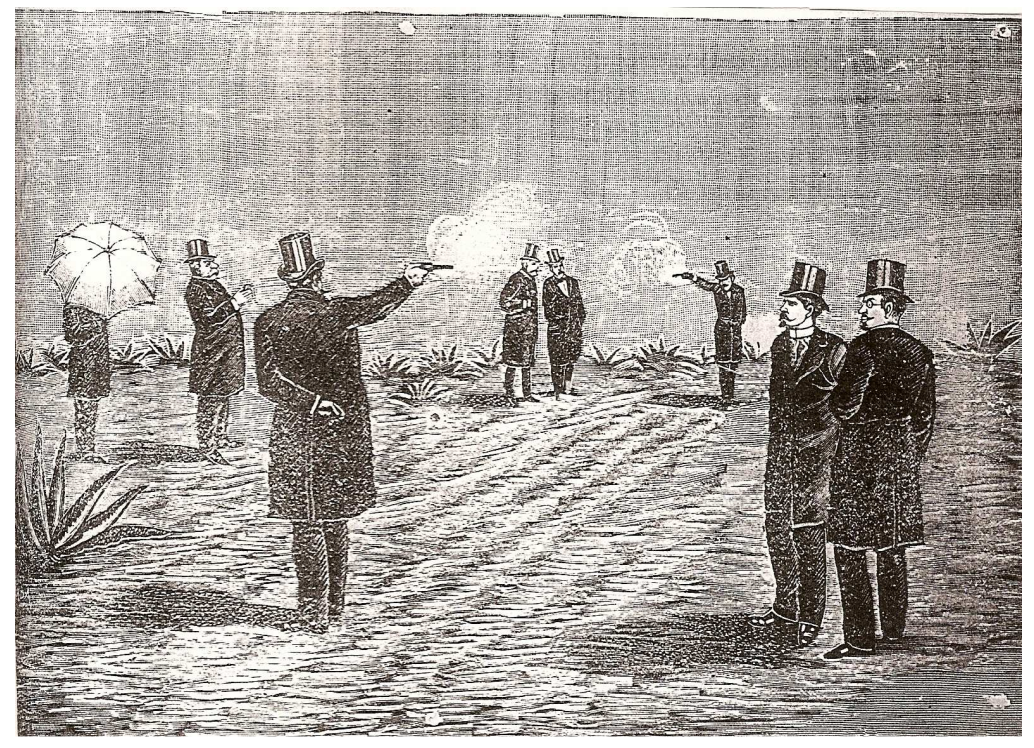

Fig. 21 El duelo de Verástegui-Romero. Grabado de José Guadalupe Posada los periodistas de este tiempo constituyeron sin duda el medio de comunicación quizá más importante y gracias a eso, la sociedad pudo estar informada de actos relacionados con-hechos criminales $y$ delictivos .

Un episodio de veras sensacionalista llevado por el periódico El

Federalista fue el secuestro del señor Juan Cervantes el 5 de julio de 1872 sentando las bases para el incremento del tiraje. ${ }^{36}$

\footnotetext{
${ }^{35}$ Lozano Armendarez, op. cit., p. 144, nota 179.

${ }^{36}$ Sobre la cifras de población consúltese Alberto del Castillo, "Prensa, poder y criminalidad a finales del siglo XIX en la Ciudad de México", en Hábitos, normas y escándalo Prensa, criminalidad y drogas durante el porfiriato tardío, CIESAS/Plaza y Valdés, México 1997, p.20. En el. asunto de la criminalidad, tema muy viejo en la Ciudad de México, el geógrafo Antonio García Cubas, en "El libro de mis recuerdos", menciona el alto grado de peligrosidad que residía en alejarse de la capital a sólo unos cuantos kilómetros en la primera mitad del XIX. En
} 
Otros asuntos no menos impactantes fueron las acciones de duelo de connotados personajes públicos que se batían a muerte para solucionar "asuntos de honor" y que dieron motivo para realizar el seguimiento reporteril. El grabador Posada realizó varias planchas utilizando un dibujo copiado de "El Mundo" reconstruyendo para los lectores del Gil Blas Cómico las acciones de pistola como fue el duelo Verástegui- Romero la tarde del 9 de agosto de 1894 a un costado de un panteón. (fig 21)

Uno de los duelos que más impactaron en la opinión pública fue la muerte del literato Santiago Sierra en un duelo a pistola con el escritor e impresor Ireneo Paz (abuelo de nuestro premio Nobel, Octavio Paz). En este asunto, se reunieron dos periodistas que apoyaban a dos candidatos a la presidencia de la república: Los hermanos Sierra -Justo y Santiago- y su periódico La Libertad apoyando a Manuel González. En el lado opuesto Ireneo Paz, que apoyaba en su periódico La Patria a Trinidad García de la Cadena y a partir de allí se desencadena una serie de ataques personales y vituperios que desembocaron en el duelo llevado a cabo en la antigua hacienda de San Javier en los Ilanos de Tlalnepantla:

enfundados en sus vestimentas de gala acudieron puntuales los contendientes acompañados de sus padrinos, y el duelo dio comienzo. El general Ángel Martínez -testigo de Paz- dio las voces

una ocasión, haciendo una medición topográfica, acompañado de dos peones, estuvo a punto de ser secuestrado por una gavilla de esas, que asolaban diligencias y viajeros y despojando y matando a sus víctimas. Con las mujeres eran violadores y con los hombres cuando lograban conservar la vida eran devueltos en las diligencias en ocasiones completamente desnudos.

Un caso lamentable fue el de Thomas Egerton pintor y dibujante inglés que murió junto con su esposa en un asalto a manos de bandoleros, hecho del que se ocupó mucho tiempo la prensa inglesa para hablar de un lugar salvaje como México. Por otra parte, la literatura le dio al género un matiz desgraciadamente romántico mediante historias noveladas, o de literatura bandidesca, muy "ad hoc" con el momento en que vivía, y aquí habría que mencionar a estos personajes creados a partir de la delincuencia y criminalidad de esos intranquilos e inseguros días, como "El Zarco" de Altamirano; "Los bandidos de Río Frío" de Payno, "Los Plateados de Tierra Caliente" de Pablo Robles, por citar solo algunos de ellos. El caso del asesino de mujeres Francisco Guerrero El Chalequero, como veremos más adelante, es interesante porque a través de su propio testimonio dado a la prensa, el criminal comenta sobre su gusto por las lecturas de vidas "de criminales y bandoleros y otros personajes de bajos fondos" que motivaron o incentivaron su imaginación violenta y criminal. Estos hechos no fueron aislados y representaron un común denominador en los tiempos del porfiriato al magnificar y engrandecer al trasgresor de la ley lo que favoreció ante la opinión pública un lugar destacado ante la sociedad. En los tiempos modernos, muy pocas publicaciones periódicas en la Ciudad de México evitan en lo posible la llamada "nota roja" pero es sabido que desgraciadamente en los medios impresos junto con la imagen es lo que más vende Un caso concreto, es el periódico "La Jornada", que desde sus inicios y con ética profesional descartó de su diario la publicación de estas noticias con el pretexto de no contribuir hacia una apología de la violencia. 
de mando. Ambos duelistas procuraron no herirse tirando en otra dirección. Los testigos de Paz, General Martínez y Topete expusieron que debería darse por terminado el lance, pues ambos adversarios habían probado su valor. Pero los padrinos de Sierra, Hammecken y Garay, alegaron que se debería cumplir lo pactado "hasta sus últimas consecuencias", de modo que se volvieron a cargar las pistolas y se redujeron las distancias.

Ángel Escudero describe detalladamente el desenlace final: "Don Ireneo debió pensar que debía apresurarse a poner fuera de combate a su contrario si no quería ser inmolado, y don Santiago, pensando lo mismo, se dedicó a tirar sobre su adversario, pero con la delicadeza de sus sentimientos, para evitarse el sangriento espectáculo de verlo caer, al extender el brazo para disparar, agacho la cabeza pegando la barba al pecho y al verificarse el doble disparo recibió el proyectil en la parte alta de la frente, ya dentro de la región del cuero cabelludo". ${ }^{37}$

Por supuesto, que no fue el un caso aislado. Este tipo de eventos sucedió con gran frecuencia debido a que el Porfiriato lo permitia para lavar la afrenta. (fig. 22) Está por demás decir que

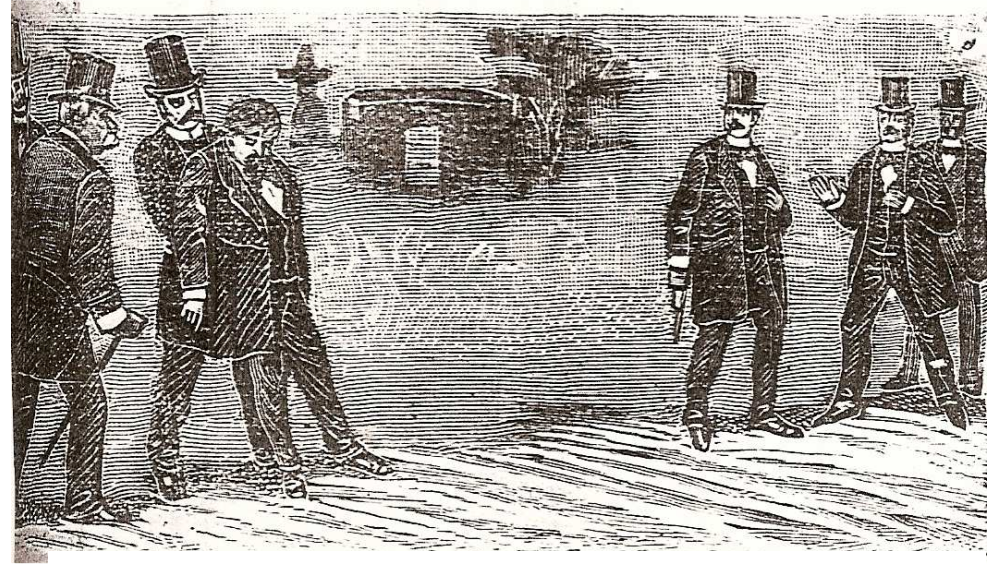

Fig. 22 Duelo. Grabado de Posada como conclusión Ireneo

Paz sufrió el resto de su vida la acusación de matar a un hombre de letras cobardemente. Las vueltas de la vida hicieron que Justo Sierrra, hermano de la víctima fuese con el tiempo ministro de Porfirio Díaz lo que pesó en la carrera del editor Paz.

\section{2 Prensa y violencia}

La segunda mitad del XIX manifiesta el auge de la imagen gráfica en la vida cotidiana del país. La aparición del periódico El Imparcial en la vida social, motivó una serie de cambios en los medios impresos de la época sobre todo

\footnotetext{
${ }^{37}$ Napoleón Rodríguez, Ireneo Paz letra y espada liberal, Editorial Fontamara, número 322, $1^{\text {a }}$ edición 2002, p. 98.
} 
porque es en este medio de don Rafael Reyes cuando surge en México el concepto de la "nota roja". El Imparcial comenzó con cuatro páginas y un tiraje modesto de 8 a 10,000 ejemplares. Para dar fe de que el periódico mantenía un tiraje alto, 10 notarios certificaron que el 31 de enero de 1907 alcanzó 104, 529 ejemplares y a mediados de ese año 125,000 con 8 a 10 páginas. $^{38}$

Para una ciudad en crecimiento, el periodismo brindó la posibilidad de multiplicar sus noticias y al mismo tiempo de abaratar los costos de un medio que ofrecía noticias frescas gracias a la incorporación de nuevos conceptos: Formato diferente para un lector acostumbrado a periódicos reducidos; la inserción de publicidad a gran escala, el uso de la fotografía y sobre todo la accesibilidad del precio: 2 centavos. ${ }^{39}$ Esto permitió eliminar a la competencia periodística de medios eminentemente políticos que se vendían a 6 centavos como El Monitor Republicano (1844-1896) o El Siglo XIX (1846-1896). ${ }^{40}$

La utilización de la imagen del delincuente peligroso, primero mediante la técnica del grabado, y después con refuerzos fotográficos, permitieron una doble interpretación de las imágenes enviadas a la sociedad mexicana. Por un lado, en una primera acción, la que llegaba al pueblo directamente por medio de volantes callejeros ilustrados en papeles de colores por grabadores populares y que cantores populares daban cuenta de los hechos sangrientos sucedidos en la vía pública. Por otro, el juicio de los lectores letrados que acudían a la información de periódicos del momento.

En este sentido, “...las imágenes - dice Alberto del Castillo-, poseían una serie de significados para los lectores del porfiriato pues podían certificar,

\footnotetext{
${ }^{38}$ Moisés Gonzáles Navarro, Historia Moderna de México, Editorial Hermes, 3a․ Edición, México,1973, p. 680.

39 "El Fandango", semanario contemporáneo donde colaboraba Posada como ilustrador y contemporáneo de "El Imparcial" costaba la mitad de precio: Un centavo. Moisés Gonzáles Navarrro en la obra citada comenta que su competencia más cercana El País le concedió sólo dos novedades: matar a la prensa con la subvención y el escándalo.

${ }^{40}$ Esta manera diferente de hacer periodismo está vinculado con la estabilidad social del país y el control que comienza a ejercer el Estado sobre las publicaciones de tipo político. Es, para decirlo más concretamente, una fuga de emociones sociales experimentada por la ciudadanía que se vierte en la nueva prensa. Se puede atacar a las instituciones del Estado, pero no calumniar. Se puede criticar abiertamente, pero no se permite nunca que se desborden las masas, además de que la prensa se encontraba subvencionada por el gobierno. Este fenómeno es más evidente a partir del porfirismo. Un estudio sobre los temas que trataban los periódicos era el siguiente análisis: "En sus ocho planas de siete columnas cada una, o sea 56 en total, 30 eran de anuncios, 10 de cables extranjeros, 6 de chismes de comisaría, 3 de asuntos sociales y personales; 2 sobre la cárcel de Belén, una de comercio y finazas; media de agricultura y minería; 3 de propaganda de las grandes empresas y la media restante trataba de sociedades mutualistas". Daniel Cosío Villegas, p 676.
} 
comprobar una realidad; constituían una prueba de primer grado que no podía mentir. Era un documento que reflejaba de la manera más fidedigna, una realidad. En este sentido, la fotografía avalaba la propuesta de difusión de los nuevos diarios sensacionalistas. Además, las fotos ocuparían un nexo estratégico con los mensajes morales y políticos que los nuevos periódicos dirigían a la población ${ }^{41}$

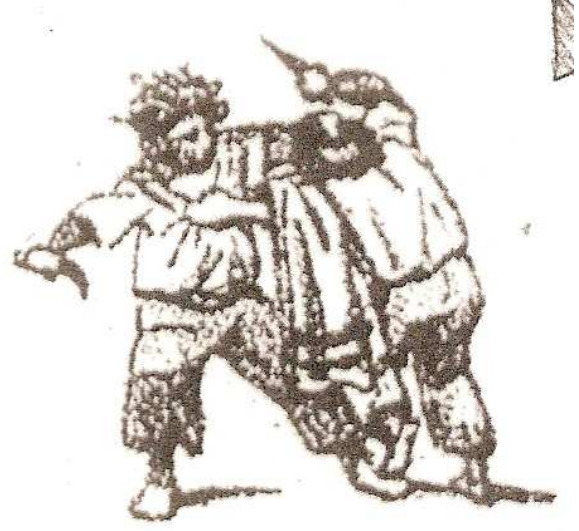

Fig. 23 "Pendencieros" Grabado de Posada

Para evitar un sensacionalismo injustificado con noticias falsas o desfiguradas que podían producir desordenes públicos, en 1895 el Presidente Díaz expidió una ley que prohibía a los voceadores enunciar cualquier noticia, exigiéndoseles limitarse al nombre y a la fecha del impreso, ya que se lograba por ese medio su venta masiva ${ }^{42}$

Así visto, el asunto contempla aspectos novedosos de una cultura visual desde dos ángulos diferentes: la de los ricos y la de pobres donde los protagonistas de la mayor parte de los hechos de sangre (según los estudiosos de la época) son éstos últimos debido a sus necesidades económicas y a su incultura. ${ }^{43}$ (fig. 23) Los ejemplos en el porfirismo son evidentes pero esto sólo fue posible gracias entre otros a Vanegas Arroyo como editor y Manuel Manilla y José Guadalupe Posada como ilustradores de temas populares.

\subsection{La imprenta de Vanegas Arroyo}

La imprenta de Vanegas Arroyo se fundó en el año de 1880 en la Ciudad de México y es importante mencionar que no fue por supuesto la única imprenta, pero si de las más conocidas debido a sus actividades populares, siendo relevante también la de Eduardo Guerrero ya entrado el siglo XIX, pero ésta,

\footnotetext{
${ }^{41}$ Alberto del Castillo, en Pérez Montfort, (coordinador) en Hábitos, normas y escándalo, Prensa, criminalidad y drogas durante el porfiriato tardío, CIESAS,/ Plaza y Valdés, México, 1997, p. 34.

${ }^{42}$ Cfr. Elisa Speckman Guerra, op. ct., p 175

${ }^{43}$ La teoría es de Cesare Lambroso, adaptada por criminalistas en nuestro país, según la cual existen "criminales natos" y donde se despiertan instintos crueles donde existen "reminiscencias de los instintos sanguinarios de los aztecas".
} 
de Vanegas en sus orígenes se dedicaba a la encuadernación de libros para ampliarse a editar y publicar oraciones religiosas; y de ahí a diversificar su oferta editorial, entre otros, a cuadernillos de poemas, cuentos infantiles, juegos de serpientes y escaleras, hechos y sucedidos, lenguajes de manos y de sombrillas, cartas, fórmulas mágicas, descripciones, asesinatos, cuadernos de bordado, ilustraciones diversas, etc.

Antonio Vanegas Arroyo (fig. 24) nació en Puebla en 1852 y muy pequeño llegó a la Ciudad de México donde se casó en 1875 dedicándose a actividades relacionadas a la encuadernación junto a su padre. En 1880 se independiza y funda su Taller de Imprenta y Encuadernación primero en la calle de Encarnación número 9 y 10, y después en Santa Teresa número1 y número 43, editando devocionarios, almanaques, cuadernillos y hojas volantes siendo ilustrados por Manuel Manilla (de 1882 a 1892) y José Guadalupe Posada (de 1889 a 1912). Gracias a la colección de

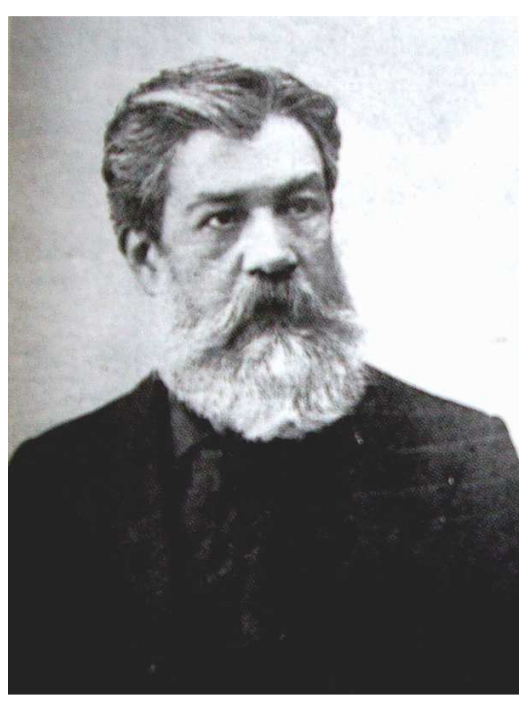

Fig. 24 Antonio Vanegas Arroyo fotografía impresos de Mercurio López Casillas ${ }^{44}$ de Vanegas Arroyo podemos saber algunas características de los productos surgidos de su taller:

...los cuadernos tenían dimensiones de aproximadamente 14 centímetros de alto por 9.5 de ancho; estaban impresos con tinta negra $\mathrm{y}$, en ocasiones, también con roja; contaban en general con ocho o dieciséis páginas intonsa de papel barato, el precio de la mayoría oscilaba entre 2 y 6 centavos. Muchos cuadernos estaban dirigidos a mujeres y niños. Editor inteligente, Vanegas Arroyo, decidió cubrir las necesidades de lectura de estos dos sectores de la población con manuales a "precios baratísimos". En el extracto del catálogo de los libros del fondo, elementales y de instrucción de venta en la imprenta y librería de Aguilar e Hijos para 1905 estaban incluidos los cuadernos ilustrados por Posada y eran los de menor precio en toda la lista. En

\footnotetext{
${ }^{44}$ Librero, coleccionista y editor, Mercurio López Casillas es dueño junto a su familia, de varias "librerías de viejo" y que al paso de lo años han logrado reunir tesoros bibliográficos provenientes de la compra / venta de bibliotecas. Estas publicaciones raras o ya incunables serían en su conjunto la envidia de historiadores, corredores bibliográficos y por supuesto, de museos nacionales. Por lo tanto nadie más autorizado que él que tiene en su poder colecciones completas.
} 
esa época, un peón en cualquier trabajo ganaba un peso diario. La gente del pueblo no se daba el lujo de comprar un libro y gastar toda su jornada, pero podía adquirir un manual con cubierta de posad por unos centavos". Los cuadernos tenían como antecedente calendarios que se publicaban desde el inicio del México independiente.

Los primeros ejemplos que publicó Vanegas Arroyo no incluían ilustraciones significativas; lo principal era tipografía. Fue hasta 1882, cuando el grabador Manilla comenzó a laborar para él, que las publicaciones empezaron a lucir vistosas imágenes. Éste realizó series, donde cada número constituía una parte o fascículo de un libro completo como La cría de canarios, Apuntes para el toreo y La salud en el hogar: 300 recetas útiles de medicina. Los grabados de Manilla contaban con un cuadrito o espacio en blanco para que el editor cambiara la numeración a gusto y había otros lugares libres para sustituir el título o subtítulo de la serie. De este modo, el editor los podía reutilizar sin necesidad de "retocar" el grabado. Cuando Posada entró a trabajar para Vanegas Arroyo, siguió los lineamientos marcados por Manilla".

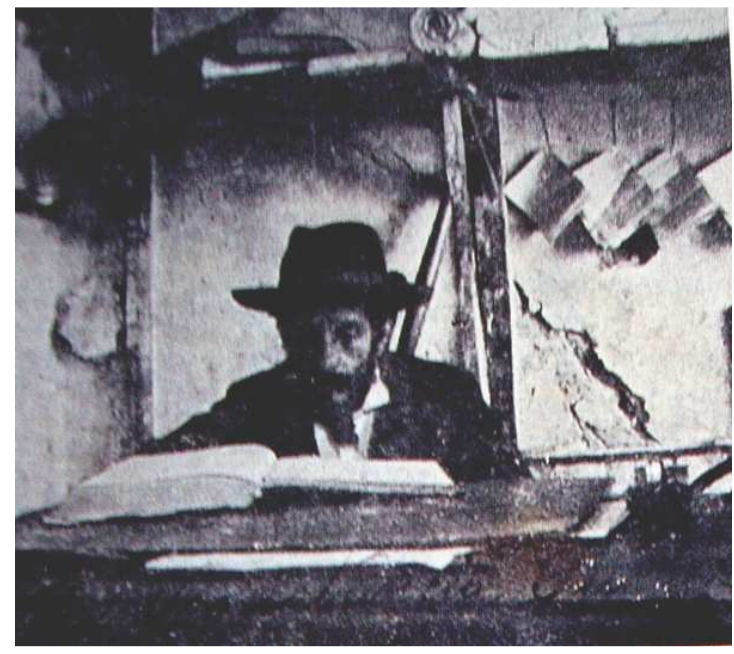

Fig. 25 Constancio Suárez. Fotografía

El editor Vanegas Arroyo reunió un grupo amplio de colaboradores que realizaban los textos, adaptando e inventando cuentos, adivinanzas, canciones, juegos, etc., y que incluso coloreaban con anilinas los grabados que después salían a la venta: Manuel Romero, Constancio Suárez, (fig. 25) Manuel Flores del Campo, Francisco Zacar, Ramón N. Franco, Arturo Espinoza "Chóforo Vico", Armando Molina, Francisco Oscar, Gabriel Corchado, Rafael Romero, Abundio Martínez y Pablo Calderón de Becerra. El tema de la muerte en los impresos de Vanegas Arroyo (suicidio, asesinato, fusilamiento, degollamiento, matricidio, parricidio, etcétera), provocaba gran revuelo y escándalo en una ciudad aún pequeña y excesivamente creyente de castigos divinos y terrenales, y es sólo un pequeño panorama de la vida en la sociedad mexicana decimonónica, en la que medianamente existía una parte de verdad y de ficción en la literatura popular

\footnotetext{
${ }^{45}$ Mercurio López Casillas, José Guadalupe Posada, ilustrador de cuadernos populares, 2 ․ Número de la Biblioteca de llustradores Mexicanos, Editorial RM, México 2003. pp 20-21.
} 
de la época. Los impresos podían comprarse en el expendio de Vanegas Arroyo, pero también podían comprase en la vía pública en calles, plazas, mercados o ferias. Los vendedores ambulantes pregonaban entonces su contenido. Para su lectura, por lo general, el narrador actuaba las partes, cantaba, daba juicios de valor, y trataba de formar criterios del auditorio compuesto por gente de la clase baja.

Probablemente el éxito de la abundantísima producción del taller de Vanegas Arroyo puede deberse a los hechos coloniales en lo que se refiere a aspectos violentos y de muerte y por otro a sus orígenes europeos. Según las investigadoras Guadalupe García y Silvia García en su nota introductoria sobre la "La Nota Roja en México" "46, se sabe históricamente que la Santa Inquisición, ejecutó a 43 personas y que sancionó con castigos severos a más de 35 .

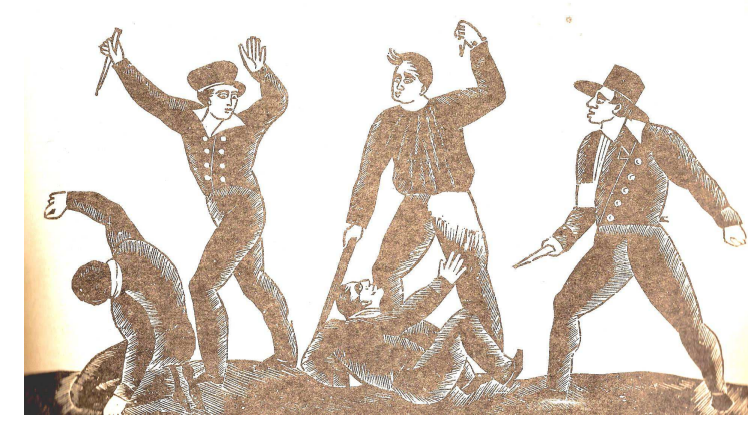

Fig. 26 Anónimo "Horrible Asesinato" Canard francés. Grabado
Textos enormes impresos en papel con las sentencias respectivas fueron colocados en las puertas de las iglesias a manera de edictos con un característico sello rojo, símbolo de la autoridad eclesiástica. ${ }^{47}$ Podría ser este un antecedente de la forma cartelística que

llamaba pues, la atención de los primeros habitantes de la Nueva España. Posteriormente, con el nacimiento del periodismo nacieron los canards, género populachero que se deriva de los ocasionéis europeos, esto es, de las hojas volantes como la Gaceta Callejera, que se publicaron en México bajo la forma de hojas volantes. La característica principal de estos ejemplos son los títulos sensacionalistas, la tipografía espectacular, los grabados en grandes dimensiones, el relato pormenorizado con la intención moralizante y su distribución son el resultado de una actividad colectiva, reflejándola en "hojas volantes" - hojas impresas por una o dos caras o dobladas en dos para formar cuatro páginas-. Un canard francés es aquel que se refiere al "Horrible

\footnotetext{
${ }^{46}$ Guadalupe García y Silvia Solís, La nota roja en México, CEHIPO, México, 1999, p. 20.

${ }^{47}$ Así parece ser que este sello rojo con las noticias fue conocido con el correr de los años como la llamada "nota roja"
} 
Asesinato" (fig. 26)) que se divide en tres secciones: Una de la explicación de la historia, la otra con los versos, y la central con la imagen grabada de 5 personajes en las que se observa a dos de ellos armados con puñales. ${ }^{48}$

Por otro lado está por supuesto, una rica herencia de una labor colectiva europea que proviene desde la Edad Media, de la literatura del Siglo de Oro española o hasta de colecciones como los "Cuentos de Calleja" ${ }^{49}$ transportados al ambiente mexicano llamada por los estudiosos como "literatura de cordel" o "de buhonería". El impreso popular mexicano en concreto, está directamente ligada de las aucas españolas y con la literatura de cordel y para muestra allí están los grabados que acompañan el texto de la "Relación y curioso romance del glorioso San Albano" de enorme difusión masiva en el siglo XVIII. ${ }^{50}$ (fig. 27)

Algo muy parecido se manejaba en la época de Vanegas Arroyo y de Posada, ya que se incluían para dar veracidad al asunto nombres, lugares públicos, y ubicaciones cercanas lo que producía un efecto de veracidad en los

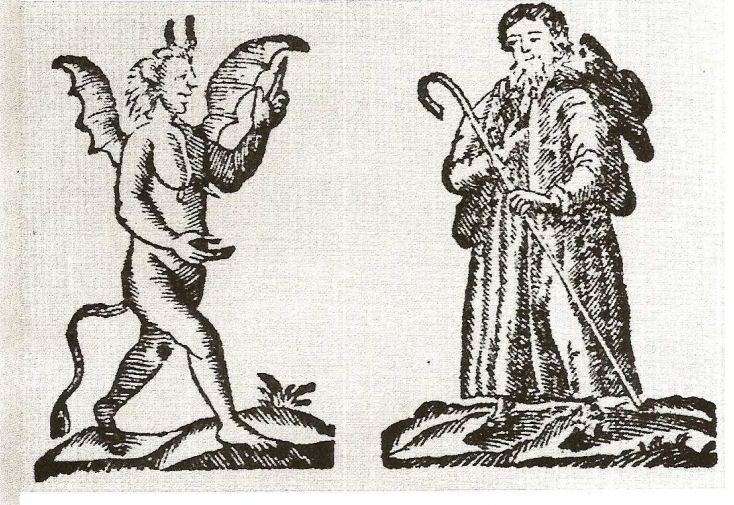

Fig. 27 Anónimo "Vida de San Albano". Xilografía oyentes conviviendo personajes ficticios, lugares poco accesibles a la mayoría, y figuras derivas de la ficción como "el demonio", "la muerte", "el fantasma", por citar algunos personajes. Se conocen impresos que los sucedidos del momento son cambiados de lugar dependiendo del mercado de la oferta y la demanda. Existen

\footnotetext{
${ }^{48}$ Antonio Rodríguez, Posada "el artista que retrató una época", Editorial Domes, S.A., México, pp. 29- 31

${ }^{49}$ Así llamados por Saturnino Calleja que fundó su editorial en Madrid en 1876 con colecciones de cuentos para niños que alcanzaron 300 números diferentes. Mercurio López Casillas, Posada ilustrador de cuadernos populares, op. cit p. 79.

${ }^{50}$ Un auca es una hoja dividida en viñetas que representan una historia terminada y existen ejemplos del siglo XVI como el "Libro de las suertes" (1515) o "Las maravillas del mundo" ambos de los impresores Alfonso de la Fuente y Juan Jofré. En el siglo XVI aparecen aucas llamadas dels oficis (los oficio). Las aucas abarca el género político, moral, religioso, histórico, educativo, de sucesos, etc., asimismo eran presentadas por auquers que divulgaban su contenido. http://es.wikipedia.org/wiki/Auca. Por otra parte, un ejemplo predicador en los pliegos de cordel es la leyenda de San Albano en la cultura española del siglo XVIII en la que pueden observarse algunas de las soluciones gráficas utilizados por Manilla y Posada años después y que pudieron ser vistas o conocidas en México: El demonio, ser cornudo, alado y con cola para representar el mal y el santo Albano de rostro afable. pp 73-91.
} 
constancias en libros de contabilidad de los impresos de Vanegas Arroyo que confirman que eran vendidos en diferentes partes de la República Mexicana y de aquí su popularidad nacional. ${ }^{51}$

Vanegas Arroyo muere en la capital el 14 de marzo de 1917 donde sus hijos, nietos y bisnietos han continuado con la imprenta hasta la fecha. Por una pequeña nota en un periódico capitalino sabemos que la muerte del ilustre impresor no pasó desapercibida para la opinión pública:

Por lo que el arte popular respecta juzgo sobresaliente el artículo que publicó Nicolás Rangel a raíz de la muerte del editor Antonio Vanegas Arroyo, ocurrida el 14 de marzo de 1917: "El alma popular y Vanegas Arroyo".

Ahí se encuentran valiosos datos biográficos de don Antonio y, lo que es igualmente importante para la historiografía artística, una temprana mención de las ilustraciones populares de Posada. Califica Rangel a "Guadalupe Posadas (sic) de...grabador único en su género, pues nadie como él ha tenido la percepción de lo caricaturesco del pueblo bajo de la capital. ${ }^{52}$

Es indudable que la obra del impresor quedará ligada en la historia del arte a la obra de Manuel Manilla y de José Guadalupe Posada entendiéndose como mancuernas representativa del arte popular del siglo XIX y XX. Veamos por separado a cada artista.

\subsection{Manuel Manilla}

Manuel Manilla fue el primer grabador en la imprenta de Venegas Arroyo, quien utilizó numerosas veces el tema de la muerte en infinidad de temas (fig. 28) y dejó una obra considerada anónima, misma que fue rescatada, al igual que el trabajo de otros

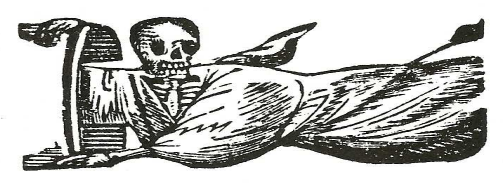

Fig. 28 Viñeta de Manuel Manilla

\footnotetext{
${ }^{51}$ Elisa Speckman Guerra, De amor y desamor, ideas, imágenes, recetas y códigos en los impresos de Antonio Vanegas Arroyo, en Revista de Literaturas Populares, FFy L, UNAM, p. 68.

${ }^{52}$ Citado por Fausto Ramírez, en Crónica de las Artes Plásticas en los años de López Velarde, UNAM, México, 1982, p. 76.
} 
grabadores de los años 20's del siglo XX. Nace Manilla en 1830, desconociéndose el lugar de su nacimiento y los antecedentes de su enseñanza en el grabado aunque es posible -sin llegar a afirmarlo- que haya sido un artista autodidacta. ${ }^{53}$ Según Mercurio López Casillas, en su monografía sobre el grabador, Manilla trabajaba desde 1850 con el grabador e impresor Juan Lagarza, en 1875 con el impresor Ildefonso T. Orellana, en 1880 sus grabados para carteles son utilizados por la Imprenta de F. Casillas y hacia 1882 comienza a colaborar en la imprenta de Vanegas Arroyo donde hace todo tipo de ilustraciones. ${ }^{54}$ Por sus grabados sabemos que tenía un hijo de la misma profesión, y que hacían trabajos gráficos conjuntos con un mismo estilo lo cual dificulta la identificación entre la producción del padre y del hijo. El taller de Manilla e Hijo se localizaba en Pulquería de Palacio número 12. (hoy Corregidora, entre Roldán y $2^{\circ}$ Callejón de Manzanares ${ }^{55}$ ) También se habla de toda una familia dedicada al oficio que firmaba su trabajo "Manilla", lo cual comienza a formar una leyenda en torno al personaje. Lo cierto es que hacia 1892 Manuel Manilla se retira del trabajo comercial y muere de tifo en 1895.

Aquí hay un dato interesante: Westheim menciona que Manilla deja de trabajar en 1892 y muere en $1895^{56}$, aproximadamente a la edad de sesenta años (lo que permite deducir que habría nacido aproximadamente entre 1830 y 1835). ${ }^{57}$ Este dato ayuda a establecer que trabajó casi 10 años para el impresor Vanegas Arroyo, ya que se le adjudica la autoría de centenares de estampas grabadas en aleación de plomo y $z_{\text {inc }}^{58}$, lo que lleva a suponer a algunos que “...tan dudoso es que sean suyos todos los que se le atribuyen como es seguro que sean de él muchos de los grabados anónimos de la segunda mitad del siglo..." Comentario certero: yo mismo he encontrado grabados que le son

\footnotetext{
${ }^{53}$ Es una apreciación personal basada en la revisión de su obra, de ahí que su trabajo desde mi punto de vista se vea fresco y natural que lo acerca a soluciones gráficas populares sin el acartonamiento académico.

54 Mercurio López Casillas, monografía de 598 estampas de Manuel Manilla grabador mexicano, editorial RM, México, 2005.

${ }^{55}$ La zona era enormemente populosa según se observa en fotografías de la época, tal vez por eso Manilla consideró la ubicación de su negocio como correcta.

${ }_{56}$ Joyce Bailley menciona el año de 1897. Véase Helia Bonilla, op. cit., p. 11.

${ }^{57}$ Cfr. Westheim, El grabado en madera, FCE, México, 1954, Helia Bonilla también ofrece otro dato en el libro Manuel Manilla.

${ }^{58}$ Este dato se obtuvo del catálogo publicado a propósito de la exposición 330 grabados originales de Manuel Manilla, Catálogo de la Exposición Temporal, (México, Museo de la Ciudad, 1971).

${ }^{59}$ Westheim, op. cit., p. 244.
} 
adjudicados por críticos reconocidos a José Guadalupe Posada y son del poco conocido Manuel Manilla.

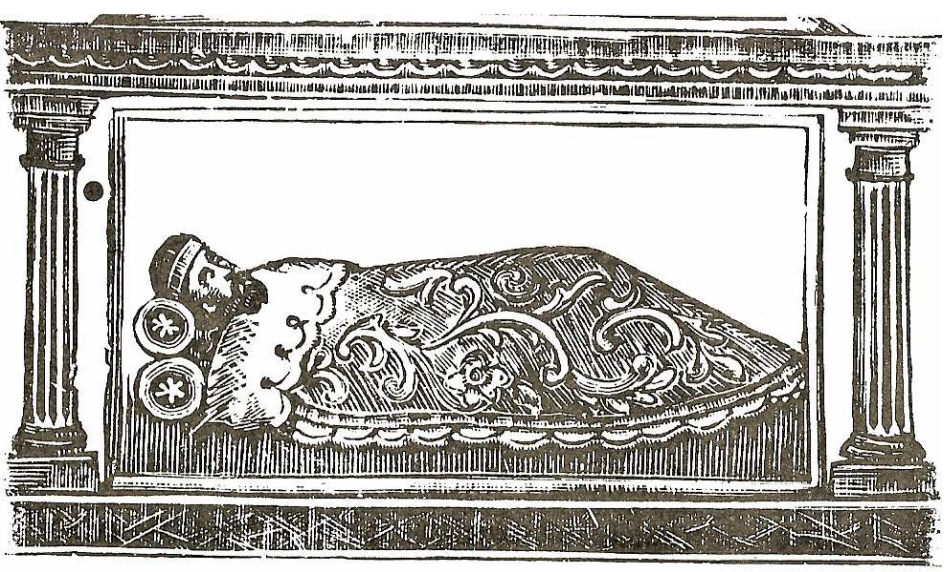

Fig. 29 "Visita y Despedimento al Señor de Ixtapalapa" de Manuel Manilla.

Xilografía

Su

abarca diversidad estilística, y su presencia más importante se haya en los impresos de carácter comercial y en especial de imágenes religiosas. (fig. 29) Así, se pueden encontrar hojas volantes, colaboraciones en periódico, peleas de gallos, funciones de teatro, caricaturas de prensa, folletería, juegos de mesa, programas de circo, calaveras, invitaciones, tipografías, etcétera. En el caso de su obra gráfica.

Hasta ahora se ha conocido sólo parte de la producción de Manilla: las hojas volantes y los cuadernillos que ilustró para el editor popular Antonio Vanegas Arroyo. Por ello su obra se ha creído restringida a ciertos temas, géneros y recursos y se la ha concebido como continuadora de una tradición del grabado popular mexicano de raigambre colonial. Pero Manilla no sólo contribuyó a renovar dicha tradición, sino que rebasa la preconcebida figura del grabador de impresos populares, pues fue un artesano independiente que atendió requerimientos diversos, incursionó en otras vertientes de la gráfica mexicana decimonónica y se adaptó a las innovaciones de una época que pretendía ponerse a tono con el progreso mundial. ${ }^{60}$

Un aspecto interesante de la obra de Manilla fue el hecho de realizar sus tallas en los momentos en que la litografía era la reina de los procesos gráficos de entonces para la ilustración de libros, lo cual implica la búsqueda de soluciones de estilo y de rapidez que en el caso de la imprenta de Vanegas Arroyo debió de haber buscado entonces debido a las necesidades del mercado. Sin embargo al observar su trazo de buril sobre la madera o sobre el metal se nota

${ }^{60}$ Helia Emma Boniilla, op. cit, pp. 9-10. 
un cuidado al utilizar la herramienta que no queda más que pensar que debió de haber sido un artista cuidadoso con su trabajo. La prensa de la época, por ejemplo, utilizaba el lápiz litográfico sobre la piedra sensible como una solución inmediata a las necesidades políticas del momento, y se imprimía en tirajes que hacían lucir ideas y dibujo del artista. En la obra de Manilla se observa una paciencia para la construcción de las imágenes gráficas y no deja uno de admirar su ingenio y su creatividad.

Manuel Manilla tuvo aciertos visuales de belleza popular con la navaja y la gubia. Al ver su trazo y su manejo del instrumento de grabar, se descubre un trabajo pausado y reflexivo, no permitió el efecto del velo suelto en la plancha, sino al contrario, obligó a la precisión y a la meticulosidad. Lo que en Posada será soltura y efecto en el buril, en Manilla se observa paciencia y detalle. Su dibujo, si se observan con detenimiento los dos ejemplos aquí mostrados, es duro, no obstante suplió esa deficiencia con el preciosismo de la herramienta. La solución es agradable visualmente y no desmerece para nada el trabajo de su competidor de Aguascalientes.

Muy joven, Manuel Manilla comenzó a ilustrar para las imprentas que ofrecían sus servicios para una sociedad demandante de estampas de figuras de santos, y vírgenes. En la segunda mitad del siglo XIX, México era entonces una ciudad de 185, 000 habitantes, más del $95 \%$ profesaba la fe católica y para cubrir esa demanda de necesidades religiosas de 54 curatos y 28 conventos, había casi 46 talleres impresores y tipográficos en las que impresores y grabadores seguían en sus calendarios religiosos y festividades realizando impresos para los santos patrones de los templos. Se encontraban imprentas como la Imprenta de Murguía (Puente Quebrado número 10), la Imprenta del Popular (Cerca de Santo Domingo número 10), la Tipográfica de Juan Lagarza (Venero número 12), la Imprenta y Encuadernación de Antonio Vanegas Arroyo (Encarnación números 9 y 10), la Tipográfica Callejón de Verdeja o la Imprenta de Callejón de Vázquez número $12 .{ }^{61}$

61 En los anexos se da una relación de las imprentas y tipográficas en la segunda mitad del siglo XIX. 
Se realizaban entonces dos presentaciones. Los pequeños grabados para un rezo íntimo y personal, las imágenes más grandes para adornar las paredes de la casa. De los primeros trabajos de Manilla se encuentra la pequeña ilustración Triduo para implorar de la Divina Infantita, que se veneraba en la iglesia de San José de Gracia, el remedio de nuestras necesidades, dispuesto por Francisco Calapiz, quien lo dedica a la misma Soberana Señora. (fig. 30) En ella una figura femenina acostada sobre una humilde cama sostiene en su mano derecha unas flores que ofrece a los pequeños ángeles que van hacia el centro de la composición donde se encuentra el monograma de María.

Es indudable que Manilla debió de sentirse a gusto realizando obras de esta naturaleza, que conformaron su identificación con el pueblo y más en las fiestas del mes de noviembre. Mercurio López Casillas dice al respecto:

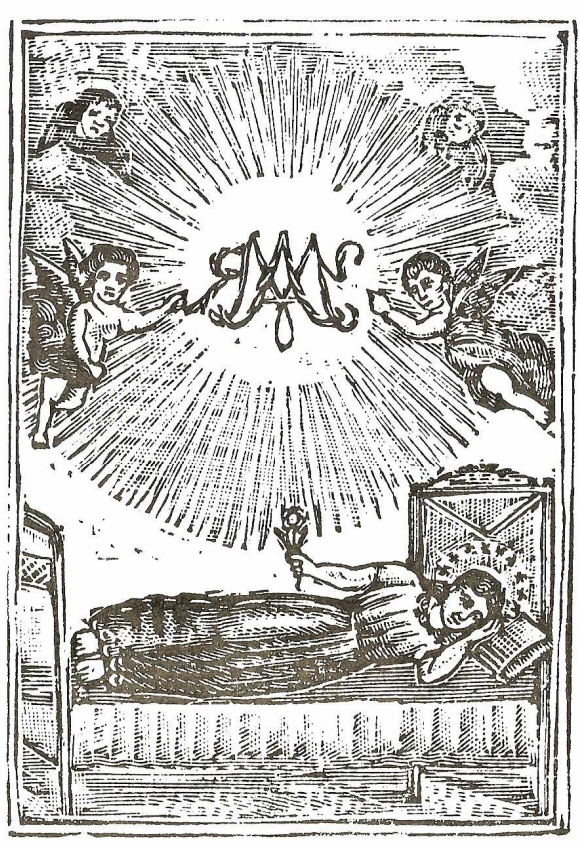

LA DIVINA INFANTITA

Fig. 30 "La Divina Infantita". Grabado de Manilla

De las fiestas religiosas de esa época, la de los Fieles Difuntos, el 2 de noviembre, era la de mayor convocatoria. La gente iba al panteón a visitar a sus muertos y hacía, alrededor de la tumba, un pequeño festín. También acudía al teatro para ver la obra de José Zorrilla, Don Juan Tenorio (que se presentaba, desde 1864, cada mes de noviembre) y compraba hojas volantes con versos y grabados de calaveras. Manilla fue de los primeros que retrató a los muertos de manera festiva, con resultados estupendos. Desarrolladas por Posada, estas representaciones tendrían una influencia incalculable sobre la imaginería mexicana del siglo XX. Además de las hojas, Manilla realizó cráneos y huesos para prensa y carteles. A fines de octubre y principios de noviembre, su taller contaba con un acervo considerable de pequeños clichés de calaveras para cubrir la demanda de distintas imprentas. ${ }^{62}$

${ }^{62}$ Mercurio López Casillas, Manilla, p. 18. 
En efecto, Manilla tiene la gracia para la realización de calaveras festivas. Varios ejemplos han sobrevivido hasta nuestros tiempos. Veamos algunos: Un grabado de Manilla de difícil composición es aquella que recuerda la construcción de una torre en base a cráneos y huesos que, separadas por un fémur humano, están colocados en siete niveles a manera de torre Eiffel. (fig. 31) En la parte superior se encuentra una calavera sentada con los brazos

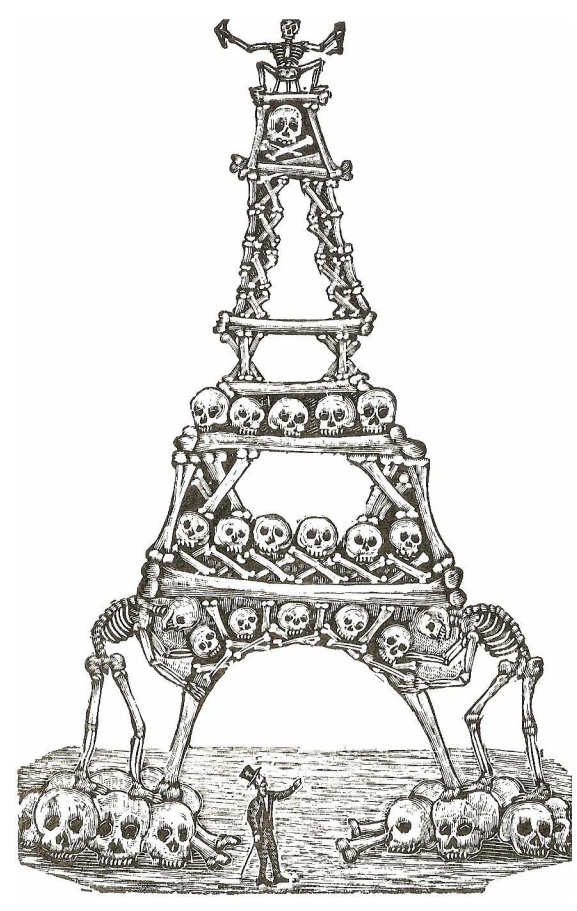

Fig. 31 Viñeta. Xilografía extendidos y sostiene unas botas con las manos. En su base están colocados dos esqueletos, que a su vez pisan sobre cráneos, que sostienen parte de la estructura piramidal. También aparece un empequeñecido personaje humano tocado con bastón y sombrero de copa que mira la escena y parece increpar al esqueleto de su lado derecho.

El otro grabado, no menos interesante, muestra un esqueleto con sombrero de copa (que después utilizaría Posada con cierta recurrencia en otros grabados) que va cargando en forma precavida su propio ataúd. Obsérvese sus acabados de vértebras posteriores finamente trabajadas. Asimismo, en el otro brazo lleva una serie de aditamentos inusuales para una calavera: un libro, un serrucho, unas tijeras, un peine, etcétera. Por su parte, el ataúd fue trabajado sobre un fondo oscuro al que sólo se le perfiló en líneas blancas con la uñeta. Un detalle curioso en el trabajo de Manilla es la utilización de grandes espacios blancos en las planchas matrices, así como en los espacios tipográficos y en las figuras con el fin de ajustar fechas o productos comerciales que convenían al editor. (fig. 32)

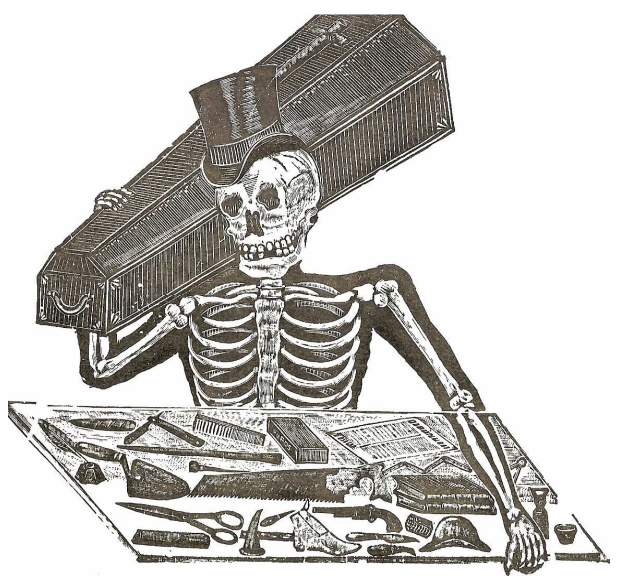

Fig. 32 Viñeta. Xilografía. 
De este autor se rescatan algunas obras que se relacionan con el tema de la muerte: la primera, mencionada líneas atrás, fue encontrada en la revista Forma; en ella se muestran el velorio dentro de una habitación de una familia pudiente, donde se están 7 figuras enlutadas que velan un cuerpo con rasgos femeninos envuelta en una túnica blanca; sus rostros reflejan su pesar mostrando sus ojos entrecerrados. En el extremo derecho del grabado, un niño llora. Dos largos cirios acompañan el ataúd y su pabilo está inclinado hacia atrás debido a una corriente a aire que entra por la puerta que ha dejado abierta una parienta de la difunta, quien lleva a los acompañantes dos tazas de café. En el fondo se observan como elemento decorativo marcos de cuadros en la pared principal. En otra llamada "El toro embolado", ${ }^{3}$ (fig. 33) se refiere a las calaveras gráficas de las cuales años más tarde Posada será un maestro consumado. Esta gráfica presenta cuatro calaveras bufas tocadas con montera, dos de ellas portan panderos, otra una mandolina y una más un capote; éstas incitan a la lidia a un toro esqueleto que no acierta a embestir a alguno de ellos. En esta estampa el movimiento es el elemento que le da a la composición un rasgo peculiar que caracterizará al grabado mexicano.

Un tercer ejemplo se refiere a una ilustración para el periódico popular El Monitor del Pueblo $\quad(1887)^{64}$, realizada a propósito de las festividades del

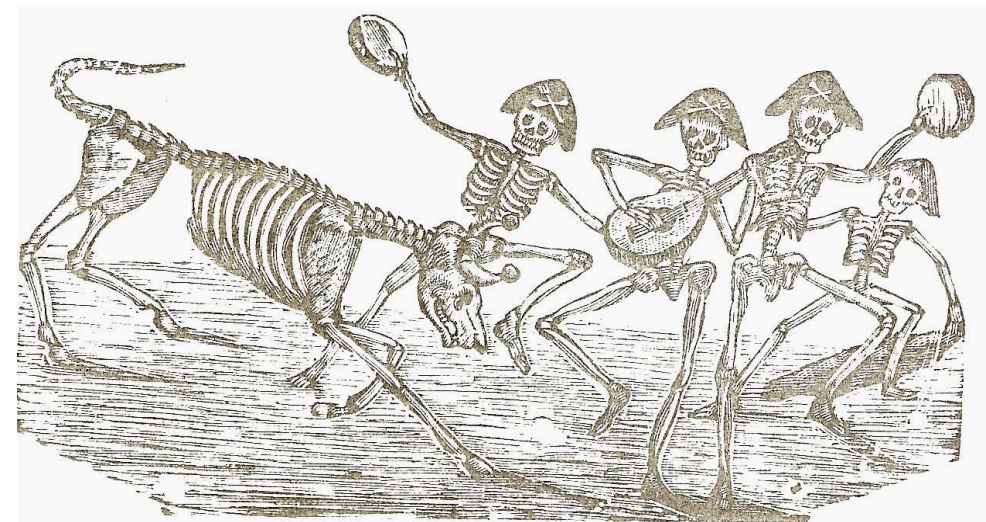

Fig. 33 Manuel Manilla, "El toro embolado". Xilografía

\footnotetext{
${ }^{63}$ Este grabado tiene una doble significancia: por un lado, podría estar relacionado con la vieja tradición valenciana trasladada a México de colocar unas bolas de brea y paja en los cuernos que las prenden procediendo a soltar al toro por las calles que arrasa a los mozos que borrachos le molestan. Por otra parte, pudiera ser la razón que los toreros frecuentemente llegaran a las corridas alcoholizados lo que demeritaba el espectáculo. Por esta razón el primer reglamento taurino mexicano que se conoce de abril de 1822 señalaba la obligación de las cuadrillas de apersonarse ante el alcalde "para que éste vea si hay algún ebrio, en cuyo caso no les permitirá torear y les impondrá una pena proporcionada". Véase Jesús Gómez Serrano, Mercaderes Artesanos y Toreros, La Feria de Aguascalientes en el siglo XIX, Instituto Cultural de Aguascalientes, 1985, cap. "Toreadores y Empresarios", p. 62

64 José Guadalupe Posada posteriormente también colaborará en esa publicación. Cfr. en "Cronología", en José Guadalupe Posada, ilustrador de cuadernos populares, p. 211.
} 
Día de Muertos del $1^{0}$ de noviembre. Esta pequeña viñeta muestra dos esqueletos a media cintura que representan al grabador Manilla, que porta un sombrero, y su hijo, que tenía del mismo oficio, que lleva pequeños impresos en la mano derecha. (fig. 34) Como era usual, estos iban acompañados con un texto en verso en relación a la imagen:

\author{
Manuel Manilla \\ É hijo-en la calle del Banco \\ De la Santísima están \\ $Y$ siguen grabando en blanco \\ ¿Cuándo resucitarán? \\ Llega Cambeses y vete \\ Si quieren resucitar, \\ Porque te van á enterrar \\ En su casa que es el siete.
}

Como comentario final podemos decir que la obra de Manilla es base del aprendizaje para la obra de su continuador José Guadalupe Posada, de obra gráfica más abundante debido a la rapidez con el buril y el metal. Un aspecto no contemplado es la utilización de ácidos para grabar más rápido sobre el metal, a diferencia del trabajo pausado de las maderas empleadas por Manilla. Insisto que Manilla es popular y de ahí su candor y su frescura que no hubiese sido posible si el grabador hubiese sido un tallista

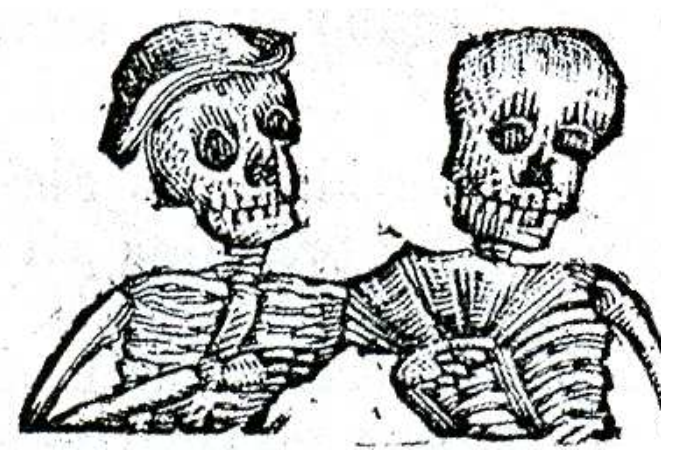
académico. De ahí su revaloración como artista presente que permitió la presencia de imprentas y talleres

Fig. 34 Manuel Manilla. Xilografía tipográficos que usaron la obra de Manilla como forma de supervivencia en la difícil competencia de impresos y folletos a los que los grabadores se enfrentaron en la segunda mitad del siglo XIX. 


\subsection{José Guadalupe Posada}

Nació este artista en la ciudad de Aguascalientes el 2 de febrero de 1851, Sus padres fueron Germán Posada y Petra Aguilar. Tuvo tres hermanos y una

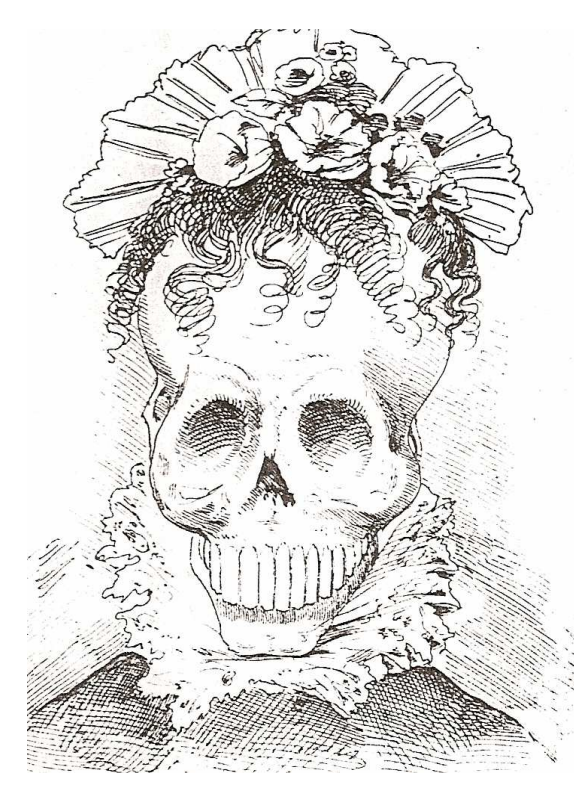

Fig. 35 "Calavera catrina" Grabado de Posada hermana. Se dedicó un tiempo de su vida a ser maestro de escuela. Fue asimismo un artista prolífico desde 1871 hasta 1912 y su habilidad para el dibujo y su capacidad creativa lo llevaron a trabajar en los periódicos como "Argos", "La Patria Ilustrada", "El Ahizote", y "El Hijo del Ahuizote", órganos de oposición al gobierno de Porfirio Díaz. Se ha considerado que en el semanario La Patria Ilustrada, cuyo propietario era el editor y escritor Ireneo Paz, José Guadalupe Posada dio a conocer las primicias del arte que le dio singular

renombre: las calaveras. "Un grabado [probable aguafuerte] publicado en 1889 apareció por vez primera en las páginas de este semanario inaugurándose este género; en él apareció 'una calavera patética con cráneo enflorado, un resplandor de listones y un cuello de barroca encajaría'. Fue a no dudarlo, la primera calavera catrina". ${ }^{65}$ (fig. 35)

Si bien Posada trabajaba para cualquier cliente que se acercara a su taller, (fig. 36) se puede considerar que su obra gráfica junto a los artistas José María Villasana y Santiago

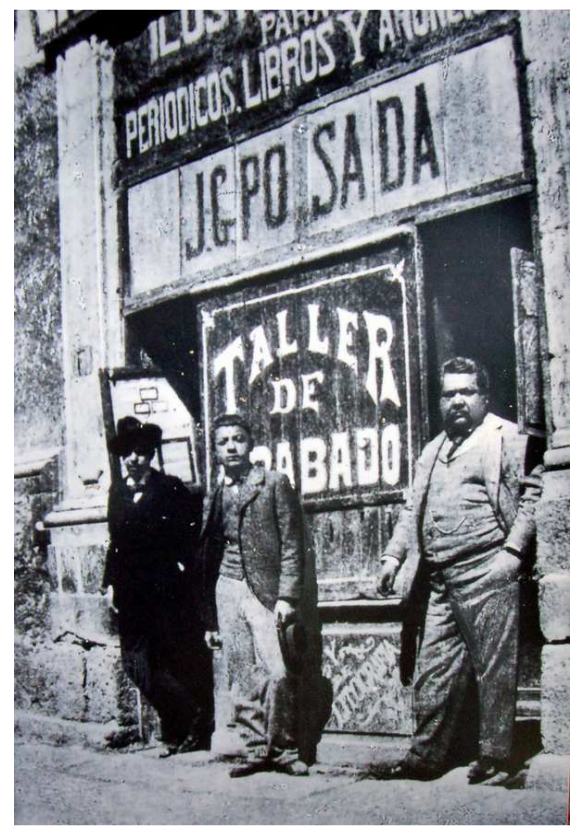

Fig. 36 José Guadalupe Posada afuera de su taller Hernández en la imprenta de Paz hablan de su obra de carácter político; la

${ }^{65}$ Napoleón Rodríguez, Op. cit., pp. 59-61. 
mayor difusión de sus grabados y litografías fueron al lado del impresor y editor popular Antonio Vanegas Arroyo. El Taller de Posada primer estuvo en la calle de Santa Teresa (ahora avenida Guatemala) y después se cambió al número 5 de Santa Inés ahora calle de Moneda muy cerca del edificio de la Academia de San Carlos. En forma humilde daba a conocer su trabajo: J. G. Posada. Ilustraciones para periódicos, libros y anuncios. Taller de Grabado y Litografía. El muralista José Clemente Orozco en su Autobiografía publicada en 1945 relata en relación a sus años juveniles la influencia que ejerció la imagen del grabador:

“...En la misma calle y a pocos pasos de la escuela tenía Vanegas Arroyo su imprenta, en donde José Guadalupe Posada trabajaba en sus famosos grabados.

Bien sabido es que Vanegas Arroyo fue el editor de extraordinarias publicaciones populares, desde cuentos para niños hasta los corridos, que eran algo así como los extras periodísticos de entonces, y el maestro Posada ilustraba todas esas publicaciones con grabados que jamás han sido superados, si bien muy imitados hasta la fecha...

Posada trabajaba a la vista del público, detrás de la vidriera que daba a la calle, y yo me detenía encantado por algunos minutos, camino de la escuela a contemplar al grabador, cuatro veces al día, a la entrada y salida de las clases, y algunas veces me atrevía a entrar al taller a hurtar un poco de las virutas de metal que resultaban al correr el buril del maestro sobre la plancha de metal de imprenta pintada con azarcón.

Éste fue el primer estímulo que despertó en mi imaginación y me impulsó a emborronar papel con los primeros muñecos, la primera revelación de la existencia del arte de la pintura...66

La importancia de la obra de Posada reside en el hecho de que el grabado en la segunda mitad del siglo XIX adquiere características muy particulares. Westheim en su libro sobre el Grabado en madera ${ }^{67}$, apunta que el nuevo grabado mexicano se definió por un cambio de estilo y contenido, ${ }^{68}$ y estos cambios ocurrieron gracias al trabajo de un grabador hasta entonces desconocido llamado José Guadalupe Posada, quien alcanzó, según Justino Fernández "...un arte liberado de la tradición académica naturalista, de los

\footnotetext{
${ }^{66}$ José Clemente Orozco, Autobiografía, (México, ERA), pp. 13-14.

${ }^{67}$ Westheim, op. cit., pp. 227-276.

${ }^{68}$ Hasta mediados del siglo XIX el grabado académico seguía una rigurosa disciplina de estudio. Abelardo Carrillo y Gariel en su libro Grabados de la Colección de la Academia de San Carlos, da cuenta de las diferentes secciones en que estaba dividido para su estudio en la Academia., pp. 27-28.
} 
bellos idealismos y de los asuntos religiosos". ${ }^{69}$ La importancia de este comentario reside en la verdad que encierra con respecto a las tendencias estilísticas y técnicas que entonces permeaban el ambiente artístico mexicano, pues, de acuerdo a las acotaciones que Carrillo y Gariel se sabe del poco interés que mostraban por el grabado los alumnos en la Academia de San Carlos en los tiempos de Posada. ${ }^{70}$ Posada fue, asimismo, autor de calaveras y de imágenes de la muerte a través de grabados moralistas llamados ejemplos, los cuales eran modelos éticos cuyo efecto era decisivo entre la gente humilde. Hemos comentado páginas atrás sobre las "aucas" estas imágenes españolas

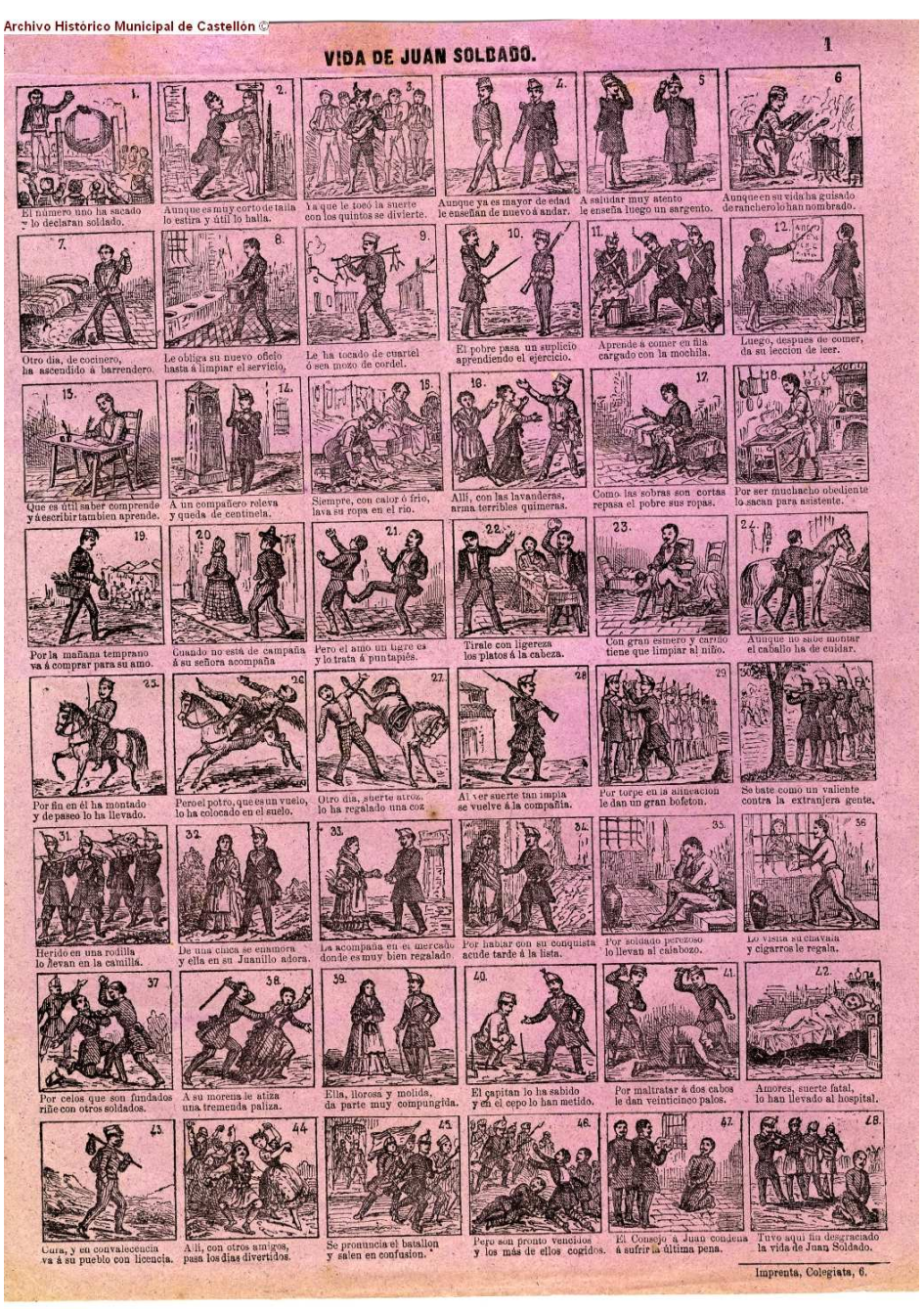

Fig. 37 Auca de la Vida de Juan Soldado que debieron de haberse conocido de alguna manera en América. No dudamos que también pudo existir una coincidencia artística sobre todo con la sensibilidad de los ilustradores en la manera de tratar los temas; sin embargo, creo firmemente en el conocimiento de Vanegas Arroyo de este género y sus derivados. Como fin ilustrativo la figura muestra la hoja llamada "Vida de Juan Soldado" (fig. 37) quien a manera de una

\footnotetext{
${ }^{69}$ Véase José Guadalupe Posada, ilustrador de la vida mexicana, México, Fondo Editorial de la Plástica Mexicana, 1992, p. 37.

${ }^{70}$ Otra confirmación son los Catálogos de las Exposiciones de la Antigua Academia de San Carlos de México (1850-1898), en una edición de Manuel Romero de Terreros que muestra el panorama artístico en relación al grabado en las diversas exposiciones presentadas en la mitad del siglo XIX.
} 
moderna tira cómica relata una historia en dibujo en cuadros pequeños numerados (casi siempre de 48 cuadros o escenas) y de dos textos en verso impresas en Colegiata 6 y que funciona a manera de "ejemplo" sobre el lector sobre las desventuras del personaje de Juan metido de soldado y quien siempre le va mal hasta que merece ser fusilado por su mala reputación. SI se observan cuidadosamente, los dibujos recuerdan la forma en que Posada en México soluciona su trabajo con elementos compositivos similares. ¿Son estas coincidencias gráficas? o bien, cabria preguntarse si trasplantó Vanegas Arroyo como editor ideas y soluciones vistas en otro lugar y que Posada ejecuto vertidas a ideas moralizantes del porfiriato mediante hojas de papel de colores. En otro ejemplo llamado "El País de las monas" (fig. 38) los simios realizan

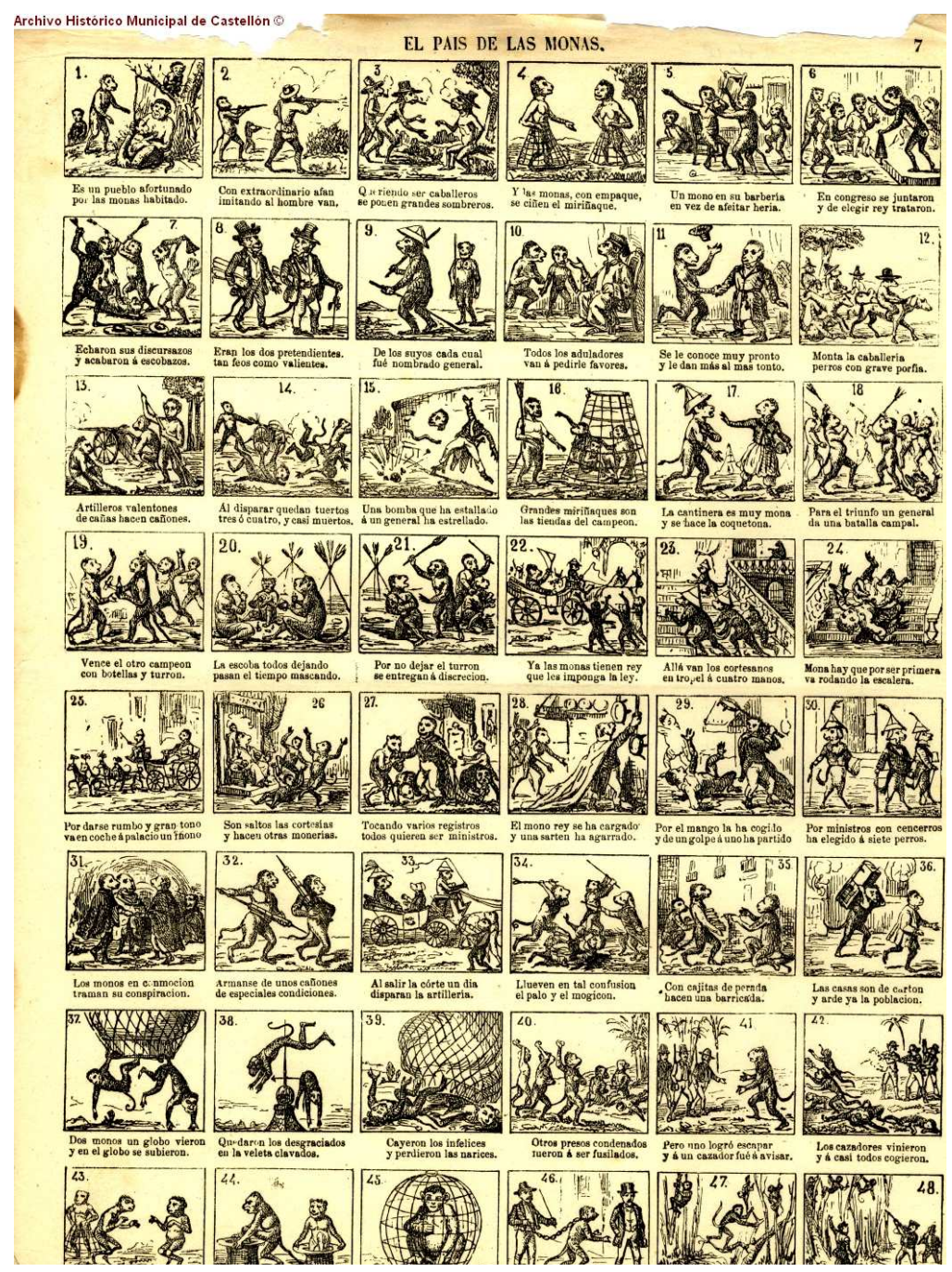

Fig. 38 Auca de El pais de las monas actividades comunes del ser humano: guerra, actos cotidianos, política, juegos, etc., hasta que los cazadores hacen acto de presencia y acaban con su fiesta, regresando a aquellos a su lugar de origen que son los árboles. Es posible que la forma de realizar estas ideas hayan sido las mismas que en México se implementaran con el tiempo en las grandes casas editoras y son las que se solicitaba a escritores populares desarrollaran la idea para después transferirla a un procedimiento gráfico que permitiera imprimirlo 
en grandes tirajes. Desconozco la autoría de los dibujos de las Aucas de España, pero son similares al tratamiento a las que Posada acostumbraría a sus lectores años después en México. Como ejemplo pueden servir cuatro cuadros de la tira de "Las aventuras del pan pringado" que desde su nacimiento es un ser marginado debido a su enorme nariz y su mala suerte. Estas formas de castigo social, sobre todo funcionaba como elementos de "premio" y de "castigo" y tenían una intención moralizadora a la que debemos agregar que si

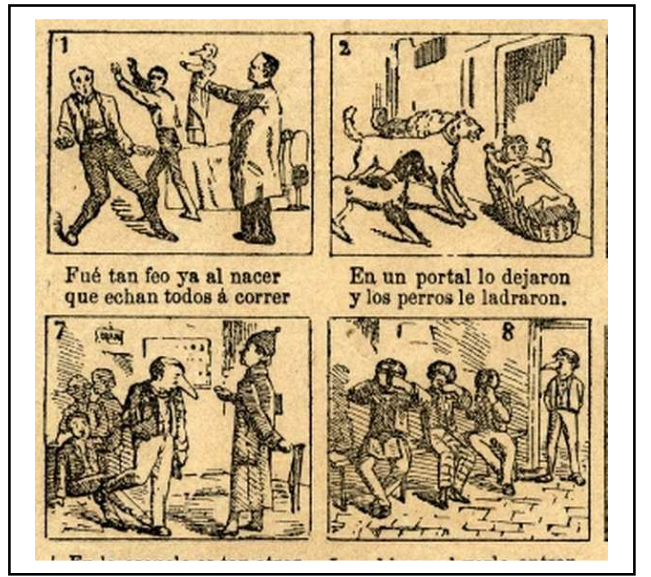

Fig.. 39 Auca Las aventuras de pan pringado los seres humanos no se parecen a nosotros, entonces deben ser malos y castigados. (fig. 39) Asimismo existe una coincidencia que los textos están destinados a un sector de iletrados en una sociedad que aún no conoce la educación escolarizada pero si educación moral que la familia, los amigos y la calle si lo hace.

menciona que:

Las Aucas constituyen en la historia de la literatura popular una atrayente lectura para los niños y para los lectores escasamente alfabetizados de las centurias pasadas. Las Aucas en el ámbito valenciano-catalán y las Aleluyas en el castellano, ofrecen una pequeña enciclopedia del saber y la imaginación del pueblo encerrados en viñetas -48 por cada pliego-, que desarrolla una historia, una hazaña, usos y costumbres. En el momento inicial los impresores valencianos divulgaron en los grabados de madera sus Aucas, artes y oficios, juegos infantiles, fábulas de Esopo; más tarde vida de Santos, fiestas carnavalescas, acrobacias e historias múltiples. Cada viñeta ciñe escenas / momentos narrativos dispuestos en sucesión con el acompañamiento de una frase, y posteriormente de un pareado. La fascinación que ejercen estos antiguos grabados en los ilustradores modernos se deriva del encanto de su simplicidad, de su jubilosa «esencia formal», resuelta en un plano, en cada una de ellas y en el conjunto del pliego, distribuyendo las figuras en una situación espacial de frontalidad. ${ }^{71}$ 
En el caso de José Guadalupe Posada, el uso de las "calaveras", son el ejemplo a seguir y que es usada en plan festivo. En México, a los personajes en vida se les hace una "calavera" en verso. Son textos cortos rimados que usan las virtudes y defectos de las personas y que esos valores o defectos pueden ser usados para hacer reír al prójimo, pero no es la única manera de moralizar. La calavera literaria es acompañada de una gráfica o de un retrato del personaje y que unidas dan el toque mexicano en cuestión. (fig. 40) Asimismo existen pequeñas "calaveras de dulce" con el nombre pegado en la

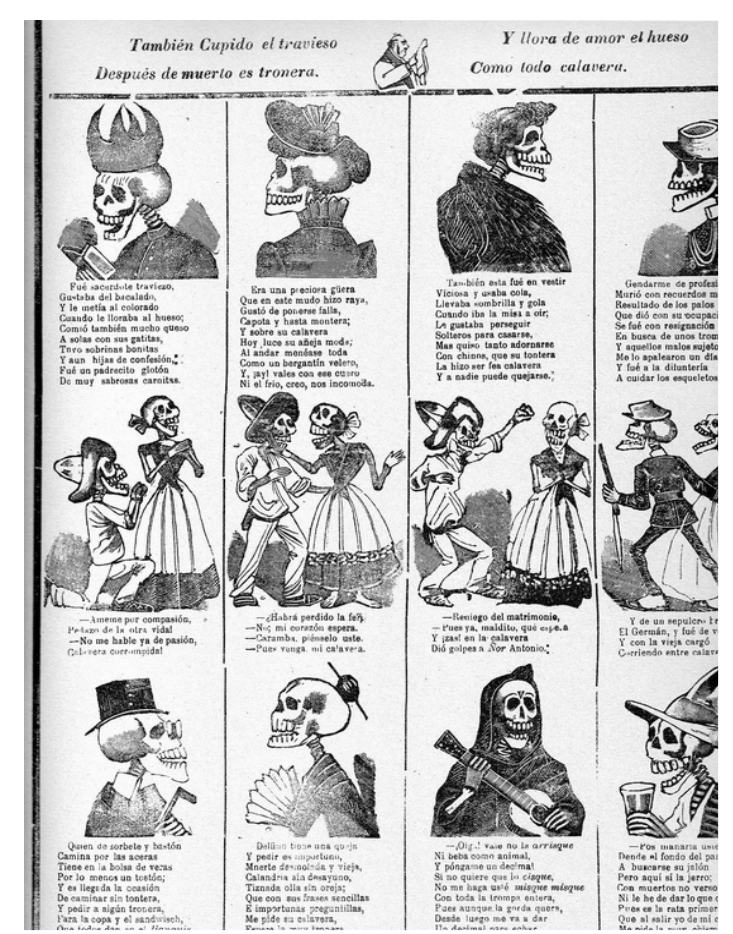

Fig. 40

José Guadalupe Posada

Hoja de "Calaveras" frente y que se coloca en la ofrenda: cada uno tendrá la suya acompañada de cirios, velas, pan de muerto, fruta, y bebida. Es una manera de decir que un día no muy lejano el vivo acompañará al muerto en una ceremonia igual. Por eso Vanegas Arroyo y Posada han realizado las "calaveras" semejantes en forma a las Aucas valencianas en papeles de colores y textos cortos. Los textos son retratos literarios de personajes ilustres del momento ya perdidos en la historia que permitirían conocer a quien se estaba dirigiendo, porque era ésta la fiesta nacional donde se permitía todo y estaban sujetas a esta burla, el presidente, autoridades religiosas y civiles, y como su lenguaje era festivo, pues no procedía su respuesta por otro medio. Aún en nuestros días cuando las "calaveras" de personajes importantes en los medios masivos son leídas, se usan teniendo en general cuidado de las formas, es decir, se coloca un retrato gráfico del aludido como tal, y el resto del cuerpo es en forma de esqueleto para impedir acciones legales. Eso sucedía con ex/ presidentes 0 actrices como María Félix, quien era sujeto año tras año de burla pública debido a su extrema delgadez y que se consideraba que era una calavera andante. Pero, en la época de Posada, el artista popular que era supo 
identificarse con el pueblo, de tal forma que su trabajo tiene ese encanto difícil de repetir.

Los procedimientos técnicos empleados por José Guadalupe Posada en su obra gráfica fueron variados lo que hace considerarlo como un conocedor en los procedimientos gráficos: grabado en madera, en plancha de metal tipográfico, grabado en piedra litográfica, litografía, litografía a colores y sobre todo de la zincografía, lo que le permitió y facilitó la realización de su vasta obra. Considerado como el grabador con mayor producción de obra con sus más de veinte mil grabados lo hacen el artista de toda una época. Entre su múltiple producción se encuentran: portadas, ilustraciones para cuentos, productos comerciales, retratos, cuadernos con canciones, sainetes,

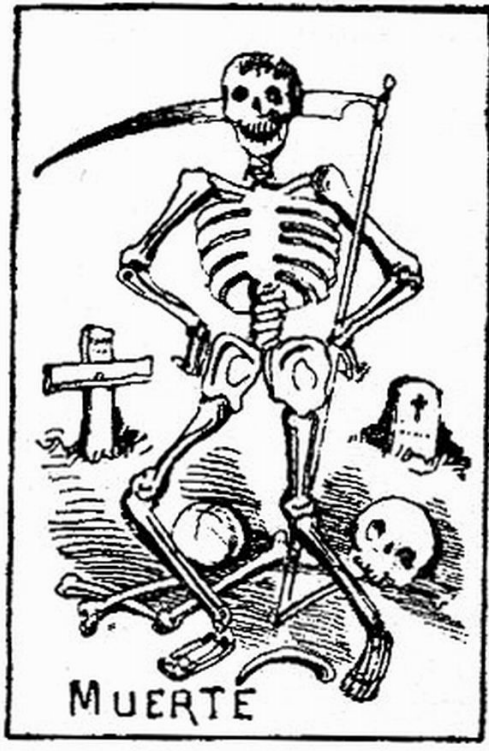

Fig. 41 José Guadalupe Posada Carta de juego pastorelas, manuales de cocina, adivinanzas, juegos, (fig. 41) colaboraciones para periódicos, novenarios, oráculos, muestrarios de cocina, recetas de medicina, comedias. Pero sin duda alguna Posada es asociado con las imágenes de la muerte que sin duda alguna en muchas partes son el referente gráfico hoy en día de México, pero, implícita existe la muerte desde el aspecto de cronista, o denunciante de la situación social en que vivía la mayoría de los mexicanos.

Díaz de León explica que Posada llegó a la expresión magistral de su arte con temas esenciales en el marco moral y religiosos de la sociedad de entonces: temor al Diablo, desprecio a la muerte. Asimismo, Posada mostró que "...el paso fatal de los mortales a las fronteras de la Muerte no debe intimidar al hombre que sabe cómo le late el corazón."72

\footnotetext{
${ }^{72}$ Francisco Díaz de León, Gahona y Posada grabadores mexicanos, p. 63.
} 
En una obra reciente editada por Editorial RM se recopiló aquella obra de Posada que muestra otros aspectos no abordados anteriormente o muy poco conocidos. Se trata de la recopilación total de los pequeños cuadernos ilustrados donde aparecen cuentos, recetas de cocina y cartas de amor. Entre estos se hallan tres bellos ejemplos del uso de la calavera y la muerte. Es importante mencionar que en estos grabados el concepto de la muerte está forjado desde el título (sin la acción implícita) donde existe la ambientación que requiere el ojo, y hasta la acción misma del cuerpo físico que se muestra desvanecido y suceden escenas alrededor del personaje que lo permiten contextualizar adecuadamente como le sucede al General Manuel González en

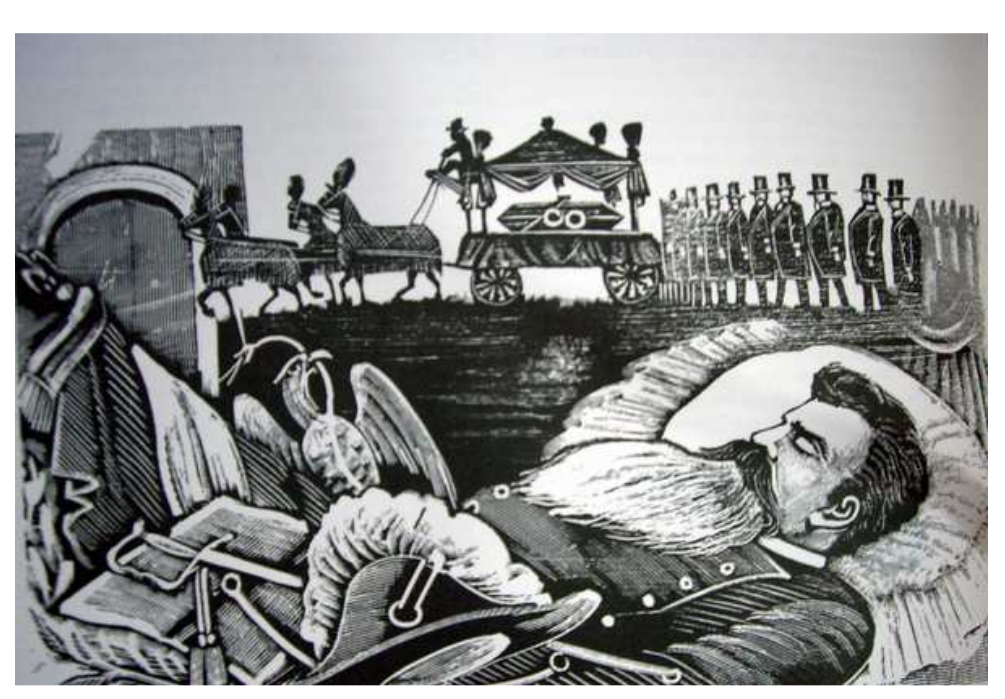

Fig. 42. Llegada del cadáver del General Manuel González, 1893. Grabado de Posada. la imagen $42 . \quad \mathrm{La}$ imagen de la calavera 0 de la muerte se presenta en cientos de grabados que incluyen pequeñas viñetas como la figura 43.

Retrato de una época y reflejo visual de las capas sociales del momento, los grabados de Posada a través de la imagen y el texto de las hojas impresas conforman un juego interesante entre ambos lenguajes, (fig. 43) mismos que Posada supo utilizar de manera certera y contundente, lo que le permitió mostrar ese eterno presente de los sucesos cotidianos que ocurren en toda comunidad -basta observar las páginas de la prensa actual-, donde se

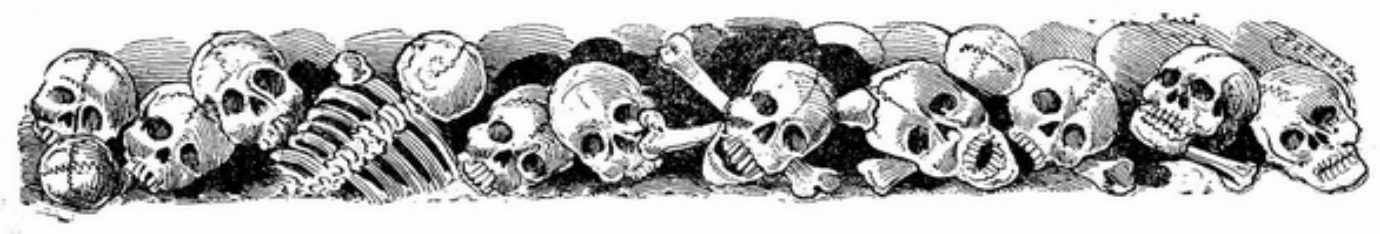

Fig. 43. José Guadalupe Posada. Viñetas de calaveras 
representaban (aún hoy), la forma más segura y más rápida de consumo popular de noticias en la segunda mitad del XIX y primera del XX.

Espectadores, lectores y participantes activos e ilustres de toda una época, el editor Vanegas Arroyo y el grabador José Guadalupe Posada obtuvieron su propia dimensión artística. Posada murió en 1913 y fue sepultado en un sitio

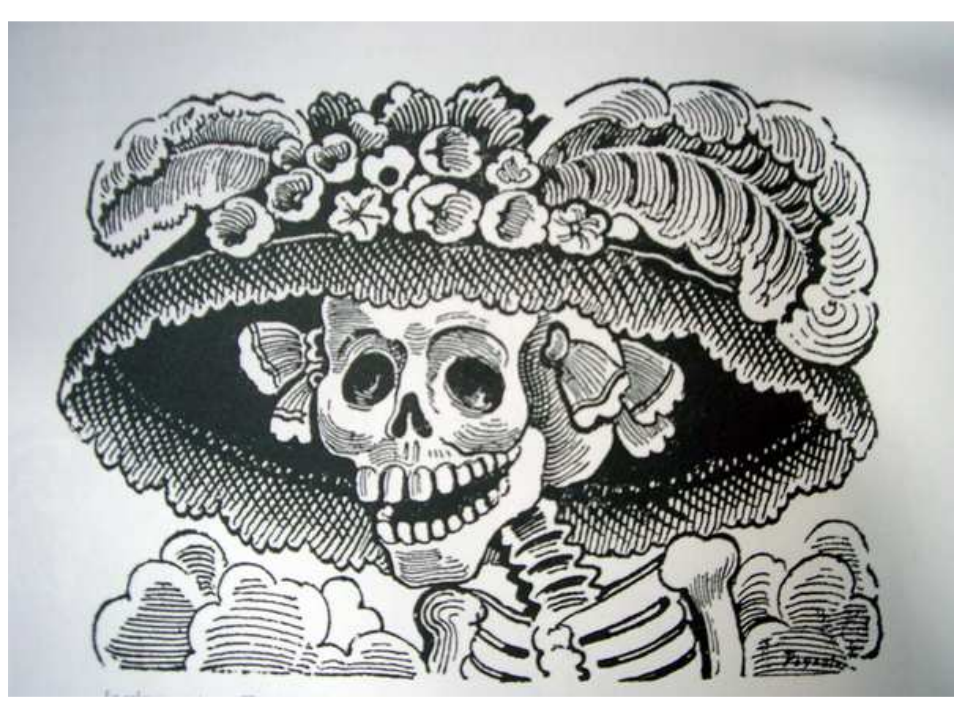
de 6 a $^{\text {clase en el }}$ Panteón Civil de Dolores, lugar donde a los pocos

Fig. 44 "Calavera Catrina" Por Posada años fue sacado para ser puesto en la fosa común y regresar por última vez al lugar a donde siempre perteneció: Al pueblo que lo recuerda como el creador de la "Calavera Catrina."73 (fig. 44) La obra de Posada es inmensa y para efectos de este

73 La presencia y el nombre de Posada han perdurado afortunadamente para las generaciones de jóvenes estudiosos del grabado que se han identificado con la callada y humilde manera de un artista con hondo sentido popular. En tiempos recientes tanto el gobierno de Aguascalientes como el Instituto Nacional de Bellas Artes (INBA) han utilizado el nombre de Posada para usarlo como impulso en concursos y eventos gráficos o culturales. Así, el concurso de grabado que lleva el nombre del artista ha incrementado el número de personas que se han interesado ahora por los aspectos gráficos que en otro tiempo pasaron desapercibidos ante el gran peso de la obra de los muralistas y de la llamada "Escuela Mexicana de Pintura", que no es otra cosa que la obra de caballete de aquellos que no practicaron o no pudieron hacer pintura monumental. Sin embargo en noviembre de 1977 se llevó a cabo en la Academia de San Carlos una exposición con el título "Homenaje a Posada". Organizada por el escultor Sebastián para celebrar los 196 años de la fundación de la Academia, y al mismo tiempo los 125 años de su nacimiento, la obra consistió en la exposición de carteles dedicados a José Guadalupe Posada con artistas con las más diversas tendencias estilísticas que diseñaron en un formato muy simple su apreciación de lo que les representaba el nombre y la producción de este celebrado y singular artista. Aún cuando no se sabe si Posada se relacionó con la Academia, teniéndola a unos cuantos pasos de su taller, la Academia no quiso pasar desapercibida al rendir un homenaje a un retratista de una época maltratada por los vaivenes sociales y políticos del siglo XIX. Raquel Tibol, Homenaje a Posada en San Carlos, revista Proceso 0054-47, 14 de noviembre de 1977. 
trabajo trataremos sólo tres ejemplos que pueden ilustrar la idea del la maldad $y$ de la muerte en tres personajes que fueron reales y cuyos casos fueron ampliamente tratados por la prensa de entonces y que los impresos populares abordaron exitosamente destinados al consumo popular como lo fueron El "Tigre de Santa Julia", El caso de María Villa (a) La Chquita" y el "Chalequero".

\section{6 "El Tigre de Santa Julia"}

Jesús Negrete (a) "El tigre de Santa Julia" fue tal vez, el criminal más respetado y temido por la prensa y la sociedad a principios del siglo XX. Prototipo del asaltante de actos sanguinarios, Jesús Negrete era sin duda el enemigo público más conocido entonces. Su trayectoria al parecer siempre estuvo sumida en acciones violentas con la gente que le rodeaba. De tez morena, rasgos toscos en los que apenas se aprecia un ralo bigote, cráneo pequeño con asomos de calva, Negrete era un tipo común del altiplano central, aunque la prensa porfirista, lo definíó por su aspecto que era "feo y repugnante"74 fig. 45)

Originario de Cuenámaro Guanajuato, desde joven ingreso al ejército con la intención al igual que muchos, de percibir un salario fijo; sin embargo, fue expulsado debido a su participación como sargento de artillería en un robo de armas en el pueblo de Tacubaya. En 1900 se apoderó de instrumentos de labranza, y más adelante robó y asesinó a dos arrieros para quitarles una carga de carbón. A principios de 1904 mató a sangre fría a un gendarme que lo había detenido en la calle por escandaloso. En esa ocasión su amante Ramona Cabrera, le había pedido al gendarme que le permitiera ofrecerle siquiera un sarape para cubrirse el frío y en el que iba

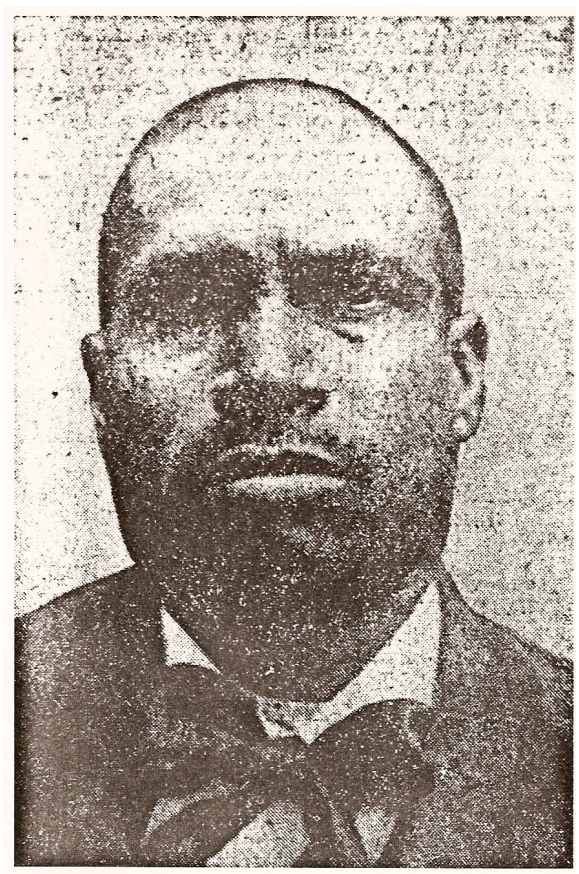

Fig. 45 Jesús Negrete "El Tigre de Santa Julia"

74 "El Imparcial." Citado por Alberto del Castillo, p. 41 
escondido una pistola con la que mató al oficial de un balazo en la cabeza. Otro crimen comentado por la prensa fue el robo cometido por Negrete y sus secuaces de tres sillas vaqueras, unas vaquetas y una báscula, cerca del Molino de Valdés.

El apodo de "El Tigre" fue puesto por el mismo jefe de la policía que de alguna manera contribuyó a su leyenda. El pueblo de Santa Julia, (colonia perdida ahora entre el metro Tacuba y Cuitláhuac) a su vez, era conocido por ser una zona marginal con pobladores de la más baja calidad humana situada en las afueras de la ciudad.

Nuestro personaje ya había sido conducido a la Penitenciaría de Belén, de donde hábilmente había huido junto con otro cómplice apodado "El Marquesito". Se sabía que Negrete era un jugador empedernido y que pocos días antes de su captura había estado en el pueblo de Jamaica apostando en las peleas de gallos donde pernoctaba al lado de sus diferentes amantes. Asimismo "El Tigre" sostenía amoríos con Inés Arredondo, y con Guadalupe Guerrero que vivía en el pueblo de Tacubaya de quien se encontraba enamorado, de tal manera que el prefecto de seguridad Francisco Chávez al saberlo pudo tenderle una trampa permitiéndole penetrar "en la misma intimidad de ese idilio salvaje, provocándole celos a la fiera, que de esta manera, desconfiada, olvidó sus medidas de seguridad y se quedó más de 24 horas en casa de su amada." 75

Así que con esta estrategia, 12 agentes entraron al jacal de Guadalupe y sorprendieron a "El Tigre" en el momento que había salido en la parte posterior para defecar a cielo abierto a la sombra de una nopalera, de tal manera que el asaltante al verse rodeado de pistolas y 4 carabinas que le apuntaban al pecho, no le quedó más remedio que rendirse ante la fuerza de las circunstancias del momento que era descargar el cuerpo. Es probable que para que no se le restaran méritos a los agentes que lo capturaron, no se registraron las condiciones de la aprehensión de Negrete y sólo fue conocido el dato de que se encontraba "detrás de un nopal".

El caso quedó en la memoria popular que recogió el hecho haciendo suya la frase cuando un sujeto es sorprendido en situación comprometedora

${ }^{75}$ Ibid. p. 42 
que "...lo encontraron como "El Tigre de Santa Julia", (aunque no sea defecando).

Ahora bien, no solamente su vida fue diferente, sino también su captura; y para variar, su juicio estuvo plagado de hechos curiosos que obviamente la prensa se ocupó de reseñar prometiendo un jurado "sensacional".

Negrete hábilmente comenzó entonces a transformarse para parecer un ciudadano acusado injustamente. La prensa recogió el "cambio de fisonomía" de "El Tigre" ya para entonces rapado de cabeza y afeitado para presentarse ante el jurado "dignamente" a las audiencias. ${ }^{76}$

Afuera de la Cárcel General, adonde fue trasladado el acusado estaba cubierto de 150 gendarmes que cuidaban la seguridad del recinto. "El Tigre" ingresó flanqueado por dos soldados vestido con un "flamante traje de charro: pantalón ayescado, chaleco y chaqueta con alamares negros, camisa blanca y de cuellos volteados y corbata roja, zapatos bayos de costura y punta de aguja". ${ }^{77}$ Un reportero escribió el concepto que se tenía del maleante:

Para darnos cuenta de la fisonomía moral de Negrete debemos llegar a la época de los trogloditas, de los seres de las cavernas y pensando con Jacker y con Darwin, convenir en que Negrete es un antropomorfo. Ved sus mandíbulas salientes, su nariz aplastada, las fosas nasales hinchadas, los belfos gruesos y la actitud que guarda cuando es interrogado, en el que pone todas las contorsiones del cuadrúmeno, ¡parece que está descoyuntado! Cuando está constreñido por la pregunta que se le hace y contestar no puede, se arquea hacia atrás, cierra los párpados, recapacita, resuella con fuerza y cuando la ola de sangre ennegrece su rostro enfurecido, contesta que no recuerda." 78

El proceso se llevó a cabo con las declaraciones de diversos testigos, y entre ellas la declaración amorosa de Inés Escogido en la que le pedía a Negrete matrimonio, que él desde luego aceptó proponiéndose el abogado defensor de padrino entre vivas del público. Esta acción emotiva logró su cometido sólo en parte, porque el jurado popular sentenció al "El Tigre" a morir fusilado. En cambio, el bandido no se consideró merecedor de la pena de muerte y comentó “¿Cinco penas de muerte? ¿Por qué (...) Yo no las debo. ¡Y

\footnotetext{
${ }_{77}^{76}$ El Imparcial. "El jurado del tigre de Santa Julia", 24 de mayo 1908.

77 Alberto del Castillo, op. cit., p 45.

${ }^{78}$ El Imparcial 13 de junio de 1908. Citado por Elisa Speckman Guerra, op., cit., p 180.
} 
luego...cinco penas de muerte...! Ni que fuera gato! ¿Pues con que pago? Sólo ellos tienen siete vidas".

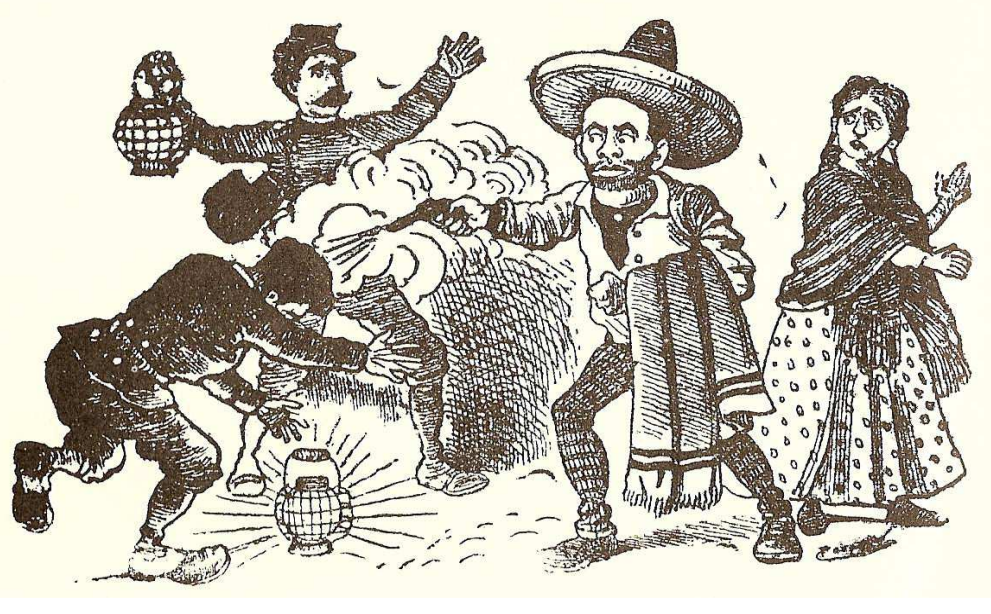

Fig. 46 Corrido de El Tigre de Santa Julia. Grabado
El caso de interés público por supuesto fue llevado a medios gráficos y Vanegas Arroyo aprovecho la ocasión para realizar una pequeña serie donde se refería a las hazañas de Jesús Negrete y poder comercializar la captura, el juicio y el

fusilamiento. Uno de ellos muestra al bandolero con su sombrero de charro disparando sobre dos sorprendidos gendarmes que cargan unas lámparas. El "Tigre" sostiene en su brazo izquierdo un sarape y a su lado se encuentra la mujer que se lo proporcionó. (fig. 46) Una fotografía de la época muestra a Negrete que se encuentra de pie y de tres cuartos de perfil ataviado con un sombrero ranchero de los que utilizaban la gente rica. Asimismo usa una chaquetilla fina en la que se deja ver sobre su pecho una elegante corbata de moño. Sus pantalones son ajustados como correspondía a los que sabían de caballos tal y como los usaban los "rurales", es decir, la policía porfirista muy temida en su época. (fig. 47)

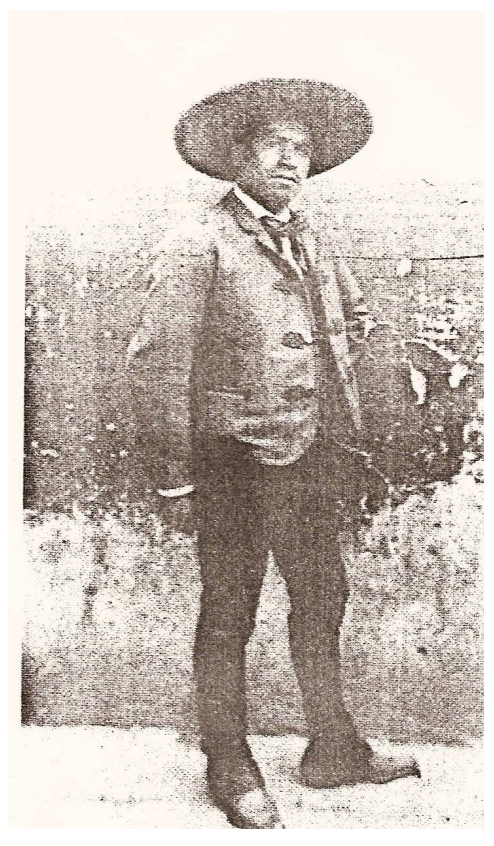

Fig. 47 Jesús Negrete. Fotografía 
El fondo de la fotografía ha sido el de una pared descascarada lo que conlleva a pensar que quizá ha sido tomada al aire libre, es decir de improviso. Por su parte, la zincografía de Posada (fig. 27) reproduce la actitud retadora del criminal e incluye un corrido titulado Jesús Negrete (a) El Tigre de Santa Julia y pertenece a "El Cancionero Popular" y que entre sus partes dice: ${ }^{79}$

\section{Escuchen todos atentos \\ Los crímenes principales \\ Que llevarán al cadalso \\ Al "Tigre" por sus maldades \\ Comenzaron sus hazañas \\ En mil novecientos tres \\ Que a dos arrieros la vida \\ Les quitó con furia cruel}

\section{Después y muy poco tiempo A un gendarme por ser fiel, Le saltó muy buen balazo Con bastante avilantez.}
Al siguiente año otra muerte En Tacubaya fue a hacer; Con traición y alevosía A otro hombre quitóle el ser
Y otro asesinato horrible Cometió junto a un maguey
Allí ocultó dio un balazo A un pobre que robo él
Después mató a otro gendarme Con dos balazos muy bien Pero no podía cogerlo Negrete muy listo fue.
Y por último el más grande De sus delitos por ley Aconteció en Santa Julia Una mañana a las seis.
El "tigre de Santa Julia" Lo pusieron aquí bien, Fue el caso en una cantina Con ferocidad muy cruel.

79 El crecimiento del narcotráfico en tiempos recientes en el mundo entero, y en especial en México, ha creado al igual que hace 100 años en los tiempos de Posada, una imagen falsa de la criminalidad, aspecto que muchas veces es idealizado por el pueblo mediante canciones y "corridos" lo que se ha dado en llamar el "narco- corrido". De encargo o de forma anónima este canto se hermana con el impreso en el aspecto comercial. 
La historia no termina con su muerte de Negrete. El criminólogo Alfonso Quiroz Cuarón célebre por haber resuelto casos de verdad horripilantes en la sociedad mexicana -entre ellos el caso del homicidio de León Trotsky- tuvo entre sus

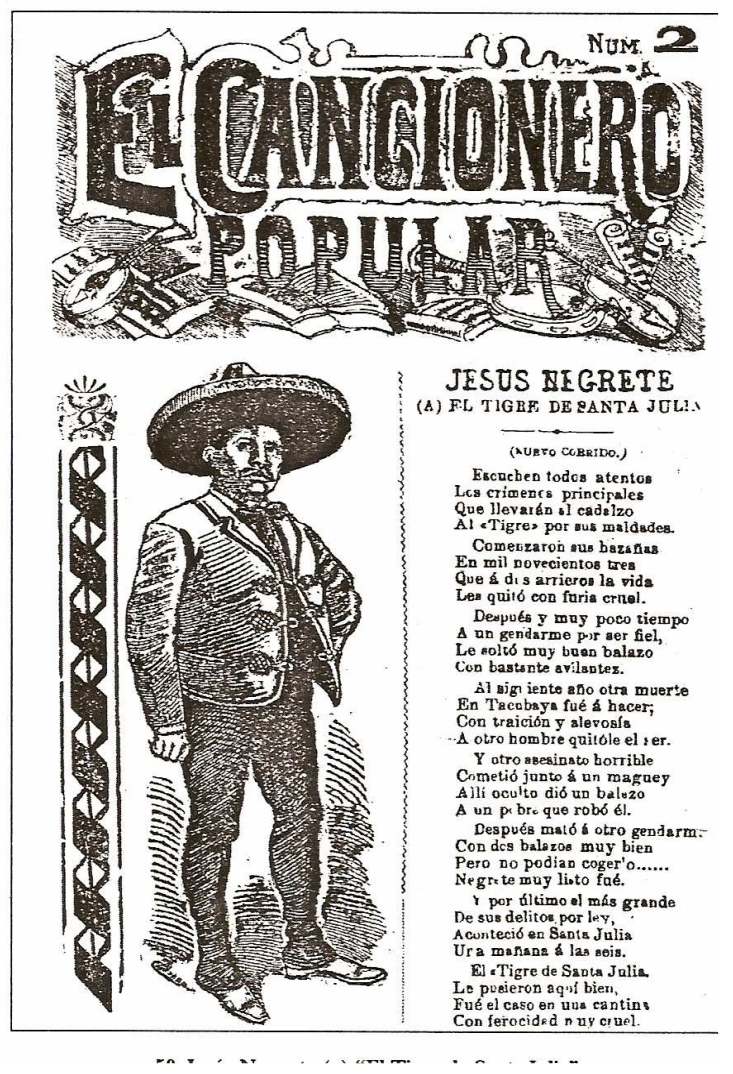

Fig. 48 Corrido de Jesús Negrete. Grabado de Posada pertenencias el cráneo de Jesús Negrete que adornó su escritorio durante varios años. La historia de cómo llegó a sus manos en forma breve es así:

El 28 de marzo de 1931, los restos de Jesús Negrete fueron exhumados [...]quedándose con el cráneo de El Tigre de Santa Julia, que al poco tiempo después obsequiaron al abogado José Ángel Ceniceros, por esos días afamado penalista y con los años secretario de Educación Pública durante el gobierno de Adolfo Ruiz Cortínez. El susodicho cráneo, guardado en una caja sombrerera, estuvo un par de años en poder de Ceniceros; sin embargo, un buen día, durante una comida, le preguntó al doctor Alfonso Quiróz Cuarón si no le interesaría conservar la pieza..."

¿Qué motivo tuvo Quiróz para tener el cráneo del que fuera el criminal más buscado del Porfirismo? Tal vez, la sensación de saberse dueño de alguien importante dentro de su profesión que había hecho historia a base de hechos delictivos y que mereció pasar a la historia ilustradas sus hazañas por el grabador Posada. (fig. 48)

Finalmente quisiera comentar el aporte al folklore nacional de la figura del que en vida llevó el nombre de Jesús Negrete, mas conocido por "El Tigre de Santa Julia", hasta la fecha sigue siendo una parte del pasado presente en este tercer milenio. Su destino quedó unido a una época en el que la gente lo recuerda de manera diferente y en que su muerte lejos de ser la de un delincuente

80 José Ramón Garmabella, El Criminólogo, los casos más impactantes del Dr. Quiróz Cuarón, Random House, México 2007, pp. 155-157 
sanguinario fue objeto de misericordia social en el que la muerte misma de El

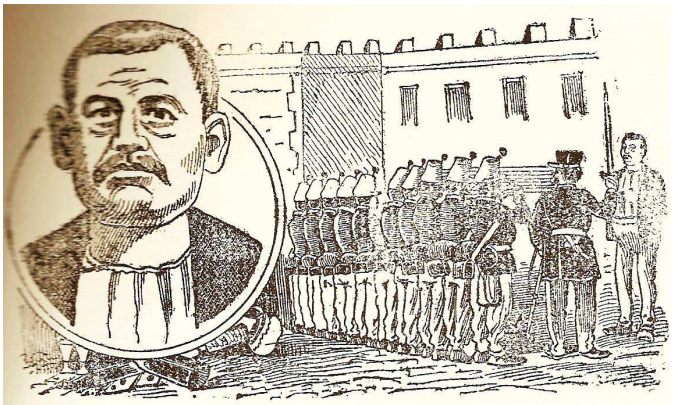

Fig. 49 La muerte de Jesús Negrete Por Posada
Tigre fue grabada como testimonio histórico por Posada. (fig. 49) Para concluir quisiera mencionar que el libro de Armando Jiménez, "Picardía Mexicana" ${ }^{81}$ rescata el lenguaje oral y visual como patrimonio de los mexicanos y da una nueva dimensión al personaje a través de la historia falseada.

La imagen de "El Tigre" es considerada no como un delincuente sino como un bandolero que quita al rico para dárselo al pobre; lo cual lo hermana a la altura de "Chucho el roto" 82 o del bandido chileno Joaquín Murieta. Con este motivo el grabador Alberto Beltrán dibujó la escena con la cual "El Tigre"

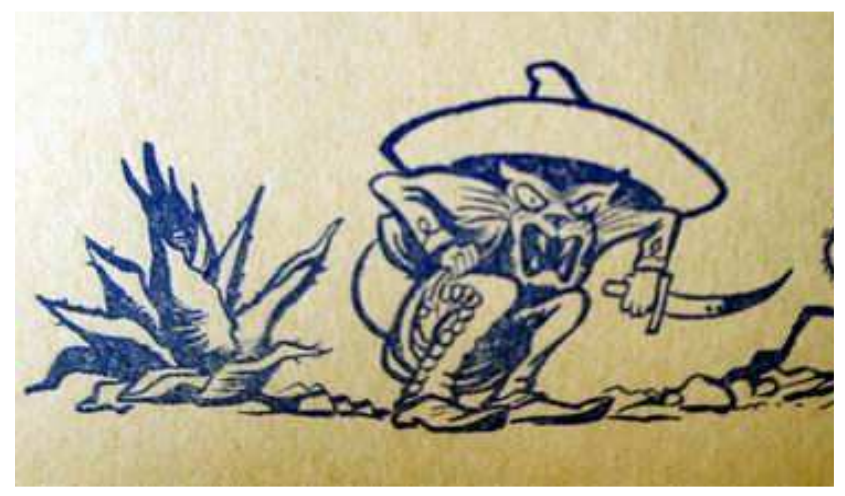

Fig. 50 "El tigre de Santa Julia" por Alberto Beltrán pasaría burlonamente a la

historia: Un ser zoomorfo que en cuclillas y con los pantalones charros defeca en una nopalera llevando en la mano un cuchillo ensangrentado desafiantemente ridículo para un momento tan inoportuno. (fig. 50)

\footnotetext{
${ }^{81}$ Armando Jiménez, Picardía Mexicana, B. Acosta-Amic, México, 1968.

82 Jesús Arriaga, "Chucho el roto", personaje mítico en la población mexicana existió realmente y murió encerrado en las mazmorras de San Juan de Ulúa en el puerto de Veracruz. Su historia llena de injusticias sociales le obligó a organizar una banda que quitaba al rico y se lo regresaba al pobre. Amo de los disfraces, Chucho cometió muchas acciones que le valieron el asombro y el temor de la sociedad del siglo XIX. La radio de los años 60's realizó una serie de largos años de duración con el actor de televisión Manuel López Ochoa en el papel protagónico de un éxito comercial sin precedentes en el que el radioescucha -con historias inventadas por supuesto- terminaba por identificarse con el malhechor que se burlaba del gobierno y nunca era atrapado.
} 


\section{7 Feminicidios en los impresos de Posada}

Como oposición de lo positivo, de los valores y la decencia de la época, los conceptos de lo perverso y lo negativo pueden estudiarse en la producción de la imprenta de Vanegas Arroyo y con esto la educación, la religión, la sexualidad, la moral, y la conducta. Aunque no es el asunto de llegar a un análisis de las hojas impresas, en general existen rasgos de moralidad en contraposición de la seducción, tentación, pecado, castigo y muerte en cualquiera de sus manifestaciones que se imponía a los habitantes iletrados en su mayoría de la gran ciudad, y donde en un mundo dominado por los hombres, lo femenino era una gran tentación que

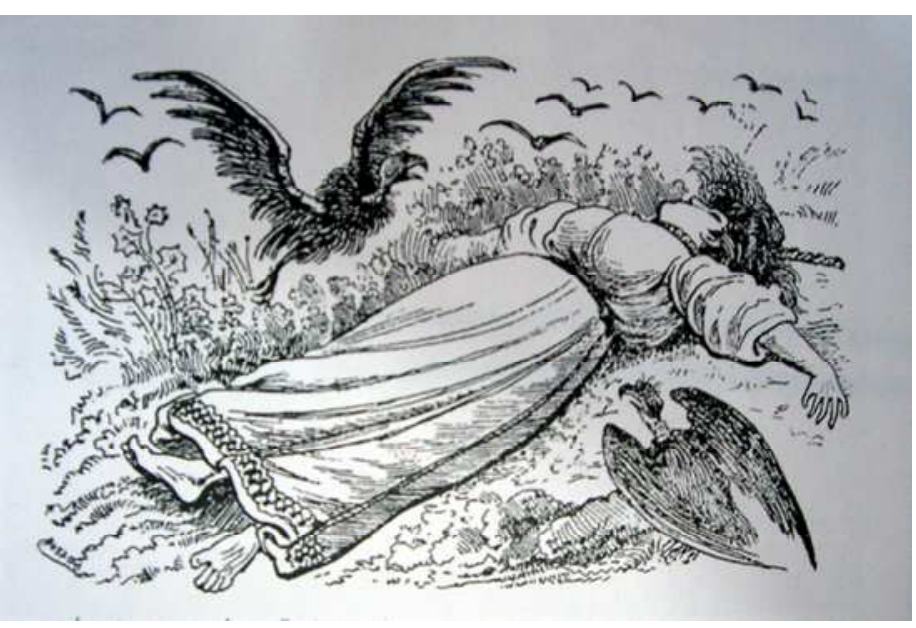

Fig. 51 Crímenes Pasionales por Posada en ocasiones se pagaba con la muerte. (fig. 51)

La muerte -dice Gabriela Nava en su estudio sobre los feminicidios en los corridos mexicanos- es un bien instranferible ganado para bien o para mal en vida pero nunca signado de manera fortuita, sino que responde a una relación de causa/efecto que se manifiesta en la muerte violenta y en forma específica en los crímenes. ${ }^{83}$

La muerte por lo menos en el discurso de la poesía y la canción popular mexicana no es igual para los dos sexos: En el hombre puede responder a salidas heroicas como la defensa de la honra familiar, o la muerte por alguna acción patriótica que puede hacer del personaje un héroe o en figura simbólica

\footnotetext{
${ }^{83}$ Gabriela Nava, "Pongan cuidado, muchachas, miren cómo van viviendo". Los feminicidios en los corridos mexicanos, ecos de una violencia censora, Revista de Literaturas Populares, FF y L. pp 124- 139.
} 


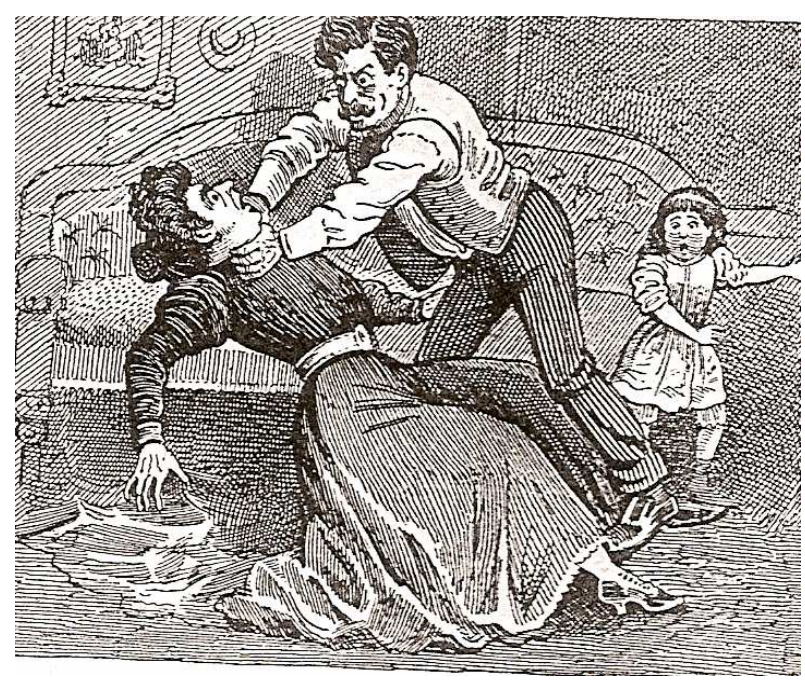

Fig. 52 "Tragedia Conyugal" Grabado de Posada a seguir que se justifica y se admira. En la mujer, la acción de la defensa del honor y la honra puede ser porque ella dio motivos de peso para ser agredida y sacrificada por el hermano, el novio, o el esposo lo cual justifica el castigo de privarla de la vida. Es decir que las mujeres no mueren en circunstancias heroicas, sino más bien trágicas. (fig. 52)

De esta manera, podríamos hablar de dos niveles de muerte en los que la violencia es justificada a nivel popular porque define los roles en la sociedad y responde a la solución de la conciencia colectiva ante la conducta de las mujeres que se manifiesta en el corrido mexicano porque:

su objeto es mostrar el conflicto en circunstancias de la moral, la ética y la justicia del grupo. El hecho violento es registrado en todos sus detalles. Los protagonistas [del corrido] son ejemplares, la representación misma de los valores colectivos. El corrido no hace apología de la violencia; al desnudarla la previene cuando es dañina, pero la justicia cuando la considera útil; en este sentido cumple con la función indispensable y capital de regulador ideológico de la violencia. El trovador asume plenamente el papel de censor social: salvaguarda y protege los valores colectivos. ${ }^{84}$

Desgraciadamente la mujer fue heredera de una mentalidad emergida de la Edad Media a partir del hecho de que Eva ofreciera el fruto de la tentación a Adán desde el siglo IV estableciéndose el círculo de mujer, carne, y pecado, donde la mujer fue vista como un ser débil por definición y por lo tanto mucho más sensible que el hombre a cometer cualquier pecado.

${ }^{84}$ Miguel Ángel Gutiérrez, “Corrido y violencia”, citado por Gabriela Nava en op. cit. p. 126-127. 
El concepto del mal y el demonio en la persona de la mujer tiene orígenes remotos, para Berta Gilabert fue "...percibida como seductora y tentadora, incluso en el siglo XI, Marbode de Rennes la llama "hechicera, serpiente, peste, polilla, prurito, veneno, llama, embriaguez, [...] la peor de las trampas que haya tendido el Enemigo, raíz del mal, rebrote de todos los vicios",. ${ }^{85}$ Una xilografía proveniente de Las serpientes y otros animales ponzoñosos del "Libro de las reglas de la salud" de 1475, la mujer adquiría en su imagen formas monstruosas con alas y cuerpo de serpiente, como se ve en la figura 53 .

Para comprender la relación de causa/ efecto hay que dejar establecido que en la mentalidad de la sociedad en la segunda mitad del siglo XIX y principios del XX, la

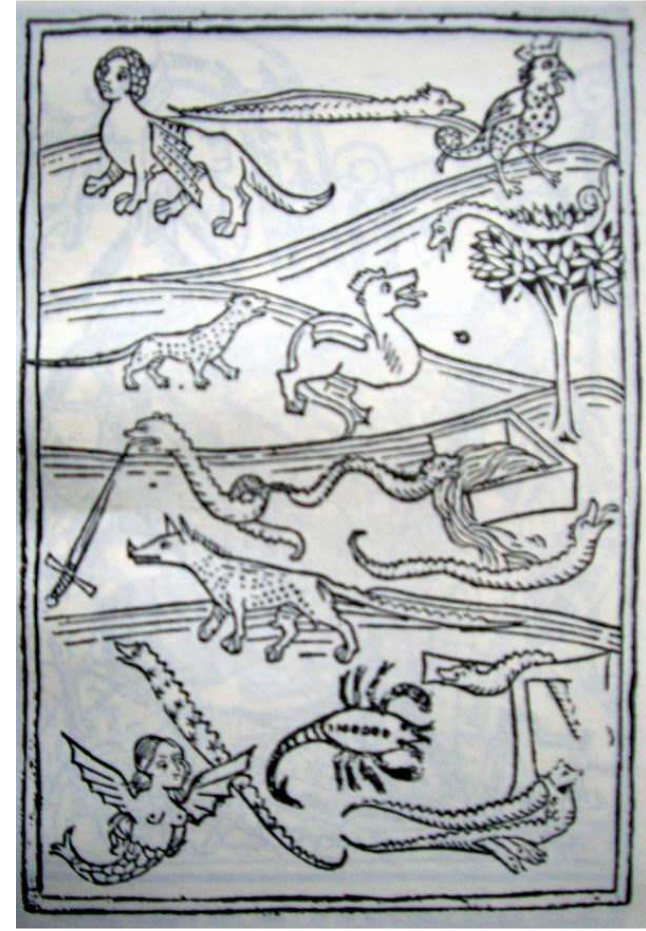

Fig. 53 De las serpientes y otros animales ponzoñosos. Xilografía del siglo XV mujer debía de contar con muchas virtudes y ningún defecto entre las que se contaba. "...la belleza, pero también virtudes como el recato, la discreción, la modestia, la moderación y sus dotes como futura esposa- madre". ${ }^{86} \mathrm{En}$ el "Manual para las mujeres" Verdollin mencionaba que "el decoro ha establecido para las mujeres unas leyes más severas que para los hombres; si éstos disfrutaban de alguna exención de las reglas generales, para ellas no hay ninguna". ${ }^{87}$ Así entendido parece ser que el concepto de la mujer en el siglo X1X, mantenía una imagen demoníaca y destructiva que llevaba al amor, al placer y a la muerte y del cual los jóvenes eran más propensos a caer por su inexperiencia. ${ }^{88}$ Un redactor de la imprenta de Vanegas Arroyo dejó un texto en un impreso con esta idea:

\footnotetext{
85 BSR/ Berta Gilabert, La idea del mal y el demonio...., p. 43.

${ }^{86}$ Speckman, De amor y desamor... p. 72

${ }^{87}$ Citado por Speckman, p. 77.

${ }^{88}$ Speckman, op., cit., 87.
} 
Estos casos tan continuos

todos los días se presentan

de jóvenes inexpertos

que a estas mujeres se entregan

Los homicidios fueron tema muy recurrente en la sociedad de Vanegas Arroyo y su equipo de trabajo, ya que rompían los cánones de comportamiento asignado al hombre y a la mujer. En "La mujer culebra" (fig. 54) el cuerpo adquiere las formas malignas que no es obviamente modelo de decencia y comportamiento. La mirada impasible

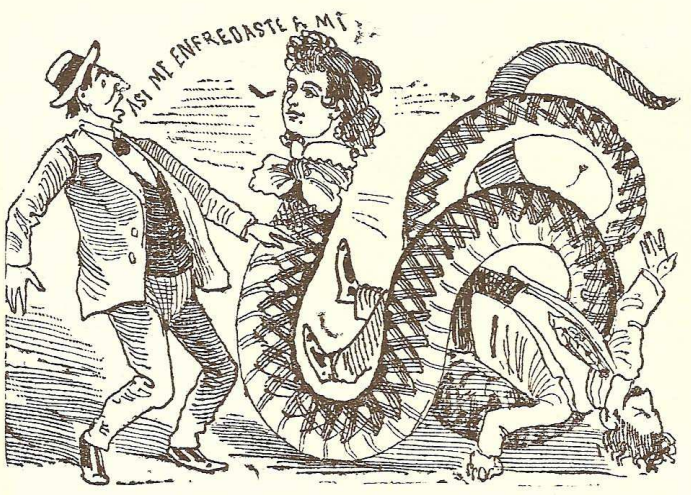

Fig. 54 "La mujer culebra" Grabado por Posada es directa hacia un "catrín" con sombrero que asustado se encuentra sorprendido con la seductora mujer. Otro personaje varón de largos bigotes ha sido ya estrangulado con la larga cola.

Así encontramos impresos en los cuales la prensa daba cuenta con precisión de los casos como "Esperanza Gutiérrez (a) "La Malagueña" asesinada después de un baile de máscaras por Maria Villa (a) "La Chiquita"; o el terrible caso que conmovió a la opinión pública de fines del siglo X1X de Guadalupe Martínez de Bejarano y de su hijo Aurelio Bejarano, por homicidio de la niña Crescencia Pineda que mereció varios impresos de la mano de Posada, tales como hojas sueltas y corridos ex profeso llamándolos "Las Bejaranos", y a ella "La Mujer Verdugo".

Como el motivo de nuestro tema es la muerte y como es abordado por los artistas, es necesario contextualizar de forma histórica el origen de dichas imágenes. Con fines ilustrativos para este tema, nos detendremos sólo en el primero de los casos: 
En México, al igual que en otros países la sexualidad comercial tuvo como modelo patrones franceses que tienen que ver indudablemente con los

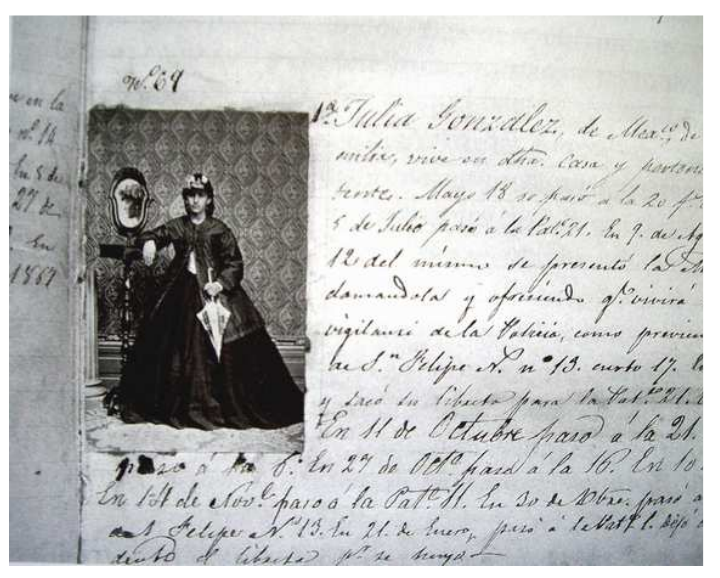

Fig. 55 Julia González. Prostituta De un control sanitario de 1865. Fotografía patrones de conducta y las normas sociales nacionales donde la prostitución integra a las mujeres de clase baja destinadas a satisfacer las necesidades físicas de la clase alta. Corbin menciona como "...las políticas que controlan a las prostitutas no son inmutables, no escapan de la historia; acompañan a la evolución de las costumbres. "89

En nuestro país, la prostitución trató de

ser numerosas veces de ser controlada pero fue hasta 1865 cuando pudieron ser registradas mediante las imágenes fotográficas en el Reglamento expedido por el Emperador Maximiliano como se muestra en la figura 55 con su respectiva ficha.

Juana Osorio, natural de Miahuatlán y vecina de esta ciudad, de 1.48 de estatura, de catorce años de edad, soltera, de color blanco, ojos negros, pelo negro, nariz redonda, boca grande, señas particulares ninguna. El 2 de mayo de 1892 se le extendió la patente relativa..." 90

En estas circunstancias el caso de María Villa alias "La Chiquita" retrata a las adolescentes que a manera de consuelo y de pocas posibilidades de supervivencia en la vida social de la mujer de la segunda mitad del siglo XIX y de inicios del siglo XX. (fig. 56) De procedencia provinciana, "La Chiquita llegó a México en 1890 a un burdel de la calle de Estampa de Jesús muy

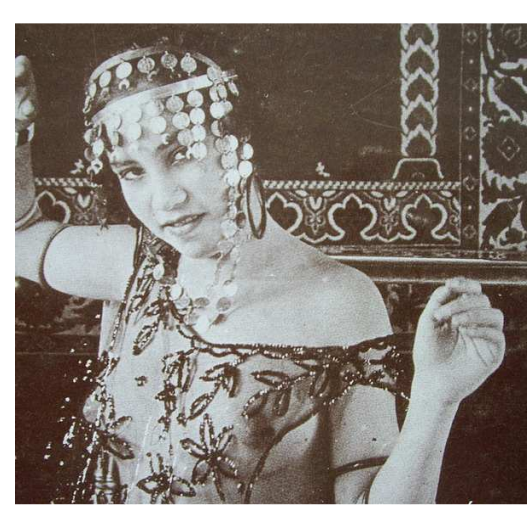

Fig. 56 Prostituta en casa de citas. ca. Principios del siglo XX. Fotografía

\footnotetext{
${ }^{89}$ Alain Corbin, Sexualidad comercial en Francia durante el siglo XIX: un sistema de imágenes y regulaciones, en "Historias 18", Revista de la Dirección de Estudios Históricos del Instituto Nacional de Antropología e Historia, julio / septiembre de 1987, p. 20.

90 Oliver Debroise, Fuga mexicana...p. 77
} 
cerca del zócalo del ahora Centro Histórico. Hasta donde se sabe, María fue una pupila de primera en la "casa de citas" o bien como dice Carlos Monsivais del comercio carnal domiciliado:

En el porfiriato, muy especialmente, la casa de citas es uno de los santuarios profanos de la "buena sociedad" (del poder, el dinero, el prestigio) en sus horas de sinceridad alcohólica, de lujuria que ahoga o impide los estallidos de concupiscencia en la alcoba tradicional, de teatralización de la hombría, de disolución de la serenidad, de rienda suelta a lo Indecible y lo Inconveniente..$^{11}$

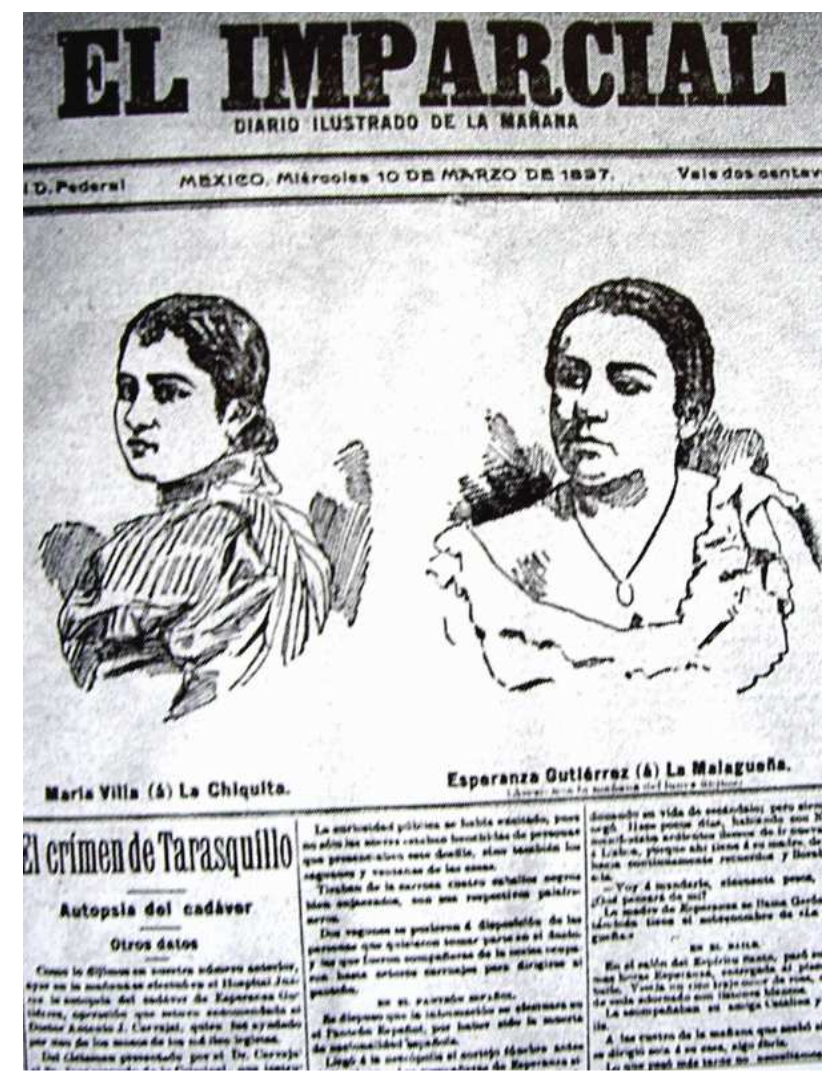

Fig. 57 Encabezado de "El Imparcial"

A raíz del crimen que cometió, su historia fue conocida ampliamente en los medios impresos de la siguiente manera: (fig. 57) María tuvo la suerte de casarse cuando un alemán prendado de su belleza se desposó con ella para regresar al poco nuevamente al lupanar, sin saberse las causas. Lo que si sabemos es que fue vista con un nuevo amante y esto al parecer no fue del agrado del "alemán" quien disparó sobre ambos, hiriendo a "La Chiquita" en la pierna dejándole secuelas de por vida. Asimismo adquirió el vicio del alcohol, el cigarro y la morfina, ésta última con señas de la huellas en la piel.

Por su parte su futura enemiga, Esperanza Gutiérrez alias "La Malagueña" era de origen español y había llegado a México en 1895 a la casa de citas de Natalia Hidalgo a la Plazuela de Tarasquillo. La rivalidad entre

${ }_{91}$ Carlos Monsivais, La casa de citas en el barrio elegante Fotografías mexicanas de la Bella Época Ava Vargas Preámbulo para darle tiempo al lector de convertirse en voyeur, en revista Mar de Tinta, número 1, CONACULTA, Verano de 1992, pp. 68- 71. 
ambas surgió lógicamente por un hombre que las hizo amantes casi al mismo tiempo desafiándose con mayor fuerza, hasta su desenlace fatal el 8 de marzo de 1897. Ese día, Salvador, -su amante- pasó por María al burdel aprovechando el día de asueto que la matrona concedía a sus pupilas para ir a visitar varios sitios entre ellos el pueblo de Tacubaya y después asistir a un baile de máscaras en el callejón del Espíritu Santo. ${ }^{92}$

Antes de despedirse de su amante, María, le pide a Salvador su pistola para guardársela; pero en el fondo, con firme intención de buscar a "La Malagueña" en su burdel y sorprender a los antiguos amantes y matarlos. Al llegar, el pretexto de saludar a su vieja amiga una criada le franquea la puerta y al creer que Salvador se esconde tras el pesado cortinaje, ciega de furia dispara contra su rival matándola en el acto. ${ }^{93}$ (fig. 58)

La tragedia tiene un proceso interesante: por un lado las consecuencias legales; y por otro las consecuencias intelectuales. En este último caso, Federico Gamboa escribirá su novela Santa, y Jesús F. Contreras realizara esculturas alrededor del tema. Por la entrada de su Diario, del 8 de marzo de 1897, se conoce que Gamboa paseaba con su amigo el escultor y pudo saludarla a su amiga "La Malagueña" antes de su

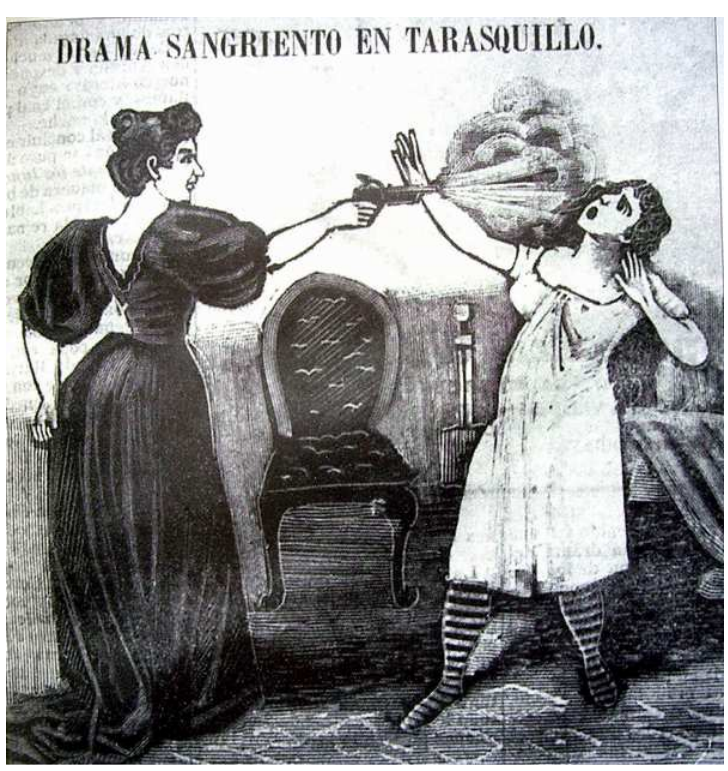

Fig. 58 "Drama sangriento en Tarasquillo" Grabado de Posada muerte.

\footnotetext{
${ }_{92}$ Rafael Sagrado, María Villa (a) La Chiquita, no. 4002, ediciones Cal y Arena, México 1996.

${ }_{93}$ La historia de María Villa pudo saberse gracias al texto que escribió desde la cárcel. Y que, sin embargo demuestra que María no se arrepintió de su crimen, sino más bien al contrario. Sabía que quitaba de en medio a una rival de amores. Así lo escribe; "...cuanto me ha tranquilizado mi pobre espíritu con las palabras tan dulces que en su carta me dices, me jura no abandonarme jamás por ningún motivo, que me sostenga en mis declaraciones, y no cambié, no cambiaré jno! ¡no! Jamás, pues yo no quiero que el pize estos lugares, ya que yo tube la fatalidad y la desgracia de perderme; pero si mil años me ponen y tengo su amparo de el que me importa todo lo demás, que me importa sufrir por el, que al fin, SUFRIR ES VIVIR..." Como colofón es importante decir que su amante con el paso del tiempo la abandonó en prisión, olvidándola para siempre. María Villa, "Diario desde la cárcel, en Historias 18, Revista de la Dirección de Estudios Históricos del Instituto Nacional de Antropología e Historia, julio / septiembre de 1987, pp. 29- 33.
} 
...En el se lee; "ayuno de sueño por la trasnochada de ayer en el baile de máscaras, al que fui [se justifica] por esa empecatada costumbre de frecuentarlos" y "medio dormido" todavía se levantó a abrir su balcón, en cuyos cristales alguien golpeaba con insistencia. Era su amigo, el escultor Jesús Contreras, con quien había pasado buena parte de la noche, "que demudado me preguntaba si nada me había ocurrido y si se lo del crimen. ¿el crimen?... ¿Qué crimen? -le digo yo- [continúa Gamboa] tratando de averiguar en su mirada si habla en serio o en broma". Contreras descifra el enigma: Esperanza Gutiérrez, guapa moza del partido, nativa de Málaga, y con quien anoche conversamos en el sarao de disfraces y de paga [escribe Gamboa] fue muerta esta mañana por María Villa, de Guadalajara, y también pecadora e irredenta" ${ }^{94}$

La acción sucedida y su desarrollo al transcurrir de los días orilló a Gamboa a escribir la novela Santa como una copia de una realidad brutal que la vida le ofrecía; en donde él, -Gamboa- tenía el motivo y el desenlace de una tragedia viva que se presentaba en una sociedad de doble moral y que ya la sociedad porfirista trataba de condenar en la figura de María Villa. (fig. 59) Con una intención morbosa tal vez Contreras y

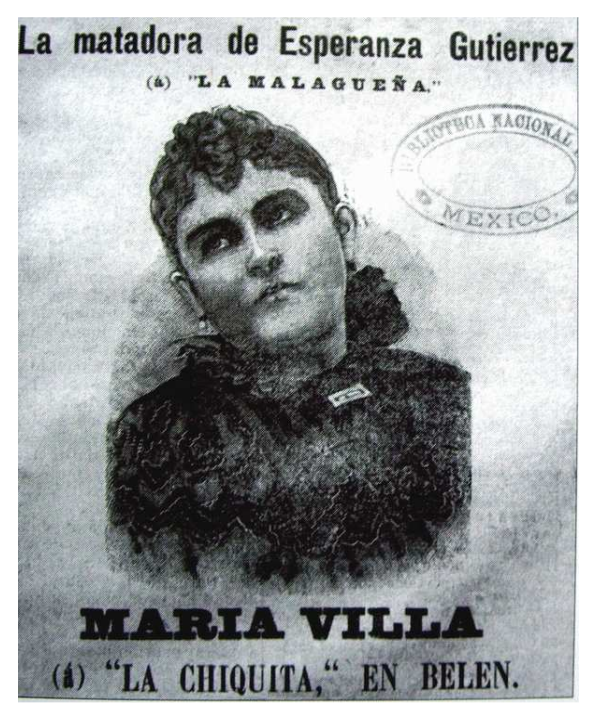

Fig. 59 María Villa "La Chiquita"

a ver a la asesinada y describe la escena macabra con lujo de detalle que aún hoy da motivo de reflexión:

Dos muertas veíanse en la sala de autopsias, o "depósito", según nos explico el muertero que nos escoltaba...; en la otra plancha, con forzada postura reposaba la Malagueña, en desnudez absoluta sin tentaciones, desnudez de cadáver, los pies exagües, tirando a marfil viejo, las carnes exuberantes manchadas de sangre; el rostro con horrible huella, abajo del ojo izquierdo, el rastro de un balazo que la quitó de penas; los labios entreabiertos, con el rictus de los que se van de veras, y que por lo mismo puede traducirse por sonrisa que por mueca, según lo que nos toque vislumbrar en las horas supremas.

94 Ibid., p. 130. 
Tan emocionado como yo, Jesús se puso a dibujar un croquis a lápiz de la muerta y mientras Jesús lo hacía, no parte de mis ojos de la Malagueña, mirando como las moscas, joh! Pero centenares de moscas tercas y medio borrachas de sol poniente, de olores sospechosos y de sangres antiguas y resecadas, paseábanse y revoloteaban por el cuerpo desnudo e indefenso; mirando sus carnes, ayer nomás complacientes y sedeñas, y hoy rígidas, en descomposición palpable. Atraíame [confiesa] fatídicamente, la cicatriz de su ojo herido, cicatriz diminuta sobre la que caían, revueltos los cabellos rubios de la soberbia cabellera deshecha y sucia:"95

De hecho, Santa, está dedicada a Jesús F. Contreras quien a modo de dios dador de vida puede modelar también las conciencias, “...con la esperanza de que, compadecido de mí, me palpes y registres hasta tropezar con una cosa que llevé adentro, muy adentro, y que calculo que sería el corazón...."96 Todavía Gamboa visitó al escultor a día de morir prematuramente:

Poco aguardo en la sala; no tardo en oir el rumor de pasos pesados que vienen a rastras por los parquets...y se me aparece Jesús... su antes hermoso cuerpo de hombre sano y fuerte trasmutado en una especie de guiñapo que a durísimas penas camina. En mis brazos llega a su sillón, en el que como trapo resbala y dóblase. Ni él ni yo despegamos los labios ¿para que?... Clávame sus ojos a punto de verter lágrimas, que al fin no salen gracias a sobrehumano esfuerzo, y los míos huyen de aquella mirada tristísimamente interrogante...-Ya ves en que estado me hallas -murmura luego. $Y$ yo persisto en callar, no acierto a contestarle palabra. Pasada la primera impresión...comenzamos a hablar; lugares comunes, para engañarnos, para alejar la pesadilla de su situación...Una delicadeza suya: -¿Cómo está SANTA?..Ahora verás, añade en seguida, si me olvidado de ella de que has dedicado...Y sale Carmen en busca de uno de los cuadernos del artista, en los que durante viajes y paseos iba apuntando con lápiz proyectos y bocetos, ideas y lineamientos de obras nonatas... para esculturas venideras... Mira a SANTA, -me dice, y no puede sostener el cuaderno -en la postura en que he de esculpirla, cuando al desnudarse en el cuarto sin luz, sus manos tropiezan con el escapulario... -Te gusta? son unos cuantos lapizazos...la novela impresa, no ha de verla Jesús." ${ }^{97}$

Considero que Contreras si pudo logró convertir esa experiencia en escultura en su obra cumbre llamada Malgre Tout (A pesar de todo). En ella, una mujer permanece sobre el piso con las manos en la espalda y con grilletes

\footnotetext{
${ }^{95}$ Ibid., p. 132.

${ }^{96}$ Federico Gamboa, Santa, Ediciones Leyenda, México, 2006.

97 Jesús F. Contreras (1866-1902), Escultor finisecular, Libro Catálogo, CONACULTA, INBA, MUNAL, mayo-julio, México, 1990.
} 
en los pies y su rostro refleja resignación. Tal vez sea sólo también un reflejo de la condición de la mujer en la sociedad porfiriana. (fig. 60)

Los asuntos de los crímenes pasionales en la prensa porfiriana

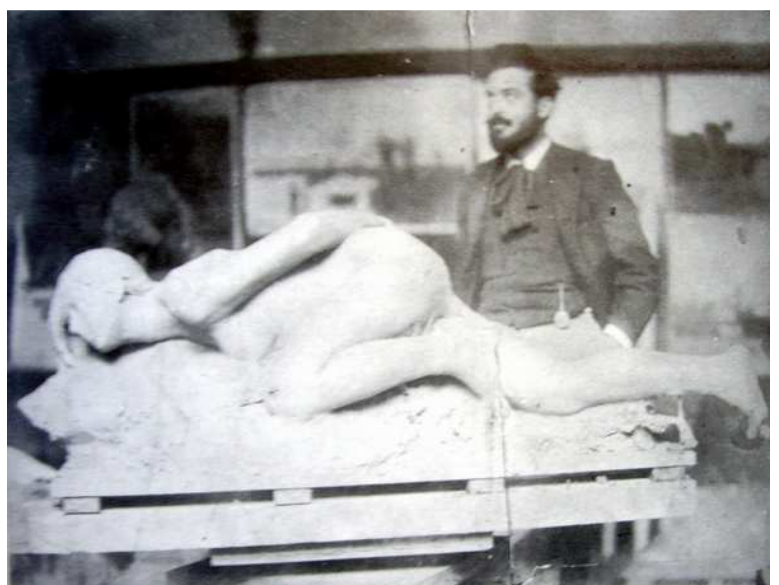

Fig. 60 Contreras con Malgre Tout Fotografía permitieron un público consumidor masivo en todas las clases sociales. La mujer adquiría de nacimiento, un nulo papel en la sociedad del momento. Su imagen quedaba limitada a ser únicamente hija, novia, esposa, y madre con todas las virtudes y además ningún defecto. Pero cuando en su relación intervenía un amigo cercano 0 amante, que desencadenaban los celos del familiar, del novio o del esposo, se podían generar reacciones de violencia y finalmente la muerte justificada de ella por coqueta. Para rematar su situación, la mujer no podía escalar posiciones socialmente ya que las miradas en público, los movimientos simples del abanico o la negación de un baile público eran consecuencia de problemas venideros $^{98}$. Los ejemplos orales e impresos en el folklore mexicano son abundantes.

De aquí se generan, -según Vicente T. Mendoza y autoridad en la materia- los llamados "corridos" sobre parricidios, maldiciones y fatalidades, que:

como tragedias pasionales forman núcleo aquellos casos típicos en que el amor es la verdadera causa de la tragedia, interviniendo, además, el orgullo varonil que no tolera humillaciones ni desprecios. En ellas aparecen casos de mujeres causantes del crimen por enredar en sus mallas a varios hombres. Este tipo de corrido es de los que gustan más al pueblo y en sus expresiones encierra rasgos característicos de la psicología del mexicano ${ }^{99}$

98 Elisa Speckman, De amor y desamor... op. cit., ha realizado un estudio sobre estos lenguajes ocultos en los cuadernillos de Antonio y Blas Vanegas Arroyo a fines del siglo XIX y principios del XX,

${ }_{99}$ Vicente T. Mendoza, El corrido mexicano, Fondo de Cultura Económica, Colección Popular, número 139, tercera reimpresión, México, 1976, pp. xxxviii-xxxix. 
Veamos sólo un caso ilustrativo alrededor de este tema. De la mayoría de los mexicanos es conocido el corrido de "Rosita Alvírez" que al asistir a un baile y negarse a bailar fue muerta a tiros por violar el recato social esperado:

\author{
Rosita no me desaires \\ La gente lo va a notar \\ -Pues que digan lo que quieran \\ Contigo no he de bailar- \\ Hecho mano a su cintura \\ y la pistola sacó \\ y a la pobre Rosita \\ No más tres tiros le dio. \\ Rosita le dice a Irene: \\ No te olvides de mi nombre, \\ Cuando vayas a los bailes \\ no desaires a los hombres.
}

De la misma manera, se retrata a la mujer inocente envuelta en escándalo al rechazar propuestas indecorosas como éste de Belén Galindo pero que sin embargo es castigada por desobedecer "a la malintencionada suegra":

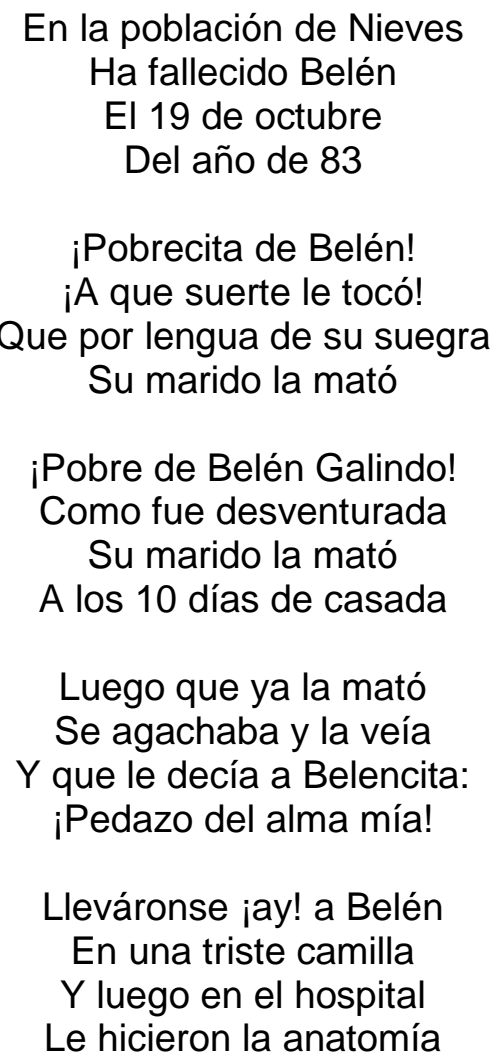


Su blanco pecho le abrieron

Para verle el corazón:

Destrozado lo tenía

¡Que Hipólito tan traidor!

Cuando Hipólito nació

¿Qué planeta reinaría?

Su madre estaría en pecado

O no lo bautizarían?

Y aquí señores, se acaba

Este trágico corrido:

Rueguen a Dios por el alma

De Belencita Galindo

Destaca el hecho de que en los textos populares el castigo al criminal en general no llega o no se hace mención del castigo aplicado al culpable lo cual permite considerar dos aspectos vertientes afines al momento: a) La consideración del castigo que le será impuesto al transgresor por medios divinos 0 celestiales y, b) que de acuerdo a las leyes de la legislación penal las penas cometidos contra mujeres era
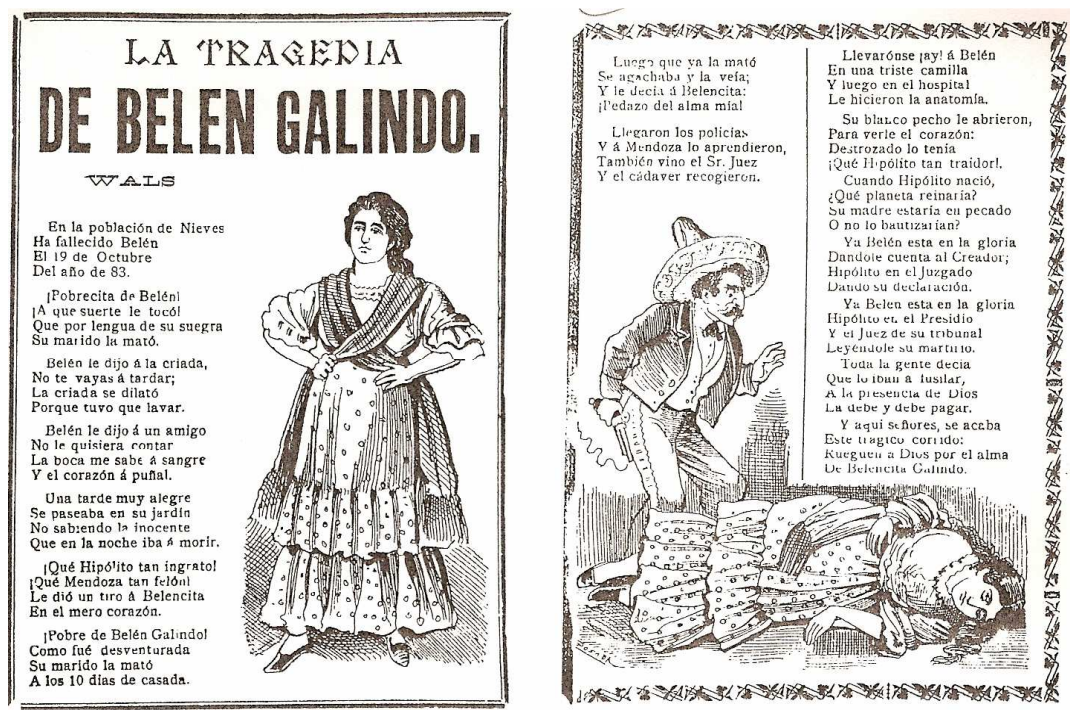
menor cuando la víctima era asesinada Fig. 61 La tragedia de Belén Galindo Grabado por Posada por un familiar o el cónyuge al defender el honor de la familia. Justificable o no, ahí como siempre Posada supo captar la esencia del momento social (fig. 61) 


\subsection{Los asesinos de mujeres}

Una contraparte masculina y criminal son aquellos conocidos en el lenguaje de la época como "los matadores de mujeres" y que sabemos ahora que son personajes asesinos de todas las clases sociales que siempre han existido en todas las épocas y en todas las partes ${ }^{100}$. Pero aquí presentados tienen las

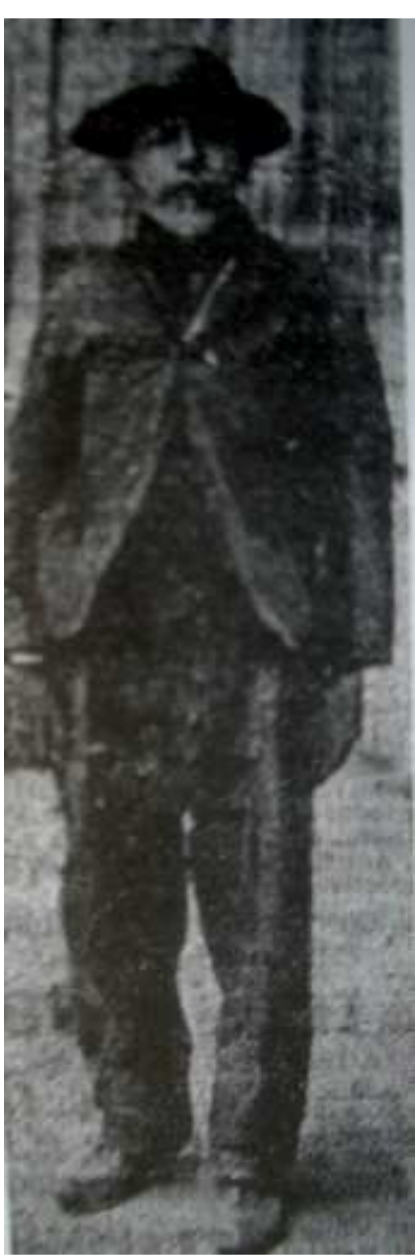

Fig. 62

Francisco Guerrero (a) "El Chalequero" características de asesinos en serie que azotaban a la asustada población. Volvemos a considerar que la manera de entender y justificar dichos crímenes en la prensa escrita es partir del concepto de la filosofía cristiana de finales del siglo XIX y principios del XX donde sigue siendo el Demonio el que tienta $y$ condena a los hombres. Eso solo significaba que "... muchos seres humanos tienen, a imitación del Demonio, de hombres necios que una vez y otra vez recurren al crimen, al delito, a la búsqueda del poder en contra de las autoridades establecidas". ${ }^{101}$ En este asunto Speckman ${ }^{102}$ ha profundizado en la nota roja y en la legislación penal de la época de Vanegas Arroyo. Un caso puede ser ilustrativo de estos momentos debidamente detallados y magnificados por la prensa del Porfiriato $y$ retomados en hojas callejeras e ilustrados por Posada: Me refiero a Francisco Guerrero (a) "El Chalequero" (fig. 62) y su historia es la siguiente: En 1908 comenzaron a aparecer en la Ciudad de México los cadáveres de más de 10 mujeres

\footnotetext{
${ }^{100}$ El periodismo porfirista y los estudiosos de la época consideraban a los delincuentes como provenientes de las clases bajas de la sociedad, es decir, a mayor pobreza, mayor necesidad de delinquir.

${ }^{101}$ Berta Gilabert, consúltese el capítulo 2, op. cit., p. 60

${ }^{102}$ Elisa Speckman Guerra, Crimen y Castigo. Legislación penal, interpretaciones de la criminalidad y administración de justicia (Ciudad de México, 1872-1910), El Colegio de México, Universidad Nacional Autónoma de México, primera edición, México, 2002.
} 
prostitutas cerca del Río Consulado, entonces una parte alejada de la ciudad. Hernán Robleto en sus "Crímenes Célebres" daba el siguiente testimonio de esos días

\begin{abstract}
Entre más días pasaban más interesantes se hacían los corrillos, especialmente en las tertulias que se formaban en los desaparecidos cafés de "La Concordia" y "El Cazador" [...] Las gentes del pueblo se agrupaba ante un vendedor de hojas impresas, corridos que eran a manera de la crónica en verso de aquellos tiempos. El vendedor leía las nuevas de la crónica en verso de aquellos tiempos. El vendedor leía las nuevas décimas de "El Chalequero", impresas en la vieja imprenta de Vanegas Arroyo, que quedaba en las calles de Santa Teresa [...] Había Chalequero para rato. Era el personaje que ocupaba la atención de todos. No había suceso de mayor atención, porque hasta la elección del general Díaz era pospuesta en esos días en los periódicos para dar el mayor lugar a el Chalequero y sus confesiones horripilantes". ${ }^{103}$
\end{abstract}

¿Desde cuando había comenzado Guerrero a realizar sus crímenes? Por lo menos se sabe que desde 1888 ya se habían encontrado los cadáveres de mujeres asesinadas y la lista crecía en forma notoria: Francisca, Emilia, Luisa, Candelaria, María de Jesús, María Refugio, Lorenza, Soledad, Margarita, Josefa, Camila y Incolaza. Los crímenes siguieron aumentando hasta que una de las víctimas logró sobrevivir y denunciar a su atacante. E agresor fue por este hecho condenado a muerte y tiempo después conmutada su sentencia por 20 años de cárcel. Un tiempo después apareció el cuerpo de una anciana apuñalada y con la cabeza cortada por el mismo rumbo de Río Consulado. Un reportero del periódico "El Imparcial" relacionó este hecho con los asesinatos cometidos por "El Chalequero" 20 años atrás, y al investigar supieron que había logrado escapar de la prisión de San Juan de Ulúa en el puerto de Veracruz. Con estos antecedentes la policía logró capturarlo confesando ser el autor de los crímenes.

Las crónicas mencionaban su indumentaria característica: Pantalón de vestir gris, chaqueta negra, sombrero ancho y zapatos negros. "Gozaba de una colección de pantalones estrechísimos y por supuesto de chalecos, con agujetas y chaquetas charras, con vivos de cuero. Era fama pública que tales ropajes no le costaban un centavo: una de sus amantes, conocida como "la Burra Panda" lo sostenía para que no trabajara, con lo que llegó a convertirse

${ }^{103}$ Citado por Alberto del Castillo, op. cit., p. 51. 
en el "sosteneur de toda la pandilla de mujerzuelas que se lo rifaban, como vulgarmente suele decirse". ${ }^{104}$ Las fotografías en el periódico de "El Imparcial" dejan ver a Guerrero como un sujeto que podía cambiar su fisonomía fácilmente. De mirada directa, de piel morena clara y gran calva, posee barba y bigote bien recortado al estilo francés como se usaba en la época. En otra foto tomada unos días antes, Guerrero esconde su calva con un sombrero y una ropa informal diríamos que hasta pequeña para su talla. Su rostro esta barbado lo cual le engorda la cara. El saco de mangas cortas no puede tapar su abultado vientre del que solo esta abrochado el primer botón. Parecen dos personas diferentes en un mismo asesino. Se puede decir que la cárcel le benefició en su aspecto físico.

Fue podríamos decir que el enfoque periodístico que cubrió " $E l$ Imparcial' fue determinante para realizar el perfil del criminal al que se refería en estos términos

No es un criminal vulgar, de esos que se amedrentan ante el impreciso fantasma de su crimen, ni de esos pusilánimes, que después de cometido el crimen no tiene reposo, pues los persigue la imagen de su víctima. No es de esos. Es un hombre que mata, que se ensaña con aquellos que elige para aniquilarlos. Es un rebelde irredento ${ }^{105}$.

Para comprender el contexto visual de los grabados de José Guadalupe Posada, me parece importante destacar el testimonio de una víctima, Lorenza Urrutia, quien relató a la prensa como pudo salvarse de morir a manos de "El Chalequero":

...en 1888, hacía dos años que conocía a "Antonio el Chaleco", porque un día yendo para la Villa de Guadalupe por el camino del ferrocarril de Veracruz, encontró a un hombre que le pidió la lumbre para encender un cigarro, y luego comenzó a platicarle que no lo podían ver las mujeres de aquel rumbo y le habían el apodo de "Antonio el Chaleco". Al oírlo, La Urrutia, por los antecedentes que tenía, entró en congoja y sintió que su cuerpo temblaba; entre tanto el hombre aparecido sacó de la cintura dos armas grandes e invitó a aquella a sentarse. La Urrutia le rogó entonces que la dejara llegar a la Villa, ofreciéndole volver, a lo que accedió el hombre. Pero el ofrecimiento, como era de esperarse, no fue cumplido, pues la mujer volvió a México en un vagón de los ferrocarriles del Distrito; y

\footnotetext{
104 Ibid., p. 50.

105 Ibid.
} 
contando a sus amigas el suceso, le manifestaron que había vuelto a nacer, porque se había salvado de las garras del "Chaleco"106

Aquí hay 3 asuntos que vale la pena destacar. En primer lugar, Guerrero, se hace llamar "Antonio" y no Francisco que es su verdadero nombre; es un alias que tal vez sirva para realizar sus crímenes sin dar a conocer el suyo.

Otro aspecto a resaltar es el misticismo religioso que demuestra al perdonar la vida de su víctima y no matarla en ese instante ya que Urrutia, "le rogó [..] que la dejara llegar a la Villa". En un artículo periodístico su perfil psicológico era contado dentro de un estilo particular al declararse católico y seguidor de la Virgen María. También creía en la existencia del alma con un concepto muy suyo donde "al morirse cree que se sale ese humo que hace vivir al corazón".

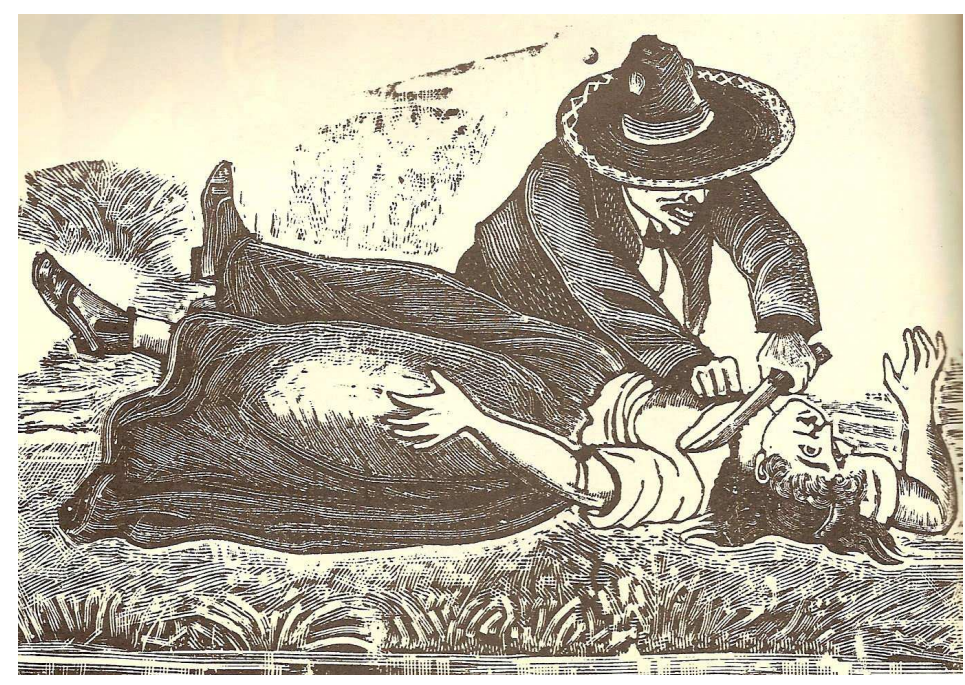

Fig. 63 "La próxima ejecución de Francisco Guerrero" Grabado de Posada

Y por último el alcoholismo y la violencia que le siguió toda su vida según se desprende de las investigaciones periodísticas en cuyo origen se encontraban sus padres. En materia sexual, (que es un aspecto importante en la gráfica de Posada) se mencionaba que El

Chalequero presentaba exigencias sexuales muy intensas con una inclinación especial por mujeres de edad avanzada y que la opinión general era que el degollamiento de las mujeres en pleno acto sexual le aumentaba el placer debido a la vista que las

\footnotetext{
${ }^{106}$ Ibid., p. 52 Véase nota 77. tomado de Alonso Rodríguez Miramón, Requisitoria pronunciada por el Agente del Ministerio Público Lic. Alonso Rodríguez Miramón en la vista en jurado de la causa instruida contra Francisco Guerrero (a) Antonio el Chalequero y contra José Montoya por robos, violaciones, heridas y homicidios perpetrados del año de 1881 a julio de 1888. Antigua Imprenta y Librería de Murguía, México, 1891
} 
convulsiones de la agonía de sus víctimas le producía. Aspecto que no pasa desapercibido para el grabador.

Finalmente, dos grabados se desprenden a partir de estos crímenes. Uno de ellos es la hoja volante con el largo título de "La próxima ejecución de Francisco Guerrero (a) "El Chalequero" degollador de mujeres. Comunicación de una sentencia. Una de las víctimas del Chalequero, asesinada en 1897 en el Río Consulado" (fig. 63). En el grabado de Posada, se presentan a los actores de este episodio, los dos personajes están colocados en una composición horizontal, en la cual "El Chalequero" se ubica sobre su victima; tocado de sombrero que permite ver tan sólo una parte de su rostro. Con la mano derecha sujeta a la mujer, con la mano izquierda el asesino sostiene el arma homicida sobre el cuello de esta. El rostro de la mujer, la cual se encuentra tendida sobre el piso, refleja el terror y su impotencia frente a la agresión.

Otro grabado es igualmente el corrido "Los crímenes del Chalequero" Asesinato de Mucia Gallardo. (fig. 64) Su composición es horizontal que se enmarca a manera de cuadro con una pequeña pleca en sus cuatro lados con incisiones y que tal vez sean los clavos para sujetar la pieza

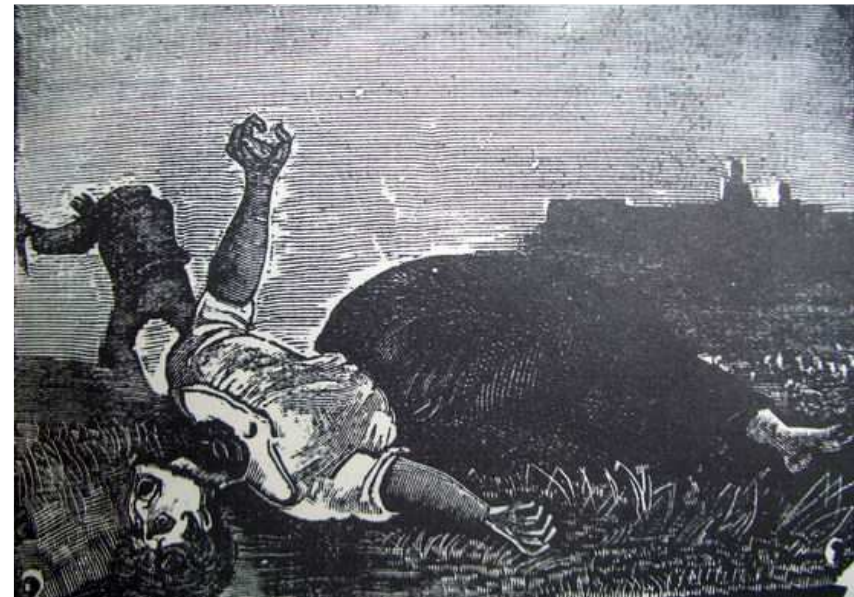

Fig. 64 Los crímenes de El Chalequero. Grabado de Posada quedado impresos en el papel.

Aquí esta magistralmente

trabajada el efecto dramático mediante el uso del "velo" del cual ya hemos hablado anteriormente y esta solución visualmente da un efecto trágico sobre la escena de tres planos: En el centro y en primer término, vemos a una mujer degollada por "El Chalequero" que yace sobre la hierba del campo; sus brazos permanecen abiertos y sus manos crispadas. Hacia la izquierda en segundo término se observa al asesino con los brazos levantados que huye con el cuchillo agresor en la mano izquierda. A la derecha y a lo lejos se dibuja en 
penumbras la cúpula de una iglesia y el contorno geométrico de la gran ciudad.

Como colofón a la vida criminal de Francisco Guerrero puede decirse que la vida misma se encargó de hacerle pagar sus delitos: una fuerte tuberculosis terminó su existencia en la Cárcel de Belén antes de proceder a la pena capital. Un editorial de "El Imparcial" a propósito de "El Chalequero" podía servir no solo para el personaje, sino también para conceptualizar la idea que hemos tratado a lo largo de este capítulo al hablar de esa relación, -equivocada por supuesto- de la criminalidad y las clases bajas de la ciudad de México:

No eres un refinado: eres un ignorante, un oscuro hijo de la miseria y el delito. Te engendraron allá abajo en las tinieblas del fondo social. Eres un incompleto, perteneces a la humanidad embrionaria. Tus sentimientos son rudimentarios, tu conciencia es confusa. Tu niñez fue probablemente maliciosa y taimada, tu juventud, desenfrenada y ardiente. Eres un epiléptico, un degenerado, un enfermo... ${ }^{107}$

${ }^{107}$ Alberto del Castillo, El Imparcial, Editorial correspondiente al 21 de junio de 1908. Véase nota 91. 



\section{IV \\ LA MUERTE EN LA GRÁFICA MODERNA Y CONTEMPORÁNEA}





\section{Introducción}

1 La Liga de Escritores y Artistas Revolucionarios (LEAR)

1.1 La obra gráfica de la LEAR

2 El Taller de Gráfica Popular (TGP)

2.1 La obra gráfica del TGP

2.2 Leopoldo Méndez, el grabador

3 La Sociedad Mexicana de Grabadores (SMG)

\section{La gráfica del 68'}

4.1 La muerte en la obra gráfica de Francisco Moreno Capdevila

4.2 José de Jesús Martínez Álvarez

4.3 Juan Soriano

5 La gráfica actual 

Introducción

Después de la Revolución de 1910, parecía inminente la consolidación del régimen de Estado. El poder heredado a un pequeño grupo envolvía todas las esferas de la vida nacional, penetrando desde las organizaciones más profundas integradas por los políticos y militares más poderosos, hasta las capas más superficiales de la vida civil. México, como nación, se había transformado después de la lucha fraticida en un país gobernado por una fuerza hegemónica indiscutible proveniente de los hombres que habían hecho la Revolución, hasta que el asesinato del caudillo Álvaro Obregón en 1928 desencadenó una profunda crisis que habría de prolongarse hasta mediados de 1935 mientras que en ese ínter se suceden cuatro presidentes en el ejercicio de poder del hombre fuerte Plutarco Elías Calles (1924-1928): Emilio Portes Gil (1928-1930), Pascual Ortiz Rubio (1930-1932), Abelardo L. Rodríguez (1932-1934) y Lázaro Cárdenas (1934-1940).

En el aspecto de desarrollo, los derechos de los trabajadores eran continuamente pisoteados por los grandes monopolios en todas las ramas de la industria con la esperanza de que las promesas de campaña dirigidas a ellos pudiesen hacer algo al respecto. "Sin duda, éstos (los obreros) gozaron entonces de mejores condiciones económicas que en épocas anteriores, pero ello, aparte de que fue cierto sólo siempre a través de la sujeción más absoluta del movimiento obrero a los designios de los grupos políticos en que se apoyaban los gobernantes y de la manipulación mas descarada de las demandas de los trabajadores para conseguir su fidelidad irrestricta a los mismos grupos". 1

En 1934, Lázaro Cárdenas asume la Presidencia de la República con una gestión ambiciosa en el proyecto de desarrollo del país y fue la suya, la administración que más logros tuvo después de la Revolución. Sus principales objetivos fueron en el área del desarrollo de la reforma agraria y la Secretaría de Hacienda tuvo la encomienda de vigilar y otorgar la atención de las necesidades de crédito de los ejidatarios y pequeños propietarios. El Departamento de

\footnotetext{
${ }^{1}$ Arnaldo Córdova, La política de masas del cardenismo, serie popular ERA, número 26, segunda edición, México, 1976, p. 15.
} 
Asistencia Social Infantil fundaría en su mandato jardines de niños y casas de maternidad. Asimismo en 1937, Cárdenas produjo un documento insólito con el cuál se proponía la sindicalización de los trabajadores al servicio del gobierno federal y el consiguiente derecho a la huelga. Un año después pudo reacomodar a los mandos medios y superiores del ejército mexicano y la reorganización del partido oficial PNR; y el hecho más importante en materia de nacionalización de la riqueza energética: la expropiación petrolera. ${ }^{2}$

Por su parte la Secretaría de Educación Pública realizó la creación de escuelas en el medio rural y uno de los aspectos más importantes en el gobierno fue la implementación de la "educación socialista", a través de las escuelas para hijos de trabajadores fundadas estratégicamente en diferentes puntos de la república. ${ }^{3}$ El sentido era despertar en los jóvenes un interés por la explotación de los recursos del país y la enseñanza técnica y formar profesionales. Con este fin se prepararon maestros rurales para educar a las masas campesinas participando en la organización de los ejidos y en la integración de sociedades cooperativas y resaltando los valores de tradiciones culturales de las comunidades rurales e indígenas. Mediante tal actividad o "acción social", los maestros se transformaron en una fuerza de apoyo del régimen cardenista. Justamente esta labor como agitadores sociales los convirtió en una fuerza peligrosa que los convirtió en víctimas de persecuciones y asesinatos supuestamente religiosos pero en el fondo se percibían como represalias de orden política y social ${ }^{4}$

\footnotetext{
${ }^{2}$ Puesto así de esta manera parece que la administración de Cárdenas no hubiese hallado ningún obstáculo, pero no hay nada más lejano, los problemas heredados y generados por las circunstancias fueron enormes. Para mayor información del lector consúltese Arnaldo Córdova, op. cit.

3. Mi madre, la profesora rural Elia Morales Parra contaba que en sus años de estudiante en estas escuelas se cantaban todos los días en sus salones de clase "La Internacional' y corridos revolucionarios entre ellos "EI Sol". Con el tiempo, los egresados de estas escuelas fundaron con el tiempo grupos fuertes de apoyo a candidatos políticos del Partido Revolucionario Institucional (PRI) de acuerdo con la aprobación de Cárdenas. De esta misma asociación la ANESHTAC salieron gobernadores y profesionistas que influyeron moral y políticamente en la vida del país. El mismo poeta Octavio Paz, en su juventud había sido comunista y en la ciudad de Mérida había sido integrante de estas escuelas primero como maestro en la Unión Estudiantil pro-Obrero y Campesino y en la segunda como secretario. Cfr/ en el artículo de Guillermo Sheridan, Octavio Paz en Yucatán, Letras Libres, enero 2001, pp 14.20.

${ }^{4}$ Véase el Catálogo de la exposición Las Misiones Culturales, los años utópicos 1920-1938, CONACULTA, INBA, 1999. La labor de las Misiones Culturales revaloradas apenas hace unos 4 años fue un movimiento de apoyo de cientos de maestros y artistas a los programas del gobierno,
} 
Durante el gobierno de Cárdenas se observó un aumento considerable de actividad política de las masas y una sólida formación de cuadros que se integraban a tareas de organización que iban radicalizándose cada vez más hacia la izquierda. Esto pudo deberse a que el Partido Comunista (PCM) concluía su etapa de clandestinidad y tener libertad de movimiento. En un principio su política fue de ataque y de franca oposición, pero poco a poco cambió su actitud sobre todo por el VII Congreso de la Internacional, en el que de acuerdo a los dictados de Stalin se consideraba mejor la política de organizar amplios frentes sobre todo a favor de la paz a través de los llamados "frentes populares" los cuales lucharían contra el fascismo y la guerra y pugnarían por defender a la URSS.

La delegación mexicana debería entonces fortalecer el Comité de Defensa Proletaria y partir de allí formar un partido de masas para que todos los campesinos, obreros, estudiantes, etc., ingresaran en él. Sin embargo la política de la "unidad nacional" no fue aceptada y quedó sujeta a los designios de la Confederación de Trabajadores de México (CTM), creando pugnas y problemas internos que terminaría por convertirla en la organización sindical más fuerte de su tiempo.

La Liga de Escritores y Artistas Revolucionarios (LEAR) y el Taller de Gráfica Popular (TGP) después, se vieron envueltos en la vorágine política debido a su filiación izquierdista de la mayoría de sus miembros que le posibilitó una presencia en el arte con obra de carácter colectivo con medios accesibles como el linóleo y puesta al servicio del pueblo con volantes, carteles, periódicos, impresos, etc.

1 La Liga de Escritores y Artistas Revolucionarios (LEAR)

La Liga de Escritores y Artistas Revolucionarios (LEAR), desempeño un papel importante en el medio político, social y artístico mexicano de los años treinta. La

ahí, mi padre León Plancarte Silva, reconocido artista de ese periodo fue uno de los tantos misioneros culturales, que realizó una intensa labor creando carteles, murales y grabados tanto para la justicia social del campo como la expropiación petrolera. 
estructura de la Liga estaba formada por secciones de artes plásticas, ciencias, pedagogía, literatura, teatro y danza. que provenían de intelectuales provenientes de organizaciones como la LIP (Lucha Intelectual Proletaria), que era el grupo madre y el primer experimento de organización de artistas y escritores formada en 1931; la FEAP (Federación de Escritores y Artistas Proletarios), y la ATA (Asociación de Trabajadores de Arte. Un aspecto relevante de la LEAR es su postura ideológica que se hace patente a través del realismo socialista proclamado en Rusia por Andrei Zhdanov, sobre todo en los grabadores miembros de la LEAR que pugnaban por ponerlo al servicio de la clase trabajadora ${ }^{5}$ y asignarle una función social al arte como forma de identidad.

Los objetivos primordiales de la organización consistieron en unificar a los intelectuales para luchar contra el imperialismo y el fascismo y apoyar a la clase trabajadora. Sus primeras demandas ante el gobierno fueron la legalización de las organizaciones revolucionarias, las reanudaciones de las relaciones con la Unión Soviética y la libertad de los presos políticos. Sus actividades eran aparte muy variadas: organizaban conferencias, mesas redondas, proyecciones de cine, exposiciones de fotografía y de carteles y pláticas sobre diversos temas entre ellos la lucha antifascista. Aunque su origen es incierto, aparece desde su arranque ligada al Partido Comunista. Sus afiliados eran integrantes en su mayoría del Partido Comunista Mexicano o compartían su ideología. El escritor campechano Juan de la Cabada dejó testimonio de esos días:

[..] Para 1934 ya habíamos organizado la LEAR, Liga de Escritores Revolucionarios. Sin modestia alguna puedo afirmar que no se puede hablar de la LEAR sin mencionarme, puesto que el nombre yo lo propuse. Aunque por otro lado, no fue ninguna gracia: yo era el único escritor de esta incipiente organización. Empezamos unos cuantos en un sitio que ni sillas tenía. Era un pequeño local en la calle de San Jerónimo, entre Cinco de

\footnotetext{
${ }^{5}$ Para profundizar en este aspecto véase a Leonor Morales "El Taller de Gráfica Popular y su vinculación con el realismo socialista", en el Primer Coloquio Mexicano de Historia del Arte denominado "Arte y Coerción" del IIE, donde se explican algunas de las ideas que pueden representar el concepto de realismo socialista. Una de ellas es el culto al hombre nuevo y reflejo de los intereses del proletariado. Zhdanov exaltaba la pintura mural mexicana y el heroísmo y resistencia del indígena. Máximo Gorki utiliza el término por primera vez a partir del 1 Congreso de Escritores Soviéticos, realizado a partir del 17 de agosto de 1934, ahí el objetivo planteado era desarrollar las dotes del hombre para que triunfe sobre la naturaleza.
} 
Febrero e Isabel la Católica. Este espacio formaba parte del convento de la jerónimas, frente a un jardín. Allí o cerca, estaría la celda, se decía, que habría ocupado Sor Juana Inés de la Cruz. Nuestro local tenía una azotehuela y un salón enorme con una especie de tapanco.

Los fundadores de la LEAR fuimos: Leopoldo Méndez, Pablo O'Higgins, Macedonia Garza, su esposa Carmen Ojanian Cargoy, Luis Arenal y yo. Éramos siete los iniciadores: Cuando surgió esta liga los grupos nazifascistas continuaron con más agresividad contra los comunistas. La organización fue muy importante en ese sentido. Su principal cometido era precisamente la lucha antifascista. La LEAR respondió a los principios que la animaron a reunir a todos los escritores y artistas del país para luchar contra el fascismo. Así llegamos a contar con la presencia y las actividades de muchos compañeros que no eran militantes pero si antifascistas: Los pintores Rufino Tamayo, Carlos Mérida, Germán Cueto, el fotógrafo Manuel Álvarez Bravo y muchos otros [...] En ésta que puede llamarse la primera época de la LEAR, lo primero que hicimos fue impulsar un periódico: Frente a Frente, nombre que también yo había sugerido. Era una pequeña publicación que hacíamos en blanco y negro y con unas cuantas páginas [...] Políticamente, comenzamos diciendo; ni con Cárdenas, ni con Calles. Ésa fue nuestra primera consigna en 1934, que duró hasta después de las elecciones. Cuando Cárdenas llegó a la presidencia publicamos un cartel donde establecíamos cuatro demandas: el regreso de nuestros compañeros de las Islas Marías: Revueltas, Badillo, Rosendo Gómez Lorenzo y otros; el respeto a la libertad de expresión; la legalidad para el Partido Comunista y la reanudación de las relaciones diplomáticas con la Unión Soviética, rotas desde la época de Portes Gil. Resultó que el señor Cárdenas dijo que aceptaba las cuatro demandas. Además, cumplió su promesa. Los compañeros regresaron de las Islas Marías, comenzaron a circular nuestros periódicos libremente e inició así lo que bien podría llamarse la era cardenista con un sentido democrático. Esto estimuló la lucha contra el fascismo. ${ }^{6}$

Efectivamente, con la llegada de Cárdenas a la presidencia, el grupo de la LEAR se unió a otros grupos más fuertes políticamente formando el Frente Popular, cuyas estrategias fueron en ese momento apoyar al gobierno, mediante campañas de alfabetización y la observación directa de las condiciones de vida ya para entonces sus miembros sumaban más de un centenar. Estas acciones no contradecían el Séptimo Congreso Mundial de la Internacional Comunista en el que se impuso la política del frente popular, mediante el llamado a la unidad. Con esto la LEAR se convirtió en la organización cultural más numerosa apoyando con impresos de todo tipo no sólo la campaña cardenista sino prácticamente los

\footnotetext{
${ }^{6}$ Gustavo Fierros, Memorial del aventurero Vida Contada de Juan de la Cabada, Colección
} Memorias Mexicanas CONACULTA, México, 2001, pp. 114.117. 
sectores marginales que no tenían ni voz ni voto. Así se ejemplifica en la portada de El Machete del 1ํ de mayo de 1936 donde se aprecia en una composición

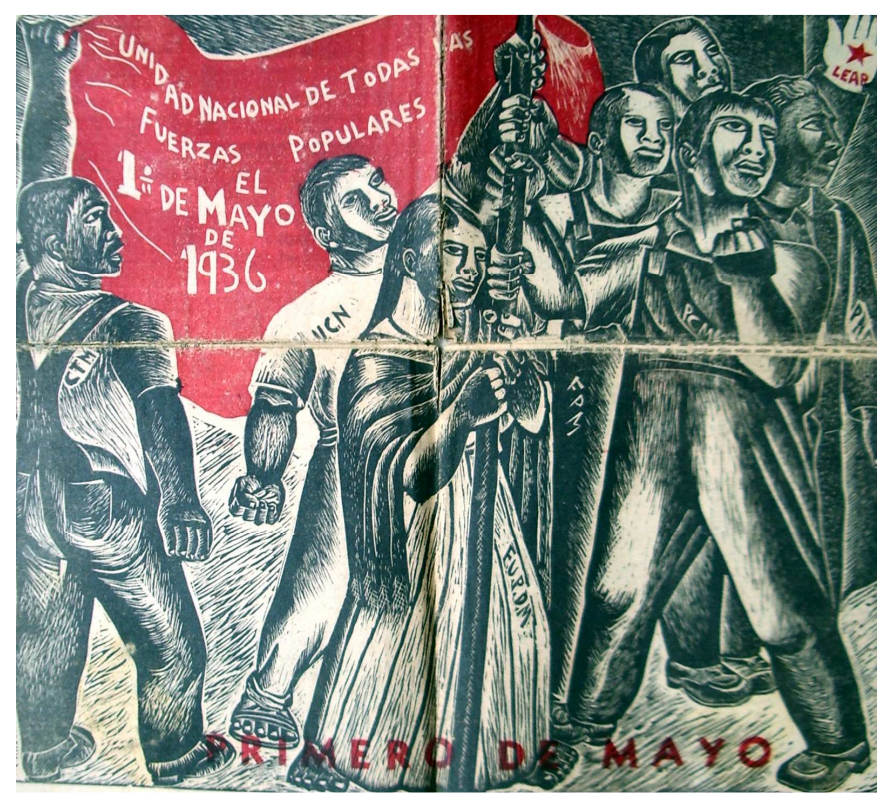

Fig. 1 El Machete 1․ de mayo 1936 triangular un grupo numeroso de trabajadores de diversas clases sociales identificados con iniciales de sus organizaciones como el PCM, PNR, FPM. UCN, y FUPDM. Una mano blanca se distingue de las otras $y$ asoma del lado derecho con la estrella roja y las siglas de la LEAR. En el fondo coloreado de rojo se encuentra una bandera sostenida por un obrero de la CTM en que se lee: "Unidad

nacional de todas las fuerzas populares $1 \stackrel{\circ}{\circ}$. De mayo de $1936^{\prime \prime}$ como se observa en la figura 1.

La influencia de la LEAR se extendió a otros estados de la república donde se formaron filiales como en Puebla, Veracruz, Mérida, Campeche, Saltillo, Torreón, Oaxaca y San Luis Potosí y estos enlaces se dieron mediante las Brigadas Culturales y el envío de folletos, propaganda gráfica y carteles.

A nivel internacional, la participación más importante de la LEAR, fue la asistencia al Primer Congreso Mundial de Estudiantes e Intelectuales contra la Guerra y el Fascismo (febrero de 1935); Congreso de Nueva York (abril de 1935); Primer Congreso Internacional de Escritores en Defensa de la Cultura de París (junio de 1935); Congreso Panamericano en Montevideo (septiembre de 1935); Congreso de Nueva York (febrero de 1936); y el Segundo Congreso de Escritores

7 “El periódico comunista El Machete, fue fundado en 1922. 
Antifascistas, celebrado en 1937, que comenzaría en Madrid, seguiría en Valencia y luego en París.

Los integrantes de la LEAR colaboraron de manera colectiva en la realización de murales como en el local de los Talleres Gráficos de la Nación, el Mercado Abelardo L. Rodríguez, el Centro Escolar Revolución y otros; así como material de lectura para escuelas de trabajadores de la Secretaría de Educación Pública $^{8}$, carteles y propaganda gráfica para asociaciones y sindicatos de trabajadores. ${ }^{9}$ Entre sus logros artísticos se encontraban colaboraciones para el periódico comunista "El Machete" y la edición de la revista Frente a Frente dirigida por Fernando Gamboa, ${ }^{10}$ que en sus buenos momentos tuvo un tiraje de 10, 000 ejemplares; para 1937 la revista apareció sólo en julio y agosto, y con esto la corta vida de la LEAR llegaba a su término después de cuatro años aproximadamente logrando en tan poco tiempo aglutinar a la mayoría de los intelectuales desarrollando una conciencia nacionalista.

\section{1 La obra gráfica de la LEAR}

Uno de los aspectos importantes de la LEAR en el tema mortuorio, fue la conmemoración del $6^{\circ}$ aniversario de la trágica muerte del cubano Julio Antonio Mella en 1928 a través de un cartel con la imagen del líder comunista muerto colocado en la base izquierda de la composición. El texto lo forman varias fuentes tipográficas sobre papel blanco. La que sobresale es el título subrayado: Manifiesto (en rojo). ¡Trabajadores! El 10 de enero, aniversario del asesinato de

\footnotetext{
${ }^{8}$ Este material consistió en ilustraciones para los diferentes números del Libro de Lectura para uso de las Escuelas Nocturnas para Trabajadores. Su contenido a través de "El Hogar Obrero", "La Gente Toma las Armas", "Los Puños en Alto" o "Flota al Aire la Bandera Roja”, en niños de primer grado, y da una idea del tipo de lecciones ahí aprendidas.

${ }^{9}$ Leopoldo Méndez sobre este aspecto mencionaba que "...la sección de artes plásticas fue la más sobresaliente, la más activa y la que contaba con mayor número de miembros, frecuentemente se llevaban a cabo exposiciones, se colaboraba con asociaciones (...) proporcionando material artístico, como pancartas, volantes, fotomontajes y demás". Leopoldo Méndez, Artista de un pueblo en lucha, México, CEESTEM, UNAM, IIE, 1981, pp. 49-50.

${ }^{10}$ Para mayor consulta sobre el tema consúltese Juana Gutiérrez, (et.al.), "La época de oro del grabado en México", en Historia del Arte Mexicano, fascículo 101, México, SEP/ INBA/ SALVAT, 1982.
} 
Julio Antonio Mella, debe ser para nosotros un día de protesta y de lucha. ¡Contra las persecuciones a los Militantes Revolucionarios!; Contra las guardias blancas que asesinan Campesinos! ¡Contra el Terror del Régimen Burgés (sic) Terrateniente! Fechado en 1935 en Morelia, Michoacán.

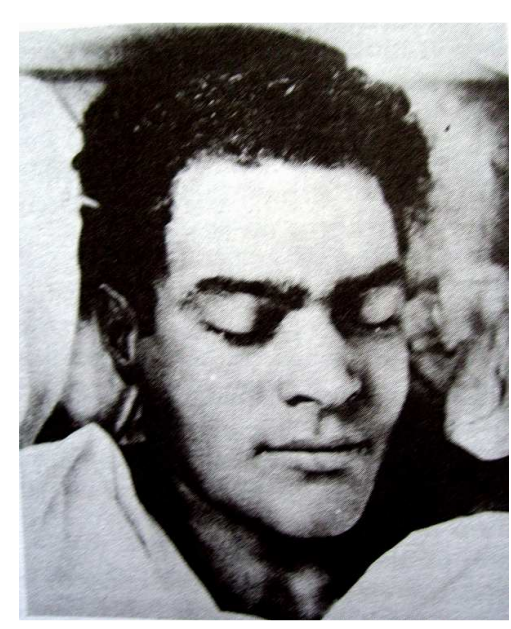

Fig. 2 Mella Muerto Fotografía de Tina Modoti

El grabado fue hecho por encargo de la Federación de Estudiantes Revolucionarios (FER) y del Socorro Rojo Internacional (SRI) ambas fundadas por Mella. El rostro está tomado de la fotografía del cadáver de Mella (fig. 2)que le fue tomada por la italiana Tina Modotti en el Hospital Juárez momentos antes de que se le practicara la autopsia, y apareció como se puede constatar en el periódico "El Machete" el 19 de de enero de 1929.

Su rostro es sereno, en el que sobresalen las cuencas de los párpados y parece que duerme.

No es un rostro dramático sino que aparenta estar lleno de una paz interior. Se aprecia una frazada de color claro que sería utilizada posteriormente como mortaja. El grabado ha sido trabajado de otra manera más sencilla. (fig. 3) No es propiamente un retrato pero capta la esencia del personaje: las pronunciadas líneas de los párpados, el cabello fuera de su lugar ondulado, los labios cerrados que apenas esbozan una sonrisa y la manta blanca que se dibuja abajo del cuello Para explicar la situación histórica es necesario aclarar que las fuerzas comunistas tenían para esa fecha una gran presencia en el

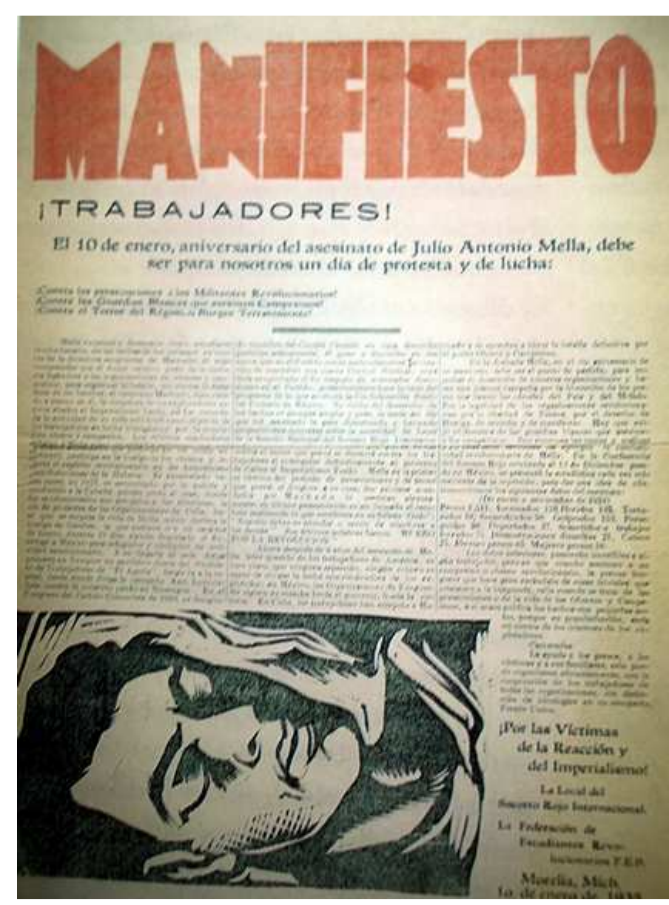

Fig. 3 Anónimo

Cartel de la FER para el Aniversario del asesinato de Julio Antonio Mella 1935 
movimiento obrero y se volvieron una fuerza indispensable en los movimientos sindicales y populares. En las manifestaciones eran violentamente perseguidos, encarcelados y asesinados. Existe una gran semejanza entre el sacrificio casi religioso y la ideología comunista, según se desprende del texto de Adela Cedillo en "Los martirios de Anacleto Gonzáles Flores y Julio Antonio Mella donde “...para los comunistas, el martirio no era algo gozoso, sino necesario, y por ello respondían a los crímenes cometidos en su contra con campañas de

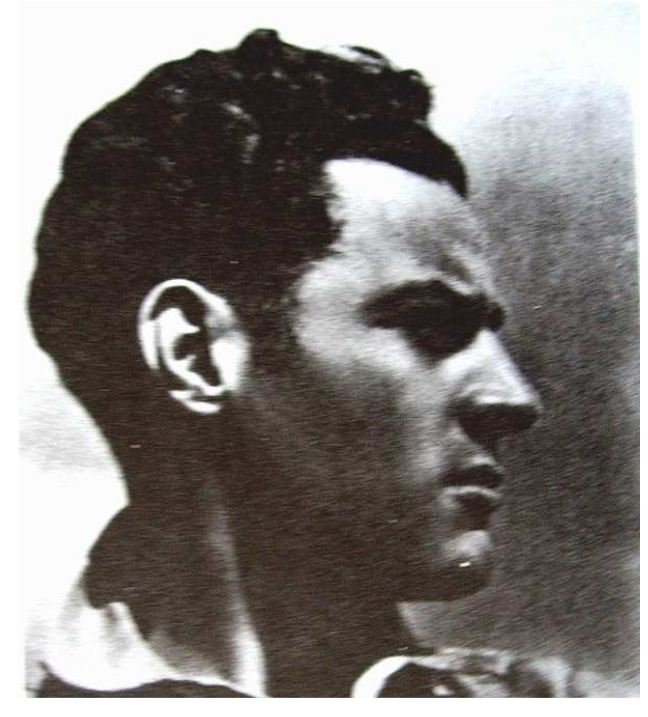

Fig. 4 Julio Antonio Mella Fotografía de Tina Modotti reclutamiento de futuros mártires...." 11 Tal vez en este contexto pueda entenderse la muerte temprana de Julio Antonio Mella. El joven Mella había llegado a México en 1926, de 23 años y de inmediato comenzó a trabajar en las agrupaciones mexicanas contra el imperialismo norteamericano Es posible que de esos momentos sea la clásica fotografía de Tina Modotti. (fig. 4) Muy pronto inició su relación con el Partido Comunista Mexicano y en sus prensas Mella editó muchos de sus escritos manifestando sus ideas encendidas en el periódico comunista "El Machete"12. Su asesinato había sido planeado desde la isla de Cuba y consumado en las calles de la ciudad de México donde se vieron involucrados varios personajes del ambiente político y cultural como su compañera Tina Modotti. "El Machete" dio cuenta de los hechos en una nota:

[...] el agente machadista José Magriña fija una cita con Mella "para informarle de lo que sabe de Cuba". Esta cita se lleva a cabo la noche del día 10 a la nueve, en la cantina situada en la esquina de bolívar y República del Salvador".

\footnotetext{
${ }^{11}$ Adela Cedillo, Los martirios de Anacleto Gonzáles Flores y Julio Antonio Mella, en "Los pinceles de la Historia”, La Arqueología del Régimen, 1910- 1955. IIE. UNAM, México 2003, pp. 103-105.

${ }^{12}$ Adys Cupull, tiene un libro de recuerdos que aporta mucho sobre la presencia de Mella en la intelectualidad mexicana cuyo titulo es "Julio Antonio Mella en los mexicanos", Ediciones El Caballito, México 1983.
} 
Allí Magriñá informa a nuestro camarada de la llegada de dos cubanos a México con el propósito de asesinarlo por órdenes de Machado. Pocos minutos después sale Mella y se encamina a las oficinas del Cable para reunirse con su compañera Tina Modotti, que precisamente había ido a depositar un mensaje desmintiendo la versión provocadora de la bandera cubana. Por la avenida Morelos marchan ambos hacia su domicilio, situado en las calles de Abraham González vuelven hacia la izquierda caminando junto a una barda y marchando directamente hacia la casa, "antes de que dieran las diez y cerraran la portería". Apenas habían caminado la pareja unos cuantos pasos por la calle citada, cuando sonaron dos disparos tan cerca que Tina pudo oler los gases de la pólvora. Sintiéndose herido Mella, trató de ponerse a salvo atravesando la calle, mientras el asesino, que según la hipótesis que parece más comprobada, se acercó a disparar unos cuantos pasos detrás de nuestros compañeros, huía por la avenida Morelos con rumbo al Paseo de la Reforma. (...) Mella cayó al otro lado de la calle, en la banqueta frente a la casa número 19, mientras Tina pedía auxilio y trataba de hallar un automóvil donde trasladar al herido. Cuando llegó el gendarme de punto en la esquina cercana, placa 772, oyó de labios de Mella, la acusación contra Machado y contra la Embajada de Cuba, a lo cual agregó nuestro camarada: "Muero por la Revolución". ${ }^{13}$

El atentado que le costó la vida a Mella motivó un gran sepelio con figuras intelectuales y artísticas de México que cobijaron al joven asesinado en su último

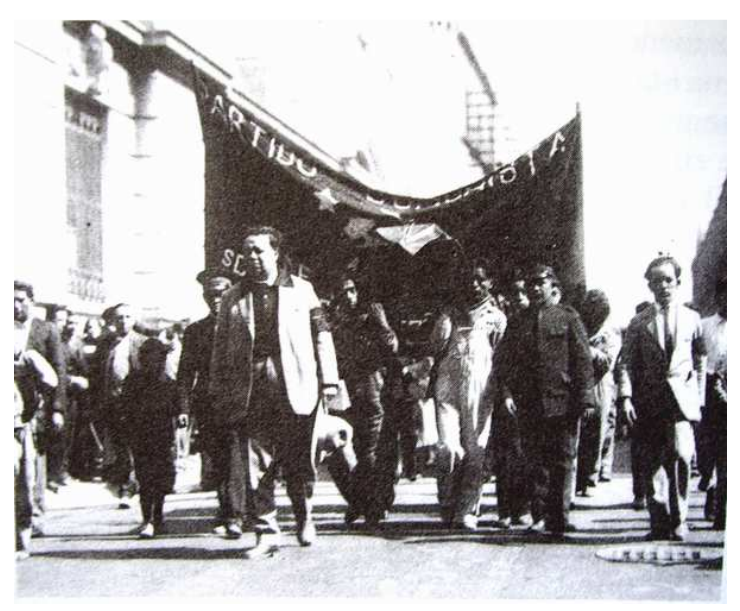

Fig. 5 Diego Rivera encabeza el sepelio de Mella. Fotografía camino al cementerio. (fig. 5) Con el tiempo, sus aniversarios producirían manifestaciones de coraje e indignación debido a su enorme presencia en la izquierda mexicana.

Los temas políticos siempre fueron tema recurrente en la gráfica producida por los miembros de la LEAR. El primer número de la revista Frente a Frente del $1^{\circ}$ de noviembre de 1934 , la LEAR presenta un grabado en madera en

\footnotetext{
${ }^{13}$ Raquel Tibol, Julio Antonio Mella en El Machete, Antología parcial de un luchador y su momento histórico, Fondo de Cultura Popular, México 1968, pp. 351-352.
} 
forma de "calaveras" titulado Concierto Sinfónico (fig. 6) y que representa una acusación de fascista al Partido Nacional Revolucionario (PNR) colocando a su representante en una silla con la cruz gamada, mientras que el representante de la IV Internacional aparece vestido de forma burguesa y en el ambos aplauden la tanda popular -género de espectáculo de barriadamuy de moda en el Distrito Federal en ese entonces. Ya casi fuera de la escena un esqueleto / golpeador, expulsa a una pareja proletaria del evento privado y que resultan empequeñecidos ante la magnificencia del espectáculo. En el piso un programa indica "Hoy El Sol" Corrido Proletario, boleto \$25.

Este grabado es una muestra clara de la injusticia social, y una crítica a algunos representantes de las clases populares. Por otra parte se incluye en la imagen el precio del boleto que representa en el momento una

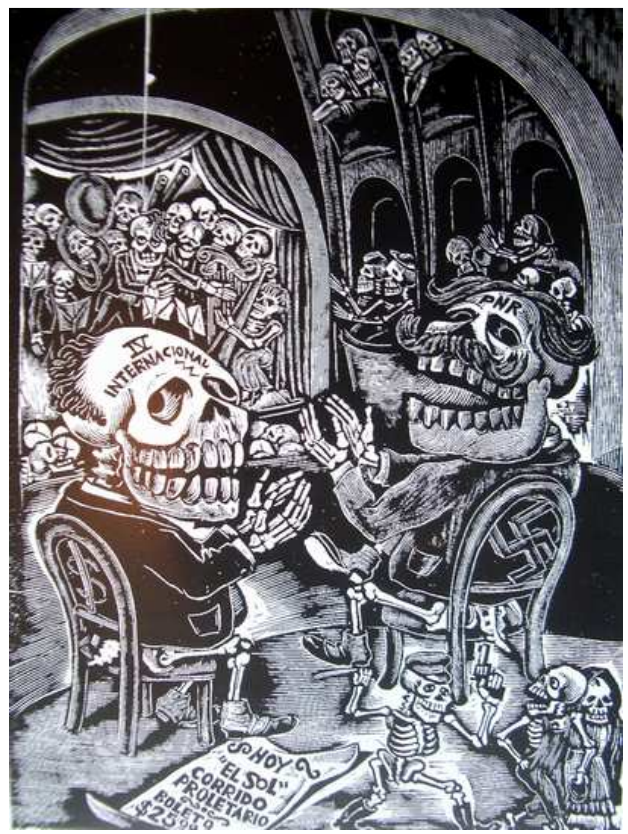

Fig. 6 Leopoldo Méndez Concierto Sinfónico de Calaveras. Xilografía 1934 ofensa y una prueba humillante de que los pobres no podían comprar ni siquiera la entrada. El texto completo del corrido de autoría de Carlos Gutiérrez al que se hace alusión es interesante por su contenido y relaciona el sentimiento popular con el conformismo social que se habría de tener ante esta situación: ${ }^{14}$

\footnotetext{
${ }^{14}$ Para tener una idea de la situación que imperaba en la sociedad mexicana es necesario mencionar que el salario mínimo comenzó a operar a partir del 1ํ de enero de 1934. En 1932, el salario mínimo aparecía como una burla para los trabajadores. En la frontera norte, en Nogales se alcanzaba los 2 pesos diarios siendo la zona más cara del país, en Nueva Rosita, Coahuila era de 1.25 pesos para los trabajadores y 0.75 , en Aguascalientes era de 1.25 pesos de la ciudad y de 0.60 para los del campo, respectivamente, pero en muchas regiones el mínimo era de apenas 0.50. La Comisión Nacional de Salarios Mínimos denunciaba que “...el salario mínimo significa el más bajo nivel de las necesidades elementales y precisas del hombre. Es el límite más reducido en que pueden caber las exigencias imperativas de la vida civilizada."Arnaldo Córdova, En una época de crisis (1928-1934), op. cit., pp.178- 184.
} 
Sol redondo y colorado

Como una rueda de cobre

Que al diario me estás mirando

$Y$ al diario me miras pobre.

Me miras con el arado

Luego con la rozadera

Una vez en la llanura

Y otra vez en la ladera.

Me miras lazando un toro

Luego arrearlo pa' el atajo

Pero siempre me vez pobre

Como todos los de abajo.

Sol: tú que eres tan parejo

Para derramar tu luz,

Habrías de enseñar al rico

A hacer lo mesmo que tú.

Sol redondo y colorado

Como una rueda de cobre

Que al diario me estás mirando

Conformando con ser pobre. ${ }^{15}$

Dentro de la producción colectiva de la LEAR sobresale por su sentido unificador y solidario la lucha contra la Acción Revolucionaria Mexicanista (ARM) también conocida por "Camisas Doradas", y que constantemente agredían de manera violenta a maestros y a miembros de la LEAR. Un enfrentamiento brutal conocido fue aquel que corresponde a la batalla campal en el Zócalo de la Ciudad de México entre el Frente Único de Trabajadores del Volante y los "Camisas Dorados" de Nicolás Rodríguez el día 20 de noviembre de 1935. (fig. 7) La imagen del

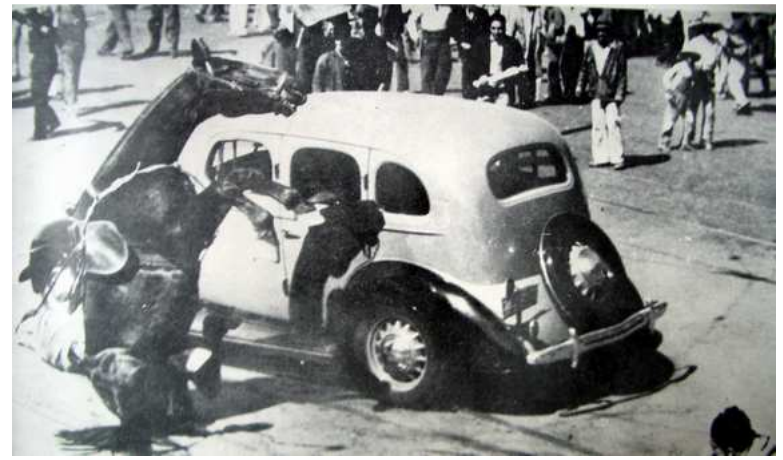

Fig. 7 Zócalo de la Ciudad de México Fotografía

\footnotetext{
15 "Sol redondo y colorado", Corrido de Carlos Gutiérrez, en Amparo Ochoa, cantado por Amparo Ochoa, $A$ lo mestizo, Grabado en vivo en el Teatro de la Ciudad los días 1, 2, y 3 de octubre de 1992, Ediciones Pentagrama, México, 1992.
} 
fotógrafo Manuel Montes de Oca es ya un clásico de la época: Un automóvil corre sobre la plancha de cemento del Zócalo y embiste a un caballo que sentado sobre sus cuartos traseros ha tirado al asustado jinete y fue utilizada por integrantes de

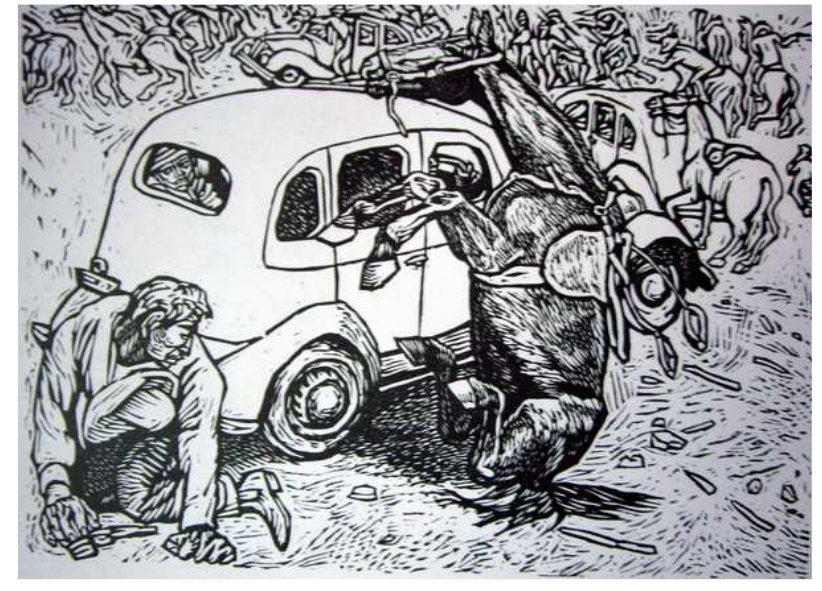

Fig. 8 Alfredo Zalce "Choferes contra "Camisas Doradas". Grabado la LEAR y posteriormente por el TGP años después en diversas publicaciones como puede verse en la figura $8 .^{16}$

Alrededor de la figura del General Plutarco Elías Calles y a la manera de las hojas callejeras de Posada, pertenece una xilografía impresa en papel de china rosa y lleva en el extremo derecho el num. 2. ${ }^{17}$ Está fechada en diciembre de 1935, y su título es "Hoja Popular Anticallista". En la parte inferior se lee "El Pirata Sueña con sus Tesoros Amasados con Sangre y Duelo del Pueblo". Es un ejemplo curioso, acaso por la cercanía de las celebraciones del mes de noviembre de las "calaveras", que el artista (o los artistas) lo ha ligado con los actos de corrupción y muerte de sus adversarios políticos que se le adjudicaron durante el "Maximato" como se le conoció a este periodo. En él grabado en cuestión se encuentra la figura de Plutarco Elías Calles con un parche en el ojo izquierdo y desnudo de la cintura para arriba en el que esta marcado el signo del dólar y tiene la pierna vendada. ${ }^{18}$

\footnotetext{
${ }^{16}$ Como puede observarse la imagen resultó invertida, resultado tal vez de realizar el dibujo en la plancha matriz al derecho.

${ }_{17}$ No se conservan la totalidad de estos grabados. El número 4 de las mismas medidas está formado de un grabado xilográfico compuesto de tres figuras. Una de ellas es la caricatura de Calles borracho con tres dientes, y desnudo de la cintura para arriba siendo sostenido por el líder obrero Luis N. Morones, a su derecha el presidente del PNR brinda con pulque. Al fondo una pulquería tiene un nombre que lo dice todo: "Los triunfos de Calles". En la parte inferior: Callismo: corrupción; garitos; monopolios; ventas de huelgas; asesinatos de campesinos; ensangrentar, saquear y entregar el país al imperialismo extranjero; oprimir bestialmente a los soldados, etc. etc...

${ }^{18}$ La personalidad de Plutarco Elías Calles es el sentido de ligarlo a tantos enemigos políticos, muertos y perseguidos políticos debido a su carácter difícil es prácticamente desconocido en
} 
Porta un cuchillo y usa una muleta con la cual se impulsa hacia delante dejando atrás pilas de cráneos humanos, así como una ave muerta en forma de perico (por lo hablador de su líder) con las siglas de la ARM y bolsas de dinero ya rotas. (fig. 9) En el extremo derecho indicaba lo siguiente: Domingo 22- 10 de la mañana GRAN MANIFESTACIÓN ANTICALLISTA" Partirá del costado Norte de la Alameda (por la Av. Hidalgo).

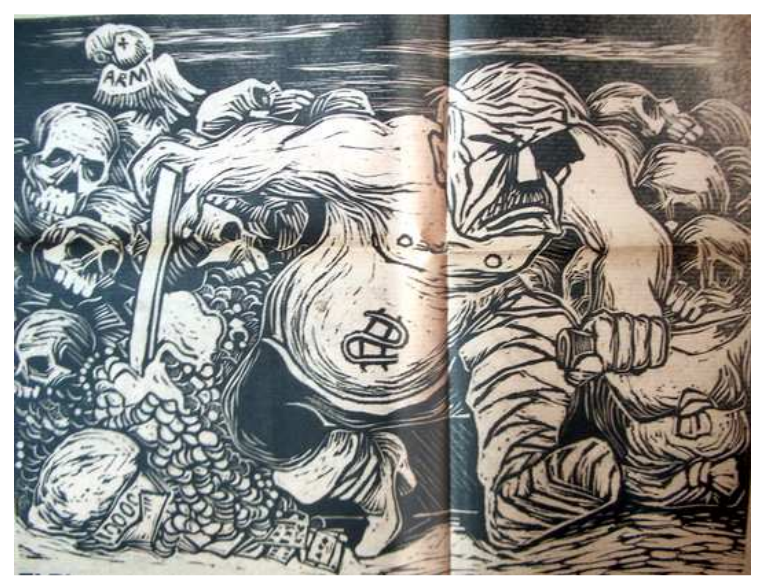

Fig. 9 Anónimo

El Pirata Sueña con sus Tesoros Amasados con Sangre y Duelo del Pueblo

Ya días antes, el periódico comunista "El Machete" había convocado a una manifestación con motivo del regreso del presidente Calles de la ciudad de California en Estados Unidos y el objeto era demostrar unión en torno a la figura presidencial de Cárdenas. Dicha convocatoria la organizaban los comunistas Rubén Magaña, Valentín Campa y Daniel García. Para el día 14 de diciembre el General Calles había sido recibido por los líderes y políticos más importantes a su llegada al aeropuerto de la Ciudad y eran de esperarse unas declaraciones en torno a la administración cardenista. Por lo que se puede ver en los testimonios fotográficos de los periódicos el general Calles se ve bien físicamente y no se observan vendajes ni muletas de ningún tipo, pero según parece se le ha retratado como un pirata moderno. ${ }^{19}$ Prudentemente Calles se abstuvo de hablar, sin embargo su presencia bastó para realizar la manifestación

nuestra historia oficial. Sin embargo la prensa opositora y los hechos parece que así lo demuestran. Un estudioso de la época como lo es Jean Meyer hace el siguiente señalamiento: “... Interesa escuchar el testimonio del general Roberto Cruz sobre Calles. "No era sanguinario, en el sentido que le gustase matar.; pero tampoco le inquietaba ese acto postrero y en cierto modo supremo de la existencia... tranquilo como si acabara de tomar un baño de agua tibia, podía disponer hasta con indiferencia, de la vida de los demás". Jean Meyer, Estado y Sociedad con Calles, Historia de la Revolución Mexicana 1924-1928, El Colegio de México, México,1996, p. 54.

19 Diario El Nacional, sábado 14 de diciembre de 1937. 
del día 22 y realizar esta adhesión de las masas de manera "espontánea" con cerca de 11 centrales obreras. ${ }^{20}$

Vale la pena resaltar la presencia de Lázaro Cárdenas en esta reunión de apoyo a su gobierno y que se puede considerar un éxito político debido a las 80,000 personas que asistieron ya que así parecen constatarlo las imágenes fotográficas y los corresponsales que asistieron del día 29 de diciembre y que mereció un suplemento especial interno. A la LEAR como organización, le correspondió estar a un costado de la Alameda Central, y de acuerdo a los rotograbados del periódico algunos sectores (los más numerosos) se repartieron las principales calles y avenidas hasta llenar por completo la plancha del zócalo capitalino. $^{21}$

En las "Memorias del General Gonzalo N. Santos" (político consentido de este periodo) encontré lo que puede ser también una explicación al "parche" colocado en el ojo de Calles y que puede deberse a las constantes substituciones de figuras políticas del momento a capricho de Calles por otras que fueran más dóciles. ${ }^{22}$ En términos más claros se entiende como un remiendo político y que de acuerdo al refrán mexicano significa "...taparle el ojo al macho", que de otra manera es cubrir las apariencias, guardar las buenas formas, y disimular a toda costa si es necesario. ${ }^{23}$

La LEAR realiza en el mismo año variantes sobre el mismo tema, por ejemplo, en la madera titulada "Mitin de apoyo al gobierno interrumpido por los camisas doradas" muestra dos cuerpos de trabajadores tirados en el suelo. Sobre la figura que está en primer plano, el artista ha puesto mayor énfasis en el dibujo y en su mensaje de violencia desproporcionada: Su indumentaria es un humilde de overol, sin camisa, sin zapatos y su mano reposa sobre el pecho. Sobre su

\footnotetext{
20 "Cual será el orden de la manifestación obrera de mañana", El Machete, sábado 21 diciembre de 1937.

21 "80,000 manifestantes, suplemento interior de "El Nacional", lunes 23 de diciembre de 1935.

${ }^{22}$ Gonzalo N. Santos, Memorias, Editorial Grijalbo, Colección Testimonios, 4aㅡ, edición, México, 1984 , p. 459.

${ }^{23}$ Miguel Velasco Valdés, Refranero Mexicano, LIBRO- MEX editores, México, 1961, p. 182.
} 
cuerpo, se ha colocado la bandera comunista y a su lado cerca de su mano, un pequeño martillo como símbolo de su condición trabajadora. (fig. 10)

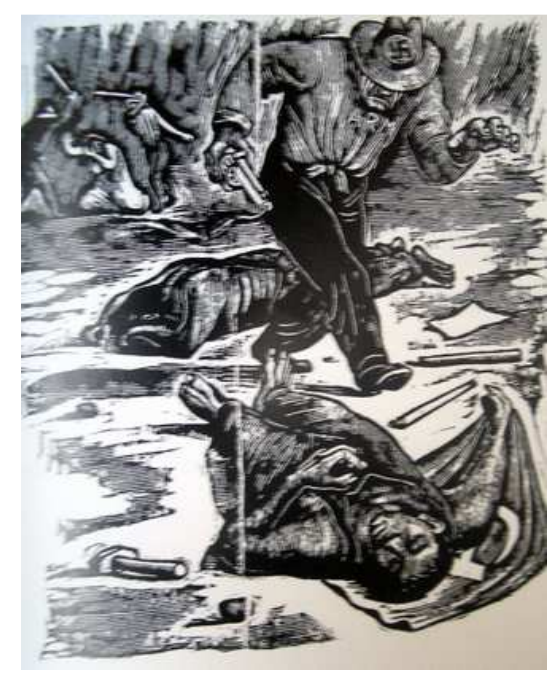

Fig. 10 Leopoldo Méndez Mitin de apoyo al gobierno... Xilografía. 1935
Caminando entre los cuerpos, un personaje armado de la que sólo se ve parte del rostro, lleva en su mano el revólver asesino. En su camisa amarrada con un nudo en la parte baja se lee las siglas ARM y en la copa de su sombrero se aprecia la svástica nazi. A lo lejos colocados del lado izquierdo (tal vez con intención política) dos rompe-huelgas golpean con palos a una indefensa mujer arrodillada que alza las manos en actitud de defensa.

El artista (probablemente Leopoldo Méndez) coloca al hombre armado con inteligencia y hace suponer que es el General Calles con su inconfundible bigote y su quijada cuadrada partida en dos. El complemento del grabado es un fondo trabajado con velo en sentido vertical lo que le da un efecto dramático. ${ }^{24}$

Una segunda imagen se muestra en el grabado en madera de 1936, "Ayuda a los revolucionarios perseguidos", (fig. 11) donde el personaje identificado como Calles ahora de traje completo y de corbata dispara en el rostro a quemarropa a un manifestante. Su actitud es fría y tranquila tal y como sus enemigos lo decían: Se quitaba enemigos políticos del camino mediante la fuerza pública o del ejército.

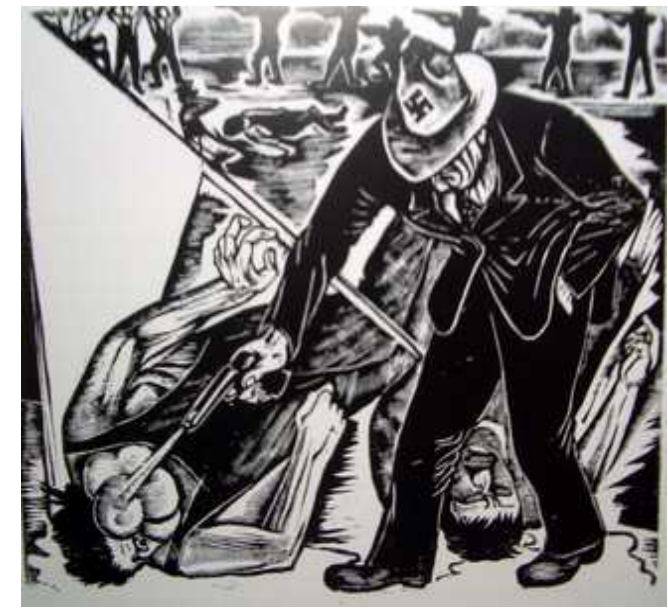

Fig. 11 Ayuda a los revolucionarios perseguidos".

\footnotetext{
${ }^{24}$ Aunque algunos historiadores y críticos le han dado crédito a Leopoldo Méndez como el autor de la mayoría de los grabados surgidos en este periodo, tal vez por el sentido estilístico, yo he creído conveniente sólo citar su nombre cuando la plancha grabada lo indica o está firmado el impreso, mientras tanto lo considero como obra colectiva y anónima de la LEAR.
} 
Su sombrero porta la insignia de la suástica, ya que Calles era admirador de Adolfo Hitler. A su lado individuo yace sobre el piso sangrante y en la parte superior de la composición las siluetas de hombres armados con gorras apuntan contra obreros, y otros masacrados yacen en el piso.

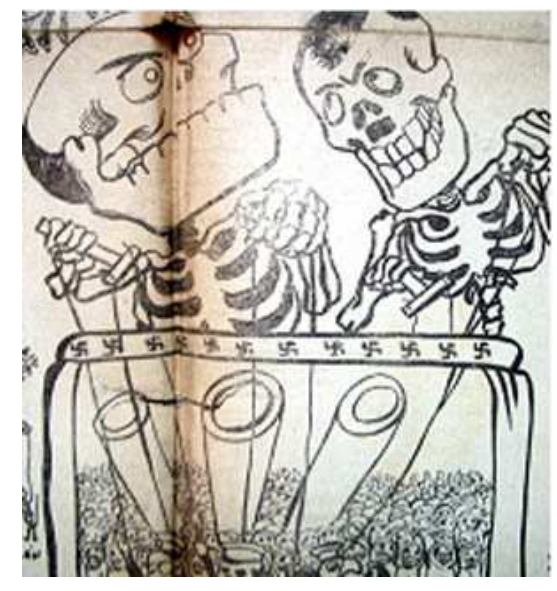

Fig. 12. El Machete 2 de noviembre de 1936
En cuanto al trabajo gráfico colectivo destinado para impresos mayores, el ejemplo más antiguo sobre el "Día de Muertos", corresponde al ya citado periódico El Machete. En este número, dedicado al tema de la muerte, aparecen algunas calaveras impresas en el frente y reverso. En la segunda plana se encuentran siete grabados de distinta factura; en la tercera página aparecen cinco grabados más y sus temas van de lo nacional con caricaturas de Emilio Portes Gil, de Plutarco Elías Calles y Gonzalo N. Santos ("Diablos")

cacique de San Luis Potosí y el hombre fuerte del entonces PNR, pasando por aspectos políticos internacionales, como la situación de Batista y Cuba y la presencia de Adolfo Hitler en Europa. Estos grabados, parecen haber sido trabajados con lápiz litográfico y tinta y otras probablemente sobre linóleo. (figs. 12 y 13)

En otro ejemplar de El Machete sin número ni fecha de publicación, lleva como cabeza "Tumulto en el panteón callista", y contiene colaboraciones de artistas como Leopoldo Méndez, Antonio Pujol, Ángel Bracho, Luis Arenal, Julio de la Fuente, Juan de la

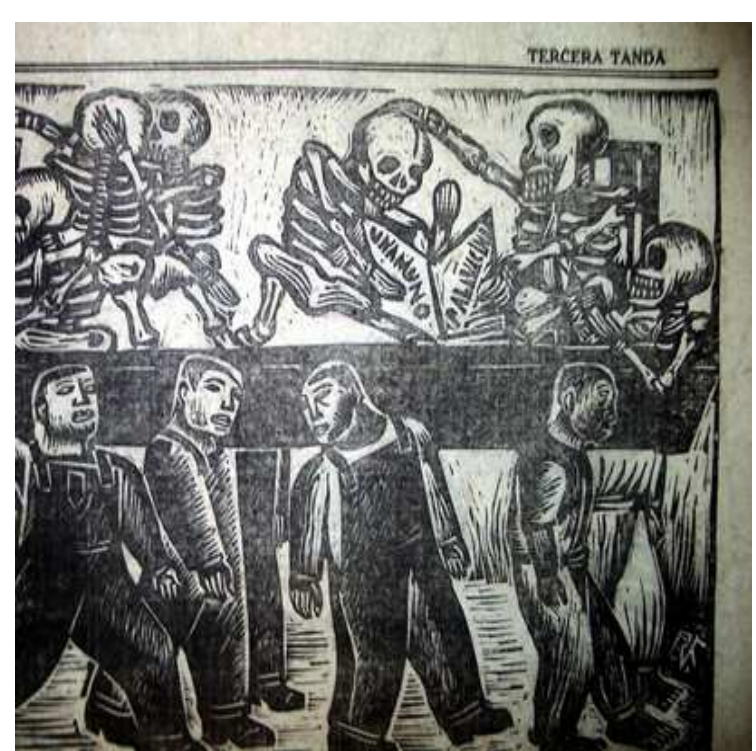

Fig. 13 Tandas de la LEAR 
Cabada y Pablo O’Higgins de la LEAR. En este número, también dedicado al "Día de Muertos", se incluyen siete grabados en la página principal, representando las ya conocidas calaveras, acompañados de textos en verso.

Uno de los grabados titulado "Rebelado todo el pueblo acaba con ese foco de putrefacción", (fig. 14) que aparece debajo de la cabeza, probablemente sea de la autoría de Leopoldo Méndez, ya que el tratamiento y la técnica empleada recuerda al usado en las hojas volantes que más tarde enviará, el TGP a los maestros rurales para protegerse de las guardias blancas. Pocos artistas como Méndez utilizaron el velo (buril de varias líneas finas), producto de una acuciosa revisión estilística de Posada y su calidad tonal que permite mayor rapidez en la incisión de la herramienta sobre el soporte, logrando una riqueza de blancos y negros. En esta imagen, de una compleja composición (cerca de 16 elementos), se representan la venganza de obreros y campesinos, que sostienen en sus manos desde martillos y hoces hasta piedras, contra los políticos/calavera corruptos. En primer plano aparece el cuerpo de calavera de Plutarco Elías Calles

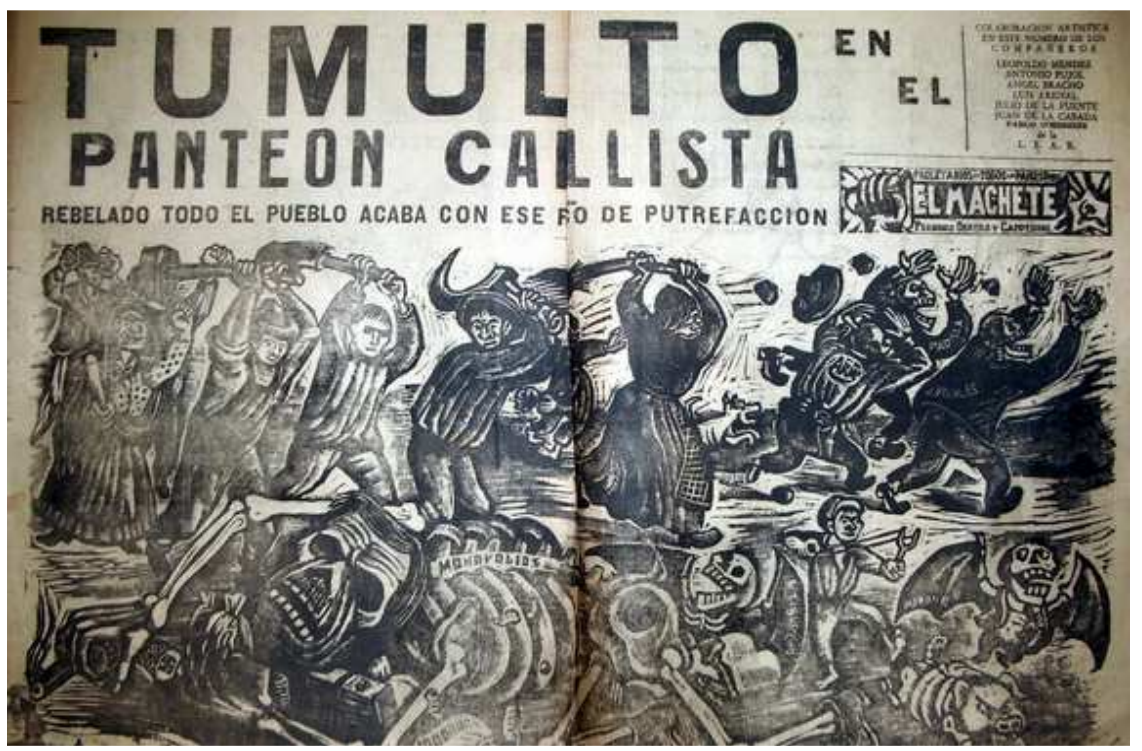
que lleva en sus huesudas costillas un letrero que reza "Monopolios", y que tumbado sobre el piso protege billetes $\mathrm{y}$ monedas con una mano, mientras que con la otra sostiene una pistola humeante.

Fig. 14 Periódico El Machete 
En tanto, puercos y vampiros calavera identificados con la persona de Morones, corren espantados en tanto un niño les apunta con una horquilla. En otra escena una ama de casa con su mandil en la cintura corre a escobazos a políticos pertenecientes al grupo de Calles.

Otra imagen significativa de grandes dimensiones y del que presentamos un detalle se encuentra en las páginas interiores y lleva el título de "Panteón del imperialismo fachismo y guerra" (fig. 15) El grabado asume una feroz crítica a la sociedad de los años 30 en México. Los estilos son diferentes y parecen ser hechos a la limón entre varios artistas: el grabado muestra una gran guadaña ("guadaña popular

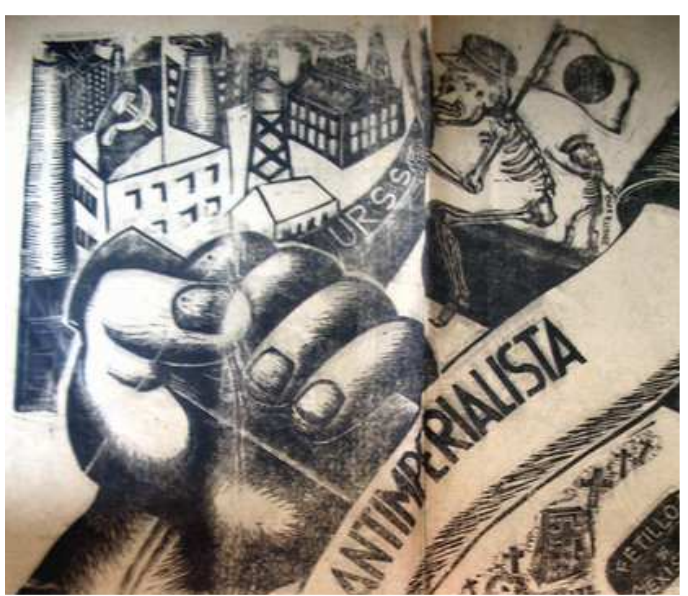

Fig. 15 Periódico El Machete antiimperialista") sostenida por dos enormes manos en actitud de llevar a cabo su

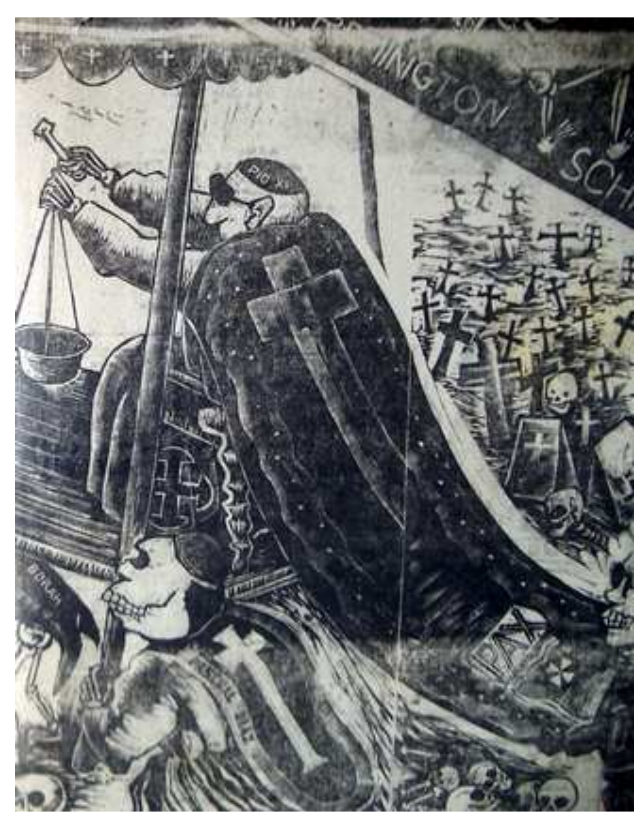

Fig. 16 Pío XI y Pascual Díaz acción, en el fondo se encuentran japoneses, alemanes, banqueros y dueños de poderosas empresas montadas sobre un gran cañón, le acompaña un texto en verso que dice: "Esqueletos, Canillas y Calaveras, Agiotistas, Locos, Borrachos y Hampones y Tecolotes Fachistas". Una escena más incluida en la ilustración representa a jerarcas religiosos calaveras acompañados de un gran séquito que se disponen a otorgar la bendición a esta acción, con el texto que dice: "Gusanera del Papa, arzobispos, sacristanes y plumíferos de campanario". (fig. 16) 
Al reverso del periódico se encuentra una sección llamada "Fosa común" que contiene 11 grabados. Ahí se encuentran las calaveras del artista Diego Rivera, conocido también como integrante notable del Partido Comunista (fig. 17) con una durísima crítica por su posición ideológica: "Por ejemplo a Juan Rejano albañil no le pagó y en conciliación ganó a fuerza de untar la mano..."), del Dr. Atl, del creador de los Batallones Rojos en Rusia Trotzki (sic) “...Sus errores en tamal, aflojó aquí este señor. Lo mató su gran tumor de Cuarta Internacional..."), así como calaveras de figuras italianas reconocidas como Pirandello, Marconi y D’Annunzzio. También aparecen otros personajes del momento que formaban parte de la vida política del país, tales como el Secretario de Guerra Quiroga ("No quiso la suerte perra del callismo injusto que yo

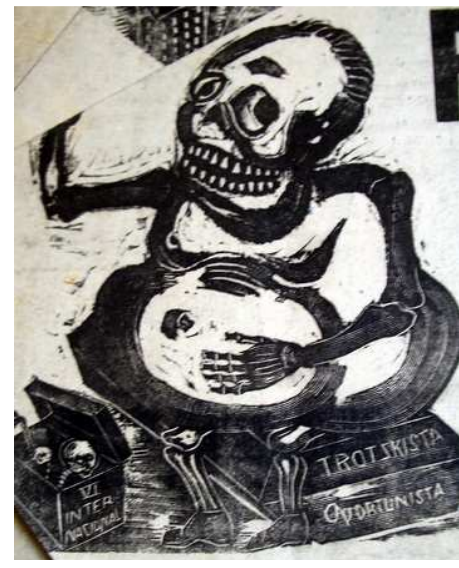

Fig. 17 Calavera de Diego Rivera en El Machete muriese a gusto de Secretario de la Guerra..."), y del político consentido del callismo: Aarón Sáez.

\section{El Taller de Gráfica Popular (TGP)}

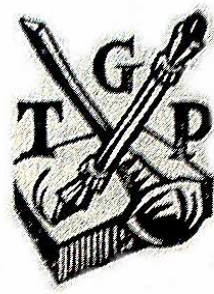

Fig. 18 Logotipo Taller de la Gráfica Popular

El Taller de Gráfica Popular (TGP) se funda en el año de 1938 con un logo que ha permanecido desde entonces. ${ }^{25}$ (fig. 18) Como ya se mencionó anteriormente formado por antiguos miembros de la LEAR y tuvo entre sus fundadores a Leopoldo Méndez, Zalce, O’Higgins, Luis Arenal, Ignacio Aguirre, Isidoro Ocampo, Everardo

\footnotetext{
${ }^{25}$ Véase el Catálogo de la exposición Leopoldo Méndez, artista de un pueblo en lucha de Ida Rodríguez Prampolini, México, CEESTEM, 1981. En relación a la opinión tenían sus propios miembros del mismo Taller, véase otro texto comparativo: "Veinte años de vida del Taller de Gráfica Popular", en Revista Artes de México, julio- agosto 1957.
} 
Ramírez, Raúl Anguiano, Jesús Escobedo y Ángel Bracho. Poco después el grupo aumentó al grado de que en sus mejores momentos rebasó la treintena, gracias a la promoción que consiguieron con los carteles que se pegaban en la vía pública y con las hojas volantes (la mayoría de las veces en formato $23 \times 34 \mathrm{~cm}$.) con las que consiguieron inundar la ciudad. Ellos tenían la convicción de ser los narradores gráficos populares del momento, de ser los artistas comprometidos a imagen y semejanza de José Guadalupe Posada logrando así una identificación con el pueblo. EI TGP pudo tener una gran presencia gráfica debido a tres aspectos fundamentales:

a) La creación de organizaciones sindicales y obreras poderosas que recibían apoyo gráfico mediante la impresión de propaganda y de carteles de grandes tirajes.

b) Movimientos sociales y políticos que cohesionaron en su momento a la nación y que fueron únicos en la historia de México, como la expropiación petrolera por el gobierno Lázaro Cárdenas.

c) El enfoque político que se dio en la producción de obra gráfica realizada en forma colectiva

\section{1 La obra gráfica del TGP}

La producción gráfica del TGP es interesante por la abundante producción de temas de muerte y violencia que en sus primeras experiencias colectivas era firmada recordando que algunos de sus integrantes habían pertenecido a la extinta LEAR, como fue el caso de la carpeta "En nombre de Cristo... han asesinado más de 200 maestros" realizada en 1939 por Leopoldo Méndez. Dicha carpeta, consiste en 7 dramáticas litografías de los maestros rurales brutalmente asesinados por las guardias blancas y son consideradas como un documento fuerte, ya que no hay concesiones con respecto a la manera de mostrar y 
representar dicho suceso, pues pasa del texto breve a la imagen directa de la muerte. Todas, sin excepción, son escenas de mártires muertos en aras de un ideal educativo; sin embargo, al ser plasmadas en la piedra litográfica le dan realismo y objetividad a la información trágica. Reyes Palma, al referirse a las ilustraciones de esta carpeta gráfica, escribe que “...la estampa adquiere tal violencia expresiva que no deja dudas de que se trata de una representación de un sentimiento de profunda indignación ante la injusticia y no la representación del hecho mismo". 26

Las litografías se hayan unidas por el

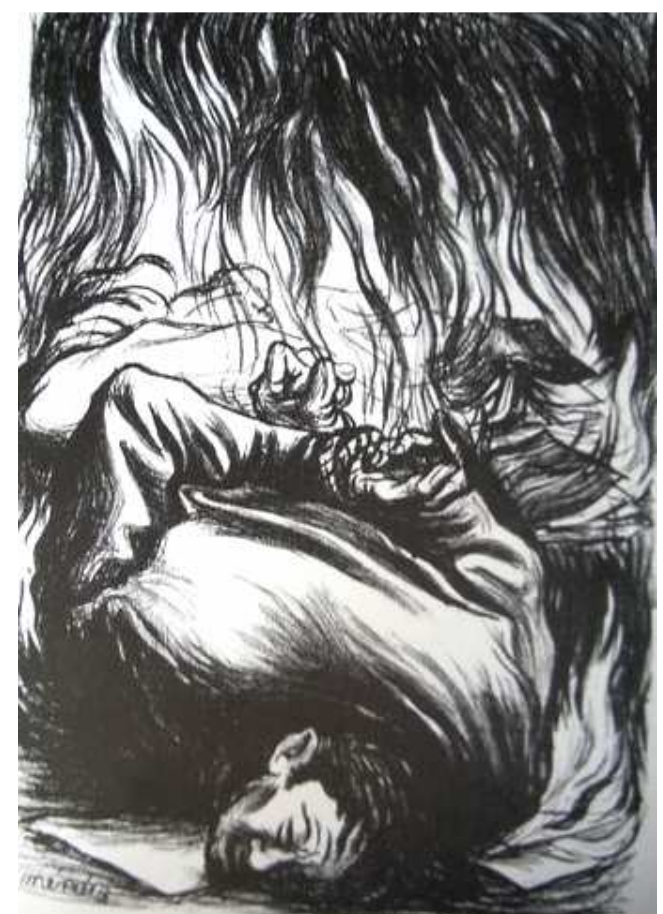

Fig. 19 De la serie En Nombre de Cristo... Litografía de Leopoldo Méndez mismo discurso visual gráfico, ya que conforman un conjunto donde no existe un grado menor de violencia, porque al fin y al cabo representan hechos vergonzosos de muerte producidas por la colectividad rural hacia la individualidad y que puede leerse como una lucha de la ignorancia contra el miedo al conocimiento, como se aprecia en la figura 19. La permanencia y trascendencia de estas imágenes se debe a que fueron recogidas en una carpeta impresa en la Ciudad de México (lo que aseguraba que la carpeta llegará a una comunidad cuya conciencia social permitiría su divulgación, no sólo de los grabados en sí, sino del suceso mismo), y cuyo contenido, que no resulta nada grato en cuanto a la información misma, representan hechos lamentables de ignorancia y barbarie acaecidos a unos cuantos años de la Revolución. Por otra parte, la matanza fue descrita de manera

${ }^{26}$ Francisco Reyes Palma, "Radicalismo artístico en el México de los años 30 una respuesta colectiva a la crisis", en Revista de la Escuela Nacional de Artes Plásticas, Volumen 2, número 7 , diciembre 1988, febrero 1999, p. 10. 
concreta, y el dibujo que representa la escena es directo. Para ese efecto la imagen de la figura 20 es cruda: Un maestro antes de ser sacrificado es obligado por un terrateniente a escribir en la mesa del salón de clase una frase aún incompleta para el espectador: "Que Viva Cristo Rey"

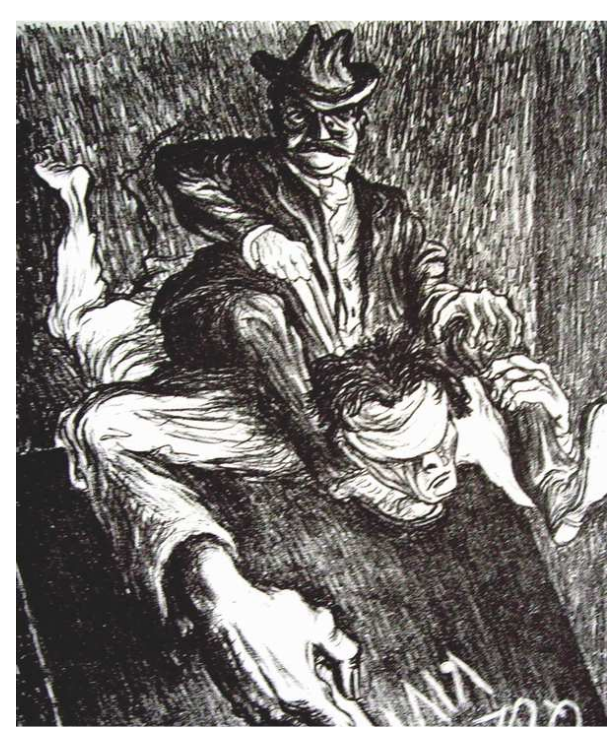

Fig. 20 De la serie

En Nombre de Cristo... Litografía de Leopoldo Méndez

La carpeta lleva en la carátula el nombre de Leopoldo Méndez que pertenecía en ese entonces al Centro Productor de Artes Plásticas del Departamento de Bellas Artes y está dedicada "A la memoria del ideólogo Aníbal Ponce como maestro y guía de las masas oprimidas de América" ${ }^{27}$. La carpeta se encuentra seccionada en dos partes: en la izquierda el texto y en la derecha la imagen interpretada litográficamente. El nombre del profesor está marcado por gruesa tipografía en altas y sin acentos; inmediatamente abajo de una gruesa pleca negra, el nombre de la víctima para dar cuenta en letra más pequeña, de los lamentables acontecimientos del lugar y los hechos. Los nombres de los profesores sacrificados fueron los siguientes:

Profesor Ramón Orta del Río. Asesinado en Barrranca del Qro, Opio. de Amatlán de la Caña, Nay., el 4 de junio de 1938.

Profesor Juan Martínez Escobar. Asesinado en presencia de sus alumnos en Acámbaro, Gto., en junio de 1938.

\footnotetext{
${ }^{27}$ En los años 30's en la Ciudad de México, el libro de Aníbal Ponce Educación y Lucha de Clases fue un texto básico en los artistas, y en los ideólogos políticos; de ahí su repercusión en amplios círculos de la intelectualidad mexicana. Era pues, en términos coloquiales, lo que puede llamarse un libro de cabecera sobre todo en los círculos de izquierda y en las formaciones de jóvenes en proceso de formación comunista.
} 
Profesor Arnulfo Sosa Portillo.

Asesinado el 6 de abril de 1937, en San Andrés Xochimilco, Pueb.

Profesor José Martínez Ramírez. Asesinado en Customatitla, Tochimilco, Pues., el 28 de febrero de 1938.

\section{Matanza de campesinos y maestros en San Felipe Torres Mochas, Gto. "16 MUERTOS Y 26 HERIDOS TODOS CAMPESINOS, NIÑOS Y MAESTROS”... ("Excélsior" 31 de marzo de 1936).}

Profesor Ildefonso Vargas. Asesinado en Cuahuigtic, Chignahuapam, Pue. el 12 de julio de 1938.

Todas las víctimas sacrificadas se encuentran entrelazadas con la violencia en lugares apartados donde era difícil, por no decir imposible, el impedimento de acciones que atentaran contra la integridad física, y que permitieron desgraciadamente para ellos la llegada de la muerte. Cabe aclarar que los crímenes nunca fueron ni aclarados, ni a las víctimas les llegó jamás la justicia por parte de autoridad alguna.

Un aspecto relevante es la utilización en el dibujo de las distorsiones del rostro de los victimarios como lo ha realizado magistralmente Méndez en la litografía de la figura 21.

El crítico alemán Peter Burke usa un paralelo cuando se refiere a la utilización de estas transformaciones monstruosas en que terminan los seres que no se parecen a nosotros:

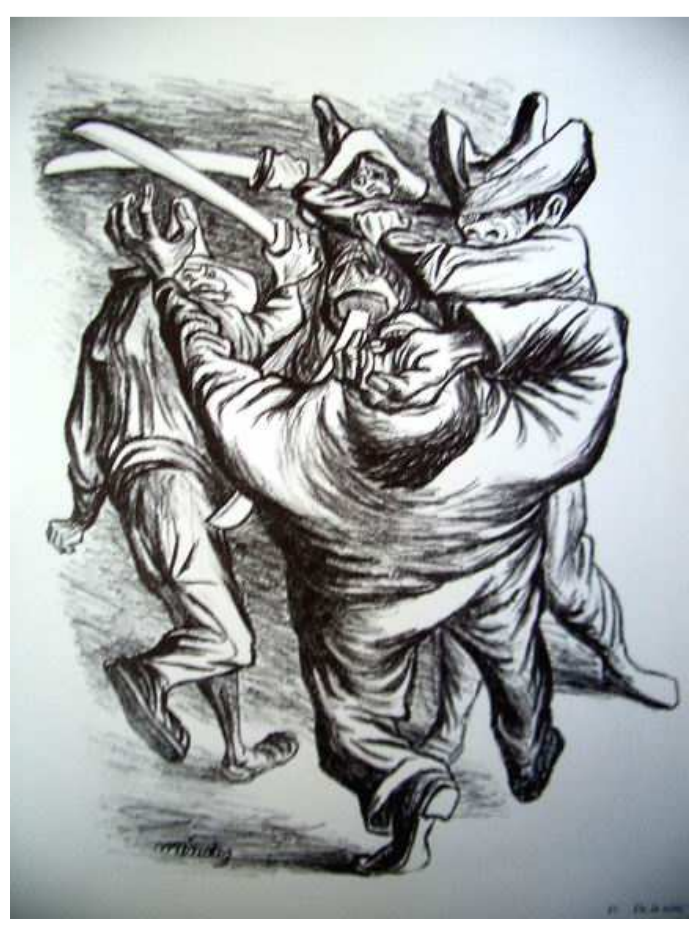

Fig. 21 De la Serie En Nombre de Cristo... Litografía de Leopoldo Méndez 
...los estereotipos más crueles se basan en la simple presunción de que "nosotros" somos humanos o civilizados, mientras que "ellos" apenas se diferencian de animales tales como el perro o el cerdo, con los que a menudo se les compara ${ }^{28}$

La escena donde se da muerte al profesor constata, en efecto, en un primer plano la acción del descuartizamiento de la figura de Arnulfo Sosa, quien por soprendido por la acción violenta es empujado hacia atrás, hacia el espectador siendo asesinado por tres personajes con rasgos caricaturizados por el grabador que quiso, con este hecho, acaso demostrar a través del dibujo que la acción propia de estas muertes sólo la podían llevar a cabo seres no racionales.

La Segunda Guerra Mundial ofrece al Taller la oportunidad de condenar los crímenes del fascismo, y al mismo tiempo abordar a través de la gráfica en blanco y negro las causas populares, mediante el linóleo y la litografía que acentúan la visión y la influencia proveniente en primer lugar de Francisco de Goya en la serie de Los Desastres de la Guerra"29 y después de los grabadores alemanes a partir de la serie sobre la guerra como Otto Dix en sus dibujos a la punta seca de cuerpos y rostros desfigurados así como de calaveras agusanadas; y de Oscar Kokoshka en los trazos sueltos a manera de bocetos sobre la piedra litográfica y de las soluciones gráficas de blanco y negro de la extraordinaria artista Käthe Kollwitz. ${ }^{30}$

En un impreso sin fecha del TGP dibujado a grandes trazos con lápiz litográfico que lleva el título de "La guerra de los frijoles. Comité de Subsistencias:

\footnotetext{
28 Peter Burke, Visto y no visto. El uso de la imagen como documento histórico, España, Traducción de Teófilo de Lozaya, Editorial Crítica, 2000. p. 159.

${ }^{29}$ Esto es solo un criterio personal, sin embargo el aspecto de los horrores de la guerra realizados por los grabadores mexicanos (Méndez, Chávez Morado, y en especial de Alfredo Zalce) no se pueden desligar de Francisco Goya y de su tratamiento gráfico, fundamentalmente por el manejo de la luz, la violencia y sobre todo por la interpretación personal sobre el tema de la muerte. Véase Francisco de Goya "Los Desastres de la Guerra" Revista / Catálogo de la exposición. Presentación de Héctor Perea, UAM, Galería Metropolitana, abril- junio, 1992.

${ }^{30}$ Véase el libro de Robin Reisenfeld, The German Print Portfolio 1890-1930 Serials for a Private Sphere, The David and Alfred Smart Museum of Art / The University of Chicago, 1992.
} 
Toma de Cristo Experiencias", se refiere a la escasez de alimentos de primera

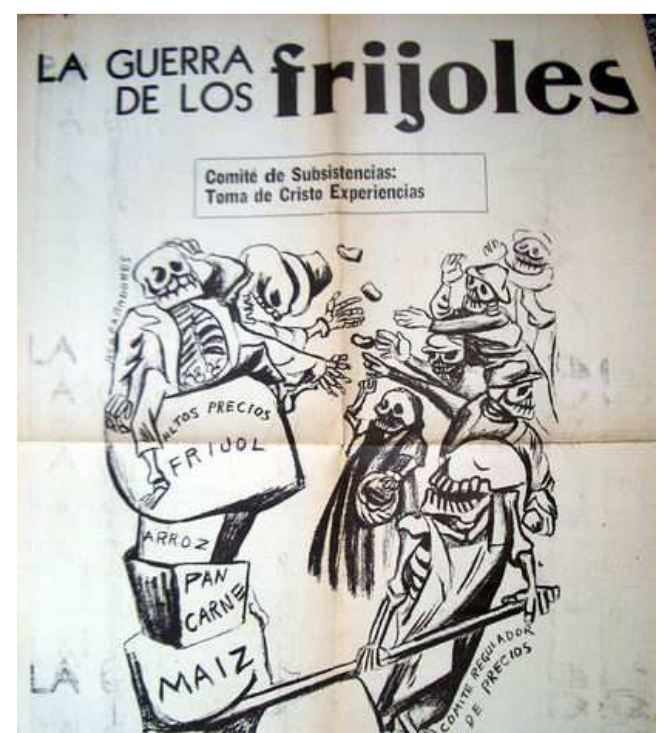

Fig. 22 Pablo O'Higgins La Guerra de los Frijoles Periódico.s/f

necesidad en el pueblo mexicano por efectos de la Guerra. ${ }^{31}$ (fig.22)

En el grabado, dos personajes calaveras identificados con letra como acaparadores, se encuentran arriba de una columna de alimentos de primera necesidad (maíz, frijol, pan, carne) y de esta cantidad de alimento sólo reparten al pueblo unas cuantas semillas. Esta escena es asistida por otra calavera que representa el "Comité Regulador de Precios". Con referencia a estas imágenes, Leopoldo Méndez explicaría a Elena Poniatowska el contenido del grabado realizado años atrás.

...los encargos de trabajo en que teníamos que reunirnos para hacerlos en común eran esporádicos. Algunos provenían de organismos oficiales y semioficiales como el Comité para el Control de Subsistencias. En nuestros grabados luchamos porque los acaparadores de semillas y de alimentos de primera necesidad no abusaran de los campesinos y el Comité era el que fijaba los precios en el Mercado. Sin embargo, cuando los comerciantes que compraban subían el precio sobre el ya fijado por el Comité Regulador, el famoso Comité desaparecía como por arte de magia, y todo quedaba en manos de los comerciantes... ${ }^{32}$

En el reverso de la página donde aparece el comentario anterior, aparece un breve texto con el título de "El misterio del gran hueso" bajo la forma de drama en 3 actos que intentan ilustran al lector la situación del momento. En el primero de ellos se muestra un sótano donde dos personajes que representan a Daladier y el primer ministro inglés Chamberlain, se encuentran sentados en una mesa

\footnotetext{
31 Adjudicados recientemente a Pablo O’Higgins. Véase Pablo O’Higgins: un cuarto de siglo en el TGP. Pablo O'Higgins voz de lucha y de arte, UNAM, CONACULTA, México, 2005, p.118.

32 Elena Poniatowska, "El Taller de Gráfica Popular en palabras de Leopoldo Méndez", en revista Galera, México, Año 4, número 31, invierno 2002, p. 19-27.
} 
repartiéndose lo que acaban de robar, en el extremo derecho, Hitler baja las escaleras armado de puñales. (fig. 23) El segundo grabado se representa un

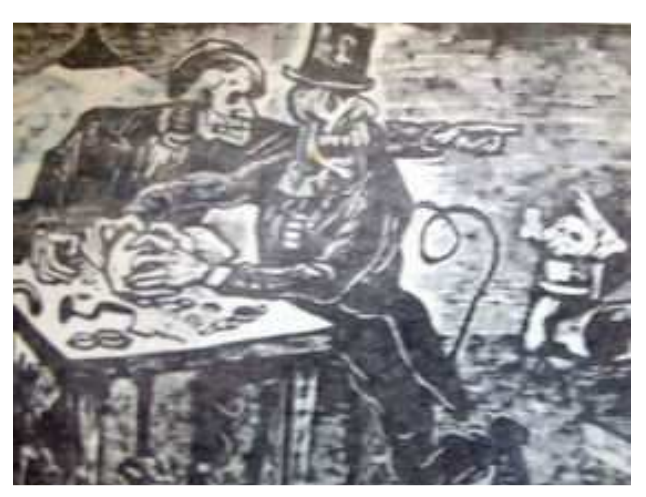

Fig 23 El misterio del gran hueso. Primer acto

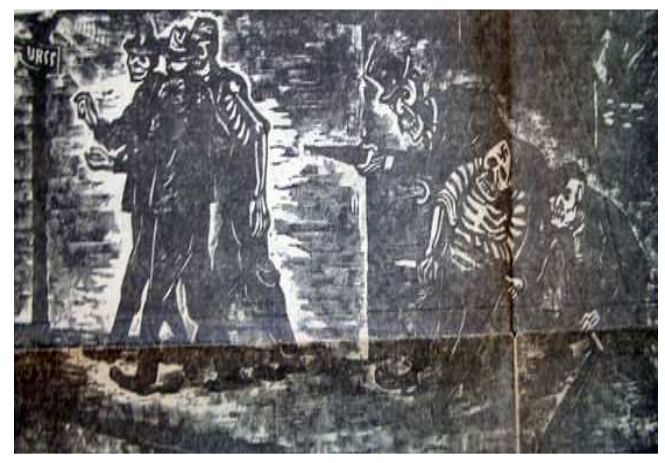

Fig 24 El misterio del gran hueso. Segundo acto

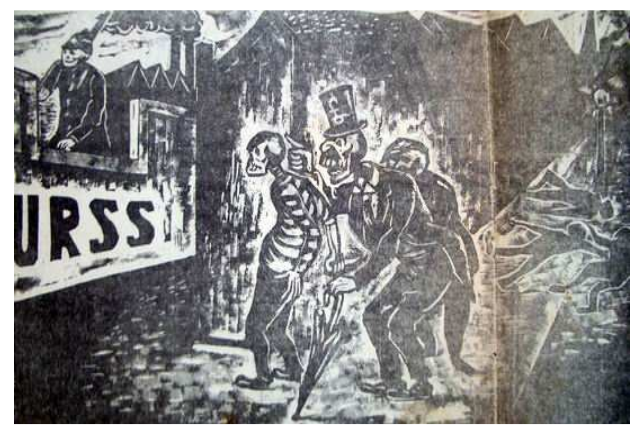

Fig 25 El misterio del gran hueso. Tercer acto callejón oscuro (callejón de Munich) donde se esconden tres ladrones: Chamberlain, Daladier y Hitler que asaltarán a otros tres personajes vestidos de campesinos y obreros que caminan hacia la calle de la URSS. (fig. 24) El tercer cuadro muestra en el lado derecho las sombras de obreros $y$ campesinos muertos, mientras los personajes centrales se topan con una barda que lleva el letrero de URSS, mismos que permite observar el contorno de una fábrica en producción que es vigilada por un celador armado con su fusil al hombro. (fig.25).

Entre los "actores" que aparecen en el reparto de esta pequeña obra de teatro se encuentran algunos protagonistas de la vida nacional de México que tienen asignado su papel como integrantes de una compañía de teatro: Adolfo Hitler: Dr. Atl; Utilero: Diego Rivera; apuntador: León Trotsky, entre otros. Finalmente, en el mismo anuncio se dice que al término de la representación de la obra habrá tacos, tortas, tepache y pulque, hasta champaña y whisky. 
El TGP en su obra colectiva, recogió las más célebres calaveras en un ejemplar que a manera de homenaje le rindiera en 1957 la revista cultural Artes de México ${ }^{33}$ como un reconocimiento a su labor popular. En el volumen se reunieron trabajos principalmente cuya temática refiere los difíciles momentos de cohesión nacional, en virtud de que los diferentes gobiernos posrevolucionarios no habían logrado una completa estabilidad del país. Sumado a lo anterior, también se tocaban los problemas de liderazgo político, la escasez de productos de primera

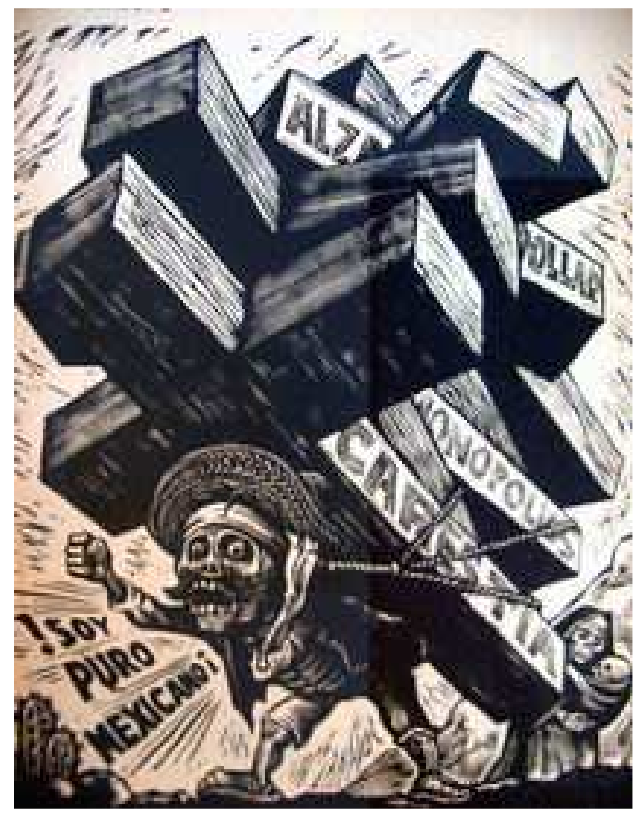

Fig. 26 ALberto Beltrán /TGP "¡Soy puro mexicano! " necesidad entre el pueblo y la difícil situación social que golpeaba a las clases más desprotegidas.

Algunos de estos grabados de temas de calaveras son interesantes por la temática versada y su solución gráfica resuelta con gracia: Un primer ejemplo se titula "Soy puro mexicano", de Alberto Beltrán (fig. 26) En este grabado se muestra una calavera sombreruda y bigotona que grita orgullosa al viento la frase que da

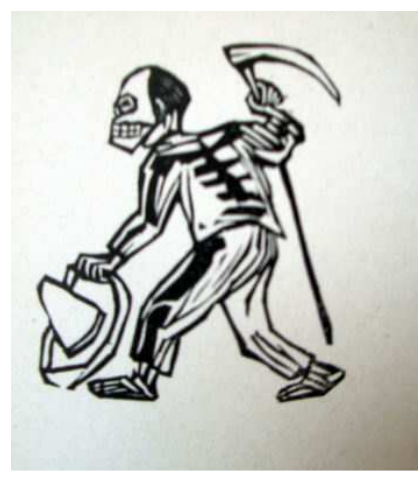

Fig. 27 Zalce viñeta para "El Sombrerón" nombre a la obra, mientras, a manera del heroico pípila, carga varias cruces sobre su espalda, las cuales llevan un letrero que indica el peso de cada una: la carestía, los monopolios, el alza del dólar, etcétera.

Otro ejemplo del uso de la muerte son las 40 ilustraciones en linóleo de Alfredo Zalce para el texto de de Bernardo Ortiz de Montellano titulado El Sombrerón ${ }^{34}$ (figs. 27 y 28) para el fondo editorial que el TGP había

\footnotetext{
33 “Veinte años de vida del Taller de Gráfica Popular”, en Revista Artes de México, Volumen III, Año V, número 18, julio y agosto de 1957.

${ }^{34}$ Bernardo Ortiz de Montellano, El Sombrerón, México, La Estampa Mexicana, 1946.
} 
creado con el asesoramiento del arquitecto suizo Hannes Meyer llamada La Estampa Mexicana. En este texto se narran las leyendas mayas-quichés de un personaje que posee poderes eróticos sobrenaturales.

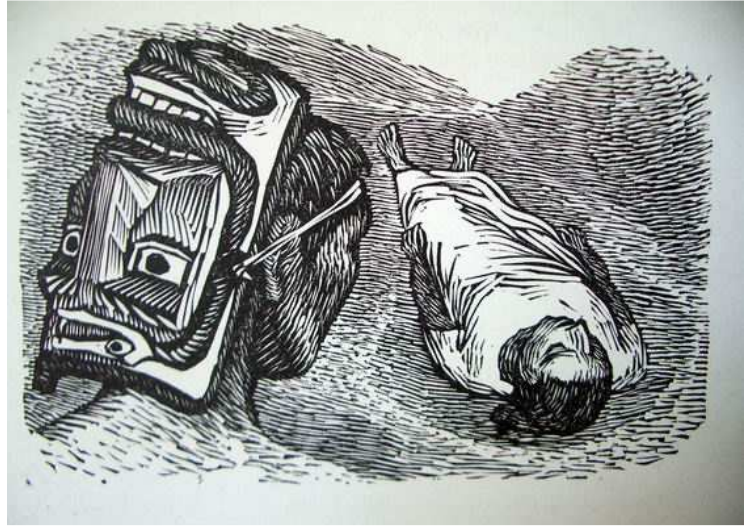

Fig. 28 Zalce viñeta para "El Sombrerón"
Terminados los años de la guerra, y la lucha antifascista, los integrantes del TGP volcaron su interés hacia los temas nacionales, en especial hacia el campesinado y el proletariado siempre marginados de las políticas nacionales. "Calaveras Televisiosas" impresa en papel morado claro puede ser un buen ejemplo. (fig. 29) La escena cotidiana se divide en dos partes con un texto central

en verso y la pobreza y la televisión como motivo.

La televisión fue introducida en el gobierno de Miguel Alemán Valdés (importante accionista) y fue al igual que en muchas partes del mundo, una sensación como atractivo visual. ${ }^{35}$ Las calaveras grabadas por el TGP agregaban un subtítulo de doble sentido como toda expresión mexicana alburera: "Todo por un hoyito". En el grabado superior un grupo de calaveras obreras que

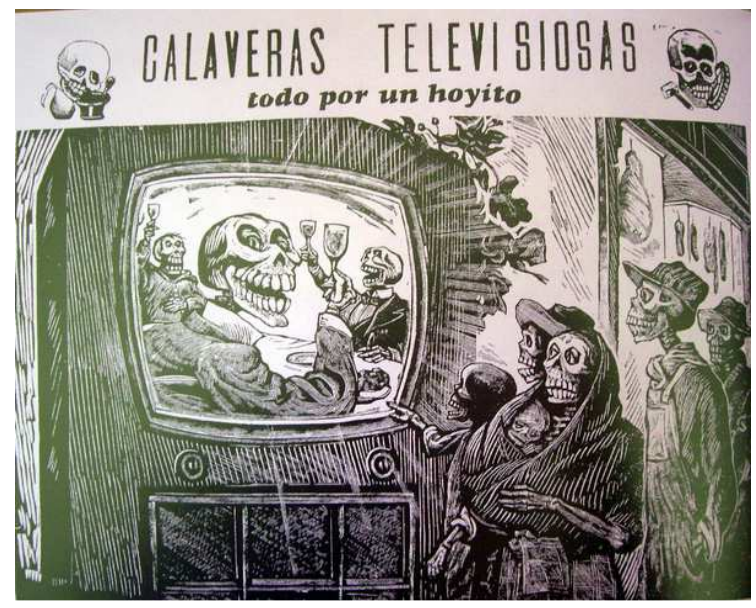

Fig. 29 TGP Calaveras televisiosas

\footnotetext{
${ }^{35}$ Está confirmado documentalmente que el gobierno de Miguel Alemán cuyo mandato fue conocido por el manejo de grandes cantidades de dinero para sobornos políticos, otorgó las concesiones de la naciente televisión a un grupo selecto de empresarios con la idea de hacer "revanchismo político". Con este fin utilizó a prestanombres poderosos para participar en el medio televisivo. Uno de ellos era el empresario Rómulo O'Farrill distribuidor de autos en Puebla y amigo de Alemán al que dio la primera concesión para la televisión mexicana en 1949. Véase mayor información en Claudia Fernández y Andrew Paxman en El Tigre Emilio Azcárraga y su imperio Televisa, Grijalbo Mondadori, México 2001, pp. 59-65.
} 
representan al pueblo observan un aparador callejero con una televisión en la cual tres elegantes calaveras comen y brindan en un banquete. De otros aparadores cuelgan jamones y chorizos. La parte inferior del grabado indica el título: "Ora si ya no hay tortillas, pero...;Que tal televisión! Acompañados de versos en los cuales es significativo el primero de ellos llamado "Carestía de la Vida":

\author{
Excelsior y Novedades \\ La Prensa y Universales \\ panteones de necedades \\ murieron hoy por venales \\ Pues los muertos de esos diarios \\ socios de acaparadores \\ resultan más mercenarios \\ al mostrarse redentores \\ Si de bajar precios hablan \\ tenga usted a buen seguro \\ que nuestra miseria entablan \\ o dejan en peor apuro.
}

En la parte inferior se acompaña con un pequeño grabado de la autoría de Mariana Yampolsky titulado "Colas". En la obra se muestra justamente una larga cola de calaveras de hombres, mujeres y niños del pueblo que esperan formados para ser atendidos en miserables locales que se encontraban afuera de las vecindades y ostentan letreros de productos de primera necesidad (fig. 30)

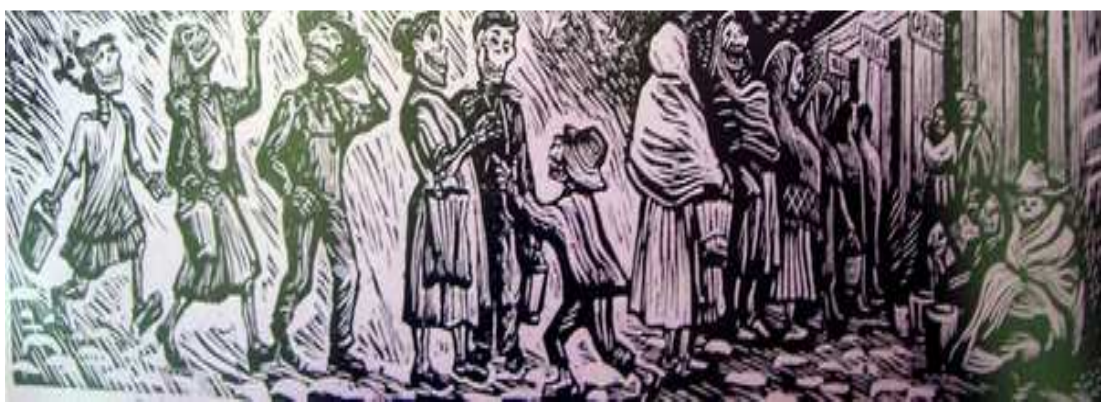
Fig. 30 "Colas" Grabado de Mariana Yampolsky 
Casi para terminar el año de 1960, el TGP realizó un álbum colectivo titulado 450

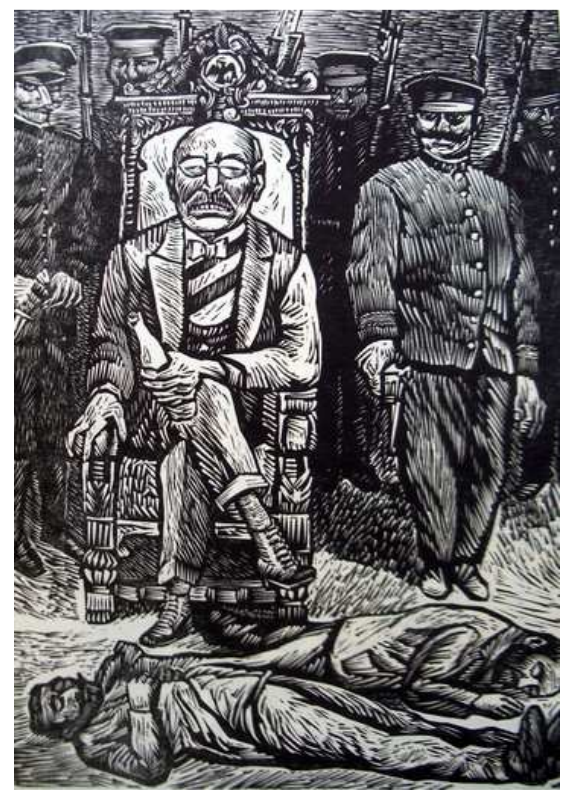

Fig. 31 Alfredo Zalce

El criminal Victoriano Huerta se adueña del poder 19 de febrero de 1913 años de lucha. Homenaje al pueblo mexicano, en el cual participaron 25 artistas. ${ }^{36}$ En él se encuentran 146 estampas la mayoría trabajadas en linóleo cuya temática giraba en torno a la lucha social del pueblo de México. Originalmente habían sido realizadas para otra carpeta llamada entonces Estampas de la Revolución Mexicana, que produciría Hannes Mayer en 1947. Del álbum se pueden extraer algunos ejemplos en los que se maneja el tema de la muerte y que ilustran, desde el punto de vista del TGP, el desarrollo de la Revolución Mexicana.

La muerte de los próceres Francisco I. Madero y José María Pino Suárez en la antigua penitenciaría de la Ciudad son colocados en primer plano del grabado de Alfredo Zalce en "El criminal Victoriano Huerta se adueña del poder el 10 de febrero de 1913", su gran dibujo destaca la figura siniestra del asesino del presidente y vicepresidente, rodeado de los soldados federales que finalmente traicionarán la Revolución. (fig 31)

Por su parte, Alberto Beltrán representa en la obra "Intentos de la dictadura de Victoriano Huerta por liquidar el zapatismo" (fig. 32) el saqueo del general federal Juvencio Robles de los pueblos

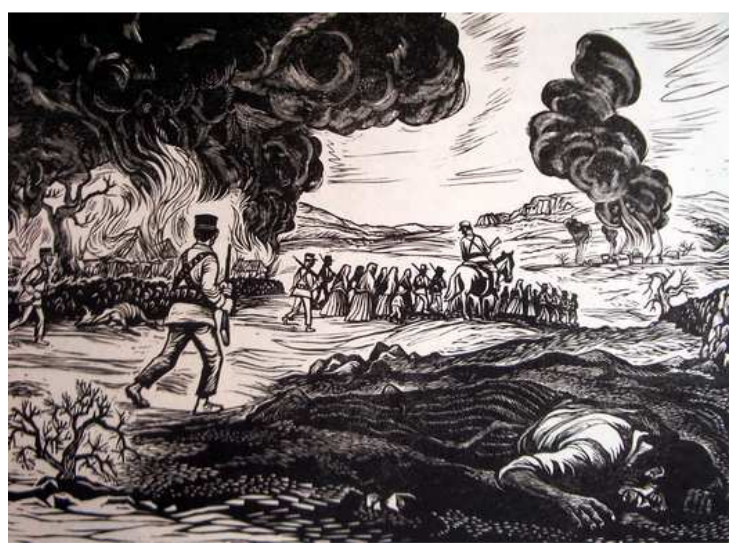

Fig. 32 Alberto Beltrán Intentos de la dictadura de Victoriano Huerta por liquidar el zapatismo.

\footnotetext{
36 Taller de Gráfica Popular 450 años de lucha. Homenaje al pueblo mexicano, obra colectiva de los artistas del Taller de Gráfica Popular en México, notas históricas de Enrique Ramírez y Ramírez, México, 1960.
} 
del Estado de Morelos. La escena muestra en primer plano el cuerpo de un ranchero muerto, mientras en el árido paisaje se observan las humildes rancherías.

Arturo García Bustos en un linóleo realiza un tema que tema que versa sobre el movimiento armado del Sinarquismo. (fig. 33) En primer término, del lado izquierdo el grabado, se observan una calavera sujeta a un poste, la bandera

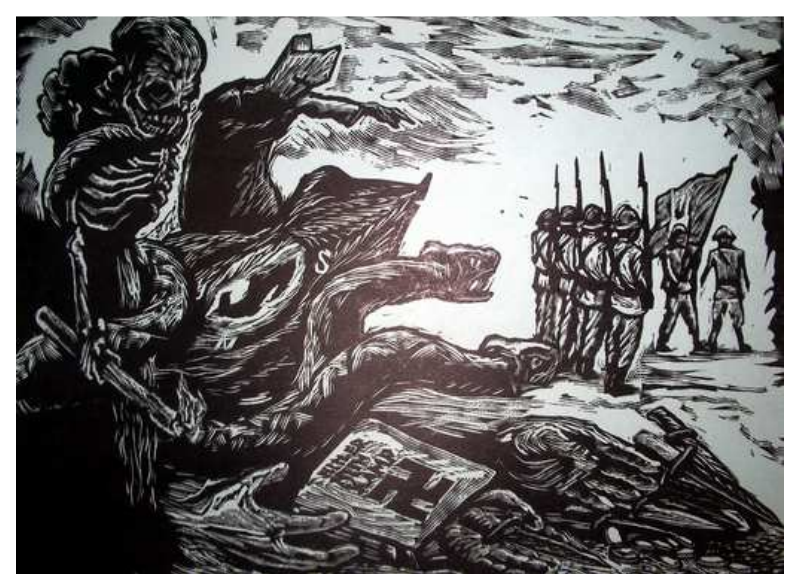

Fig. 33 Arturo García Bustos El Sinarquismo sinarquista y el libro Mi lucha de Hitler; hacia el lado derecho, unas manos ofrecen dinero y armas en forma de puñales. En el fondo y a lo lejos, un jerarca religioso inclinado señala a un pequeño grupo de soldados mexicanos que hacen honores a la bandera mexicana, hacia donde deben de dirigirse estas formas malignas.

Desgraciadamente hacia los años sesenta hubo un desmembramiento de los miembros del TGP que motivó su desaparición en forma gradual. Otro factor sin duda importante fue la prohibición durante el gobierno del presidente Adolfo López Mateos (1958-1964) y del regente (alcalde) de la Ciudad de México, Ernesto P. Uruchurtu (apodado el "Regente de Hierro"37), de pegar propaganda política lo cual dejó sin sentido la difusión de ideas de izquierda por medio de la gráfica utilizado entre los artistas del Taller.

Sin embargo es de reconocer la enorme presencia del TGP en el grabado mexicano, así como su aportación al arte universal en el siglo $\mathrm{XX}$, ya que sus miembros se entregaron a su labor y a su filosofía artística, dejando sus vidas y su arte plástico como aporte para las generaciones siguientes.

\footnotetext{
37 Debido a su dureza y a sus acciones antipopulares, un chiste muy conocido de la época Uruchurtu en la Ciudad de México fue el siguiente: “¿Cual es el colmo de un Regente? ¡Ser mula y a la vez ser re- gente!"
} 
Lo que resulta verdaderamente cierto es que fuera de la obra de Manilla y Posada, la obra colectiva del Taller de Gráfica Popular fue reconocida a nivel nacional e internacional gracias a la fuerza que como grupo demostraron, en

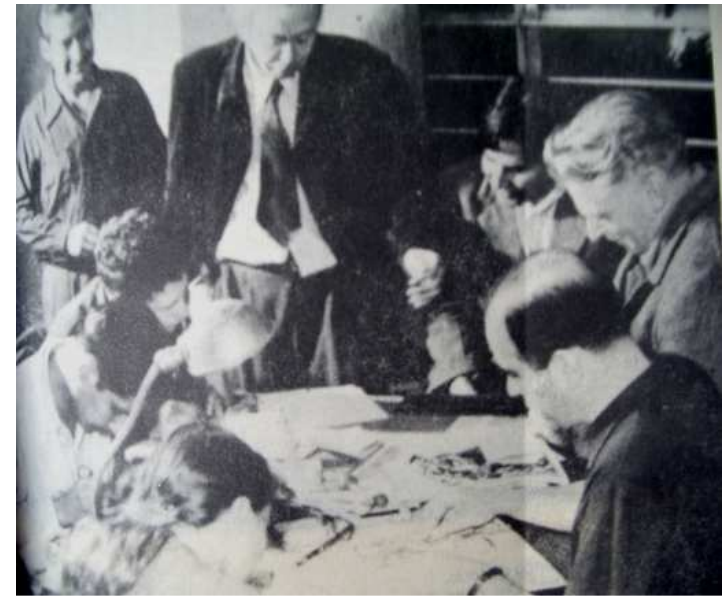

Fig. 34 Reunión de artistas para las "Calaveras" en los años 50. en el Taller de Gráfica Popular especial con las reuniones que hacían para realizar las "calaveras" que junto al texto irónico hacían las delicias del pueblo acostumbrado a reír el 2 de noviembre cuando se difundían en las calles de la ciudad de México. (fig. 34) Quizá fueron ciertos aquellos momentos a los que se referiría nostálgicamente Leopoldo Méndez, quien unos cuantos años antes de morir recordaba aquellos años del TGP:

¿La época más alegre de algunos años fue la del mes de octubre y a veces hasta el día $1^{\circ}$ de noviembre, en que debían estar nuestras "calaveras" vendiéndose en las calles! Pero aunque fuera después del día de Muertos, el 3 de noviembre, nosotros nos lanzábamos con nuestras calacas, porque teníamos que salir con ellas a como diera lugar... ${ }^{38}$

\subsection{Leopoldo Méndez, el grabador}

Sin duda alguna en el tema de la muerte no puede dejar mencionarse la presencia decisiva y contundente en el arte mexicano del grabador Leopoldo Méndez (19021969). Hábil dibujante y estupendo artista con la gubia, Méndez, supo imprimir en su obra, la fuerza de los trabajadores más desprotegidos del país. (fig. 35)

\footnotetext{
${ }^{38}$ Elena Poniatowska, op., cit., p. 27.
} 
Participante en diversas agrupaciones de artistas en los años en que los temas abordados eran prohibitivos y censurados por los gobiernos posrevolucionarios, Méndez participa joven en el movimiento del "estridentismo"39 en Veracruz; en la Secretaría de Educación Pública (SEP) mediante las llamadas Misiones Culturales, como muralista en los

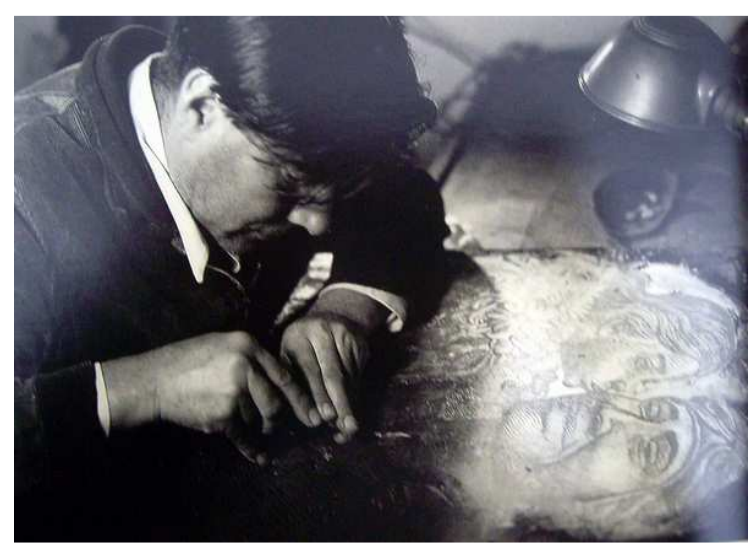

Talleres Gráficos de la Nación; y como artista en la Liga de Escritores y

Fig. 35 Leopoldo Méndez. Fotografìa

Artistas Revolucionarios (LEAR).

Funda asimismo el Taller de Gráfica Popular (TGP) donde organiza, coordina y exhibe su trabajo de factura única y estilo particular teniendo a José Guadalupe Posada como modelo a seguir por sus soluciones plásticas. (fig. 36)

Su trabajo artístico en el grabado se debe tratar aparte puesto que aportó un

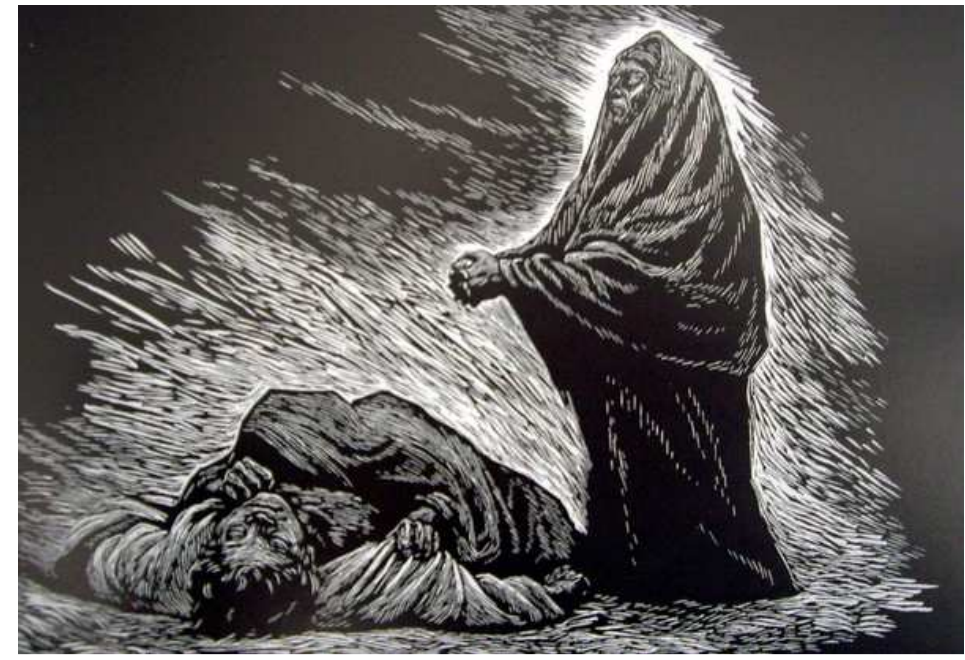

Fig. 36 Leopoldo Méndez El Fusilado trabajo consistente en la producción en las artes plásticas mexicanas. La obra de Leopoldo Méndez puede dividirse en dos partes: La que pertenece a la labor colectiva en las distintas organizaciones políticas y artísticas que ya hemos comentado en un capítulo

\footnotetext{
${ }^{39}$ Creación del escritor Manuel Maples Arce, el "estridentismo" tiene relación con el futurismo italiano de Filippo Tomasso Marinetti en donde la industrialización, el ruido, y la velocidad son factores reiterativos. Véase Laura Gonzáles Matute, "Dibujos y Murales del grabador Leopoldo Méndez", en Leopoldo Méndez 1902- 2002 Colección Carlos Monsiváis. CONACULTA, México 2002, p.96.
} 
anterior; y la que pudo realizar de manera individual en obra cartelística y editorial y fílmica por medio del Fondo de la Plástica Mexicana; y como ilustrador en libros y revistas que tienen que ver con el tema de la muerte. En el primero de los casos, - el Méndez ilustrador- sobresalen la producción para la revista Horizonte (1921), Martillo (Órgano del Departamento de Bellas Artes de la Secretaría de Educación Pública) y las "calaveras" ejecutadas por su cuenta para diferentes autores.

Su estilo comprometido le permitió colaborar en diversos proyectos editoriales. La propuesta literaria y plástica de un grupo de intelectuales contra la guerra se ve plasmada en El Libro Negro del terror nazi en Europa donde se reunieron testimonios de escritores y artistas de 16 naciones. El libro fue editado en México en 1943 por la editorial "El Libro Libre", y en él participaron con ilustraciones varios de los integrantes del TGP. A más de cincuenta años este sigue siendo un texto brutal en cuestión de contenido. No son las imágenes de guerra que se observan en libros sobre el tema de forma convencional; sino más bien la crudeza y el horror de la guerra. La selección de ilustraciones fue de Hannes Meyer y es significativo que aparezca en la primera página el dibujo de Frans Masareel ${ }^{40}$ (fig. 37) de una muerte avanzando y enarbolando una bandera hecha jirones y detrás de ella una multitud siguiéndola y una leyenda a pie de la imagen que dice:

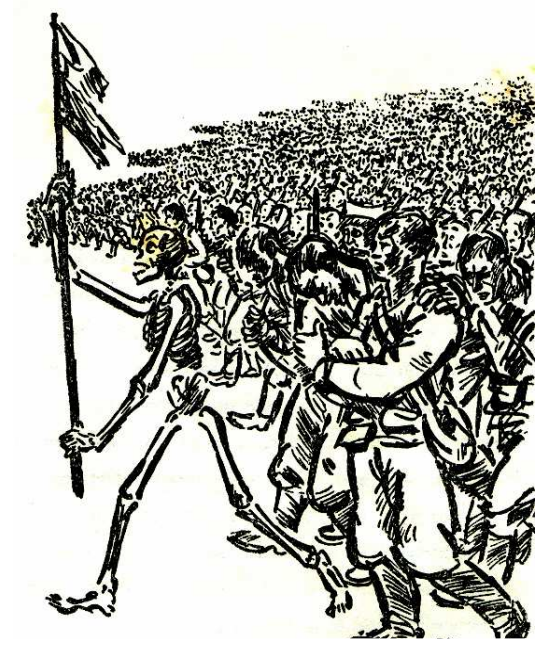

Fig. 37 Frans Masareel Viñeta para El Libro Negro

A todos los que murieron

A todos los que están luchando.

\footnotetext{
${ }^{40}$ El libro Negro del terror nazi en Europa, testimonios de escritores y artistas de 16 naciones. 164 fotografías 50 dibujos, Editorial "El Libro Libre, México, 1943. El dibujo a tinta es de F M, y corresponden al artista belga.
} 
Méndez participa, al igual que otros artistas nacionales ${ }^{41}$ con varios de sus grabados. Tal vez el más reconocido es el linóleo "Deportación a la muerte" (fig. 38). Ejemplo de excelente factura, a partir de una riqueza de grises y negros,

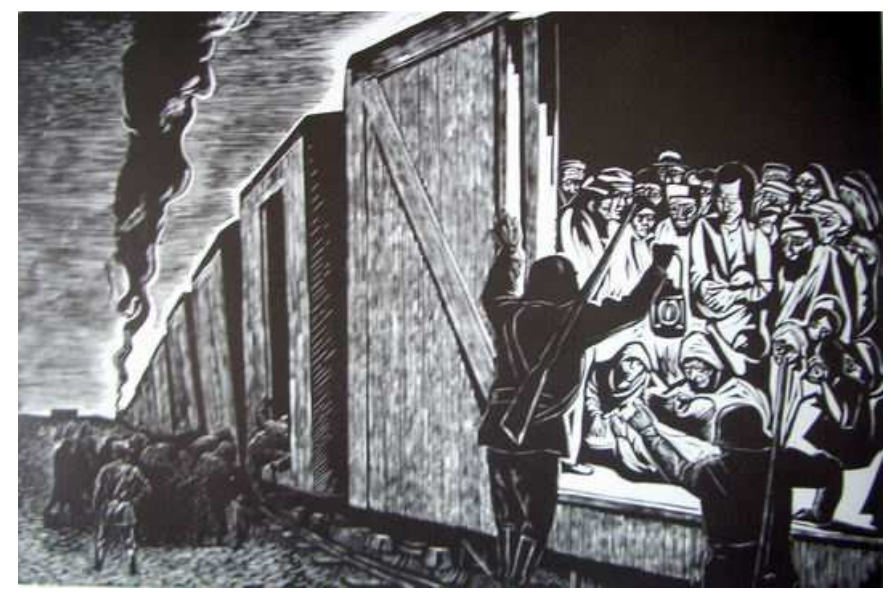

Fig. 38 Leopoldo Méndez Deportación a la muerte

dicho grabado muestra los vagones transportando judíos deportados a los campos de concentración, los cuales se hayan iluminados con el farol de un soldado nazi. La gráfica mexicana denuncia y expone a la comunidad nacional e internacional los horrores del nazismo alemán, a manera de continuadora de la obra de Kaethe Kollwitz.

Uno de los libros más bellos producidos en México en el siglo XX, es el que lleva por título Incidentes melódicos del mundo irracional ${ }^{42}$ que contiene un texto de Juan de la Cabada y 40 grabados de Leopoldo Méndez. El libro fue realizado en el año de 1944 y fue ganador del Concurso al Libro Mejor Ilustrado o Impreso en la 1V Feria del Libro $^{43}$ y estaba dedicado a la memoria del compositor Silvestre Revueltas, que había fallecido recientemente. ${ }^{44} \mathrm{El}$ escritor había contado la fábula

\footnotetext{
${ }^{41}$ Los otros participantes son Ignacio Aguirre, Ángel Bracho, Chávez Morado, Gabriel Fernández Ledesma, Pablo O' Higgins, Gonzalo de la Paz Pérez y Alfredo Zalce.

42 Juan de la Cabada, Incidentes melódicos del mundo irracional, edición facsimilar, México, Correo de las Américas, 1974.

${ }^{43}$ Para fortuna mía he localizado un viejo catálogo con datos sumamente valiosos de Leopoldo Méndez entre ellos probablemente la relación más completa de la obra de dibujo, gráfica y pintura. Aquí menciona la integración del jurado de dicho concurso y son las siguientes personas: Francisco Díaz de León, Gabriel Fernández Ledesma (compañeros de generación en la Academia de San Carlos) y Francisco Orozco Muñoz. Leopoldo Méndez 1902-1969, Academia de Artes, Exposición Homenaje, INBA, febrero- marzo 1970.

${ }^{44} \mathrm{La}$ presencia de los hermanos Revueltas es fundamental sobre todo en la década de los años 30's del siglo pasado. Silvestre Revueltas (1899-1940) músico, e intelectual comunista marcó a muchos de sus compañeros de generación y Leopoldo Méndez no es la excepción: en 1951 realizó el grabado de Silvestre Revueltas Muerto.
} 
a Silvestre Revueltas de manera informal, durante una larga travesía en barco como representantes de la LEAR en Europa.

Tres años después -a últimos de septiembre de 1940-, ya en México, Silvestre me llamó a su casa para pedirme la historia y los motivos musicales, pues tenía el encargo de una obra para el Ballet de Monte Carlo: A fines de la próxima semana murió Silvestre. De nuevo escribí la fábula. El libro Incidentes melódicos del mundo irracional, con cuarenta grabados de Leopoldo Méndez, apareció dedicado a la memoria de Silvestre Revueltas en 1944. Pronto se agotó. ${ }^{45}$

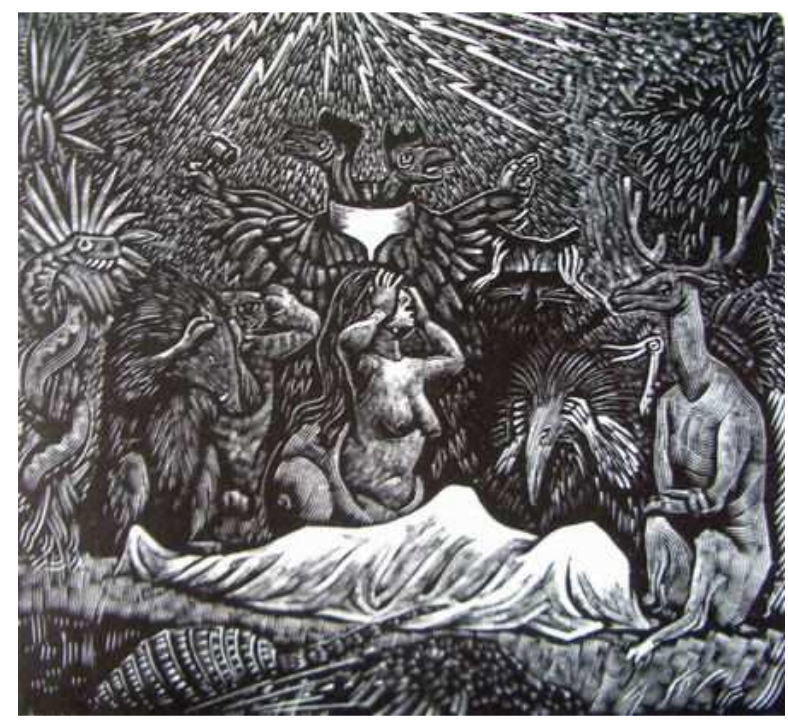

Fig. 39 Leopoldo Méndez, "El entierro del señor ardilla"
El texto es un homenaje a la vida, donde se narra la muerte de Don Ardilla, esposo de Doña Caracol, que al dejarla viuda la deja desamparada. La escena se encuentra bien desarrollada mediante un buen dibujo y un cuidadoso trabajo mediante el buril de velo. La atmósfera que rodea el velorio ese ha trabajado con

claroscuros afortunados y es de notarse el cuidado que Méndez ha puesto en el modelado de los animales que rodean a Doña Caracola muy semejantes a los velorios humanos. (fig. 39) En un intermedio del cuento, que incluye la música impresa en el papel, se presenta la

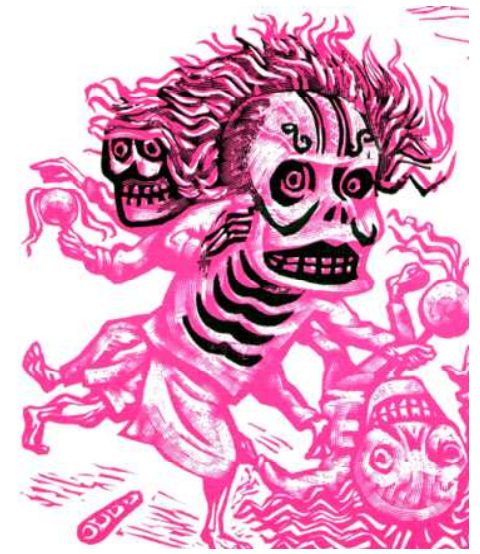

Fig. 40 Leopoldo Méndez "Danza de la muerte"

\footnotetext{
${ }^{45}$ Juan de la Cabada, C/D, serie: Voz Viva de México, Dirección General de Difusión Cultural, Departamento de Grabaciones, UNAM, México, 1968.
} 
escena, como una paráfrasis, de dos grupos de calaveras de carnaval que danzan frenéticamente. Para su realización el grabador ha utilizado la técnica del camafeo pero no son de tonos apastelados sino colores fuertes que producen un interesante contraste. (fig. 40) La historia continúa a partir de que Doña Caracol es llevada a la población de Animaletania (lugar de los seres irracionales) en las enormes alas de Don Zopilote que a cambio del viaje le pide que cuando el indique con un movimiento de alas, ella cantará como sólo ella sabe hacerlo. Lo que pretende el abusivo en el fondo es mover el pico y hacer creer a la gente que es él en realidad quien canta. El Zopilote a medida que es agasajado en la población se emborracha al grado de que pierde en un bailoteo a Doña Caracol y

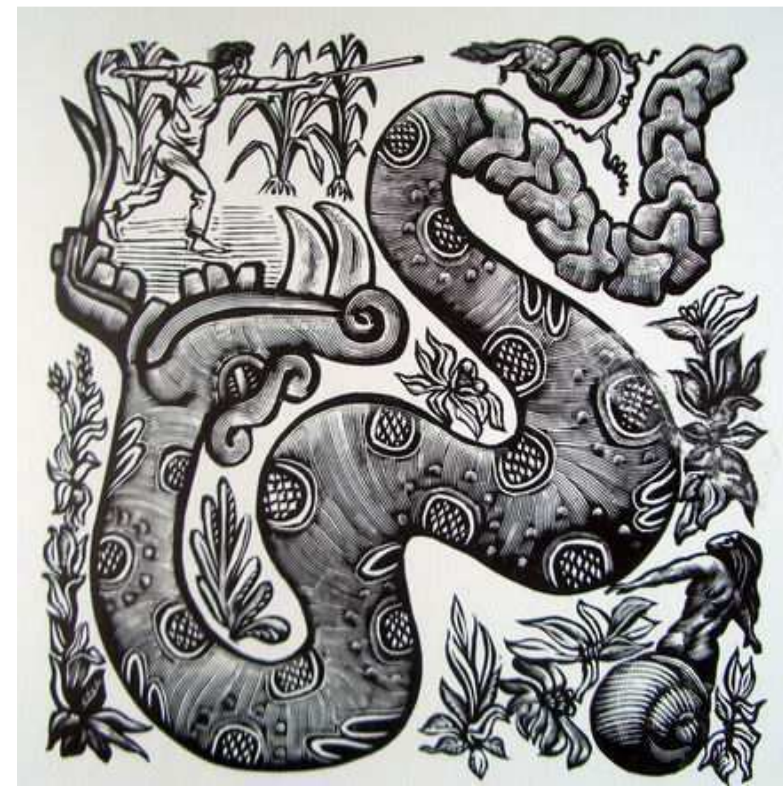

Fig. 41 Leopoldo Méndez, La serpiente de la Muerte al no poder repetir su canto dulce ante un público furioso, después de un juicio y emitido el veredicto por el cocodrilo es ahorcado en las ramas del árbol más alto por los habitantes del lugar. Mientras que, desmayada Doña Caracol, es encontrada y da cuenta de su triste historia. Ahora entienden los pobladores porque no salía gemido alguno del pico del enorme Zopilote. El único camino que le queda a la sufrida Doña Caracol al final de su historia es cantarle al sol y a la vida. Una viñeta utilizada

frecuentemente en el arte mexicano cuando se menciona el grabado mexicano, es una que precisamente procede del libro del q hemos estado hablando. La imagen es la del campesino que con su honda mata a Don Ardilla produciéndole la muerte y que ha sido bellamente enmarcada diagonalmente por una serpiente que es signo de muerte. En un espacio colocado del lado derecho se observa a Doña Caracola mirar la escena empequeñecida por la acción del campesino (fig.41) 
Por otro lado, de entre las calaveras producidas en 1947 por el artista sobresale el grabado Corrido de Stalingrado (fig. 42) con la soberbia figura triunfadora de un soldado soviético vencedor de las tropas alemanas montado en un corcel calavera. Atropellados por la furia de la acción son despedazados soldados nazis $y$ armamento. El texto que acompaña al grabado es de Juan de la Cabada y relaciona las luchas del pueblo mexicano contra la intervención extranjera y las equipara con la descabellada aventura de Hitler de apoderarse de Rusia. No hay que olvidar que en esos momentos existe en México un gran sentimiento de unidad nacional contra Alemania y que muchos de los artistas (por no decir que casi

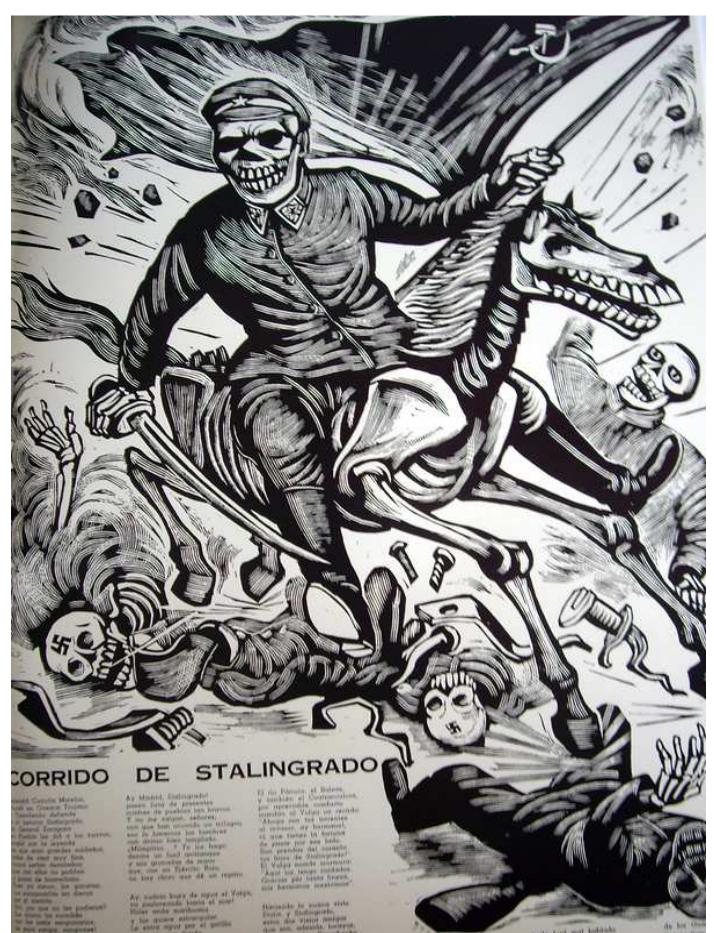
todos) pertenecían a partidos de izquierda $^{46}$. En una de sus partes dice lo Fig. 42 Leopoldo Méndez Corrido de Stalingrado siguiente:

$$
\begin{gathered}
\text { Defendió Cuautla Morelos, } \\
\text { triunfó en Oaxaca Trujado } \\
\text { y Timoshenko defiende } \\
\text { a la heroica Stalingrado } \\
(\ldots) \\
\text { El río Pánuco, el Balsas, } \\
\text { y también el Coatzacoalcos, } \\
\text { por apreciable conducto } \\
\text { mandan al Volga un recado: } \\
\text { "Ahoga con tus torrentes } \\
\text { al invasor, ay hermano! } \\
\text { tú, que tienes la fortuna } \\
\text { de pasar por ese lado. }
\end{gathered}
$$

\footnotetext{
${ }^{46}$ Aparte de su filiación política, Méndez era un gran admirador de los héroes de guerra soviéticos. Se conoce de él una litografía del rostro completo del Mariscal Timoshenko que dice en la parte superior "General Timoshenko, sus triunfos son los nuestros!"
} 
Son prendas del corazón tus hijos de Stalingrado!"

El Volga nomás murmura:

"Aquí los tengo cuidados

Gracias por tanta fineza

mis hermanos mexicanos".

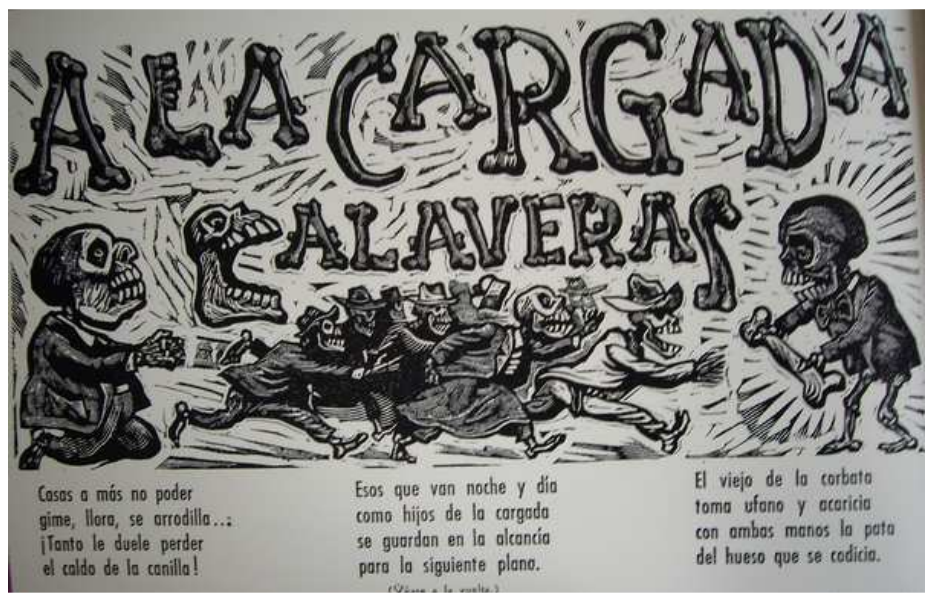

Fig 43 Leopoldo Méndez, "A la cargada calaveras"

En otra hoja de calaveras de 1951 titulada "A la cargada Calaveras" (fig. 43) Méndez juega con la tradicional costumbre de los presidentes de antaño de nombrar a su sucesor para el siguiente periodo. Así se observa la calavera prí́sta del candidato ganador Adolfo Ruiz Cortines colocada a la derecha de la cabeza del título, y con una corbata de moño ${ }^{47}$, que ofrece un gran hueso (en México así se le llama al trabajo que se busca para cobrar sin hacer nada) a otras calaveras de diferentes clases sociales que corren presurosas tras el gran hueso que les ofrece el anciano candidato. El texto indica en una de sus partes, el siguiente verso:

\author{
El viejo de la corbata \\ Toma ufano y acaricia \\ Con ambas manos la pata \\ del hueso que se codicia.
}

\footnotetext{
${ }^{47}$ Adolfo Ruiz Cortínes, candidato civil del Partido Revolucionario Institucional (PRI) para el sexenio de 1952-1958, obviamente ganó las elecciones por mayoría inclinada en lo que se ha llamado en México "La Aplanadora". Su forma de vestir fue siempre muy austera en la que su corbata de moño fue su característica principal así como su gran edad para ser candidato Sin embargo, se ha mencionado que Ruiz Cortínes ha sido el presidente que menos ha robado o que menos dejó robar a sus colaboradores. Su segunda esposa (de la que se divorció tiempo después) al contrario, tuvo fama de ambiciosa al grado de ganarse una mala reputación ante el pueblo. Al final de sus días, Ruiz Cortínes se retiró al Puerto de Veracruz donde murió en la más absoluta modestia económica.
} 
El grabado llamado "Calaveras inundadas" (fig. 44) muestra la realidad nacional en el que en un cuarto de vecindad el agua ha roto las frágiles paredes, y se hayan colgadas las pocas pertenencias de sus habitantes: unos cacharros de barro. Dos buzos armados con escafandras aparentemente ríen de la inverosímil situación, mientras sobre el pretil del muro un gato/calavera observa la situación.

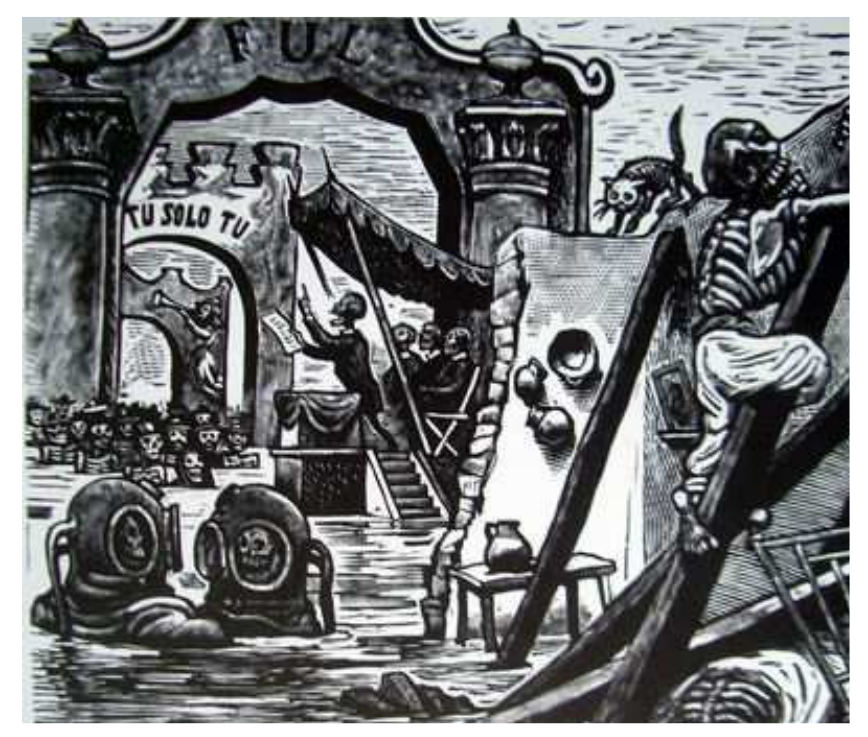

Fig. 44 Leopoldo Méndez "Calaveras Inundadas"

En el agua un ahogado yace colgado sobre la cama, mientras otra trepa ágilmente sobre una viga para salvar su vida de las aguas. En el fondo un orador, ajeno a los acontecimientos, lanza su arenga ante un público impasible, en tanto que sus seguidores lo escuchan plácidamente sentados. Tres arcos triunfales enmarcan la escena con las frases Ful y Tu sólo tu.

La temática de este grabado, tiene que ver con dos asuntos que corresponden al momento en que se vive: La participación de Leopoldo Méndez en la película Pueblerina de Emilio "Indio" Fernández con unos grabados en blanco y negro sobre el tema de la muerte del personaje principal magnificados por la pantalla cinematográfica hasta verlos como un gran mural gráfico. El título está basado en una canción ranchera de 1949 llamada "Tú sólo tú" del autor de temas campiranos Felipe Valdés Leal y fue conocida popularmente gracias al filme ${ }^{48}$ que describiremos más adelante. $\mathrm{Y}$ por otra parte la forma de sobre vivencia económica de la sociedad mexicana de la posguerra sin muchas posibilidades en ese entonces apoyándose en el refrán mexicano que dice sentirse “...con el agua

\footnotetext{
${ }^{48}$ Existe una película de 1949 llamada "Tú sólo tú" del director Miguel M. Delgado, pero con diferentes intérpretes. Por otro lado la letra completa puede encontrarse en La canción popular en el cine mexicano 1941-1950, C/D, Filmoteca Nacional UNAM, 1994.
} 
hasta el cuello". Habría que considerar como última instancia que existía un contacto inmediato entre el cine mexicano y su público en el que coincidía el desarrollo cultural con la sociedad que lo producía ${ }^{49}$. Habría que recordar que la Revolución y los temas emanados de ella fueron motivo de frecuentes manifestaciones a partir de los años 20's del pasado siglo, sobre todo en el aspecto lírico y gráfico y que hacen que el público receptor se hayan sentido identificados con los personajes que representen los tipos nacionales. Ricardo Pérez Montfort acertadamente ha mencionado que:

...mientras la academia tendía a ligarse cada vez más estrechamente con los espacios y lineamientos del poder, reproduciendo una concepción romántica y hasta cierto punto tardía de "el pueblo mexicano"; la cultura popular hacía lo propio en los escenarios baratos, en las publicaciones periódicas -sobre todo en los diarios ilustrados- y en los incipientes medios de comunicación masiva, como la radio y el cine. Poco a poco "lo popular mexicano" -representado en figuras campesinas y obreras de piel morena, en procesos de producción, en caricaturas, en artesanías, en fiestas y celebraciones, etcétera- fue entrando al arte plástico oficial y "semiculto" de los muralistas... ${ }^{50}$

Yo agregaría que éste género "popular mexicano" también fue atractivo para algunos de los grabadores estudiados. Algunos fragmentos de dicha canción ranchera son los siguientes:

\author{
Tú sólo tú \\ has llenado de luto mi vida \\ abriendo una herida en mi corazón. \\ Tú sólo tú \\ eres causa de todo mi llanto \\ de mi desencanto \\ y desesperación.
}

\footnotetext{
${ }^{49}$ Pocos años habría de tener ya el género de la canción ranchera, ya que en 1948 hicieron aparición en el mundo artístico el trío de "Los Panchos" que inició un auge del género romántico en el radio y en el celuloide. Véase "Panorama de los años cincuenta "en Yolanda Moreno, Historia de la música popular mexicana”, Alianza Editorial/ CONACULTA, México, 1989, p. 191

${ }^{50}$ El nacionalismo mexicano cubre aspectos muy amplios. La generación posterior a la Revolución de 1910 tuvo que sufrir las consecuencias primero, de una lucha fraticida y, después, entre otras cosas, el acceso a la presidencia por los revolucionarios ganadores; la lucha sindical; y la expropiación petrolera a compañías extranjeras en 1938 con el General Cárdenas lo que acrecentó más el sentido de nacionalismo que se venía acrecentando a nivel político y social y manifestado en todos los géneros. Parte de la producción cinematográfica de estos años tiene que ver con la temática aquí expuesta. Véase este asunto en "El Nacionalismo cultural y el estereotipo revolucionario". Ricardo Pérez Montfort, Estampas de nacionalismo popular mexicano, CIESAS, México, 1994. p.142.
} 
Según los datos de Emilio García Riera, vertidos en "Historia Documental del Cine Mexicano", ${ }^{51}$ Pueblerina (1948) fue una producción de Ultramar Films, teniendo de adaptador al escritor Mauricio Magdalena, una fotografía de Gabriel

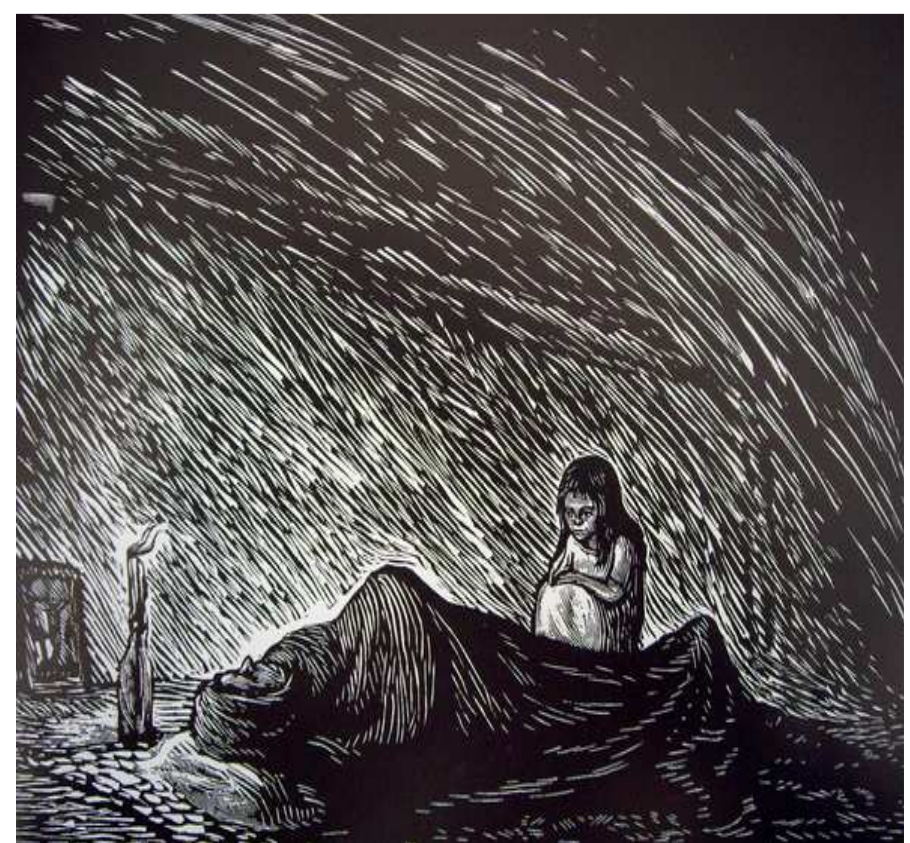

Fig. 45 Leopoldo Méndez "Pueblerina"

Figueroa y obra gráfica de Leopoldo Méndez (fig.45) y fue estrenada el 6 de julio de 1949 La sinopsis del argumento es la siguiente: Aurelio, cumplida su condena de seis años en la penitenciaría de la capital vuelve a su pueblo $y$ encuentra que su madre ha muerto y su casa está en ruinas. Los hermanos Ramiro y Julio los más ricos del pueblo, lo hostilizan y tratan de hacerlo pasar por fugitivo ante el buen delegado Rómulo. Por temor a los hermanos, ningún campesino ayuda a Aurelio. En la fiesta del pueblo, Aurelio vence a Julio en los gallos, en los naipes y, después, le gana un caballo alazán en la peligrosa carrera de los cuchillos; Aurelio se casa con Paloma, y solo consigue a tres presos como testigos de boda. Nadie acude a la fiesta de bodas y Aurelio se emborracha triste y solo. Con el tiempo, y con grandes sacrificios, la pareja logra una buena cosecha, y como solo la pueden comprar los hermanos, Aurelio decide ir con los suyos a venderla a otra parte. Los hermanos matan a la mula de Aurelio, quien debe por eso enganchar el alazán al carretón con la cosecha y cuando ésta es vendida Aurelio compra una pistola. Como Julio quiere quedarse con Felipe, y Rómulo aconseja a la pareja que se vaya, Aurelio inicia la partida con su familia.

\footnotetext{
51 Emilio García Riera, Historia Documental del Cine Mexicano 1946 -1948, Universidad de Guadalajara /CONACULTA, México, 1994, p. 285.
} 
Salen a su paso los hermanos y Aurelio los mata en el tiroteo consiguiente. Aurelio, Paloma y Felipe se van.

Se conocen varios dibujos y grabados que tienen un sentido político y social en la obra de Méndez en relación al tema de la película Pueblerina. En otro grabado llamado El Dueño de Todo, un personaje colocado de perfil y en primer plano indica y manda a unos cargadores con bultos sobre sus espaldas como si fueran esclavos. La imagen es por demás interesante: Él se encuentra

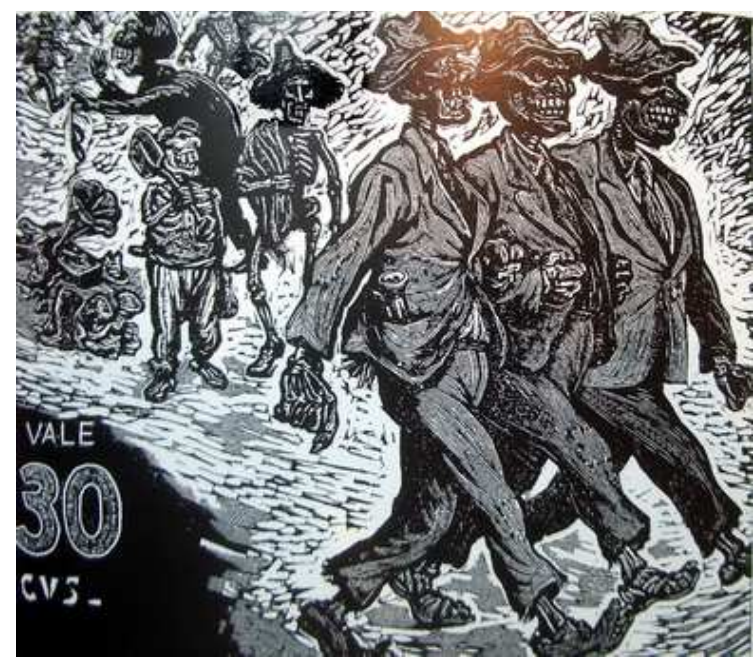

Fig. 46

Calaveras de los pobres millonarios engrandecido por la perspectiva con sus botas colocadas sobre una pequeña mesa en la que se ven botellas de licor. Ellos, empequeñecidos por la perspectiva a lo lejos que los hace aparecen como hormigas. El rostro del personaje ha sido identificado como Maximino Ávila Camacho, hermano del ex presidente Manuel Ávila (1940-1946) y reconocidísimo cacique de Puebla. Emparentadas al asunto anterior, "Calaveras de los pobre millonarios" hace notar a tres personajes (el central representa a Emilio Portes Gil) pertenecientes a la política nacional en forma de calaveras de traje de calle, sombrero y corbata tomados del brazo, formando una unidad. Atrás de ellos otras calaveras pobres, que simbolizan al pueblo, los observan sin tener mucho que ponerse encima. A lo lejos la figura del presidente saliente Miguel Alemán vocifera vendiendo objetos inútiles, mientras un fonógrafo repite como disco rayado sus discursos demagógicos sobre la pobreza. (fig. 46)

De gran fuerza es el linóleo La matanza (1950) de Leopoldo Méndez, ya para esas fechas alejado de la corriente política del TGP. En este grabado representa, sobre un polvoriento terreno en las cercanías de la Ciudad de México, 
la matanza de una res por un grupo de rancheros. En primer plano una mujer de

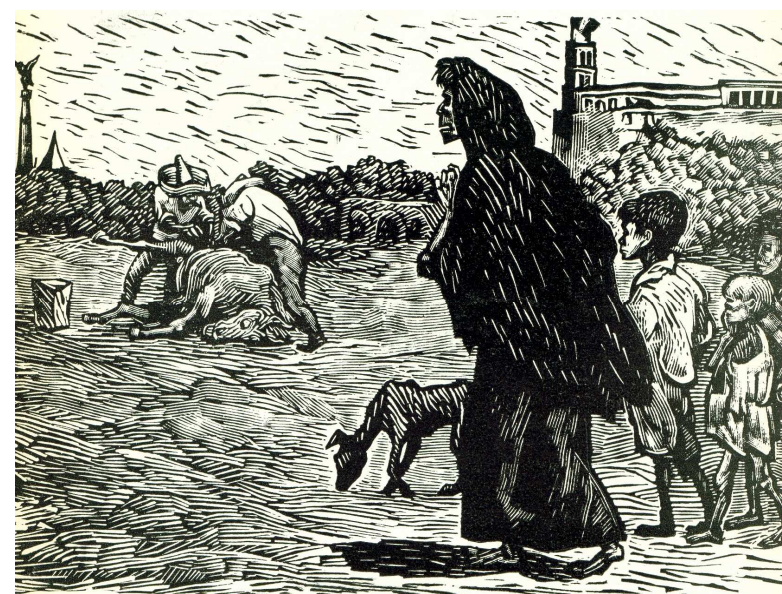

Fig. 47 Leopoldo Méndez La Matanza rostro cadavérico contempla la escena junto a sus hijos desnutridos. Un huesudo perro huele la sangrienta escena esperando el momento de que alguien se descuide para comerse algo. (fig. 47) 1950 es un buen año en la producción de Méndez, pues participa en la película Un día de Vida realizando magníficas variantes en torno a la muerte de uno de los personajes de la trama.

\section{La Sociedad Mexicana de Grabadores (SMG)}

Una alternativa gráfica del TGP fue la Sociedad Mexicana de Grabadores (SMG) fundada en 1947 por grabadores sin filiación política. Algunos de sus integrantes provenían de diferentes escuelas e instituciones como la Escuela Nacional de Artes del Libro (ENAL), Escuela Nacional de Artes Plásticas (ENAP), y la Escuela Nacional de Pintura y Escultura, "La Esmeralda" (ENPE).

En la Sociedad militaban artistas interesados en hacer a través del grabado una renovación de contenidos y enfoques, y su principal aportación fue sin duda alguna, la libertad de expresión y del uso de técnicas, en consecuencia, la temática recurrente en sus obras no seguía líneas trazadas políticamente; se grababa por el placer y por la necesidad de expresarse mediante la línea, el blanco y el negro, y en otros casos por la experimentación surgida a partir de la vivencia y la propuesta en el lenguaje visual. El crítico de arte, Justino Fernández al presentar una exposición colectiva de la SMG mencionaba que, "...lo que 
distinguía a los artistas que pertenecen a la Sociedad Mexicana de Grabadores es la seriedad y honradez con que realizan sus obras. Interesados en renovar las técnicas tradicionales, el resultado consiste en una serie de novedades que ponen de manifiesto las distintas personalidades. Pero no todo es técnica, ni mucho menos, lo más valioso son las creaciones mismas, las nuevas ideas, que contrastan con otras tradicionales, muy bien realizadas". 52

En este contexto ideológico y estético, surgen artistas independientes cuya calidad de sus propuestas permite excelentes ejemplos sobre el tema de la Muerte. Los ejemplos abundan: Francisco Moreno Capdevila y Gabriel Fernández Ledesma realizan ilustraciones y viñetas para el corrido ilustrado "El Coyote Corrido de la

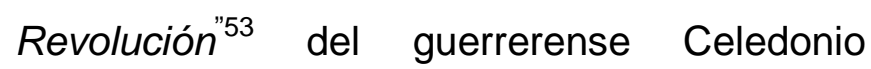
Serrano Martínez. (fig. 48) Un asunto particularmente interesante con este corrido es que el tema ahí abordado, referente al tema de la lucha revolucionaria, permitió compararlo con aspectos más universales, de tal suerte que dio pie a la representación de la lucha de la supervivencia y del triunfo de la muerte. El trabajo en la plancha impresa obra de ambos artistas tuvo un magnífico resultado que recuerda la obra de Posada ${ }^{54}$.

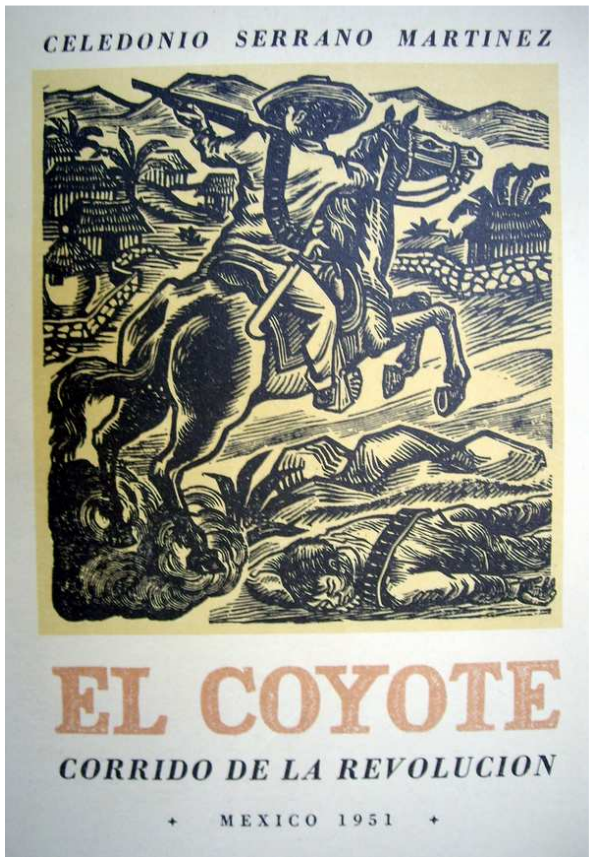

Fig. 48 Fernández Ledesma y Moreno Capdevila. Portada para "El Coyote"

\footnotetext{
52 Justino Fernández, texto de presentación a la exposición 20 años de la Sociedad Mexicana de Grabadores, Instituto Nacional de Bellas Artes, Galerías del Palacio de Bellas Artes Sala 1 y 2 , México, 1968.

${ }_{53}$ Celedonio Serrano Martínez, El Coyote. Corrido de la Revolución, ilustraciones de Gabriel Fernández Ledesma y Francisco Moreno Capdevila, Acapulco, Guerrero, Ediciones Municipales, 1978.

${ }^{54}$ Me encontrado un curioso texto de 107 páginas del año de 1982 producido por la Dirección General de Publicaciones y Bibliotecas de las SEP que utilizó parte de los grabados impresos de El Coyote para un tiraje de 100 mil ejemplares de la Constitución Política de los Estados Unidos Mexicanos con textos explicativos de Rosario Castellanos. El diseñador recortó los grabados y solo utilizó una parte breve de éstos en la parte superior para hacer más ágil su lectura perdiendo el efecto dramático seguido en la historia original de Serrano Martínez.
} 


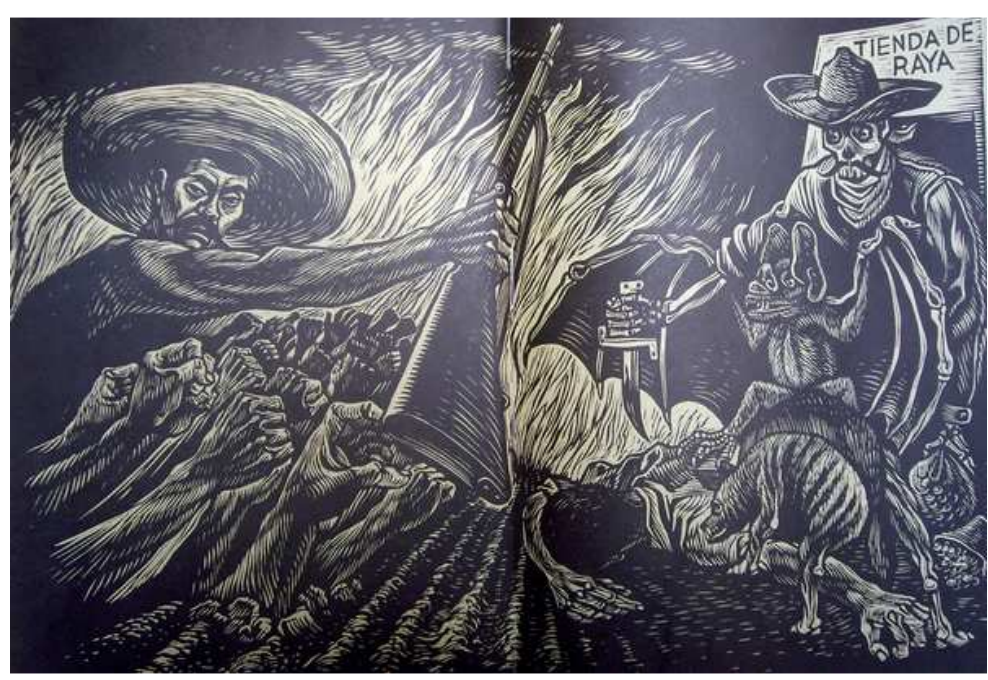

Fig. 49

"Consejos del coronel Coyote a los campesinos al entregarles la tierra" Grabado de Fernández Ledesma y Moreno Capdevila.

Basada en hechos reales, la historia narra bajo la forma de versos en un canto popular, las correrías de Nabor Mendoza personaje nacido en Cuahulotitlán, conocido como "El Coyote" quien se incorpora joven a la Revolución ascendiendo bajo las órdenes del coronel Álvaro Lagunas. "El Coyote" es apreciado por la tropa gracias a sus atinados juicios sobre como deben actuar y comportarse militarmente. A la muerte de Lagunas es nombrado coronel y tiempo después a general casándose con la hermana de un compañero de batalla. Desgraciadamente "El Coyote" cae en una traición y muere en un paraje enterrándole cerca de una piedra en la Sierra de Guerrero cerca de la Cuenca del Balsas. "El Coyote" tiene como figura a seguir al General Emiliano Zapata bajo los ideales de "Tierra y Libertad" (fig. 49) y sigue de cerca los triunfos y derrotas de los principales jefes revolucionarios lo que permite al lector ubicarse cronológicamente en relación al personaje de "El Coyote":

Por otra parte en estos asuntos de la vida y de la muerte en la Revolución son constantes las apariciones de la muerte en los dos bandos de guerra: por el lado de los federales y por el lado de los revolucionarios y esto hace que el corrido sea interesante para nuestro tema. Las viñetas que representan al revolucionario

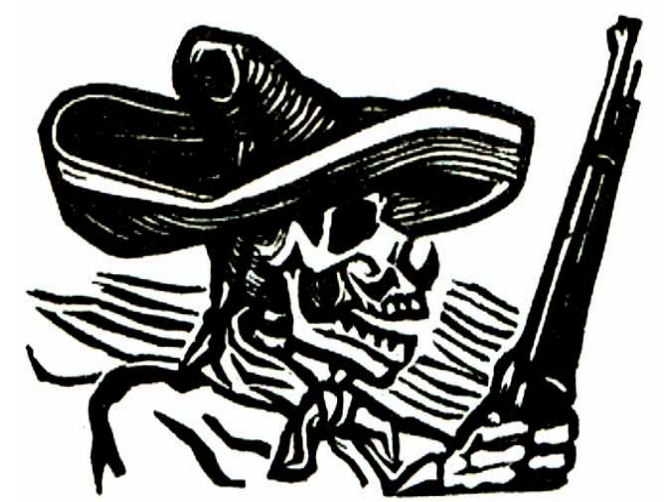

Fig. 50 Viñeta para El Coyote 
de pequeños bigotes convertido en la muerte misma (fig. 50) y que porta un fusil al hombro, o la vista interior del panteón con sus cruces sobre la tierra realizada suavemente con la herramienta de la uñeta logran sobre el fondo negro un

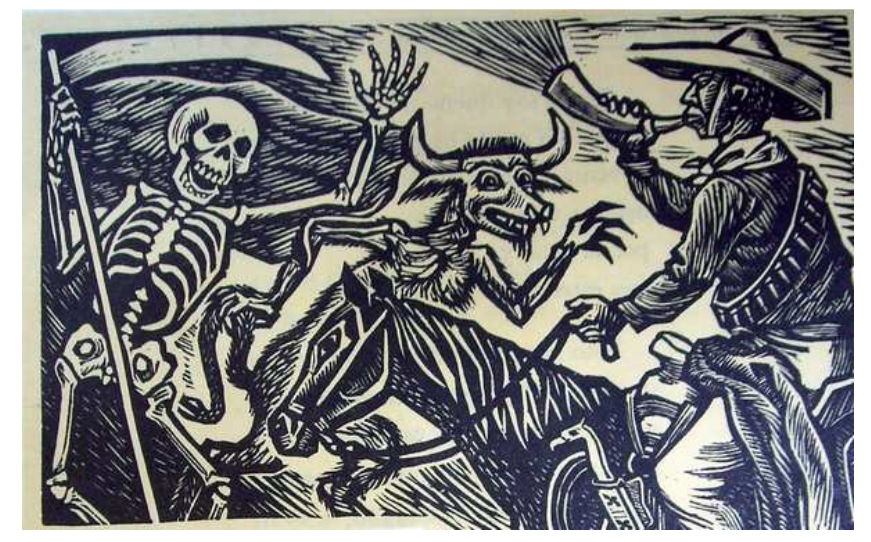

Fig. 51 "El coronel Coyote toma parte en el combate de la loma de la zorra”. Grabado de Fernández Ledesma y Capdevila aspecto lúgubre y solitario con unos cuantos trazos que hablan de la maestría de los autores. Otra de las ilustraciones muestran a una calavera que festiva carga una regla para medir la ambición, en la que se encuentra escrita la palabra nada. A lo largo de la historia las ilustraciones atraen al lector y considero que algunas sobresalen como que corresponde a "El coronel Coyote toma parte en el combate de la toma de la zorra" (fig. 51) y muestra al revolucionario tocando un cornetín montado en su caballo, y haciéndose presentes las figuras de la muerte descarnada y del diablo carnudo, personajes que en la narración se han encontrado siempre presentes como ausencia física y como tentación del alma.

Tres artistas contemporáneos paralelos en cuanto a la maestría con que usan el buril en madera y linóleo, son León Plancarte Silva y Mariano Paredes. En el primero, las escenas son de un México rural influenciado sobre todo por temas indigenistas. En "Día de Muertos". (fig. 52) las mujeres lloran sobre la tumba dolientes la pérdida del ser querido. Esta dramática representación parte de sus vivencias reales ya que su labor como maestro

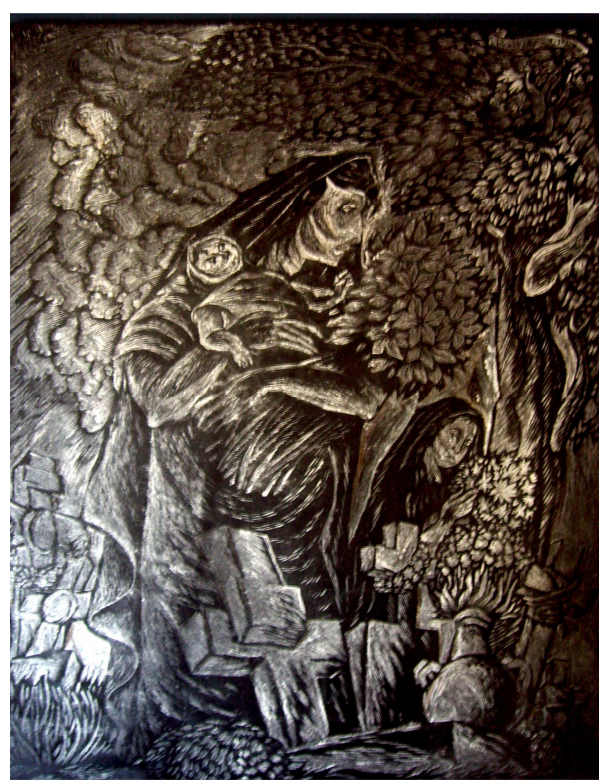

Fig. 52 León Plancarte "Día de Muertos" 
durante largos años de su juventud en las Misiones Culturales en los años treinta le permitió reflejar lo aprendido y volcarlo en el linóleo.

En la obra llamada "Entierro" de Mariano Paredes, incluida en su catálogo

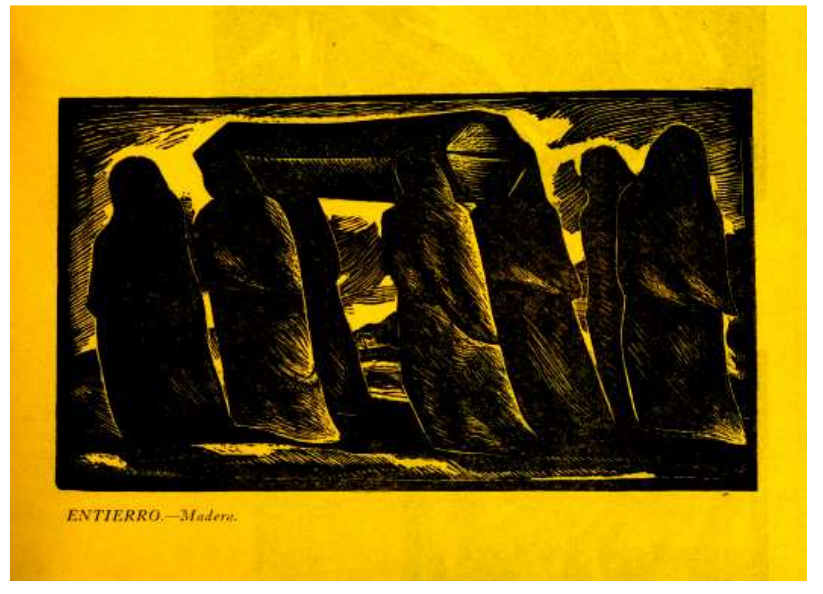

Fig. 53 Mariano Paredes El Entierro editado por la Galería Arte Moderno $^{55}$ se aprecia una de las características del trabajo del autor: una obra rica en el tratamiento sutil de la herramienta sobre el material. En este gráfico siete figuras femeninas acompañan un ataúd sobre un fondo vertido apenas de un fondo tenue. La composición sobria es además triste lo que es un acierto en este autor. (fig. 53)

En el trabajo de estos artistas se nota un estudio concienzudo de la luz y la sombra. No obstante la línea no existe, el conjunto se visualiza tenue con efectos dramáticos y escenográficos, producto del estudio paciente de las figuras en penumbra. Sus obras están trabajadas en buril sobre linóleo o sobre madera y que para la fecha de ejecución (entre los años 50 y 60 del siglo XX), las herramientas del grabado estaban en desuso.

En septiembre de 1956, la revista CANJE. Grabado mexicano, editada por la Secretaría de Educación Pública (SEP), a través del Instituto Nacional de Bellas Artes hacía un llamado a los grabadores del mundo para hacer de esta publicación un producto internacional. ${ }^{56}$ La revista hizo públicos sus objetivos, firmados y autorizados por el Director del INBA, entre los cuales se proponía la difusión del arte del grabado, la adquisición valiosa de obra gráfica (en tiempos en que el grabado mexicano interesaba más para su exhibición que para colección), hasta un posible intercambio de obra (de allí su nombre de canje).

\footnotetext{
55 Mariano Paredes, Galería Arte Moderno, Ediciones "Galerías, 25 reproducciones en blanco y negro y seis maderas, mayo de 1951.

${ }^{56}$ Revista Canje 1 Grabado mexicano, INBA, SEP, Director Lorenzo Guerrero, México, 1956.
} 
De esta rara publicación oficial, a la que no todos los exponentes acudieron a su llamado, se extrajo el trabajo de algunos artistas cuya obra es atractiva por sus soluciones gráficas. Entre ellos sobresale la figura de Fernando Castro Pacheco, que con la obra "El velorio" de 1953, recurre al uso del linóleo muy a la manera litográfica. (fig. 54) En este grabado que igualmente aborda el tema de la muerte, un grupo de mujeres que llevan cirios en las manos, acompaña el cadáver de un infante cubierto con una sábana blanca de donde asoman sólo el rostro y los pies. Una de las mujeres vestida con un lienzo blanco toma la sábana y observa detenidamente el rostro plácido. Probablemente se trate de su madre.

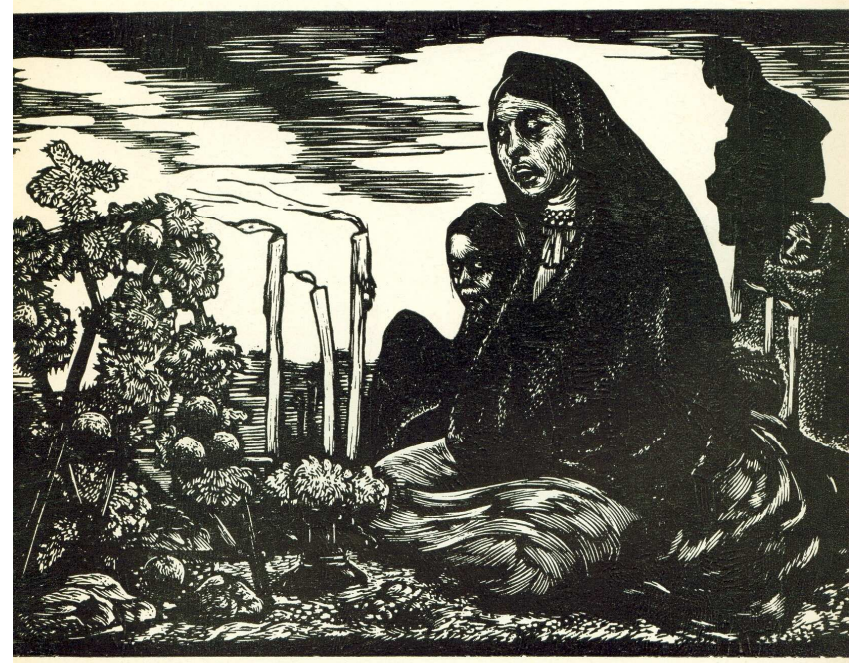

Fig. 55 Ángel Zamarripa La Ofrenda

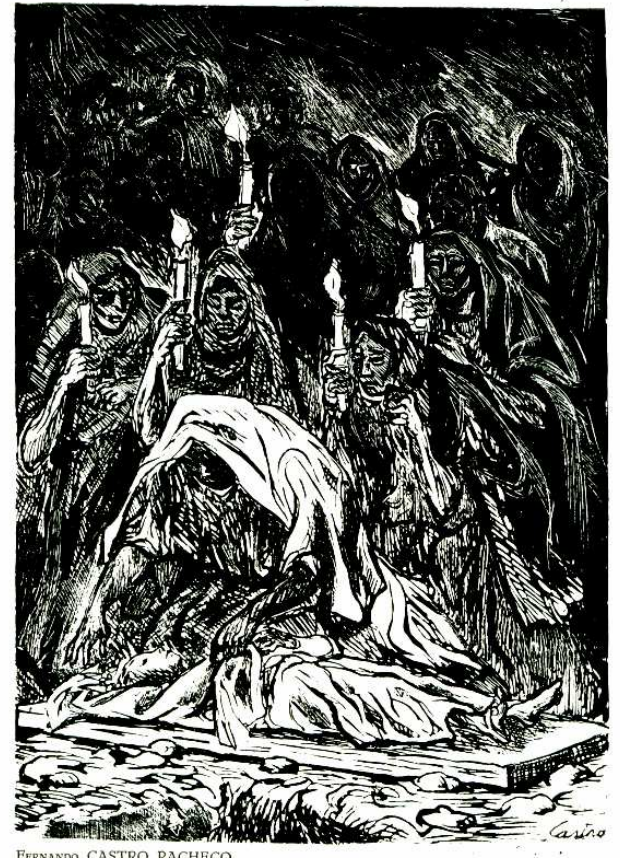

Fig. 54 Castro Pacheco El Velorio

Finalmente, Ángel Zamarripa (integrante de la SMG) en $L a$ ofrenda, con un linóleo de 1954, (fig. 55) muestra a algunos indígenas hincados que rezan plegarias ante las cruces de los difuntos. Flores de zempoaxochitl rodean el extremo izquierdo del grabado en una clara alusión de que la muerte está a la izquierda y la vida a la derecha. Asimismo, tres largos cirios inclinan su pabilo hacia la ofrenda y en el piso está preparado ya el alimento para los fieles difuntos que llegarán a comer pan y fruta fresca. 
Interesados en renovar las técnicas tradicionales, los grabadores volcaron su inquietud hacia nuevos caminos, dando como resultado la creación de una serie de novedades que ponen de manifiesto las distintas personalidades y, por lo tanto, tendencias estéticas individuales.

En suma, amén de la profusión y perfección de las técnicas, se distinguieron tres tendencias en el conjunto de artistas de la segunda mitad del siglo XX: la tradicional, más o menos figurativa, la semi-abstracta y la abstracta radical, que no tenía ningún compromiso ideológico. Esta diversidad en las direcciones estéticas y artísticas es lo que le dio a los grabadores riqueza para crear, pues lo que subyacía en este proceso era el deseo de renovación, que significa madurez y capacidad creadora.

\section{La gráfica del 68'}

Dentro de la historia nacional, la antigua ciudad de Tlatelolco ha estado ligada de manera dramática y sangrienta a fechas simbólicas. Ya sea dentro del sometimiento mexica, en tiempos prehispánicos o en lo contemporáneo con la masacre del 2 de octubre y los sismos de 1985, Tlatelolco se encuentra como hoy, presente como una herida abierta y latente que tal vez nunca se cierre. Tal vez por eso una aportación importante al tema de la muerte por su significado político en su gran producción gráfica desarrollada es sin duda, los trágicos sucesos de 1968. Para entender su problemática y su necesaria ubicación en el contexto histórico daremos paso a los hechos de manera general a su inicio, su desarrollo y sus consecuencias ya que de ello se desprende la comprensión de este apartado. El origen que generó el conflicto estudiantil tuvo antecedentes que ya se venían gestando en la sociedad mexicana desde tiempo atrás producto de los cambios sociales globales. Algunos estudiosos como el investigador Sergio Zermeño han 
tratado de estudiar y analizar este movimiento por medio de etapas de desarrollo gradual que va de menor a mayor intensidad. ${ }^{57}$

La primera etapa comienza el 24 de julio de 1968 cuando alumnos de las vocacionales 2 y 5 del Instituto Politécnico Nacional (IPN) capitaneados por los grupos "Las Arañas y "Los Ciudadelos", tuvieron un enfrentamiento con alumnos de la preparatoria particular "Isaac Ochoterena". Dichas agresiones tenían ya casi un año de venirse produciendo y una de tantas ocasiones al no recibir respuesta los estudiantes regresaron a sus planteles, entonces los granaderos empezaron a provocarlos y los estudiantes contestaron con piedras y silbidos que los uniformados respondieron con gases lacrimógenos y macanas. Después de varias corretizas llegaron a la vocacional en la que penetraron y golpearon a varios alumnos durante casi de tres horas para salir casi corriendo del plantel educativo. El ejército comienza su participación con el célebre bazucazo en la puerta centenaria de la preparatoria 1 y tomando las preparatorias 2, 3 y 5 de la UNAM y la vocacional 5 del IPN. El rector Javier Barros Sierra decreta día de luto para la Universidad e izando la bandera a media asta. En los siguientes días los representantes estudiantes de la UNAM, Politécnico, Chapingo y algunas universidades de provincia votan a huelga general.

La segunda etapa tiene momentos de gran efervescencia caracterizada de mayor violencia y represión, observándose un cambio radical en actitudes del gobierno que permiten por momentos suponer que la solución del conflicto esta próxima ya que se han entrevistado las cabezas de la Federación Nacional de Estudiantes Técnicos (FNET) con el regente Alfonso Corona del Rosal. Esto evidentemente tiene dos vertientes. Por un lado tratar de detener un conflicto que comenzaba a ser magnificado por la sociedad mexicana y por otro, fortalecer a la FNET tradicionalmente del lado gubernamental. La actitud de este último es entonces replegar las fuerzas represivas de granaderos, militares y cuerpos paramilitares y la de sugerir la integración en el IPN de una comisión compuesta por representantes del gobierno, alumnos y estudiantes.

57 Para el desarrollo de las etapas en detalle, consúltese Sergio Zermeño, México una democracia utópica El movimiento estudiantil del 68, Siglo XX1, 3ª̣ edición, México 1983. 
Una tercera etapa es aquella que podría comenzar para el día 1 de agosto cuando encabeza una manifestación de duelo un contingente de cerca de 100, 000 estudiantes y para el día 9 se integra el Consejo General de Huelga (CNH) en una magna asamblea estudiantil que pide huelga general y exige la respuesta a un pliego petitorio conformado entre otros por los siguientes puntos:

1.- Libertad a los presos políticos.

2.- Destitución de los generales Luis Cueto Ramírez y Raúl Mendiolea y del teniente coronel Armando Frías. (jefe y sub jefe de la policía; jefe del cuerpo de granaderos, respectivamente).

3.- Extinción del cuerpo de granaderos, instrumento directo en la represión y no creación de cuerpos semejantes.

4.- Derogación del artículo 145 y 145 bis del código penal federal [delito de disolución social] instrumento jurídico de la agresión.

La cuarta y última etapa, se establece a partir del 18 de septiembre cuando la escalada de represión y de violencia se maximiza hasta el genocidio. El día 23, el rector Barros Sierra debido entre otras cosas a la violación de la autonomía de la universidad entrega su renuncia a la Junta de Gobierno de la UNAM. Para el día 30 del mismo mes el ejército desocupa la Universidad. El día miércoles 2 de octubre a la 17.00 se produce una magna concentración en Tlatelolco en la llamada Plaza de las Tres Culturas donde son asesinados y heridos gravemente un incalculable número de víctimas en un intenso fuego cruzado donde son muertos vecinos de la zona, estudiantes, amas de casa y curiosos, entre ellos infinidad de niños.

El Presidente Díaz Ordaz en su V Informe de Gobierno al Congreso declaró de manera terminante: “...por mi parte, asumo íntegramente la responsabilidad personal, ética, social, jurídica e histórica, por las decisiones del gobierno en relación con los sucesos del año pasado" El pleno legislativo aplaudió de pie las palabras presidenciales.

Veamos ahora lo que respecta a nuestro tema: 
La importancia de la producción gráfica generada en esos momentos es de

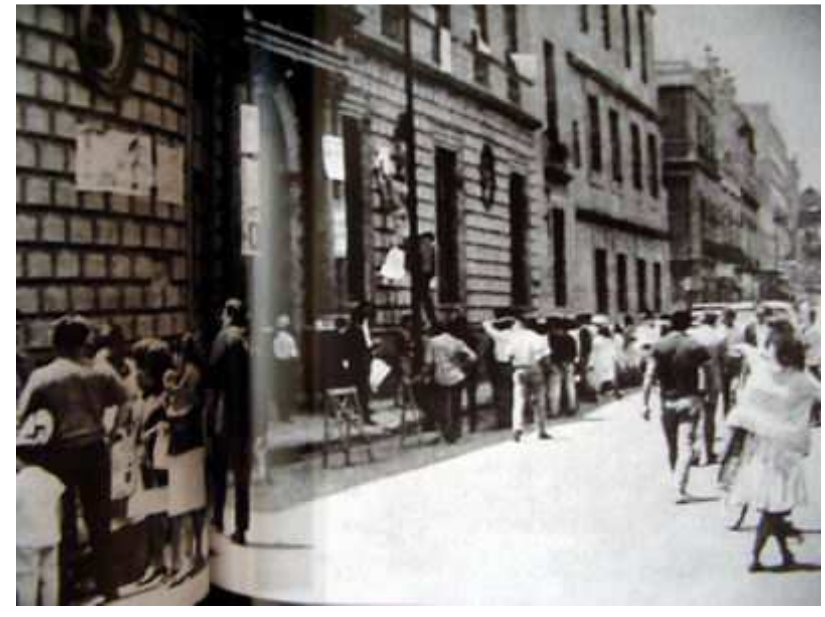

Fig. 56 Academia de San Carlos de México en el 68. Fotografía

carácter testimonial y eso nos permite observar el comportamiento de los hechos y como estos se van generando paulatinamente respondiendo a un interés propagandístico por medio de textos e imágenes que invitan a la reflexión, a la toma de decisión y a la información. Dicha labor es trabajada de manera colectiva y en muy pocos casos se conoce al autor. Su trabajo ha quedado de manifiesto gracias a las imágenes fotográficas del momento: Son varias las fotos en las que se observa el intenso movimiento que se producía en aquellos momentos. Una vista lateral de la fachada de la ENAP (que en ese entonces sólo contaba con ese edificio en la calle de Academia número 22, en el centro de la ciudad) y que va de la calle de Moneda a Corregidora se ven pegados en los muros y en los dinteles de la entrada propaganda gráfica. (fig. 56) Dos pequeños grupos en los que se ven familias con niños se encuentran observando (¿oyendo a algún orador?) con curiosidad alguna actividad del momento en que se vivía. Hay que recordar que la Academia de San Carlos se encuentra a sólo dos cuadras del Palacio Nacional lo cual no deja de asombrar que haya sido posible esa movilidad estudiantil en ese lugar. Ya en el interior del plantel se observan a numerosos

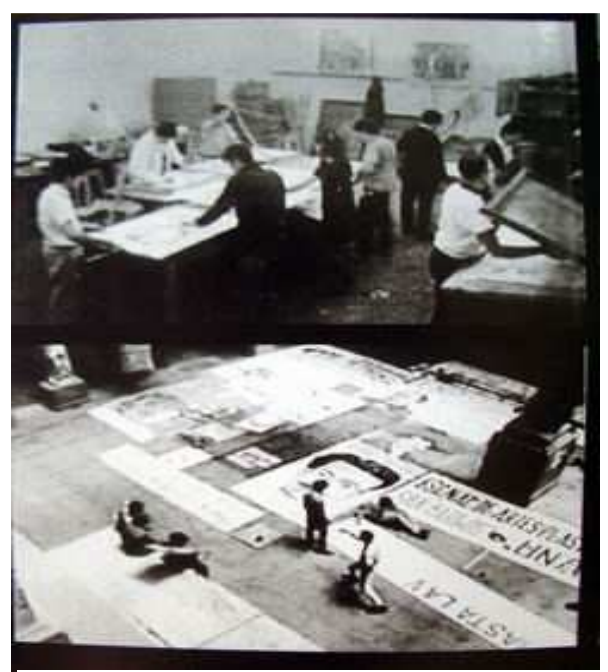

Fig. 57 Estudiantes de San Carlos haciendo propaganda. Fotografía activistas dentro de un taller de serigrafía imprimiendo propaganda gráfica. (fig. 
57) Es muy probable que sea el taller de serigrafía del maestro Becerril localizado en la parte baja que va al pasillo del segundo patio de la Academia de San Carlos.

En el caso de la producción gráfica del año de 1968 su carácter fue de carácter urbano- popular y respondió a las necesidades del momento por medio

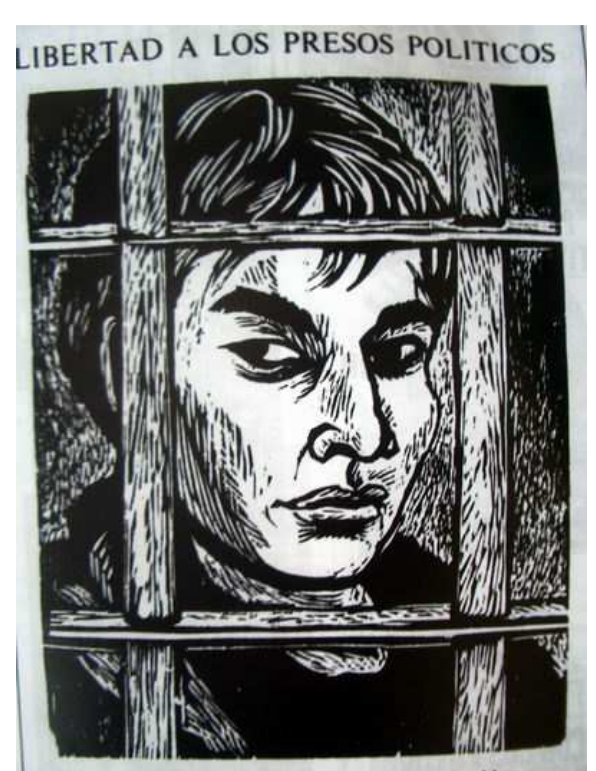

Fig. 58 Libertad a los presos políticos Cartel gráfico de 1968 de brigadas de producción emergidas principalmente de la Escuela Nacional de Artes Plásticas (ENAP), la Escuela de Pintura y Escultura (La Esmeralda) y de grupos independientes que apoyaron a los Comités de Huelga de las diferentes escuelas e institutos. “...es interesante señalar que para esos días se repartían aproximadamente seiscientos mil volantes diarios y juntábamos de mil a dos mil pesos diarios... señalaba un participante. $^{58}$

Nacen así, imágenes que se van ligando con el momento histórico que se vive: La paloma, símbolo de la paz se transforma en una ave ensangrentada; los cuerpos policíacos del gobierno en gorilas de casco y bayoneta; la figura presidencial reverenciada en una figura grotesca e indigna; y el silencio por una figura encarcelada o manifestado por un enorme candado en la boca. (figs. 58 y 59)

Se suceden entonces con una rapidez asombrosa, la producción en masa de carteles,

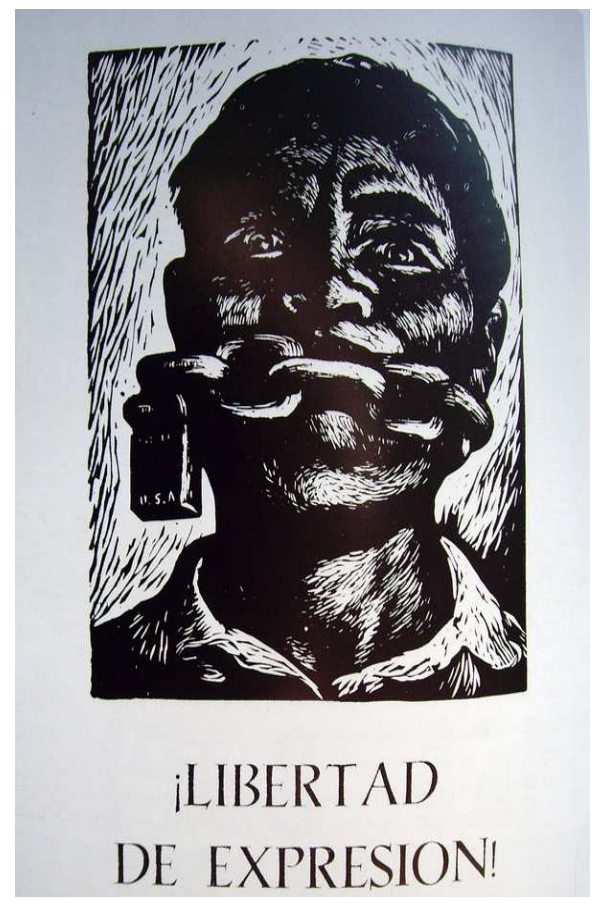

Fig. 59 ¡Libertad de Expresión! cartel gráfico de 1968

\footnotetext{
${ }^{58}$ Elena Poniatowska, La noche de Tlatelolco, editorial ERA, 4ㄹa reimpresión 2001, p. 33.
} 
volantes, y grabados impresos en roles de prueba y tórculos, mimeógrafo, serigrafía, offset y fotograbado que manifiestan la represión por parte del gobierno acompañados de canciones transformadas en voz popular:

La masacre en Tlatelolco nunca habremos de olvidar, donde estudiantes le dieron su vida a la libertad,

Que me voy, que me voy, que voy pa' al paredón, ya parece que la llevo como espina en el talón, ya parece que la llevo como espina en el talón.

La traicion del mal gobierno no acaba de acabar Ya hasta el pinche de Toledo un balazo le fue a dar

Que me voy, que me voy, que me voy, que ya voy pa' el paredón, ya parece que la llevo como espina en el talón, ya parece que la llevo como espina en el talón... 59

El mérito del movimiento y de la nueva gráfica es sin duda que “...Ante las condiciones cada vez más difíciles para realizar pintas en las bardas y todo tipo de soportes debido a la constante represión hacia los brigadistas, varias posibilidades de comunicación fueron puestas en práctica; desde la reproducción de una pega en rollos de papel engomado o el volante-grabado, hasta carteles de diversas dimensiones." 60 Se pueden ver en las calles de la ciudad, en las plazas y en el transporte público las imágenes del viejo luchador Demetrio Vallejo, los tan solicitados pliegos petitorios de los estudiantes, el rostro del Che Guevara, el puño tensionado en alto, y la mano con la señal de la victoria.

Debido a la forma tan inmediata en que fue abordada la temática de la represión, la violencia y la muerte por el movimiento estudiantil, existen numerosos ejemplos de imágenes grabadas en linóleo o estampadas generalmente en serigrafía. Al igual que en otros capítulos de este trabajo se destacan por su fuerza y valen la pena destacarse de otras.

\footnotetext{
59 "La masacre de Tlatelolco", CD, Oscar Chávez, México 68. La música y la balada proceden de una canción antigua mexicana. La letra es de J. Ortega y de Oscar Chávez, la música es "EI Palomo" que procede de Guerrero.

${ }^{60}$ La Gráfica del 68, Homenaje al Movimiento Estudiantil, tercera edición, recopilación, texto y diseño: Grupo Mira, México, 1981, p. 21.
} 
Una primera imagen corresponde a una madre que sostiene el cuerpo desnudo sin vida de su hijo. Trazado con rasgos geométricos la composición recuerda las "madonnas" renacentistas en las que la mujer envuelta con una especie de velo negro mira con gran fuerza de su rostro hacia arriba o cielo. Por otra parte, el cuerpo desnudo del joven se encuentra inerte inclinado hacia atrás

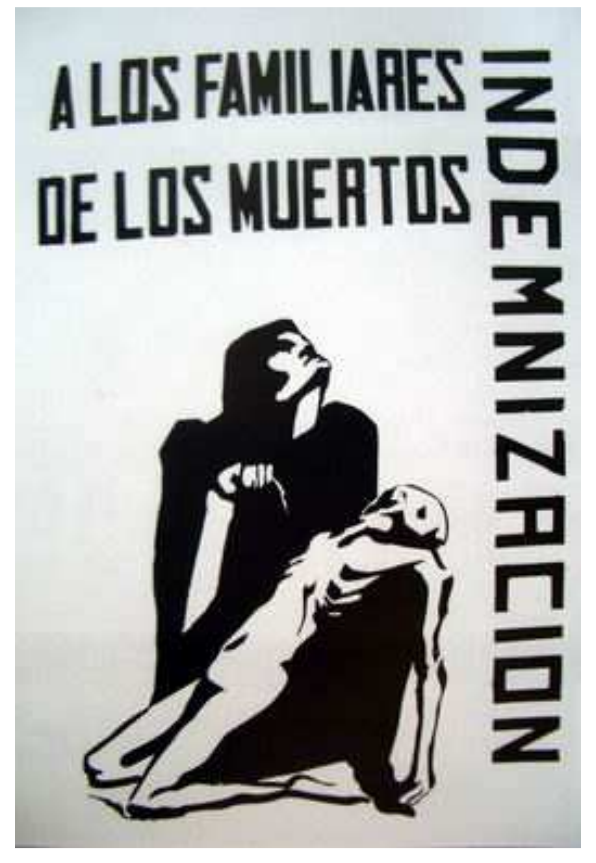

Fig. 60 "A los familiares de los muertos Indemnización". Cartel del 68 sobre sus rodillas. Su delgadez llama la atención al observar sus costillas marcadas en un juego interesante de alto contraste. El artista supo sacar partido al tema. El texto se halla colocado en la parte superior y escrito en altas: A LOS FAMILIARES DE LOS MUERTOS y en la lateral derecha con mayor puntaje INDEMNIZACIÓN. (fig. 60)

Un cartel en serigrafía interesante por su composición sencilla y su trazo de pincel es el que lleva el título de "Monumento Olímpico a la Constitución" manejado con cambios tipográficos que van de menor a mayor intensidad visual. En la parte superior un tanque militar con las siluetas de un soldado y su arma avanzan sobre un libro abierto. Las ruedas del vehículo forman los aros olímpicos entrelazados con centros disparados. El aplastamiento el autor lo ha simbolizado con dos cráneos que asoman por el lado derecho del cartel. La idea muy bien estructurada, es directa al espectador. (fig.61)

Otro grabado atribuido a estudiantes de La Esmeralda (con una reminiscencia de Posada al

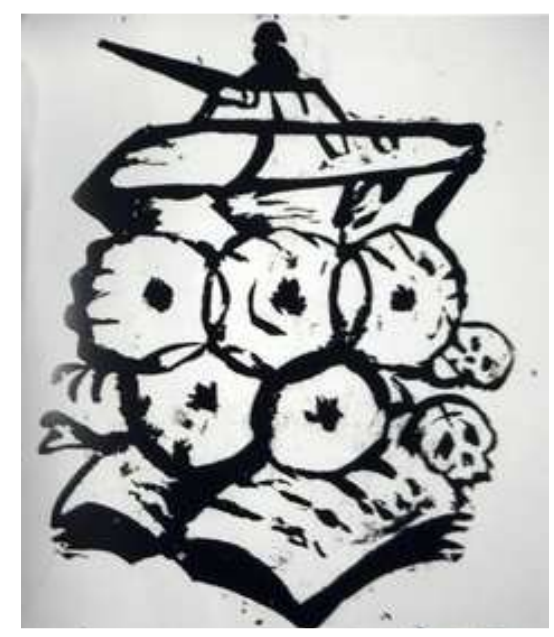

Fig. 61 "Todo es posible en la paz". Cartel de 1968 


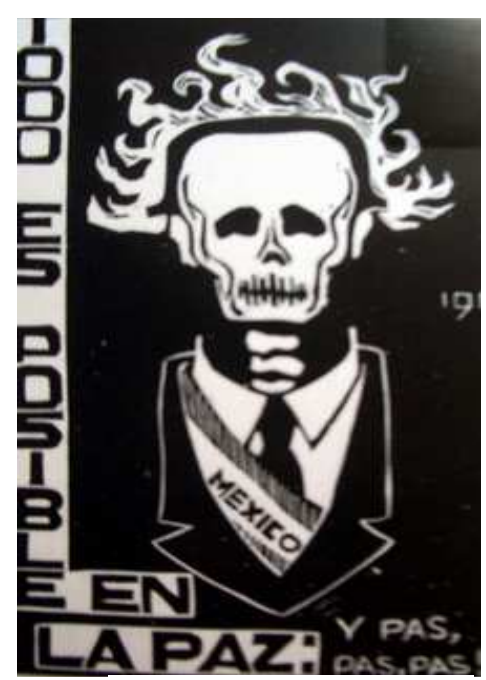

Fig. 62 "Todo es posible en la paz". Cartel de 1968

vestir el esqueleto) es una calavera retrato del Presidente Díaz Ordaz que porta sobre su traje una banda presidencial con la palabra "MEXICO". Su cabello se encuentra revuelto a manera de iridiscencia solar a la altura de las orejas (!). En su costado izquierdo y su base se lee el texto en negro sobre fondo blanco: TODO ES POSIBLE EN LA $P A Z$ : Continuando con la idea se le agregado en forma inversa con letra blanca y fondo negro $Y P A S$; PAS; PAS! La ironía creativa es haberle anexado las onomatopeyas del ruido de las balas. (fig. 62)

4.1 La muerte en la obra gráfica de Francisco Moreno Capdevila

El crítico e historiador del arte, Jorge Alberto Manrique ${ }^{61}$ ha encontrado un paralelismo entre la Escuela Mexicana de Pintura y el grabado a la que llama de la "Escuela Mexicana" con el mismo tipo de preocupaciones sociales y nacionales. Esta repetición de contenidos artísticos propició que los artistas de las nuevas generaciones se inconformaran contra el arte denominado "oficial": Hugo Covantes $^{62}$ se refiere a los años sesenta como la década definitiva, destacándola como un resurgimiento parecido a lo sucedido 40 años antes donde los ciclos históricos se repiten. En ese entonces se produjeron tres Bienales Internacionales de Pintura y Grabado (1958, 60 y 62) y el momento que se vivía exigía una confrontación generacional que debía darse en el en el terreno del modernismo y la experimentación. El grabado entonces, se enfrentaba inevitablemente a la necesidad de tomar el paso a los movimientos de vanguardia

\footnotetext{
61 Jorge Alberto Manrique, Arte y Artistas del Siglo XX, Lecturas Mexicanas, CONACULTA, México, 2000.

${ }^{62}$ Hugo Covantes, op.cit., p. 58.
} 
En 1961, bajo las iniciativas de Arnold Belkin y Francisco Icaza, surgió una agrupación artística que más tarde se denominó Nueva Presencia ${ }^{63}$; de efímera vida su intención por revivir la tradición del grabado poco se relacionaba con el de la Ilamada Escuela Mexicana. De este grupo Francisco Moreno Capdevila, es quizá ell que pudo integrar en su obra la tradición y la vanguardia a través de la experimentación de las técnicas del grabado y de la estampa.

Francisco Moreno Capdevila, nace en Barcelona, España el año de 1926, llega a México como refugiado político en 1939 y adopta la ciudadanía mexicana recibiendo la influencia directa de su primer maestro Santos Balmori. Fue profesor de la clase de grabado en hueco, e impartió diversos talleres de pintura, dibujo y proyecto mural. Asimismo fue integrante de la Sociedad Mexicana de Grabadores, del Salón de la Plástica Mexicana desde 1961 y Académico de número en la sección de gráfica de la Academia de Artes de México a partir de 1987.

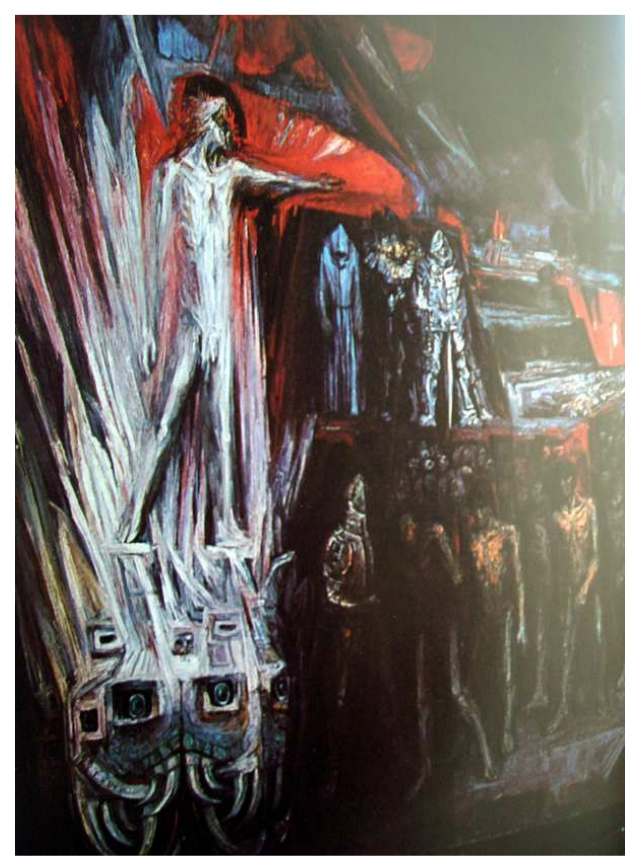

Fig. 63 Francisco M. Capdevla "Conquista y Destrucción de Tenochtitlan", Obra Mural 1964.

Artista preocupado por una constante en su obra del pasado/ presente (dualidad heredada en su discípulo Jesús Martínez como veremos mas adelante) realiza en 1964 para la Sala Visión de los Vencidos del Museo de la Ciudad de México (antigua Casa Señorial de los Condes de Santiago de Calimaya, también conocida como "Casa de los Cañones") el mural "Conquista y destrucción de México Tenochtitlán”. (fig 63) Los motivos principales del mural son: Quetzalcóatl, los prisioneros, los muertos que entierran a sus propios muertos, los caballos de la conquista, los presagios y

${ }^{63}$ La lista de los integrantes era: Benito Messeguer, Capdevila, José Hernández Delgadillo y Leonel Góngora. El mismo Moreno Capdevila muchas veces consideró su no pertenencia al grupo y así lo expresó en varias ocasiones. 
síntesis de la tragedia. Elaborado en la técnica de pintura acrílica aplicada sobre lámina de aluminio cortado en segmento de curva, y trabajado con mucha carga dramática, fue pensado para que el espectador participe al observar el mural en un espacio oscuro donde solo la pintura adquiere la luz necesaria para que el ojo humano tenga la observación necesaria. Existe y hay que decirlo así, ciertas actitudes de resolución que recuerdan la pincelada expresionista de José Clemente Orozco y a su hombre en llamas. Sobre todo por la figura de la que emerge distintas tonalidades que van del blanco, pasando al amarillo y al rojo intenso -rojo sangre- colocada arriba de una máscara de Tláloc, que señala la acción destructiva llevada a cabo.

Antes que Capdevila, por supuesto, otros artistas se habían ocupado del tema del pasado y del presente ya sea en el terreno pictórico a través de obra mural y de caballete, como de pequeño formato por medio del grabado y la estampa. El crítico de arte Antonio Rodríguez a este respecto escribe que:

\footnotetext{
"...A pesar de sus concretas referencias al mundo náhuatl (las premoniciones o amenazas de Quetzalcóatl y la imagen de Coatlicue como vientre de un Cuauhtémoc renacido) el mural de Capdevila en vez de ceñirse exclusivamente al pasado, se presentó, pues, en lo temático como presagio de apocalípticas catástrofes y en el dominio del lenguaje plástico, como adopción de nuevas formas..." 64
}

Sin duda Antonio Rodríguez tuvo la feliz ocurrencia al redactar este texto escrito en 1987 cuando a propósito de un homenaje y reconocimiento público en una institución del Estado (el INBA), relacionaba el hecho dramático de la Conquista planteado con la hechura de la obra creada en 1964, con el Movimiento Estudiantil que cuatro años después cubriría de rojo un antiguo barrio prehispánico de la gran ciudad de la entonces llamada México- Tenochtitlán y que tanto impresionaría a la sociedad mexicana e indignaría a la generación de artistas de la generación siguiente retomando el tema ya que pareciera que al

\footnotetext{
${ }^{64}$ Antonio Rodríguez Luna. El hombre, la ciudad y la luz en la obra de Capdevila, catálogo de Capdevila visión múltiple 1987, Museo del Palacio de Bellas Artes, mayo-agosto, México, 1987, p.11
} 
igual que en un ciclo azteca se manifestaba una y otra vez el pasado y el presente en un hecho diacrónico y sincrónico, así como el contrapunto de destrucción y construcción al mismo tiempo, la luz y las tinieblas. La barbarie, el sacrificio inútil y la desesperanza.

Influenciado en sus inicios por la obra del Taller de Grafica Popular y de la presencia de Leopoldo Méndez, Capdevila supo salir airoso en aquellos días, proponiendo nuevas formas de expresión a través del grabado en metal y el color, aspectos fundamentales en el nuevo grabado mexicano de cual con el tiempo sería un pilar cimentado logrando nuevos lenguajes en las artes visuales y así mismo un resultado diferente de acuerdo a los tiempos modernos. De ahí que de su obra y de su taller en la Escuela Nacional de Artes Plásticas hayan abrevado numerosos artistas que a su vez transmitieron lo enseñado por Moreno Capdevila.

Conocedor de prácticamente todos los procedimientos de grabadoCapdevila, es sin lugar a dudas el artista que más experimentó con las técnicas del grabado, y el artista que pudo y supo tener la libertad de expresarse por medio de la línea grabada, de la textura impresa y del sentido del color, y asignarle al grabado un lugar en el panorama artístico paralelo a la pintura y la escultura, y al que solo había sido relegado muchos años como propaganda política y social y condenado a utilizarse en las paredes por medio de carteles. Sin duda alguna la serie titulada "Luz y Tinieblas" es la obra grande del 68. En ella se recupera la tradición del grabado popular asimilando lo tradicional y vanguardista al mismo tiempo, y es lo que felizmente ha conjugado entre literatura y arte gráfico para lograr una presencia de gráfica testimonial. En una breve pero sustanciosa entrevista con Margarita García Flores, el artista comentaba de viva voz su preferencia por el grabado sobre la pintura como un vehículo ideológico adecuado:

“...Sufrí una evolución. [de la pintura al grabado] Dicha evolución se marcó fundamentalmente en la serie de grabados acerca de lo ocurrido en la Plaza de Tlatelolco en 1968. Hice una serie entonces que se llamó "Luz y Tinieblas". Tal parece que el 68 marca una etapa inicial en una serie de 
cosas fundamentales en México, hasta en el arte. Este 68 marcó también de alguna manera la necesidad de hablar sobre aquello sin hacer panfleto. Entonces era un problema para mí tener que explicar lo que yo había sentido, y no lo que se podía. El problema era decir una serie de aspectos que estaban totalmente con la forma como yo lo viví y lo sentí; y era tanto lo que pasó en la calle como lo que pasaba con los presos políticos. Entonces en mi obra empezó a reflejarse un poco esa geometría carcelaria que yo vivía en forma muy fuerte. Las gentes que por algún motivo íbamos a visitar a los presos políticos íbamos a un lugar siniestro muy disgustante: la Cárcel de Lecumberri. Todas estas estructuras me dieron una relación formal visual en la que yo encontré una posibilidad de lenguaje que ya era diferente a lo que yo había usado, incluso en el manejo de espacio, en la manera de relatar las cosas; porque la posibilidad de fragmentación del espacio le daba la cárcel misma."

En efecto. En una entrevista reciente que sostuve con el grabador Jesús Martínez, discípulo e impresor de Capdevila, comentaba que:

“...La serie de "Luz y Tinieblas" la emparentó con la represión, porque el tenía un amigo íntimo -nunca nos lo dijo- que escribía en la "Revista Siempre", creo que se llamaba Víctor Rico Galán y entonces a partir de ahí empezó a hacer una serie de cárceles que se pudieron culminar con lo del 68. Hay una serie de elementos que son a través de diferentes dimensiones: rejas, la represión, la idea de la cárcel y la muerte, que creo que son los motivos principales de esa serie, y yo creo que hay una relación muy cercana con los aguafuertes Goya en la guerra contra los franceses en España. Es la misma sensación de angustia, de impotencia y de represión..."66

La exposición con la serie completa de "Luz y Tinieblas", pudo verse en el Salón de la Plástica Mexicana con 35 grabados de Capdevila como una muestra maravillosa del blanco y el negro La crítica e historiadora del arte Raquel Tibol tuvo la oportunidad de platicar con el grabador en numerosas ocasiones sobre su quehacer como artista y al hablar sobre lo que ella llama la "tragedia mexicana" del 68 en México dice que una vez pasado el conflicto del 68 que:

\footnotetext{
${ }^{65}$ Margarita García Flores, "Francisco Moreno Capdevila, Vivo para pintar, pinto por terco", Aproximaciones y Reintegros, UNAM, Textos de Humanidades, núm. 33, pp 121-122

${ }^{66}$ Entrevista a Jesús Martínez, 31 de octubre 2004, ENAP /UNAM.
} 
Capdevila fue de los que no se acogió al sosiego del olvido, sino que dio vida a algo que no podían consignar las fotografías: el conflicto psicológico e ideológico de quienes de una u otra manera fueron las víctimas, los agredidos de 1968. representó lo que no era ilustrable: la búsqueda de luces en una tiniebla que teje su enredada trama..."
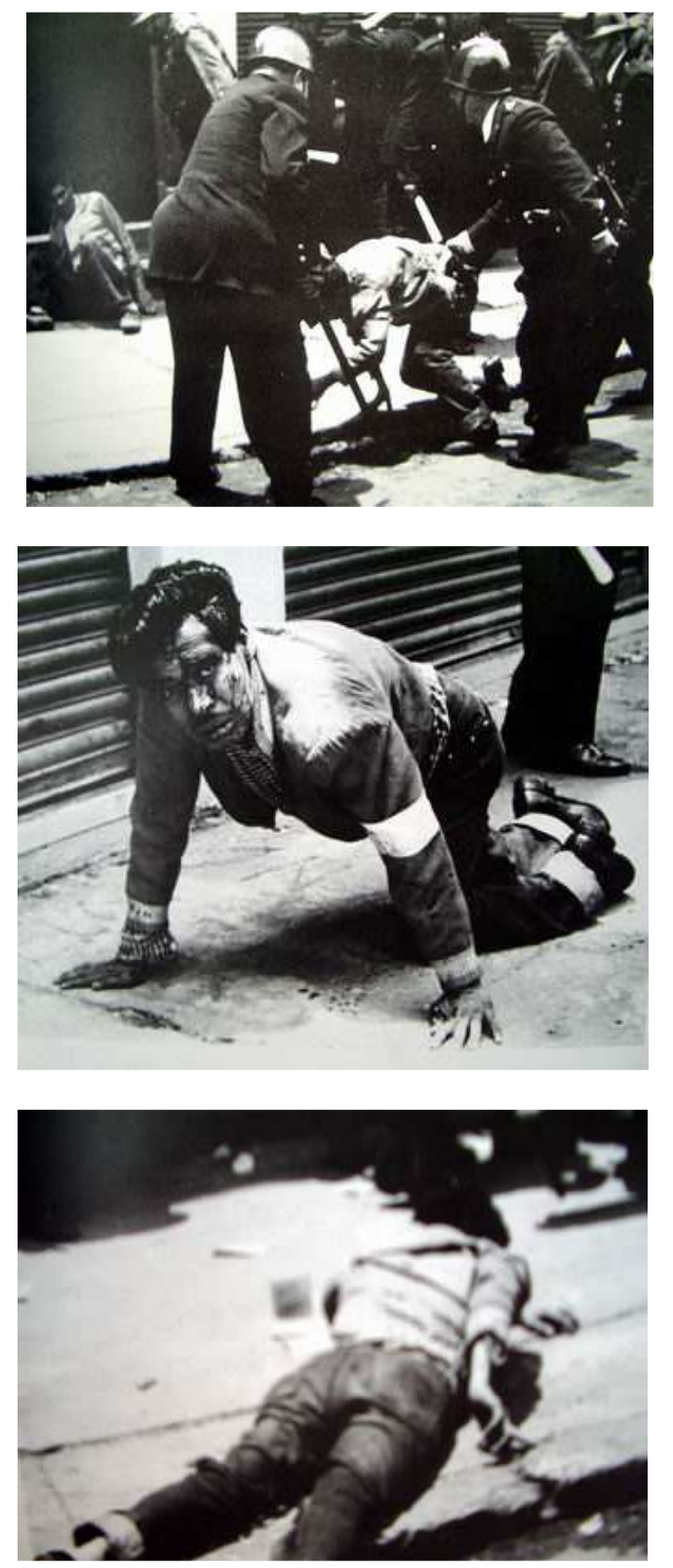

Figs. 64, 65 y 66 Fotos: Héctor García

En efecto. Capdevila vé la realidad de su entorno y es un recurrente constante cuando se trata de mostrar la violencia y la fuerza desmedida ejercida por el Estado en los movimientos populares; en las constantes medidas de dureza oficial que se otorgaron a los diversos sindicatos; a las reprimidas huelgas; a las manifestaciones golpeadas con violencia; las eternas luchas del magisterio nacional; de los gremios de ferrocarrileros y del movimiento de médicos durante el sexenio de Adolfo López Mateos y que tienen su prolongación más allá hasta el movimiento estudiantil a través de su serie gráfica titulada "La represión" (1958) donde es probable que el artista se halla valido de las imágenes fotográficas de Héctor García y de su publicación Ojo! una revista que ve"68 como se observa en la secuencia de las figuras 64,65 y 66 .

Las imágenes están grabadas en diversos materiales como punta seca, al buril, y barniz blando y tienen la característica de ser

\footnotetext{
${ }^{67}$ Raquel Tibol, Gráficas y Neográficas en México, SEP/ UNAM, p. 224

${ }^{6}$ Héctor García y su tiempo, Revista Luna Cornea, número 26, 2003, pp. 67-74.
} 
escenas callejeras no recreadas sino retenidas y documentadas de hechos reales y no inventados: En el número 1 (y único) del 6 de septiembre de 1958, García presentaba con el título de "El principio de autoridad" una secuencia fotográfica de la severa golpiza por medio de culatazos y patadas que había recibido un ciudadano por varios granaderos. Las fotos muestran las escenas desde que lo increpan hasta que es sometido brutalmente por varios de ellos en el piso (no está claro si un ambulante o un integrante del Movimiento Revolucionario del Magisterio, que en el caso es lo de menos). Estas mismas imágenes le harán acreedor al año siguiente a una Mención Honorífica en el Certamen Nacional de Periodismo, y que recuerdan fuertemente los dibujos de Capdevila llevados al metal. Lo cuál me parece válido como argumento visual. ${ }^{69}$.

Así pueden observarse en las fotos que ilustran el artículo de la citada revista largas manifestaciones de maestros, estudiantes y ferrocarrileros en la Ciudad de México que serían con el tiempo un cóctel sumamente explosivo para el gobierno y el entonces Departamento del Distrito Federal y que Capdevila debió de utilizar para recrear la realidad de la sociedad mexicana. Héctor García llama a este hecho la "creación a 4 manos" y como autor ha estado consciente de la utilización de sus fotografías para diferentes fines a los que fue creada. Aunque para ser sinceros, las transformaciones de la imagen fotográfica en forma de impresos gráficos en ciertos temas parecen ser hechos comunes en el arte mexicano. Yo por mi parte, he encontrado imágenes fotográficas de la Revolución que fueron utilizadas por grabadores como Posada y que son concepciones válidas para reflejar la realidad de los hechos vividos; teniendo presente indudablemente que son préstamos autorales que enriquecen el aspecto visual y que a través de la manipulación de otros artistas pueden entenderse a partir de direcciones opuestas y por diferentes medios técnicos. ${ }^{70}$

\footnotetext{
${ }^{69}$ El poder de la imagen y la imagen del poder, fotografía de prensa del Porfiriato a la época actual, Universidad Autónoma Chapingo, 1aㅡ edición, México 1985.

70 Este "proceso a 4 manos" como lo comenta Héctor García, fuera de sorprenderlo le pareció interesante sobre todo por el manejo que había hecho Capdevila de sus imágenes. Casa Lamm. Conversación personal. (31 de octubre 2004).
} 
Un ejemplo de la serie puede ser interesante: La utilización del grabado a la punta seca sobre duraluminio titulado Las Botas" (fig. 67), -que recuerda por la composición, la temática y el trazo directo a la artista Kathë Kollwitz- representa en primer plano las botas militares de dos granaderos que reprimen a un ciudadano golpeado en el suelo, y que fue utilizada años más adelante durante el movimiento estudiantil del 68. Esta misma imagen serigrafiada con alto contraste y con mala calidad de impresión, fue ampliada en un formato diferente ( $87 \times 60$ $\mathrm{cm}$.) para darle la forma de cartel lo que cubriría una mayor cantidad de espectadores ${ }^{71}$. Se le ha agregado el texto "No mas agresión!", colocado en la parte superior y que abarca prácticamente lo largo del cartel en una tipografía gruesa de palo

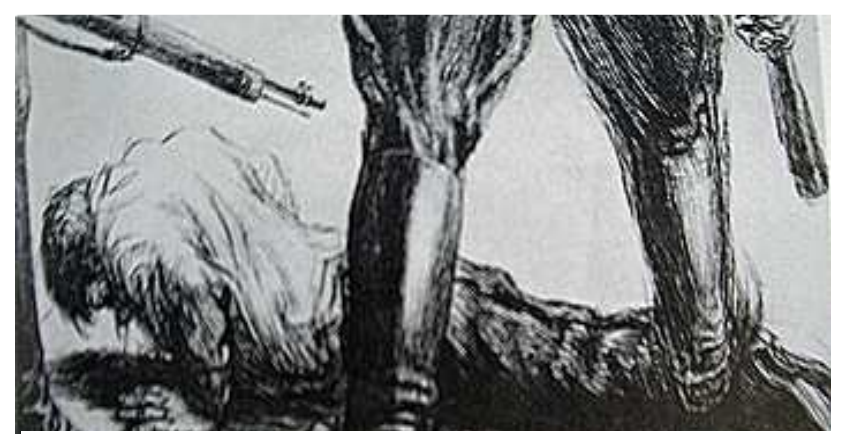

Fig. 67 Francisco M. Capdevila. Las Botas seco. Se comprueba su utilización en una fotografía de aquella época de un transporte urbano de pasajeros con el cartel pegado a su costado lateral y que acompañan irónicamente la antorcha y los cinco aros olímpicos con dos pequeños rectángulos laterales con la leyenda México en la izquierda y 1968 a la derecha.

A principios de los años 70's, Capdevila realizó la serie denominada "Monte Albán, usando materiales del grabado no convencionales como ensambles, sobre posiciones, y placas recortadas, imprimiendo color en todas las variantes. Vemos asimismo aplicaciones de materiales plásticos sobre aluminio y tallas; incrustaciones de recortes de latón y tratamiento de punta mecánica y tratamientos de ácido. La serie se encuentra numerada por variantes gráficas del 1 al $1 \mathrm{~V}$ probablemente denominadas así por las fases históricas por las que atravesó la cultura del valle que van desde el siglo I al siglo XVI. ${ }^{72}$ Existen en Monte Albán tumbas que pertenecen a la época 1 en donde los muertos aparecen siempre acostados boca arriba y las ofrendas son numerosas, y muestran el

\footnotetext{
${ }^{71}$ La imagen se tomó del libro La Grafica del 68 Homenaje al Movimiento Estudiantil, tercera edición, recopilación, texto y diseño: Grupo Mira, México, 1993

${ }^{72}$ Historia de México, Ignacio Bernal, tomo 3.
} 
desarrollo que iba a tener en un futuro como una gran urbe. Asimismo existían murales con escenas de la época. Un aspecto interesante es la gran proliferación de tumbas. En ninguna parte de Mesoamérica se observa un culto a los muertos como Monte Albán. El origen de esta serie de más de diez grabados como lo cuenta Jesús Martínez puede ser de interés para nuestro tema:

...Cuando llegó aquí Capdevila, necesariamente tenía que ser expresionista, no podía ser un pintor, o un grabador de otro tipo Entonces toda su obra estuvo marcada por un traumatismo intenso. $Y$ su encuentro con la muerte aquí en México, lo hizo a través del conocimiento de la muerte en Oaxaca. [...] Después de eso comenzó a hacer la serie de los pectorales y de las muertes. Tal vez lo influyó la manera en que vieron los mixtecos y los zapotecas la muerte. Sobre todo la muerte dorada la muerte de metales preciosos que Capdevila supo manejar con los amarillos y los ocres. Toda esas serie de muertes en dos placas. El pectoral ese famoso que hay en Oaxaca que parece que son dos placas y en el centro está la muerte lo desarrolló muy bien desde su punto de vista. ${ }^{73}$

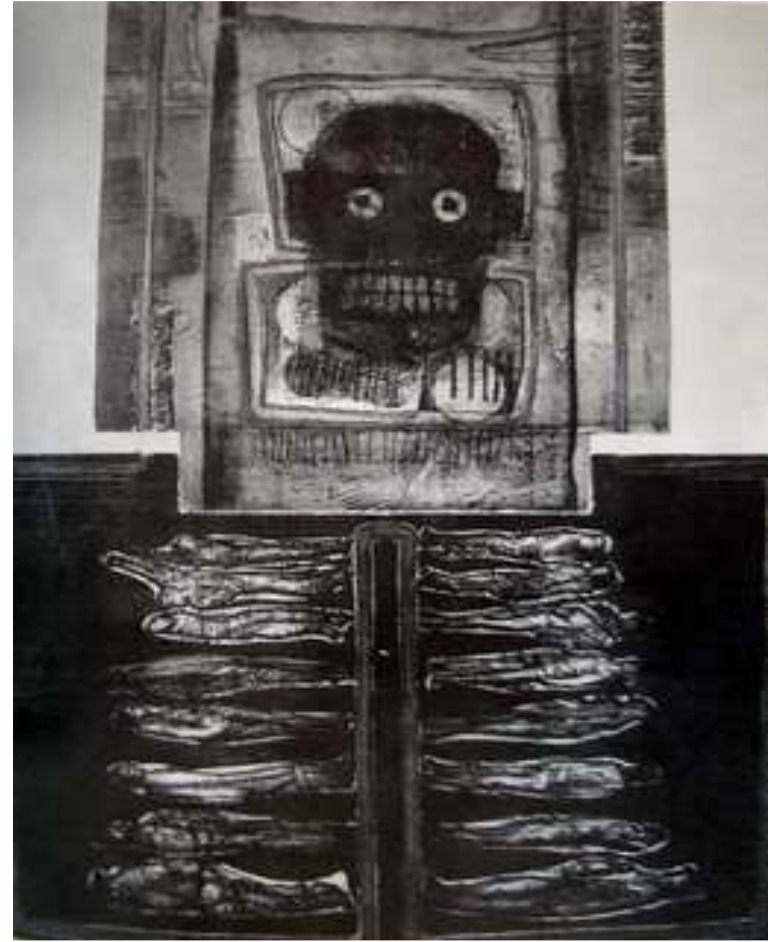

Fig. 68 Capdevila:" El orden de la Negación"
Es este un ejemplo de riqueza tonal y de creatividad personal, y permite al artista mezclar formas de la cultura mixteca con sus recuerdos de la guerra en España, en una temática hecha suya. Algunos de los grabados son realmente sorprendentes por su realización magistral. Me detendré en tres de ellos que me parecen impresionantes debido a la utilización de la muerte.

"El orden de la negación" pieza de 1974, es un grabado pequeño fig. 68) al aguafuerte con aguatinta, ensamble de dos placas con

\footnotetext{
${ }^{73}$ Entrevista a Jesús Martínez, véase nota 66.
} 
impresión de color rojo, café y negro. La composición se integra con dos piezas acanaladas que cortadas embonan en su parte inferior con la superior. La placa de arriba es a su vez una yuxtaposición de placas con el dibujo de una calavera prehispánica vista de frente que con sus ojos mira al espectador. Sus dientes están pensionados en actitud guerrera. El cráneo humano como figura central es de origen mixteco y es el que tiene incrustaciones de turquesa en el rostro y concha en los ojos. La enmarcan piezas dos piezas de metal cruzadas en forma de cruz. La placa inferior muestra cuerpos humanos de diversos tamaños y de diferentes tamaños sobre un fondo negro amortajados y divididos en hileras de 8 cuerpos. No hay detalles en estas pequeñas figuras aquí, solamente la forma de enterramiento que semejan los códices de los antiguos tlacuilos cuando representaban la muerte.

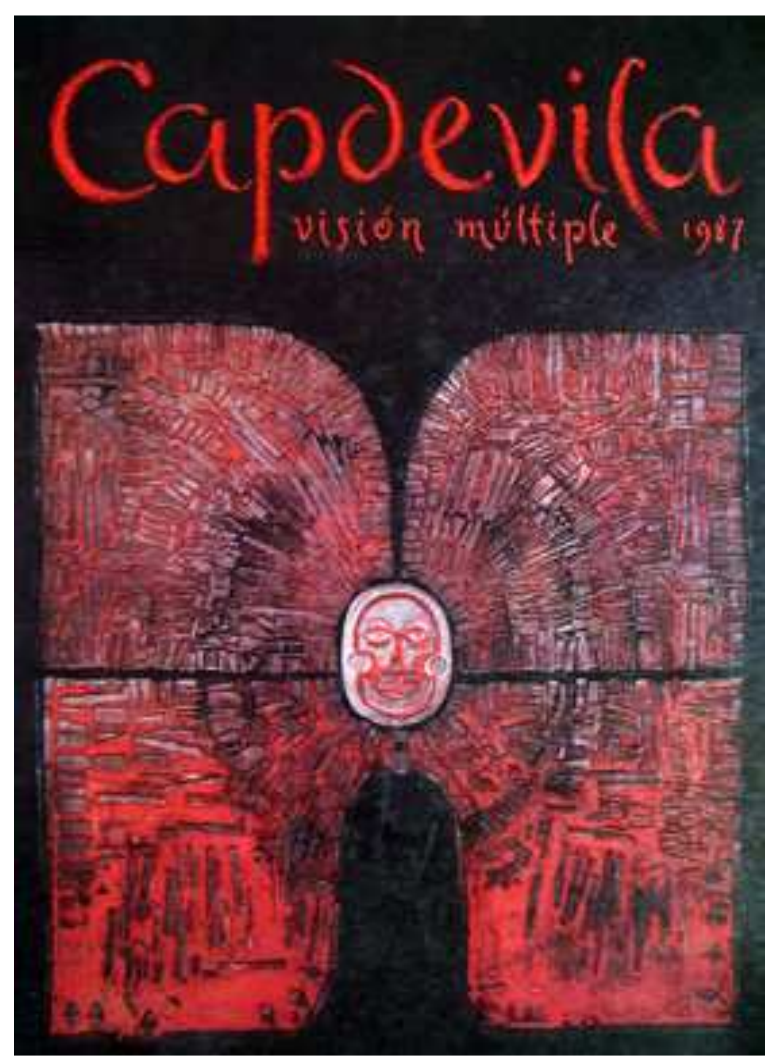

Otra pieza de la misma serie está trabajada en aguatintas e intaglio. La parte central es una pequeña cabeza en forma rectangular del dios de la muerte. Al igual que la anterior los círculos de los ojos poseen perforaciones a manera de concha de nácar. Cinco piezas rectangulares alargadas semejan sus macizos dientes para finalmente terminar en dos grandes piezas arriba y abajo que la enmarcan con texturas que parecen cortezas terrestres vistas desde arriba lo que le da un aspecto mágico y misterioso. (fig. 69)

Fig. 69 Catálogo "Capdevilda Visón múltiple". 


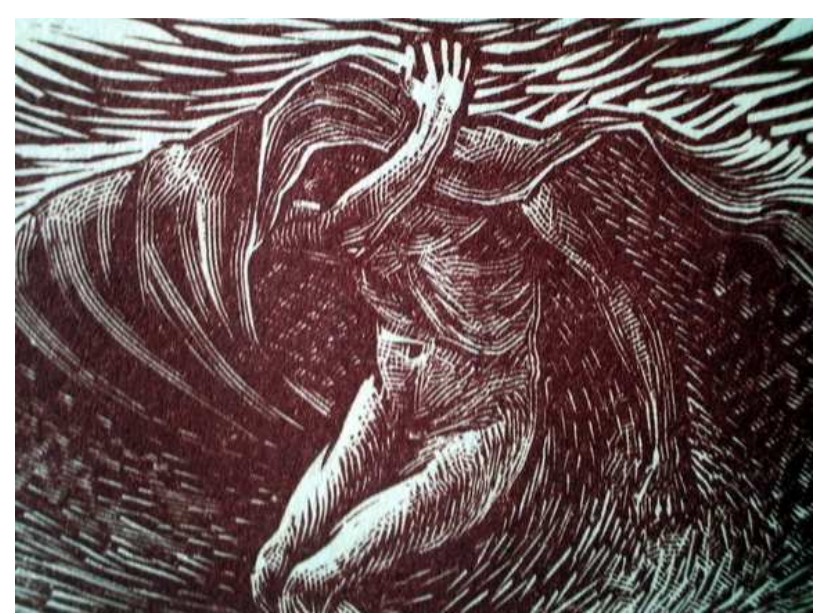

Fig. 70 Idilio Salvaje grabado de Capdevila

Hábil ilustrador y grabador Moreno Capdevila se inició trabajando en la Escuela de Artes del Libro; trabajando muchos años para la Imprenta de la Universidad Nacional de Autónoma de México, la Secretaría de Educación Pública (SEP) y para los Talleres Gráficos de la Nación.

Vale la pena detenernos en dos textos ilustrados bellamente por Capdevila. Uno de ellos corresponde al poema de José Manuel Othón titulado "En el desierto Idilio Salvaje", de tiraje limitado (600 ejemplares) y publicado por la Imprenta Universitaria en el año de 1952. (figs. 70 y 71) El poema fue concebido y

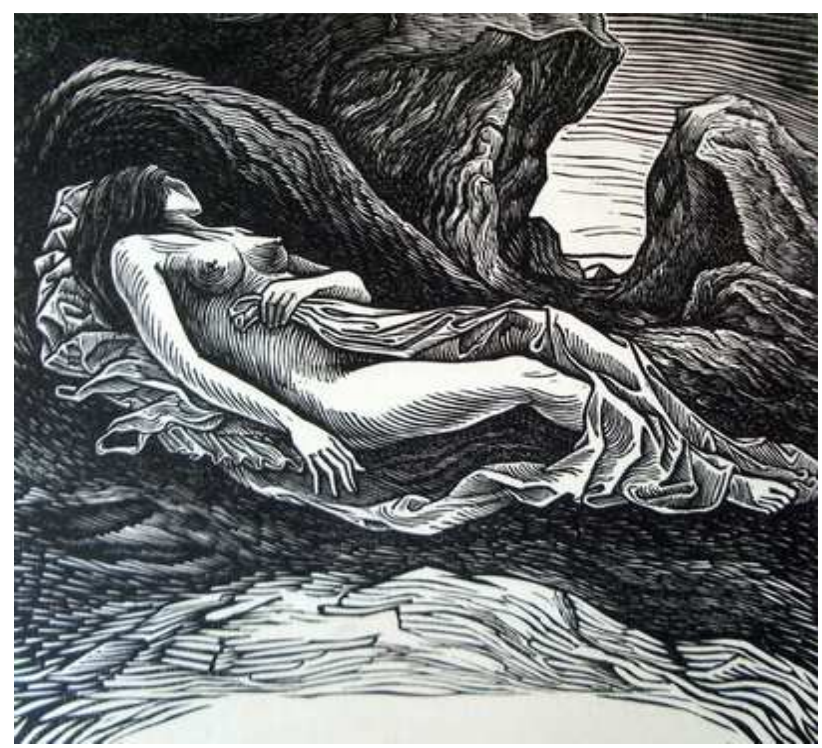

Fig. 71 "Idilio Salvaje" grabado de Capdevila escrito hacia el año de 1904 y de su origen puede decirse que Othón lo creó debido al amor de una mujer de la cual se enamoró perdidamente. Esto es importante ya que el tema gira alrededor del personaje femenino y de la tristeza $y$ de la amargura que se cierne sobre el corazón del poeta. ${ }^{74}$

La técnica empleada por el artista fue el linóleo, material dúctil y capaz de reproducir fielmente los grises y negros. En el texto se encuentran 19 grabados de

${ }^{74}$ José Manuel Othón, En el desierto Idilio Salvaje, Imprenta Universitaria, México, 1952. 
diversas medidas que incluyen la portada trabajada en la técnica de camafeo y que podría considerarse como una de sus últimas obras de carácter editorial puesto que al jubilarse de la ENAP, se abocó de lleno a la producción gráfica. (fig. 72) Una constante que se observa es el uso de la figura humana muy bien trabajada con el buril que refleja por consecuencia el manejo de un buen dibujo proporcionado que ha estudiado en forma conveniente el uso de la luz y la sombra. Es ejemplo de estudio y reflexión de un texto al que la imagen se le ha complementado como una unidad integrada. (“... En la estepa maldita, bajo el peso de silbante gris que asesina, irgues tu talla escultural y fina, como un relieve en el confín impreso...") No es la línea dura y fría, sino un trazo suave que envuelve a la mujer de largos cabellos en su túnica en la que se adivina su cuerpo torneado. Lo mismo sucede con los paisajes de rocoso contraste donde se ha plasmado sensaciones de lejanía y de primeros planos (“...inmensidad abajo, inmensidad, inmensidad arriba; en el hondo perfil, la sierra altiva al pie minada por horrendo tajo..."

Otro libro poco conocido es el titulado "Inventario de cenizas", poemas de Octavio Novaro de circulación un poco más amplia que el libro de poemas anterior (2000 ejemplares) ${ }^{75}$.

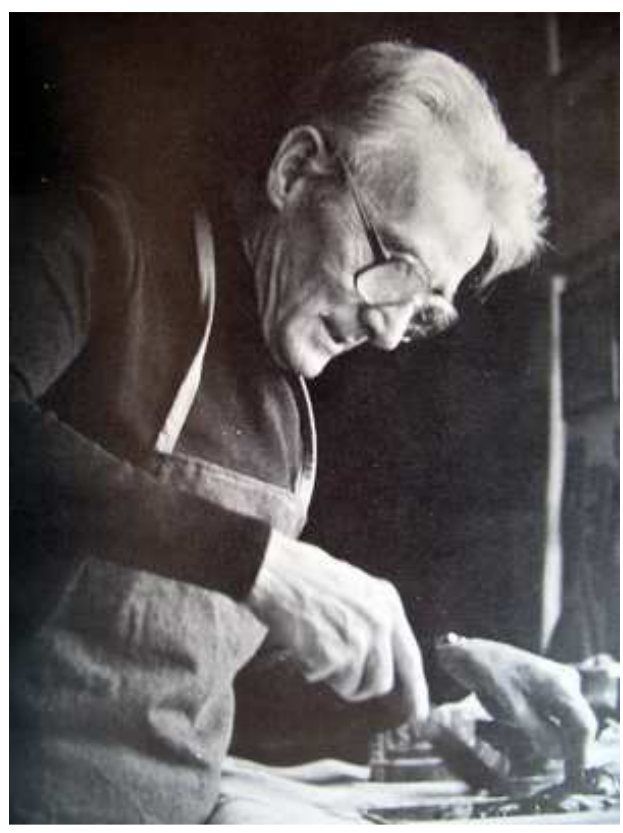

Fig. 72 Francisco Moreno Capdevila. Fotograf\{ia

El poeta fue en su juventud compañero de

Octavio Paz futuro premio Nóbel de Literatura. Maestro de tendencias socialistas en la época de Lázaro Cárdenas y difusor de la cultura, Novaro fue asimismo director de una editorial poderosísima ya desaparecida desgraciadamente, y gracias a esto pudo imprimir sus propios textos. El libro contiene diversos poemas de diversa índole: desde invocaciones, el amor, cartas a la madre y la muerte. Sobre este último nos detendremos en un poema particularmente porque lleva por

\footnotetext{
${ }^{75}$ Octavio Novaro, Inventario de Cenizas, grabados de Capdevila, Edt. Novaro, México 1964
} 
título "Siempre la muerte" y algunas de sus partes me parecen interesantes por el tema que trata y que son las siguientes:

La muerte desde adentro. Aquella muerte

Con que muere la llama en el pabilo,

Con que muere la flor en el florero

Cuando cierro los ojos y la olvido.

Yo trato de la muerte verdadera

Con que muere por dentro el crucifijo.

Aquel morirse todo, que sucede

cuando yo muero a solas y conmigo.

El grabado de Capdevila que acompaña al texto es un camafeo a dos placas

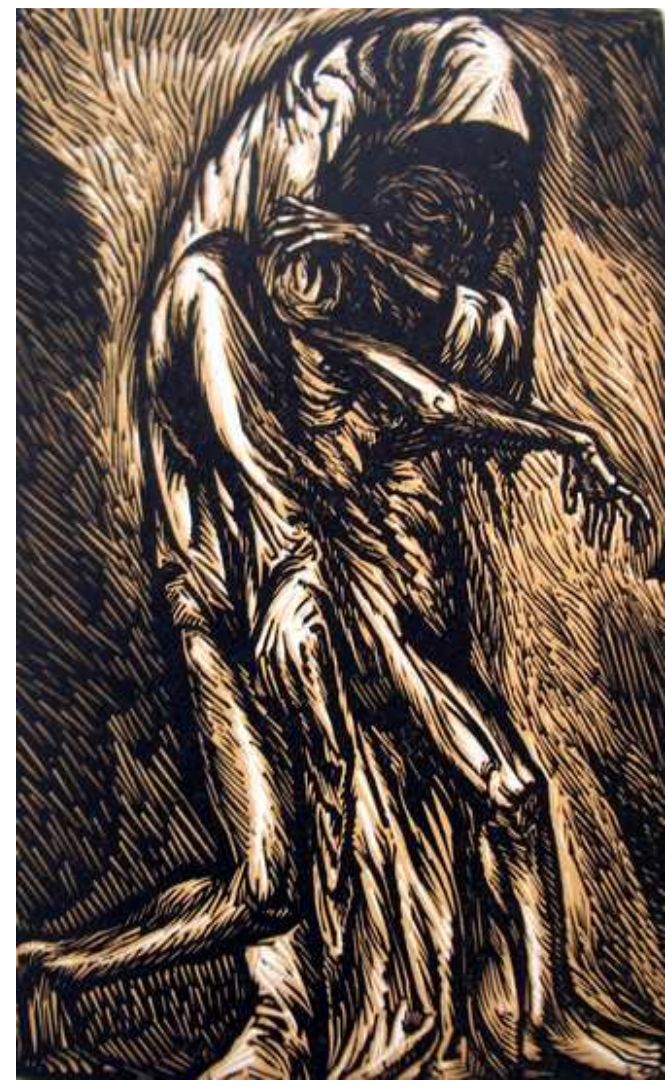

Fig. 73

"Siempre la Muerte" Grabado de Capdevila que tiene dos figuras muy bien trabajadas y en composición vertical. (fig. 73) Una de ellas mantiene una túnica larga de excelente factura que le oculta el rostro y se encuentra ligeramente flexionada hacia el frente. Sus huesudas manos atrapan y detienen la cabeza de un hombre al que se ha cubierto el torso de la túnica. Éste, vigoroso, apenas si puede sostenerse de pie. Por instantes la imagen se pierde entre las figuras. No se aprecia donde esta el primer cuerpo y donde se distingue del segundo; y de ahí que el espectador tenga una confusa imagen del grabado al que se le han agregado pequeñas líneas alrededor a la manera de un halo de mayor a menor intensidad en las orillas dando una sensación permanente de 
movimiento. La dos figuras del grabado se encuentran unidas sin poderse separar y de ahí la importancia de la vida y de muerte indisolublemente ligadas.

\section{2 José de Jesús Martínez Álvarez}

Pintor, diseñador, dibujante José de Jesús Martínez Álvarez es un grabador consumado (1942). Relacionado en línea directa con el oficio emerge como el artista que desde su producción, revalora y experimenta con los elementos que le ofrece la tradición para articular un lenguaje renovado. Su trayectoria es el punto de partida para desarrollar un trabajo de investigación, que proporcione respuestas a algunas interrogantes que necesariamente surgen al enfrentarse a los productos artísticos. $\mathrm{Y}$ sobre todo, estructurar un análisis, donde a partir de su discurso reconocer como su propuesta de trabajo, el empleo de los recursos de la tradición gráfica junto con la experimentación como medios alternativos para renovar el lenguaje del grabado mexicano de la

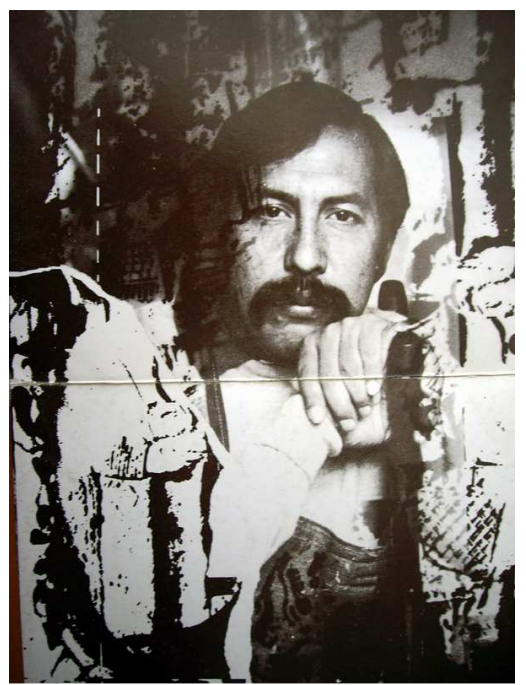

Fig. 74 José de Jesús Martínez fotogrfa\{ia última década de fin de siglo

Jesús Martínez, (fig. 74) ingresa a la Escuela Nacional de Artes Plásticas de la UNAM en el año de 1966, en donde estudia las distintas disciplinas plásticas, siendo fundamentales para su posterior desarrollo las clases de pintura con Antonio Rodríguez Luna (1910-1985)), y de grabado con Francisco Moreno Capdevila (1926-1995), los dos coincidentemente de origen español. Es de este último, donde Jesús Martínez abreva su sed de conocimientos. Es una fusión estrecha entre lo conocido y por conocer; entre el discípulo y el maestro, entre lo que es oficio y lo que es arte. Jaime Labastida, el poeta, menciona que: 
Jesús Martínez es un grabador que no solo pinta lo que ve, sino que construye con osadía, una nueva manera de ver. Aquí habitan animales alucinados, perros mitológicos, tigres arrancados del tatuaje nocturno atascado de estrellas, insectos prehispánicos que liban una miel eternamente joven, mapas coloniales, papel moneda dignificado de pronto hasta la altura del arte, los periódicos de ayer, la palabra represión, los poemas. $^{76}$

En 1968, tiene la oportunidad de llevar a cabo su propia interpretación de la historia vivida a partir del movimiento del movimiento estudiantil. Era Martínez, uno de los muchos artistas que se sumaban a las demandas de ese momento, desarrollando su callada labor desde el antiguo edificio de San Carlos donde se vivía, dormía y comía y se hacia grabado y se imprimía de día y de noche. 20 años después recordaría los sucesos y los narraría en una entrevista concedida al periódico "La Jornada":

“...evoca: El movimiento en San Carlos no cesaba. Llegaba Fernández Ledesma con sus diseños; ahí estaba Moreno Capdevila a pesar del peligro que corría de ser deportado a España. Le decíamos que se fuera, que ahí venían los granaderos y seguía trabajando. Justamente después de una larga jornada nos fuimos a la manifestación; llegamos temprano, goteaba y nos quedamos hasta que pasó todo." (...) "Desde entonces empecé a entender muchas cosas, porque luego de la matanza que presenciamos el trauma era tremendo y vino el cuestionamiento de que fue realmente lo que sucedió" (...) "Hubo que rascarle al asunto históricamente con el afán de comprender la realidad; desde entonces me remonté a lo prehispánico que se convirtió en una motivación en mi obra”. (...) Mi primera muestra en el IFAL, estuvo integrada por 20 dibujos, alusivos a la represión del 2 de octubre." (...) "Desde entonces, también, se inició mi relación con los poetas..." 77

Estos primeros dibujos representaron una interpretación de un momento tan intenso para Jesús Martínez. Sus títulos por si solos son una narración visual de un hecho histórico lamentable: Invitación (invitación al mitin) /Mitin (la masa que se arremolina en Tlatelolco)/ La señal (representa el momento de las luces de

\footnotetext{
76 Jaime Labastida, presentación del catálogo de Jesús Martínez: Agua grabada, Museo del Palacio de Bellas Artes, pp. 5-6

77 Adrana Malvido en Testimonio de Jesús Martínez, artista plástico. Del 68 Zabludovsky decía que "no pasaba nada", La Jornada, 9 de octubre 1988.
} 
bengala)/ La masacre (el universo de ruidos de metralla)/ La huida (la escapatoria de los ahí reunidos) / La angustia (tríptico de sensaciones).

En 1969, publica su primer álbum con 10 grabados de tiraje limitado (cuarenta ejemplares) $^{78}$, en colaboración con el poeta Juan Bañuelos con el titulo "No Consta en Actas" con motivo del movimiento estudiantil del año anterior. Martínez siempre ha coincidido con los poetas y este primer acercamiento se convierte en un arranque emocional y la oportunidad de hacer un planteamiento

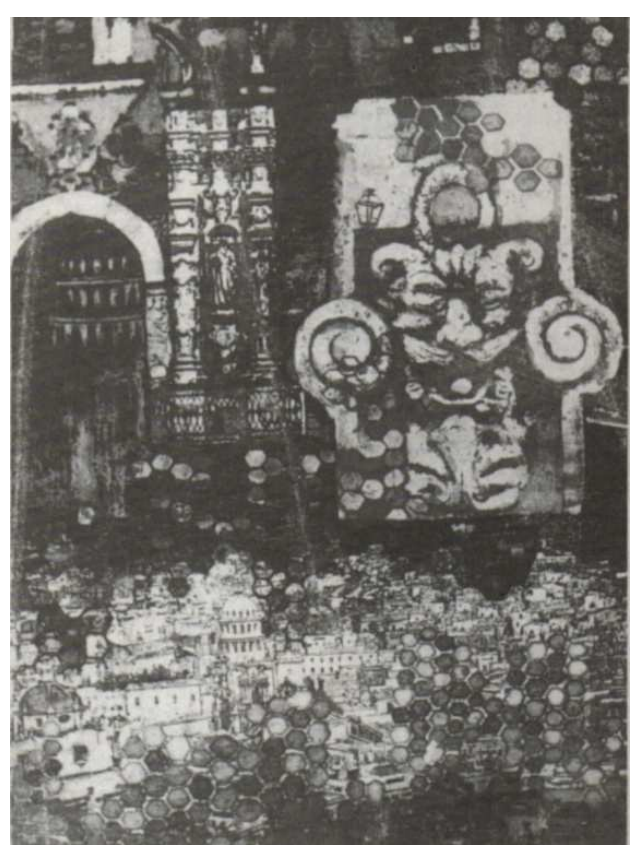

Fig. 75 Jesús Martínez Paisaje en siete actos V. Aguafuerte complementario y al mismo tiempo independiente del contexto literario. $\mathrm{Y}$ al establecerlo permite planteamientos existenciales alrededor de la masacre del 2 de octubre para en primera instancia identificarse y poder entenderse a si mismo. Acaso en las clases de la Academia de San Carlos descubrió, lo fundamental que le permitirá descubrir el principio de su obra gráfica: la intensa relación que existe entre la reflexión profunda y el vacío

La experiencia de crear analogías entre la poesía y la línea entre lo plástico y lo literario y vertirlo hacia la denuncia no pasa desapercibida en el ambiente cultural de la primera década de los años 70 y 80 . Véase para este ejemplo la figura 75 saturada de estas reflexiones en las que semejan manifestaciones y masas humanas con reminiscencias prehispánicas.

\footnotetext{
78 En este sentido es importante aclarar que aunque los tirajes son de absoluta responsabilidad de los autores, se considera que una edición normal es de 100 ejemplares como promedio. Aquí el tiraje fue limitado.
} 
Jesús Martínez encontró en la relación entre tradición e innovación el punto de interés que le abrió muchas perspectivas de enfoque de su obra, supo conciliar la renovación cimentando sus cambios sobre los pilares de la tradición gráfica mexicana y no sobre sus ruinas, y a la manera de los antiguos tlatelolcas, glorifica el momento del sacrificio, y opta por escuadriñar en las profundidad de sus raíces. (fig. 76) Este es un pensamiento firme y definitivo que le permitirá definir el rumbo trazado. Así lo reafirma cuando encuentra en la poesía la relación más estrecha que existe entre las artes. Un poema le da el apoyo conceptual que le proporciona la síntesis, la musicalidad y el ritmo; la sonoridad y la fuerza.

Ahora bien, este encuentro con la presencia eterna de la muerte se da en Jesús Martínez a partir de la relación con los poetas como Juan Bañuelos

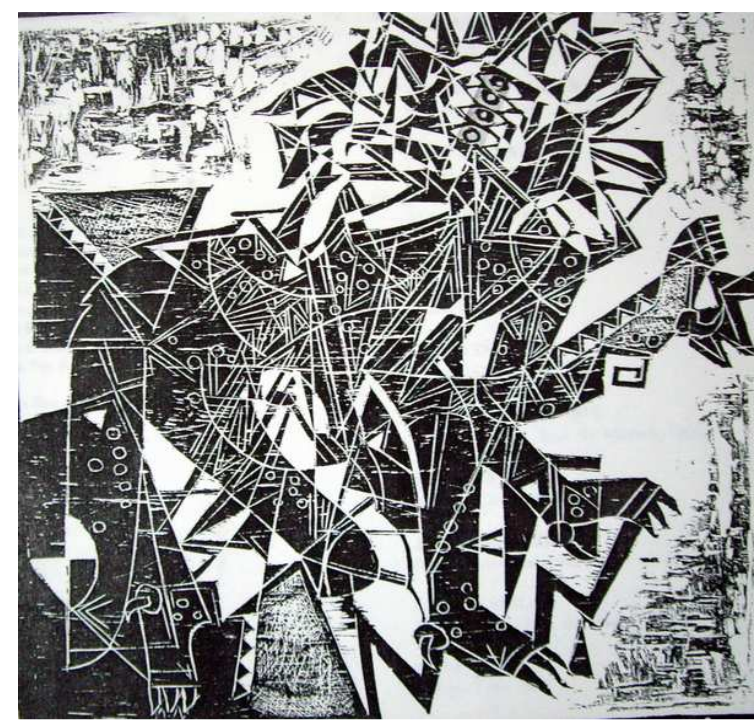

Fig. 76 Jesús Martínez Alvarez Grabado en madera de quien laboraba en ese entonces en un texto náhuatl de La Visión de los Vencidos del historiador Miguel León Portilla o como Jaime Labastida o como Carlos Pellicer, Eraclio Zepeda o Elva Macías sobre sus textos sobre los insectos y al que Martínez iba agregando su propia experiencia teniendo como cómplices de un proceso creativo al zinc a los ácidos, y al barniz de aguafuerte y aguatinta que crean en el papel impreso una ilusión de realidad por medio de una madeja de líneas, de sombras que definen una forma y de texturas en el tiempo y con esto su propia vida y su propia fuerza expresiva en un códice gráfico.

A fines de octubre de 2004, tuve la oportunidad de hacerle una larga entrevista a propósito de su quehacer plástico y saber su punto de vista en este tema tan recurrente de la muerte como pretexto en su obra gráfica. Su plática fluida e interesante en experiencias personales y artísticas se derivó hacia temas análogos que tenían que ver con su infancia y la generación de formas que tenían 
que ver en una primera instancia con los movimientos políticos, con la violencia, con la represión y con la muerte. No en balde atesora en su memoria aspectos fragmentados que une a voluntad y los integra para reconocer y unir su pasado gráfico. Su obra es ahora más abundante con manejo de formatos que van desde pequeños a grandes dimensiones, escudriñando la luz para llegar a la oscuridad, con toda la gama tonal que hay de grises del ácido, utilizando como base la riqueza del mundo prehispánico y de los cronistas antiguos y donde la revaloración del grabado, del dibujo, y de la textura como obra de arte, ha sido una constante en el trabajo del artista desde sus inicios hasta su obra reciente. La relatoría de su vida la expongo en forma inmediata porque considero que hará entendible su propia obra.

\section{3 Juan Soriano}

Un caso excepcional en el arte mexicano contemporáneo por su atracción hacia el tema de la muerte, es sin duda alguna el artista jalicience Juan Soriano (1920-

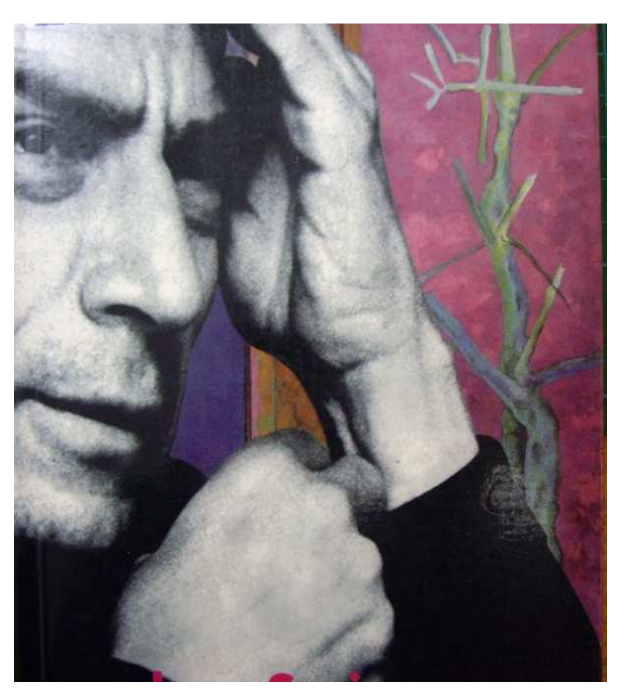

Fig. 77 Juan Soriano. Fotografía 2006). Pintor y dibujante autodidacta -salvo un corto periodo de iniciación con el pintor Santos Balmori- llega a la ciudad de México en 1935 y decide vivir de la pintura. Los mitos clásicos se encuentran en su dibujo de tendencia clásica y alargada y son el punto de avance en el mundo artístico. Adquiere a partir de viajes a Grecia un interés particular por las formas de seres mitológicos de centauros, sílfides, peces, serpientes, toros y pájaros fantásticos que van apareciendo en su trabajo por series: peces, juegos de artificio, y calaveras. ${ }^{79}$ (fig. 77)

\footnotetext{
${ }^{79}$ Elena Poniatowska, Juan Soriano niño de mil años, Plaza y Janes, México, 1998.
} 
Intelectual y amigo de personajes notables tanto mexicanos como Octavio Paz, Xavier Villaurrutia, Salvador Novo, como de españoles republicanos como los poetas León Felipe, Manolo Altolaguirre, y Luis Cernuda, Soriano se involucra pronto en el medio teatral y realiza diseños y decorados para el teatro innovador de los años treinta y cuarenta de la gran metrópoli. La naturaleza del artista, le permite desarrollar un estilo personal a base de un manejo extraordinario de color, a partir de la utilización de grandes formatos donde las formas compositivas adquieren libertades sobre el lienzo. Soriano se enfrenta tarde a la gráfica producto de una beca Olivetti en París en el taller de Stanley Hayter lo que permite un acercamiento a la complejidad del grabado contemporáneo, pero su aprendiaje es total porque logra un estilo único y personal. El tema de la muerte, es abordada por el artista en fechas tempranas primero en

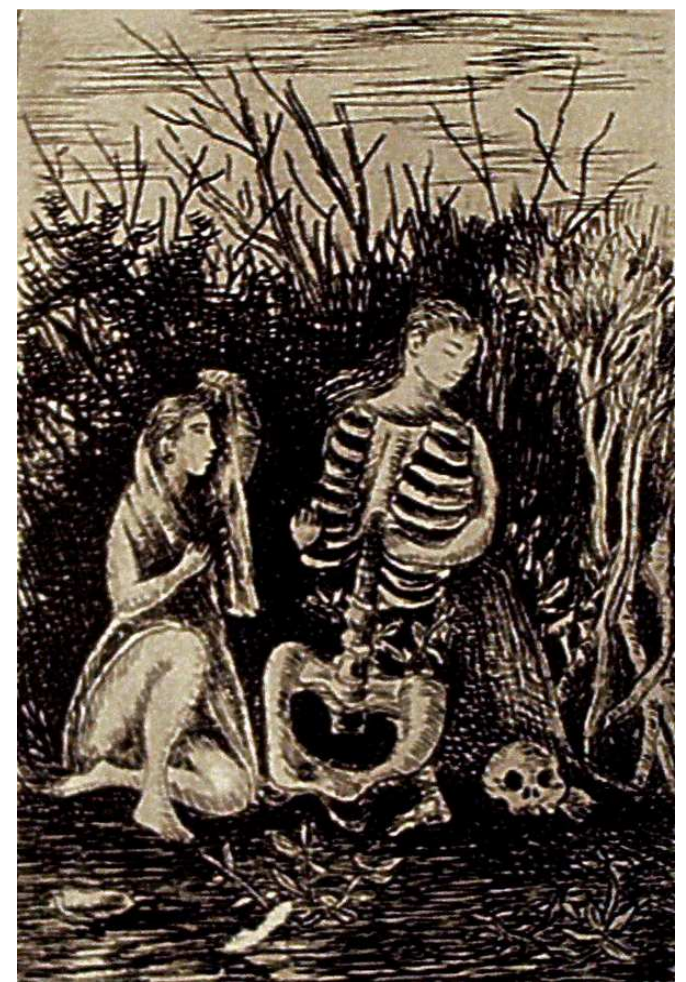

Fig. 78 Juan Soriano "Sin titulo". Aguafuerte y punta seca dibujo, después en óleos sobre tela y trabajados igualmente en el grabado en metal debido a que eran regalos de tiraje reducido a su círculo íntimo de amistades-. Son estampas exquisitas por su tamaño (que para su gozo visual sólo pueden observarse con lupa) y que sus temas eróticos. En la serie de "Ciudades y Días" un personaje mitad esqueleto permanece sentado sobre un raro paisaje de hierbas altas, mientras una doncella trata de cubrirse el rostro ante la escena sorprendente. Tal pareciera que ha sido comido por animales salvajes y solo ha quedado de su rostro algo humano. En el piso como sinónimo de muerte un cráneo humano es testigo de la escena dramática de vida y muerte al mismo tiempo. (fig. 77) 
Otra punta seca es sorprendente por la finura de sus trazos es el grabado de un viejo y podrido árbol en forma de falo donde descansa un esqueleto sireno de espalda. Hacia el lado derecho de la composición una sirena esqueleto es atraida

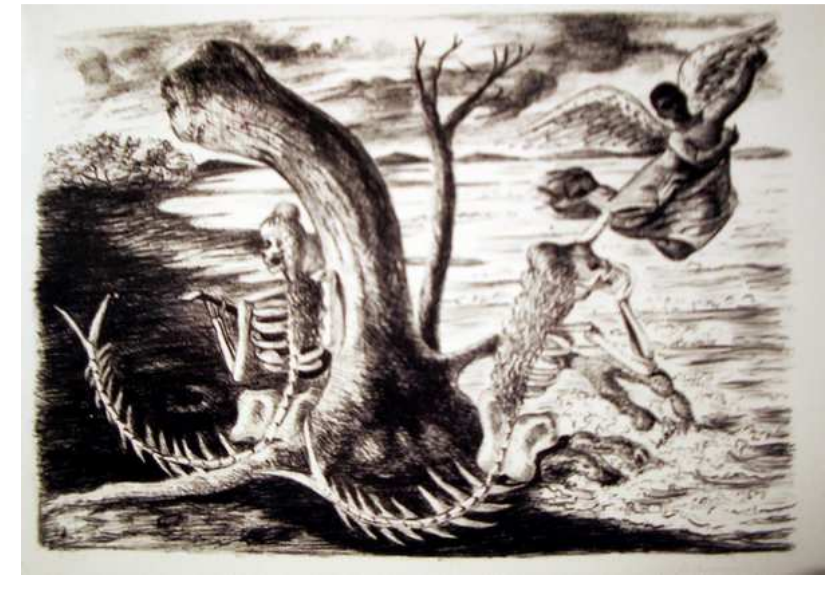

Fig. 79 Juan Soriano. "Ciudades y Dias" Aguafuerte y punta seca por un ángel negro sobre un paisaje marino. (fig. 79)

Soriano es abundante en su producción gráfica sobre todo en el tema de calaveras que se mueven en el mundo en acciones fantásticas como si fueran seres humanos: duermen, comen, abren o cierran puertas (fig. 80) hacen vida social, hacen el amor

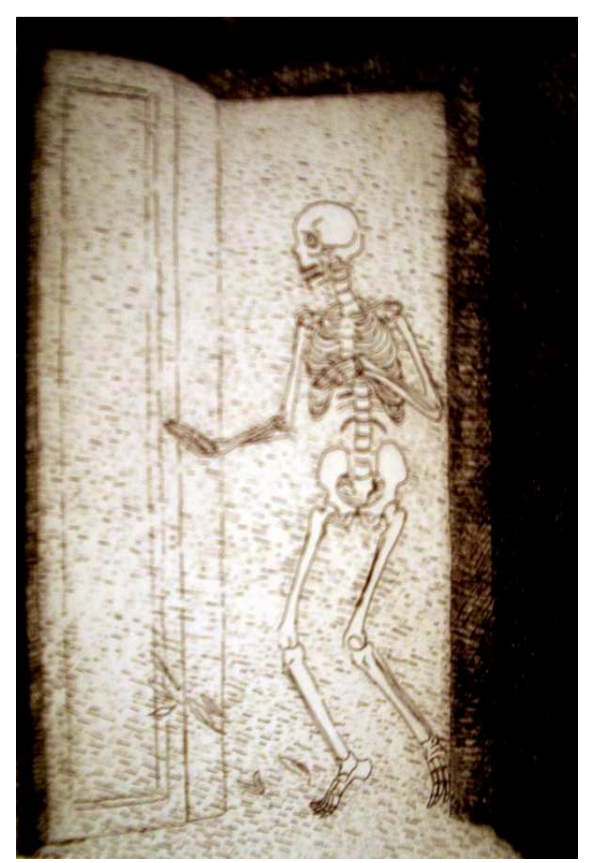

Fig. 80 Juan Soriano.

"Puerta Abierta". Aguafuerte y punta seca

Sicilia sobre el tema mortuorio que dice: 
Morir es olvidarse de los nombres, Entrar al interior de la materia

Mostrar el esqueleto y su miseria, No saber nada de goce de los nombres.

Morir es descender, desencarnarse, Perder el cuerpo, hacerse calavera, Sumirse entre las sobras la espera, No saber de luz y amordazarse...

En un pequeño aguafuerte ${ }^{80}$, (fig. 81) la muerte alada protegida por una suave túnica que moldea su cuerpo huesudo, cabalga sobre un caballo en elegante

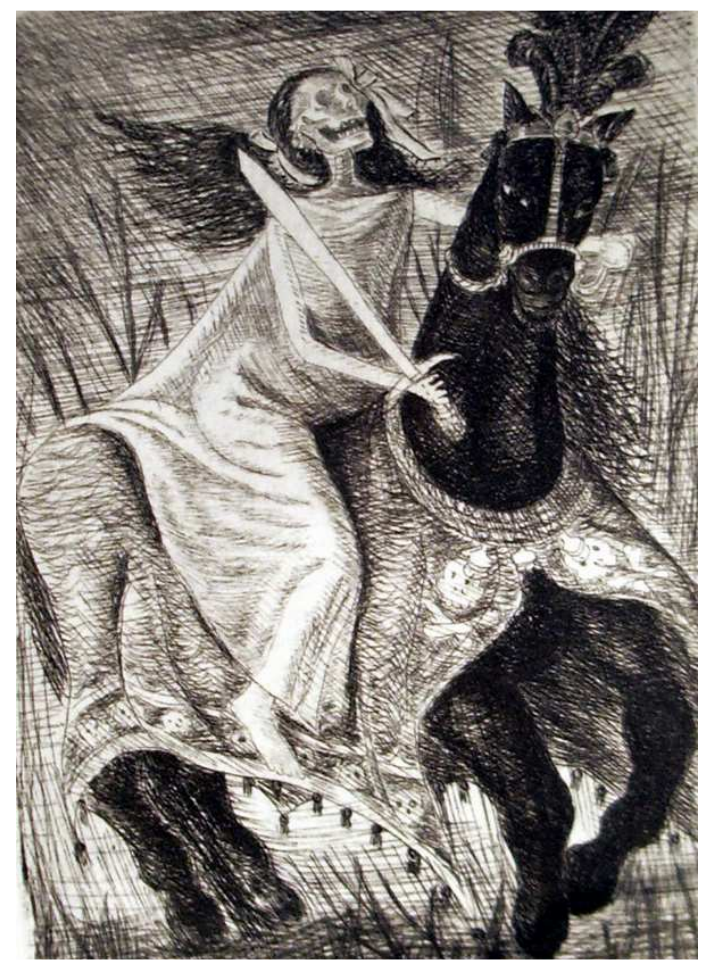

Fig. 81 Juan Soriano. "Ciudades y Días"' Aguafuerte y punta seca tropel, y en que el artista ha hecho énfasis en el primer plano del movimiento de las patas delanteras del animal. Aquí nuestro personaje porta una espada (la que corta el hilo de la vida quizás?) y llama la atención que el animal se encuentre adornada su cabeza con plumas y su cuerpo protegido por una frazada decorada tanto en su cuello como la que cae sobre sus costados a la manera de los caballos protegidos del toreo.

Soriano fue amante de los paisajes de naturaleza griega y romana, y existe una constante en el uso de árboles y florestas exuberantes donde tal parece que el tiempo se detiene: sólo es la escena con los personajes solitarios, realizando actividades cotidianas y el espectador tiene la sensación de ser

\footnotetext{
${ }^{80}$ Las medidas de la serie la "Moda y la Muerte" son en general de $33 \times 25.5 \mathrm{~cm}$. y su fecha de realización de 1984 .
} 
"voyeur" de un tiempo y acción totalmente privados. Por ejemplo, la imagen de un ser fornido de anchos hombros con senos frondosos que corta altas hierbas con ayuda de una hoz puede representar una imagen romántica campirana; sin embargo llama la atención la posición de la mano derecha, que tal parece que lo que quiere arrancar de un tajo es su propio sexo que se florecido y lleno de luz en contraposición al resto de las hierbas. (fig. 81) Estas ideas eróticas le fueron siempre propias a Soriano, quien nunca escondió sus preferencias sexuales y que demostraba como artista el interés que tenía en la búsqueda de hombres con quien relacionarse sentimentalmente en un México donde sus ideas no tenían cabida.

Fiel a sus ideas y a fina sensibilidad, Juan Soriano siguió creando aún en sus últimos años pero ahora en la escultura monumental con temáticas recurrentes de animales fabulosos. Antes de morir había

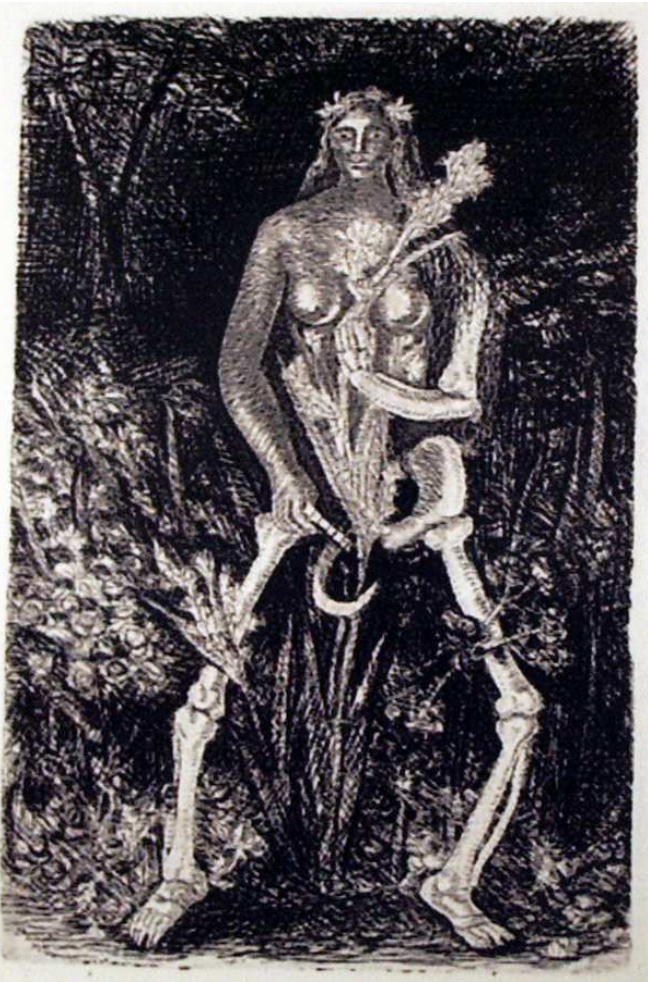

Fig. 82 Juan Soriano. "Ciudades y Días"”" Aguafuerte y punta seca hablado de su concepto de muerte en un texto a propósito del tema:

Sin la muerte nada tendría valor. Nunca me ha preocupado la idea de que yo voy a desaparecer como Juan o como individuo. Me parece maravillosa la muerte que me da valor a cada dibujo que uno hace, a cada conversación que uno tiene, a cada momento que se vive, que es único e irrepetible y lo es porque va a pasar el Yo que lo vive. Entonces es maravilloso ten la facultad de hacer pequeños objetos que representan esa variedad de emociones que constituyen la vida de mi yo.

Juan Soriano ${ }^{81}$

\footnotetext{
${ }^{81}$ Texto tomado de la presentación de "Moda y la Muerte" que incluye estas palabras de Soriano.
} 


\section{La gráfica actual}

Numerosos son los artistas que han utilizado el cuerpo humano como motivo principal de sus obras ya sea creando, recreando o modificando y destruyendo lo que puede ser un universo y un espacio como valor plástico. En nuestro país las

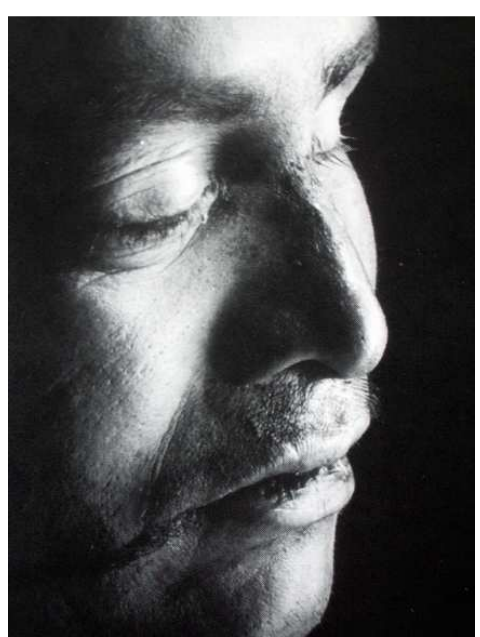

Fig. 83 Perfiles (de la serie de la Fosa Común) Fotografía de José R. Pérez . mutilaciones al cuerpo y dentales fueron hechos comunes que reflejaban valores importantes en la sociedad prehispánica. Hasta nosotros han llegado ejemplos de mutilaciones de la cultura azteca que siguen siendo impresionantes. Los mayas, asimismo acostumbraban deformarse el cráneo como una forma estética común en su concepción de belleza.

Dentro de la historia documentada, son sobradamente conocidos los estudios sobre el dolor del Dr. Duchene y Adrien Tournachon realizados en 1856. Sus estudios tienen que ver con las contracciones musculares en el mundo de la medicina. Usando diversos instrumentos para provocar dolor, Duchene de Bolulogne, perteneciente a la Sociedad de Medicina de París consideraba el uso de la fotografía como una herramienta indispensable para los estudios científicos. (figs. 83 y 84) Ya León Foucault se había ocupado anteriormente en 1844 de producir daguerrotipos sobre el tema. Sin embargo Duchene deseaba saber si el dolor constituía un característica humana universal, y con este fin en 1852 cinco voluntarios cinco pigmeos de guinea, dos mujeres, un joven, un anciano, un estudiante de anatomía y un trabajador alcohólico comenzaron

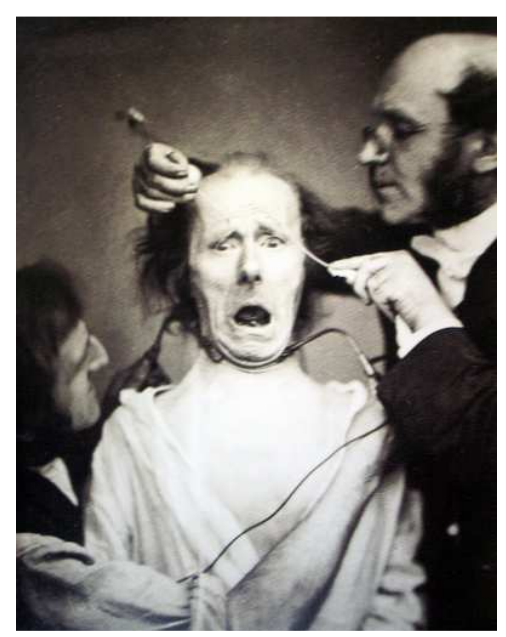

Fig. 84 Duchenne de Boulogne Estudios de Dolor lo que serían los horribles experimentos sobre el dolor a través de la aplicación de corriente eléctrica conectado a un generador (hoy en el Museo París de la historia de la medicina). Conforme se avanzaba en 
sus estudios fluían las placas fotográficas registrando las actitudes, gestos y deformidades del rostro humano conforme se aumentaba la carga de voltaje. Duchene tomo más de 72 placas en su trabajo que el denominaba de "investigación" ilustrando con ellas su artículo "El Mecanismo de la fisonomía". ${ }^{82}$

Fernand Léger había comentado tiempos atrás su uso válido al expresarse que "... si la cara, el cuerpo humano se convierte en objeto, se ofrecerá una gran libertad al artista moderno... "83 Con esa idea en 1997 el Consejo Nacional para la Cultura y las Artes, el INBA y el Museo de Arte Contemporáneo Alvar y Carmen Carillo Gil realizaron la exposición Las Transgresiones al Cuerpo con la presencia de 57 artistas nacidos entre 1940 a 1970, convocados para ofrecer distintas propuestas en relación a nuestro cuerpo que en la muestra, tuvo la posibilidad de ofrecer como el cuerpo puede ser manipulado y persuadido a voluntad de los creadores y manifestarlo en imágenes biológicas, físicas y plásticas (fig. 85) Se establecían desde luego, los conceptos tradicionales de occidente y

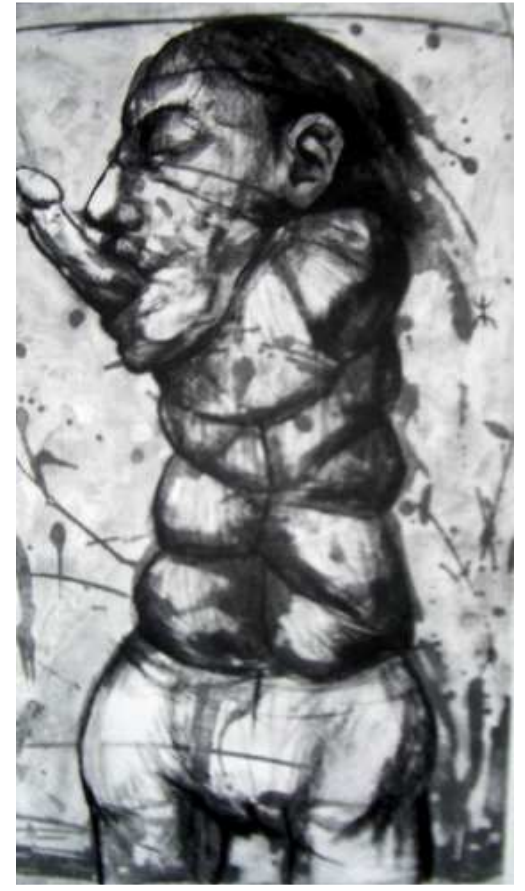

Fig. 85 Miguel Canseco "Deep troat" Punta seca del valor y la concepción de la belleza del cuerpo, la salud, la fortaleza y la vejéz y el aspecto de la muerte. Edgardo Ganado Kim, curador de la muestra escribió al respecto:

La muerte es una imagen que no se define por si misma, sino que es usada como un estado del individuo, en el que lo real y lo representado se tocan sólo en tanto imágenes, pues los valores morales que les otorgamos son distintos evidentemente no es lo mismo ver la representación pictórica de un cadáver o su proyección por la televisión, que estar frente a él.

\footnotetext{
${ }^{82}$ Duchenne de Boulogne, Contractions musculaires en Hans-MichaelKoetzle, Photo Icons The story behind the pictures volume 1, Taschen, 2002.

${ }^{83} \mathrm{CL} /$ Libro/ Catálogo Transgresiones al cuerpo, Museo Carrillo Gil, mayo-julio 1997.
} 
Parecería ser que la muerte, como concepto, está cada vez más cerca, como retando los avances de las técnicas médicas y químicas para la prolongación de la vida; las interrogantes en torno a la muerte se vuelven cada vez más ambiguas, pero también se nota un miedo a la muerte lenta y dolorosa, que se inscribe sólo y nada más en el cuerpo. ${ }^{84}$

Entre los participantes de dicha exposición se distinguieron por su obra gráfica Armando Eguiza con una plaquette llamada El sueño de Cronos, con dibujos de restos humanos en calidad de despojos sin valor con técnicas que iban desde la

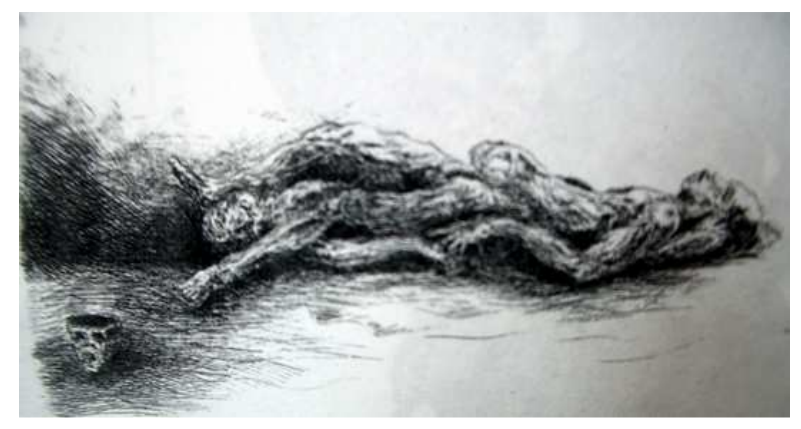

Fig, 86 Armando Eguiza "El sueño de Cronos". punta seca sobre cobre hasta el aguatinta y aguafuerte convencionales. (fig. 86)

También se encontraba representado en la muestra el grupo SEMEFO (siglas del Servicio Médico Forense) cuyo interés principal no es el acto de morir,

sino el cuerpo mismo y su proceso de transformación en los que incluyen el proceso de descomposición física del cuerpo, que va desde los materiales emanados del cuerpo hasta la ceniza y los gusanos producto del fin del cuerpo. (fig. 87) Ellos mismos tuvieron el cuidado de elaborar una defensa para no etiquetar su obra por medio de Osvaldo Sánchez cuando escribieron a propósito del catálogo de Arte Contemporáneo de México en el Carrillo Gil: "...Hemos insistido mucho en que nuestra obra no es un ready-made del objeto, sino

${ }^{84}$ Edgardo Ganado Kim, ibid., 19-20.

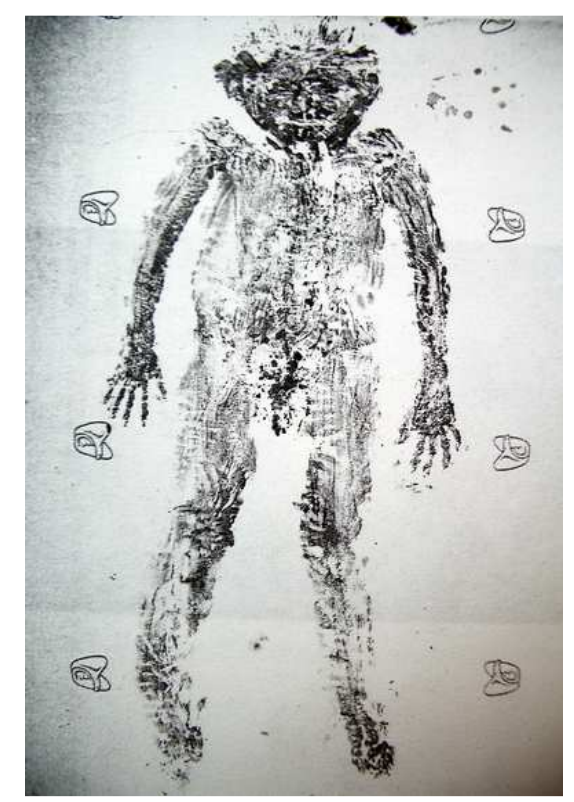

Fig. 87 Grupo SEMEFO Dermis 1996 
un ready made de otra vida, de la vida del cadáver". Y daban cuenta de los objetos y materias que se habían expuesto que tenían esta cercanía con la muerte en forma directa: esqueletos en posiciones insólitas (fig. 88)

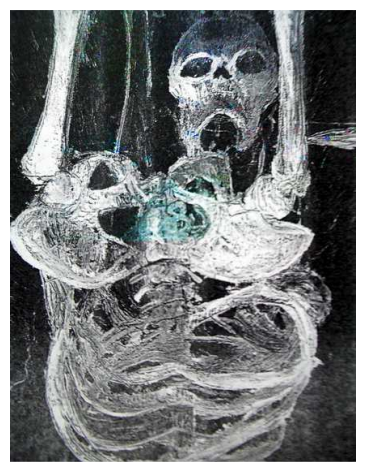

Fig. 88 Alberto Castro Leñero

Vecinos 1990 Pintura Materia orgánica sobre yeso (vaciados de yeso con secreciones de cuerpos humanos; Art and ldea (se expusieron las latas donde se reúnen las secreciones de grasa que dejan los cadáveres; en otros ejemplos se expusieron las sábanas con sangre de hospitales con que se cubren a los muertos sin identificar. $Y$ como ellos mismos afirman es la vida del cadáver que sigue generando gérmenes, microbios, gusanos... un olor que también es vida. $^{85}$

En el año 2003, la Galería José María Velasco perteneciente al Instituto Nacional de Bellas Artes (INBA) realizó una exposición con el tema MUERTE con la participación de números artistas que ofrecieron su punto de vista sobre la inexistencia de vida. (fig. 89) Revisando las imágenes de dicho catálogo se observa una constante de la utilización de la muerte en su forma violenta. Es posible que la violencia desatada en los últimos años en la ciudad propicie que se manifieste la temática surgida de la violencia diaria leída, vista y observada hasta en los medios masivos. Un aspecto novedoso en los países latinoamericanos son las imágenes televisadas que se presentan día con día y que propician competencia entre compañías televisoras. Hace pocos meses Televisa presentó en vivo las escenas de un linchamiento de miembros de la

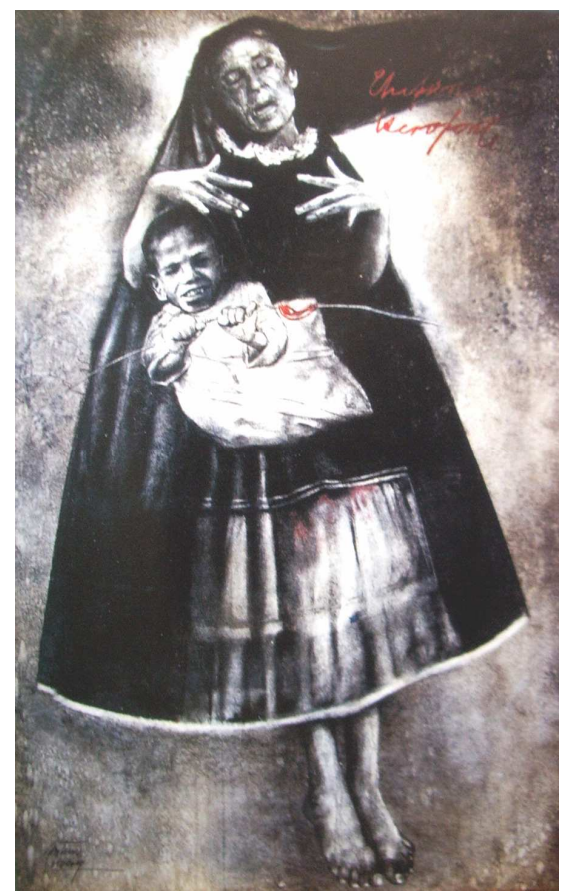

Fig. 89 Arturo Rivera Aire Encáustica y carbón

85 Arte contemporáneo de México, Grupo SEMEFO, Museo Carrillo Gil, CONACULTA/ INBA, México 1996. 203 pp. 
AFI (Agencia Federal de Investigaciones) en una población cercana al Distrito Federal Ilamada Tulyeahulaco. Los agentes habían sido comisionados para actividades no muy claras en los que se hablaba de venta de drogas o de una operación encubierta apostados cerca de una escuela primaria y terminaron confundidos con "roba-chicos". Los padres de familia, al tener el temor de que sus hijos fueron raptados decidieron tomarse la venganza por su propia mano y

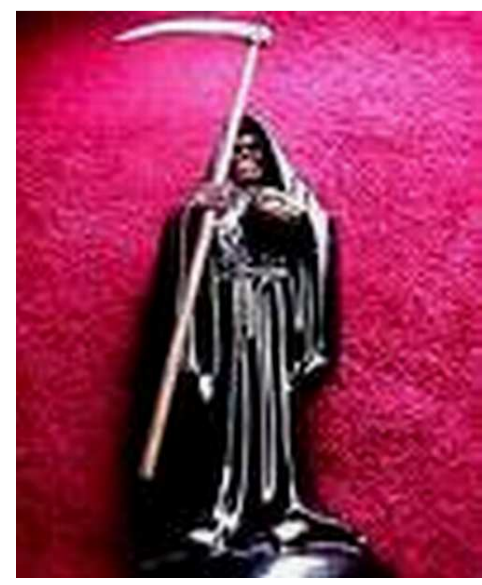

Fig. 90 La Santa Muerte decidieron cercar a los agentes, agredirlos físicamente y al final quemarlos con gasolina.

El noticiero prolongó su horario habitual de transmisión hasta que el espectador televisivo contempló horrorizado como se presentaba la muerte de manera inesperada.

No lo es todo, actualmente se habla del fenómeno espiritual de la Santa Muerte, una figura que representa la muerte descarnada vestida con una larga túnica levando una guadaña, que representa para muchos grupos sociales, en especial de Tepito un escape para pedir cualquier cosa a manera de las santidades católicas. (fig. 90) Y es que, la ciudad de México adquiere día con día el mote de la "ciudad más peligrosa del mundo" y eso habla de la incertidumbre de miles y millones de ciudadanos que creen que es difícil que no les pase algo en el lugar más poblada del planeta y que por lo tanto

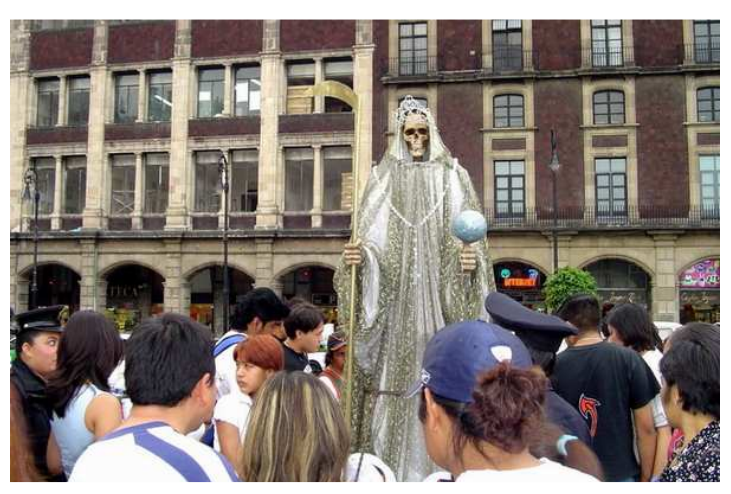

Fig. 91 La Santa Muerte en el zócalo de la ciudad de México es necesario acudir a otras instancias de alguien muy cercano a la muerte. De tal manera que en la ciudad pueden adquirirse al lado de imágenes en resina de la Santa Muerte estampas, Ilaveros y plegarias de todo tipo, convergiendo unidas la Virgen de Guadalupe con la Santa Muerte. La admiración y la atracción por su culto ha crecido en 
estos últimos años que incluso han realizado recorridos en el centro de la ciudad llamado popularmente "Zócalo" y que ha sido tolerado por las altas jerarquías católicas en la mitad espiritual de la república mexicana: el Distrito Federal, la Ciudad de la Esperanza de más de veinte millones de habitantes. (fig. 91)

Según un censo realizado por David Romo, cabeza de la Arquidiócesis, el culto a la Santa Muerte alcanza los 2 millones y medio de personas que se reúnen de 400 puntos de todos los estados de la república. Este fenómeno es para el escritor Homero Aridjis "un sincretismo de la tradición religiosa europea que llegó a México con los españoles, o sea, la tradición cristiana, con los cultos mexicanos a la muerte". ${ }^{86}$ La Santa Muerte, en los últimos meses ha dado un giro comercial: se pueden comprar zapatos tenis, películas alrededor del tema, tatuajes, camisetas, cirios, y un largo etc. (fig. 92)

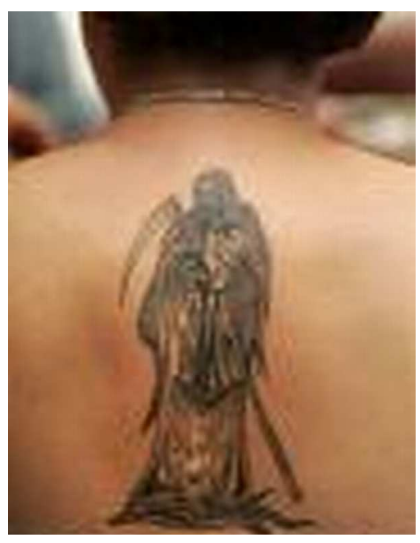

Fig. 92 La Santa Muerte en la piel

No quiero decir con esto que la exposición tenga esta motivación, pero indudablemente los medios están presentes en la obra artística. Tal vez sea ésta una explicación bastante realista, pero el artista se nutre en la mayoría de los casos de las vivencias diarias y no es difícil el carácter de intencionalidad surgida de los hechos. Verónica Volkow escribió en el texto de presentación.

En esta exposición alrededor del tema de la muerte violenta rrencontramos una dimensión perdida para las vanguardias plásticas del siglo $\mathrm{XX}$ : la aventura del mirar. Para el siglo XX fue mucho más importante el inventar que el mirar, no así en el origen de la plástica occidental. [...] En estas imágenes sobre la muerte violenta, en pleno siglo XX!, mirar duele, el ver con cuidado es casi un rato de sacrificio, una daga o una quemadura sobre los ojos y la conciencia. $Y$ nos recuerdan que cuando se ensancha el espacio de comprensión de los otros o de nuestra propia vida, el aceptar lo visible implica una ruptura, es un descubrimiento que no se da sin una guerra, o por lo menos sin una lucha interna. Mirar exige un cambio y no sólo de tecnología sino de compromiso con los demás y con nosotros. ${ }^{87}$

\footnotetext{
${ }^{86}$ Francesc Relea, "El barrio que se venera a la Santa Muerte, suplemento en El País Semanal, 15, 06,08 , pp. 52-60.

${ }^{87}$ Catálogo de presentación de la exposición MUERTE, Galería José María Velasco, INBA, México 2003.
} 
Los artistas participantes tuvieron una constante: en general son artistas nacidos en los años 60's, salvo dos de ellos como Arturo Rivera y Reynaldo Velásquez. La lista completa de participantes fue Miguel Canseco; Olga Chorro; Marianela de la Hoz; Armando Eguiza; Ana Fuentes; Cristiana Kalho; Teresa Margolles; Jorge Marín; Alejandro Montoya; Martha Pacheco; José Raúl Pérez; Trinidad Ramírez; Arturo Rivera; Gustavo Salmones; María Eugenia Torresarpi; Reynaldo Velásquez.

De ellos la obra de Armando Eguiza (México, 1969) de fuerte dibujo y de línea fina me parece que es sobresaliente por las calidades tan sutiles en el manejo de la punta seca y del aguafuerte. El catálogo muestra dos aguafuertes. Aquí estoy ¿No me sientes (fig. 93) es un fragmento de un cuerpo bofo que

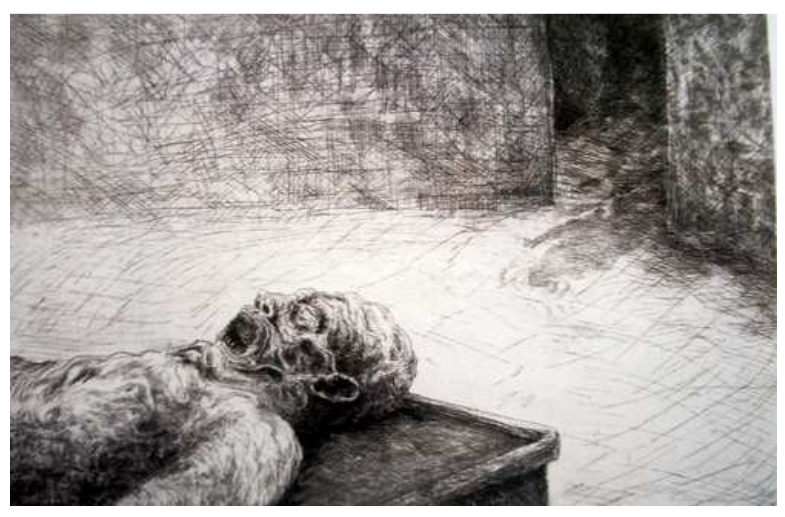

Fig. 93 Armando Eguiza Aquí estoy, ¿No me sientes? Aguafuerte 1995

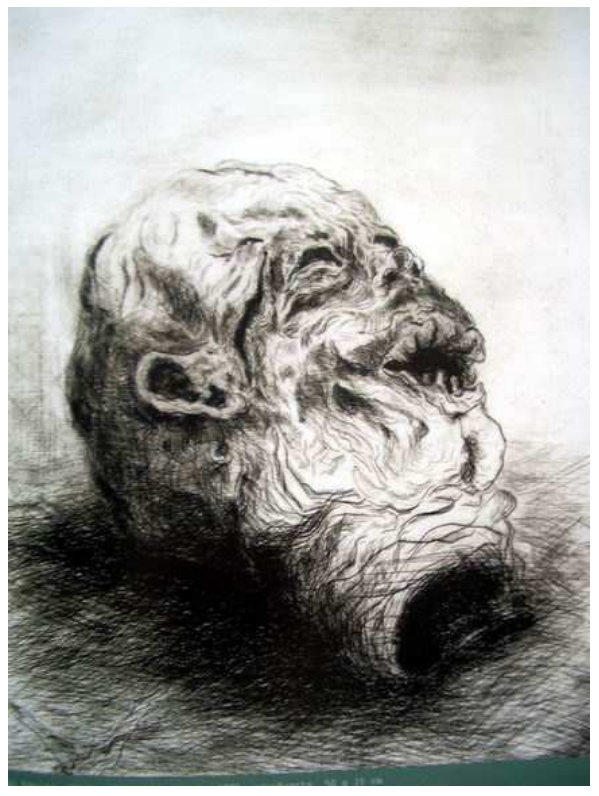

Fig. 94 Armando Eguiza Ni los días que cuentas Aguafuerte permanece con la boca abierta acostado sobre una plancha o una mesa. Al fondo un espacio se abre rompiendo el segmento de una pared a manera de una puerta abierta en la que la penumbra sólo permite observar un cuarto oscuro. El rostro del personaje tiene los ojos abiertos y una apenas simulada una cabellera blanca de pelo quebrado. Un detalle visual que personalizan en lo que podemos llamar un estilo, son los trazos cortos con la punta de metal que "peinan" ciertas áreas del dibujo propiciando zonas oscuras y claras que semejan protuberancias en la cara y el rostro. 
Esta forma personal de tratamiento en el aguafuerte es más evidente en $\mathrm{Ni}$ los días que cuentas (fig. 94) en los que una cabeza cortada del tronco se encuentra en casi toda la imagen. La gestualidad se presenta en un rostro sin ojos deformado en rictus de dolor con una boca forzada en la que se ven unos cuantos dientes. El fondo ha sido trabajado con una sombra intensa debajo de la cabeza

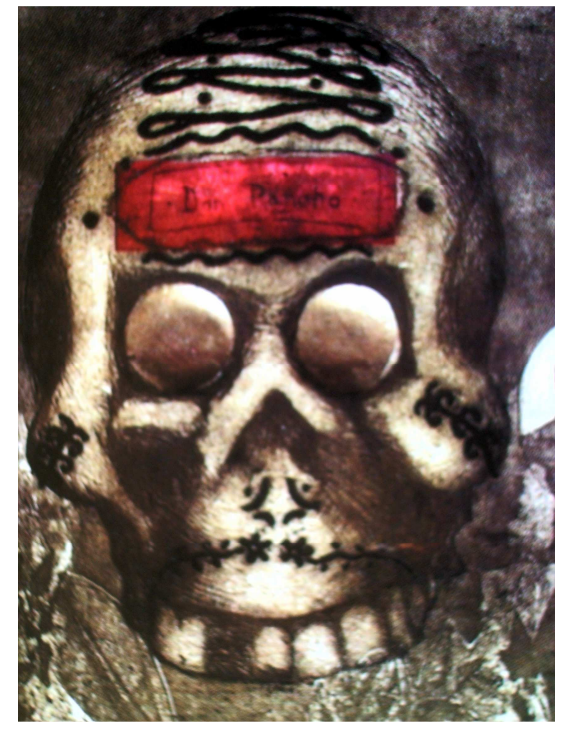

Fig. 95 Mario Vázquez Ofrenda a Francisco Vega Mixta que termina en el hueco formado por el cuello como si estuviera sobre un piso sucio o gastado como si fuera un objeto indeseable.

En el año 2000 Edgar Valverde, Víctor Ríos, y Francisco Trejo Candelas ayudantes de los talleres de grabado en metal, litografía y xilografía respectivamente de la Escuela Nacional de Artes Plásticas de la UNAM organizaron y curaron la exposición alrededor del tema de la muerte llamada Variaciones sobre un tema TZOMPANTLI, con la

participación de casi 60 artistas gráficos. La invitación para participar consistía en la entrega de una o varias obras en un formato cuadrado que tuviera el tema de tzompantli azteca (muro de calaveras o sujetas de los parietales sobre un grueso madero circular de cual ya hemos hablado en el primer capítulo) que pusiese ser mostrada el 2 de noviembre. (figs. 95 y 96) La idea en un

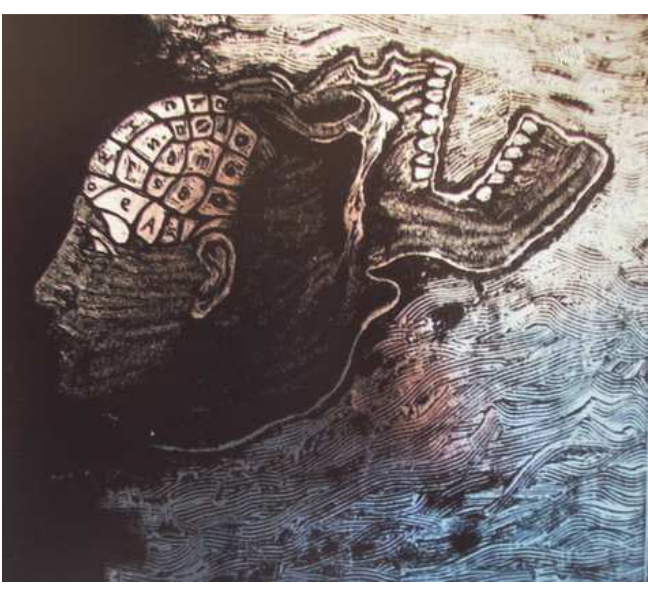

Fig. 96 Francisco Plancarte "Sin t\{itulo" Xilografía principio fue la de reunir cráneos gráficos con diversas interpretaciones que pudiesen estar unidas en un todo pero que cada pieza fuese independiente y que tuviese su propio valor estético manejada 
estilísticamente de acuerdo a cada autor en la técnica de su preferencia. Sin imaginarse la cantidad de obra tan enorme que llegó fue necesaria la ayuda de un curador especializado para seleccionar a los participantes y limitar la cantidad de obra teniendo la muestra $t$ un éxito sin precedentes por el apoyo del CONACULTA, su organización y la excelente museografía a partir de una luz tenue que apenas iluminaba las obras lo que generaba un aspecto fantástico a las casi 100 obras exhibidas. De los lugares donde se exhibió la muestra, el Museo de Dolores Olmedo en Xochimilco fue el espacio donde lucieron las obras a manera en una enorme pared de tzompantli alumbradas por decenas de veladoras en el piso.

Allí se pudieron observar litografías, xilografías y metales, camafeos, electrografías y sus respectivas combinaciones de

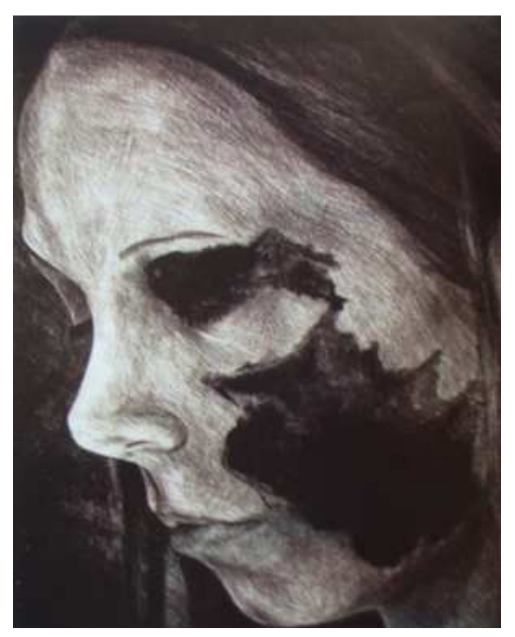

Fig. 97 Katia Olalde Autorretrato Grabado en cobre un impacto asombroso por la solución acertada. ((fig. 97) Es importante mencionar que la temática de la muerte fue abordada esta vez por los artistas gráficos con una mentalidad distinta a la que recurrentemente en las artes visuales se venía tomando de ejemplo a la obra de José Guadalupe Posada: nos referimos a calaveras en actitudes jocosas, o políticas como es costumbre todos los años por los herederos de lo que quedó del Taller de Gráfica Popular. En este caso se dieron cita pintores, artista digitales, dibujantes, litógrafos, fotógrafos, y xilógrafos con un resultado exitoso.

(fig. 97) Refiriéndose a la exposición, Jesús Martínez maestro y participante en la muestra escribió en el texto de presentación del catálogo:

Hoy formalmente mostramos estas muertes, espejos, instantes de reflexión, espacios oscuros recogidos por artistas gráficos en pulidas placas de metal, en tibias maderas tropicales o en finas y porosas piedras milenarias. 
Así: la muerte sin fin. La muerte fuego, la vida agua. La muerte polvo, la vida flores. La muerte oscuridad, la vida luz.

En este Tzompantli grafico donde conviven varias expresiones y una sola intención, encuentre el espejo que reflejará su propio rostro, después piense, frente a la que le guste o con la que se identifique, que la forma descarnada le dirá: Como te veo me ví, como me ves te verás. ${ }^{88}$

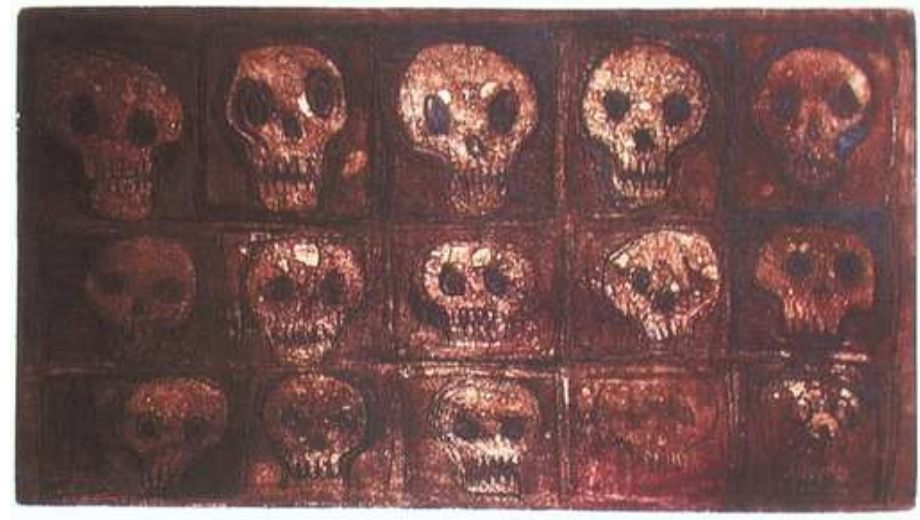

Fig. 98 Juan Manuel Salazar "Bajo tu Mirada" Aguafuerte

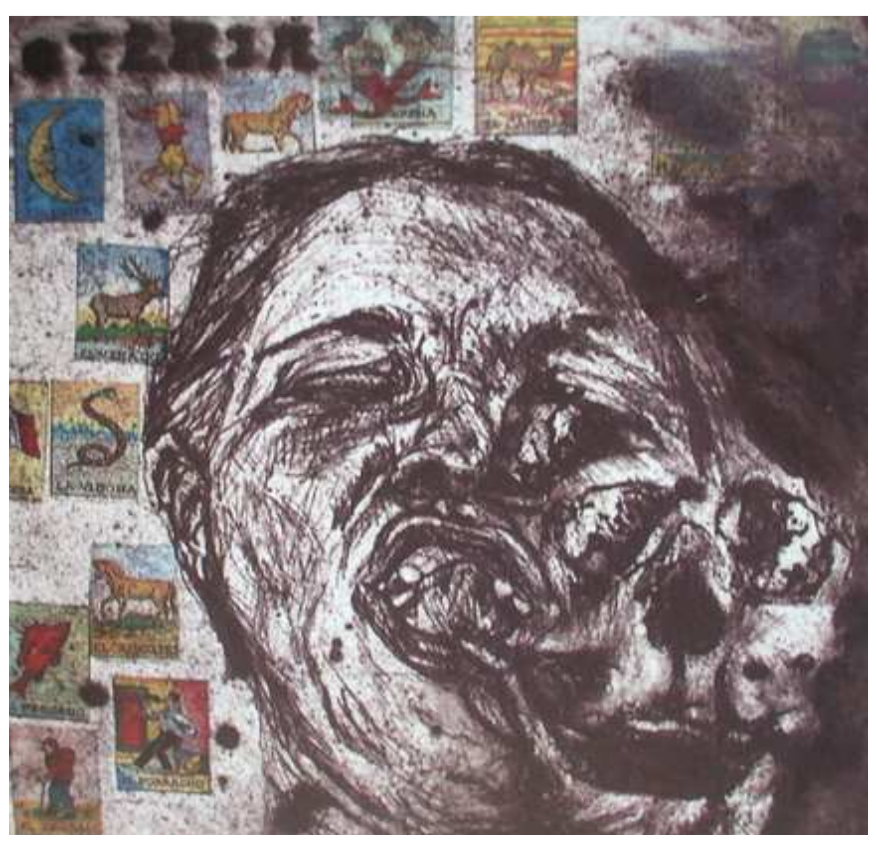

Fig. 99 Verónica Sahagún,

"La que acaba con sus alegrías, mixta sobre zinc
El cuidadoso catálogo realizado en color de casi noventa páginas fue impreso con ayuda del CONACULTA y da cuenta de los participantes en su mayor parte maestros $y$ alumnos de la ENAP entre otros: Edgar Pichardo Daniel, Francisco Plancarte, Alicia Portillo, Edgar Valverde, Ruth Hernández, Katia Olalde, María Eugenia Figueroa, Dabt Monreal, Jesús Martínez, Rafael Ángel Torres, César Santana. Juan Manuel Salazar y Verónica Sahún (figs. 98 y 99)

A propósito de la celebración de 2 de noviembre, la UNAM, en su campus de Ciudad

\footnotetext{
${ }^{88}$ Catálogo de exposición Tzompantli Variaciones sobre un tema, CONACULTA, México 2000
} 
Universitaria, al sur de la ciudad de México realiza con ayuda de profesores y alumnos lo que se ha conocido como "Mega/ Ofrendas" donde intervienen facultades institutos y escuelas y donde la ENAP año con año participa con

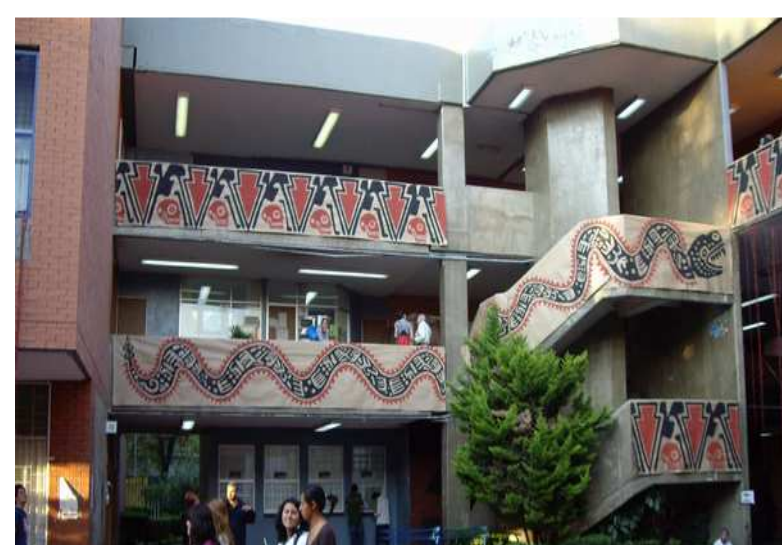

Fig. 100

Tzompantli de máscaras de cartón en la ENAP. Fotografía 2007.

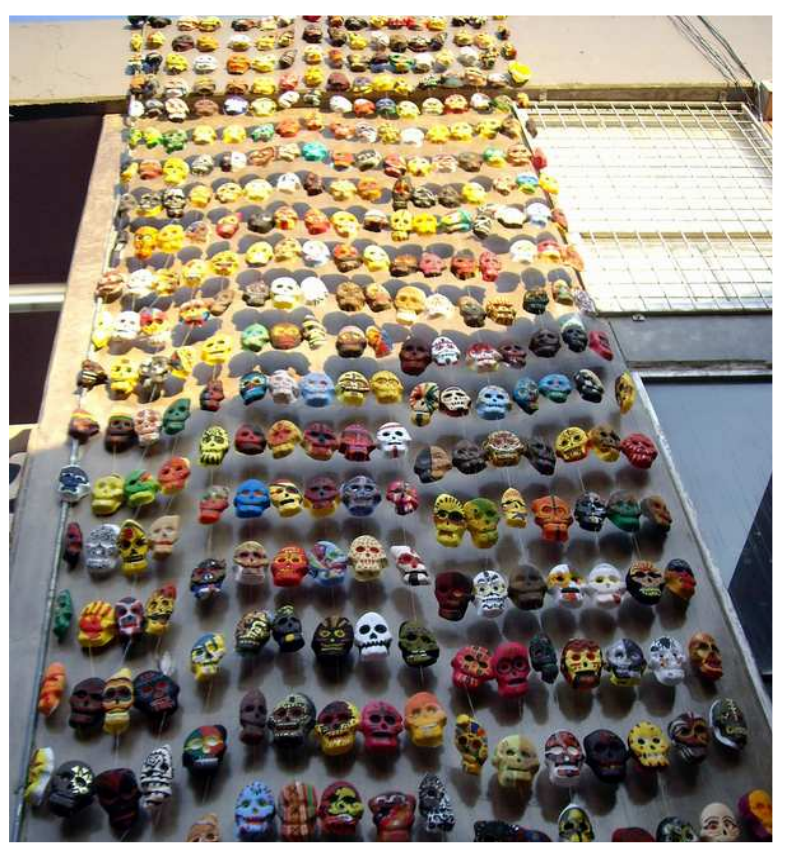

Fig. 101 El día de muertos en a ENAP Fotografía 2007 enormes esqueletos móviles a manera de títeres gigantes y carteles.

El pasado 2007 se decoró la escuela con tiras de papel kraft con motivos repetitivos prehispánicos de muerte y de serpientes como se aprecia en la figuras 100 y 101.

En los espacios externos de muros y columnas de los talleres de grabado de huecograbado y de xilografía se reprodujeron mega estampas de José Guadalupe Posada y los alumnos realizaron obra "ex profeso" lo que permitió una integración visual interesante. La idea de la celebración a los difuntos era costumbre antigua en el viejo edificio de San Carlos y se realizaba en otro edificio Ilamado "anexo". Con el tiempo y con el cambio de la escuela a su sede de licenciatura a Xochimilco se dejó de realizar. Al parecer esta buena costumbre esta siendo retomada con acierto y buen gusto. Se pudo apreciar un "tzompantli" de máscaras de cartón decoradas en color colocadas sobre papel kraft que caían desde el 
techo hasta el piso como cascada. En el patio principal paralelo al acceso de la escuela se colgaron igualmente máscaras vibrantes.

En otra parte de la escuela, los alumnos realizaron una pequeña ofrenda gráfica a "Che" Guevara colocado en un ventanal del Taller de Producción Gráfica., y de

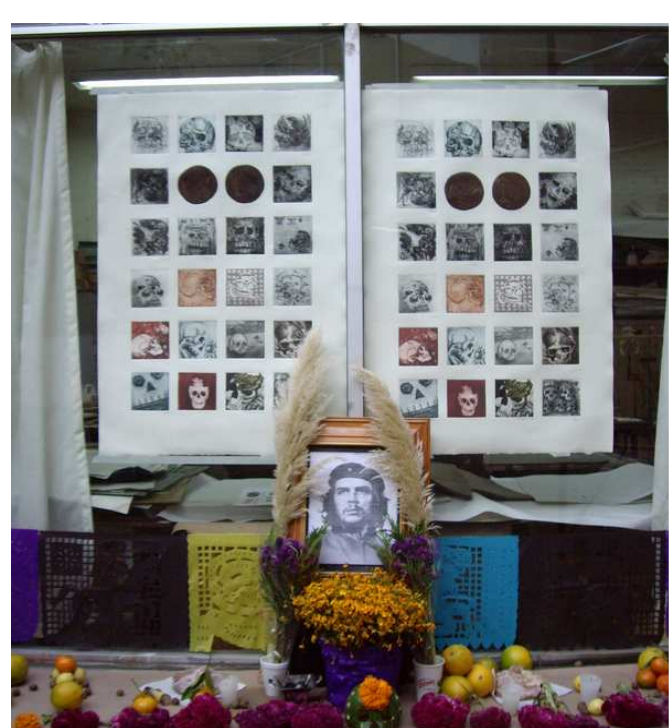

Fig. 102

Ofrenda al "Che" Guevara en la ENAP Fotograf\{ia

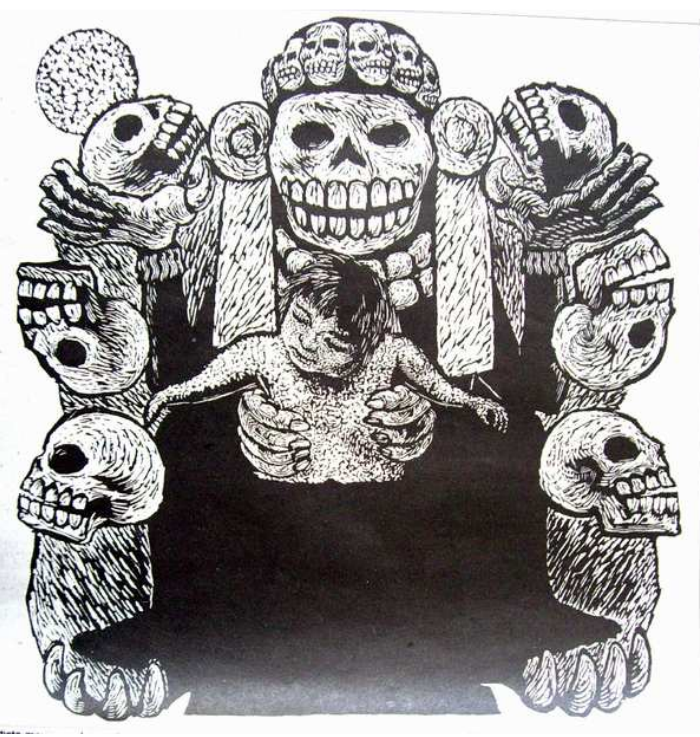

manera sencilla colocaron fruta, papel de china y flores de zempazuchitl y al fondo pequeñas imágenes de muerte realizadas en aguafuerte y aguatinta de fino trazo impresas en papel de algodón. (fig. 102)

Una apreciación final es el considerar que ésta puede ser una forma positiva de retomar las costumbres nacionales que como se planteado a lo largo del presente trabajo tiene hondas raíces frente a la penetración culturas más fuertes en el que la celebración del día de brujas se ha vuelto más frecuente sobre todo por los jóvenes.

Tal vez por eso, quisiera que el grabado de Arturo García Bustos (fig. 103) cerrara este capítulo porque muestra que a pesar de la tecnología, el avance científico y de la pérdida cultural debido al mundo globalizado debemos conservar pese a todo, nuestra identidad como mexicanos.

\section{Invierno 2008.}





\section{Conclusiones}

Para realizar la investigación Presencia de la Muerte en la Gráfica Mexicana se han consultado libros, revistas, periódicos de la época, tesis, discografía y páginas electrónicas, tanto de acervos públicos como privados, y se han incluido 260 imágenes con la idea de conformar un corpus visual que sirva de refuerzo al contexto histórico / documental de cuatro grandes temas alrededor de la muerte cuyos aspectos han sido: a) El mundo prehispánico y su concepción de dualidad de vida/ muerte a través de crónicas y testimonios de conquistadores españoles; b) La vida espiritual de la Colonia mediante impresos e imágenes llamados "literatura para el alma" para la salvación del pecador; c) El nacimiento de México como nación independiente y su relación con los medios de impresión como lo fueron el grabado y la litografía con Manilla y Posada como figuras destacadas; y d) La producción de grabados de carácter político y social mediante organizaciones colectivas como la Liga de Escritores y Artistas Revolucionarios (LEAR) y el Taller de Gráfica Popular (TGP) así como destacados artistas actuales utilizando técnicas y lenguajes de expresión novedosos donde la muerte como personaje renace a través de lenguajes y contenidos actuales.

La metodología utilizada se ha basado en la búsqueda de autores y temas cuyo trabajo tuviera similitud en el empleo de imágenes impresas, como lo han sido los estudios de W. Ivins sobre el desarrollo de la técnica del grabado y la historia paralelas en Imagen impresa y conocimiento Análisis de la imagen pre-fotográfica; el libro de El Grabado en Madera de Paul Westheim ha sido también fundamental al hacer una referencia al resurgimiento del grabado y la estampa mexicana con apartados específicos sobre la obra de Posada y el Taller de Gráfica Popular. Otros autores a quienes se les debe aportaciones metodológicas han sido, Berta Gilabert y Alberto Soto Mortal en su tesis de historia, Agonía Orden de Clérigos Regulares Ministros de los enfermos Agonizantes de San Camilo de Lelis en México, Caridad, salud, enfermedad y muerte en la ciudad de México (siglos XVIII y XIX); Verónica Zárate quien realizó un estudio histórico que abarca un periodo del periodo colonial y del México independiente llamado Los nobles ante al muerte en México, Actitudes, ceremonias y memoria (1750-1850); Elisa Speckman en Crimen y Castigo, 
legislación penal, interpretaciones de la criminalidad y administración de justicia (Ciudad de México, 1872-1910) XIX); y el estudio de Alberto del Castillo en Hábitos, normas y escándalo, prensa, criminalidad y drogas durante el porfiriato tardío que ha sido valioso por su enfoque y cuyas referencias principales han sido el grabado y la fotografía de fines del siglo XIX y principios del XX.

Nuestro marco de referencia en lo que respecta al grabado y la estampa popular con el tema de la muerte ha tenido un espacio temporal muy amplio que ha comprendido del siglo XVI al siglo XX y pretendió mostrar la presencia de la muerte en la gráfica mexicana desde la época colonial hasta ejemplos recientes con motivo de la celebración del Día de Muertos en la Escuela Nacional de Artes Plásticas con la idea que el lector posea una concepción del uso de la imagen mortuoria desde la óptica religiosa, fúnebre, violenta, retórica y satírica.

Es importante subrayar que nuestra intención ha sido tratar un tema desde la perspectiva de las Bellas Artes tratando de explicar pasajes históricos alrededor de las cuales han sido creadas las imágenes. No se ha pretendido agotar el tema, antes al contrario, se han dejado fuera, ejemplos interesantes de grabados y estampas que hubieran nutrido más una idea o un capítulo y que, sin embargo, la falta de procedencia o la dificultad de registrarla fotográficamente para esta investigación imposibilitó ese deseo.

Para desarrollar nuestra investigación he considerado definir para el primer capítulo conceptos continuamente usados en este trabajo como han sido la cultura, la imagen y la muerte:

A la cultura se le ha definido como el conjunto de herramientas, implementos, utensilios, costumbres, etc., que vienen a representar el todo formado por el hombre, que, unido a ideas, valores, moralidad, y estética expresados en forma simbólica permiten formas de identificación. Existen, además, mecanismos de cambio cultural en los que se dan rasgos de prestamos culturales, como son la aculturación; la invención independiente; la globalización; o los cambios por mutación. La cultura popular está compuesta de una pluralidad de identidades culturales donde el individuo como ser social puede ser visto como objeto, o como sujeto.

La imagen, se enmarca en variables que tienen correspondencia con el contexto histórico, donde, si bien las imágenes pueden ser pruebas 
documentales, sólo expresan la mentalidad del autor y del editor, siendo una parte fragmentaria de una visión total de esa realidad que el artista quiere y desea representar. Para su validez, tienen que formarse un cuerpo de imágenes, lo suficientemente amplio que complementen aspectos que enriquezcan la información. La historia de los objetos, de las imágenes y de lo cotidiano como historia de las mentalidades utiliza los aportes de la antropología en las que los sujetos de estudio tienen que ver con lo imaginario y lo simbólico.

A la cesación de la vida es lo que se le ha llamado muerte, observándose como un suceso de paso en donde puede existir de acuerdo a la concepción cristiana, otra vida "más allá" que puede premiar nuestra vida terrenal en el Cielo por nuestras buenas acciones; y en contraposición, puede castigarla en un lugar llamado Infierno, y donde como parte intermedia para el alma humana se encuentra el Purgatorio. Físicamente la muerte es el personaje central de un acto festivo o luctuoso que depende de cada cultura y si bien el morir parece trágico, la vida después de la muerte no lo es tanto, debido al concepto de inmortalidad y salvación. La personificación de la muerte se presenta en forma de esqueleto o hueso descarnado que ha adquirido simbologías distintas siendo utilizada en México bajo la forma festiva de "calaveras" que pueden ser de materiales diversos: de dulce, de cartón, de hoja de lata, dibujos, pinturas, esculturas, grabados y estampas.

En el segundo capítulo se han definido los términos de grabado y estampa. Como grabado nombraremos así a la impresión en papel de las imágenes realizadas por medio de incisiones sobre una superficie y a la litografía como el procedimiento de impresión utilizado a partir del siglo XIX basado en las propiedades químicas de la piedra calcárea, que permite ser dibujada fácilmente siendo un procedimiento de producción de imágenes versátil y económico. Ambas prácticas debido a su fácil factura tuvieron repercusiones masivas y una alta demanda popular en impresos y grabados

Se ha considerado en este trabajo, que las desgracias individuales o colectivas como las epidemias, incendios, temblores, y la aparición de fenómenos celestes como eclipses y cometas permiten estudiar la vida cotidiana y como en el imaginario colectivo se interpretaba esas desgracias como señales de castigo provenientes del Cielo. Es importante subrayar que la 
presencia del grabado se manifiesta en las inquietudes de ese imaginario popular tratando de explicar las causas de los fenómenos naturales.

En lo que respecta a la muerte en la sociedad que va de la Nueva España del siglo XVI al México independiente del siglo XIX, no se puede hablar sino del gran peso que tuvo la religión en la vida cotidiana. La religión tan sólo llegó a competir con algunas disposiciones civiles hasta bien entrado el siglo XIX que reflejaron la irrupción de una mentalidad ilustrada. Junto a las ánimas, la piedad popular reunió a un conjunto de santos, imágenes gráficas, reliquias y espacios a las que otorgaba un carácter mágico/ milagroso que se invocaba cuando había la necesidad de superar alguna desgracia personal y las imágenes ofrecidas a través de textos religiosos o de estampas callejeras funcionaron para que el individuo entrara en un diálogo íntimo y personal para lograr salvar su vida, sus penitencias, su muerte y finalmente su salvación.

En el tercer capítulo, se ha planteado que las representaciones gráficas en los primeros años del México del siglo XIX, estaban ligados a los acontecimientos de Europa, en el que fue determinante para la prensa el invento de la litografía. Introducida en México por Claudio Linati permitió el surgimiento de docenas de periódicos en los que el contenido de algunas imágenes estaba compuesto de códigos y significados construidos en circunstancias históricas específicas dando paso a la gráfica satírica mediante la literatura, el lenguaje cotidiano y la retórica. Dentro del contexto de la formación del Estado mexicano, la litografía se encuentra presente mediante representaciones de las guerras así como de una interesante iconografía litográfica relacionada con la muerte, producto de las revueltas internas en la que varios escritores y particularmente los liberales, entre 1830 y 1890 intentaron precisar el perfil de la nación, sirviéndose de las estampas para describir el estado social.

Para una ciudad en crecimiento, el periodismo brindó la posibilidad de la comunicación masiva. La utilización de la imagen del delincuente peligroso, primero mediante la técnica del grabado, y después con refuerzos fotográficos, permitieron una doble interpretación de las imágenes enviadas a la sociedad mexicana. En una primera acción, la que llegaba al pueblo directamente por medio de volantes callejeros ilustrados por grabadores populares como Manuel 
Manilla y José Guadalupe Posada que daban cuenta de los hechos sangrientos sucedidos en la vía pública destinado a los sectores marginales de la población. Por otro, el juicio de los lectores letrados que acudían a la información de periódicos del momento.

En el cuarto capítulo se ha realizado un recorrido por los diversos caminos de la gráfica con sentido social y político como han sido las instituciones de la LEAR (Liga de Escritores y Artistas Revolucionarios) y el TGP (Taller de Gráfica Popular). Debido a distintas circunstancias tanto internas (el fin de la Revolución Mexicana, el acomodo de clases dominantes surgidas del movimiento armado, la expropiación petrolera, etc.), como externas (los conflictos bélicos como la Segunda Guerra Mundial, la Guerra Civil española, entre otras), en las obras de éstos grupos artísticos se percibe una constante en el uso de la imagen como violencia y muerte. Por otra parte, los sindicatos y agrupaciones artísticas permitieron cohesionar a ciertos grupos de tendencia izquierdista agrupados en un frente común con la idea de desarrollar un nacionalismo mexicano alejado de tendencias yanquis y alrededor de éstas ideas se fue ciñendo una unidad cultural dándose un entramado entre la literatura, la música y las artes visuales teniendo a José Guadalupe Posada como ejemplo a seguir del artista sencillo que es identificado con el pueblo. El ejemplo más notable en el aspecto ideológico y de estilo en el grabado fue Leopoldo Méndez del que se ha realizado una semblanza como ilustrador de la vida cotidiana que corresponde a un artista comprometido.

La Sociedad Mexicana de Grabadores (SMG) permitió al artista producir su obra libre de apasionamientos políticos y sociales y que agrupados con un fin común lograron el reconocimiento de la crítica y de los medios culturales. El grabado hacia los años sesenta se presenta como correspondencia de la Escuela Mexicana de Pintura ya que presenta el mismo tipo de preocupaciones sociales y nacionales, y esta repetición de contenidos propició que los artistas de las nuevas generaciones se inconformaran contra el arte denominado "oficial" y de este grupo, Francisco Moreno Capdevila, es el artista que pudo integrar en su obra la tradición y la vanguardia a través de la experimentación de las técnicas del grabado, proponiendo nuevas formas de expresión a través 
del grabado. Tanto Capdevila como Jesús Martínez son dos artistas que han dejado extraordinarios ejemplos en cuanto a tema de la muerte, teniendo como base el mundo prehispánico y la poesía de antiguos testimonios prehispánicos.

El movimiento de 1968, rompió el esquema de estabilidad social en la sociedad mexicana impuesta por el partido gobernante y permitió a la sociedad volcar sus protestas y manifestaciones en la vía pública a través de la violencia y la muerte por medio del grabado y la fotografía.

Una propuesta interesante hacia los años setenta y ochenta en el tema de muerte en especial de pequeñas piezas realizadas en aguafuerte y punta seca, fue la obra del artista jalicience Juan Soriano, quien utilizó como motivos los mitos clásicos y los seres mitológicos de centauros, sílfides, peces, serpientes, toros y pájaros fantásticos por series: peces, juegos de artificio, y esqueletos que adquieren formas del quehacer cotidiano.

En el aspecto de la gráfica contemporánea han sido numerosos los artistas que han utilizado el cuerpo humano y la muerte como motivo principal de sus obras ya sea creando, recreando, modificando y destruyendo lo que puede ser un universo y un espacio como valor plástico. La muerte es la imagen del cuerpo sin vida que ha sido manipulado y persuadido a voluntad de los creadores gráficos donde la propuesta del grabado contemporáneo es justamente retomar las tradiciones que le dieron reconocimiento internacional pero con la visión actual.

Curiosamente a inicios del siglo XXI, se han vuelto los ojos a concepciones plásticas cuyo origen tiene que ver con nuestros valores nacionales: las imágenes prehispánicas de sellos con temas mortuorios y la obra de los grabadores como Posada de sus "calaveras" que se han retomado por las nuevas generaciones adecuándolas a los tiempos recientes con carácter monumental.

En efecto, ante las invasiones visuales poderosas de nuestro vecino del norte, los mexicanos han tornado de manera afortunada hacia los temas que le son propios y es de reconocer que el ingenio es positivo porque año tras año, la UNAM realiza en sus instalaciones cada 2 de noviembre mega-ofrendas nocturnas acompañadas de cirios donde todas las escuelas, institutos y 
facultades participan con sus diseños y en donde se pueden ver enormes figuras de cartón y de alambre de las "calaveras" de Posada que cobran vida y son accionadas por los mismos estudiantes siendo un espectáculo asombroso. Esa es una prueba de que todavía los mexicanos se siguen riendo de la muerte. 



\section{Glosario de técnicas gráficas}

Aguafuerte. Ácido nítrico, diluido en agua, usado en el grabado sobre metal/ Técnica calcográfica de incisión indirecta en la que un mordente atacará e incidirá en el metal. Sobre una plancha se extiende regularmente un barniz protector y con una punta se dibujan las formas de la imagen descubriendo a la vez la plancha. Seguidamente se somete a un baño de mordiente (ácido nítrico, clorhídrico o percloruro de hierro, según el tipo de metal) que corroerá los trazos al descubierto, dejándolos ahondados de tal forma que acogerán la tinta par la impresión.

Aguatinta. Grabado de incisión indirecta que permite obtener medias tintas con tramas no lineales, sino circulares. Se hace una dispersión de polvo de resina sobre la plancha, y se calienta ésta hasta que dichos granos queden adheridos en su superficie. EL mordiente ataca los intersticios que quedan entre los granos y los profundiza formando una microscópica retícula que da diversas valoraciones.

"Aquaforti" / "Aqua”. Señala al aguafortista. En un grabado pueden haber varias técnicas, por ejemplo buril y aguafuerte. Entre los siglos XVII y XIX era frecuente que el grabado de reproducción o interpretación se empezara con una base de tallas primeras al aguafuerte y se continuara la valoración al buril, de esta manera, también el nombre del aguafortista queda reflejado.

Berceau. Instrumento de origen francés de finos canales paralelos, que sirve para formar en la plancha la idea de un sombreado.o de granulado.

Buril. Útil de acero de forma poliédrica cortada por la punta en diferentes secciones (cuadradas, rectangulares, romboidales, etc.). Grabado de incisión directa sobre la matriz hecho a buril. EL corte del buril no deja barbas ( a diferencia de lo que ocurre con la técnica de la punta seca) sino que levanta una viruta que se corta al final. Se reconoce el grabado al buril por su nitidez de trazo.

Calcografía. Del griego "kalkós", cobre y aleaciones, y "grapho", escribir. Se denomina así el tipo de grabados realizados sobre matriz de metal, tanto los trabajados de forma directa (buril, punta seca, etc.) como de forma indirecta (aguafuerte, aguatinta, barniz blando, etc.).

Cobre.* Metal utilizado en grabado en hueco, resistente y dúctil. Permite ser grabado con punta seca, buril o aguafuerte, permitiendo trazados nítidos, tanto en las líneas más sutiles como en las intensas. Es el metal preferido por los grabadores calcográficos. 
Entintar. Acción de poner tinta. En calcografía se entinta con una muñequilla, distribuyendo la tinta por toda la superficie de la plancha, procurando que penetre en los surcos. Con una mazorca de tarlatana se retira de forma que sólo quede depositada dentro de cada incisión. La habilidad de cada impresor hará que, según la intención, quede la superficie totalmente limpia o, por el contrario, que se provoquen algunas veladuras o tono de fondo. En xilografía y litografía, la tinta se extiende con rodillo y ya queda depositada donde es preciso sin ulteriores operaciones.

Estampa. ${ }^{*}$ La estampa es una imagen impresa. En el ámbito de la obra gráfica denominamos Estampas a las pruebas sobre papel estampadas de una plancha o matriz conseguida por cualquier procedimiento y por todos los medios de estampación conocidos, siendo el resultado final de todo el proceso de elaboración de un grabado.

Fotografía. ${ }^{*}$ La fotografía tiene numerosos puntos de contacto con la imagen impresa y relaciones constantes con las diversas técnicas de las artes gráficas. La utilización de la fotografía puede ejercerse a muchos niveles. Podemos clasificar en dos grandes grupos las intenciones que son el origen de su elección. Puede ser en principio, una creación directa, la de una imagen sobre papel sensible, estando considerado este último como soporte definitivo. Es el caso de la fotografía, del fotograma, del cliché-verre. La fotografía puede servir a además para la obtención de un negativo o de un positivo que permiten obtener: una copia sobre un soporte metálico, una madera, piedra o tejido, o bien, un reporte sobre estos mismos soportes por la intermediación de un film o película sensible. Este es el caso del fotograbado, de la fotolitografía, del heliograbado manual e industrial, del offset, de la fototípia o de la fotoserigrafía.

Fotolitografía.* Con el descubrimiento de los productos fotosensibles y la aplicación por Poitevin de los bicromatos a la litografía (1855), se llegaron a preparar las primeras matrices fotolitografías para la impresión. Las posibilidades que ofrecía la aplicación de la fotolitografía a la imagen impresa eran básicamente: mayor automatismo, rapidez y fidelidad. Esto hizo que en la industria de las Artes Gráficas se impusiera su aplicación frente a otros medios de reproducción de imágenes. Hemos de decir que la fotolitografía como medio creativo, está mal comprendida por algunos que ven en ella un simple proceso de copia o reproducción de una imagen. En realidad estos métodos se encuentran en la frontera que separa el grabado original del grabado de reproducción. Sin embargo no podemos limitar al artista actual que se encuentra ante unas potentes herramientas de trabajo que le ofrece la industria de las artes gráficas. Las nuevas planchas, máquinas, películas, y procesos de trabajo pueden ser llevados a su terreno y correctamente utilizados, pueden enriquecer enormemente su lenguaje gráfico. 
Grabado.* Con el término genérico de grabado hacemos referencia a una amplia diversidad de manifestaciones de la obra gráfica y se utiliza actualmente a menudo para hacer referencia a la obra gráfica impresa y seriada, englobando las diferentes técnicas. El grabado actual, como medio de expresión, utiliza como la pintura o la escultura una gran variedad de recursos. En algunos casos se mezclan varias técnicas en busca de los resultados plásticos deseados. En el término grabado y estampación se encuentran implícitas las dos fases que intervienen en la realización de una obra gráfica impresa. Tan importante en el resultado final es la realización de la imagen y los recursos técnicos para grabarla o fijarla en el soporte, como el uso apropiado de las tintas el papel y la prensa. Siendo estas dos fases: el grabado y la estampación, complementarias.

Grabar. * El término genérico de grabado es muy utilizado para hacer referencia a la obra gráfica impresa y seriada. Histórica y etimológicamente, quiere decir hacer una incisión. Deberíamos denominar por ello grabados, aquellas pruebas estampadas de una plancha matriz cuya realización se haya efectuado por medio de incisiones en su materia. Partiendo de esta definición, deberíamos decir que Técnicas de Grabado, son aquellas que se realizan en planchas grabadas con incisiones y cuya estampación da origen a Grabado. El termino estampa es utilizado para definir la obra impresa sobre papel; siendo el termino grabado más específico par definir la plancha en la que se han realizado tallas o incisiones, denominaremos sistemas de estampación a los medios de impresión como la litografía o la serigrafía que no requieren la mediación de tallas o incisiones. El grabado actual, como medio de expresión, utiliza como la pintura - la escultura una gran variedad de recursos. $n$ algunos casos se mezclan varias técnicas en busca de los resultados plásticos deseados. En el término grabado y estampación se encuentran implícitas las dos fases que intervienen en la realización de una obra gráfica impresa. Tan importante en el resultado final es la realización de la imagen y los recursos técnicos para grabarla o fijarla en el soporte, como el uso apropiado de las tintas el papel y la prensa. Siendo estas dos fases: el grabado y la estampación, complementarias.

Huecograbado.* Agrupa los procedimientos de grabado en los que la imagen es elaborada por diferentes procedimientos sobre la plancha de tal forma que, las zonas que retendrán la tinta quedan en hueco. Dentro de este bloque se encuentran los procedimientos de grabado calcográfico: buril, aguafuerte, aguatinta, etc. También en este grupo se encuentra el heliograbado. Otro bloque de procedimientos de grabado es el grabado en relieve, al que pertenecen los procedimientos de grabado en los que la imagen que recibirá la tinta para ser impresa queda en relieve sobre la plancha, rebajándose el resto con diferentes herramientas. A este grupo pertenece la xilografía, la linoleografía y en su vertiente industrial la tipografía y el fotograbado. 
Litografía. Técnica de impresión plana, inventada por Alois Senefelder en Munich en 1796. Este procedimiento está basado en el antagonismo del aguay/ - los cuerpos grasos. Sobre una piedra calcárea, porosa, de grano fino y regular, se dibuja con lápiz o con tinta grasa (un preparado especial para la litografía a base de ceras y jabones). Se acidula la superficie con una mezcla a base de goma arábiga y ácido nítrico. La imagen queda fijada y las zonas blancas impermeabilizadas manteniendo siempre esta superficie húmeda, cuando se pasa el rodillo entintado, la tinta sólo se deposita sobre las zonas previamente dibujadas, mientras que el resto de las partes húmedas la rechazan. Poniendo una hoja de papel encima y pasándola por la prensa litográfica, obtenemos una estampa. Se pueden sustituir las piedras por planchas metálicas tratadas ex profeso (zinc y aluminio) y entonces se llama zincografía o metalografía.

Matriz.* Se denomina así a la plancha en hueco o relieve susceptible de ser entintada y estampada. También se denomina matriz al molde de carácter tipográfico. En litografía se trata de la piedra en la que se hace el dibujo original, que puede ser transferido otras piedras al utilizar tinta y papel reporte para poder conservar el dibujo original.

Offset.* Es el derivado industrial de la Litografía, en realidad puede afirmarse que se trata de una litografía indirecta. El principio de las dos técnicas es el mismo: el antagonismo entre la grasa y el agua; sin embargo la aplicación presenta una particularidad fundamental: la estampación no se realiza directamente del elemento impresor al papel, sino por mediación de un cilindro recubierto de caucho, la mantilla, que toma la imagen y la reporta al papel de estampar. Este es el origen mismo del término inglés offset que significa: reporte, traslación, pasar de un sitio a otro. El reporte permite realizar la imagen sobre la plancha sin necesidad de invertir, pudiendo incluir en la obra fácilmente letras y otras imágenes asimétricas. La plancha de offset permito realizar la composición con un ritmo más rápido y mas cómodo que sobre la plancha. La mantilla de caucho que traslada la imagen ofrece una elasticidad mucho mayor que la piedra o el metal, lo que permite estampar con una gran nitidez sobre todo tipo de papeles, incluso de grano grueso. Las ligeras capas de tinta que transmite el caucho, no alteran las que se han impreso antes, ni la textura del papel. A causa de su extraordinaria fidelidad de reproducción y el bajo coste de realización que presenta, así como su rapidez y economía constituye actualmente la principal fuente de producción de imágenes en la industria gráfica. Su nivel de mecanización y su evidente asociación con las reproducciones comerciales han provocado serios prejuicios entre los profesionales que se niegan a reconocer su vinculación con la obra gráfica original. Resulta evidente su error en tanto se trata de tecnología avanzada que presenta una considerable, actual y característica expresión en el proceso de creación artística, permitiendo más posibilidades de control y transformación que cualquier otra. 
Papel.* Soporte esencial de la estampa. En el grabado y la estampación se utilizan diversas clases de papeles como: Papeles de calco, papeles de pruebas, papeles de edición. En litografía se utilizan papeles autográficos que permiten ser dibujados para trasladar la imagen a la plancha o la piedra y papeles reporte que permiten reportar los dibujos sobre varias piedras 0 planchas.

Punta seca. ${ }^{*}$ Punta afilada de acero templado que se utiliza para grabar sobre metal. También es utilizado este término para definir el procedimiento de grabado en hueco realizado con esta herramienta, en el que directamente sobre el metal en seco se realizan los trazos del dibujo, Tanto el hueco producido en los trazos, como las rebabas de metal que se producen en los bordes de las líneas son los que retendrán la tinta. Las estampas con esta técnica, que permite una corta tirada, se caracterizan por que muestran una gran espontaneidad y libertad, adquiriendo los trazos un carácter aterciopelado.

Plancha. Lámina delgada de material duro, regular y pulida, de metal o madera, que en grabado se utiliza como matriz.

Serigrafía. ${ }^{*}$ Procedimiento de estampación que como el grabado, la xilografía o la litografía es utilizado por los artistas. Se trata de un sistema de estampación permeográfico (véase permeografía). Su origen es oriental, utilizándose originalmente un tejido de seda como elemento impresor. Hoy este procedimiento ha sido considerablemente modificado y mejorado, utilizándose tejidos sintéticos como el poliéster, también en la industria son utilizados tejidos metálicos. El principio de la impresión serigráfica consiste en obturar por procedimientos manuales o fotográficos ciertas partes la malla de una pantalla formada por un bastidor sobre el que se ha tensado un tejido de seda, sintético o metálico, para que la tinta no pueda penetrar a través de esos lugares. En las otras zonas, por el contrario, la tinta atraviesa el tejido y estampa el papel o cualquier otro soporte de impresión. La serigrafía permite estampar sobre una amplia variedad de soportes.

Tórculo. Prensa calcográfica compuesta de dos cilindros, uno superior y otro inferior, entre los cuales hay una platina que transporta la plancha y el papel bajo la presión. Se acciona con un volante.

Velo. Buril con sección de varias puntas. Se utiliza para obtener varias líneas paralelas de una sola pasada.

Xilografía. Grabado sobre madera. Técnica de impresión en relieve que utiliza una matriz de madera. Sobre un taco de madera (especialmente de árboles frutales o de boj), el artista marca su diseño y con la ayuda de gubias o de burile vaciará los blancos, dejando intactas sólo las partes que se imprimirán, o sea, el diseño. Si el taco esta cortado siguiendo el hilo de la madera, se utilizan gubias o cuchillas para la incisión y se conoce como grabado a fibra o al hilo. Si por el contrario, el taco está cortado en sentido transversal a las vetas del 
árbol, se utilizan buriles y entonces se llama grabado a contrafibra o a testa. Para esta segunda modalidad se utiliza a menudo la madera de boj.

Los términos están tomados de Rosa Vives, Del cobre al papel La imagen multiplicada, Icaria, Barcelona, 1994. Los marcados con asterisco de José Manuel Guillen Ramón procedentes del catálogo Archivo Gráfico, Grabados, litografías y serigrafías Universidad Politécnica de Valencia Editorial UPV, 2003. 


\section{ANEXO I \\ Obra con referencia a la muerte}

Obra Gráfica de José Guadalupe Posada

Nota/ Los comentarios de los grabados son autoría de Leopoldo Méndez. No se menciona el lugar donde fue publicada, ya que en muchos casos las obras cambiaban de título y de publicación, según las necesidades de los editores de la obra de Posada. Las medidas cuando se ha podido son mencionadas en milímetros (primero la base y luego la altura).

Los procedimientos empleados se señalan con las siguientes claves: d: dibujogmp- grabado en madera- gmt grabado en plancha de metal tipográfico -gspgrabado en piedra litográfica - I: litografía lc litografía en colores z: zincografía.

Gran Calavera eléctrica -Hoja suelta-México 1907, z -256 x 120

Calavera revolucionaria-Hoja suelta $-\mathrm{z}-113 \times 186$

Cadáveres de moros a orillas del mar (ilustración de un folletín) 1894- gmt- 150 x 100

El cadáver del corneta Bruno Labastida, Velorio- Hoja suelta- gmt- $152 \times 112$

El fusilamiento del soldado Bruno Apresa- Hoja Suelta- México 1904- gmt-134 x87

El fusilamiento de Timoteo Andrade México 1903- z- 125 x 95

Gran espanto. Aparición del fantasma de Pachita la alfajorera- 1893, Clisé-gmt$205 \times 111$

Alucinaciones de un dispsómano, 1904

Espectros y aparecidos, Pachita la alfajorera, 1893-gmt- 49 × 34

Los espantos de la Amargura 1904 -z- 62 x 65

La confesión de un esqueleto- Hoja suelta- 1903 z- 132 x 76

Amor y muerte- 1895- gmt- 94 x 118

El doctor improvisado, Carátula del cuento 1890 y 1899- gmt- 2 colores 84 x 132

El ahorcado en la calle de las rejas de Balvanera. Horrible suicidio el lunes 8 de enero de 1892. Hoja suelta, 1892- gmt- 98 x 161

Los crímenes pasionales 1904 
Sobre las aguas. ¿Suicida? 1904

Historia de sangre 1904

Crimen en el misterio 1904

La muerte antes que la deshonra 1904 gmt- $110 \times 88$

El último suicidio 1904

Las mujeres que se matan 1904

El suicida del panteón 1904

Horrible tragedia pasional. Un gendarme mata a su novia cruelmente. Hoja suelta 1912 z- 143 x 89

Suicidio -gmt- $170 \times 116$

Asesino y suicida 1904

Asesinato 1893-1894 -gmt- $110 \times 76$

En el canal de Xochimilco. Tragedia entre hombres de trueno 1903

Drama sangriento en la Plazuela de Tarasquillo. Asesinato de La Malagueña. Hoja suelta en la que se relata el asesinato cometido por María villa -gmt- 141 × 90

María Villa (a) La Chiquita asesina de La Malagueña en Belén, 1897 gmt -65 x 89

Esperanza Gutiérrez (a) La Malagueña asesinada por María Villa después de un baile de máscaras a las 6 de la mañana del lunes 8 de marzo de 1897 en la casa No. 5 de la Plazuela de Tarasquillo 1897 -gmt- 97 × 115

La tragedia de Belén Galindo. Corrido anverso. Hoja suelta -z- 61 x 120

Idem. Reverso 114 × 112

Tragedia conyugal 1903

El duelo Verástegui- Romero, la tarde del 9 de agosto de 1894 a un costado del Panteón reconstruido fielmente, 1895 -gmt-163 x 81

Duelo Verástegui- Romero 1894 -gmt- $163 \times 81$

La muerte de un avaro 1904

Asesinato 1892 y 1893 -gmt- 127 × 99

Los crímenes del Chalequero. Asesinato de Mucia gallardo. Hoja suelta $1890-$ gmt- $150 \times 115$

Un destripador 1904

La próxima ejecución de Francisco Guererro (a) El Chalequero, degollador de mujeres. Comunicación de la sentencia. Una de las víctimas del Chalequero asesinada en 1897 en el Río Consulado. Hoja suelta 1890 -gmt- 179 × 130

Crímenes, desgracias y escándalos. Cabeza de columna 1892 -gmt- 55 × 49

Los crímenes de la Bejarano. Hoja suelta 1892 -gmt- 111 x 78 
El jurado de Guadalupe Martínez de Bejarano. Hoja suelta 1892 -gmt-112 x 130

Guadalupe bejarano en las bartolinas de Belén. Hoja suelta 1892 -gmt- 196 × 140

Balazos en la calle de San Hipólito, en un tren de las corridas de Azcapotzalco.

Asesinato de Teodora Piedras por Leopoldo Cárdenas. 1892 -gmt- 176 x 113

Muerte de Teodora Piedras y agresión a dos gendarmes -gmt- 109 × 73

Una víctima del deber 1904

La confesión de un asesino 1904

Martirio de una niña 1893 -gmt- 144 x 166

El castigo espantoso o La lluvia de sangre. Carátula -Ic- 70 × 100

La última suicida -d-1904

Los crímenes de la ambición o El anatema de la víctima. Carátula -Ic-70 x 100

La terrible noche del 17 de agosto de 1890. Corrido. Hoja suelta 1890 -gmt- $192 \mathrm{x}$ 138

El consejo de guerra del corneta Bruno Labastida, cómplice en el asesinato del teniente Calapiz. Hoja suelta. -gmt- $103 \times 88$

Despedimiento de Bruno Labastida, cómplice en el asesinato del teniente Calapiz. Hoja suelta -gmt- $97 \times 83$

Ejecución de Zeferino y Trinidad Martínez el $1^{\circ}$ de octubre de 1890. Hoja suelta 1890 -gmt- 167 x 106

Corrido de los cuatro zapatistas fusilados. Hoja suelta -z- 146 × 85

Fusilamiento de Rosendo Ramírez en los Ilanos de San Lázaro. Hoja suelta 1891 -gmt- $230 \times 111$

Ejecución de Luis Tapia, reo de homicidio 1893- 1894 -gmt- 190 x 83

Pormenores de la última ejecución. Fusilamiento de Manuel García en el jardín de Belén. Hoja suelta 1891 -gmt- 238 × 150

El jurado de los asesinos del señor Tomás Hernández Aguirre muerto en el robo de la Profesa. Hoja suelta 1892 -gmt- 189 - 1891260 x 151

Próximas ejecuciones de la justicia: Luis Izaguirre, Bruno Martínez, Francisco Guerrero y Alberto Fernández, relacionados con el robo de la Profesa. Hoja suelta 1892 -gmt- 181 x 130

Últimas noticias de Gerardo Nevraumont y compañeros autores del robo de la Profesa. Hoja suelta. 1892 -gmt- 183 x 143

Jesús Bruno Martínez en las bartolinas de Belén. Relacionado con el crimen de la Profesa. Hoja suelta 1892 -gmt- 177 x 132

El asesinato de Leandra Martínez. Hoja suelta 1891 -gmt- 159 x 139

Enrique Rode dando muerte a su mujer Amelia Sornoza, el 13 de agosto de 1888 - gmt- $238 \times 153$ 
Asesinato de una mujer 1893 -gmt- $110 \times 85$

Muerte de Aurelia Caballero por el vómito en Veracruz. Uno de los inodados en el crimen de la profesa. Hoja suelta 1892 -gmt- 182 x 129

El pánico de la peste 1904

Peste en el campo -z- 135 x 72

Terribles y espantosísimos estragos habidos por la suma escasez de semillas y el terrible tifo que ha causado gran sensación en la Ciudad de México, Durando, Zacatecas, Guadalajara, Sinaloa, Matamoros en el presente año de 1893 -gmt$163 \times 249$

Encontraban y no. Se refiere a la epidemia de tifo 1908 -z-165 x 96

Terrible suceso acaecido en la ciudad de Toluca. Treinta y siete envenenados con carne infectada de triquina. Hoja suelta $1910-z-158 \times 87$

El último siniestro ferroviario 1904 -z- 170 x 100

El descarrilamiento de Temamatla. Hoja suelta 1900 -gmt- 164 x 110

Descarrilamiento de Temamatla. Cuadernos de canciones. 1902 -gmt- $89 \times 137$

El gran descarrilamiento de Temamatla. Corrido Hoja suelta 1903 -z- 133 x 77

La catástrofe en el ferrocarril del sur 1892 -gmt- 69 × 70

Camino de ultratumba $1908-z-162$ x 93

La inundación de León. Carátula. Cuaderno de canciones -gmt- 98 × 146

La hecatombe de Chalchicomula. Carátula. Cuento histórico -gmt- 88 × 135

Grandes y espantosas inundaciones. Tremendos temblores de 1897. Hoja suelta z- 238 x 130

Un incendio $1894-z-160 \times 114$

La gran destrucción y terrible incendio de la plaza de toros de Puebla. Hoja suelta $-z-164 \times 250-$

Gran cometa y quemazón. Hoja suelta -z- 124 x 87

Muerte de unos artilleros al hacer la salva el 5 de mayo 1904

La familia del señor general Ramón Corona (Con motivo del asesinato del general y gobernador Ramón Corona el 11 de noviembre de 1889) 1889, -I- 335 x 273

La sentida muerte del ilustrado general José Ceballos gobernador del Distrito Federal 1893 -gmt- $118 \times 80$

Los funerales del general Ceballos 1893 -gmt- 285 x 100

Llegada del cadáver del general González, ex presidente de México y ex gobernador de Guanajuato a la ciudad de México 1893 -gmt- 182 x 97

Muerte del general Manuel Gonzáles en la hacienda de Chapingo. Primera versión 1893 -gmt- 195 x 112 
Llegada del cadáver del general Gonzáles a esta capital. Segunda versión 1893 gmt- $195 \times 112$

El entierro del general González -gmt- 280 x 83

El ahorcado. Revolucionario por los hacendados 1910-1912-z- 80 x 186

Los sangrientos sucesos en la ciudad de Puebla. Hoja suelta. (Se trata de de los acontecimientos del 20 de noviembre de 1910, en los que perdió la vida Aquiles Serdán y con los que inicia la Revolución Mexicana. 1910 -z- 141 x 87

Revolucionario muerto. Hoja suelta -z- $145 \times 177$

La ejecución de Vaillant, asesino de Sadi Carnot 1894 -gmt- 107 × 81

Asesinato de M. Carnot 1894 -gmt- 255 ×147

Esta es la de don Quijote, la primera, la sin par, la gigante calavera. Hoja suelta gmt- $342 \times 560$

Aquí está la calavera del editor popular A. Vanegas Arroyo $1902-z-261$ x 211

Varias calaveras. Hoja suelta. -z- 127 x 198

Calavera de mujer elegante ( la primera calavera catrina) $1889-\mid-193 \times 199$

Panteón de periódicos $1893-$-l- $269 \times 199$

El purgatorio artístico en el que yacen las calaveras de los artistas y artesanos. Hoja suelta. -gmt- $342 \times 557$

Rebumbio de calaveras. Hoja suelta. -gmt- $230 \times 154$

Calaveras. Atención seres humanos -gmt- $230 \times 154$

Barata de calaveras. Lindas gatas, hermosas garbanceras. Hoja suelta -gmt- 182 $x 116$

Calavera de Don Folías y el negrito. Hoja suelta. -z- 265 x 145

La calaverita nueva/ que sale en estos momentos / de los cabos y sargentos / de la segunda reserva. Hoja suelta $-z-86 \times 232$

Gran fandango y francachela de todas las calaveras. Hoja suelta -gmt- $205 \times 120$

Calavera de los patinadores. Hoja suelta. -gmt- 121 x 83

Aquí la calavera está, señores/ de toditos los buenos valedores. Viñeta primera. Hoja suelta. 1894 -gmt- 121 x 83

Un gendarme y un catrín. Calavera de los patinadores. Hoja suelta. 1894 -gmt- 42 $\times 27$

Un valiente y un gendarme. Calavera de los patinadores. Hoja suelta 1894 -gmt$42 \times 27$

Aquí la calavera esta, señores / de toditos los buenos valedores. Viñeta segunda. Hoja suelta 1894 -gmt- 83 × 60 
La calavera de cupido. En esta hoja suelta se publican 12 grabados diferentes. Hoja suelta -gmt- $269 \times 361$

El gran panteón de amoroso. Consta de 12 grabados diferentes -gmt- 273 x 369

Las bravísimas calaveras guatemaltecas de Mora y de Morales (Se refiere a los asesinos del Gral. Barillas. Hoja suelta -z- 274 x 363

La calavera oaxaqueña. Hoja suelta. -z- 144 x 273

La calavera revuelta. Hoja suelta. 1911 -z- 267 x 143

Don Chepito contempla a las presentes / calavera de amigos y parientes. Hoja suelta 1890 - 1900 -gmt- 102 x 192

Calavera de un revolucionario. Hoja suelta. 1910- 1912 Clisé -z- 70 x 146

La calavera catrina. Hoja suelta -z- $154 \times 110$

Calaverita cupletista. Hoja suelta. $-z-28 \times 38$

Una calaverita con chistera y puro. Hoja suelta -z- $26 \times 39$

Una calavera chusca/ dedicada a las placeras, tortilleras, verduleras/ y toda la gente de lucha (Anverso) Consta de 6 grabados diferentes. Hoja suelta. $-z-67 x$ $77 \mathrm{c} / \mathrm{u}$

Ídem. (Reverso) Consta de 7 grabados diferentes. Hoja suelta. -z- 60 x 77

Calavera de María Conesa 1911 -d-

Calavera de Francisco I. Madero 1911 -d-

Calavera de Don José Ives Limantour, 1911 -d-

Calavera de Guillermo Landa y Escandón 1911 -d-

Calavera de Don Justo Sierra 1911 -d-

Calavera del general Bernardo Reyes 1911 -d-

Calavera de Néstor Pirulí ( fue amigo de Limantour. De pobre, se volió millonario $1911-d-$

Calavera de don Benito Juárez Maza 1911 -d-

Calaveras de a montón. Calavera de Madero. Hoja suelta. $1902-z-y-g m t-259 x$ 360

Calavera llorando el hueso. Publicado en la hoja "La calavera de los peleles. Hoja suelta. 1909 -z- 258 x 345

Panteón político en terrenos del Diablito Rojo 1910 -z- 223 x 150

Fuente: José Guadalupe Posada Ilustrador de la vida mexicana. Fondo Editorial de la Plástica Mexicana, México 1963. 


\author{
ANEXO 2 \\ TALLER DE GRÁFICA POPULAR \\ 1937-1965
}

\title{
1938
}

Ignacio Aguirre: Calaveras Unite. Volante a partir de una litografía. Tema: Escisión de la CGT. Tiraje: 4000 ejemplares, encargo del Sr. M. Salas Anzures, 56.5 x 43 cm. Col. TGP

Colectivo: Calaveras locas por la música. Ocho páginas con numerosos dibujos y litografías. Publicado por el TGP, $47 \times 34.5 \mathrm{~cm}$. Col. TGP.

p.1 Contra el monopolio de los carniceros, p. 2 Sobre la prensa revolucionaria y reaccionaria, p. 3 Sobre Max Shmeling, Joe Luis y Cantinflas, p. 4-5 Sobre la lucha de Cárdenas, Vasconcelos y Vicente Lombardo Toledano contra la reacción, entre otros también contra el Dr. Atl, p.6 Contra Morones y León Osorio, para los agraristas de Chaparro, p.7 Sobre el Banco de Crédito Ejidal, contra René Capistrán Gonga y María Elena Blanco, p.8 Sobre el pacto de Munich, Daladier, Mussolini, Hitler, Chamberlain, Viva la CTM.

\section{9}

Alfredo Zalce, Pablo O’Higgins, José Chávez Morado y otros: Calaveras Extra Guerra Extra, publicado por el TGP, 51 x 40 cm., p.1 Alfredo Zalce: Contra la guerra imperialista, p. 2 Pablo O'Higgins: Sobre la expropiación petrolera, p.3 José Chávez Morado: Sobre la prensa reaccionaria, p. 4 Alfredo Zalce: El misterio del gran hueso, sobre los planes de Daladier, Chamberlain, Mussolini y Hitler de apoderarse de la URSS, p. 5 La guerra de los frijoles, sobre los esfuerzos para regular los aumentos de los precios, p. 6 José Chávez Morado: Pleito de perros, sobre la reacción en México; Morones, Almazán, Amaro, Diego Rivera, Trotsky, Osorio.

\section{0}

Anónimo: Calaveras del Taller de Gráfica Popular, Cartel a partir de un dibujo, con un poema de Cálamo Currente sobre el TGP, 67 x $47 \mathrm{~cm}$.

\section{2}

Leopoldo Méndez, Alfredo Zalce, Pablo O’Higgins, Bob Mallory y otros: Calaveras Estranguladoras, cuatro páginas con once ilustraciones, grabados en linóleo y publicados por el TGP con textos de Juan de la Cabada, 47 x $5.35 \mathrm{cms}$.: p. 1 Camioneros y tenderos, Gregorio Cárdenas Hernández contra el monopolio de los 
camiones y contra los acaparadores, p 2 Sobre el aumento de los precios de los medicamentos contra la mala leche y el arzobispo, p.3 A laval, Pétain y Cía. Se exige un segundo frente, p. 4 Leopoldo Méndez Corrido de Stalingrado.

1944

José Chávez Morado: Calaveras contra el pueblo, grabado en linóleo, 17x 25 cm.

\section{7}

Colectivo: Chávez Morado, Zalce, Covarrubias, Beltrán, Díaz, Méndez, López, Escobedo, Mora, Franco, Yampolsky, Anguiano, Juárez, García Bustos, Peña, Aguirre y Castro Pacheco: Calaveras aftosas con medias nylon, ocho páginas con 26 ilustraciones, grabados en linóleo, colaboración de los escritores Luis Córdova, Che Cánovas, Gonzalo Beltrán y Emanuel Placios, 40.5 x $31 \mathrm{~cm}$., p. 1 Leopoldo Méndez: ilustración de la portada, Contra el aumento de los precios, p. 2 Contra Amilpa y el PRI, por el partido nuevo PP, p.3 Contra el radicalismo de la derecha, contra Amilpa, Ireta y Abelardo Rodríguez, por el mejoramiento de las escuelas, p. 4-5 Contra Franco, el Club Rotario, Club de Leones, el Plan Playton, contra la industria emergente y la prensa "independiente", p. 6 Contra la "vaca sagrada" que es el armamentismo en los Estados Unidos contra Franco, p. 7 Contra el plan Marshall y los imperialistas ingleses, p. 8 Contra los nuevos planes de guerra.

1949

Gómez, Beltrán, Yampolsky, Mora y Aguirre, Calaveras televisoras, dos páginas con nueve grabados en linóleo publicadas en la editorial Vanegas Arroyo, 47 x 34 cm., p 1 Contra los altos precios y contra la pena de muerte, p. 2 Sobre Cuauhtémoc, contra Mac Arthur y la Guerra de Corea.

Ignacio Aguirre, Elizabeth Catlett, Oscar Frías y Francisco Mora: Calaveras Guasp, una página con doce grabados en linóleo, publicada en una página del diario El Popular del 2 de noviembre de 1949 sobre la guerra de Corea, la revolución china, contra el armamentismo y la inflación, 57 x $43 \mathrm{~cm}$.

Luis Córdova, Andrea Gómez y Francisco Mora, Calaveras Voladoras,

\section{2}

Aguirre, Mexiac, Bracho, O’Higgins, Beltrán, Méndez y Yampolsky: Calaveras a la cargada, ocho páginas con 19 grabados en linóleo, textos de Luis Córdova y Juan de la Cabada, 48 x 35 cm., p. 1 Leopoldo Méndez ilustración de la portada: Sobre el fin del sexenio de Miguel Alemán, p. 2 Alberto Beltrán: Contra el teatro del PRI, p. 3 Pablo O'Higgins: Contra la justicia burguesa, contra Truman, por la liberación de Campa, p. 4-5 Ángel Bracho: Este es el circo del siglo Yanqui, p. 6 Mariana 
Yampolsky: Fosa Films S.A, Sobre Figueroa, Emilio Fernández, Jorge Negrete, Cantinflas, Tamayo, Siqueiros, Rivera y Zalce, p. 7 Ignacio Aguirre: Swift \& Co. Caldo de perros, Made in USA, Sobre la explotación de los braceros en los Estados Unidos, p. 8 Adolfo Mexiac: Carestía de vida y monopolios.

Alberto Beltrán: Calaveras de San Cristóbal, volante en papel de china con ilustración de A. Beltrán, publicado en San Cristóbal de las Casas, Chiapas, el 2 de noviembre de 1952, 20.5 x $30.5 \mathrm{~cm}$.

\section{3}

Colectivo: Calaveras apretadas que aparentan ser honradas, Cuatro páginas con numerosos grabados en linóleo, con textos de Juan de la Cabada y Luis Córdova. Dos páginas están publicadas en Calaveras resurrectas, México 1954.

\section{4}

Alberto Beltrán, (ed): Calaveras resurrectas. 16 años de calaveras políticas del Taller de Gráfica popular, veinte páginas con reproducciones de las calaveras hasta entonces publicadas, con un prefacio de José Alvarado y portada de Alberto Beltrán, 22 × $17.5 \mathrm{~cm}$.

Colectivo: Calaveras desvalorizadas...al trabajo fecundo y creador. Plegado con cuatro páginas y quince grabados en linóleo: p.1 Contra el imperialismo yanqui y la devaluación del peso, p. 2 Contra el aumento de los precios hasta en la iglesia, la electricidad; éxodo de los braceros, p. 3 Contra la carestía, los monopolios y el sindicato de los boxeadores, p. 4 Ángel Bracho y Celia Calderón: Contra el rearme.

\section{5}

Gómez, Rabel, O’Higgins, Aguirre, Beltrán, Bracho, Mexiac, Yampolsky, Jiménez, Calderón y Méndez: Calaveras ciclónicas, número especial de la revista Ahí va el golpe, número 10, 1 de noviembre de 1955, doce páginas con 19 grabados en linóleo, 27.5 x $21.5 \mathrm{~cm}$., p. 1 Andrea Gómez: Sobre el fraude con las donaciones a las víctimas del ciclón, p. 2 Fanny Rabel: Sobre la avaricia de la burguesía nacional, p. 3 Pablo O'Higgins: Sobre la Conferencia de Ginebra entre los EEUU y la URSS; sobre los braceros, p. 4 Alberto Beltrán e Ignacio Aguirre: Sobre las intervenciones de los EEUU en América Latina, p. 5 Ángel Bracho: Sobre el imperialismo de los EEUU, p. 5 Adolfo Mexiac: Sobre negocios con armas. P. 6-7 Alberto Beltrán: Sobre los ciclones y los negocios que hacen de esto los EEUU, p. 8 Beltrán y Mexiac: Sobre el mal gobierno, Sara Jiménez: Sobre el colonialismo, p. 9 Mariana Yampolsky: Sobre el gran escándalo de la desaparición de los votos de las elecciones, p. 10 Celia Calderón y Alberto Beltrán: Carestía, p. 11, Gustavo Casillas Sobre Tamayo, los teléfonos, los camiones y la misericordia, p. 12 Leopoldo Méndez: Sobre los turistas y la venta del país a los ladrones norteamericanos. 
Colectivo: Calacas con su corneta y pelona bayoneta, cuatro páginas con siete grabados en linóleo, $47.5 \times 34.5 \mathrm{~cm}$., p. 1 Sobre la ocupación militar del IPN, p.2 Sobre los braceros, p. 3 Sobre la intromisión de los EEUU en América Latina, p. 4 Sobre el dictador Somoza, sobre la carestía.

\section{7}

Francisco Mora, Alberto Beltrán y Ángel Bracho: A destaparse calaveras, Una página con seis ilustraciones en el diario La voz de México, del 1‥ De diciembre de 1957 contra el tapadismo, $60 \times 40 \mathrm{~cm}$.

Leopoldo Méndez, Mariana Yampolsky, Alberto Beltrán, Fanny Rabel y Ángel Bracho: Calaveras, seis ilustraciones para un artículo de Juan Almagre: "El Taller de Gráfica Popular, Su función pública y aportación estética". En: Paralelo 20, año 11, número 33, México, D. F., 31 de diciembre de 1957. Sobre el aumento de precios, los temblores y los sputniks.

\section{8}

Colectivo: Calaveras refrescadas, remojadas y retenidas, Seis páginas con catorce grabados en linóleo, 40 × 30 cm., p.1 Sobre las inundaciones en Guanajuato, Nuevo León, Nayarit y Tamaulipas, así como sobre los lanza aguas contra los manifestantes, p. 2 Sobre la primera mujer como diputada Macrina Rabadán, p.3 Contra el arte abstracto, contra Gotilla y sobre los acontecimientos en el IPN, p. 4. Sobre la lucha de los ferrocarrileros contra los líderes sindicales corruptos, p. 5 Sobre los éxitos de los pueblos latinoamericanos en la lucha contra los dictadores, p. 6 Sobre la relación entre el gobierno y la oposición.

\section{9}

Colectivo: Calaveras tapadas, cuatro páginas con siete grabados en linóleo, $34 \mathrm{x}$ $23.5 \mathrm{~cm}$., p.1 Sobre el candidato presidencial del PRI, p.2 Sobre el huracán Flora encima de Cuba; contra Franco, p.3 Sobre la Alianza para el Progreso, Nuevas escuelas religiosas, Sobre la nueva Confederación campesina Independiente, p. 4 Sobre los golpes de estado en América Latina.

\section{1}

Colectivo: Adolfo Mexiac, Enrique Alatorre, María Antonieta Castilla, Héctor Cruz, Luis G. Robledo, Mariano Paredes y Víctor M. Limón: Calaveras oligárquicas, boquiflojas poco parcas, Ocho páginas con numerosos dibujos y algunas litografías, editadas por el TGP y el Movimiento de Liberación Nacional, p.1 Contra la reacción nacional, los radicales de derecha, contra la industria cinematográfica 
nacional, p.2 idem, p.3 Sobre los presos políticos, contra los periodistas al servicio de la embajada norteamericana, págs. 4-5 Sobre la Alianza para el Progreso por Cuba, p. 6 Sobre la discriminación racial de delegados de la ONU en Nueva York, sobre los cosmonautas soviéticos Gagarin y Titov, sobre De Gaulle y los acontecimientos en Argelia, sobre Lumumba, p. 7 Sobre Kennedy, contra la bomba atómica, contra el rearme en Alemania, contra Berlín Occidental, p. 8 Fosa común para el Movimiento de Liberación Nacional.

Colectivo: Calaveras académicas, suplemento humorístico de la Academia Mexicana de la Educación, publicado el 1ํ de noviembre de 1961.

\section{2}

Colectivo: Alianza calada de calacas agusanadas. Ocho páginas con 32 grabados en linóleo, 47.5 x $35 \mathrm{~cm}$. p. 1 Contra la política de Kennedy acerca de Cuba, contra los gusanos, p. 2 Sobre el fin de la Reforma Agraria y de los libros de texto gratuitos, sobre la Conferencia por la Paz, p. 3 Sobre el proceso contra Siqueiros, sobre Bertrand Russel, sobre el teatro el parlamento, sobre la Alianza para el Progreso, P. 4-5 Sobre Cuba y la ONU, sobre los acontecimientos en Mexicali, sobre los precios aumentados en el pan y la electricidad, p.6 Sobre las visitas oficiales de Nehru y Goulard en México, sobre los precios políticos, sobre la suspensión del club de periodistas y sobre Cuba, p. 7 Sobre los cosmonautos, sobre Marilyn Monroe, sobre Argelia y sobre el desarme, p. 8 Contra Fidel Velásquez, sobre los intereses comunes de la burguesía norteamericana y la mexicana.

1963

Colectivo: Calaveras 1963, tiraje de 1000 ejemplares.

\section{4}

Colectivo: Calaveras desenchufadas y no comprometidas. Ocho páginas con diez grabados en linóleo, 48 × 35 cm., p.1 Sara Jiménez, Adolfo Quinteros y Jesús Gutiérrez, Sobre la visita del presidente Díaz Ordaz a los EEUU, p. 2 Francisco Luna y Octavio Bajonero: Sobre el nuevo Gobierno, p. 3 Mercedes Quevedo, Fermín Rojas: Sobre el delito social, sobre el arte abstracto, p. 4-5 Arturo García Bustos, Celia Calderón, Franco Valadés y Octavio Bajonero: Sobre las visitas oficiales, sobre Juliana, la reina de Holanda, p. 6 Elizabeth Catlett y Francisco Mora. Sobre los acontecimientos en el Congo, sobre Goldwater y Jonson (EEUU), p. 7 Francisco Luna y Francisco Dosamantes: 25 años de dictadura en España, sobre el Congo, p.8 Antonio Pujol y Ángel Bracho: La Alianza para el Progreso. 
Pujol, Aguirre, Zalce, Quinteros, Arenal, Luna, castilla, Bracho, Jiménez, Vadillo, Jorge Ramírez, Jesús Gutiérrez, Álvarez Amaya, Sosamontes, René Arteaga, Revueltas, Marco Antonio Millán, José Arenas y Luis Sánchez Arreola: Calaveras macabras, macabritas y macabrones, Ocho páginas con numerosas ilustraciones, $48 \times 35 \mathrm{~cm}$., p. 1 Contra los norteamericanos, por las norteamericanas, p. 2 Sobre Vietnam, sobre la revista Life, p. 3 Sobre el viaje del Papa Pablo V1, págs. 4-5 Sobre Johnson, la doctrina Monroe y sobre Vietnam, p. 6 Sobre la Reforma Agraria en Yucatán, contra los homosexuales, p. 7 Sobre la Reforma Agraria, ¿Dónde está Zapata?, p. 8 Sobre las intrigas del gobernador de Chihuahua, Práxedes Giner Durán: Contra los gusanos.

Fuente/ Prignitz, Helga, El taller de Gráfica popular en México 1937-1977, INBA; México 1992 


\section{ANEXO 3}

Calaveras de Leopoldo Méndez

Calaveras aftosas con medias nylon, 1947 (linóleo)

Concierto de Calaveras 1934-1935 (grabado en madera)

Calaveras del montón 1936 (linóleo)

Calaveras de los pobres millonarios, 1951 (linóleo)

Calavera de la cigüeña, 1952 (linóleo)

Calaveras del camarón, 1956 (linóleo)

Calavera de la 2ª. Guerra Mundial, 1942 (linóleo)

Calaveras Estranguladas, cartel. (En colaboración con Alfredo Zalce)

Fuente: Leopoldo Méndez (1902-1969) Academia de Artes. Exposición Homenaje, INBA, Galerías del Palacio de Bellas Artes, febrero- marzo 1970.

Nota/ no se agregan medidas. 



\section{Fuentes de Consulta}

Archivos Consultados

HN Hemeroteca Nacional

FRHN Fondo Reservado de la Hemeroteca Nacional

CEHM Centro de Estudios sobre Historia de México CONDUMEX

BSR Biblioteca Samuel Ramos Facultad de Filosofia y Letras, UNAM

CIESAS Centro de Investigaciones y Estudios Superiores en Antropología Social

MS Museo Soumaya

CCCL Centro Cultural Casa Lamm

AK/S Archivo Keller/Soriano

CFP Colección Francisco Plancarte

\section{BIBLIOGRAFÍA}

Aguirre Beltrán Gonzalo, El proceso de aculturación en México, México, UIA, Instituto de Ciencias Sociales, 1970.

Anguiano Arturo, El estado y la política obrera del cardenismo, México, Ediciones Era, colección Problemas de México, 11a․ Reimpresión, 1990.

Alanís Figueroa, Judith, Gabriel Fernández Ledesma, México, UNAM, ENAP 1985.

Alberro, Solange Estampas de la Colonia, México, Ediciones Tecolote, 2004.

Bocaccio, Giovanni, El Decamerón, Círculo de Lectores, México, Complejo Editorial Mexicano, 1972.

Bolaños Joaquín, Fray, La Portentosa vida de la Muerte, edición y crítica y notas de Blanca López de Mariscal, México, Biblioteca Novohispana II, El Colegio de México, 1992.

Boulogne, Duchenne de, Contractions musculaires en Hans-MichaelKoetzle, Photo Icons The story behind the pictures volume 1, Taschen, 2002.

Bonilla Reyna, Helia, Manuel Manilla Protagonista de los cambios en el grabado decimonónico, México, 1a․ Edición en Círculo del Arte, 2000. 
Burke Peter, Visto y no visto. El uso de la imagen como documento histórico, España, Traducción de Teófilo de Lozaya, Editorial Crítica, 2000.

Baudrillard, Jean, El sistema de los objetos, México, Editorial Siglo XX1, traducción de Francisco Gonzáles, 6ª . edición, 1981.

Bataille, Georges, Las lágrimas de Eros, México, traducción de David Fernández, Ensayo Tusquets, 3ª. edición, 2002.

Cabada, Juan de la, / Méndez Leopoldo, Incidentes melódicos del mundo irracional, México ,Editorial Correo de las Américas, 1a. Edición, 1974. (edición facsimilar)

Camacho Morfín, Thelma, Imágenes de México, las historietas de El Buen Tono de Juan B. Urrutia, México, Instituto Mora, colección: historia social y cultural, primera edición, 2002.

Cardoza y Aragón, José Guadalupe Posada, México, UNAM, Dirección General de Publicaciones, Colección de Arte, número 15, 1963.

Caso, Alfonso, El pueblo del Sol, México colección Lecturas Mexicanas, coedición FCE / SEP, 1983.

Cervantes de Salazar, Francisco, México en 1554, México, presentación de Margarita Peña, Editorial Trillas, 1986.

Cervantes de Salazar Francisco, México en 1554 y Túmulo Imperial, edición, prólogo y notas de Edmundo O'Gorman, México, Editorial Porrúa, Colección: sepan cuantos, número $25,2000$.

Cooper, J. C., Diccionario de símbolos, Barcelona, traducción de Enrique Góngora Padilla, Editorial Gustavo Gili, 2ª̣. Edición, 2002.

Córdova, Arnaldo, En una época de crisis (1928-1934), México, Colección: La clase obrera en la Historia de México, Editorial Siglo XX1, tercera edición, 1984.

Córdova Arnaldo, La política de masas del cardenismo, México, serie popular ERA, número 26, segunda edición, 1987. 
Covantes Hugo, El grabado mexicano en el siglo xx 1922-1981, México edición del autor, 1982.

Castro Leal, Antonio, (et a), El libro negro del terror nazi en Europa, Testimonios de escritores y artistas de 16 naciones, México selección de ilustraciones Hannes Meyer, Editorial "El libro libre", 1943.

Cohen Josef, Sensación y percepción visual, s/t México, Editorial Trillas, 1973.

Cupull, Adys, Julio Antonio Mella en los mexicanos, Ediciones El Caballito, México 1983. 118 págs.

Charlot, Jean, El renacimiento del muralismo mexicano 1920-1925, México versión en español Maria Cristina Torquilha, Editorial Domés, 1985.

Diccionario Larousse Enciclopédico, México 1999.

Díaz del Castillo, Bernal, Historia verdadera de la conquista de la Nueva España, introducción y notas de Joaquín Ramírez Cabañas, México, editorial Porrúa, col. "sepan cuantos", número 5, 2004.

Díaz de León, Francisco, Gahona y Posada, grabadores mexicanos, México, Fondo de Cultura Económica, 1a․ Edición en Colección Popular, 1985.

Díaz de León Francisco, Juan B. Urrutia Litógrafo y apologista del tabaco, México Ediciones del Seminario de Cultura Mexicana, 1971.

Debroise, Oliver, Fuga Mexicana Un recorrido por la fotografía en México, México, Lecturas Mexicanas, $1^{\mathfrak{a}}$ edición, CONACULTA, 1994.

de la Vega Alfaro Eduardo, La aventura de Eisenstein en México, México Cuadernos de la Cineteca Nacional, número 6, 1996.

de la Torre Villar, Ernesto, Breve historia del libro en México, México, Coordinación de Humanidades, Dirección general de Fomento Editorial, colección Biblioteca del Editor, UNAM,1990. 
de la Maza, Francisco, Obras Escogidas, prólogo y selección Dra. Elisa Vargas Lugo, Comité organizador "San Luis 400", México, Instituto de Investigaciones Estéticas, UNAM, 1992.

De la Vega, Eduardo, Del muro a la pantalla, S. M. Eisenstein y el arte pictórico mexicano, México, Instituto Mexiquense de Cultura, IMCINE, Canal 22, 1977.

Defoe, Daniel, Diario del año de la peste, España, traducción de Carlos Pujol, Bruñera, 1995.

Enciso, Jorge, Sellos del Antiguo México, México, Editorial Innovación, 1985,

Everett Boyer, Richard, La gran inundación, vida y sociedad en la ciudad de México, México, SepSetentas, número 128, 1975.

Febvre, Lucien y Martin, Henry Jean, La aparición del libro, FCE, CONACULTA, México, 2002.

Fernández, Claudia y Paxman, Andrew, El Tigre Emilio Azcárraga y su imperio Televisa, México, Editorial. Grijalbo, Mondadori, 2001.

Fernández Ledesma, Gabriel, Fernando Castillo pintor popular 1895-1940, México Cuadernos de Historia del Arte, Instituto de Investigaciones Estéticas, UNAM,1984.

Fierros Gustavo, Memorial del aventurero Vida Contada de Juan de la Cabada, México, Col. Memorias Mexicanas CONACULTA, 1aa edición, 2001.

Gamboa, Federico, Santa, México, Ediciones Leyenda, 2006.

García, Guadalupe/ Solís, Silvia (compiladoras y notas), La nota roja en México, Centro de Estudios Históricos del Porfirismo (CEHIPO), México,

García Cubas Antonio, El libro de mis recuerdos, México, Editorial Patria, Colección México en el siglo XIX, 1950.

García Flores, Margarita, Aproximaciones y Reintegros, México, UNAM, Textos de Humanidades, núm. 33, 1982. 
García Riera, Emilio, Historia Documental del Cine Mexicano 1946 -1948, México, Tomo 4, Universidad de Guadalajara / CONACULTA, 1978.

García Riera, Emilio, Historia Documental del Cine Mexicano 1949 -1950, Tomo 5, Universidad de Guadalajara /CONACULTA, México, 1978.

García Riera, Emilio, Historia Documental del Cine Mexicano 1953 -1954, Tomo 7, Universidad de Guadalajara /CONACULTA, México, 1978.

Garmabella, José Ramón, El Criminólogo, los casos más impactantes del Dr. Quiróz Cuarón, México, Random House, 2007.

Gómez Serrano, Jesús, Mercaderes, Artesanos y Toreros, La Feria de Aguascalientes en el siglo XIX, México, Instituto Cultural de Aguascalientes, 1985.

González, Cesar, Imagen y sentido, México, Editorial UNAM, 1986.

González Obregón, Luis, Las calles de México leyendas y sucedidos vida y costumbres de otros tiempos, prólogos de Carlos G. Peña y Luis G. Urbina, México, Editorial Porrúa, colección “sepan cuantos” número 568, 2003.

González Rodríguez, Sergio, Los bajos fondos El antro, la bohemia y el café, México, Editorial Cal y Arena, México, 1990.

Honour, Hugo, El Romanticismo, Madrid, versión española de Remigio Gómez Díaz, Alianza Editorial, 1979.

Ivins, W.M., Imagen impresa y conocimiento, Análisis de la imagen pre fotográfica, Barcelona, Colección Comunicación Visual, versión castellana de Justo $\mathrm{G}$. Beramendi, s/ año.

Jiménez Armando, Picardía Mexicana, México, trigésima tercera edición, B. CostaAmic Editor, 1968.

Jiménez Gómez, Juan Ricardo, Un formulario notarial mexicano del siglo XVIII. La institución de escribanos de Juan Elías Ortiz de Logroño, México Editorial de Miguel Ángel Porrúa / Universidad Autónoma de Querétaro, 2005. 
Lafragua José María, Orozco y Berra, Manuel, La ciudad de México, prólogo de Ernesto de la Torre Villar, México, Editorial Porrúa, Col. "sepan cuantos." número 520, 1997.

Lenz Hans, Historia del papel en México y cosas relacionadas: 1525-1950, México, 2ª , edición 2001, Miguel Ángel Porrúa, CRUCP.

León Portilla, Miguel (selección y notas), Visión de los Vencidos relaciones indígenas de la conquista, Versión de los textos nahuas Ángel María Garibay, México, ilustraciones de Alberto Beltrán, UNAM, 1971.

Linati, Claudio, Trajes civiles, militares y religiosos de México, introducción estudio y traducción de Justino Fernández, prólogo de Manuel Toussaint, México, Instituto de Investigaciones Estéticas, UNAM, 1956.

López Casillas Mercurio, José Guadalupe Posada llustrador de Cuadernos Populares, segundo número de la Biblioteca de llustradores Mexicanos, México, Editorial RM, 2002.

López Casillas, Mercurio, Monografía de 598 estampas de Manuel Manilla grabador mexicano, texto introductorio de Jean Charlot, México Editorial RM, 2005.

López de Gómara, Francisco, Historia de la conquista de México, estudio preliminar de Juan Miralles Ostos, México Col. "sepan cuantos", tercera edición, editorial Porrúa, número 566, 1997.

Koetzle, Hans Michael, Photo Icons The story behind the pictures Volume 1, Taschen, Alemania, 2002.

MacLachlan M. Colín, La justicia criminal del siglo XVIII en México, Un estudio sobre el Tribunal de la Acordada, México, SepSetentas, número 240, 1976.

Madame Calderón de la Barca, La vida en México durante una residencia de dos años en ese país, traducción y prólogo de Felipe Teixidor, México Editorial Porrúa, Colección "Sepan cuantos”, número 74. 2006.

Manrique, Jorge Alberto, Arte y Artistas del Siglo XX, México, Lecturas Mexicanas, CONACULTA, 2000. 
Martínez Lambarry Margarita (Coordinadora), Los años 60, Investigación inédita colectiva en el Seminario de Arte Contemporáneo, México, Facultad de Filosofía y Letras, UNAM, 2001.

Mayer, Ralph, Manual del artista, materiales y técnicas, traducción de Abel Camps, México, Editorial. Continental, 1956.

Mindek Dubravka, Fiestas de gremios ayer y hoy, México, CONACULTA, 2001.

Micheli, Mario de, Vanguardias artísticas del siglo XX, traducción de Ángel Sánchez, Madrid, Alianza Editorial, 1984.

Moles, Abraham. La imagen, comunicación funcional, traducción de Gastón Melo Medina, México, Editorial Trillas, SIGMA, 1991.

Monografía de 406 grabados de José Guadalupe Posada, introducción de Diego Rivera, publicada por Mexican Folkways, México, (edición facsimilar), Ediciones Toledo, 1991.

Moreno Rivas, Yolanda, Historia de la música popular mexicana, México col. Los Noventa, Alianza Editorial/ CONACULTA, 1989.

Monografía de 406 grabados de José Guadalupe Posada, introducción de Diego Rivera, México, Edición facsimilar, México, Ediciones Toledo, 1991.

Mendoza, T. Vicente, El corrido mexicano, México, Fondo de Cultura Económica, Colección Popular, número 139, tercera reimpresión, 1976.

Mendoza T. Vicente, Glosas y décimas de México, México, Fondo de Cultura Económica, Col. Letras Mexicanas, séptima reimpresión, 1996.

Mendoza, T. Vicente, El Romance español y el corrido mexicano. Estudio comparativo, México, UNAM, 1993.

Meyer, Jean, Estado y Sociedad con Calles, en Historia de la Revolución Mexicana 1924-1928, México El Colegio de México, 2ª․ Reimpresión, 1996.

Molina del Villar, América, La Nueva España y el matlazahuatl 1736-1739, México, Centro de Investigaciones y Estudios Superiores en Antropología Social/ El Colegio de Michoacán, 2001. 
Morales Miguel Ángel, Cómicos de México, México, Editorial Panorama, 1987.

Morales, Francisco Clero y política en México (1767-1834) Algunas ideas sobre autoridad, la independencia y la reforma eclesiástica, México Colección SepSetentas, número 224, 1975.

Müller-Brockmann, Josef. Historia de la comunicación visual, traducción de Joaquin Chamorro Mielke, Barcelona, Editorial Gustavo Gilli, 1998.

Novaro, Octavio, Inventario de Cenizas, grabados de Capdevila, México, Editorial. Novaro, 1964

Ochoa, Jesús Ángel, La muerte y los muertos, Culto servicio, ofrenda y humor de una comunidad, México, SEP col. sepSetentas, núm. 153, 1974.

O’Gorman, Edmundo, La invención de América, México, FCE, 1958.

Ortiz de Montellano Bernardo, El Sombrerón, México, Editorial La Estampa Mexicana, 1946.

Ortiz Monasterio, José, "Patria", tu ronca voz me repetía... Vicente Riva Palacio y Guerrero, México, UNAM/ Instituto Mora, 1999.

Othón, José Manuel, En el desierto Idilio Salvaje, grabados de Francisco Moreno Capdevila, México, Imprenta Universitaria, 1952.

Paz, Octavio, El laberinto de la soledad, México, FCE, Col. Popular, número 107. 1980.

Pérez Montfort, Ricardo, Estampas de nacionalismo popular mexicano, México, colección Miguel Othón de Mendizábal, CIESAS, 1994. .

Pérez Montfort, Ricardo (coordinador), del Castillo, Alberto y Piccato Pablo, Hábitos, normas y escándalo, Prensa, criminalidad y drogas durante el porfiriato tardío, México, CIESAS/ Plaza y Valdés, 1ํ. Edición, México 1997. 
Pérez Salas, María Esther, Costumbrismo y Litografía en México: un nuevo modo de ver, México, UNAM /Instituto de Investigaciones Estéticas, 2005.

Poniatowska, Elena, Juan Soriano niño de mil años, México, Plaza y Janes, México, 1998.

Poniatowska, Elena, La noche de Tlatelolco, México, Editorial ERA, 4aㅜ reimpresión 2001.

Poniatowska, Elena, Tinísima, México Editorial ERA, 2002.

Payno, Manuel, Los Bandidos del Río Frío, México, obras completas IX, Edición Manuel Sol, Prólogo Margo Glantz, CONACULTA, 2000.

Prieto, Cana María, Acerca de la pendenciera e indisciplinada vida de los léperos capitalinos, México, CONACULTA, 2001.

Ramírez Fausto, Crónica de las Artes Plásticas en los años de López Velarde: 1914- 1921, México, Instituto de Investigaciones Estéticas, UNAM, 1990.

Ramírez Plancarte Francisco, La ciudad de México durante la revolución constitucionalista, México, Impresores Unidos, 1940.

Read, Herbert, Imagen e idea. La función del arte en el desarrollo de la conciencia humana, traducción, Horacio Flores Sánchez, México FCE, Col. Breviarios número 127, 1955,

Ríos, Guadalupe / Alegría Margarita, et. al., De muertitos, cementerios, Iloronas y corridos, (1920-1940), México, UAM, 2002.

Reisenfeld Robin, The German Print Portfolio 1890-1930 Serials for a Private Sphere, The David and Alfred Smart Museum of Art / The University of Chicago, 1992.

Rubio Martínez Mariano, Ayer y hoy del grabado y sistemas de estampación, conceptos fundamentales, historia técnicas, Barcelona, Editorial Tarraco, 1979.

Rodríguez, María de los Ángeles, Usos y costumbres funerarias en la Nueva España, México, El Colegio de Michoacán / El Colegio Mexiquense, 2001. 
Rodríguez, Antonio, Posada: el artista que retrató a una época, México, Editorial Domes, S.A., 1977.

Rodríguez, Cristina, (et. al), El grabado historia y trascendencia, México Universidad Autónoma Metropolitana, 1989.

Rodríguez, Napoleón, Ireneo Paz, letra y espada liberal, Editorial Fontamara, número 322, 2002.

María Luisa Rodríguez Sala et al., El Hospital Real de los Naturales, Sus administradores y sus cirujanos (1531-1764) ¿Miembros de un estamento profesional o de una comunidad científica? Serie Los cirujanos en la Nueva España, México, Instituto de Investigaciones Sociales, UNAM, México, 2005.

Romero de Terreros, Manuel, (Editor), Catálogos de la Exposiciones de la Antigua Academia de San Carlos de México (1850-1898), México, Instituto de Investigaciones Estéticas, UNAM, Colección: Estudios y Fuentes del Arte en México XIV, Imprenta Universitaria, 1963.

Romero de Terreros, Manuel, El arte en México durante el virreinato. Resumen histórico, México, Editorial Porrúa, 1951.

Rowe William y Schelling, Vivian, Memoria y Modernidad, cultura popular en América Latina, Editorial Grijalbo, México, 1993.

s/a José Guadalupe Posada, ilustrador de la vida mexicana, texto introductoria de Leopoldo Méndez, México, Fondo Editorial de la Plástica Mexicana, 1963.

Sagrado, Rafael, María Villa (a) La Chiquita, no. 4002, México, Ediciones Cal y Arena, 1996.

Santos, N. Gonzalo, Memorias, México, Editorial Grijalbo, Colección Testimonios, 4a․ Edición, 1984.

Santorius, Carl Christian, México hacia 1850, México, Colección Cien de México, CONACULTA, México.

Secretaría de Educación Pública, Libro de Lectura para uso de las Escuelas Nocturnas para Trabajadores Comisión Editora Popular, Primer Grado, México 1938, (edición facsimilar por Ediciones Toledo, 1990) 
Séjourné Laurette, Pensamiento y religión en el México antiguo, traducción de A. Orfila Reynal, México, Breviarios del Fondo de Cultura Económica, Núm. 128, undécima reimpresión,1994.

Speckman G, Elisa, Crimen y Castigo. Legislación penal, interpretaciones de la criminalidad y administración de justicia (Ciudad de México, 1872-1910), México, El Colegio de México, Universidad Nacional Autónoma de México, primera edición, 2002.

Serrano Martínez, Celedonio, El Coyote corrido de la Revolución, ilustraciones de Gabriel Fernández Ledesma y Francisco Moreno Capdevila, México Secretaría de Educación Pública, 1985 (edición facsimilar)

Serrano Martínez, Celedonio, El Coyote corrido de la Revolución, ilustraciones de Gabriel Fernández Ledesma y Francisco Moreno Capdevila, México, Ediciones Municipales, Acapulco, Guerrero, 1978.

Suárez de la Torre Laura (coordinadora). Empresa y Cultura en tinta y papel (1800-1860) México, Instituto de Investigaciones Dr. José María Mora/ UNAM, 2001.

Tello Díaz, Carlos, El exilio Un relato de familia, México, ediciones cal y arena, séptima edición Cal y Arena, 1994.

Terán, Ma. Isabel, Los recursos de la persuasión, la portentosa vida de la Muerte de fray Joaquín Bolaños, México, El Colegio de Michoacán/ Universidad Autónoma de Zacatecas, 1997.

Tibol, Raquel, Gráficas y Neográficas en México, UNAM/ SEP, 1987.

Tibol Raquel, Julio Antonio Mella en "El Machete", Antología parcial de un luchador y su momento histórico, México, Fondo de Cultura Popular, 1968.

Tovar y de Teresa, Guillermo, La Ciudad de los Palacios, crónica de un patrimonio perdido, México, 1aㅡ edición del tomo II, Ediciones Vuelta, 1990.

Thomas, Louis-Vincent, Antropología de la muerte, traducción de Marcos Lara, México, Fondo de Cultura Económica, 1983. 
Vega, Eduardo de la, Del muro a la pantalla, S. M. Eisenstein y el arte pictórico mexicano, México, Instituto Mexiquense de Cultura, IMCINE, Canal 22, 1977.

Velasco Valdés, Miguel, Refranero Mexicano, México, LIBRO- MEX Editores, 1961.

Westheim, Paul. El grabado en madera, traducción de Mariana Frenk, México, Breviarios Fondo de Cultura Económica, Núm. 95, 1954.

Westheim, Paul. La calavera, traducción de Mariana Frenk, México, 1a. Edición en Lecturas Mexicanas, Fondo de Cultura Económica / Secretaría de Educación Pública, 1985.

Zahar Vergara, Juana, Historia de las librerías de la Ciudad de México, una evocación, México, serie monografías 18, Centro Universitario de Investigaciones Bibliotecológicas, UNAM, 1995.

Zárate Toscano, Verónica, Los nobles ante la muerte en México, Actitudes, ceremonias y memoria (1750-1850), México, El Colegio de México / Instituto Mora, Centro de Estudios Históricos, 1a. Edición, 2000.

Zermeño, Sergio, México una democracia utópica El movimiento estudiantil del 68, Siglo XX1, México, 3ª edición, 1983.

\section{TESIS CONSULTADAS}

BSR/ Cervantes López, Julio Cesar, La archicofradía de la Santísima Trinidad. Una cofradía novohispana. Tesis licenciatura en Historia, Facultad de Filosofía y Letras, UNAM, México 2000.

BSR/ Gilabert Berta y Soto Alberto, Mortal Agonía Orden de Clérigos Regulares Ministros de los enfermos Agonizantes de San Camilo de Lelis en México, Caridad, salud, enfermedad y muerte en la ciudad de México (siglos XVIII y XIX). Tesis, licenciatura en historia, Facultad de Filosofía y Letras, UNAM, 2000. 
BSR/ Otaola Gonzáles, Javier, Muerte y Salvación. Sociedad novohispana entre los siglos XVII y XVIII, Tesis en Historia. Facultad de Filosofía y Letras, UNAM, 2002.

BSR/ Liberal, María José, Los calendarios y la gráfica decimonónica como expresión visual del acontecimiento político y social en México. 1821-1850. Tesis de maestría en Historia del Arte, Facultad de Filosofía y Letras, 2004.

BSR/ Morera y González Jaime Ángel, Las pinturas coloniales de Ánimas del Purgatorio, iconografía de una creencia, Tesis de maestría en Historia del Arte, Facultad de Filosofía y Letras. UNAM, 1999.

BSR/ Suárez Escobar Marcela, Sexualidad y norma sobre lo prohibido, La Ciudad de México y las postrimerías del Virreinato. Tesis, Doctorado en Historia, Facultad de Filosofía y Letras, UNAM, México 1994.

BSR/ Lozano Arrendares, Teresa, La criminalidad en la Ciudad de México 18001812, Tesis licenciatura en Historia, Facultad de Filosofía y Letras. UNAM, México, 1983.

BSR/ Gilabert Hidalgo, Berta, La idea del mal y el Demonio en los sermones novohispanos Arquidiócesis metropolitana, siglo XVII, Tesis de maestría en Historia, Facultad de Filosofía y Letras. UNAM, 2005.

\section{FUENTES HEMEROGRÁFICAS}

\section{Periódicos}

Amador Tello, Judith, "Se mutiló la historia de México", revista Proceso, número 1625, México, 23 de Diciembre, de 2007, pp. 66-68.

Galarza, Yuriria "La escritura mesoamericana", entrevista a Joaquín Galarza, La Jornada, suplemento La Jornada Semanal Num. 499, domingo 26 de septiembre de 2004.

García, Manuel, "Testimonios mexicanos de la guerra civil española: Juan de la Cabada, José Chávez Morado y Fernando Gamboa", periódico Unomasuno, suplemento Sábado del 19 de septiembre de 1987. pp. 1-3. 
"La Carabina de Ambrosio, periódico joco-serio con caricaturas", México, 1 volumen, mayo 1875- julio 1876.

"La cucaracha. Semanario Político de caricatura", México, años Julio-1916Febrero 1918. Volúmen 1.

"La Cucaracha Papelito Alegre, Entrometido, Zumbón”, México, noviembre 1864febrero 1865, Volumen I.

Paz, Ireneo (Director y Fundador) "La Patria" Año 2, números 337-341 ( 4 -9 mayo 1878) Imprenta de Ireneo Paz 1878.

s/a "La manifestación de obreros se efectúa hoy por la mañana"/ "Cual va a ser su itinerario y su formación"/ "Serán radiados los discursos del mitin". Domingo 22 de diciembre de 1935, año VII, tomo V, número 2, 392, El Nacional, Director Froylán C. Manjarrez.

s/a "Que Calles y los suyos sientan la verguenza de sus actos y el peso de sus responsabilidades". Lunes 23 de diciembre de 1935, año VII, tomo V, número 2, 392, El Nacional, Director Froylán C. Manjarrez.

Herner, Irene, "Taller de Gráfica Popular Realismo ¿Engaño de la vista?", periódico, Unomásuno, suplemento Sábado, del 21 de noviembre de 1987.

Pérez Tamayo, Ruy, "El final de la vida”, en Letras Libres, revista mensual, enero, año X, número 109, México, 2008.

"El Monitor del Pueblo" México, marzo-diciembre 1885; Julio 1886-Agosto 1888; enero /octubre 1889; Marzo-Julio 1893.

s/a "Por la unificación proletaria",. El Nacional, Director: Froylán C. Manjares, , año V11, tomo X, 19 de diciembre de 1935.

s/a "Cual será el orden de la manifestación obrera de mañana", Periódico El Nacional, Director: Froylán C. Manjarrez, año V11, tomo XV, sábado 21 diciembre de 1937, 
s/a "80,000 Manifestantes", suplemento interior del Periódico El Nacional, Director: Froylán C. Manjarrez, año V11, tomo XV, lunes 23 de diciembre de 1935.

s/a “Enamorado Tenaz”, Periódico El Imparcial, 24 de mayo 1908

s/a "Una tragedia en la calle de las Escalerillas", Periódico El Imparcial, 27 de mayo de 1908.

s/a "Los amores de una cocinera", Periódico El Imparcial, 27 de mayo de 1908.

\section{COLECCIONES}

Historia Moderna de México El Porfiriato, La Vida Social, Daniel Cossió Villegas, (coordinador), González Navarro Moisés, México, Editorial Herrero, 3a. edición, 1973.

Bernal Ignacio, Enciclopedia Historia de México, tomo 3, El Valle de Oaxaca hasta la caída de Monte Albán, México, Salvat, 1986.

O'Gorman, Edmundo, et., al., 40 Siglos de Arte Mexicano, Tomo 5․ Arte Moderno y Contemporáneo México, Editorial Galería de Arte Herrero, 2a․ Edición,1981.

Riva Palacio, Vicente, México a través de los siglos, tomo II, El Virreinato, México, Editorial Cumbre, 16a‥ Edición, 1980.

Coloquio Internacional de Historia del Arte, Arte Funerario, México Vol. 11, Beatriz de la Fuente, (coordinadora) Instituto de Investigaciones Estéticas; UNAM,1987.

Coloquio Mexicano de Historia del Arte, Arte y Coerción, México, IIE, UNAM,1992.

Hamblin, Dora Jane, Las Primeras Ciudades, colección "Orígenes del Hombre", México, libros TIME/ LIFE, 1979.

Ramírez Leyva, Edelmira, La censura inquisitorial novohispana sobre imágenes y objetos, en Arte y Coerción Coloquio del Comité Mexicano de Historia del Arte. IIE, UNAM; México, 1992. 
Romano Pacheco, Arturo La ofrenda funeraria en Tlatilco, en Arte Funerario. Coloquio Internacional de Historia del Arte, vol. 11 UNAM, México 1987.

\section{CATÁLOGOS}

1951 “Mariano Paredes”, Catálogo en Galería Arte Moderno, 25 reproducciones en blanco y negro y seis maderas impresas con las planchas originales. Notas de Margarita Nelken, Enrique F. Gual, Ceferino Palencia, Antonio Rodríguez y Salvador Moreno, Ediciones "Galerías", México, mayo de 1951.

1960 "450 años de Lucha Homenaje al pueblo mexicano", Taller de Gráfica Popular, 146 estampas de la lucha del pueblo de México. Obra colectiva de los artistas del Taller de Gráfica Popular en México, notas históricas de Enrique Ramírez y Ramírez (libro / catálogo).

1968 "20 Años de la Sociedad Mexicana de Grabadores", texto de presentación de Justino Fernández, México, INBA.

1969 "Exposición Nacional de Grabado", textos de Víctor M. Reyes, México, Partido Revolucionario Institucional.

1970 “Leopoldo Méndez 1902-1969”, Academia de Artes, Exposición Homenaje, Sala Nacional y Verde del INBA, febrero- marzo.

1977 "Salón Nacional de Artes Plásticas. Sección Bienal de Gráfica", México, Cultura SEP-INBA.

1978 "Salón Nacional de Bellas Artes. Sección Bienal de Gráfica", México, INBA /SEP.

1979 "Actualidad Gráfica. Panorama Artístico", textos de Raquel Tibol, México, Colección: Cartón y Papel de México.

1980 "Salón Nacional de Artes Plásticas. Sección Bienal de Gráfica", México, INBA/SEP. 
1981 "Leopoldo Méndez, Artista de un pueblo en lucha", México, Centro de Estudios Económicos y Sociales del Tercer Mundo, Universidad Nacional Autónoma de México, Instituto de Investigaciones Estéticas, 1981. (libro /catálogo)

1981 "La Gráfica del 68, Homenaje al Movimiento Estudiantil”, tercera edición, recopilación, texto y diseño: Grupo Mira, México, 1981.

1984, 'Leopoldo Méndez", dibujos grabados pinturas, prólogo de Rafael Carrillo Azpeitia, México, Fondo Editorial de la Plástica Mexicana, (libro /catálogo)

1984 “Juan Soriano" Catálogo de la Exposición, textos de Javier Sicilia.

1985 "El poder de la imagen y la imagen del poder". Fotografía de prensa del Porfiriato a la época actual, México, Universidad Autónoma Chapingo, 1985.

1987 “Capdevila visión múltiple 1987”, Museo del Palacio de Bellas Artes, 7 mayo2 de agosto, 1987. (libro/catálogo)

1990 "Jesús F. Contreras (1866-1902)", Escultor finisecular, Libro Catálogo, México, CONACULTA, INBA, MUNAL, mayo-julio. (libro/catálogo)

1993 "La Grafica del 68, Homenaje al Movimiento Estudiantil", México, tercera edición, recopilación, texto y diseño: Grupo Mira, (libro /catálogo)

1994 "Nación de imágenes, La litografía mexicana del siglo X1X," México, Museo Nacional de Arte, abril-junio, 1994. (libro /catálogo)

1996 “Grupo SEMEFO," Catálogo Arte contemporáneo de México, México, CONACULTA, INBA, (libro /catálogo)

1997 "México y su tiempo de nacer 1750-1821", México, Fomento Cultural Banamex, 1997. (libro /catálogo)

1999 "Misiones Culturales los años utópicos 1920-1938”, México, Museo Casa Estudio Diego Rivera, México, CONACULTA, INBA, (libro/catálogo)

2000 "Leopoldo Méndez 1902- 2002". Colección Carlos Monsiváis. México, CONACULTA, (libro /catálogo) 
2000 'Los pinceles de la historia, De la Patria Criolla a la nación mexicana, 17501860 ", México, INBA/ MUNAL, 2000. (libro /catálogo)

2000 "Tzompantli Variaciones sobre un tema" Catálogo de la exposición, México, CONACULTA.

2002 "Monografía de 406 grabados de José Guadalupe Posada", edición facsimilar, México, CONACULTA, (libro /catálogo)

2003 "Los pinceles de la Historia", La Arqueología del Régimen, 1910- 1955. México, Instituto de Investigaciones Estéticas. UNAM, (libro /catálogo).

2003 “Archivo Gráfico, Grabados, litografías y serigrafías”, Universidad Politécnica de Valencia, Editorial UPV, textos de Fernando Aranda, Joan Llavería, Joan Aliaga, Carlos Plasencia, José Manuel Guillén, "2003.

2005 "Pablo O’Higgins voz de lucha y de arte", textos de Ricardo Pérez Montfort, Alberto Híjar, Miguel, León Portilla, Arnoldo Martínez Verdugo, Maricela González, Leonard Folgarait, Larissa Pavlioukova y Adrián Soto, Leticia López Orozco, Helga Prignitz, Eduardo Espinosa, Eliseo Mijangos, Carlos Blas Galindo, Luis Rius, México, UNAM, CONACULTA. (libro /catálogo).

\section{REVISTAS MONOGRÁFICAS}

Artes de México, "Veinte años de vida del Taller de Gráfica Popular", México, vol. 111, año v, núm. 18, julio y agosto de 1957.

Artes de México, "El Libro Mexicano durante la Colonia", México, número 131, año XV11, 1970.

Artes de México “Ex votos”, México, número 53, año 2000.

Artes de México “Risa y Calavera II”, México, número 67, 1ª edición, 2003. 
La Gaceta del Fondo de Cultura Económica, "450 Años de la imprenta en México", México, nueva época, número 225, septiembre de 1989.

Revista / Catálogo Francisco de Goya "Los Desastres de la Guerra". Presentación de Héctor Perea, México, UAM, Galería Metropolitana, Abril-Junio 1992.

Luna Cornea, "Héctor García y su tiempo", México, CONACULTA, número 26, 2003.

\section{REVISTAS DIVERSAS}

Revista Canje 1 Grabado mexicano, INBA, SEP, Director Lorenzo Guerrero, México, de 1956.

Tradiciones y Leyendas de la Colonia "El maldito del Templo de San Camilo", Revista Semanal publicada por "Ediciones Latinoamericana", S.S. número 65, 17 de septiembre de 1964 .

Anales del Instituto de Investigaciones Estéticas, Directora Dra. Beatriz de la Fuente, editor Xavier Moyssén, UNAM, número 56, México 1986.

Anales del Instituto de Investigaciones Estéticas, Directora Dra. Elisa García Barragán, coordinador: Xavier Moyssén, UNAM, número 60, México 1989.

Revista de Literaturas Populares, Facultad de Filosofía y Letras, UNAM, año I, número 2 julio-diciembre de 2001.

Revista de Literaturas Populares, Facultad de Filosofía y Letras, UNAM, año III, número 1, enero-junio de 2003.

Revista de Literaturas Populares, Facultad de Filosofía y Letras, UNAM, año III, número 2 julio-diciembre de 2003.

\section{ARTÍCULOS EN REVISTAS}

Aguilera Murguía, Ramón y Martínez Barbosa, Xóchitl, "Libros, Inquisición y Devoción", en Inquisición Novohispana, volumen II, México, UNAM/ UAM/ 1ª edición, 2000. 
Báez Macías, Eduardo, "El grabado durante la época Colonial”, en Historia del Arte Mexicano Fascículo 60, México, SEP/ INBA /SALVAT, 1982.

Bonilla Reyna, Helia Emma, "El Calavera: caricaturas en tiempos de guerra", Anales Revista del Instituto de Investigaciones Estéticas, México, 2001, vol. xxiv, núm. 79, UNAM,

Corbin, Alain, "Sexualidad comercial en Francia durante el siglo XIX: un sistema de imágenes y regulaciones", en Historias 18, México, Revista de la Dirección de Estudios Históricos del Instituto Nacional de Antropología e Historia, julio / septiembre de 1987.

de Solano, Francisco, "Las Voces de la Ciudad. Aproximaciones a la historiografía de la Ciudad de México", en VI Coloquio de Historia del Arte. La Ciudad, concepto y obra, México, Instituto de Investigaciones Estéticas, UNAM, 1987.

de Gerlero Elena, "La escatología en el arte monástico novohispano del siglo XV1", en Arte Funerario. Coloquio Internacional de Historia del Arte, vol. 1 UNAM, México 1987

Díaz y de Ovando, Clementina, "El panteón de Santa Paula”, en Crónicas de la Ciudad de México a pié, México, nueva época, Año 1, núm. 3, octubre-diciembre, 2003.

Fernández Ledesma, Gabriel, Pan y dulces funerarios, en La cultura popular vista por las elites, antología de artículos publicados entre 1920 y 1952, México, Introducción y Selección de Irene Vázquez Valle, UNAM.

Fernández Ledesma, Gabriel, "El triunfo de la muerte, las calaveras y la sátira en México", en Galera, México, nueva época, año 4, núm. 30, primavera 2002.

Foncerrada de Molina María "Cacaxtla: muerte en la guerra", en Arte Funerario, México, Coloquio Internacional de Historia del Arte, vol. 11, Instituto de Investigaciones Estéticas, UNAM, México. 1987.

Gamboa, Fernando y otros, "Actualidad gráfica panorama artístico 1971-1979”, en Artes de México, México, INBA/SEP, , noviembre-enero, 1980.

García Bustos, Arturo "Ofrenda a la vida", periódico La Jornada, México, sección cultural, viernes 3 de noviembre de 2006. 
Gutiérrez, Juana y otros, "La Época de Oro del grabado en México", en Historia del Arte Mexicano, SEP/ INBA/ SALVAT, México, núm 101, 1982.

"Julio Ruelas", en Galera, Revista de bibliofilia y arte mexicano, México, nueva época, año 4, núm. 32, verano 2003.

Labastida, Jaime, "Jesús Martínez: el arte como conciencia", en Plural, México, núm.107, agosto de 1980.

Monsivais, Carlos, "Preámbulo para darle tiempo al lector de convertirse en voyeur", La casa de citas en el barrio elegante Fotografías mexicanas de la Bella Época Ava Vargas en revista Mar de Tinta, México, número 1, CONACULTA, Verano de 1992.

Monsivais, Carlos, "Si el gobierno supiera que así lo vemos" (política, sociedad y litografía en el México del siglo X1X), Libro/ Catálogo Nación de Imágenes, la litografía mexicana del siglo X1X, MUNAL, México, abril- junio 1994.

Morales, Leonor, "El Taller de Gráfica Popular y su vinculación con el realismo socialista", en Arte y Coerción, primer coloquio del comité mexicano de historia del arte, Instituto de Investigaciones Estéticas, UNAM, 1a․ Edición, México 1992.

PIPSA "El papel periódico en la comunicación social y la cultura”, México, Secretaría de Gobernación, 1988.

Escamilla, Pérez Escamilla, "Arriba el telón. Los litógrafos mexicanos, vanguardia artística y política del siglo X1X”, en Libro /Catálogo, La litografía mexicana del siglo X1X, México, MUNAL, abril-junio 1994.

Portilla, Miguel León, "Aquiauhzin de Ayapango, poesía erótica náhuatl”, en Revista Plural, México núm. 49, 1975.

Poniatowska, Elena, 'El Taller de Gráfica Popular en palabras de Leopoldo Méndez", en Galera, México, núm. 31, invierno 2002. 
Quijano, Álvaro, “Arte popular, sueños sin bautizo”, en Memoria de papel, Crónicas de la cultura en México, año 4, núm. 11, septiembre de 1994.

Ramírez Montes, Mina, "Arte en tránsito a la Nueva España durante el siglo XVI", Anales del Instituto de Investigaciones Estéticas, México, UNAM, 1989.

Relea, Francesc, "El barrio que se venera a la Santa Muerte", en El País Semanal, 15, 06, 08, pp. 52-60.

Reyna, María del Carmen, "Sermones y oraciones prohibidas por el tribunal de la Santa Inquisición", en Inquisición Novohispana, volumen II, México, UNAM/ UAM/ $1^{\underline{a}}$ edición, 2000.

Reyes Palma, Francisco, "Radicalismo artístico en el México de los años 30 una respuesta colectiva a la crisis", en Revista de la Escuela Nacional de Artes Plásticas, México, vol. 2, núm. 7, diciembre 1988- febrero 1999.

Rubial García, Antonio, "Santos para pensar, Enfoques y materiales para el estudio de la hagiografía novohispana", en Prolija Memoria. Estudios de cultura virreinal, México, Facultad de Filosofía y Letras/ Claustro de Sor Juana, año 1, volumen 1.

Sheridan, Sheridan, “Octavio Paz en Yucatán”, en Vidas Literarias en Revista Letras Libres, México, Revista mensual, director Enrique Krautze, enero 2001, año 111, número 25.

Tiempo de México, segunda época, junio de 1911 a enero de 1913, reimpresión de la Secretaría de Educación Pública, mayo 1984.

Tibol, Raquel, “Homenaje a Posada en San Carlos”, Proceso, número 0054-47, 14 noviembre de 1977.

s/a "La muerte en el México Prehispánico", en Revista Arqueología Mexicana, CNCA, vol. II, núm. 40, noviembre-diciembre de 1999.

s/a "Leopoldo Méndez. 100 años", en Galera, Revista de bibliofilia y arte mexicano, nueva época, núm. 3, invierno 2002. 
Secretaría de Gobernación "Autos y diligencias en orden a la visita de los obrajes y haciendas de la jurisdicción de la villa de Cuyoacán, obraje de Melchor Díaz de Posadas 1660", México, en Boletín del Archivo General de la Nación, tomo XI, 1940.

Sego Eugene, "Un homicidio del siglo XVI, el caso de Pascualillo", México, Cuadernos del Centro, El Colegio de San Luis, 1997.

Serrano Espinosa Teresa E, y Talavera Gonzáles Jorge A. La obra de imprenta y la Inquisición en la Nueva España: los libros prohibidos, en Inquisición Novohispana, volumen II, México, UNAM/ UAM, 1a edición, 2000.

Todorov, Tzvetan, "La conquista vista por los aztecas", en La Jornada Semanal. suplemento de La Jornada Semanal, nueva época, núm. 203, 2 de mayo de 1993.

Villa, María, "Diario desde la cárcel", en Historias 18, Revista de la Dirección de Estudios Históricos México, Instituto Nacional de Antropología e Historia, julio / septiembre de 1987.

Villela F. Samuel, "Arte y testimonio funerario en México", México en el Tiempo, Revista de historia y conservación, INAH, abril-mayo 1996.

\section{IMPRESOS}

CEHM /Graxales, Francisco, Fr., Sermón Fúnebre En las exequias, que hizo la Provincia de México en su Convento grande de dicha Ciudad a Nuestro Rmo. P. M. FR. Joan Antonio Velasco Maestro General de todo el Real, y Militar Orden de Nuestra Señora de la Merced, Redención de Cautivos, Señor de las Varonias de Algar, y Escales, Diputado mayor de el Reyno de Valencia, Theologo de la Real Junta de la Concepción de María Santisima. Predicolo el M.R.P.M. FR. Francisco Graxales Ardila Vicario General de las Provincias de Nueva España, Calificador del Santo Oficio, y examinador Synodal de el Opispado de Guatemala, Sacalo a luz El R.P. M FR. Baltasar de Alcocer, y Sariñana de dicho orden; Comendador actual del Covento de México Maestro en Sagrada Teología en la Real Universidad y Catedrático de ella de Visperas de Philosophia Dedicalo A N: Rmo P.M. FR. Joan Navarro, maestro General de dicho Real, y militar Orden de Nuestra Señora de la Merded Redencion de Cautivos, Señor de las Varonias de Algar y Escales en el Reyno de Valencia Con licencia: en Mexico, por los herederos de la Viuda de Francisco Rodríguez Lupercio. 
CEHM /Correa Antonio, Fr., Fúnebre Panegyris, que a las honras del muy piadoso y nobilisimo Republicano Diego del Castillo Comprador de Plata, consagro como a Patrono de su Iglesia El Muy llustre Convento de las Señoras Religiosas Descalzas de Santa Isabel, de esta Ciudad de México el dia 29 de marzo de 1683 Predico El P. Fray Antonio Correa Predicador mayor del Convento de N.P.S. Francisco desta Ciudad. Dedicalo, A.N.M.R.P.Fr. Francisco de Avila. Lector jubilado, Qualificador del Santo Oficio; y Ministro Provincial de la Provincia del Santo Evangelio, Dado a la estampa a expensas suyas El Capitan Domingo de la Rea Y Zarate natural de Eribo en la provincia de Alava, y comprador de Plat en la Imperial de México. Con licencia en México, por Francisco Rodriguez Lupercio Año de 1683

CFP/ El Machete, periódico obrero y campesino, Núm. 389, Director: Hernán Laborde, México, sábado 22 de febrero de 1936. ilustraciones de Leopoldo Méndez, Fernando Gamboa, Jesús Guerrero Galván, Julio de la Fuente, Miguel Piña, Feliciano Peña, Hermanos Alonso de la LEAR.

CFP/ El Machete, periódico obrero y campesino, Núm. 404, Director: Hernán Laborde, edición especial, México, 1ํ de Mayo de 1936, México. (61 x 46 cm.)

CFP/ El Machete, periódico obrero y campesino, Núm. 444, Director: Rafael Carrillo, México, lunes 2 de noviembre de 1936. Calaveras de Fernando Gamboa, Eduardo Ramírez, Fermín Martínez, Filiberto Cisneros, Víctor M. Reyes, Julio de la Fuente, Julio Castellanos, Gabriel F. Ledesma, Pablo O’Higgins, Alfredo Zalce de la LEAR.

CFP/ El Machete, periódico obrero y campesino. Calavera Tumulto en el panteón callista. Colaboración artística de Leopoldo Méndez, Antonio Pujol, Ángel Bracho, Luis Arenal, Julio de la Fuente, Juan de la Cabada de la LEAR. documento s/f.

CFP/ "Calaveras de La guerra de los frijoles, y El misterio del gran hueso" c. 1940. LEAR impreso $(57 \times 45 \mathrm{~cm}$.)

CFP/ "Hoja Popular Anticallista”, LEAR, número 4, México, D.F., diciembre de $1935(41.5 \times 30 \mathrm{~cm}$.)

CFP/ "Despertador Christiano Sanctoral de varios sermones de santos, de Aniversarios de Änimas y Honras, en orden a excitar en los Fieles la devoción de los Santos, y la imitación de sus virtudes. Su autor el ilustrissimo, i reverendissimo señor Don Jseph de bracia y Zambrana, Obispo de Cadeiz, y Algeciras, del Consejo de su Magestad, Vc. Al excelentissimo señor Don Diego de Astorga y 
Céspedes, Arzobispo de Toledo, Primado de las Españas, Chanciller Mayor de Castilla, Adelantado Mayor de Cazorla, del Consejo de su Magestad, \&c. Corregida y enmendada esta ultima impresion Año 1759 con licencia en Madrid: En la imprenta de los herederos de la Viuda Juan García Infanzón.

CFP/ Oración y Plegaria a S. Camilo de Lelis, Librería Papelería Nieto, Puebla, Pue, s/f

\section{DISCOGRAFÍA}

Juan de la Cabada, C/D Voz Viva de México, Dirección General de Difusión Cultural, Departamento de Grabaciones UNAM, México, 1968.

La canción popular en el cine mexicano 1941-1950, C/D, Filmoteca UNAM, Dirección General de Actividades Cinematográficas, 1994.

Oscar Chávez, México 68' volúmen 1, CD, s/f.

Oscar Chávez, México 68' volúmen 11, CD, s/f

Amparo Ochoa, A lo mestizo, CD, Grabado en vivo en el Teatro de la Ciudad los días 1, 2, y 3 de octubre de 1992, Ediciones Pentagrama, México.

\section{PÁGINAS ELECTRÓNICAS:}

http://goya.unizar.es/InfoGoya/Obra/TecnicaGrabado.html (12 -07- 2008)

Biblioteca Luis Ángel Arango http://www.lablaa

org/blaavirtual/publicacionesbanrep/bolmuseo/1997 enjn42/enjn02a.htm (12- 07 2008)

Sayra Guinnette, Aldana Hernández, La treponematosis en la historia de Colombia:una mirada desde la Ecología Histórica.

http://www.inversa.unal.edu.co/articulos_publicados_en_html/publicado_vol1_no2_ la_treponematosis_en_la_historia_de_colombia.htm. (12 -07-2008)

http://www.arqhys.com/articulos/acuarela-historia.html (10 -07- 2008)

http://www.ebrisa.com/portalc/ShowArticle.do?articleld=76779 (17- 07-2008)

http://www.patriagrande.net/mexico/molino.del.rey.jpg (11-03-2008)

http://www.esteticas.unam.mx/revista_imagenes/rastros/ras_romero01.html (1503-2008) 
http://redescolar.ilce.edu.mx/redescolar/act_permanentes/historia/html/guerra47b.j pg (21-03-2008)

http://es.wikipedia.org/wiki/Segunda_Intervenci\%C3\%B3n_Francesa_en_M\%C3\% A9xico (21-03-2008)

http://www.cddhcu.gob.mx/museo/s_surg7.htm (23-03-2008)

http://es.wikipedia.org/wiki/Aby_Warburg (30-07- 2008)

http://es.wikipedia.org/wiki/Palimpsesto (1 agosto 20008)

http://www.cervantesvirtual.com/servlet/SirveObras/mcp/092561521887694730856 35/p0000001.htm (03-08-2008)

http://es. wikipedia.org/wiki/Auca

http://archivo.castello.es/valencia/colecciones/aucas.html

http://images.google.es/images?imgsz=small\%7Cmedium\%7Clarge\%7Cxlarge\&gb $\mathrm{v}=2 \& \mathrm{hl}=$ es\&q=santa+muerte\&btnG=Buscar+im\%C3\%A1genes (fotografía de Jorge Arana con título: Santa Muerte en el Zócalo. (05-08-2008)

Santa Muerte Religiones del mundo.

http://images.google.es/images?imgsz=small\%7Cmedium\%7Clarge\%7Cxlarge\&gb $\mathrm{v}=2 \& \mathrm{hl}=\mathrm{es} \& \mathrm{q}=$ santa + muerte\&btnG=Buscar+im\%C3\%A1genes $(06-08-2008)$

Tatuaje de la muerte Sin autor http://images.google.es/images?imgsz=small\%7Cmedium\%7Clarge\%7Cxlarge\&gb $\mathrm{v}=2 \& \mathrm{hl}=\mathrm{es} \& \mathrm{q}=\mathrm{santa}+\mathrm{muerte} \& \mathrm{start}=18 \& \mathrm{sa}=\mathrm{N} \& \mathrm{ndsp}=18(06-08-2008)$ 